\title{
Realizacja
} funkcji perswazyjnej w tekstach gwarowych 

BEATA BURSKA-RATAJCZYK

\section{Realizacja funkcji perswazyjnej w tekstach gwarowych}


Beata Burska-Ratajczyk - Katedra Współczesnego Języka Polskiego, Instytut Filologii Polskiej Wydział Filologiczny, Uniwersytet Łódzki, 90-514 Łódź, al. Kościuszki 65

\author{
RECENZENT \\ Janina Gardzińska \\ REDAKTOR WYDAWNICTWA UŁ \\ Dorota Stępień
}

SKŁAD I ŁAMANIE

AGENT PR

OKŁADKĘ PROJEKTOWAŁA

Barbara Grzejszczak

(C) Copyright by Uniwersytet Łódzki, Łódź 2013

Wydane przez Wydawnictwo Uniwersytetu Łódzkiego

Wydanie I. 6082/2012

ISBN (wersja papierowa) 978-83-7525-856-1

ISBN (ebook) 978-83-7969-598-0

\author{
Wydawnictwo Uniwersytetu Łódzkiego \\ 90-131 Łódź, ul. Lindleya 8 \\ www.wydawnictwo.uni.lodz.pl \\ e-mail: ksiegarnia@uni.lodz.pl \\ tel. (42) 6655863 , faks (42) 6655862
}




\section{Spis treści}

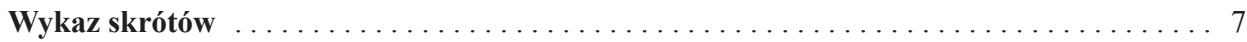

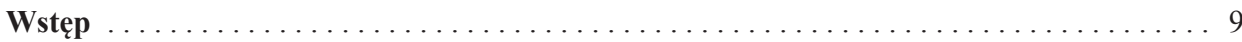

ROZDZIAL I. Problematyka perswazji w języku i w tekście $\ldots \ldots \ldots \ldots \ldots \ldots \ldots 27$

1. Przeobrażenia w komunikacji mieszkańców wsi - status dialektów wobec współczes-

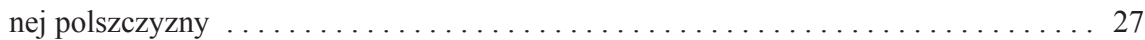

2. Uwarunkowania socjologiczne, psychologiczne i kulturowe komunikacji językowej

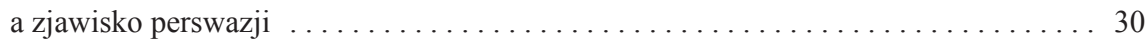

3. Pojęcie perswazji i zasięg oddziaływań perswazyjnych $\ldots \ldots \ldots \ldots \ldots \ldots \ldots \ldots$

3.1. Czynniki warunkujące przekaz perswazyjny $\ldots \ldots \ldots \ldots \ldots \ldots \ldots \ldots \ldots \ldots \ldots \ldots$

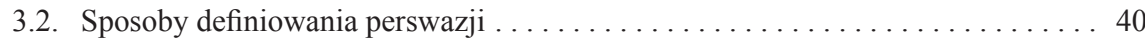

4. Historia i stan badań nad perswazją . ........................ 41

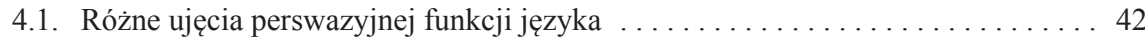

4.2. Opracowania dotyczące różnych aspektów perswazji językowej . . . . . . . 49

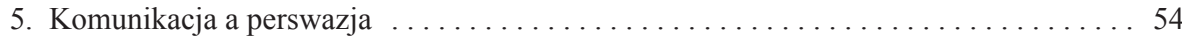

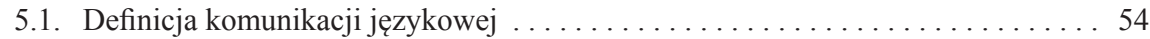

5.2. Komunikacja interpersonalna a perswazja $\ldots \ldots \ldots \ldots \ldots \ldots \ldots \ldots \ldots$

5.3. Komunikacja bezpośrednia a perswazyjność przekazu ............. 59

6. Perswazja a manipulacja językowa - określenie pojęć, stan badań . . . . . . . . . 64

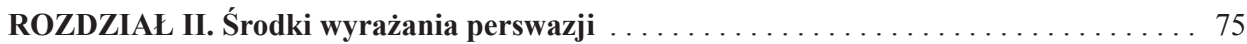

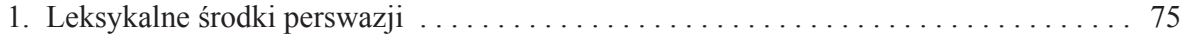

1.1. Wartościowanie, rodzaje wartości i sposoby wartościowania $\ldots \ldots \ldots \ldots \ldots 75$

1.1.1. Wartościowanie bezpośrednie. Wyrażanie ocen za pomocą słownictwa wartościującego - wyrazy wprowadzające pozytywną lub negatywną ocenę . . 77

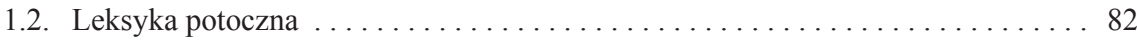

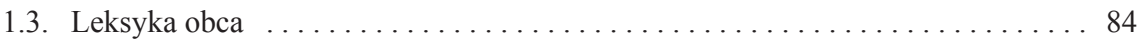

1.4. Zapożyczenia wewnątrzjęzykowe - słownictwo pochodzące z innych odmian języka . 87

1.5. Wyrazy modne . . . . . . . . . . . . . . . . . . . . . . . . 89

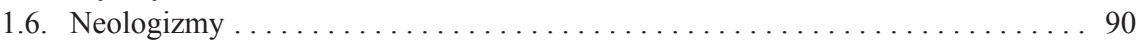

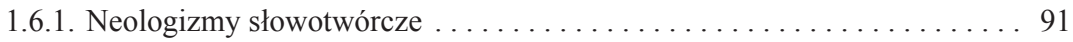

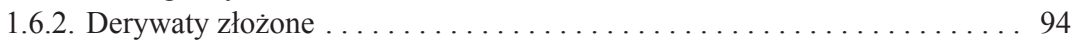

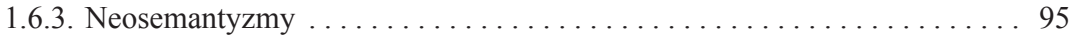

1.7. Stereotyp jako środek wartościowania $\ldots \ldots \ldots \ldots \ldots \ldots \ldots \ldots \ldots \ldots \ldots \ldots$

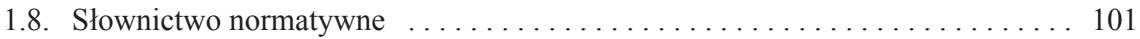

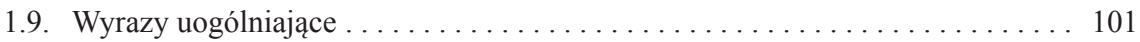

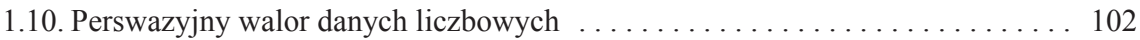

1.11. Rozbudowana synonimika a intensywność ocen $\ldots \ldots \ldots \ldots \ldots . \ldots \ldots$

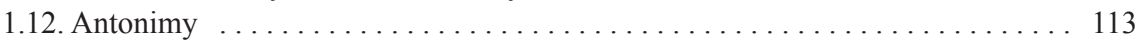

1.13. Polisemia . . . . . . . . . . . . . . . . . . . . . . . . . 116

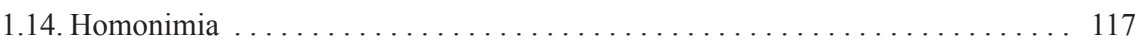




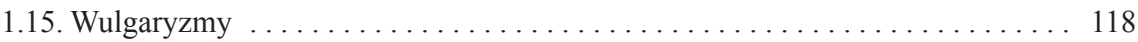

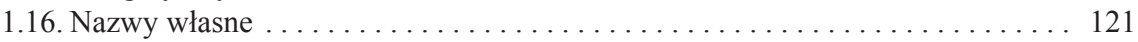

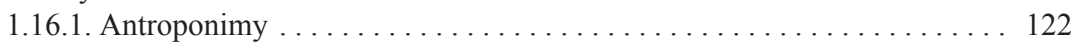

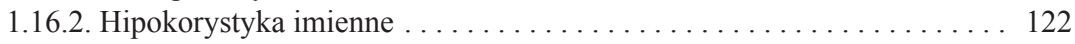

1.16.3. Bezpośrednie zwroty do rozmówcy $\ldots \ldots \ldots \ldots \ldots \ldots \ldots \ldots \ldots \ldots \ldots \ldots \ldots \ldots \ldots \ldots$

1.16.4. Nazwiska . . . . . . . . . . . . . . . . . . . . . . . . . . 126

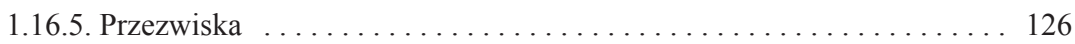

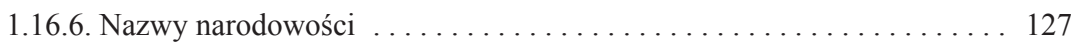

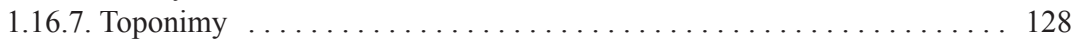

1.16.8. Przekształcenia nazw własnych $\ldots \ldots \ldots \ldots \ldots \ldots \ldots \ldots \ldots \ldots \ldots$

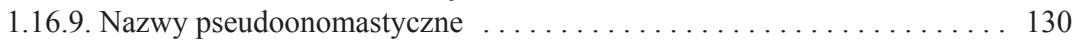

2. Przekształcenia semantyczne w tekstach gwarowych a mechanizm przekonywania

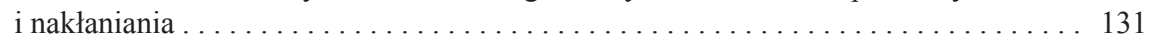

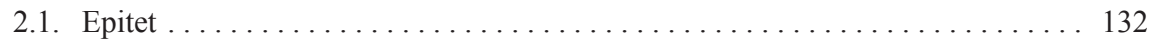

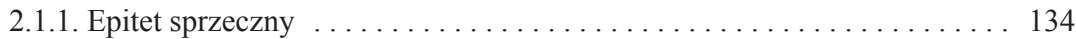

2.2. Środki metaforyczne o funkcji perswazyjnej $\ldots \ldots \ldots \ldots \ldots \ldots \ldots \ldots \ldots \ldots$

2.3. Struktury metaforyczne - klasyfikacja semantyczna . . . . . . . . . . . 137

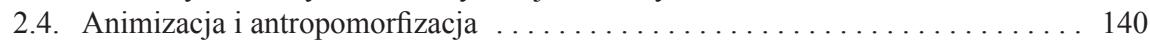

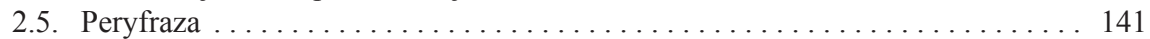

2.6. Hiperbola . . . . . . . . . . . . . . . . . . . . . . . . . . . . . . . . 142

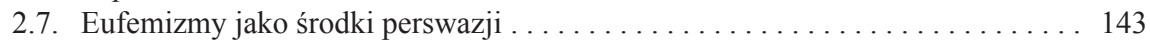

2.8. Porównanie . . . . . . . . . . . . . . . . . . . . . . . . . . . . . . 146

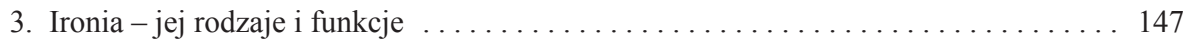

3.1. Kontrast a wyrażanie postawy ironicznej . . . . . . . . . . . . . . . . 149

3.2. Leksyka, frazeologia, metaforyka, gra słów, znaczeń jako element ironii . . . . 150

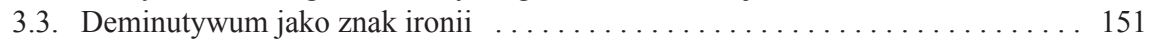

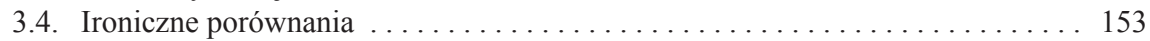

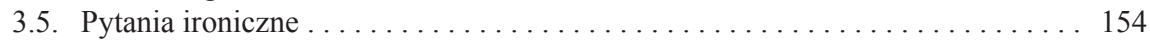

3.6. Pochwała jako strategia wprowadzania ironii . . . . . . . . . . . . . . 155

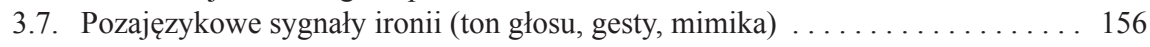

4. Związki frazeologiczne jako środek perswazji $\ldots \ldots \ldots \ldots \ldots \ldots \ldots \ldots \ldots \ldots \ldots$

4.1. Frazeologia gwarowa. Pojęcie frazeologizm gwarowy . . . . . . . . . . . . 159

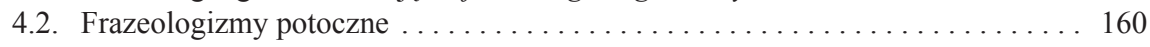

4.3. Frazeologizmy o ograniczonym zasięgu występowania ............. 161

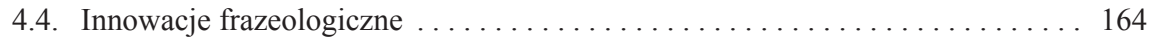

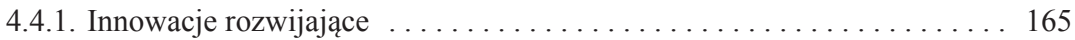

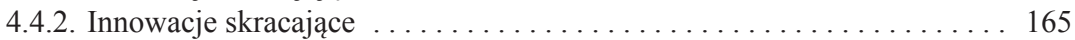

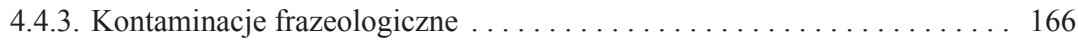

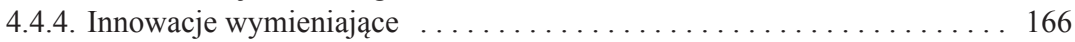

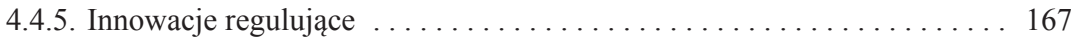

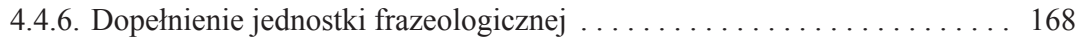

5. Intertekstualność jako atrakcyjny środek strategii perswazyjnej . . . . . . . . . . 169

5.1. Nawiązania do wydarzeń historycznych i współczesnych . . . . . . . . . . . 171

5.2. Odwołania polityczne . . . . . . . . . . . . . . . . . . . . . . . . 172

5.3. Odniesienia do znanych tekstów . . . . . . . . . . . . . . . . . . . . 172

5.3.1. Odwołania do Biblii ... . . . . . . . . . . . . . . . . . . . . . 173

5.3.2. Piosenki ludowe ............................. 173

5.4. Przysłowia jako skuteczny chwyt perswazyjny $\ldots \ldots \ldots \ldots \ldots \ldots \ldots \ldots \ldots$

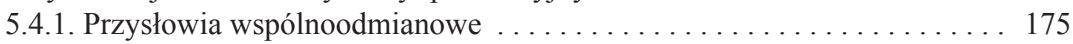

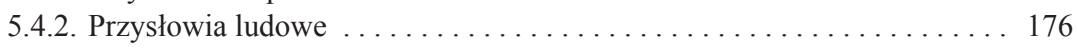




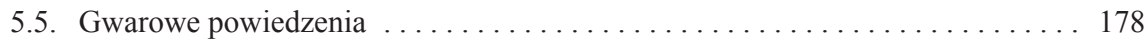

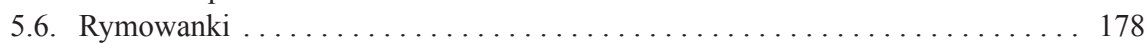

5.7. Stylizacja a stylizowanie. Typy stylizacji $\ldots \ldots \ldots \ldots \ldots \ldots \ldots \ldots \ldots \ldots$

5.7.1. Nawiązania gatunkowe . . . . . . . . . . . . . . . . . . . 180

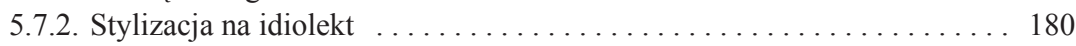

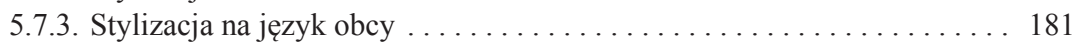

6. Środki morfologiczne stosowane w celu kształtowania opinii i odbioru rzeczywistości

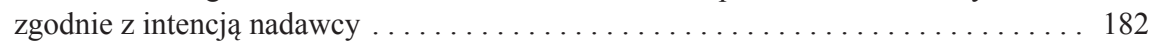

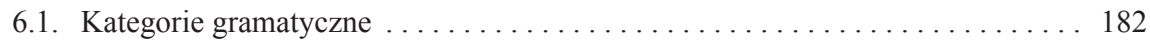

6.1.1. Kategoria gramatyczna osoby - czasownikowe formy 1 i 2 os. 1. poj.,

1 i 2 os. 1. mn. oraz odpowiadające im zaimki ja, ty, my, nasz ....... 182

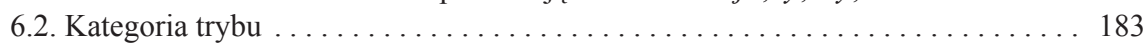

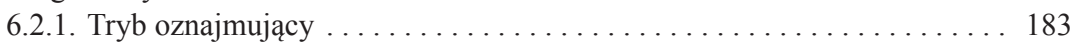

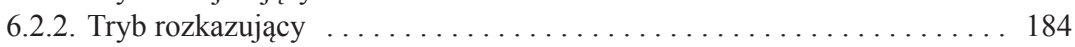

6.2.3. Bezpośrednie zwroty do nadawcy - używanie 2 os. 1. poj. i 2 os. 1. mn. . 185

6.2.4. Tryb warunkowy (przypuszczający) … . . . . . . . . . . 187

6.3. Czasowniki modalne . . . . . . . . . . . . . . . . . . . . . 187

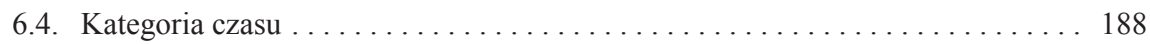

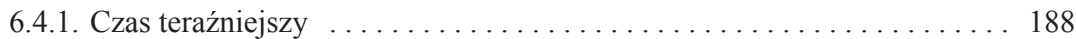

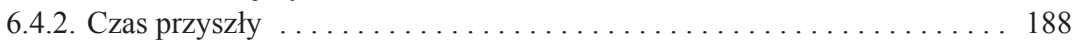

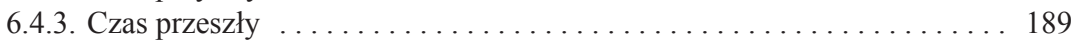

6.5. Konstrukcje nieokreślone . . . . . . . . . . . . . . . . . . . . . . . . . . . 189

6.6. Aspekt czasownika . . . . . . . . . . . . . . . . . . . . . . . . . . . . 190

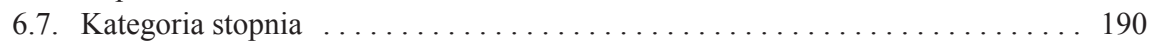

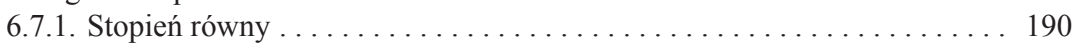

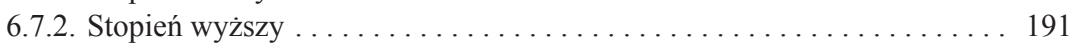

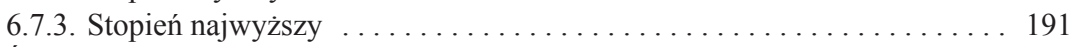

6.8. Środki słowotwórcze jako wykładniki pozytywnych i negatywnych emocji . . . 191

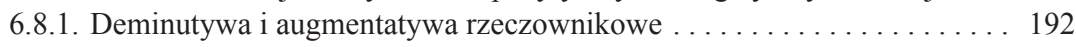

6.8.2. Ekspresywizmy rzeczownikowe $\ldots \ldots \ldots \ldots \ldots \ldots \ldots \ldots \ldots \ldots \ldots$

6.8.3. Deminutywa przymiotnikowe i przysłówkowe $\ldots \ldots \ldots \ldots \ldots \ldots . \ldots 194$

7. Środki składniowe a perswazyjność przekazu . . . . . . . . . . . . . . . . . . . . 195

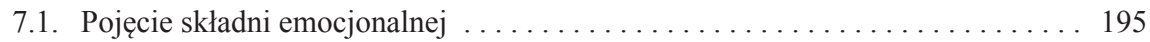

7.2. Składnia wewnątrzwypowiedzeniowa $\ldots \ldots \ldots \ldots \ldots \ldots \ldots \ldots \ldots \ldots . \ldots \ldots$

7.2.1. Podmiot .................................... 196

7.2.2. Orzeczenie . .................................... 196

7.3. Typy wypowiedzeń a perswazyjność przekazu $\ldots \ldots \ldots \ldots \ldots \ldots \ldots \ldots . \ldots \ldots$

7.3.1. Równoważniki zdań . . . . . . . . . . . . . . . . . . . . . . . . . . 198

7.3.2. Zdania pojedyncze nierozwinięte: oznajmujące, żądające, pytajne . . . . 199

7.3.3. Zdania pojedyncze rozwinięte: oznajmujące, żądające, pytajne . . . . 200

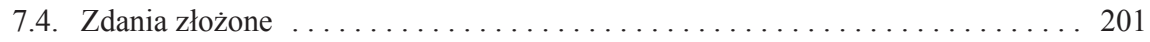

7.4.1. Zdania współrzędne w funkcji ekspresywnej . . . . . . . . . . . 202

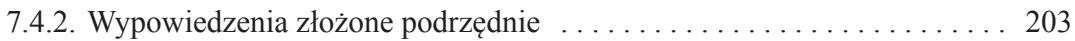

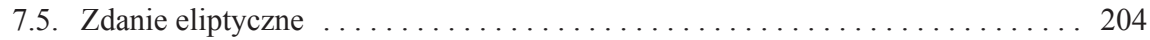

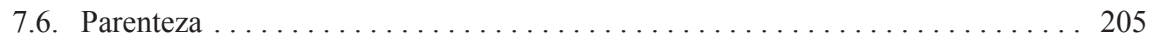

7.7. Aposjopeza .................................... 206

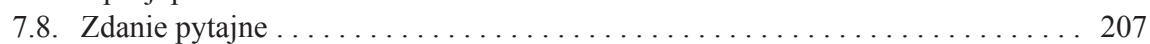

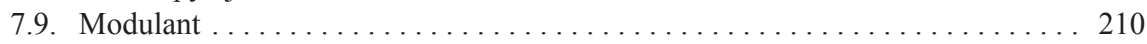

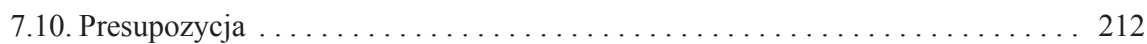


7.11. Kompozycja tekstu $\ldots \ldots \ldots \ldots \ldots \ldots \ldots \ldots \ldots \ldots \ldots \ldots \ldots \ldots \ldots . \ldots \ldots \ldots$

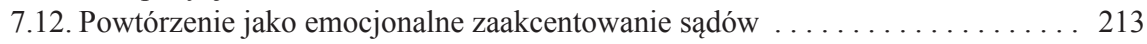

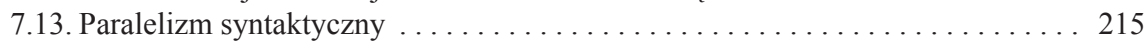

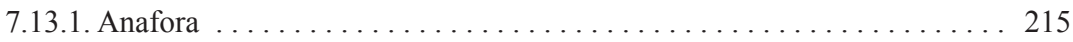

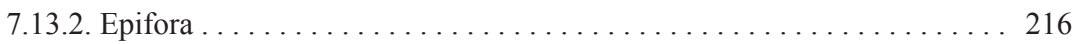

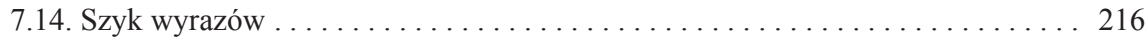

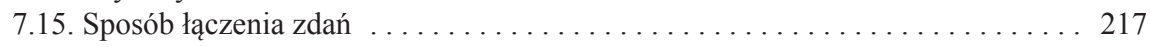

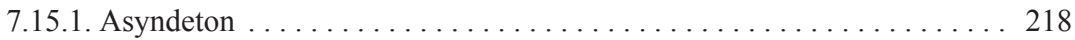

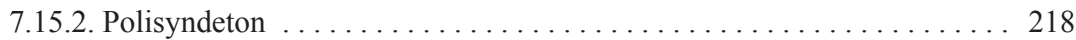

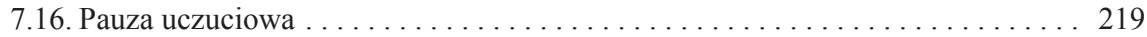

7.17. Wykrzyknienie ............................... 219

8. Pojęcia argumentowanie, argumentacja, argument ............... 221

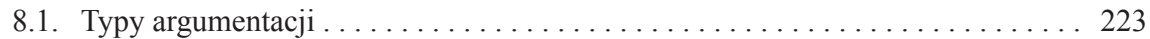

8.1.1. Argumentacja odwołująca się do natury . . . . . . . . . . . . 223

8.1 .2 . Argumentacja podkreślająca zaangażowanie w pracę . . . . . . . . 224

8.1.3. Argumentacja ukierunkowana na przewidywanie przyszłości . . . . . . 224

8.1.4. Argumentacja odwołująca się do podnoszenia wiedzy . . . . . . . . 225

8.1.5. Argumentacja odwołująca się do interesów materialnych słuchacza . . . . 225

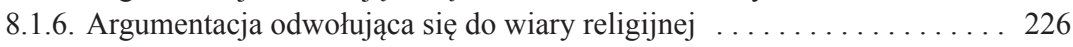

8.1.7. Argumentacja podkreślająca więzi międzyludzkie ........... 226

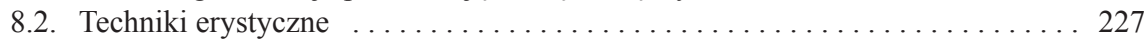

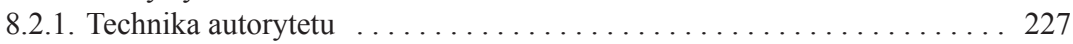

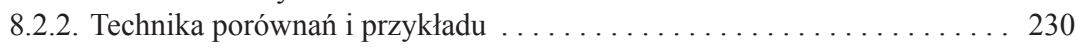

8.2.3. Technika nagromadzenia, akcentowania $\ldots \ldots \ldots \ldots \ldots \ldots \ldots . \ldots \ldots$

8.2.4. Technika uprzedzania zarzutów $\ldots \ldots \ldots \ldots \ldots \ldots \ldots \ldots \ldots \ldots \ldots \ldots \ldots \ldots \ldots \ldots$

9. Komunikacja niewerbalna jako element wzmacniający perswazyjność przekazu $\ldots .231$

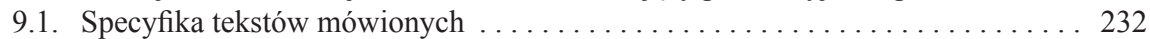

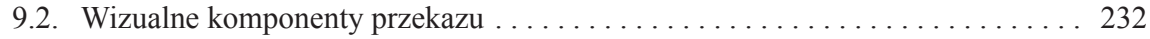

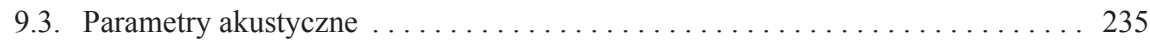

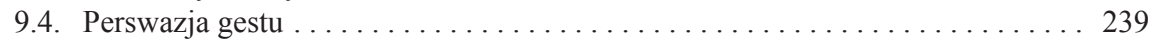

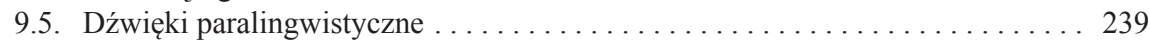

9.6. Dystans fizyczny między rozmówcami $\ldots \ldots \ldots \ldots \ldots \ldots \ldots \ldots \ldots \ldots \ldots$

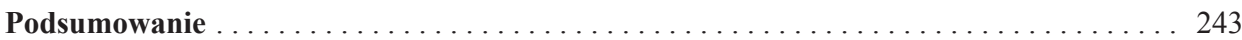

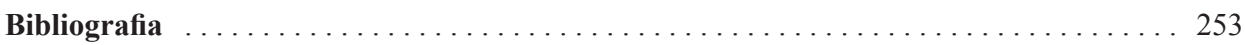

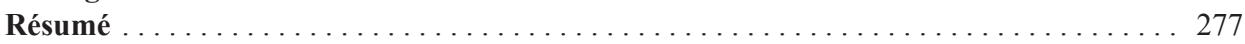

Od Redakcji . . . . . . . . . . . . . . . . . . . . . . . . . . 279 


\section{Wykaz skrótów}

\begin{tabular}{|c|c|}
\hline $\mathrm{Bu}$ & - bierny uczestnik \\
\hline $\mathrm{D}$ & - dialog \\
\hline $\mathrm{Dz}$ & - dziecko \\
\hline Ind / $\mathrm{k}$ & - kontakt indywidualny \\
\hline $\mathrm{K}$ & - kobieta \\
\hline M & - mężczyzna \\
\hline $\mathrm{Mn}$ & - monolog \\
\hline $\mathrm{N}$ & - nadawca \\
\hline $\mathrm{N}-\mathrm{O}$ & - równorzędny status nadawcy i odbiorcy \\
\hline $\mathrm{N}>\mathrm{O}$ & - $\quad$ wyższy status nadawcy \\
\hline $\mathrm{N}<\mathrm{O}$ & - wyższy status odbiorcy \\
\hline $\mathrm{P}$ & - polilog \\
\hline $\mathrm{O}$ & - odbiorca \\
\hline $\mathrm{Og} / \mathrm{k}$ & - kontakt ogólny \\
\hline So & - sytuacja oficjalna \\
\hline I & - wiek od 14 do 25 lat \\
\hline II & - wiek od 26 do 55 lat \\
\hline III & - wiek od 56 do 75 lat \\
\hline IV & - wiek powyżej 75 lat \\
\hline ang. & - angielski \\
\hline augm. & - augmentatyw \\
\hline augm.-ekspr. & - augmentatywno-ekspresywny \\
\hline czas. & - czasownik \\
\hline daw. & - dawniej \\
\hline dem. & - deminutywum \\
\hline ekspr. & - ekspresywnie \\
\hline fr. & - francuski \\
\hline fraz. & - związek frazeologiczny \\
\hline grub. & - grubiański \\
\hline gw. & - gwarowy \\
\hline iron. & - ironicznie \\
\hline łac. & - łacina \\
\hline med. & - medyczny \\
\hline niem. & - niemiecki \\
\hline pogard. & - pogardliwie \\
\hline posp. & - pospolity \\
\hline pot. & - potoczny \\
\hline przen. & - przenośnie \\
\hline przestarz. & - przestarzały \\
\hline
\end{tabular}




$\begin{array}{lll}\text { przym. } & - & \text { przymiotnik } \\ \text { ros. } & - & \text { rosyjski } \\ \text { rub. } & - & \text { rubasznie } \\ \text { rzad. } & - & \text { rzadko używany } \\ \text { rzecz. } & - & \text { rzeczownik } \\ \text { suf. } & - & \text { sufiks } \\ \text { tur. } & - & \text { turecki } \\ \text { wulg. } & - & \text { wulgarnie } \\ \text { wykrz. } & - & \text { wykrzyknik } \\ \text { zdr. } & - & \text { zdrobniały } \\ \text { zn. } & - & \text { znaczenie } \\ \text { żart. } & - & \text { żartobliwie }\end{array}$




\section{Wstęp}

\section{Cel opracowania i założenia metodologiczne}

Bezpośrednią inspiracją do podjęcia badań nad perswazją w wiejskiej wspólnocie językowo-kulturowej był brak publikacji o zjawisku w opracowaniach z zakresu dialektologii, problematyka ta pozostawała niezauważona przez środowiska językoznawcze. Mechanizmy przekonywania, występujące w sferze codziennych zachowań językowych mieszkańców wsi, nie były dotąd przedmiotem badań i nie ma publikacji, która stanowiłaby syntetyczny i w miarę całościowy wykład na ten temat (zob. Labocha 1999). K. Pisarkowa (1994) wskazywała, że pragmatyczna funkcja gwary jako narzędzia kształtującego opinie, przekonania i postawy ludzkie nie była obiektem osobnych analiz, a perswazja, mimo funkcji, jaką pełni w kontaktach interpersonalnych, nie posiada w polskich badaniach dialektologicznych opisu na płaszczyźnie synchronicznej.

Ponieważ perswazja bywa rozmaicie pojmowana, a definicje pojęcia, występujące w opracowaniach, niekiedy znacznie się od siebie różnią, jako podstawę rozważań przyjmuję definicję perswazji językowej, sprecyzowaną przez W. Pisarka (2006: 144-145), który ujmuje ją jako: ,proces świadomego namawiania, nakłaniania, przekonywania kogoś do czegoś lub odradzania komuś czegoś, polegający na wykorzystaniu argumentacji słownej, a więc wykluczający użycie siły”. Perswazję rozumiem jako swoistą funkcję języka, która obejmuje swym zasięgiem wszystkie płaszczyzny tekstu: leksykę, semantykę, frazeologię, składnię, a także językowy obraz świata.

Zakładam, że można mówić o interpersonalnej retoryce tekstów gwarowych, ujawniającej się na poziomie wypowiedzi. Wychodzę z założenia, że język, będąc narzędziem komunikacji, oddziałuje na podmioty biorące udział w procesie obustronnego przekazywania informacji, czyli na nadawcę i na odbiorcę, co wynika ze zwrotności, czyli dialogowości komunikacji. Uważam, że w ramach codziennych stosunków międzyludzkich, wszędzie tam, gdzie ludzie spotykają się i przebywają ze sobą, mogą się uruchamiać pewne mechanizmy perswazji, występują one także w bezpośrednich, nieoficjalnych rozmowach, obejmujących konwersację mieszkańców wsi. Jak wskazują badania (zob. Ziemska 1975; Mikułowski-Pomorski, Nęcki 1983), uczestnictwo w grupie rodzinnej czy społeczności lokalnej, czyli w grupach opartych na relacjach „twarzą w twarz”, sprzyja perswazji, ponieważ ludzie bardziej wierzą swoim znajomym niż mediom, wzory zachowań 
i wartości kształtują się przede wszystkim w relacjach bezpośrednich, w których treści przekazywane przez tradycję o wiele więcej znaczą niż treści przekazywane przez mass media.

S. Reczek (1973: 92) w języku wsi upatruje najlepiej zachowanego pragmatyzmu językowego, „lud bowiem [...] kieruje się zdrowym odwiecznym instynktem językowym, czyli [...] naturalnym wyczuciem systemu językowego". Językoznawcy podkreślają, że badania pragmatycznej funkcji gwary mają szczególne znaczenie w sytuacji przeobrażeń kulturowych, które nieuchronnie prowadzą do dezintegracji i zaniku polszczyzny ludowej. K. Ożóg (1998b: 125) wskazuje, że: „[... ] język wsi polskiej na przełomie XX i XXI w. jest nadal zjawiskiem bardzo interesującym i należy podjąć szerokie badania dialektologiczne i socjolingwistyczne, aby ten fenomen dokładnie opisać".

Przedmiotem badań uczyniono dyskurs perswazyjny (por. Pisarek 2006: 40), który traktuję jako narzędzie komunikacji związane z kontekstem społecznym, charakteryzujące się użyciem języka (lub innych kodów), które faworyzuje pewne słownictwo, składnię, gatunki wypowiedzi itp. Przyjmuję, że dyskurs (zob. Grabias 1994: 231) to ciąg zachowań językowych powiązanych tematem, celem i sposobem ukształtowania wypowiedzi. Istotnym rysem dyskursu niepublicznego jest ograniczoność odbiorców. Ujmuję dyskurs podobnie jak A. Duszak (1998) jako: jednostkę komunikacyjna (nośnik informacji), obiekt funkcjonalny (tzn. wypełniający inne funkcje niż tylko informacyjne), obiekt fatyczny (zapis śladów autora i odbiorcy), obiekt, który tworzy świat lub światy, nośnik systemu wartości i realizację konwencji gatunkowych. Uważam, że dzięki dyskursowi, który jest wypowiedzią o określonych regułach logicznych, opierających się na argumentacji, jednostka może oddziaływać na innych. Dyskurs staje się także czynnikiem sprawczym organizowania tekstu, nadawca rozwijający dyskurs odnosi się do określonej rzeczywistości, wyraża w nim siebie, ale kieruje go do określonego rozmówcy. Analiza dyskursu ma na celu zbadanie strategii perswazyjnych stosowanych przy tworzeniu wypowiedzi na tle określonych wzorców społecznych i kulturowych. Zachowania komunikacyjne i powstające w ich trakcie zróżnicowane gatunki wypowiedzi interesują mnie w perspektywie realizacji perswazyjnej funkcji języka. Zagadnienie ujmuję z różnych perspektyw badawczych, z uwzględnieniem pragmatycznych (por. Pisarkowa 1976b: 265-279; Awdiejew 1987), psychologicznych (zob. Kurcz 1976), socjologicznych (por. Lubaś 1979a: 11-27; Lubaś 1979b: 139-147; Hymes 1980: 41-82) oraz kulturowych aspektów (zob. Bugajski 1993; Bartmiński 2001a: 13-22).

Badaniami objęto płaszczyznę interakcyjną w zakresie działań związanych z językiem i komunikacją pozasłowną nadawcy, czyli wszystkie możliwe zachowania komunikacyjne, które mogą wywołać w odbiorcy określone przeżycia, myśli i zachowania zgodne $\mathrm{z}$ intencjami nadawcy. W analizie zagadnienia perswazji językowej przyjęto założenie, że leksyka służy rozmówcy do tworzenia określonego intencjonalnego obrazu rzeczywistości. Słowo jest podstawowym, 
uniwersalnym i wygodnym w praktyce tworzywem perswazji językowej, ponieważ $\mathrm{w}$ relacjach międzyludzkich przekonywanie przebiega przede wszystkim na obszarze słowa mówionego. Ważne jest znaczenie leksemów, cechy konotacyjnie towarzyszące desygnacji oraz właściwości słowotwórcze wyrazów, które odkrywają sposób ujmowania świata przez rozmówcę. Perswazja jest widoczna na różnych poziomach języka, obejmuje również komunikację pozawerbalną, toteż obiektem badań uczyniono językowe, pozajęzykowe i paralingwistyczne środki wykorzystywane w celach perswazyjnych. Badano zjawisko na gruncie codziennej komunikacji mieszkańców wsi w kontekście jej społecznych uwarunkowań związanych z różnymi rolami społecznymi, zmiennością kontaktu językowego i statusem społecznym rozmówców. Analizie poddano wypowiedzi w naturalnej sytuacji mówienia, kiedy rozmówcy swobodnie ujawniają swoje uczucia i oceny wobec rzeczywistości. Komunikacja w nieformalnych relacjach międzyludzkich, obejmujących bliskie więzi interpersonalne: rodzinne, przyjacielskie, sąsiedzkie, szczególnie zaś w układzie hierarchicznej równości, jest oparta na przywiązaniu, zaufaniu, niekiedy bezwarunkowej akceptacji rozmówcy.

Z socjolingwistycznego punktu widzenia środowisko, w którym człowiek przebywa, stanowi ważną wspólnotę komunikacyjną, która oddziałuje na jednostkę w sposób długotrwały i bezpośredni. W relacjach rodzinnych i sąsiedzkich mamy do czynienia z bezpośrednim kontaktem, opartym na bliskiej więzi łączącej nadawcę i odbiorcę, a jak wiadomo, bliska znajomość i zaufanie to czynniki, które zwiększają szansę na skuteczność perswazji (zob. Pisarek 1974: 175-179). Lokalne społeczności stanowią niewielkie grupy oparte na kontaktach bezpośrednich, osobistych, o dużym stopniu zaangażowania emocjonalnego.

Komunikacja perswazyjna w bezpośrednich kontaktach była przedmiotem badań zachowań komunikacyjnych młodzieży. G. Marwell i D. Schmidt wyodrębnili cztery ogólne strategie stużace nakłanianiu: strategię możliwych korzyści lub strat, strategię zaszczytu, strategię samopotępienia; w latach 80. podział uzupełniono o dwie kolejne strategie: strategie przenoszenia kompetencji i strategie konformizacji (zob. Nęcki 1996a: 72-75).

Celem opracowania jest poszerzenie zasięgu badań nad przekonywaniem o nowy materiał językowy. Chodzi o pokazanie rozmiaru i dynamiki zjawiska w obszarze konwersacji, w którym panuje znaczna swoboda komunikacyjna, o porównanie repertuaru technik i środków językowych stosowanych w perswazji, o wskazanie uniwersalnych, wykorzystywanych w różnych typach dyskursu oraz wyróżnienie charakterystycznych dla komunikacji ludowej, wynikających z odmienności warunków, w których przebiega komunikacja. Zbadanie zależności, jakie istnieją między środkami oddziaływania używanymi w komunikacji potocznej a tymi, które mają zastosowanie w różnych odmianach stylistycznych współczesnej polszczyzny, w języku polityki, w reklamie, literaturze czy dydaktyce itp., może posłużyć do dalszych badań językowych rozszerzających i syntetyzujących pole badawcze zjawiska. 
Różnice w zakresie repertuaru środków stosowanych w nakłanianiu w sferze komunikacji potocznej i publicznej wynikają z faktu, że język zapewnia nieograniczone niemal możliwości wyboru elementów, którymi mówiący potencjalnie dysponują w danej sytuacji konwersacyjnej. S. Grabias (1994: 231), który wyróżnia sprawność systemową, komunikacyjną, sytuacyjną i pragmatyczną, pisze: „człowiek w swoich zachowaniach językowych jest zdeterminowany i kreatywny jednocześnie, są bowiem sytuacje, w których mówiący zachowują się analogicznie, ale są i takie, w których nie sposób doszukać się istotnych podobieństw". W badanych tekstach (por. Żydek-Bednarczuk 2005; Kamińska-Szmaj, Piekot, Zaśko-Zielińska 2006; Mazur, Rzeszutko-Iwan 2006) szczegółowo koncentruję się na zagadnieniu sprawności pragmatycznych nadawcy, które mają służyć osiąganiu założonego celu wypowiedzi.

W wielu sytuacjach podstawowym celem, jaki ma spełniać język, poza przekazywaniem informacji, jest wyrażanie pewnych idei, które służą zaspokojeniu określonych potrzeb i dostarczają korzyści uczestnikom komunikacji. Na ten przejaw porozumiewania się zwracano uwagę od dawna. „Klasyczna pochodząca od Arystotelesa, definicja istoty człowieka głosi, że człowiek jest żywą istotą, która posiada logos. [...] Greckie słowo 'logos' oddawano więc przez 'rozum' lub 'myślenie'. W istocie słowo to oznacza jednak również - a nawet przede wszystkim - ‘język' [...] Tylko człowiekowi dany jest logos, by mógł ujawniać innym, co jest korzystne, a co szkodliwe, i przez to zarazem to, co jest słuszne, a co niesłuszne" (Gadamer 1979: 47).

Język jest narzędziem poznawania i opisywania rzeczywistości, ale zawiera się w nim i ujawnia także intencja nadawcy, a opis konkretnych aktów mowy dostarcza informacji o sposobach konceptualizacji owych intencji, ponieważ jak twierdzi H. Lemmermann (1997: 13): „Wygłaszanie własnych opinii i polemizowanie z cudzymi to istotne elementy międzyludzkiej komunikacji”.

Komunikację rozumiem jako złożony proces interakcji, czyli zbiór działań językowych i pozajęzykowych mających określony cel, komunikowany przez nadawcę, który odbiorca odczytuje i interpretuje. W komunikacji istotne znaczenie ma aktywna postawa odbiorcy, który nie tylko przyjmuje to, co przedstawił nadawca, ale równocześnie porównuje, interpretuje i ocenia jego wypowiedź. Badacze komunikacji językowej wskazują dwa typy zachowań człowieka: reaktywne - zachodzące w rzeczywistości biologiczno-fizycznej, mające uwarunkowanie genetyczne, obligatoryjne dla całego rodzaju ludzkiego oraz aktywne, tzn. działania polegające na celowości, skierowane na zmianę stanów rzeczy, obejmujące przede wszystkim rzeczywistość psychiczną i społeczną człowieka. Zdaniem S. Grabiasa (1997: 216) właśnie działania językowe oraz odpowiednie intencje nadawcy (zob. Bartmiński, Niebrzegowska-Bartmińska 2006) są obiektem pragmalingwistyki. Współtwórca współczesnej pragmalingwistyki J. L. Austin (1987) zwrócił uwagę, że zachowania komunikacyjne człowieka mają nie tylko aspekt aktywny, celowy (finitywny), perspektywiczny - po co się mówi?, ale 
także aspekt reaktywny, przyczynowy (kauzatywny), retrospektywny - dlaczego się mówi?

Zjawisko perswazji, stanowiące dość szeroki obszar komunikacji, traktuję jako rozmaite działania przygotowujące komunikację i towarzyszące jej procesowi, takie np. jak: hierarchizacja przekazywanej informacji, apelacja do odbiorcy, argumentacja oraz wszystkie inne środki werbalne i pozawerbalne sprzyjające skuteczności zastosowanych aktów mowy. Przyjmuję, że komunikacja perswazyjna to zjawisko związane $\mathrm{z}$ interakcyjnym charakterem języka, rządzące się pewnymi zasadami, którego opis wymaga również szczegółowych badań kulturowych, bowiem o tym, czy dana wypowiedź zostanie odebrana jako perswazyjna, czy nie, decyduje konkretna sytuacja mówienia (niekoniecznie jej typ), w szczególności zaś partnerzy mówienia i ich wiedza o sobie - kontekst wypowiedzi.

Ponieważ intencje nadawcy nie podlegają bezpośredniemu oglądowi, przyjmuję bardzo szerokie rozumienie perswazji językowej. Uważam, że może ona mieć różne formy, może nią być wypowiedź o funkcji impresywnej, dyrektywne akty mowy, których celem jest wywarcie wpływu na odbiorcę, skłonienie go do jakiegoś działania i wiele spośród deklaratywnych czy ekspresywnych aktów mowy, które również sterują zachowaniami interlokutora.

Określenie granic zjawiska i klasyfikacja różnych działań perswazyjnych należy do najtrudniejszych zadań w badaniach procesu komunikacji językowej. Podjęte w pracy zagadnienia ujmuję $\mathrm{w}$ perspektywie szeroko pojętej pragmatyki językowej, to jest intencjonalnego użycia języka przez nadawcę w konkretnym akcie komunikacji w celu wywołania określonych reakcji odbiorcy. Metodologiczne podstawy opracowania zakładają zastosowanie teorii aktów mowy w jej klasycznym kształcie przyjętym przez J. L. Austina i rozwiniętym przez Searle'a. W teorii aktów mowy zakłada się, że każda wypowiedź ma trzy aspekty: jest po pierwsze lokucją, czyli fizycznym zachowaniem; po drugie illokucja, czyli robieniem czegoś za pośrednictwem tej lokucji (mówiąc coś, robimy coś innego, np. chwalimy, ostrzegamy, powiadamiamy, namawiamy) i po trzecie perlokucja, czyli zrobieniem czegoś poprzez illokucję. O powodzeniu działań nadawcy świadczy dopiero efekt, jaki mogą one wywołać w zachowaniu odbiorcy.

Zakładam, że akty perswazyjne nie stanowią samodzielnej grupy w obrębie aktów illokucyjnych, a są tylko dodatkowym elementem obecnym niejako ,przy okazji”, uważam, że są aktami pośrednimi, na poziomie bezpośrednim może zaś wystąpić zasadniczo każdy z wyodrębnionych przez Searle'a typów. Realizacji perswazyjnej funkcji tekstów towarzyszą inne funkcje, m.in.: informacyjna, ekspresywno-emotywna, ludyczna.

Opis mechanizmów językowych perswazji w badanym typie komunikacji obejmuje analizę zjawiska w perspektywie semantycznej, pragmatycznej i tekstologicznej. Perswazyjna funkcja języka realizuje się przede wszystkim na poziomie słownictwa, dotyczy różnych strukturalnych warstw wypowiedzi, np.: morfologicznej, składniowej, a zabiegi perswazyjne odnoszą się także do swoistej organizacji 
tekstu. Część badaczy (Awdiejew, Habrajska 2004: 40) podkreśla, że: „W języku naturalnym ważne jest nie tylko co, ale i jak to coś zostało przekazane".

Dla prezentacji zjawiska perswazji w dialektach bardzo istotna jest rejestracja wyselekcjonowanych zjawisk językowych ze wszystkich poziomów języka.

Tekst gwarowy definiuję jako typ dyskursu tworzony przez mieszkańców wsi i przede wszystkim dla nich przeznaczony, ponieważ gwara jest nie tylko sposobem komunikowania się, ale także ważnym elementem integrującym lokalną społeczność. Na ten aspekt komunikacji zwraca uwagę m.in. K. Sikora (1994: 195-204). Podobnie jak J. Gardzińska (2001: 183) uważam, że tekst gwarowy to komunikat słowny, wypowiedziany przez użytkownika języka, który na co dzień obcuje z tradycyjną wiejską kulturą i dla którego gwara ludowa jest językiem prymarnym i środkiem społecznego porozumiewania się, ale jest także zaznajomiony z polszczyzną ogólną i potrafi jej używać w pewnych sytuacjach. Definicję tę uzupełniłam o pozostałe składniki komunikacji, tj. środki niewerbalne oraz pragmalingwistyczne.

Materiał językowy pracy stanowią zarejestrowane, swobodne rozmowy mieszkańców wsi. Rozmowa dotyczy odmiany mówionej języka; w pracy przyjmuję podejście metodologiczne, które traktuje rozmowę jako samowystarczalny system wewnętrznych relacji, a więc połączenie semantyki i syntaktyki oraz jako zdarzenie językowe rozumiane w kategoriach pragmatycznego zachowania i działania językowego (zob. Żydek-Bednarczuk 1993: 24). Wykorzystuję zaproponowaną przez badaczkę definicję rozmowy, która ujmuje ją jako: „wydarzenie komunikacyjne w komunikacji face to face realizowane werbalnie, w którym uczestniczy co najmniej 2 partnerów uwikłanych w kontekst językowy, społeczny i kulturowy" (Żydek-Bednarczuk 2004a: 425). Partnerzy realizują określony cel - intencję, podejmując temat rozmowy. Warunkiem powodzenia komunikacji jest interakcja, kooperacja między rozmówcami oraz tematyczność" (Żydek-Bednarczuk 1993: 22).

Zebrany materiał stanowią wypowiedzi zróżnicowane pod względem treści i formy, ilustrujące różnorodne sytuacje komunikacyjne (dom rodzinny, sklep, targ, podróż) oraz różne relacje między uczestnikami konwersacji (rodzice - dzieci, małżonkowie, przyjaciele, sąsiedzi, rzadko osoby spoza lokalnego środowiska), z czego wynikają odmienne zachowania językowe rozmówców i ich różna motywacja pragmatyczna. $\mathrm{Na}$ intencjonalny z punktu widzenia nadawcy aspekt użycia języka oraz jego pragmatyczny wymiar z perspektywy odbiorcy w interakcyjnym uwikłaniu sytuacyjnym zwrócili uwagę badacze w kontekście takich teorii językoznawczych, jak pragmatyka lingwistyczna, teoria aktów mowy, gramatyka kognitywna (zob. Lakoff, Jonhson 1988; Tabakowska 2001) i semantyka rozumienia (por. Pelc 1982). Ch. Morris wskazywał, że: „pragmatyka opisuje relacje między znakami językowymi i ich użytkownikami (nadawcą i odbiorcą)" (Polański 1993), jej zadaniem jest „m.in. formułowanie zaleceń, jakiego rodzaju środków językowych nadawca powinien użyć, by odbiorca zareagował zgodnie 
z jego życzeniem" (Urbańczyk 1991: 264). Punktem wyjścia dla badań pragmatycznych (zob. Kalisz 1993; Skowronek 1993; Maćkiewicz 2001; Chudzik 2002) są znaki językowe, a następnie motywacje mówiących, które są przedmiotem zainteresowania psychologii społecznej, dalej uwarunkowania wyborów, które bada socjolingwistyka, wreszcie wiedza o świecie mówiących, na której badaniu skupia się etnolingwistyka.

Teoretyczne rozważania na temat perswazji koncentruję na nadawcy, który tworzy konkretną wypowiedź w określonej sytuacji i w określonym celu, wykorzystując środki językowe, które najlepiej służą realizacji założonego dążenia. Ważną rolę nadawcy w komunikacji perswazyjnej potwierdzają najnowsze badania, prowadzone w zakresie psychologii społecznej (zob. Ohme 2003; Jarymowicz, Ohme 2003; Ohme 2007). Jak uważa W. Lubaś (2006: 56): „W realizacji intencji perswazyjnej, którą wyraża nadawca z nadzieją na jej skuteczność, uczestniczą wszystkie składniki funkcjonalne języka, gdyż tylko pod tym warunkiem może się udać zamiar nadawcy. Wchodzą więc w skład czynników perswazyjnych zarówno argumenty, tj. czynniki intelektualne, jak i zjawiska emocjonalne wyrażone przez odpowiednie formy językowe a ponadto ze strony Odbiorcy także jego zachowania i postawy". Niemal każdej perswazji towarzyszą emocje, ponieważ wpływanie na uczucia jest bardzo skutecznym elementem przekonywania.

Z faktu, że język mówiony traktuję jako zespół systemowych i pozasystemowych, ale znaczących dźwięków i gestów ruchowych, wynikały postulaty metodologiczne dotyczące gromadzenia materiału. Sferę zjawisk języka mówionego nie ograniczam jedynie do kodu werbalnego, lecz wskazuję wszystkie sposoby komunikowania się: przekazywanie informacji gestem, mimiką, a także intonacją, ponieważ w osiąganiu skutecznego oddziaływania na odbiorcę, oprócz samej treści, istotny udział mają wszelkie zabiegi pozajęzykowe (por. Niedzielski 1991: 109-114; Brocki 2000; Tkaczyk 2000), środki paralingwistyczne i ekstralingwistyczne, które wraz ze środkami językowymi oddziałują na odbiorcę.

Rolę komunikacji niewerbalnej, tj. zespołu środków kinetycznych i proksemicznych, podkreśla wielu badaczy, wskazując, że jest ona ważnym elementem przekazu i także spełnia określone funkcje perswazyjne (zob. Birdwhistell 1970; Kneblewski 1980: 237-250; Jarząbek 1989). K. Jarząbek (1992: 186) pisze: „[...] zainteresowania językoznawców bardzo długo skupiały się wyłącznie na słowie, które, choć niewątpliwie stanowi najważniejszy z czynników w przebiegu aktu komunikacji, nie jest czynnikiem jedynym". Użytkownicy języka stosują elementy werbalne i niewerbalne łącznie m.in. w celu wzmocnienia zachowań językowych (Brocki 2000). Na rolę elementów niewerbalnych w interpretacji przekazu przez odbiorcę wskazuje J. Warchala (2001: 168): „W sytuacjach potocznych wnioski wyciągamy nie tylko z tego, co interlokutor do nas mówi, ale też z jego wyglądu, stanu emocjonalnego, barwy i tonu głosu, rodzaju języka, którym do nas mówi itd." 
Dla potrzeb opracowania przyjęto, że nadrzędnym celem perswazji jest dążenie do zmiany przekonań i postaw odbiorcy względem pewnego wycinka rzeczywistości, aby zrównały się z przekonaniami i postawami prezentowanymi przez nadawcę. Skuteczność perswazji polega na tym, by odbiorca uświadomił sobie, co się do niego mówi, uwierzył temu, przyznał rację mówiącemu i postąpił zgodnie $\mathrm{z}$ jego sugestią.

Aby zdefiniować zjawisko perswazji, występujące w komunikacji gwarowej, należy najpierw przyjrzeć się terminowi polszczyzna mówiona mieszkańców wsi. W opracowaniach językoznawczych różne odmiany polszczyzny wiejskiej określane są terminem: język wsi, język mówiony mieszkańców współczesnej wsi (zob. Węgier, Oronowicz 1992; Sierociuk 1998), nazwę polszczyzna mówiona mieszkańców wsi używam wymiennie z określeniami: język ustny, język mówiony, obiegowy, codzienny, mowa mieszkańców wsi i traktuję jako odmianę języka etnicznego, charakteryzującą się osobliwymi cechami systemowymi (gramatycznymi i leksykalnymi), a także komunikacyjnymi. Z badań dialektologicznych wynika, że język mieszkańców wsi nie ma jednolitej struktury, ponieważ obejmuje wiele odmian komunikowania się. Polszczyzna ludowa rozwija się na podłożu grupy społecznej określonej wspólnotą zamieszkania i służy przede wszystkim wyrażeniu potrzeb życia codziennego, ma więc w pewien sposób ograniczoną przydatność komunikatywną. Gwarę, jako jeden z wariantów porozumiewania się, stosują użytkownicy jedynie w określonym środowisku i w konkretnych sytuacjach. K. Ożóg (1998b: 125) wskazuje, że: „Konsekwentna, piękna gwara jest już dziś na wsi polskiej zjawiskiem coraz rzadszym. Dominuje obecnie odmiana mieszana, przejściowa, niejednorodna, składa się bowiem z różnych elementów”. Współcześnie systemy gwarowe dezintegrują się, przejmują wiele elementów z innych odmian języka, a w komunikacji obserwuje się różne sposoby mówienia w zależności od sytuacji i typu kontaktu.

Wychodzę z założenia, że nowe koncepcje z zakresu teorii komunikacji, intensywnie rozwijające się w ostatnim trzydziestoleciu XX wieku, mogą być wykorzystane do badań rozmów mieszkańców wsi. Właściwa do opisu wewnętrznego zróżnicowania komunikacyjno-stylowego (zob. Grabias, Skubalanka 1979; Dubisz 2004: 3-19; Habrajska 2006; Zdunkiewicz-Jedynak 2008) wydaje się teoria dyskursu (por. Lizisowa 2006; Witosz 2009), ponieważ przedmiotem badań są naturalne zachowania językowe obejmujące teksty, które powstały w warunkach ustnej, bezpośredniej, spontanicznej i niewymuszonej rozmowy, prowadzonej w najbardziej typowych sytuacjach życia codziennego. W komunikacji interpersonalnej koncentruję się na relacji: nadawca - komunikat - odbiorca, zwracam uwagę na czynności podejmowane w toku komunikowania się z innymi ludźmi, które służą wyrażaniu intencji nadawcy. Przedmiotem analizy językowej uczyniłam cechy stylistyczne wypowiedzi z punktu widzenia ich prawdopodobnego oddziaływania na odbiorcę, ich widocznej intencji retorycznej. W opracowaniu rozpatruję zagadnienie stylu i tekstu w ujęciu pragmatycznym, ponieważ przyjmuję 
pojęcie czynności (działania) za podstawę teoretycznej interpretacji opisu, rozpatrywanego zgodnie z założeniami Austina i Searle'a (zob. Mazur 1990: 71-72). W zebranych tekstach badałam sposoby językowego oddziaływania na odbiorcę, sformułowane na podstawie analizy konkretnych aktów mowy. Moim zamiarem było przedstawienie metod służących osiąganiu perswazji.

Uważam, że w typie kontaktu bezpośredniego, który jest przedmiotem badań, rozmówcy wybierają pewien styl komunikowania, często rubaszno-dosadny, nacechowany ironią i sarkazmem, swobodnie ujawniający emocje, oceny, a odzwierciedlający się m.in. w doborze środków językowych i w sposobie wartościowania. Zachowania językowe mieszkańców wsi ujmuję jako kategorię stylistyczno-komunikacyjna (zob. Kita 2001: 170), pozostającą w związku z określoną sferą funkcjonalno-komunikatywną. Pogląd taki w odniesieniu do polszczyzny potocznej reprezentuje w opracowaniach wielu badaczy (por. Buttler, Furdala, Skubalanka 1991). Styl (por. Skubalanka 1991; 1993; 1995) rozumiem jako sposób wyrażania określonej treści, charakteryzujący się doborem takich środków językowych, które uznane są za szczególnie przydatne ze względu na określony typ wypowiedzi i pełnione przez nią funkcje oraz cel, dla którego tworzona jest wypowiedź. Uważam, że styl to struktura tekstu, swoisty sposób wiedzenia świata, znajdujący odbicie w tworzywie słownym.

Gwarę ujmuję jako kategorię stylistycznej komunikacji charakterystyczną dla określonej grupy środowiskowej, uwarunkowaną wpływami kulturowymi, wiedzą o świecie, zainteresowaniami, skłonnościami i wykształceniem mieszkańców wsi. Amerykański badacz stylu R. Ohmann (1977: 126) dowodzi, że nie istnieje jedna definicja stylu, ponieważ poszczególne koncepcje nie są ze sobą sprzeczne, a proponowane przez nie analizy uzupełniają się. Autor, przywołując różne stanowiska badaczy, definiuje styl: ,jako wynik w y borów pomiędzy rozmaitymi wariantami, [...] wybory te nie są obojętne dla znaczenia; [...] jako ekspresywny, emocjonalny lub estetyczny akcent dołączony do przenoszonej informacji, zakładając tym samym rozróżnienie między informacją a znaczeniem ekspresywnym [...], wreszcie sposób, w jaki struktura tekstu przedstawia rzeczywistość".

Komunikację językową mieszkańców wsi traktuję jako płaszczyznę badań interdyscyplinarnych (zob. Doroszewski 1973). Lingwiści zauważyli zalety łączenia językoznawstwa z innymi dyscyplinami wiedzy: antropologią, socjologią, biologią, psychologią, neurofizjologią (Doroszewski 1973: 18), wskazywali na międzydyscyplinarny obszar badań, obejmujących polszczyznę mówioną oraz wzajemne wykorzystywanie metod oraz doświadczeń: dialektologii i socjolingwistyki (zob. Dunaj, Lubaś 1996), a także etnolingwistyki oraz językoznawstwa kognitywnego (por. Habrajska 1998: 55-61). Zalety interdyscyplinarności dostrzega się również w zakresie podejmowanych badań dialektologicznych (zob. Gala 1998), współczesne gwaroznawstwo zmienia cele badawcze i metodologię. W opisie polszczyzny ludowej zaleca się wielostronność stanowisk metodologicznych (Mrózek 1998: 63-68), wskazuje na potrzebę łączenia problematyki dialek- 
tologicznej z socjologiczną, psychologiczną oraz kulturową (Zagórski 1998: 29). H. Pelcowa (1998: 117) podkreśla, że: „W badaniach dzisiejszych gwar trzeba uwzględnić zarówno czynniki kulturowe, cywilizacyjne, społeczne, jak też pokoleniowe i sytuacyjne, w tym oficjalność i nieoficjalność, czas, miejsce i przedmiot rozmowy, typ i rodzaj rozmówcy, płeć, wiek, obligujące do używania pewnych form czy wyrazów".

Rozpatrując komunikacyjną płaszczyznę języka mieszkańców wsi, koncentrowałam się na intencjach nadawcy oraz kontekście socjologicznym. Wybór ukierunkowania socjologicznego (zob. Homa 1979; Kurek 1996: 169-173) wynikał z przypisywania ważnej roli czynnikowi sytuacyjnemu oraz czynnikom pokoleniowym i geograficznym w konkretnych aktach komunikacji. Socjolingwistyka traktowana bywa jako metoda interdyscyplinarna, która według Lubasia (1982: 14) „[...] musi włączyć do swoich metod badawczych [...] ludzką psychikę, otoczenie społeczne i interakcję językową". Natomiast w opisie tekstów uwzględniłam przesłanki pragmalingwistyczne (zob. Pisarkowa 1994: 11-23; Kurek 1997: 129-133), ponieważ przedmiot niniejszej pracy stanowi praktyczny aspekt komunikacji, czyli zagadnienie relacji pomiędzy znakiem a jego użytkownikiem. Analiza wypowiedzi miała na celu wskazanie w aktach komunikacji elementów, decydujących o skuteczności perswazyjnej przekazu.

Prowadzone badania sytuują się na płaszczyźnie idiolektu (por. Żurek 2011), czyli indywidualnego mówienia i socjolektu, czyli „mowy grup społecznych bądź mowy używanej w pewnych społecznych sytuacjach" (Głowiński 1980: 8), ponieważ uważam, że opis komunikacji perswazyjnej wymaga dostrzeżenia zarówno indywidualnego, jak i społecznego charakteru języka oraz międzyludzkiego zakresu komunikacji.

W spontanicznej, swobodnej komunikacji badanie perswazji jest zadaniem trudnym, ponieważ rozmówcy często wprowadzają złożone, ukryte treści, wykraczające poza zasady kooperacji i maksymy konwersacyjne ustalone przez H. P. Grice'a (1980: 91-114). Ostateczny efekt działań perswazyjnych zależy od intencji i zabiegów nadawcy komunikatu, ale także od percepcyjnej gotowości i podatności na perswazję odbiorcy tekstu. Powszechnie wiadomo, że mówiący dostosowuje swą wypowiedź do odbiorcy, a o doborze środków językowych w znacznym stopniu decydują relacje, jakie między nimi zachodzą (por. Dunaj 1985: 88-97). Rozmowa toczy się między partnerami i zawsze jest skierowana do kogoś. Tworząc konkretne wypowiedzi, nadawca posługuje się względnie trwałymi, typowymi formami ich konstruowania, by osiągnąc cele, wciela myśli i zamiary w określone ramy językowe.

Rozważania opieram na założeniu, że wypowiedzi mówione na wzór komunikatów pisanych można traktować jako teksty. Jak podkreśla T. Dobrzyńska (1993: 7): „Jednostka zwana tekstem obejmuje ciągi wyrazowe o różnej rozpiętości, rozmaitym stopniu złożoności i różnie przekazywane. Jej manifestację stanowią wypowiedzi zarówno wielo- jak i jednozdaniowe, proste komunikaty potocz- 
ne i teksty literackie [...], przekazy pisane oraz mówione". Termin tekst zgodnie $\mathrm{z}$ ujęciem teorii tekstu traktuję jako wypowiedź całościową, będącą wyrazem intencji komunikacyjnej mówiącego i przyjmuję, że pojęcie tekstu może być rozumiane dwutorowo: „z jednej strony jako jednostka językowa”, z drugiej - jako efekt perswazyjny (zob. Żydek-Bednarczuk 2005: 56). Ponieważ w perswazji istotna jest efektywność osiągania celów, illokucję rozumiem jako akt mowy, który spełnia się poprzez komunikowanie intencji, tj. zawiera się w tym, co nadawca chce osiągnąć poprzez wypowiedzenie danego komunikatu. Wartość aktu illokucyjnego leży w jego mocy mierzonej w kategoriach skuteczności. K. Pisarkowa (1994: 11-23) podkreśla, że komunikacja przebiega ze względu na odbiorcę, do którego jest adresowana wypowiedź i na niego ma wywrzeć wpływ.

Podstawą teoretyczną opracowania jest założenie, że teksty gwarowe stanowią akty mowy, ponieważ dana czynność mówienia ma spełniać określoną funkcję. W analizowanym materiale znalazły się ciekawe i zróżnicowane pod względem pragmatycznym gatunki mowy, mające formę oddziaływania bezpośredniego: zachęty, namowy, prośby, groźby, obietnicy, polecenia, rozkazu, zakazu, sądu, oceny, chwalenia się lub oddziaływania pośredniego: inspirowania, motywowania, rady, przestrogi, polemiki, wyjaśniania, pouczenia, informowania, przedstawienia, opisu.

Stosuję określenie komunikaty perswazyjne, ponieważ w codziennej praktyce komunikacyjnej trudno oddzielić perswazję od manipulacji. Termin funkcja perswazyjna traktuję bardzo szeroko, włączając do obszaru perswazji także nakazy, polecenia, komendy, a więc formy oddziaływania językowego, które wykluczają możliwość oporu odbiorcy. Zamierzeniem moim jest pokazanie perswazyjnego aktu komunikacji na tle typów illokucyjnych, ze wskazaniem strategii językowych, jakie wykorzystują mieszkańcy wsi. Szczególność tekstów gwarowych polega m.in. na tym, że niektóre akty mowy odbiegają od występujących w polszczyźnie ogólnej. J. Waniakowa (1992: 280) zauważa, że np.: „Sposób proszenia na wsi nieco różni się od przyjętego w polszczyźnie ogólnej. Jak wiadomo, akt prośby ma szanse powodzenia, gdy zawiera pewne elementy wyrażające, jak bardzo zależy nadawcy na jej spełnieniu. [...] niezwykle ważny jest postulat grzeczności. Tymczasem prośby na wsi w większości mają trochę postać zwykłych poleceń czy propozycji”.

F. de Saussure (1961) traktował język jako zjawisko społeczne i uważał, że w dociekaniach lingwistycznych należy skupić uwagę przede wszystkim na tekście, w badaniu którego najważniejsza jest analiza funkcjonalna środków językowych. Tekst traktuję jako wytwór komunikacji, jako strukturę, w której wszystkie elementy są ze sobą wzajemnie powiązane i konstytuują się dopiero w swej funkcjonalności. Wyznacznikiem tekstowości jest szeroko przyjęta spójność - składa się na nią kohezja (dające się odczytać zależności gramatyczne) i koherencja (związki znaczeniowe). W bogatej literaturze dotyczącej tekstowości badacze reprezentują różne stanowiska i definicje tekstu, który w zależności od przyjętej kon- 
cepcji poznawczej bywa różnie definiowany. W lingwistyce tekstu jest „to spójny zbiór następujących po sobie zdań lub jakikolwiek komunikat dający się odgraniczyć od innych komunikatów" (Urbańczyk 1991: 355), natomiast w teorii literatury (zob. Sławiński 1988: 575) to „wypowiedź [...] powstała w obrębie określonego systemu językowego, stanowiąca zamkniętą i logiczną całość z punktu widzenia treściowego".

\section{Materiał badawczy: źródła, cechy badanej grupy, metoda rejestrowania}

Źródłem ekscerpcji materiału były spontaniczne wypowiedzi skierowane do wąskiego grona odbiorców, które rejestrowałam w różnych sytuacjach komunikacyjnych: w warunkach domowych, podczas pracy, w trakcie przypadkowych spotkań, podczas różnych form spędzania wolnego czasu. Rozmówcami były najczęściej osoby znane sobie, połączone więziami emocjonalnymi: członkowie rodziny, przyjaciele, dobrzy znajomi, sąsiedzi. Komunikacja między partnerami, których łączą bliskie relacje, prowadzi do wzajemnej otwartości i powoduje, że teksty są bogatsze w różnorodne środki językowego oddziaływania. Badanie i opis zachowań komunikacyjnych w ich naturalnym kształcie, służącym realizacji rozmaitych ludzkich potrzeb, koncentrowałam głównie na odczytaniu intencji nadawcy. W badaniach zastosowałam techniki obserwacji uczestniczącej i swobodnej rozmowy.

Działaniom komunikacyjnym mieszkańców wsi przyglądałam się z perspektywy nazwanej socjolingwistyczną i pragmatycznojęzykową. Sposób gromadzenia materiału wyznacza metodę właściwą socjolingwistyce, a cel, jakiemu ma służyć tekst, metodę właściwą pragmatyce, aspekt socjolingwistyczny i pragmalingwistyczny uzupełniają się. Podobieństwo między tymi metodami bywa bardziej lub mniej odczuwalne. Socjolingwistyka (zob. Gołąb, Heinz, Polański 1968) jako metoda badawcza określa wpływ czynników społecznych na kształt systemu językowego, a pragmalingwistyka (Maas, Wunderlich 1972) jako teoria aktów mowy jest zainteresowana wypowiedzią i jej otoczeniem, bada te cechy zachowań mownych, na które wpływa sytuacja aktu komunikacyjnego wyznaczana przez takie kategorie, jak: rola komunikacyjna nadawcy/odbiorcy; łączące ich relacje: symetryczna/niesymetryczna, miejsce, czas, cele. W praktyce trudno w sposób jednoznaczny rozgraniczyć socjolingwistyczne podejście do zagadnień językowych od kontekstu pragmalingwistycznego, ponieważ przedmiotem zainteresowania tych metod jest wypowiedź i jej otoczenie.

We współczesnych badaniach nad językiem mieszkańców wsi dialektolodzy wskazują na zastosowanie socjolingwistyki, której jedną z podstawowych zasad jest założenie, że język należy opisywać w ścisłym powiązaniu z czynnikami społeczno-kulturowymi. H. Kurek (2001: 117) pisze: „Poniewaź źródłem wiedzy o kulturze każdej społeczności jest język gromadzący i przechowujący doświadczenia pokoleń, to podstawą informacji na temat kultury wiejskiej będzie gwara - macierzysta mowa mieszkańców wsi”. 
W bezpośredniej komunikacji ustnej, która jest przedmiotem analizy, pod kątem perswazyjnego oddziaływania wykorzystuje się wszystkie środki językowe skorelowane z czynnikami sytuacyjnymi, toteż dla pełnego zrozumienia intencji wypowiedzi konieczne jest wskazanie kontekstu społecznego, w którym wypowiedź powstała. Rolę czynnika sytuacyjnego w akcie komunikacji podkreśla wielu badaczy (zob. Dunaj 1985: 88-97; Grabias 1994; Pelcowa 2000: 91-104). Opracowania socjolingwistyczne wykazały, że na wybór określonej formy językowej mają wpływ następujące czynniki socjologiczne i sytuacyjne: relacja między nadawcą a odbiorcą, pełnione przez nich role społeczne, wiek, płeć; typ kontaktu między nadawcą i odbiorcą (zob. Dunaj 1981: 11-20). Społeczność wiejska - tak jak i inne grupy społeczne, np. mieszkańcy większych lub mniejszych ośrodków miejskich - tworzy swoje własne środowisko językowe, na które składają się specyficzne sytuacje komunikacyjne. Na wsi do najbardziej typowych należą: rozmowy między domownikami i sąsiadami, ale na komunikację językową składają się również kontakty z mieszkańcami pobliskich miast, pracownikami banków i urzędów, personelem służby zdrowia itp. Małe, lokalne grupy ludzkie, szczególnie społeczności wiejskie, są z reguły bardziej spójne i łączą je silniejsze więzi prospołeczne, które mają wpływ na zachowania międzyludzkie (zob. Grabias 1994), w tym zachowania językowe, które są częścią zarówno określonej kultury społecznej, jak i realizacją obowiązującej w tym środowisku normy językowej.

Na podstawę materiałową pracy składa się 210 godzin prywatnych rozmów, których byłam świadkiem lub uczestnikiem. W opracowaniu zostały wykorzystane teksty z moich wieloletnich, bo trwających ponad 20 lat, badań języka mówionego mieszkańców wsi przede wszystkim z obszaru Mazowsza, Małopolski i Śląska. Eksploracją terenową objęto 12 wsi w okolicach Łodzi, Grójca, Białobrzegów i Częstochowy, należących do 3 różnych dialektów. Część materiału pochodzi od Polaków przesiedlonych ze Wschodu po II wojnie światowej. Analizowany materiał obejmuje zróżnicowane gatunkowo teksty mówione, zarejestrowane w latach: 1995-2010. Współcześnie prowadzona eksploracja została poszerzona o materiały starsze, które pochodzą sprzed 1995 roku. Granice czasowe materiału stanowią lata: 1990-2010. Wykorzystano rozmowy ze 104 mieszkańcami wsi. Badana społeczność była zróżnicowana wiekiem (14-98 lat) i wykształceniem, teksty pochodzą od informatorów o różnym (przeważnie podstawowym) stopniu wykształcenia.

Pod kątem wykorzystania mechanizmów perswazyjnych badano mowę, którą mieszkańcy wsi posługują się na co dzień w domu, czyli odmianę, która bywa określana jako: „kod pierwotny (domowy)” (zob. Zagórski 1998: 29). Bezpośrednie rozmowy, obejmujące kontakty w wąskim kręgu najbliższej rodziny, dobrych znajomych, sąsiadów, sytuują się w tzw. ludowym języku familijnym (zob. Handke 2006); w ten sposób badaczka określa potoczną, głównie mówioną odmianę języka narodowego, używaną w środowisku rodzinno-przyjacielsko-sąsiedzkim, wskazując m.in. na jej charakterystyczny rys, jakim jest kolokwialność. Więk- 
szość przykładów rejestruje kontakty wewnątrzrodzinne, obejmujące rozmowy osób, które pozostają w relacjach trwatych, tj. komunikację między małżonkami, rodzicami i dziećmi, dziadkami i wnukami oraz kontakty międzysąsiedzkie, obejmujące zachowania językowe w komunikacji wewnątrzgrupowej, rozmowy między sąsiadami, znajomymi, kontakty towarzyskie (rozmowy osób równych rangą), rzadziej (w interakcjach przedstawicieli różnych środowisk). Czasem w relacjach sąsiedzkich interlokutorzy pochodzą z lokalnej społeczności, ale nie znają się zbyt dobrze lub dzieli ich duża różnica wieku. Część materiału obejmuje także zachowania językowe mieszkańców wsi z osobami, które nie mówią gwarą. Są to interakcje werbalne, zachodzące między reprezentantami różnych grup i środowisk społecznych, rozmowy z osobami nieznanymi w miejscach publicznych (w środkach komunikacji, w sklepach, na targowisku, w ośrodkach zdrowia). Obserwacji poddano komunikację w różnych kontekstach sytuacyjnych: podczas pracy, zakupów, podróży, spotkań towarzyskich i w różnych miejscach: w domu, na targowisku, w sklepie, na przystanku autobusowym, w otwartej przestrzeni, takiej jak pole, las, łąka. Komunikacja miała charakter naturalny, swobodny, nie były jej narzucane żadne ograniczenia, badani mieli poczucie swobody.

Analizowane teksty można podzielić na dwa typy płaszczyzn kontaktów językowych. Sytuacja pierwsza, gdy badająca przytacza zachowania językowe interlokutorów, na ogół osób bardzo dobrze się znających, pozostających względem siebie w hierarchii równorzędnej. Sytuacja druga, gdy sama uczestniczy w rozmowie. Ponieważ materiał rejestrowano w środowisku dobrze znanym eksploratorowi, nawiązanie kontaktu $\mathrm{z}$ informatorami nie było trudne.

Podstawową metodą zbierania materiału były nagrania tekstów ciągłych języka mówionego, przy którego rejestracji i analizie uwzględniono kontekst społecznych zachowań językowych ze wszystkimi składnikami aktu komunikacji. Techniką zastosowaną do pozyskiwania materiału językowego była obserwacja uczestnicząca o charakterze niejawnym, polegająca na rejestrowaniu $\mathrm{z}$ podsłuchu wypowiedzi $\mathrm{w}$ naturalnych, autentycznych sytuacjach komunikacyjnych. Gromadzenie materiału językowego wymagało zastosowania metody, którą można uznać za nieetyczną. Powodem jej wyboru była troska o wiarygodność uzyskiwanych informacji oraz przekonanie, że metoda zapewnia precyzję badań i pozwala prześledzić praktykę językową, ponadto zapewnia spontaniczność wypowiedzi oraz pozwala lepiej wniknąć w sferę wzajemnych oddziaływań zachodzących w procesach interakcji. Rozmówcy nie wiedzieli, że wypowiedzi są nagrywane. O celu prowadzonych badań byli informowani po dokonaniu rejestracji materiału i w przypadku wyrażenia zgody na publikację tekstu dowiadywali się o sposobie wykorzystania ich wypowiedzi. Prywatne rozmowy ukazane są $\mathrm{w}$ pracy $\mathrm{z}$ należytą dyskrecją, m.in. zrezygnowano z umieszczenia obok tekstów szczegółowych danych, dotyczących informatorów czy lokalizacji wsi, ograniczając się jedynie do wskazania płci rozmówców i wyjaśnienia osobliwości językowych, występujących w gwarze, z której pochodzą wybrane przykłady. 
Dialektolodzy (zob. Gardzińska 1997: 31-38; Kurek 1998: 50-54) podkreślają zalety materiału językowego uzyskiwanego metodą rejestrowania z podsłuchu i wskazują, że sposób badania polszczyzny ludowej ze względu na dynamikę oraz wymiar zmian językowych, zachodzących w komunikacji mieszkańców wsi, musi być dostosowany do wymagań współczesności (por. Kleszcz 1998: 159-167; Paryl 1998: 153-158; Pelcowa 1998: 105-117).

\section{Tematyka tekstów}

Materiał zawiera swobodne rozmowy zwykłych ludzi rejestrowane w codziennych okolicznościach życiowych. Wypowiedzi mają charakter osobisty, dotyczą spraw, z którymi stykają się mieszkańcy wsi, nawiązują do aktualnych wydarzeń rodzinnych, niekiedy w rozmowach powracają bolesne wspomnienia wojenne, czasem rozmówcy koncentrują się na kwestiach publicznych, sytuacji społecznej, politycznej czy gospodarczej kraju. Zawartość treściową opracowania stanowią teksty związane z rzeczywistością lokalnej społeczności, dotyczące najczęściej bieżącej sytuacji, konkretnych osób lub zdarzeń. Rozmówcy wspominają wydarzenia, w których uczestniczyli, opowiadają o ludziach, których dobrze znają, zwłaszcza o swoich bliskich: współmałżonkach, dzieciach, wnukach. Tematyka analizowanych tekstów ma związek głównie z realiami i sprawami życia codziennego, odnosi się do aktualnych lub minionych wydarzeń rodzinnych. Mieszkańcy wsi opowiadają o problemach w rodzinie i w pracy, o relacjach z sąsiadami, dzielą się uwagami na temat zdrowia, wychowania i kształcenia dzieci, zwracają uwagę na zmiany sposobu prowadzenia gospodarstwa i pracy na roli, wskazują na ginącą tradycję i obrzędowość ludową. Rozmówcy informują o sprawach dla nich ważnych, dzielą się emocjami, niekiedy mówią o swoich bardzo osobistych, wręcz intymnych przeżyciach.

Korpus tekstów stanowią rozmaite typy wypowiedzi nagrane w różnych kontekstach. Przy doborze populacji kierowałam się zasadą właściwej reprezentacji socjalnej (kulturowej) i naturalnego aktu mówienia (por. Lubaś 1979b: 186).

\section{Sposób opracowania i prezentacji materiału}

Komunikację mieszkańców wsi podaję w transkrypcji fonetycznej, żeby utrwalić wszystkie cechy języka naturalnego, ponieważ taki zapis najlepiej odzwierciedla żywą mowę z zachowaniem właściwości fonetycznych, morfologicznych i składniowych, występujących w danej wypowiedzi. Rodzaj zapisu wynika ze specyfiki badanego materiału i podyktowany został faktem, że pochodzi on z różnych rejonów kraju: z Mazowsza, Małopolski i Śląska oraz był zbierany na przestrzeni wielu lat. Jedynie w nazwach własnych, zapisanych zgodnie z normą ortograficzną, zastosowano wielkie litery. Przetranskrybowane nagrania tekstów zostały poddane jedynie drobnym i koniecznym skrótom, by jak najlepiej odzwierciedlały perswazyjną funkcję wypowiedzi. 
Materiał egzemplifikacyjny składa się z części wprowadzającej, która zawiera informacje o rodzaju komunikacji, sytuacji komunikacyjnej, typie kontaktu, tle wypowiedzi: temacie rozmowy, danych o uczestnikach komunikacji (płci rozmówców, randze społecznej). Analizowane teksty umieszczone są na tle szerszego kontekstu, który rozumiany jest jako wieloaspektowy element komunikacji, obejmujący m.in.: kontekst fizyczny, społeczny, kulturowy. Znajomość kontekstu ma istotne znaczenie w każdej sytuacji komunikacyjnej, bowiem warunkuje właściwe odczytanie komunikatu, decyduje o funkcji wypowiedzi. Zwłaszcza kontekst sytuacyjny może także wywierać wpływ na zmianę odcieni znaczeniowych przekazu językowego, ponadto podsuwa właściwą interpretację, pomaga, a czasem jest wręcz niezbędny, w zrozumieniu intencjonalności wypowiedzi.

Ponieważ badane teksty występują w formie mówionej i zawierają informacje dostępne dla wąskiego kręgu osób, aby je zrozumieć, prawidłowo odczytać i zinterpretować, należy znać sytuację, w której zostały zarejestrowane. Szerszy kontekst umożliwia wyjaśnienie brakujących wiadomości, odczytanie podtekstów, ukrytych sensów, które towarzyszą komunikacji, bowiem jedynie rozmówcy w określonym czasie, miejscu, warunkach i okolicznościach, z racji posiadanej wiedzy, mogą uchwycić wszystkie komunikacyjne niuanse. Na istotną rolę czynnika sytuacyjnego w akcie komunikacji zwraca uwagę wielu badaczy (zob. Dunaj 1985: 88-97; Grabias 1994; Szczepankowska 1993: 87-91). Opisując składniki tła komunikacji, uwzględniam klasyfikację zaproponowaną przez K. Pisarkową (1978b: 7-20), która wyróżniła trzy ogólne grupy składników tła komunikacji:fizyczne, społeczne, merytoryczne.

I. Składniki (zmienne) tworzące kontekst fizyczny:

1) liczba uczestników komunikacji,

2) medium komunikacji (narzędzie przekazu),

3) miejsce komunikacji - przestrzeń, która w mniejszym lub większym stopniu wpływa na sposób komunikowania.

II. Składniki tworzące kontekst społeczny:

1) ranga i podział ról partnerów: nadawca - odbiorca,

2) wiek/płeć partnerów: nadawca - odbiorca.

III. Składniki merytoryczne (dotyczące tematu):

1) rodzaj tematu,

2) sposób jego opracowania.

Przy wypowiedzi, która jest przedmiotem językowego opisu, podaję następujące informacje:

- rodzaj relacji, statusu społecznego między nadawcą i odbiorcą,

- zasięg wypowiedzi (tj. kontakt językowy: prywatny, lokalny),

- stopień oficjalności sytuacji (stopień zażyłości między nadawcą i odbiorcą: sytuacja nieoficjalna, półoficjalna i oficjalna),

- rodzaj tekstu, z którego pochodzi dany fragment, ponieważ materiał uwzględnia różne formy podawcze (dialog, monolog, polilog),

- o towarzyszących jej elementach niewerbalnych, 
- czasem przy cytowanych wypowiedziach odnotowuję także niezbędne objaśnienia semantyczne.

Przy wyborze wypowiedzi, które weszły w skład opracowania, kierowałam się podstawowym kryterium najlepiej odzwierciedlającym perswazyjność przekazu. Celem doboru fragmentów, pochodzących z tekstów ciągłych, było wydobycie występujących reprezentatywnych przykładów związanych z realizacją perswazyjnej funkcji języka. W analizowanych wypowiedziach wyodrębniłam służące perswazji środki językowe, stanowiące egzemplifikację określonych mechanizmów nakłaniania. Elementy te zostały podkreślone, wyróżnienie graficzne ma podnieść czytelność i ułatwić odbiór tekstu. Opis uwzględnia także towarzyszące komunikacji werbalnej pozajęzykowe i paralingwistyczne środki wykorzystywane w celach perswazyjnych, którym został poświęcony oddzielny podrozdział pracy (zob. II.9. Komunikacja niewerbalna jako element wzmacniajacy perswazyjność przekazu). W rozmowach spontanicznych słowa często są ilustrowane gestem, co wzmaga siłę oddziaływania perswazji, prowadząc do głębokiego utrwalenia przekazanej treści. Istotne znaczenie ma także uzależnienie treści od sposobu jej wypowiedzenia, np. ironia, uszczypliwość częściej zaznacza się w intonacji niż w samej treści słów.

Na początku pracy zamieszczono wykaz zastosowanych skrótów.

Analizowane teksty pochodzą z następujących wsi:

- Konopiska, Rększowice (w okolicach Częstochowy),

- Michałowice, Otaląż, Stamirowice, Ulaski Grzmiąckie, Wólka (w okolicach Grójca),

- Cedrowice, Ostrów, Krasnodęby, Jastrzębiec, Bratków koło Poddębic (w okolicach Łodzi).

\section{Zakres i budowa pracy}

Praca składa się ze wstępu, dwóch rozdziałów i podsumowania. We wstępie wskazuję cel opracowania i omawiam założenia metodologiczne, zakres oraz budowę pracy.

W rozdziale pierwszym przedstawiam uwarunkowania socjologiczne, psychologiczne i kulturowe komunikacji językowej, ponadto przybliżam tematykę perswazji, stanowiącą jej istotny element. Podaję również definicję terminu perswazja językowa oraz zasadnicze elementy współtworzące to pojęcie; wskazuję na kwestie sporne, dotyczące odróżnienia perswazji od manipulacji językowej oraz na powiązania pomiędzy komunikacja a perswazja i manipulacja językowa.

Jako że perswazja jest zjawiskiem trudno definiowalnym, a samo pojęcie jest niejednoznaczne, szerokie i pojemne, w pierwszym rozdziale zawarto także ustalenia terminologiczne oraz informacje na temat: stanu badań nad perswazja językowa w różnych dziedzinach humanistyki. Wieloznaczność terminu wskazano, odwołując się do współczesnych słowników, leksykonów i opracowań naukowych, które podają różne możliwości rozumienia perswazji, a także do rozpraw definiu- 
jących i systematyzujących przedmiot badań oraz porządkujących podejmowaną problematykę terminologiczną. Z uwagi na fakt, że wciąż nie ma powszechnej zgody co do samej istoty perswazji, ta część opracowania jest próbą odpowiedzi na pytanie, czym właściwie jest perswazja i jak można ją badać w odniesieniu do mowy mieszkańców wsi. W pierwszym rozdziale pracy zawarto informacje na temat przeobrażeń zachodzących współcześnie w polszczyźnie ludowej, które mają wpływ na sposób komunikowania się i realizację perswazyjnej funkcji języka.

W rozdziale drugim, który został w całości poświęcony analizie zebranego materiału językowego, prezentuję od strony funkcjonalnej i pragmatycznej wybrane teksty gwarowe, zwracając uwagę na ich celowość i skuteczność oddziaływania na odbiorcę. Badania obejmują teksty, reprezentujące różne gatunki mowy w ścisłym powiązaniu z wykorzystanymi w nich mechanizmami oraz środkami językowymi i pozajęzykowymi, które służą przekonywaniu. Całość materiału została podzielona na podrozdziały, obejmujące środki leksykalne, przeksztatcenia semantyczne, środki morfologiczne, składniowe oraz środki komunikacji niewerbalnej. Zakres zagadnień, które zostały przedstawione w części materiałowo-analitycznej pracy, obejmuje trzy cele: pierwszy to wyodrębnienie poszczególnych elementów językowych, kompozycyjnych, argumentacyjnych oraz wskazanie ich perswazyjnej funkcji w aktach komunikacji, drugi to przedstawienie tych mechanizmów nakłaniania, które dla opisu badanego środowiska są najbardziej typowe i ostatni, polegający na odniesieniu rezultatów opisu metod i środków stosowanych w tekstach gwarowych do tych, które wykorzystywane są w innych dyskursach językowych.

Najważniejszym celem drugiego rozdziału opracowania jest przedstawienie zachowań komunikacyjnych rozmówców oraz określenie: jakie strategie są stosowane przez uczestników komunikacji w celu perswazyjnym? jaki kształt przyjmuje argumentacja? jaki jest udział w procesie przekonywania współrozmówców kanału werbalnego i niewerbalnego?

Przedstawiona analiza łączy ujęcia: językowe, stylistyczne i tekstowe. Wyodrębnione mechanizmy i środki perswazji obecne w gwarze zestawiono $\mathrm{z}$ analogicznymi występującymi w polszczyźnie ogólnej z uwzględnieniem różnych form dyskursu. Językoznawczy opis działań perswazyjnych został skonfrontowany z ujęciami proponowanymi przez przedstawicieli innych dyscyplin wiedzy, badających perswazję językową, np.: socjologów, psychologów, politologów.

Ostatnia część pracy, podsumowanie, służy prezentacji wyników badań. Analizowane teksty zostały tam porównane pod kątem podobieństw i różnic w zakresie wykorzystanych mechanizmów perswazyjnych i środków językowych im służących $\mathrm{z}$ występującymi w innych typach dyskursu. Ukazano, które z wyodrębnionych w toku badań mechanizmów perswazyjnych są wspólne gwarom i polszczyźnie ogólnej, a które stanowią o ich odrębności, szczególnie skoncentrowano się na wskazaniu osobliwości wykorzystanych mechanizmów i środków. 


\section{ROZDZIAŁ I}

\section{Problematyka perswazji w języku i w tekście}

\section{Przeobrażenia w komunikacji mieszkańców wsi - status dialektów wobec współczesnej polszczyzny}

W polskiej literaturze językoznawczej przyjmuje się powszechnie istnienie dwóch podstawowych odmian języka polskiego: polszczyzny ogólnej i gwar ludowych. Na temat statusu języka ogólnego i gwar powstało wiele opracowań (por. Dejna 1998: 13-29; Skudrzyk 2004: 169-176; Wronicz 2007: 91-176). W opozycji do języka ogólnopolskiego wskazuje się także odmiany środowiskowe polszczyzny - socjolekty. Dialektolodzy podkreślają, że zarówno gwary ludowe, jak i socjolekty sytuują się na obrzeżach języka ogólnego, ponieważ pod względem gramatycznym należą do polszczyzny ogólnej, znaczna jednak część słownictwa tych odmian pozostaje dla ogółu społeczności niezrozumiała.

W opracowaniach lingwistycznych wskazuje się na zróżnicowanie stylistyczne języków (Wierzbicka 1965: 127). Gwara, którą K. Dejna (1998: 14) uważa za jedną „z odmian formalno-funkcjonalnych polskiego języka etnicznego”, także wykazuje wewnętrzne zróżnicowanie. Mowa środowiska wiejskiego służy przede wszystkim zaspokajaniu codziennych potrzeb komunikacyjnych mieszkańców i podobnie jak polszczyzna miejska stanowi zjawisko złożone, w którego opisie należy uwzględnić różne warianty.

Współczesną mówioną odmianę polszczyzny ludowej charakteryzuje dynamizm rozwojowy. Dialektolodzy podkreślają, że obecnie trudno spotkać na wsi osoby mówiące konsekwentnie gwarą (zob. Kurek 1988: 50-54; Reichan 1999: 262-278). Gwary używają dziś przedstawiciele najstarszego pokolenia, pokolenie średnie stosuje gwarę z elementami polszczyzny ogólnej, potocznej, natomiast młodzież mówi polszczyzną standardową. Gwara, jako jeden z wariantów polszczyzny ludowej, obsługuje współcześnie sferę komunikacji charakterystyczną dla kontaktów prywatnych, wewnątrzrodzinnych, towarzyskich i nie jest dziś jedynym środkiem komunikacji językowej w środowisku wiejskim (zob. Wronicz 2007: 91-96). Ogranicza ona swe funkcje wobec polszczyzny ogólnej i potocznej oraz różnych odmian stylistycznych. J. Bartmiński (1977: 222) postrzega gwarę jako swoisty wariant funkcjonalny o określonym wyspecjalizowanym przeznaczeniu tematycznym 
i sytuacyjnym, ,jako język rodzinny, towarzyski, sąsiedzki, regionalny itp.” H. Kurek (2001: 122) zauważa, że: „,...] konkurujące ze sobą systemy językowe - dialekt i standard [podkr. - B. B.-R.] - powoli opanowują określone «pola komunikacyjne», to znaczy ograniczają swe funkcje do roli jednego z kodów, na przykład rodzinno-domowego w opozycji do kodu oficjalnego".

Język mieszkańców wsi rozumiem jako środek komunikacji używany w codziennych, swobodnych rozmowach i traktuję jako odmianę języka ogólnego, mającą specyficzne właściwości ze względu na odrębność językową i kulturową tej społeczności. W opracowaniach językoznawczych gwara definiowana jest jako odmiana języka etnicznego, która obok cech wspólnych z językiem ogólnonarodowym odznacza się zespołem cech właściwych tylko jej nosicielom, tj. zamkniętej społeczności wiejskiej, a także szczególnymi cechami systemowymi, które są wyznaczane przez fonologię i gramatykę (zob. Dejna 1973: 115). Regionalne warianty języka narodowego, będące częścią składową wspólnoty narodowej, stanowiące o bogactwie polszczyzny ogólnej, należą do tych odmian współczesnego języka polskiego, które od dawna były przedmiotem zainteresowania i troski wielu dialektologów (Nitsch 1915; Urbańczyk 1968; Dejna 1973). W badaniach nad mową mieszkańców wsi istotne znaczenie ma sama kwestia miejsca i obecności gwary w komunikacji językowej. W pełni akceptuję tezę wyrażoną przez wielu badaczy (Kucała 1960; Ożóg 1998b; Pelcowa 1998; Gala 2002; Kajtoch 2009), że wskutek oddziaływania na mowę mieszkańców wsi polszczyzny ogólnej, będącej nie jedynym, ale istotnym bodźcem zmian, zmienia się stosunek mówiących do gwary i ewoluuje sama gwara. Zróżnicowanie współczesnej polszczyzny ludowej najlepiej obrazuje analiza wypowiedzi mieszkańców wsi, szczególnie przedstawicieli najstarszego pokolenia, od dziecka używających gwary oraz pokolenia najmłodszego, które dobrze opanowało polszczyznę ogólną i oddaliło się językowo od sposobu komunikowania się dziadków i rodziców. Kontakt młodych z gwarą ma raczej charakter bierny. Różnice językowe między pokoleniami istniały zawsze i były przyczyną rozwoju języka, dziś jednak zwiększyła się dynamika zmian językowych o podłożu językowo-kulturowym.

Wśród najważniejszych przeobrażeń zachodzących współcześnie w polszczyźnie ludowej K. Ożóg (2001: 21) wymienia zanik gwar i tworzenie się „nowej jakości języka wsi”. W opracowaniach dialektologicznych (zob. Kurek 1995; Pelcowa 2000: 91-104) podkreśla się, że w gwarach od dawna obserwuje się zmiany formy zachowań werbalnych i sposobów użycia języka w różnych typach kontaktów międzyludzkich - w komunikacji indywidualnej, masowej, grupowej czy międzypokoleniowej - wskazuje się na wariantywność form językowych i mieszanie różnych systemów mówienia. $Z$ ustaleń badawczych wynika, że na sposób komunikowania się na wsi mają wpływ zmieniające się uwarunkowania zewnętrzne, w szczególności społeczne, polityczne, kulturalne, które dokonały się w Polsce po II wojnie światowej, a nasiliły się po 1989 roku. Gwara nie jest obecnie jedynym środkiem komunikowania się w środowisku wiejskim, ponieważ mieszkańcy wsi w coraz szerszym zakresie sięgają po język ogólny, szczególnie 
w kontaktach z osobami reprezentującymi inne środowiska kulturowe (zob. Kucała 1960). H. Kurek (1995: 12-13) stwierdza: ,[...] konwencjonalne znaczenie terminu «gwara», jako mowa ludności wiejskiej, staje się nieprecyzyjne, bowiem nie odzwierciedla rzeczywistości językowej współczesnego środowiska wiejskiego [...]. Poprawniej byłoby posługiwać się nadrzędnym w stosunku do gwary określeniem «polszczyzna mówiona wsi». Zaproponowany termin nie tylko nie wyklucza pojawienia się w mowie ludności wiejskiej elementów języka ogólnego, ale wręcz dopuszcza możliwość funkcjonowania na wsi odmiany literackiej, która obecnie zwłaszcza dla wielu wykształconych mieszkańców wsi w pewnych sytuacjach komunikacyjnych jest typowym sposobem porozumiewania się".

Proces upowszechniania się polszczyzny ogólnej przybrał na sile w XX wieku wskutek rozwoju oświaty, migracji ludności, awansu społecznego mieszkańców wsi. Na: „wyższość języka literackiego nad gwarą i usiłowanie zastąpienia tego, co gwarowe, tym, co literackie" wskazywał M. Kucała (1960: 154). Pod wpływem uwarunkowań zewnętrznych zmienił się status gwar, tworzeniu nowych systemów komunikacyjnych sprzyja integracja językowa.

We współczesnej polszczyźnie ludowej dialektolodzy wskazują współistniejące zróżnicowane kody językowe. Funkcjonujący obecnie na wsi językowy kod komunikacyjny ma charakter mieszany. Najstarsi mieszkańcy wsi obok gwary posługują się kodem mieszanym, który powstał na pograniczu języka ogólnego i rodzimej gwary. Charakteryzuje się on obecnością cech dialektalnych w postaci elementów gramatycznych i leksykalno-frazeologicznych oraz występowaniem nowych środków wyrazu i sposobów wysłowienia, zwłaszcza przenikającymi do gwary obcymi strukturami, aktywizacją leksyki obcej. Obecnie mieszkańcy wsi są $d w u$, a nawet trójjęzyczni.

Opisując zachowania językowe użytkowników polszczyzny ludowej, H. Kurek (1987: 63-69) wprowadziła termin przełączanie kodów i wyodrębniła trzy podstawowe odmiany językowe, występujące w środowisku wiejskim: gwarę, polszczyznę ogólna i kod mieszany, który powstał w wyniku przenikania się obu systemów. W „polszczyźnie wiejskiego obszaru językowo-kulturowego” autorka (2001: 117) wskazuje „gwarę, która jest normą komunikacji językowej mieszkańców wsi w kontaktach rodzinno-domowych, oraz odmianę gwarowo-literacką lub literacko-gwarową pojawiającą się na skutek przełączania kodu gwarowego na ogólnopolski. Dochodzi do tego najczęściej w rozmowie mieszkańca wsi z osobą pochodzącą spoza lokalnego, gwarowego obszaru językowo-kulturowego". A. Wilkoń (1979: 405-414) wyróżnia trzy systemy językowe funkcjonujące w środowisku wiejskim: system gwarowy (wyjściowy), system przejściowy, który charakteryzuje się największym rozchwianiem w zakresie norm gwarowych i system ogólnopolski (możliwy po przejęciu ogólnopolskiego typu wymowy w miejsce gwarowego). Z kolei J. Kąś (1994a: 33-79) wskazuje, że na sposób komunikacji mieszkańców wsi ma wpływ także funkcjonowanie trzech filtrów: sytuacyjnego, kulturowego i informacyjnego. 
W wielu opracowaniach dialektologicznych podkreśla się, że gwary ludowe zanikają (Kurek 1988: 50-54), zmieniają się (Pelcowa 1994; Wyderka 1994: 24; Kurek 1995; Ożóg 1998b: 119-125), przejmując elementy polszczyzny ogólnej i potocznej (Węgier 1978; Dunaj 1980: 99-108; Kajtoch 2009: 208-220). K. Dejna (1991/1992: 81) wskazywał, że zjawisko ma różny stopień nasilenia: „,...] w mowie poszczególnych mieszkańców wsi, zależnie od wykształcenia, oczytania, zainteresowań postępem itd., cechy gwarowe utrzymują się w bardzo nierównym, nieraz małym stopniu".

Zdaniem K. Ożoga (2001: 216) na szybkie obecnie tempo przeobrażeń gwar miała wpływ zmiana stosunków ekonomicznych i społecznych na wsi polskiej, zwłaszcza „,dezintegracja społeczności wiejskiej” i ,jej tradycyjnego języka”. Według S. Gali (2006: 81): „Aktualny stan gwar jest więc dziedzictwem historycznym, wynikiem interferencji międzygwarowych oraz następstwem procesów integracyjnych z polszczyzną ogólną, a przede wszystkim z jej odmianą potoczną".

J. Kowalikowa (2002: 243) podkreśla, że: „Do innego spojrzenia na gwarę skłania zmiana jej miejsca oraz funkcji w ogólnospołecznym pejzażu komunikacyjnym”, gwarę traktuje się jako „swoisty wariant funkcyjny o określonym wyspecjalizowanym przeznaczeniu tematycznym i sytuacyjnym, jako język rodzinny, towarzyski, sąsiedzki” (Bartmiński 1973: 232).

Przeobrażenia językowe i stylistyczne, dokonujące się ostatnio w mowie mieszkańców wsi, stanowią interesujące zjawisko językowe, którego opis wymaga zastosowania nowych metod badawczych (Pelcowa 1998: 111-112). O zainteresowaniu tą problematyką świadczą liczne opracowania z zakresu dialektologii (zob. Węgier, Oronowicz 1992; Gardzińska 1993a; Sędziak 1996; Czyżewski, Warchoł 1998), szczególnie ujmujące zachowania komunikacyjne mieszkańców wsi w kontekście społecznych uwarunkowań funkcjonowania gwary i innych odmian językowych (zob. Kurek 1994; Mrózek 2002: 353-358).

\section{Uwarunkowania socjologiczne, psychologiczne i kulturowe komunikacji językowej a zjawisko perswazji}

Każdy codziennie komunikuje się z różnymi osobami, ponieważ porozumiewanie się z innymi jest najbardziej powszechną i podstawową formą kontaktów interpersonalnych, a perswazja stanowi ważny element codziennego języka i procesu komunikacji. Na sposób przebiegu komunikacji, która jest działaniem językowym służącym realizacji różnorodnych ludzkich potrzeb, ma wpływ wiedza, doświadczenie oraz otoczenie społeczne, w jakim człowiek funkcjonuje. Tą sferą ludzkiego działania oraz jej różnorodnymi aspektami zajmują się badacze reprezentujący różne dyscypliny naukowe, a język w kontekście komunikacji stał się przedmiotem zainteresowania lingwistów (por. Wolski 1998; Dobek-Ostrowska 
2004b; Kamińska-Szmaj i in. 2006; Bugajski 2008), szczególnie teoretyków języka (por. Jakobson 1989), a także teoretyków literatury (Mayenowa 1979; Skubalanka 1991), twórców socjolingwistyki (zob. Bokszański 1972; Lubaś 1979b), filozofii (por. Austin 1987), psychologów (zob. Nęcki 1996a).

Komunikacja jest niezwykłym narzędziem budowania społecznych relacji, a posługiwanie się językiem - naturalną czynnością o charakterze społecznym, mającą motywację socjologiczną (por. Piotrowski, Ziółkowski 1976), kulturową (zob. Habrajska 2008; Anusiewicz 1994) i psychologiczną (por. Sujak 2006). Zawsze komunikując się z kimś, nadawca (mniej lub bardziej świadomie) odpowiada sobie na pytania: kim jest dla mnie odbiorca? kim ja jestem dla niego? jak powinienem z nim rozmawiać, jeśli chcę osiągnąć określony cel komunikacyjny?

M. Wojtak (1993: 235) pisze: „Zgodnie z ustaleniami socjolingwistyki konkretny nadawca tekstu podejmuje zwykle działania językowe zdeterminowane społecznie i kulturowo, występując w stosunku do odbiorcy w określonej roli społecznej”. M. Filipiak (1996: 85) wskazuje, że: „Mechanizm wpływu kultury na życie społeczne jest złożony i skomplikowany". Rozważania na temat sytuacji socjolingwistycznej znajdują odzwierciedlenie w licznych pracach z zakresu komunikacji językowej (por. Lubaś 1979a: 11-27; Miodunka, Ropa 1979; Dunaj 1985: 88-97), także tych, poświęconych perswazji. W. Tomasik (1988: 20) podkreśla, że: ,[...] w analizie aktu perswazyjnego w maksymalnym stopniu uwzględnić trzeba elementy natury intersubiektywnej, właściwe nie konkretnej jednostce, ale całej grupie. Proces komunikowania nigdy nie zachodzi w społecznej próżni. [...] w elementarnej postaci powołuje najmniejszą grupę [...], sprzęgając ze sobą nadawcę i odbiorcę, lecz także dlatego że komunikujący zanurzeni są w przestrzeni społecznej i oddziaływania jej na proces porozumienia nie sposób wyeliminować”.

Dla właściwego zrozumienia zjawiska perswazji niezbędne jest przeanalizowanie dwóch zasadniczych problemów: po pierwsze, określenie relacji komunikacja a perswazja oraz sprecyzowanie wzajemnego związku dwóch pojęć - perswazji i manipulacji, ponieważ wyrazy perswazja i manipulacja bywają używane zamiennie.

Język w ujęciu komunikacyjnym (por. Awdiejew, Habrajska 2004: 19) definiowany jest jako: ,proces werbalizacji przez człowieka jego intencji przedstawieniowych (gdy celem jest opis rzeczywistości) i pragmatycznych (gdy celem jest wpływanie na przekonania i zachowania odbiorcy), realizowany w postaci różnych gatunków tekstu".

Wychodzę z założenia, że wypowiedź może pełnić wiele funkcji, może przekazywać informacje, ekspresje, ale także wywoływać pożądane postawy odbiorcy. Na wielofunkcyjność przekazu zwraca uwagę m.in. R. Jakobson (zob. Kurcz 1975: 411-489) wskazując, że może on być skoncentrowany na: stuchaczu, zawierać prośby, polecenia, rozkazy; na mówcy - pełni wtedy funkcję ekspresywną; nastawiony na przedmiot - pełni wówczas funkcję reprezentatywną; stosowany jako metakomunikat, gdy uwaga nadawcy skupia się na uzgadnianiu bądź na 
weryfikacji kodu czy też na kanale, w jakim jest przekazywany. Niewątpliwie najważniejszą funkcją języka jest funkcja komunikatywna, inne funkcje, jak określa A. Wierzbicka (1967: 134), stanowią tylko „nadbudówkę” nad tą podstawową.

W socjologii i psychologii społecznej (zob. Kłoskowska 1983a: 170) komunikowanie definiowane jest jako: ,,proces przekazywania z centrum, określonego jako źródło, treści zawartych w symbolicznej postaci znaków, skierowanych do odbiorców posiadających zdolność do ich przyjęcia". Komunikowanie masowe skierowane jest do bardzo licznej, zróżnicowanej i szeroko rozproszonej publiczności, natomiast istotnym rysem komunikacji interpersonalnej jest ograniczoność odbiorców.

Język jako środek komunikacji interpersonalnej oprócz formułowania myśli umożliwia również wartościowanie i ocenę rzeczywistości. Zakładam, że perswazja obecna jest także w aktach mowy nastawionych na przekazywanie informacji, ponieważ każdy komunikat poza treścią, jaką zawiera, może ponadto wiązać się $\mathrm{z}$ określonym nakazem, zakazem czy instrukcją dla jego odbiorcy.

Przyjmuję, że w komunikacji interpersonalnej informacja często jest jedynie tłem dla wyrażenia oceny, która ma na celu skłonienie odbiorcy do podzielenia przekonania wartościującego wyrażonego przez nadawcę. E. Laskowska (2009: 57), która analizowała wartościowanie, zauważa, że granica między informowaniem a wartościowaniem nie zawsze jest łatwa do wyznaczenia. W kontekście ujęcia problematyki perswazji wydaje się, że rację należy przyznać W. Pisarkowi (2004: 124), który twierdzi, że komunikowanie się służy nie tylko przekazywaniu informacji, ale także przekonywaniu rozmówcy, a sposoby przekonywania ludzie stosują intuicyjnie, „odkąd zaczęli porozumiewać się za pomocą języka, a może jeszcze wcześniej”.

Komunikowanie się, podobnie jak przekonywanie, opisywane jest z różnych perspektyw badawczych. Refleksja nad językiem i sposobami wykorzystywania go przez użytkowników przyczyniła się do wyodrębnienia w językoznawstwie różnych jego nurtów. Teoretycznej problematyce interakcji poświęcone są opracowania dotyczące gramatyki komunikacyjnej (zob. Awdiejew 1999; Awdiejew, Habrajska 2004; 2006; Habrajska 2008; 2009), lingwistyki kulturowej (por. Anusiewicz 1994; Duszak 1998), stylistyki pragmatycznej (zob. Kalisz 1993; Sławkowa 2002), tekstologii lingwistycznej (por. Bartmiński, Boniecka 1998).

Jest rzeczą oczywistą, że także perswazji - zjawisku złożonemu, wieloaspektowemu, stanowiącemu istotny element komunikacji w wielu przejawach życia społecznego, poświęcono dużo uwagi. Działania perswazyjne dotyczą zachowań ogólnokulturowych, pojawiają się nie tylko w oficjalnych wystąpieniach, ale także w codziennych sytuacjach życiowych, w zwyczajnych, bezpośrednich kontaktach międzyludzkich. Perswazja, jako ważna i powszechna część aktywności człowieka, praktycznie może zaistnieć wszędzie i może mieć różny charakter. Komunikowanie interpersonalne (zob. Bietka, Kierubiński 1982; Proctor II Russell 2006) określane jest jako porozumiewanie się pomiędzy dwiema osobami 
lub w niewielkich grupach ludzi. W tym typie komunikacji wpływ na perswazyjność komunikatu mają przede wszystkim relacje, w jakich pozostają nadawca i odbiorca, ponieważ w rozmowie bezpośredniej efektywność osiągania celów zależy od zaufania odbiorcy do nadawcy.

Problematyce komunikacji lingwiści poświęcili wiele uwagi, komunikacja jest badana w ramach językoznawstwa oraz innych dyscyplin humanistycznych. Teoretyczna refleksja nad mechanizmami funkcjonowania języka jest przedmiotem zainteresowania takich dziedzin humanistyki, jak: filozofia, socjologia, psychologia czy kulturoznawstwo. Specjaliści różnych dyscyplin wiedzy, zajmujący się analizą języka, badają problematykę zagadnienia komunikacji we właściwej sobie perspektywie. Z punktu widzenia psychologii i socjologii podkreśla się wpływ grupy na język jednostki, a istotne znaczenie ma tu rodzina, społeczność lokalno-sąsiedzka (por. Ziemska 1975). W. Doroszewski (1973: 20) pojmuje język jako rodzaj komunikacji, formę przekazu i odwołuje się do O. Jespersena, który pisał: „Język jest czynnością, czynnością celową, toteż nigdy nie powinno się zapominać o jednostkach mówiących i o celu, jaki one mają, działając w ten szczególny sposób".

W modelach komunikowania interpersonalnego podmiotem są jednostki, które role nadawcy i odbiorcy pełnią wymiennie i jednocześnie. Na ten typ komunikacji składają się dwa podstawowe elementy: bezpośrednia obecność uczestników i nawiązanie osobistego kontaktu (twarzą w twarz). Podkreśla się, że komunikowanie interpersonalne ma charakter dwustronny, interaktywny i zwykle przybiera formę dialogu, rozmowy. Mówienie pojmowane bywa jako kształtowanie relacji między ludźmi (por. Gajda, Rymut, Żydek-Bednarczuk 2002; Grybosiowa 2003; Wolski 1998). Język jako narzędzie społecznej komunikacji stwarza użytkownikom niezwykłe możliwości kształtowania wypowiedzi i oddziaływania na odbiorcę tekstu poprzez wykorzystanie różnych technik perswazji. Z punktu widzenia realizacji perswazyjnej funkcji języka $w$ relacjach interpersonalnych oprócz komunikacji werbalnej istotne znaczenie ma najczęściej występująca w połączeniu z nią komunikacja niewerbalna (zob. Kneblewski 1980: 237-249; Brocki 2001). Komunikowanie pozasłowne obejmuje wszelkie zachowania intencjonalne (celowe lub nieświadome, mające sens), tj. mimikę, pozycję i ruchy ciała, kontakt na płaszczyźnie wzrokowej, słuchowej i dotykowej. Wyróżnia się komunikację kinezyjna (ruch ciała i mimikę), komunikację proksemiczna (informacje przekazywane przez usytuowanie podmiotów w przestrzeni) oraz komunikację paralingwistyczna (sposób artykulacji, tonację, głośność wypowiedzi), które wzmacniają oddziaływanie komunikatu słownego i mają wpływ na sposób interpretowania wypowiedzi przez odbiorcę.

Badania prowadzone m.in. przez językoznawców, psychologów, etnolingwistów dowiodły, że ukształtowanie wypowiedzi oddziaływa na percepcję wrażeń zmysłowych. A. Wierzbicka (1967: 172) wskazuje, że: „Język w pewnym stopniu kształtuje naszą myśl, a w każdym razie zabarwia ją w określony sposób”. Etno- 
lingwiści (zob. Sapir 1978; Whorf 1982) podkreślają, że język wpływa na sposób myślenia, stosunek do otaczającego świata czy postrzeganie rzeczywistości.

Uważam, że w procesie komunikacji równie ważna i ściśle związana z funkcją komunikatywną jest funkcja perswazyjna, nazywana także impresywna, imperatywna, nakłaniajaca, regulacyjna lub dyrektywna (por. Grzegorczykowa 1985: 378-381; Grzegorczykowa 1991: 11-28), której celem jest wpływanie na sądy i postawy uczestników dialogu, ponieważ informowanie może być również środkiem oddziaływania na poglądy i zachowania innych ludzi. Każdy użytkownik wykorzystuje komunikację do realizacji określonych celów, a jego działania językowe mogą mieć charakter bardziej lub mniej świadomy.

Przez perswazje w kontekście zabiegów stosowanych w komunikacji interpersonalnej rozumiem ogół starań nadawcy o wywarcie - bez przymusu, za pomocą celowo ukształtowanych przekazów - wpływu na przekonania, opinie, postawy, nastroje, a co za tym idzie i zachowania bezpośrednich oraz pośrednich adresatów tych przekazów. Samo przekonywanie może mieć wydźwięk pozytywny - prowokuje do myślenia, zachęca do konstruktywnych działań, daje motywację itp.; ale także negatywny - sprowadzający się do manipulowania informacjami, sugerowania pewnych zachowań korzystnych dla nadawcy komunikatu.

Wśród uczonych zajmujących się relacjami między perswazją a manipulacją pojawiają się bardzo zróżnicowane opinie - jedni utożsamiają pojęcia, część badaczy traktuje manipulację jako rodzaj wynaturzonej perswazji, jeszcze inni uważają je za zupełnie odrębne pojęcia (por. Pisarek 1974; Barańczak 1975; Grzegorczykowa 1991; Lewiński 2001). W pracy termin perswazja traktuję jako nadrzędny wobec manipulacji, którą uważam za metodę ukrytego, nieuczciwego oddziaływania na świadomość i zachowanie jednostki lub grupy. Uważam, że perswazja to działanie, które respektuje wolność wyboru, swobodę komunikowania się, zaś manipulacja jest działaniem, w którym nadawca świadomie ukrywa przed odbiorcą rzeczywiste intencje swojej wypowiedzi. Traktuję manipulację jako działanie unikające jawnego przekonywania. Powodów zabiegów manipulacyjnych może być wiele, np.: chęć przekonania do swoich racji, zmiana rzeczywistości, kontrola nad odbiorcą/ grupą, przede wszystkim zaś własna korzyść. Bezinteresowność nadawcy uważam za istotny element perswazji. Przyjmuję jednak, że kryterium to ma charakter intuicyjnego założenia, obciążony subiektywizmem oceny badacza, ponieważ rzeczywiste intencje nadawcy bardzo trudno odkryć, jeżeli w ogóle da się je wyjaśnić, szczególnie w sytuacji, kiedy komunikacja odbywa się wśród ludzi, których zdaniu się ufa. Jest to zadanie niełatwe nawet w przypadku analizy przebiegu komunikacji z perspektywy postronnego obserwatora, który zakłada określone kryteria jej oceny. Należy bowiem pamiętać, że każdy sąd jest w pewnym stopniu subiektywny.

Perswazyjna funkcja języka realizuje się poprzez wykorzystanie wszystkich możliwych zachowań komunikacyjnych zdolnych wywołać w odbierającym je człowieku określone przeżycia, uczucia, myśli i wrażenia, które zgodne są z intencjami nadawcy, a które w założeniu w istotny sposób mają wpływać na 
ukształtowanie poglądów odbiorcy. Będą to wszelkie zachowania mające na celu zwrócenie uwagi, wyrażenie opinii lub poparcia dla czegoś bądź zaprotestowanie w jakiejś sprawie. Dla potrzeb opracowania przyjąć należy, że nadrzędnym celem wypowiedzi perswazyjnej jest skuteczne przekonywanie odbiorcy do głoszonych tez czy rad udzielanych przez nadawcę, których konsekwencją ma być określone postępowanie odbiorcy. Tak rozumianej perswazji służą elementy słowne, gdyż perswazja widoczna jest także na różnych poziomach języka, ponadto obejmuje komunikację pozawerbalną, ponieważ sukces przekonywania tkwi w umiejętnym wykorzystaniu przez nadawcę bogactwa środków językowych i sugestywnego łączenia ich z elementami kodu pozasłownego. Perswazja jest możliwa we wszystkich podsystemach języka, szczególnie widoczna jest na poziomie leksykalnym, ze względu na jego znacznie szersze niż w innych podsystemach możliwości wartościowania. Za słuszny uważam pogląd D. Galasińskiego (1992: 26), że: „Wpływ na poglądy czy przekonania odbiorcy dokonuje się poprzez mniej lub bardziej widoczne zawarcie oceny w wypowiedzi (na wartościowaniu opiera się główny mechanizm perswazyjny $[\ldots])$ ".

Wszędzie tam, gdzie nadawcy chodzi o wywołanie odpowiednich reakcji w zachowaniu odbiorcy, pojawiają się zabiegi perswazyjne, które nieodłącznie związane są z różnymi aspektami życia społecznego. Perswazja występuje w różnorodnych układach międzyludzkich, także w kontaktach codziennych. Wywiera wpływ na sposób komunikowania się w kręgu rodziny, domowników, przyjaciół, sąsiadów i znajomych, choć często nie zdajemy sobie sprawy z jej obecności. Oczywiście różna jest w różnych tekstach hierarchizacja funkcji (por. Koj 1991: 36-52; Bartmiński, Niebrzegowska-Bartmińska 2006), a więc dominowanie w wypowiedzi konkretnej funkcji, co nie zmienia w niczym zasadniczego prymatu funkcji komunikatywnej.

Sądzę, że zwłaszcza w codziennych, bezpośrednich kontaktach międzyludzkich przekonywanie odgrywa istotną rolę, bowiem każdy człowiek, mając do dyspozycji określone zasoby językowe, może wyrażać swoje myśli, uczucia i poglądy w sposób spontaniczny, przy czym wybór środków językowych determinowany bywa także presją innych przedstawicieli społeczeństwa, w którym jednostka funkcjonuje. Badania wykazują, że język, którego używa określona społeczność, jest formą poznania świata i zwierciadłem ludzkich zachowań (zob. Grabias 1994: 134-164), lingwiści zwracają uwagę na kilka aspektów powiązań między językiem i kulturą (por. Ożdżyński 1993: 7-20). Po pierwsze, język, będąc częścią kultury, stanowi najważniejszy składnik komunikacyjnej sfery kultury, po drugie, język może być środkiem poznania kultury i po trzecie, jest elementem przekazywania dziedzictwa kulturowego. Amerykańscy etnolingwiści E. Sapir i B. Whorf wskazywali na zależność między myśleniem i językiem, która wynika z podwójnej funkcji mowy, będącej składnikiem kultury i przekaźnikiem tradycji, wierzeń, systemu wartości, doświadczania. Również antropolog C. Lévi-Strauss (zob. Charbonnier 1968: 140) traktował język jako fakt kulturowy, środek, dzięki 
któremu przyswajamy kulturę danej grupy, element niezbędny do zrozumienia sztuki, religii, prawa czy zasad dobrego wychowania.

Każdy język naturalny jest ponadto miarą osobowości człowieka i odbiciem jego indywidualnej kultury (por. Bugajski 1993; Bartmiński 2001a: 13-22). W lingwistyce kulturowej, koncentrującej się na zależnościach między językiem a kulturą, człowiekiem a rzeczywistością, podkreśla się, że: „trzeba badać język poprzez badanie uwikłań, relacji oraz zależności, w jakie wchodzą one z kulturą, społeczeństwem, rzeczywistością oraz człowiekiem rozumianym jako jednostka społeczna, a zarazem osobowość - byt psychiczny, mentalny, wartościujący, samoświadomy, a także kulturowy" (Anusiewicz 1994: 3).

Lingwistyka kulturowa traktuje perswazję jako swoistą rolę języka. J. Anusiewicz (1994: 3) wśród ważnych funkcji języka wskazuje również to, że: „[...] oddziałuje na zachowania i działania społeczne, organizując je i sterując nimi”, język jest magazynem doświadczenia zbiorowego danej społeczności, odzwierciedlającego hierarchie wartości i systemy znaczeń, „służy do ich utrwalania, transmitowania, a także do ich kodyfikowania i weryfikowania".

Celem niniejszej pracy jest pokazanie strategii komunikacyjnych wykorzystywanych w działaniach perswazyjnych przez mieszkańców wsi i przedstawienie ich specyfiki na tle kulturowym, socjologicznym, psychologicznym, co jest zjawiskiem zupełnie naturalnym w przypadku problematyki komunikowania się, która wymaga uwzględnienia rzeczywistości pozajęzykowej, czyli szeroko rozumianego kontekstu kulturowego. Wskazuję środki językowe i określam ich funkcję w związku z nadrzędnym celem, jakim jest perswazyjność oraz wyjaśniam, jakie miejsce zajmują one $\mathrm{w}$ całokształcie przekazu. W części poświęconej zagadnieniom teoretycznym (por. I.4.1. Różne ujęcia perswazyjnej funkcji języka; I.6. Perswazja a manipulacja językowa - określenie pojęć, stan badań) staram się spojrzeć na perswazję z perspektywy różnych stanowisk badawczych. W rozważaniach nad perswazyjną funkcją języka, która silnie angażuje odbiorcę, istotne wydaje się uwzględnienie szczegółów obyczajowych badanego środowiska, ponieważ nie można wpłynąć na zachowanie człowieka bez wzbudzenia zainteresowania treścią przekazu, bez odwołania się do jego emocji czy do jego świata wartości (por. Tokarski, Nowak 1999: 207-215).

W pracy przyjmuję założenie, że na proces komunikacji wpływają czynniki społeczne (typ kontaktu, role rozmówców, sytuacja itp.) oraz osobowościowe nadawcy i odbiorcy, a także biologiczne (wiek, płeć). Według B. Dunaja (1986b: 18) ,[...] występowanie pewnych wariantów językowych bywa zdeterminowane zjednej strony określonymi cechami socjalno-biologicznymi użytkowników języka, z drugiej zaś - sytuacją komunikacyjną, tzn. typem kontaktu językowego, relacją rangi (równorzędna - nierównorzędna) i typem relacji pomiędzy rozmówcami (ludzie obcy, znajomi, krewni)". Jednostka, posługując się językiem, selekcjonuje sposoby użyć form językowych ,zgodnie z wzorami interakcji przewidzianymi dla aktualnie realizowanej roli” (zob. Piotrowski, Ziółkowski 1976; Lubaś 1979b). 
Konwersację perswazyjną mieszkańców wsi, dotyczącą różnych okoliczności życiowych, przedstawiam na tle konkretnych sytuacji komunikacyjnych. Rozmowy analizuję z punktu widzenia wykorzystanych przez nadawcę środków służących nakłanianiu, szczególnie koncentrując się na procesach konstruowania wypowiedzi, pojawiających się w konkretnych, sytuacyjnie uwarunkowanych aktach użycia języka (por. Ziółkowski 1981: 197).

$\mathrm{W}$ badaniu zjawiska perswazji językowej w tekstach gwarowych istotne znaczenie mają obserwacje poczynione przez dialektologów. Analiza zachowań komunikacyjnych mieszkańców wsi pokazuje, że polszczyzna ludowa podlega współcześnie bardzo dynamicznym przeobrażeniom, bezpośredni i wyrazisty wpływ na gwary wiejskie mają polszczyzna ogólna i różne odmiany stylistyczne (zob. Zagórski 1998: 27). Dokładnie opisano zjawisko przełączania kodów jako problem socjo- i psycholingwistyczny (por. Kurek 1995), wskazując, że istotny wpływ na sposób porozumiewania się użytkowników gwary mają: wiek, wykształcenie, płeć rozmówców, ważną rolę odgrywa sytuacja, w jakiej odbywa się akt komunikacji: oficjalna - nieoficjalna, typ rozmowy czy rodzaj rozmówcy: gwarowy - niegwarowy, miejscowy - obcy (zob. Kurek 1994: 109-114; Pelcowa 1996).

W opracowaniach językoznawczych dialekt, który do tej pory definiowany był jako „mowa ludności wiejskiej pewnej dzielnicy kraju różniąca się od języka ogólnonarodowego i innych dialektów swoistymi cechami, głównie fonetycznymi i leksykalnymi” coraz częściej ujmowany jest nie tylko jako „lingwistyczna jednostka terytorialna, ale jednocześnie jednostka etnograficzna i kulturologiczna” (Tołstoj 1992: 19). Na gruncie socjologii wskazuje się, że: „Życie człowieka jest zarazem społeczne i kulturowe" (Nowicka 1991: 43-44), a w zakres kultury wchodzą także zachowania ludzkie. W naukach o kulturze stosuje się termin wzór kulturowy, który definiowany jest jako: „mniej lub bardziej ustalony w zbiorowości sposób zachowania się i myślenia" (Nowicka 1991: 77). Współzależność między systemem społecznym a systemem kultury A. Rodziński (1989: 27) określa następująco: „Osoba jako podmiot działań jest czymś wtórnym w stosunku do tego, w czym istnieje. Osoba w stosunku do kultury jest podstawowym i pierwotnym punktem wyjścia. Nie ma osoby, która by nie tworzyła kultury, ale też nie ma osoby, która by mogła rozwijać się bez kultury".

Posługując się określeniem gwara ludowa, przyjmuję znaczenie "mowa ludności wiejskiej z niewielkiego terytorium, przeważnie z kilku lub kilkunastu wsi, różniąca się od języka ogólnego i mowy sąsiednich okolic pewnymi cechami, zwłaszcza fonetycznymi i leksykalnymi, podrzędna w stosunku do dialektu' (Urbańczyk 1991: 58, 105) i określam tym terminem zróżnicowaną wewnętrznie polszczyznę mówioną współczesnej wsi, którą w znacznym stopniu kształtują czynniki zewnętrzne. Obecny stan gwary jest rezultatem wielowiekowego rozwoju, który jest procesem w znacznej mierze żywiołowym i niekontrolowanym.

W socjologii (zob. Kłoskowska 1983b) wyróżnia się trzy typy kontaktów społecznych: bezpośredni, instytucjonalny i masowy. A. Kłoskowska (1983b: 324-370) 
wprowadziła pojęcie trzech układów kultury: układ pierwotny, instytucjonalny i kultury masowych środków komunikowania. Przedmiotem moich badań jest pierwszy układ, do którego autorka zalicza kultury pierwotne i kultury wspólnot tradycyjnego typu: mała społeczność lokalna, wieś, sąsiedztwo. Wśród charakterystycznych cech tego układu wymienić należy przewagę styczności bezpośrednich: twarzą w twarz i nieformalnych. W takich wspólnotach, jak dowodzi M. Filipiak (1996: 62), komunikowanie jest ułatwione dzięki „bliskości psychofizycznej jej członków, podobieństwu ich życiowych losów i doświadczeń”. Przedmiotem moich badań jest układ kultury w kontaktach bezpośrednich, tj. osobistych i zindywidualizowanych, odpowiada mu polszczyzna potoczna, przejawiająca się w relacjach rodzinnych, sąsiedzkich oraz towarzyskich. Obszar prezentowanych i omawianych problemów ujmuję w kontekście faktów psychicznych, społecznych i kulturowych, ponieważ uważam, że działania komunikacyjne nadawcy (w tym również perswazyjne) determinowane są przez szereg czynników, wśród których najważniejsze są: psychologiczne (postawy, osobowość, samoocena), społeczne (struktura społeczna) i kulturowe (orientacje poznawcze, ekspresywne, wartościujące). Zakładam, że istnieje ścisła zależność między językiem a wiedzą i kulturą posługującej się nim grupy (por. Grabias 1994: 61-63). Badania potwierdzają, że: „W kulturze ludowej małych społeczności pojawia się jednak pewna forma przymusu nakazującego stosowanie się do form uświęconych tradycją" (Filipiak 1996: 64).

\section{Pojęcie perswazji i zasięg oddziaływań perswazyjnych}

Perswazja - istotny element komunikacji językowej, pomimo wielu prób, dotąd nie posiada precyzyjnej i powszechnie akceptowanej eksplikacji. Samo pojęcie ma wielopłaszczyznowy charakter i jest przez badaczy różnie definiowane. Wokół problematyki wywierania wpływu na myślenie, odczuwanie, a przede wszystkim na postępowanie odbiorcy, koncentrują się zainteresowania i polemiki przedstawicieli różnych dziedzin wiedzy. Badanie zagadnienia perswazji jest zasadne w związku z różnymi formami komunikacji językowej. Jeden z najwybitniejszych amerykańskich prawników G. Spence (2001: 7) pisze: „Sztuka perswazji i przekonywania to sztuka życia. Sprzeczamy się, wysuwamy argumenty, bo taka jest życiowa konieczność. Życie samo w sobie to nic innego, jak debata i spory”. Autor podkreśla, że perswazja ma doniosłe znaczenie w komunikacji, ponieważ uczymy się myślenia i rozumowania, słuchając tego, co mówią inni, sami także tworzymy wewnętrzne argumentacje, dzięki którym staramy się wpływać na innych.

Sztuka przekonywania odgrywa ważną rolę także w spontanicznej komunikacji interpersonalnej. Opublikowane dotąd prace, dotyczące nakłaniania, są przede wszystkim komentarzami do konkretnych mechanizmów perswazji publicznej i opierają się na analizie funkcjonujących w Polsce mass mediów. Opisują zabiegi 
występujące w polityce, szczególnie w działaniach propagandowych i marketingowych, zwłaszcza w reklamie i handlu. Perswazyjną funkcję języka łączono przede wszystkim z problematyką wolności i zniewolenia, badając różne typy dyskursów politycznych. Nie wyczerpuje to jednak całości problematyki, ponieważ zjawisko nie ogranicza się wyłącznie do sfery działalności publicznej, ale obejmuje także różne formy kontaktów codziennych, które charakteryzuje największa siła przekonywania. Obecnie badacze dostrzegają także istotną rolę perswazji w komunikacji potocznej. Z. Bokszański (1983: 18) uważa, że: „W świecie współczesnym, w którym wiele można zdobyć i stracić, kontakty potoczne stają się w coraz większym stopniu przesycone wątkiem działań strategicznych".

Treści perswazyjne można przekazywać w sposób jawny lub skryty, od komunikatów jawnie perswazyjnych po zabiegi subtelne, utajone, niedostrzegalne, stąd perswazja może przybierać różne formy językowego oddziaływania - od bardzo delikatnych wskazań, podpowiedzi, po wyraźne narzucanie własnych poglądów innym. W badaniach perswazji interpersonalnej należy skoncentrować się na: intencji nadawcy, sposobie ukształtowania przekazu oraz reakcji adresata komunikatu perswazyjnego. Działaniu słownemu nadawcy zawsze towarzyszy intencjalność, zamiar pragmatyczny, jaki mówiący pragnie zrealizować, kierując określony komunikat do odbiorcy. Wypowiedź można rozpatrywać w dwu perspektywach - z punktu widzenia intencji nadawcy, który poprzez dyskurs pragnie osiągnąć określony cel i z punktu widzenia odbiorcy, który może ten przekaz zaakceptować lub odrzucić.

Zakładam, że każdy poprawny tekst jest nośnikiem uporządkowanego pod względem logicznym i gramatycznym ciągu informacji, czyli komunikatu, który może realizować treść i kształtować postawę odbiorcy. W działaniach perswazyjnych ważna jest kwestia skuteczności, mająca związek z językiem, jakiego używa nadawca (Lubaś 1979b: 139-147). Formułując komunikat, nadawca musi dostosowywać repertuar środków wyrazu do możliwości percepcyjnych odbiorcy. Natomiast odbiorca, interpretując wypowiedź, może uzupełnić wiedzę na jakiś temat, odkryć jej głębszy podtekst, wydobyć na jaw aluzję, ukryty sens komunikatu i podzielić lub odrzucić sugestie nadawcy. Na sposób interpretowania komunikatu przez odbiorcę (zob. Szwabe 2008) istotny wpływ ma ocena informacji, po jej dokonaniu odbiorca może pozostać wobec przekazu obojętny, może się z nim zgodzić lub go zanegować, ponieważ, jak twierdzi Hymes (1980), znaczenie formy językowej (jej sens komunikacyjny) jest w pewnym zakresie potencjalne, musi być ukonkretnione przez odbiorcę w zależności od sytuacji jej użycia.

O skuteczności perswazji decyduje m.in. możliwość rozpoznania jej przez odbiorcę. Badanie zjawiska jest utrudnione, gdyż ten sam przekaz może być uznany w jednym przypadku za perswazję skuteczną, w innym za nieskuteczną, a kiedy indziej za przekaz łączący system wartości tożsamy nadawcy i odbiorcy. Co więcej, adresat wypowiedzi bezpośredniej może nawet nie być tożsamy $\mathrm{z}$ adresatem perswazji. 


\subsection{Czynniki warunkujące przekaz perswazyjny}

Do najczęściej opisywanych czynników skutecznej perswazji należą m.in.: waga zagadnienia, będącego przedmiotem przekonywania, wiarygodność źródła informacji i nadawcy przekazu, osobowość perswadującego, społeczny i kulturowy wizerunek instytucji prowadzącej perswazję, kontekst aktu perswazji. Z perspektywy systemu językowego na perswazyjną skuteczność przekazu ma wpływ użycie odpowiednich argumentów oraz sposób zestawienia środków językowych. Argumentacja (zob. Perelman 2004; Szymanek 2005) rozumiana jest jako aktywność myślowa związana z uzasadnieniem lub obaleniem tezy. Czynnikami uwarunkowanymi samym przekazem perswazji są: typy zastosowanych argumentów i kolejność ich przedstawienia, jednostronność/dwustronność argumentacji (kontrargumentacja), sposób traktowania argumentacji przeciwnej, wyrażania konkluzji explicite lub implicite, zróżnicowanie i stopień intensywności języka, sugestywność i kategoryczność wypowiedzi, zakres słownictwa oraz powtarzalność przekazu.

\subsection{Sposoby definiowania perswazji}

W opracowaniach dotyczących przekonywania wyodrębnia się działania perswazyjne o charakterze przemyślanym, wyreżyserowanym, będące rezultatem przygotowanej wcześniej i zastosowanej przez nadawcę strategii nakłaniania lub o charakterze żywiołowym, będące działaniem spontanicznym, gdy nadawca komunikatu nie jest motywowany obmyśloną wcześniej intencją informacyjną. K. Hogan (1996) uważa perswazję za umiejętność skłaniania ludzi do przyjęcia swoich przekonań i wartości poprzez oddziaływanie na ich myśli i zachowania przy użyciu specyficznych strategii i podejmuje próbę usystematyzowania perswazji, wyodrębniając dwie zasadnicze odmiany:

1) naturalną, nieuświadomioną skłonność do informowania rozmówcy o czymś z intencją, aby ta informacja została przyjęta z aprobatą lub z dezaprobatą zgodnie z zamiarem nadawcy, z czego może on czerpać satysfakcję,

2) wyreżyserowaną, „spektakl teatralny”, w którym scenariusz i aktorstwo bierze na siebie nadawca, a odbiorcy pozostawia rolę aktywnego widza nakłanianego do przejmowania przekonań i postaw oraz wykonywania czynności zalecanych przez jego rozmówcę.

W konsekwencji tego rozróżnienia perswazję można podzielić na:

1) naturalna, z udziałem (wyłącznie lub w przeważającej mierze) argumentów jako racjonalnego składnika nakłaniającego - perswazja naturalna racjonalna, z udziałem wyłącznie lub w przeważającej mierze emocji jako składnika nakłaniającego - perswazja naturalna emocjonalna z udziałem wyrazów ekspresywnych, 
2) strategiczna (planowaną, obmyślaną), która jest używana w wypowiedziach życzeniowych pragmatycznych, na przykład w niektórych tekstach publicystycznych i literackich, gdzie wykorzystuje się swoistą grę słowami (Lubaś 2006: 44).

Typowymi narzędziami perswazji są np.: apele budzące lęk (bądź inną emocję), rekomendacja popularnej lub szanowanej osoby, tropy i figury retoryczne. W języku perswazji wykorzystuje się trzy techniki oddziaływania na odbiorcę: apelowanie o zajęcie określonego stanowiska i podjęcie określonych działań; sugerowanie pożądanej interpretacji rzeczywistości i jedynie słusznego systemu wartości; argumentowanie, czyli racjonalne uzasadnienie prawdziwości i wagi przedstawionych treści.

Ze względu na stopień zaangażowania odbiorcy w procesie komunikacji możliwe są dwa sposoby osiagnięcia celu perswazji: centralny (zakłada wysoki stopień zaangażowania odbiorcy i jego krytyczne podejście do zawartości komunikatu) i peryferyjny (zaangażowanie adresata komunikatu jest niskie).

\section{Historia i stan badań nad perswazją}

Badania nad perswazją mają długą tradycję. Z możliwości wpływania na człowieka zdawali sobie sprawę już filozofowie starożytni, którzy wskazywali, że język jest nie tylko narzędziem przekazywania informacji, ale również środkiem oddziaływania na poglądy i zachowania innych ludzi. Zbiór technik właściwych przekonywaniu najwcześniej stanowił przedmiot zainteresowania retoryki i poetyki. Teoretyczne zasady i przepisy wymowy, wskazówki praktyczne ilustrowane przykładami, w jaki sposób mówić, by inni słuchali i przyjmowali określone poglądy i postawy, znaleźć można w wielu podręcznikach retoryki i poetyki. Wskazywały one i uczyły, jak pięknie mówić i pisać.

W retoryce - sztuce wyzwolonej - istotną rolę odgrywała umiejętność przekonywania, rozumiana jako dydaktyczne, emocjonalne i estetyczne oddziaływanie na odbiorcę. Retoryka była sztuką mówienia. Retorzy uważnie czytali i studiowali dawnych autorów, sięgali do wzorów klasycznych, ujmowali oracje w reguły kompozycji i rytmu.

W teorii retorycznej, stworzonej przez Arystotelesa, perswazja pojmowana jest jako wpływanie na przekonania odbiorcy za pomocą mowy przez oddziaływanie na jego rozum, wolę i emocje. Wyjątkowo cenili umiejętność przekonywania greccy sofiści, którzy uczyli sztuki mówienia i argumentacji, doskonalili się w biegłości prowadzenia sporów i skutecznego obalania argumentacji przeciwnika, czyli erystyce. Współcześni sofistom Sokrates i Platon zajmowali się dialektyka, tj. umiejętnością dochodzenia prawdy i przekonywania poprzez sekwencje pytań i odpowiedzi. Jednym z największych mówców starożytnej Grecji był Demostenes, doskonałym mówcą i nauczycielem retoryki w starożytnym Rzymie 
był Cyceron (właśc. Marcus Tullius Cicero; 106-43 p.n.e), uważany za autorytet w sztuce przekonywania i argumentacji, najbardziej znany orator starożytności, mówca, filozof i polityk, którego dorobek literacki stanowią dzieła retoryczne: O mówcy, Brutus, Orator, a także rozprawy filozoficzne: O państwie, O powinnościach, O granicach dobra i zła. Trzysta lat później Augustyn w czwartym tomie dzieła $O$ doktrynie chrześcijańskiej poświęcił wiele miejsca retoryce. Uznawał, że celem nadrzędnym każdego przemówienia powinno być poszukiwanie prawdy.

W wiekach średnich retoryka stała się jedną z siedmiu sztuk wyzwolonych, domeną jej zainteresowania była umiejętność wygłaszania mów oraz pisania listów. Znaczenie sztuki wysławiania się w mowie i piśmie umocnił okres renesansu. Na początku XX wieku, w 1910 roku na uniwersytetach amerykańskich wyodrębniła się nowa dyscyplina o nazwie comunication, która szybko upowszechniła się na uczelniach całego świata.

\subsection{Różne ujęcia perswazyjnej funkcji języka}

Na gruncie polszczyzny perswazja jest różnie ujmowana, toteż jej definicja wymaga uściśleń i ograniczeń. Wyraźniejszemu objaśnieniu istoty i mechanizmów perswazji językowej oraz określeniu jej granic służy przegląd definicji słownikowych i różnych stanowisk badawczych. Jak wyjaśnia M. Korolko (1998: 32), pojęcie perswazja etymologicznie wywodzi się od łacińskiego persuasio 'przekonywanie, wiara, uspokojenie, opinia', jest przekładem greckiego czasownika peitho 'namawiać, nakłaniać, starać się przekonać, radzić, zachęcać, ustąpić, oczarować, zwabić, zjednać'. Opracowania leksykograficzne podkreślają różne aspekty perswazji. Definicję czasownika: ,perswadować - [...] namawiać do czego; [...] i rzeczownika perswazya [...] namawianie do czego, namowa [...]" podaje Linde w Stowniku języka polskiego (1854-1860), synonimy leksemu: perswada, perswadunek, perswadowanie, namowa; doradzanie a. odradzanie, przektadanie komu zawiera nieco późniejszy słownik (Słownik języka polskiego 1900-1927). Opracowania z XX wieku zawierają objaśnienia podobne do definicji historycznych. W Stowniku języka polskiego (Doroszewski 1958-1969) perswazja definiowana jest jako: „tłumaczenie komu czego, przekonywanie kogo o czym: perswadowanie” oraz z kwalifikatorem daw. „przekonywanie, przeświadczenie, rozumienie”, w Stowniku wyrazów obcych i zwrotów obcojęzycznych z almanachem (Kopaliński 2007: 69) jako: „,przekonanie; wiara; opinia; przesąd”. Kolejny słownik (Stownik języka polskiego 1979) podaje definicję hasła perswazja: „tłumaczenie komuś czegoś, namawianie, odradzanie; przekonywanie kogoś o czymś; perswadowanie”, ponadto zawiera czasownik perswadować: „tłumaczyć coś komuś, przekonywać kogoś o czymś, dowodzić coś komuś". W Słowniku współczesnej polszczyzny (Dunaj 1996) wyraz perswazja objaśniony jest jako: „wpływanie na kogoś w celu skłonienia go, by w coś uwierzył” oraz „,przekonywanie, tłumaczenie”, w definicji 
leksemu podkreśla się czynnik retoryczny. Część opracowań słownikowych podnosi w definicji kwestię argumentacji, np. Stownik wyrazów obcych (Stownik wyrazów obcych 2002) wskazuje, że głównym celem perswazji jest argumentowanie: „przekonywanie o czymś, namawianie lub odradzanie z przytoczeniem argumentów popierających słuszność zdania". Podobną definicję perswazji zawiera Słownik terminologii medialnej (Pisarek 2006: 144), według którego jest to: ,proces świadomego namawiania, nakłaniania, przekonywania kogoś do czegoś, polegający na wykorzystaniu argumentacji słownej, a więc wykluczający użycie siły". W Małym słowniku terminów z zakresu socjolingwistyki i pragmatyki językowej (Skudrzykowa, Urban 2000: 110-111) podkreśla się, że perswazja jest jednym ze specyficznych przejawów funkcji impresywnej języka, jest to: ,sposób wykorzystania języka, polegający na oddziaływaniu jednych na drugich. Człowiek - istota społeczna - przez całe życie sam przekonuje i jest przekonywany przez innych (wychowanie, terapia, polityka, reklama). Przedmiotem perswazji może być każda sprawa, a perswadujący ma zamiar skłonić odbiorcę do przyjęcia akceptowanych przez siebie wartości”.

W działaniach perswazyjnych istotne znaczenie ma respektowanie wolności wyboru odbiorcy. Poszczególni badacze zjawiska różnie rozumieją i wyjaśniają pojęcie, niektórzy traktują perswazję jako takie działanie nadawcy, które zmusza odbiorcę do zmiany stanu mentalnego, postawy i/lub zachowania (zob. Laskowska 2007: 93), inni wskazują, że jest to: ,proces świadomego namawiania, nakłaniania, przekonywania kogoś do czegoś, polegający na wykorzystaniu argumentacji słownej, a więc wykluczający użycie siły”, celem perswazji jest „przekonanie o słuszności swojej tezy w dyskusji, podtrzymanie jej aż do uzyskania korzystnego dla siebie wyroku albo wykazanie zalet omawianego zdarzenia, czy osoby" (Pisarek 2006: 144-145).

W definicji perswazji wskazuje się również na sposób ukształtowania komunikatu językowego. W językoznawstwie lat siedemdziesiątych i osiemdziesiątych ze względu na ówczesną sytuację polityczną pojęcie perswazji łączone było z działaniami mającymi na celu wpływanie na cudze poglądy i postawy w sposób niejawny, poza świadomością odbiorcy. Takie ujęcie można znaleźć w opracowaniu S. Barańczaka (1975: 49), według którego ,perswazyjna funkcja wypowiedzi jest szczególną odmianą funkcji konatywnej, polegającej na usiłowaniu uzyskania realnego wpływu na sposób myślenia lub postępowania odbiorcy, jednakże nie drogą bezpośredniego rozkazu, lecz metodą utajoną i pośrednią tak, iż w wypowiedzi dominuje z pozoru inna niż konatywna funkcja językowa (np. funkcja estetyczna, poznawcza, emotywna itp.)". Autor wymienia cztery mechanizmy stosowane w tekstach kultury masowej w funkcji perswazyjnej:

- mechanizm emocjonalizacji odbioru i bezrefleksyjnej percepcji, który jest często wykorzystywany, gdy nadawca stara się osłabić możliwości intelektualne i refleksyjne odbiorcy, a spotęgować nastawianie emocjonalne,

- mechanizm wspólnoty świata i wspólnoty języka, czyli spełnienie warunku pełnego porozumienia, mechanizm polegający na wykorzystywaniu sformułowań, które tworzą pozory jakiegoś „my” oraz sugerują wspólnotę interesów 
i wartości, owemu umacnianiu wspólnoty towarzyszy niekiedy negatywne wartościowanie ,innych”, „obcych”,

- mechanizm uproszczenia nieskończonej skali aksjologicznej i zredukowania jej do czarno-białego przeciwstawienia wartości ,naszych”, czyli pozytywnych i „obcych”, czyli negatywnych, ponieważ perswazja kieruje się zawsze przeciw czemuś i w imię czegoś, w tekstach perswazyjnych nie ma miejsca na wartości pośrednie,

- mechanizm odbioru bezalternatywnego, czyli zwolnienie od decyzji, polegający na tym, że wypowiedzi nadawcy pozornie odwołują się do wolnej woli odbiorcy, w rzeczywistości są jednak tak sformułowane, aby odbiorca poczuł się całkowicie zwolniony z samodzielnych decyzji interpretacyjnych, gdyż czuje, że wybór jest tylko jeden.

Na sposób ujmowania perswazji, jak podkreśla I. Kamińska-Szmaj (2004: 20), mają wpływ także poszczególne odwołania badawcze: „Pojęcie perswazji definiuje się z jednej strony w nawiązaniu do tradycji retorycznej, z drugiej zaś, do teorii funkcji językowych oraz teorii aktów mowy. W klasycznej teorii retorycznej, której fundamenty stworzył Arystoteles, perswazja jest rozumiana jako wpływanie na przekonania odbiorcy za pomocą mowy poprzez oddziaływania na jego rozum, wolę i emocje”. Natomiast „W teorii funkcji językowych słowne oddziaływanie nadawcy na odbiorcę określa się terminami: funkcja apelatywna, dyrektywna, nakłaniajaca, konatywna, impresywna, perswazyjna [podkr. - B. B.-R.]”.

Zdaniem R. Grzegorczykowej (1985: 379), funkcja perswazyjna polega na wytwarzaniu u odbiorcy pewnego stanu przekonaniowego, ukształtowaniu w nim ocen i poglądów, a cel ten uzyskuje się przede wszystkim poprzez przekazanie emocji i ocen ukrytych w używanych wyrazach. Pomaga temu cały system presupozycji, a więc poglądów założonych jako wspólne nadawcy i odbiorcy tekstu, przyjmowanych bez refleksji, one właśnie kształtują w sposób nieświadomy dla odbiorcy jego postawę".

Z kolei J. Warchala (2004: 50) wskazuje, że: „Perswazja ma naturę językową, wiąże się z funkcją znaku w procesie wymiany komunikacyjnej i może być ujawniona poprzez formalną analizę reguł użycia języka. Ma ona swoje eksponenty na wszystkich poziomach struktury języka, na płaszczyźnie suprasegmentalnej, w zastosowanej leksyce, konstrukcji tekstu i jego warstwie informacyjnej, a także może wykraczać poza język, gdy zastosowanie znaku językowego (np. jego wybór) uwarunkowane jest kulturowo".

W opracowaniach dotyczących perswazji wskazuje się na etykę zachowań komunikacyjnych rozmówców, oddzielając nieuczciwe, ukryte wpływanie na postawy i decyzje ludzi od perswazji, która rozumiana jest jako: ,proces komunikacyjny mający na celu wywarcie wpływu na sposób postrzegania świata przez odbiorcę (zmianę lub modyfikację jego postaw poglądów, wierzeń, przekonań, sądów) w celu osiągnięcia określonych efektów perlokucyjnych z zaznaczeniem, że odbiorca musi dysponować wolnością wyboru" (Lewiński 2001: 292). 
P. H. Lewiński (2001), który nieco inaczej postrzega i traktuje perswazję, wskazuje, że istnieją trzy sposoby rozwiązywania sprzeczności między nadawcą i odbiorcą: przymus, refleksja i perswazja. Perswazję określa jako: „usiłowanie uzyskania realnego wpływu na sposób myślenia lub postępowania odbiorcy, jednakże nie drogą bezpośredniego rozkazu, lecz metodą pośrednią, poprzez podporządkowanie założonemu celowi wszystkich pozostałych zachowań komunikacyjnych, które odbiorca byłby w stanie zrozumieć i właściwie zinterpretować" i zakłada, że: „każdy człowiek, posługując się inteligencją i etyką, jest zdolny rozpoznać, co jest dobre i prawdziwe, i jest $\mathrm{w}$ stanie na podstawie przedstawionych argumentów podjąć właściwą decyzję". Wskazuje, że istota perswazji zakłada konieczność dokonywania wyboru. Perswazja jest zatem działaniem ,etycznym, demokratycznym i koniecznym w każdej grupie społecznej" (Lewiński 2001: 284-285), jej celem jest dążenie do zmiany przekonań i postaw odbiorcy względem jakiegoś odcinka rzeczywistości w taki sposób, aby przystawały, a w końcu zrównały się z przekonaniami i postawami reprezentowanymi przez nadawcę.

W wielu opracowaniach podkreśla się, że zjawisko perswazji opiera się na wartościowaniu, a wypowiedzi perswazyjne zawierają w swej strukturze jakiś element wartościujący, w którym przejawia się swego rodzaju imperatywność. Do zabiegów służących wyrażaniu wartości należą także środki parajęzykowe: gesty, intonacja, symbolika dźwiękowa i graficzna oraz środki językowe: fleksyjne, słowotwórcze, składniowe i leksykalne, a także frazeologizmy i figury stylistyczne, które szczegółowo analizowała J. Puzynina (1992). Badaczka (1992: 214) traktuje perswazję jako działania mające na celu kierowanie postawami odbiorcy bez wartościowania negatywnego nadawcy i bez groźby stosowania sankcji. Umieszcza perswazję wśród takich działan, jak: przekonywanie, namowa, rada i podkreśla, że czynnikiem różnicującym działania jest element aksjologiczny, tj. uczciwość w perswazji wobec nieuczciwości w manipulacji. Istotą funkcji impresywnej jest wpływanie na odbiorcę i kształtowanie jego postaw (uczuć, poglądów i woli) lub skłanianie go do pewnych zachowań (zob. Puzynina 1987: 168).

Ze względu na intencje wypowiadającego przeprowadza się zróżnicowanie funkcji nakłaniającej w zależności od tego, czy nacisk na odbiorcę ma na celu wywołanie działania słownego (pytania lub dyrektywy: rozkazu, groźby, prośby), czy dąży do wpłynięcia zwłaszcza na stan mentalny odbiorcy poprzez perswazję (rady i innego typu wypowiedzi wartościujące), bądź poprzez działanie unikające jawnego postrzegania (zob. Grzegorczykowa 1991: 24) i wyodrębnia różne aspekty nakłaniania: dyrektywność i perswazję (Bralczyk 1987: 18). J. Bralczyk dyrektywność określa jako „wezwanie do aktywnych zachowan”, perswazję traktuje jako „wypowiedzi stymulujące postawy, które z kolei powinny sprzyjać pożądanym zachowaniom".

Natomiast I. Kamińska-Szmaj (2004: 13-27) łączy perswazję z propagandą i mówi wówczas o nakłanianiu. Istotną cechą definicyjną perswazji jest pozostawienie wyboru zachowania czy wyboru postawy samemu odbiorcy. To znaczy, że 
każdy człowiek, posługując się własnym rozumem i etyką, weryfikuje przedstawione argumenty i rozpoznaje, co jest dobre i prawdziwe, następnie na tej podstawie podejmuje właściwą decyzję. To odbiorca ma możliwość wyboru.

Wyróżnia się perswazję uczciwa i nieuczciwa. Ta druga bywa utożsamiana z manipulacją, której działanie polega na kierowaniu podświadomością jednostki, bez poszanowania prawa odbiorcy do samodzielnego podejmowania decyzji.

Badacze zgodnie podkreślają, że najważniejszym kryterium oceny perswazji jest jej skuteczność, na którą ma wpływ decyzja odbiorcy, bo to „on ma przecież odrzucić swoje dawne poglądy i przyjąć sposób myślenia sugerowany przez nadawcę" (Mamcarz 1996: 22-23).

Z zagadnieniem perswazyjnego wpływania na świadomość słuchaczy poprzez stosowanie potencjału środków wartościujących wiąże się pojęcie stylu perswazyjnego (zob. Siwek 1992: 162). Jego istota przejawia się w odpowiednim doborze słów, odznacza się on nasyceniem pewnymi typowymi wyrazami oraz zabiegami stylistycznymi, mającymi na celu ukierunkowanie odbioru wypowiedzi. Badania lingwistyczne pokazują, że perswazji służy argumentacja oraz systemowe środki, perswazyjny charakter może mieć sam wybór elementów rzeczywistości, o których nadawca mówi w tekście, także organizacja tekstu, ponieważ perswazja może obejmować każdy etap komunikacji.

Ze względu na zróżnicowanie działań perswazyjnych wyróżnia się perswazję: polityczna, ideologiczna, handlowa, natomiast ze względu na zasięg oddziatywania: perswazję interpersonalna i publiczna. Typowym przykładem tej pierwszej jest doraźna perswazja obejmująca komunikację w niewielkich grupach, z kolei perswazja publiczna może mieć charakter doraźny, agitujący (celem nadawcy jest skłonienie odbiorcy do przyjęcia poglądu lub podjęcia natychmiastowego działania) albo też dtugotrwaty - nakłaniający (instytucjonalni nadawcy przekonują masowych odbiorców do przyjęcia określonej ideologii). Zwykle perswazja publiczna odbywa się za pomocą mediów masowych. Typowymi odmianami perswazji publicznej są propaganda i reklama.

Większość badaczy wskazuje, że perswazja dotyczy sytuacji, gdy przekonywanie odbiorcy odbywa się w warunkach wolności, a efekt perswazji zależy od siły i sposobów argumentowania. W literaturze wyróżnia się pięć koncepcji perswazji (Mamcarz 1996):

1) koncepcja behawiorystyczna - odwołuje się do wzajemności oddziaływania perswazji. Sama perswazja traktowana jest jako pewien bodziec, akcja, która wywołuje odpowiednie reakcje odbiorcy. Pierwszą reakcją na bodziec jest zmiana zachowania, a skutkiem - zmiana postawy. Perswazja skierowana jest tu na wywołanie u odbiorcy postaw aktywnych; w psychologicznym aspekcie perswazja przedstawia sięjako zbiór pewnych motywów i reguł postępowania, form ekspresji, nakazów i zakazów, ocen i sądów, poprzez które nadawca oddziałuje na odbiorcę,

2) koncepcja „,wolnościowa” - zakłada rozróżnienie między perswazją a przymusem. Przekonywanie może odbywać się w warunkach wolności. Podob- 
na cecha ujawnia się w koncepcji retorycznej, jednak w koncepcji wolnościowej chodzi także o wolność wewnętrzną,

3) koncepcja „głęboka” - zwraca uwagę na oddziaływanie perswazji na osobowość i psychikę człowieka. Istotne znaczenie ma nie tyle dokonana przez perswazję modyfikacja zachowania odbiorcy, co raczej głębsze i bardziej trwałe przekonanie go. Perswazja istnieje o tyle, o ile uda się skłonić adresata do przyjęcia określonej postawy, poglądu, sposobu myślenia. Najpierw dokonuje się w odbiorcy weryfikacja dotychczasowego sposobu patrzenia na świat, a dopiero później wynika z tego konkretna aktywność,

4) koncepcja Barańczaka - w swojej definicji autor podkreśla tajność, pośredniość nakłaniania; funkcję perswazyjną wypowiedzi ujmuje jako szczególną odmianę funkcji konatywnej, polegającą na usiłowaniu uzyskania realnego wpływu na sposób myślenia lub postępowania odbiorcy, jednak nie drogą bezpośredniego rozkazu, lecz metodą utajoną i pośrednią, tak że w wypowiedzi dominuje z pozoru inna niż konatywna funkcja językowa (np. funkcja estetyczna, poznawcza, emotywna itp.),

5) koncepcja retoryczna, w której ważną rolę odgrywa relacja między przekonującym a przekonywanym. Relacja ta jest nieproporcjonalna, ponieważ nadawca jest niemal wszechwładny nad odbiorcą komunikatu. Istotne jest wywołanie w kimś stanu wewnętrznego zwanego przekonaniem. W tej koncepcji skutek, jakim jest przekonanie rozmówcy, osiąga się wszelkimi (względnie uczciwymi) sposobami.

W kontekście wymienionych koncepcji można wskazać cechy i sfery oddziatywania perswazji oraz jej rodzaje. Perswazja jest syntezą różnorodnych działań i oddziałuje na różne sfery osobowości człowieka - od zwykłej reakcji na bodziec (konkretne zachowanie) przez emocje, język, aż po przyjęcie określonego światopoglądu, jest dwuwymiarowa - negatywna i pozytywna, może być jawna lub utajona. Wpływa ona na zachowanie, emocje, język, myślenie. W każdej z tych sfer może oddziaływać wprost lub pośrednio. Istotne znaczenie w perswazji ma wiele elementów, np.: dobór słów, jasność wypowiedzi, wybór argumentów, celność uwag itp. Perswazji sprzyja wiarygodność i naturalność.

Wyróżnia się etyczna perswazję, która polega na okazaniu odbiorcy szacun$\mathrm{ku}$, zbudowaniu sugestii wskazującej, że realizacja tego, co nadawca proponuje, pozwoli na osiągnięcie przez odbiorcę sukcesu oraz perswazję nieetyczna, odwołującą się do szantażu, korupcji, zastraszania, przymusu.

Perswazja jest działaniem językowym, polegającym na doborze informacji oraz środków językowych, dzięki którym wybrane zdarzenia, osoby i cechy mogą zostać przedstawione w sposób życzliwy, z sympatią lub nieuprzejmie, uszczypliwie. W. Lubaś (zob. 2006: 44) twierdzi, że: „Pierwszorzędnym celem perswazji nie jest logicznie poprawne dowiedzenie słuszności jakiegoś poglądu, tylko uzyskanie wpływu na odbiorcę. Wielostronne oddziaływanie na stan wewnętrzny i procesy motywacyjne odbiorcy dokonują się w perswazji poprzez 
zastosowanie środków zaczerpniętych z bogatego arsenału technik łączących elementy intelektualne $\mathrm{z}$ emocjonalnymi i estetycznymi. Wzajemny stosunek między zamiarem perswazyjnym a emocjami uczestników aktu mowy i skutecznością wybranej strategii nie jest łatwy do uchwycenia, a tym bardziej do oceny. Potencjał emocjonalny perswazji polega na tym, że są one z jednej strony nosicielami jakiś uczuć, które wzmacniają lub zubażają argumentację, a z drugiej strony są zawsze nosicielami wartościowania przedmiotu, o którym mówi komunikat".

We współczesnych opracowaniach nie ma jednej, powszechnie akceptowanej definicji dla określenia perswazji. Na podstawie przeglądu różnych koncepcji perswazji można podjąć próbę ich usystematyzowania według następujących kryteriów:

- podmiot perswazji,

- istota procesu,

- czas trwania,

- postawa nadawcy,

- postawa odbiorcy,

- czynniki oddziałujące na przebieg procesu,

- charakter oddziaływań.

Ze względu na podmiot perswazji można wyróżnić: perswazję publiczna i interpersonalna; podstawowym podmiotem perswazji jest jednostka lub grupa, która w trakcie oddziaływania przyswaja sobie cele, wartości, normy i wzory zachowań nadawcy i w ten sposób przystosowuje się do jego wymagań.

Czynniki perswazji, które oddziałują na przebieg i efekty perswazji, można podzielić na trzy grupy: uwarunkowania $i$ wpływy makrospołeczne, czynniki bezpośredniego otoczenia jednostki, cechy osobowościowe (temperament, zainteresowania, charakter) nadawcy i odbiorcy przekazu perswazyjnego.

Charakter oddziaływań czynników perswazji jest kolejnym zagadnieniem, które dzieli badaczy perswazji na dwie grupy. Jedni akcentują bardziej jednokierunkowy wpływ perswadujacego, drudzy zaś podkreślają świadomy i aktywny udział samych odbiorców w procesie perswazji.

Wszyscy cytowani autorzy traktują perswazję jako proces powodujący występowanie zmian w zachowaniu jednostki.

W literaturze spotyka się również szerokie rozumienie perswazji, to znaczy takie, które obejmuje wszelkie oddziaływanie przynoszące wartość odbiorcy, jak też destrukcyjne, zapewniające wartość jedynie nadawcy.

Na podstawie przeglądu i systematyzacji różnych koncepcji perswazji można podjąć próbę sformułowania takiego opisu zjawiska, który wyraża jego istotę i obejmuje podstawowe jego elementy:

- perswazję można najogólniej określić jako proces stałych interakcji między przekonywanym/-ymi a przekonującym,

- proces ten obejmuje różne grupy i różne typy kontaktu, 
- w procesie perswazji można wyróżnić dwa wymiary: subiektywny, ujmujący to zjawisko z punktu widzenia uczestników komunikacji perswazyjnej i obiektywny, formułowany na podstawie obserwacji badacza.

Można powiedzieć, że perswazja obejmuje te procesy, w których jednostka dostosowuje swoje zachowania do oczekiwań odbiorcy, względnie im się przeciwstawia. Perswazję można rozpatrywać z punktu widzenia skuteczności oddziaływań, w sytuacji przystosowania się odbiorcy do wymagań nadawcy, lecz trzeba w niej widzieć proces, którego wynik każdorazowo jest trudny do przewidzenia, bowiem odbiorca może okazać się wobec działań nadawcy aktywny lub bierny.

Perswazja językowa jest zjawiskiem fascynującym, ale i niebezpiecznym. Stanowi ważny element komunikacji związany z wkraczaniem w sferę zachowań człowieka. Istotą działań perswazyjnych jest komunikowanie się, które ma doprowadzić do ukształtowania określonych postaw odbiorcy. Stosowanie perswazji polega, w miarę możliwości, na łącznym odwoływaniu się do rozumu, woli i uczuć adresata za pomocą dostępnych we wspólnej dla nadawcy i odbiorcy kulturze środków językowego i pozajęzykowego oddziaływania (zob. Pisarek 2006: 144-145).

Syntetyczną definicję zjawiska podaje K. Szymanek (2005: 228), traktując perswazję jako: „świadome użycie znaków i symboli, a zwłaszcza pisanego i mówionego słowa, obrazu itp. w celu wywarcia wpływu na czyjeś przekonania, postawy i decyzje: zdobycia czyjejś akceptacji dla proponowanych poglądów, sposobu zachowania, decyzji".

\subsection{Opracowania dotyczące różnych aspektów perswazji językowej}

Istota $\mathrm{i}$ rola perswazji $\mathrm{w}$ komunikacji językowej jest zagadnieniem we współczesnej literaturze szeroko omówionym (zob. Pisarek 2003: 9-17; Batko 2005; Stefańczyk 2008). Zjawisko było przedmiotem dociekań naukowych począwszy od starożytności do czasów współczesnych, a zabiegi, które mu służą, ludzkość stosowała od tysiącleci w różnych działaniach i w różnych typach komunikacji. Współcześnie perswazja analizowana jest na tle retoryki, tradycyjnie rozumianej jako sztuka wymowy, przemawiania i jest pojmowana jako „sztuka argumentacji” (por. Ziomek 1990; Dubisz 1992; Lichański 1996; Korolko 1998; Lewiński 1999; Przybylska, Przyczyna 2001; Fish 2002; Pisarek 2002; Korolko 2003; Obremski 2004; Perelman 2004; Turk 2004; Rusinek, Załazińska 2005; Marcjanik 2006).

Słowne oddziaływanie nadawcy na odbiorcę badano także w kontekście teorii funkcji językowych, gdzie określa się je następującymi terminami: funkcja apelatywna, dyrektywna, nakłaniajaca, impresywna, konatywna, perswazyjna (zob. Pisarek 1974: 175-179; Grzegorczykowa 1991). Bogatą dokumentację ma analiza perswazji we współczesnym językoznawstwie, m.in. w ramach lingwistyki 
tekstu i gramatyki funkcjonalnej. Szczegółowo opisano teorię i praktykę publicznej perswazji, o czym świadczy wszechstronność opracowań i ich zróżnicowanie tematyczne, obejmujące płaszczyznę polityczną, prawną, gospodarczą, społeczną, wychowawczą czy kulturową. Nie jest możliwe wskazanie opracowań dotyczących wszystkich aspektów funkcjonowania perswazji, z konieczności wymieniam jedynie niektóre, omawiające metody, strategie i techniki, które w różnych typach dyskursu pozwalają nadawcy sterować zachowaniami odbiorców.

Istotne znaczenie w badaniu perswazji mają ujęcia o charakterze interdyscyplinarnym (zob. Garpiel, Leszczyńska 2004). Liczne opracowania teoretyczne dotyczą metodologii i teorii perswazji, a literatura opisująca zjawisko jest rzetelnie udokumentowana w opracowaniach krajowych (zob. Szymanek 1999; Wieczorek 1999; Mosiołek-Kłosińska, Zgółka 2003; Batko 2005; Doliński 2005; Szymanek, Wieczorek, Wójcik 2005; Lubaś 2006; Tokarz 2006) i zagranicznych (Reardon 1981; Grać 1985; O’Keefe 1990; Cialdini 1999; Spence 2001; Pratkanis, Aronson 2003). Ponieważ perswazja jest działaniem z pogranicza psychologii społecznej, etyki, pragmatyki oraz lingwistyki, była i jest przedmiotem zainteresowania różnych dyscyplin badawczych, zwłaszcza nauk humanistycznych: psychologii, socjologii, filozofii, politologii, logiki, etyki i językoznawstwa.

Zjawisko stanowiło obiekt wnikliwej analizy zwłaszcza na gruncie nauk psychologicznych (zob. Kozielecki 1975; Wojciszke 2006), a w opracowaniach z zakresu psychologii wskazywano nowoczesne metody psychoterapeutyczne, wzbudzające lub thumiące pobudki do pewnych działań. K. Dąbrowski $(1975 ; 1979)$, badając oddziaływanie zabiegów perswazyjnych na psychikę człowieka, wykazywał, że perswazja wpływa na sferę zachowań i reakcji międzyludzkich, skłania jednostki i grupy do określonych poczynań, służy korygowaniu zachowań człowieka wobec innych ludzi. Znaczenie perswazji jest szczególnie ważne w terapii, obecnie powstają specjalistyczne firmy szkoleniowe, zatrudniające psychologów i trenerów personalnych, którzy prowadzą treningi z technik komunikacji oraz negocjacji. Przygotowuje się opracowania i specjalne programy, mające na celu poprawę porozumienia między małżonkami, rodzicami i dziećmi (zob. Covey 2003) czy osobami wspólnie pracującymi, analizowane są efekty psychicznych oddziaływań na ludzi w środowisku rodzinnym, w szkole i w zespołach pracowniczych. Mechanizmy perswazji, techniki wpływu i motywację w celu tworzenia dobrych relacji międzyludzkich opisują specjaliści w zakresie poradnictwa rodzinnego oraz zarządzania i pracy zespołowej (Benedikt 2003; Kobjoll 2004; Ślósarska 2000: 45-50; Brzeziński 2008). Istotnym elementem perswazji w relacjach zawodowych jest pobudzanie kreatywności oraz zwiększenie zaangażowania osób w wykonywaną pracę. Wiele współczesnych opracowań i poradników, omawiających najnowocześniejsze strategie psychologiczne, przedstawia mechanizmy rządzące ludzką psychiką, których znajomość sprawia, że jednostki lub grupy ulegają określonym sugestiom (zob. Brown 1996; Carnegie 1996; Hogan 1996; Liberman 2005; Sujak 2006). 
Perswazja była także przedmiotem refleksji filozoficznej (zob. Austin 1987), socjologicznej (Marody 2003: 18-27; Hałas 2001) i politologicznej (Karwat 1999; 2006), podejmowano próby rozgraniczenia terminów: perswazja i manipulacja oraz propaganda (zob. Kamińska-Szmaj 2004: 13-27; Kudrowie 2004: 91-100), stosowanych zwłaszcza w opisie języka polityki. Zainteresowanie problematyką i początki badań perswazji w Polsce są ściśle związane właśnie z dyskursem politycznym, w którym perswazyjna funkcja języka wykorzystywana jest do kształtowania światopoglądu. We współczesnej lingwistyce badania związane z językiem jako instrumentem władzy społecznej zajmują ważne miejsce. Badacze perswazji ideologicznej, która dostarcza obfitego materiału językowego, szczególnie w obszarze zjawisk propagandowych (zob. Wojtasik 1973; Dobek-Ostrowska, Fras, Ociepka 1997), wskazywali, że język może deformować rzeczywistość i stać się narzędziem manipulacji. Badaniom różnych metod i płaszczyzn komunikacji ideologicznej poświęcono wiele opracowań z zakresu mechanizmów, metod i technik działania, traktujących o deformacji życia politycznego (Bednarczuk 1981: 93-102; Bralczyk 1981a: 336-354;Barańczak 1983; Dubisz 1983: 150-158; Grzegorczykowa, Bartmiński 1999; Głowiński 1991a; 1991b; Pabijańska 2007). Szczegółowo przedstawiano PRL-owską propagandę i charakterystyczne dla niej metody budowy dyskursu, funkcjonujące w nim formuly propagandowe, sposoby nadużywania i manipulowania słowami, które w opracowaniach są określane jako nowomowa (zob. Grzegorczykowa 1985: 365-378; Sambor 1985: Michalewski 1994: 65-70; Wesołowska 1996: 349-354). Wskazywano na wyraźną tendencję do przesycania treściami politycznymi literatury, sztuki, nauki, obyczajowości, a nawet życia codziennego. W pracach nad sterowaniem szczególnym zainteresowaniem badaczy cieszył się język osób publicznych. Z punktu widzenia mechanizmów perswazji analizowano oficjalne wypowiedzi polityków z uwzględnieniem środków językowych obserwowanych na różnych poziomach języka, zwłaszcza na płaszczyźnie leksykalnej i stylistycznej. Wskazywano wykorzystywane w celach perswazyjnych określone strategie komunikacyjne, często oparte na znajomości zasad psychologii społecznej. Politycy świadomie stosują pewne wzorce zachowań, środki językowe oraz pozajęzykowe, pozwalające wywierać wpływ na sposób myślenia i działanie odbiorców. Część opracowań dotyczy perswazji w kampaniach wyborczych (Mosiołek-Kłosińska 1996: 12-20; Ożóg 2001: 126-175), autorzy badają sposób prezentacji kandydatów, który jest najbardziej skutecznym środkiem oddziaływania marketingu wyborczego, sztuką politycznej autokreacji (Dobek-Ostrowska 2004a; Michalewski 2004b: 271-280; Obrębska 2007: 489-498; Burska-Ratajczyk: 2010a: 211-224). Uwagę poświęcono także sloganom oraz hasłom wyborczym o pozytywnej sile oddziaływania perswazyjnego, wykorzystywanym w dyskursie politycznym (Galasiński 1991: 85-97; Kochan 2002). Nurt badań nad działaniami manipulacyjnymi związanymi z państwem i łączonymi z działalnością polityczną stanowi przedmiot szczególnego zainteresowania politologów (zob. Karwat 1999; 2006) i psychologów (zob. Cwalina 2000; Falkowski, Cwalina 2005). 
Realizacji perswazyjnej funkcji języka w biznesie poświęcone są badania nad komunikacją marketingowa (Małyska 2006: 245-257; Łabuz, Urbański 2006) i strategiami językowymi wykorzystywanymi w zarządzaniu i handlu (Sztucki 1995; Pałka 206: 117-130; Edwards, Edwards, Clampitt Douglas 2006). Powstały opracowania z zakresu psychologii komunikacji marketingowej, dotyczące leksyki i frazeologii nacechowanej perswazyjnie (Lewandowska-Tarasiuk 2005). Wiele znaczących publikacji dotyczy strategii i języka perswazji w różnych typach komunikatów reklamowych, zwłaszcza w reklamie prasowej, radiowej i telewizyjnej. Reklama - współcześnie stały element rynku i gospodarki - jest wszechobecna, wpływowa i modna. Ponieważ przekaz reklamowy jest podporządkowany zasadzie skuteczności, toteż w sposobach promocji produktów i usług wiele uwagi poświęca się wykorzystywanym strategiom i środkom językowym, zwłaszcza wizualności, funkcjonalności i celność słowa oraz indywidualizacji przekazu. Teksty reklamowe, jako komunikaty o dominującej funkcji perswazyjnej (zob. Skowronek 1993; Golka 1994; Tokarski 1995a, 1995b; Bralczyk 1999a: 218-227; Albin 2000; Giedz 2000: 216-224; Kopertowska 2000: 231-237; Budzyński 2001; Kamińska-Szmaj 2003: 77-79; Benedikt 2006), analizowane były m.in. przez językoznawców, teoretyków reklamy, socjologów, psychologów.

Następną grupę tematyczną stanowią prace poświęcone perswazji $w$ literaturze, dotyczą one tekstów artystycznych o różnych kwalifikacjach gatunkowych i stylowych (Barańczak 1977: 44-57; Woźniakiewicz-Dziadosz 2004: 233-242). Badano zjawisko z perspektywy autorów i epok, w których utwory powstały, uwzględniając rolę perswazji w planie ideowym utworów. Analizowano teksty pod kątem wykorzystania środków językowych, które służą utrwaleniu w społeczeństwie określonych wzorców i przekonań. Przedmiotem zainteresowania były $\mathrm{m} . i n$. powieści tworzone $\mathrm{w}$ duchu realizmu socjalistycznego (Tomasik 1988), literatura łagrowa (Nagy 2004: 243-260), poezja patriotyczna (Pogonowska 2007 : 125-140).

Interesującym polem badawczym są prace dotyczące zagadnień perswazji stosowanej w nauce, związane z realiami i doświadczeniami życia szkolnego. Autorzy próbują interpretować zjawisko w kategoriach dydaktycznych, zwracając uwagę na problematykę perswazji w kontekście nauczania i wychowania ku wartościom (Włodek-Chronowska 1993; Wojtczuk 2000: 391-398; Karwatowska 2004: 175-186; Łuczeńczyk 2007: 383-396).

Rolę perswazji doceniono także na gruncie badań teologicznych, analizowano językowe środki perswazji w różnych typach tekstów (Zdunkiewicz-Jedynak 1991: 149-157; 1996; Zachwieja 2002: 329-336). Obserwuje się wzrastające zainteresowanie zjawiskiem w języku religijnym (Bajerowa 1994; Makuchowska 2001: 392-402; Urbański 2003), szczególnie w jego odmianie kaznodziejskiej (Pilch 1958; Siwek 1992; Matuszczyk 2002: 318-323).

Przedmiotem zainteresowania badaczy stała się także urzędowa odmiana polszczyzny, będąca ważną częścią każdego języka (Libura 2000: 92-103; Winiarska 
2007: 320-322). Zjawisko perswazji dotyczy dyskursu prawnego, którego funkcja polega na wcielaniu w życie i egzekwowaniu przepisów. Analizowano perswazję w tekstach prawnych i prawniczych (Zgółka, Zieliński 2003: 182-189; Spence 2001), wskazując jej elementy w ustawach, rozporządzeniach i wystąpieniach procesowych (Habrajska 2000: 70-83).

Ostatnie lata cechuje wzmożone zainteresowanie zjawiskiem perswazji, szczególnie zaś jej siłą i zasięgiem oddziaływania $w$ mediach masowych (Wilk 2000): w telewizji, radiu, prasie, a także w Internecie (Łobodzińska, Peisert 2004: 211-220; Sobstyl 2008: 242-249). Powstają opracowania, dotyczące różnych rodzajów i form wypowiedzi. Autorzy podkreślają manipulacyjny charakter (Lewicki, Nowak 2000; Michalewski 2004c: 187-198) różnorakich typów przekazu medialnego. Ważne miejsce zajmują prace poświęcone publicystyce, ciekawym kierunkiem eksploracji są opisy perswazji $w$ wypowiedziach prasowych (Abramczyk 2006; Lizisowa 2009; Znyk 2008). Przedmiotem zainteresowania badaczy jest realizacja perswazyjnej funkcji języka w różnych gatunkach dziennikarskich i w różnych typach przekazu (Puzynina 1984b: 69-78; Wolińska 1987; Błażejewska 2000: 140-150; Kajtoch, Kołodziej, Planeta 2000: 120-134; Siwek 2002: 29-41; Florczak 2004: 71-88; Lewicki 2004: 101-114; Rejakowa 2004: 161-174; Sławek 2007). Współczesne media są istotną formą komunikowania się z masowym odbiorcą i najbardziej skutecznym sposobem zdobywania jego względów. Wiele uwagi poświęcono perswazji w przekazach telewizyjnych (Michalewski 1999: 63-69; 2004a: 271-280), ponieważ to medium ma obecnie największy zasięg oddziaływania na odbiorców.

Wpływ na efektywność perswazji ma wiele różnych czynników. Celem studiów nad perswazją jest poznanie mechanizmów i środków językowych, jakimi operują zróżnicowane językowo teksty. Funkcja perswazyjna realizuje się dzięki wykorzystaniu społecznego wartościowania (Wieczorek 1999; Bralczyk, Majkowska 2000: 43-50; Laskowska 2008: 219-226), stąd zainteresowanie badaczy zjawiska jest poświęcone waloryzowaniu. Ważne są także opracowania dotyczące $k u l$ tury języka stylu perswazyjnego (Kajtoch 1999: 159-169) różnych typów tekstów. Wnikliwie analizowanojęzyk wypowiedzi, środki stylistyczne(Sławek 2005: 79-91) stosowane w celach perswazyjnych, służące wzmocnieniu przekazywanych treści. Sporo publikacji poświęcono słownictwu w szczególności leksyce nacechowanej aksjologicznie (Laskowska 2000: 342-348) i emocjonalnie (Bugajski 2000: 419424; Kacprzak 2008: 69-73), wykorzystywanej w dyskursie politycznym (Kudra 1997: 169-176; Laskowska 2000: 342-348; Michalewski 2001: 3-8), zwłaszcza w tekstach propagandowych (Kwiatkowski 1974), w marketingu (Ryzza-Woźniak 2000: 261-267) oraz w komunikatach reklamowych (Kamińska-Szmaj 1998).

Istotne znaczenie $\mathrm{w}$ dyskursie perswazyjnym mają także elementy pozaleksykalne (Smól 2000: 233-244), w tym środki morfologiczne (Kowalewska-Dąbrowska 2007: 79-87) i składniowe (Maciuszek 2007: 29-48) stosowane jako czynnik wzmagający siłę przekazu. 
Uwagę poświęcono także perswazyjnej funkcji komunikacji niewerbalnej (Antas, Załazińska 2004; Szkudlarek-Śmiechowicz 2007: 299-308), wspomagającej komunikację słowną. Środki pozawerbalne, które wzmacniają sugestywność przekazu lub nadają nowe znaczenie, są istotne dla powodzenia perswazji, ponieważ skuteczność oddziaływania na odbiorcę zależy od odpowiedniego łączenia ich z elementami językowymi (Jarząbek 1989; Nęcki 1996b: 212-213). Komunikacja pozasłowna jako rodzaj wymiany informacji między ludźmi, dostarcza kontekstu, w którego ramach dokonuje się interpretacja komunikatów językowych. Mowa ciała dotyczy wszystkich zachowań, postaw i obiektów innych niż słowa, obejmuje: wygląd fizyczny, ruchy ciała, gesty, wyraz twarzy, ruchy oczu, dotyk, głos. Jej funkcja polega na informowaniu o stanie emocjonalnym nadawcy, jego intencjach i oczekiwaniach wobec rozmówcy.

Jak pokazuje przegląd opracowań, zagadnienie wywierania wpływu na ludzi stanowi przedmiot zainteresowania wielu badaczy zarówno w Polsce, jak i na świecie. Obecnie badania nad perswazją są dynamicznie rozwijającą się dziedziną wiedzy, analizuje się perswazję w różnych typach tekstów, a problematyka ta znajduje odbicie w licznych pracach poświęconych zwłaszcza perswazji publicznej. Opracowania, dotyczące zjawiska, zarówno o charakterze teoretycznym, jak $i$ te, odnoszące się do pewnych wyodrębnionych zagadnień, wskazują, że perswazja jest wszechobecna, występuje w różnych typach dyskursu i ma swoją bogatą dokumentację zwłaszcza w zakresie oficjalnej polszczyzny pisanej i mówionej.

Przekonywanie jest niezwykle potrzebną i ważną umiejętnością, toteż w nurt rozważań nad perswazją, jej rolą i miejscem w komunikacji językowej obok lingwistów włączają się reprezentanci różnych dyscyplin humanistycznych: filozofii, psychologii, pedagogiki, socjologii, politologii. Literatura dotycząca zjawiska jest obszerna, bogata i różnorodna, a szczególny udział językoznawców w badaniach nad perswazją sprawił, że zagadnienie to stało się przykładem badań pogranicznych, syntetyzujących elementy wiedzy z zakresu nakłaniania.

\section{Komunikacja a perswazja}

\subsection{Definicja komunikacji językowej}

Problematyce komunikowania międzyludzkiego autorzy poświęcili wiele uwagi w różnych modelach badawczych (Grzesiuk, Trzebińska 1978; Grice 1980: 91-114; Friske 1999; Dziewiecki 2000; Kurcz 2000; Dobek-Ostrowska 2001; Fleischer 2002; Steward 2005) i typach dyskursu (zob. Lalewicz 1975; Gajda, Rymut, Żydek-Bednarczuk 2002; Goban-Klas 2004). Prowadzone przez lata m.in. przez językoznawców, filozofów, psychologów, socjologów badania nad przebiegiem procesów komunikacyjnych wskazują czynniki, od których są one zależne. 
Wywieranie wpływu na ludzi, stanowiące istotny element procesu komunikowania się, jest również przedmiotem zainteresowania różnych dyscyplin naukowych.

Słowo komunikacja pochodzi od łacińskiego communio oznaczającego 'uczestnictwo, więź, to, co łączy', komunikowanie etymologicznie wywodzi się od communicare (być w relacji z, uczestniczyć w) (Goban-Klas 2004: 41), po łacinie oznacza także dzielenie się; to sposób wymiany myśli, uczuć, przekonań i poglądów, wynikający z naturalnej potrzeby psychicznego kontaktu z otoczeniem. Opracowania leksykograficzne wyjaśniają - komunikować coś komuś to dzielić się z nim jakąś myślą, wiedzą, spostrzeżeniem, prosić o coś, zlecać jakieś zadanie, wypowiadać opinię, wydawać polecenia itp. Współcześnie termin (Słownik języka polskiego 1979: 981) jest rozumiany zgodnie z językiem angielskim i oznacza porozumiewanie się, udzielanie wiadomości; łączność. W socjologii (Olechnicki, Załęcki 1988: 97) termin komunikacja społeczna jest definiowany jako: „przekaz informacji między jednostkami lub grupami zajmującymi w danej hierarchii społecznej czy strukturze organizacyjnej takie same lub podobne pozycje". Komunikacja jest procesem dwukierunkowym, polegającym na przekazywaniu informacji między ludźmi za pośrednictwem symboli werbalnych i niewerbalnych w celu wywołania określonych zmian w zachowaniu lub myśleniu odbiorcy.

\subsection{Komunikacja interpersonalna a perswazja}

Komunikowanie interpersonalne (Pisarek 2006: 100; Marcjanik 2007) oznacza, że dana wiadomość jest kierowana do dwu osób lub niewielkiej grupy. W tym typie komunikowania „niezbędna jest bezpośrednia obecność uczestników i nawiązanie osobistego kontaktu (k. «twarzą w twarz»). Komunikowanie interpersonalne ma charakter dwustronny, interaktywny i zwykle przybiera formę dialogu, rozmowy", zachodzi wtedy, gdy jego uczestnicy są w sytuacji twarzą w twarz, umożliwiającej bezpośrednią oraz bezzwłoczną reakcję odbiorcy na wypowiedź nadawcy i vice versa.

P. Grice (1980) uznawał rozmowę za rodzaj współpracy jej uczestników i sformułował ogólną zasadę swojej koncepcji - „Wnoś swój wkład do konwersacji tak, jak tego w danym momencie wymaga cel rozmowy, w której bierzesz udział".

Komunikowanie wpływa na kształtowanie opinii i postaw oraz systemu wartości. Istnieje wiele definicji pojęcia komunikowanie się, np. R. Buck (1984) rozumie je jako wzajemne przekazywanie informacji, umiejętności, pojęć, idei, uczuć za pomocą symboli tworzonych przez słowa, dźwięki, obrazy czy dotyk.

W opracowaniach zwraca się uwagę na społeczny aspekt komunikacji językowej (Aronson 1994; Nęcki 1996a; Gajda, Rymut, Żydek-Bednarczuk, 2002; Awdiejew 2004a; Awdiejew, Habrajska 2006; Bugajski 2007; Griffin 2010). Teoretyk języka E. Benveniste (1980: 27) pisze: „Język dla człowieka jest środkiem, 
właściwie jedynym środkiem pozwalającym dosięgnąć innego człowieka, przekazać mu i odebrać od niego komunikat. W konsekwencji język zakłada i potwierdza istnienie kogoś drugiego". W modelu komunikacji językowej L. Bloomfielda (1933) komunikat językowy traktowany jest jako instrument werbalnej interakcji subiektów, jako zastępcza, mowna, reakcja mówiącego na bodziec zewnętrzny, czyli określoną potrzebę.

W kontekście rozpatrywania perswazji za najodpowiedniejsze uznaję określenie, które zaproponował D. Hymes (1980: 67), twórca teoretycznych i metodologicznych podstaw etnografii mówienia, traktujący komunikację językową jako działanie o określonej intencji: „Mowa, w tym także struktura językowa (stanowiąca podstawowe, ale nie wyłączne jej zaplecze), pośredniczy między osobami i sytuacjami, w których się one znajdują. Zwykła struktura językowa jest w tym ujęciu składnikiem organizacji mowy i nie wystarcza do tego, by rozpocząć ujawnienie jej organizacji. Zacząć należy od mówienia ujawnianego jako forma działania, nie zaś od języka jako mechanizmu pozbawionego motywacji”.

Uważam, że komunikacja jest przekazywaniem i porównywaniem informacji oraz konfrontowaniem poglądów w celu wyciągnięcia określonych wniosków, służy porządkowaniu myśli i kontroli przekonań. Komunikując się, nadawca przekazuje odbiorcy swoje odczucia, opinie i życiowe doświadczenia, komunikowanie służy zaspokojeniu pewnych potrzeb: korygowaniu lub umacnianiu własnego stanowiska czy sposobu spojrzenia na jakiś problem, własnej interpretacji lub własnego punktu widzenia. Na ten aspekt komunikacji językowej zwraca uwagę m.in. J. Lalewicz (1985: 31): ,[...] komunikacja to porozumiewanie się - tj. przekazywanie i wymiana informacji, propozycji, poleceń czy deklaracji w celu ustalenia lub uzgodnienia wspólnych lub wzajemnych opinii, zamiarów, stanowisk albo działań w jakiejś sprawie lub jakiejś sferze współżycia - nawiązywanie i podtrzymywanie kontaktów, stwarzanie i integrowanie wspólnoty zainteresowań, poglądów lub działań, koordynowanie współdziałania itd.”.

Podzielam pogląd, że język jest nie tylko narzędziem komunikowania, ale może być także perfekcyjnie wykorzystywanym narzędziem wpływania na ludzi. Uważam, że perswazja stanowi istotny element procesu komunikowania się, ponieważ odpowiednie użycie języka kształtuje sposób myślenia i postępowanie człowieka i może prowadzić do znacznych zmian zachowań odbiorcy. W wielu opracowaniach podkreśla się fakt, że perswazja jest integralną częścią zachowań językowych i wskazuje się na jej ważną funkcję w życiu społecznym. W procesie komunikacji istotne znaczenie ma: sposób wyrażania opinii, reakcja na krytykę, myślenie wielostronne. Porozumiewanie się możliwe jest przede wszystkim dzięki wykorzystaniu bardzo potężnego narzędzia, jakim jest mowa, podstawowe narzędzie komunikacji międzyludzkiej. W ten sposób ludzie przekazują sobie większość informacji, ale komunikacja obejmuje wszystkie elementy wypowiedzi, zarówno werbalne, jak i niewerbalne, te dające się bezpośrednio odczytać, jak $\mathrm{i}$ te, często ukryte w presupozycjach. W prawie każdej wypowiedzi można wy- 
różnić pewne składniki: zawartość treściową, relacje z rozmówcą, intencje, towarzyszące wypowiadanym słowom. Z komunikacją językową wiążą się określone motywy (przyczyny) i cel działania oraz przewidywane skutki, które nie zawsze muszą być zgodne z założeniami nadawcy.

Cel działań komunikacyjnych jest podporządkowany określonej idei. W perswazji komunikacja jest dwuetapowa - chodzi w niej nie tylko o przekazanie informacji, ale przede wszystkim o przekonanie do niej odbiorcy. Zabiegi perswazyjne łączone są najczęściej z działalnością polityczną, handlową czy marketingiem, ale należy mieć świadomość, że obiektem perswazji może okazać się praktycznie każdy temat. Współcześnie perswazja bywa postrzegana jako jeden z podstawowych celów komunikacji językowej. Badacze wskazują, że obserwuje się ją w codziennej praktyce językowej, a przeciętny użytkownik języka nieustannie jest jej poddawany, zarówno jako obiekt perswazji, jak i podmiot perswadujący. Działania perswazyjne spełniają bardzo ważną funkcję także w codziennej komunikacji językowej. W. Pisarek (2004: 125) dowodzi, że w praktyce każde działanie językowe jest przekonywaniem: ,[...] ludzie się ze sobą komunikują najczęściej po to, by się wzajemnie do czegoś przekonywać", analogicznie ujmuje zagadnienie E. Lewandowska-Tarasiuk (2005: 34): „Każda rozmowa jest próbą przekonania rozmówcy do swoich racji, a i on także - wchodząc w dialog z nami, radząc, zachęcając, tłumacząc, ustępując, namawiając czy nakłaniając - również przekonuje nas do swoich racji, do swojego odbioru świata".

W komunikacyjno-działaniowym zachowaniu człowieka język może być traktowany jako narzędzie wpływu na innych. Jeśli za słuszne uznamy stwierdzenie, że perswazja tkwi w samej naturze języka (mówionego i pisanego), a przekonywanie stanowi integralną część każdej wypowiedzi językowej, to perswazyjna funkcja języka realizuje się bez mała w każdej wypowiedzi: „Niemal w każdym tekście jednocześnie informujemy, wyrażamy coś i staramy się wpłynąć na odbiorcę" (Cegieła, Markowski 1982: 27).

Funkcja nakłaniająca jest silnie związana z funkcją komunikacyjną. Oddziaływanie systemu językowego na sposób myślenia i zachowania ludzi było przedmiotem szczególnego zainteresowania badaczy komunikacji językowej (zob. Humboldt 1965: 141), którzy wskazywali, że: „Potencjalnie w każdym języku można wyrażać wszelkie treści [...], ale jest istotna różnica między tym, czego dany język «nie umożliwia», a tym, co dany język podsuwa, ułatwia i sugeruje" (Wierzbicka 1978: 22).

W opracowaniach lingwistycznych (Kamińska-Szmaj 2004: 20): „definiując pojęcie perswazji, z jednej strony, nawiązuje się do tradycji retorycznej, z drugiej zaś, do teorii funkcji językowych oraz teorii aktów mowy". Perswazja jest centralnym pojęciem w teorii sztuki wymowy (retoryce). W teorii retorycznej perswazję rozumie się jako wpływanie na przekonania odbiorcy za pomocą mowy poprzez oddziaływanie na jego rozum, wolę lub emocje. Pierwotnie oznaczała ona umiejętność stosowania przekonujących dowodów. Według klasycznego określenia 
Arystotelesa mówca mógł oprzeć swoją wypowiedź na perswazyjnej sile własnego charakteru, wywołaniu u odbiorców korzystnych emocji lub sile „oczywistego dowodu". Odpowiadało to trzem rodzajom mowy, a przy okazji trzem odmianom perswazji - opartej na apelach natury etycznej, emocjonalnej bądź logicznej.

We współczesnym językoznawstwie, m.in. w ramach lingwistyki tekstu i gramatyki funkcjonalnej, coraz aktualniejsze staje się badanie zjawiska perswazji w kontekście różnych sytuacji językowych i w różnych typach tekstów.

Wskazując relacje między komunikowaniem się a perswazją, odwołuję się do założenia J. Warchali (2004: 41-60), który traktuje mówienie jako działanie zdeterminowane teleologicznie, nastawione na współpracę i porozumienie, zaś perswazję, która stanowi jeden z jawnych sposobów realizacji założonych celów komunikacyjnych, jako stały element towarzyszący komunikowaniu. Uważam, że perswazja językowa jest nieodłącznym składnikiem życia społecznego i komunikacji międzyludzkiej, perswazyjny charakter ma większość interakcji społecznych oraz publicznych aktów komunikowania. Perswazję rozumiem jako nakłanianie odbiorcy do zmiany poglądów, wskazywanie mu oceny kogoś lub czegoś. Używając terminu perswazja, mam na myśli przede wszystkim pewną sumę właściwości formy wypowiedzi, która opiera się na dążeniu do przetworzenia poglądów, zapatrywań, ocen człowieka lub zbiorowości. Jak stwierdza E. Tomiczek (1992: 15): „rzadko zdajemy sobie sprawę z tego, że każdy język dysponuje sporym potencjałem form, które nie tylko umożliwiają człowiekowi działanie w ramach przyjętych norm społecznych (konwencji), lecz często w sposób subtelny a zamierzony stają się narzędziem bezpośredniego oddziaływania na partnera (-ów) interakcji”.

Przekonywanie zależy od umiejętności wchodzenia w interakcje i wybierania takich zachowań komunikacyjnych, które mogą zapewnić skuteczność porozumienia. Zasady skutecznego przekonywania uwarunkowane są wieloma czynnikami: umiejętnościami nadawcy, podatnością odbiorcy, tematyką wypowiedzi itp. W. Pisarek (2004: 138) wskazuje, że perswazja w komunikacji językowej odwołuje się do mechanizmu doboru środków językowych: „Istota mechanizmu przekonywania za pomocą komunikowania słownego zasadza się na selekcji. Zazwyczaj dokonuje się jej na dwóch poziomach: poziom pierwszy odpowiada selekcji samych faktów (informacji), poziom drugi - selekcji środków językowych opisujących te fakty. Zgodnie z prawem selekcji motywowanej perswazyjnie informuje się więc tylko o niektórych właściwościach przedmiotów lub o niektórych cechach i rolach osób. Wspomina się zaś albo uwydatnia te właściwości, cechy i role, które odpowiadają intencjom nadawcy".

W opracowaniach badacze podkreślają, że: „W perswazji mamy do czynienia ze szczególnym typem nadawcy: perswadorem, czyli tym, który stosuje perswazję, oraz odbiorcą perswazji, czyli tym, wobec kogo perswazja jest stosowana" (zob. Laskowska 2007: 93).

Skuteczność perswazji w dużym stopniu zależy od zachowań językowych nadawcy, od umiejętności zaprezentowania swoich racji, przełożenia myśli i są- 
dów na odpowiednie słowa. Ważna jest jego kompetencja komunikacyjna, czyli umiejętność posługiwania się językiem, która warunkuje sukces przekazu i pomaga kształtować postępowanie odbiorcy zgodne z intencjami rozmówcy. By przekonująco wpływać na czyjeś zachowania, należy umieć wczuwać się w emocje innych ludzi, odczytywać ich potrzeby i oczekiwania, a przede wszystkim umiejętnie budować interakcyjne relacje. W skutecznych działaniach perswazyjnych pierwszorzędne znaczenie ma również wiedza o odbiorcy, która stwarza ważną w perswazji więź między nadawcą a odbiorcą. Istotne znaczenie ma: wiek, płeć, status społeczny, zawodowy, intelektualny, kulturowy, a nawet majątkowy osoby, a także wiedza o poglądach ideowych, politycznych czy moralno-obyczajowych, o doświadczeniach życiowych, gustach czy sympatiach rozmówcy. E. Lewandowska-Tarasiuk (2005: 35) pisze: „Chcąc być perswazyjnym, trzeba mieć świadomość, do kogo się zwracamy, a więc odpowiedzieć sobie na pytanie, kto będzie stanowić nasze audytorium".

\subsection{Komunikacja bezpośrednia a perswazyjność przekazu}

Przyjmuję następujące rozumienie komunikacji bezpośredniej - jest to komunikacja face to face, w której istotna jest fizyczna obecność odbiorcy, jedność czasu między aktem nadawczym a zaistnieniem komunikatu. Komunikację bezpośrednią cechuje typowa swoboda językowa, nadawcę i odbiorcę łączy bliska więź, która znajduje odbicie w doborze środków językowych. Język mówiony realizuje się przede wszystkim w rozmowie, w formie mówionego dialogu, w którym uczestnicy formułują myśli na gorąco, przekazując informacje za pomocą kodu werbalnego i mowy ciała, istotne znaczenie ma także mimika, gestykulacja, intonacja, tempo mowy oraz natężenie głosu. Bezpośrednia komunikacja ustna wykorzystuje wszystkie środki językowe skorelowane z czynnikami sytuacyjnymi. Istotne znaczenie w tym typie komunikacji ma współobecność odbiorcy, żywy kontakt (sygnały fatyczne i konatywne, system dodatkowych pytań).

Właściwa interpretacja komunikacji mówionej zależy od wielu czynników: od tego, gdzie odbywa się rozmowa, kto jest jej uczestnikiem, jakie towarzyszą jej gesty itp. Badacze podkreślają rolę czynników paralingwistycznych, towarzyszących językowi mówionemu, ściśle związanych z określonymi zwerbalizowanymi informacjami. W kontaktach interpersonalnych ważna jest mimika, dystans przestrzenny (Nęcki 1996b: 212-213; Niedzielski 1991: 108-114), z punktu widzenia perswazji istotne znaczenie mają gesty: „wskazujące na przeżywane uczucia bądź podkreślające treść wypowiedzi” (Polański 1999: 199), „[...] czasem komunikowanie kinestetyczno-sensualne może być ekonomiczniejsze i precyzyjniejsze" (Kneblewski 1980: 241).

Podczas bezpośredniej komunikacji międzyludzkiej najważniejszą formą przekazu jest język potoczny. Polszczyzna potoczna, która stosunkowo późno, bo 
w latach siedemdziesiątych XX wieku, stała się przedmiotem zainteresowania językoznawców, posiada dziś bogatą dokumentację naukową (Buttler 1982; Anusiewicz, Nieckula 1992; Lubaś 2003), szczególnie w zakresie regionalnej polszczyzny miejskiej (Dunaj i in. 1986a; Gardzińska 1989; Kamińska 1989; Kamińska 1992) oraz dialektów (Sędziak 1996; Sędziak, Frąckiewicz 1999). J. Bartmiński (1993: 115-134) uważa, że polszczyzna potoczna jest centrum stylowym języka polskiego, A. Wilkoń (1987: 61) uznaje język potoczny za: „odmianę języka mówionego mającą najszerszy uzus i związaną z codzienną komunikacją". Badacze (Kita 1993: 33-41) wskazują, że ten wariant języka jest wykorzystywany w funkcji perswazyjnej w kontakcie ogólnym.

Publikacje językoznawcze wyróżniają następujące właściwości komunikacji potocznej: dialogowość, komunikatywność, obrazowość, emocjonalność. W przekonywaniu istotną wartość ma dialogowość, która polega na utrzymywaniu żywego kontaktu ze słuchaczem i wciąganiu go w prowadzone rozumowanie. G. Siwek (1992: 120) uważa, że: „dialogowość dotyczy każdej postaci języka, również szczególnej postaci języka mówionego, jaką jest wypowiedź monologowa. Może ona być w swej stylistycznej warstwie bardziej lub mniej dialogowa”.

W budowaniu kontaktu ze współpartnerem ważna jest także komunikatywność, czyli zwięzłość i jasność wypowiedzi. Osiągana jest ona poprzez odpowiedni dobór słownictwa i konstrukcji zdaniowych, ponieważ „proces komunikacji najsprawniej przebiega wówczas, kiedy wykorzystuje się system znaków znanych nadawcy i odbiorcy i jednakowo przez nich dekodowanych, stąd pierwszym obowiązkiem w procesie komunikacji jest odpowiedni dobór słów (znaków), w których zamyka się i koduje myśl" (Siwek 1992: 134).

Kolejna cecha polszczyzny potocznej wpływająca na perswazyjność przekazu to zwięzłość wypowiedzi (Siwek 1992: 137-138), która „polega na niewystępowaniu w niej elementów zbędnych ze względu na jej funkcję komunikatywną i nie pełniących żadnych funkcji stylistycznych”. Konkretyzacja języka potocznego przejawia się również w zdolności przekazywania informacji między nadawcą i odbiorcą w sposób możliwie najkrótszy i sprawiający najmniej problemów przy dekodowaniu. Najważniejszą wartością staje się wówczas sama informacja.

Natomiast obrazowość (plastyczność) to zespół elementów, dzięki którym apeluje się do przedstawień wyobrażeniowych słuchacza.

Cechą charakterystyczną komunikacji potocznej jest niezwykła bezpośredniość i emocjonalność, wynikająca z relacji zachodzących między osobami bliskimi sobie psychicznie i uczuciowo, które w codziennym obcowaniu wyrażają i przekazują różne emocje wprost. W komunikacji członków rodziny, przyjaciół, wąskiego grona lokalnych wiejskich społeczności przekaz informacji odbywa się w sposób spontaniczny i nieskrępowany, za pomocą mowy oraz kanałów niewerbalnych.

Spośród innych form komunikacji polszczyzna potoczna wyróżnia się przede wszystkim większą swobodą w zakresie poprawności językowej, niejednokrotnie przekraczając granice przyjętych norm gramatycznych. J. Bartmiński (2001b: 
124-125) uważa, że: „Racjonalność potoczna jest praktyczna i zdroworozsądkowa: ujmuje rzeczywistość pod kątem konkretnego człowieka i wedle jego zdolności percepcyjnych; dopuszcza się istnienie wewnętrznych sprzeczności i różnorodności środków służących do osiągania zamierzonych celów", natomiast J. Warchala (2001: 165) wskazuje, że: „Potoczność rozpatrywać należy [...] w kategoriach ogólnych reakcji między wiedzą potoczną a logiką (wiedzą naukową)". J. Skawiński (1992: 85) tak pisze o języku potocznym: „Istota tego systemu leży w specyficznym sposobie spojrzenia na rzeczywistość, regulowanym przez inny typ doświadczeń. Źródeł tego stanu rzeczy należy upatrywać w rozbieżności między społecznie uznawanymi normami postępowania i wartościami kulturowymi a stylem i realiami współczesnego życia”.

Język wykorzystywany do porozumiewania się w codziennych, najróżnorodniejszych sytuacjach życiowych utrwala podstawowe struktury myślenia i percepcji świata (zob. Hołówka 1986) oraz składa się na językowy obraz świata, który według badaczy (Anusiewicz, Dąbrowska, Fleischer 2000: 25): „stanowi podsumowanie i zestawienie codziennych doświadczeń i przejętych, tudzież zaakceptowanych przez daną wspólnotę komunikatywną norm, wartości, sposobów wartościowania oraz wyobrażeń i nastawień wobec tej rzeczywistości i to zarówno materialnej, substancjalnej, zewnętrznej, jak i duchowej, psychicznej, świadomościowej, wewnętrznej”.

Wśród pierwszorzędnych cech składających się na zjawisko komunikacji bezpośredniej ma ustnośćc, która determinuje specyficzne warunki tworzenia wypowiedzi, dlatego w opisie i ocenie tego rodzaju komunikacji uwzględnić należy sytuację mówienia (Anusiewicz, Nieckula 1978: 21-39; Warchala 1991). Polszczyźnie mówionej poświęcono sporo uwagi w literaturze (Banach 1983; Dunaj 1985: 88-98), była obiektem wnikliwych badań dialektologii i socjolingwistyki (Perczyńska 1975; Skubalanka 1978; Wilkoń 1979; Ożóg 1990), koncentrowano się zwłaszcza na strukturze rozmów potocznych (Lubaś 1988: 45-47; Lubaś 2003), według J. Warchali (2001: 167-168) komunikaty w potocznej odmianie języka są: „efektem współdziałania co najmniej dwóch interlokutorów, którzy współtworzą ten komunikat, ale są także kompleksowym współwystępowaniem różnych płaszczyzn, na których odbywa się komunikowanie treści”, tj. płaszczyzny werbalnej; płaszczyzny gestów pozawerbalnych oraz płaszczyzny inferencji i presupozycji, a istotę tekstu potocznego wyznaczają następujące tendencje: dążenie do konkretności obrazowania; intersubiektywność (współprodukowanie); sytuacyjność (sytuacja jako interpretant sensów); ulotność indywidualnych wykonań; trwałość schematów i stereotypowość. U. Żydek-Bednarczuk (2004a) wśród charakterystycznych cech rozmów potocznych wskazuje:

- przekaz ustny, mówiony, który uzupełnia kod awerbalny, mimika, gest;

- brak przygotowania, spontaniczność, naturalność;

- naturalne pełnienie ról językowych w rozmowach rodzinnych, towarzyskich; 
- symetryczność i równorzędność rangi społecznej lub zażyłość partnerów rozmowy, która niweluje asymetrię wiedzy, rangi społecznej;

- kontakt indywidualny, prywatny, nieoficjalny, bezpośredni w typie komunikacji ,face to face”;

- mała liczba partnerów rozmowy, małe grupy;

- codzienna, bytowa tematyka, konkretyzacja, leksykalna antropocentryczność, aktualizacja;

- interakcja i kooperacja partnerów rozmowy;

- uzusowy stopień abstrakcji językowej i w związku z tym możliwość wystąpienia elementów gwarowych.

Komunikacja mówiona (por. Lubaś 1979b; 2003) w bezpośrednich kontaktach, zazwyczaj mających charakter osobisty, utożsamiana bywa z kolokwialnością, ewentualnie z potocznością i określana jest jako język mówiony, komunikacja mówiona. F. Nieckula (1992) zwraca uwagę, że wariant nieoficjalny polszczyzny mówionej, który stanowi centrum komunikacji, znacznie różni się od wariantu oficjalnego. Wśród typowych cech komunikacji mówionej wymienia się kolokwialność, która definiowana jest jako: „,echa środków językowych nadających się do użycia wyłącznie lub prawie wyłącznie w bezpośrednich kontaktach między ludźmi, zwłaszcza zaś w swobodnej rozmowie osób występujących w takich samych lub zbliżonych rolach społecznych" (Urbańczyk 1991: 160).

W opracowaniach lingwistycznych wymienia się następujące cechy komunikacji ustnej: spontaniczność, bezpośredni kontakt nadawcy i odbiorcy oraz akustyczno-artykulacyjny kanał komunikacyjny.

Ustność komunikatu kojarzona jest na ogół ze spontanicznością, ponieważ tekst ustny w odróżnieniu od pisanego, powstaje bezpośrednio i żywiołowo podczas aktu komunikacji. Cechą charakterystyczną tekstów ustnych jest niezwykła bezpośredniość i emocjonalność, ponieważ mamy do czynienia z komunikacją właściwą dla relacji między osobami bliskimi sobie psychicznie i emocjonalnie: rodzicami i dziećmi, małżonkami, przyjaciółmi, osobami, które w codziennym obcowaniu z sobą wyrażają i przekazują różne uczucia w sposób bezpośredni.

Spontaniczność, czyli równoczesność mówienia i budowania wypowiedzi, w kontekście realizacji perswazyjnej funkcji języka, stawia mówiącego w trudniejszej sytuacji przede wszystkim z powodu braku czasu na zaplanowanie kompozycji wypowiedzi, jednak czasem wypowiedź ustna może być owocem gruntownych i długich przemyśleń.

Bezpośredniość kontaktu rozmówców i towarzysząca jej naprzemienność ról nadawczo-odbiorczych usprawnia komunikację i jest okolicznością korzystną dla przebiegu oraz skuteczności perswazji.

W przekazie mówionym nadawca staje twarzą w twarz z odbiorcą, może więc myśli wyrazić nie tylko słowami, ale również gestami, mimiką, czyli mową ciała, która ułatwia właściwe odczytanie i interpretację wypowiedzi. W komunikacji uczestniczą spostrzeżenia wszystkich zmysłów, bowiem wszystko, co słyszy- 
my i spostrzegamy w wyglądzie oraz zachowaniach ludzi, to komunikaty. Mogą one być zamierzone i starannie dobrane, niekiedy nieświadome, czasem nawet sprzeczne z intencjami nadawcy. Informacje przekazuje: sposób poruszania się, gestykulacja, mniej lub bardziej kontrolowany wyraz twarzy. Decydujący wpływ na wrażenia odbiorcy ma komunikat wzrokowy, który dociera do rozmówcy jako pierwszy, ponadto ważne są: brzmienie głosu i ton wypowiedzi oraz kanał akustyczno-artykulacyjny, który pozwala nadawcy rozporządzać elementami prozodycznymi wypowiedzi, takimi jak intonacja zdania, zawieszenie głosu, co umożliwia wyrażanie myśli w sposób klarowny.

Siłę perswazji wzmacnia także umiejętność komunikowania się, budowania autorytetu nadawcy oraz wzbudzania zaufania odbiorcy. W przekonywaniu istotny jest zwłaszcza ostatni z wymienionych czynników, ponieważ bez zaufania odbiorcy nadawca niewiele może osiągnąć. Perswazja przynosi efekty, gdy pozwala na nawiązanie specyficznego kontaktu z odbiorcą, a warunkiem decydującym o zaangażowaniu odbiorcy jest poziom zaufania, jakim obdarza nadawcę. Istotne jest silne poczucie więzi, łączące rozmówców, bowiem akceptacja i zaufanie sprzyjają komunikacji i przekonywaniu. Odbiorca, który zakłada szczerość nadawcy, ufa mu, nie doszukuje się w jego zachowaniu działań nieetycznych, więc chętniej przyjmuje jego sugestie. Sukces lub porażka działań perswazyjnych zależą od relacji między rozmówcami, ponieważ u podstaw przekonywania leży zaufanie, które gwarantuje skuteczność porozumienia między nadawcą a odbiorcą. Jak podkreśla W. Pisarek (2004: 127): „Perswazyjność szczerości wiąże się zapewne ściśle z zaufaniem odbiorców do nadawcy. [...] wchodzi tu w grę zaufanie oparte na przeświadczeniu raczej o uczciwości nadawcy niż o jego kompetencji”.

Charakterystyczną cechą wariantu mówionego polszczyzny, mającą wpływ na perswazyjność przekazu, jest możliwość wykorzystania w komunikacji bezpośrednich zwrotów do rozmówcy, które podkreślają swego rodzaju więź z odbiorcą. Komunikacja perswazyjna odwołuje się także do elementów wspólnej wiedzy, przekonań, norm obyczajowych, a także sposobu użycia języka przez rozmówców. Życie intelektualne jednostek koncentruje się wokół określonej - mniejszej lub większej grupy społecznej, a postawy światopoglądowe i sympatie estetyczne środowiska wpływają na sposób bycia i postrzegania siebie oraz innych. Środowisko w znacznym stopniu kształtuje opinie i postępowanie człowieka, szczególnie silny wpływ na sposób myślenia i zachowanie mają najbliżsi. Ton rozmowy potocznej uzależniony jest przede wszystkim od wzajemnych relacji łączących interlokutorów, które są wyznaczone przez miejsce każdego z nich w hierarchii społecznej, ważne są także i inne parametry: wiek, wykształcenie, poziom intelektualny oraz stanowisko zawodowe rozmówców. Spontaniczny, swobodny charakter wypowiedzi mieszkańców wsi wynika z rodzaju więzi, zachodzącej między rozmówcami, którą można określić jako ,język bliskości”, kategorię tę do opisu polszczyzny potocznej włączyła M. Kita (2001: 172), wskazując na wpływ aspektu przestrzennego oraz na znaczenie parametru interakcyjnego: ,relację między uczestnikami 
komunikacji: co do stopnia wzajemnej znajomości czy zażyłości” w tym typie komunikacji. Codzienną, żywiołową komunikację cechuje bliska więź, łącząca nadawcę i odbiorcę, zbudowana na specyficznej formie porozumienia między uczestnikami dialogu, w której najważniejszym czynnikiem nawiązania stosunków pomiędzy rozmówcami jest istnienie wspólnego świata, czyli ,zespołu sądów, które podzielają wszyscy uczestnicy dyskursu" (Szczerbowski 1994: 27). Badacze zjawiska perswazji zwracają uwagę, że: „W przeciwieństwie do życia publicznego atmosfera życia prywatnego jest ciepła i intymna. [...] «Swój człowiek» to ktoś, kto myśli podobnie jak ty, ktoś do kogo masz zaufanie i z kim dzielisz określone wartości i przekonania" (Szarota 2006: 97). W badanym typie kontaktów interpersonalnych rozmówcami są osoby z najbliższego kręgu, co sprzyja przekonaniu, że rozmawia się z osobami życzliwymi.

\section{Perswazja a manipulacja językowa - określenie pojęć, stan badań}

Perswazja, przedmiot uwagi przedstawicieli różnych dyscyplin humanistycznych, bez wątpienia należy do pojęć trudno definiowalnych, świadczy o tym bogata literatura poświęcona tej problematyce. Mimo że zagadnienie doczekało się wielu opracowań, rozpatrywanych w kontekście szeroko pojętych działań społecznych, to nadal kwestią dyskusyjną pozostaje sama definicja zjawiska i precyzyjne wyznaczenie granicy między perswazja i manipulacją. Zwłaszcza postawy manipulacyjne (zob. Klemantowicz 1982: 247-260; Grodziński 1983; Lewicki, Nowak 2000; Kita 2004: 199-210), jako charakterystyczny przejaw instrumentalnego stosunku do ludzi, od dawna stanowiły obiekt wnikliwej analizy psychologów (por. Jarymowicz 1980: 285-315; Lis-Turska 1980: 317-354), politologów (Karwat 1999; Karwat 2006) oraz językoznawców (Puzynina 1992; Krzyżanowski, Nowak 2004). Rozważania dotyczące przekonywania warto zacząć od ustaleń terminologicznych. Perswazja i manipulacja, będące realizacją funkcji naktaniającej, dotyczą działań, które mają na celu kierowanie postawami oraz zachowaniami ludzkimi. Pojęcia nie są jednak tożsame i wymagają uporządkowania związanej z nimi terminologii.

Złożoność problematyki przekonywania, wieloaspektowość badań i mnogość powstałych od starożytności teorii powoduje, że definicje terminów: perswazja i manipulacja nie zostały ostatecznie unormowane i usystematyzowane, stąd czasami traktuje się je jako tożsame. Brak ujednoliconej terminologii wynika z rozbieżnych stanowisk językoznawców co do samego zjawiska przekonywania. $\mathrm{W}$ opracowaniach $\mathrm{z}$ zakresu perswazji kategoria ta jest pojmowana $\mathrm{w}$ nieco odmienny sposób. Liczne wątpliwości budzi zwłaszcza termin manipulacja, który cechuje nieostrość znaczeniowa - zarówno jego treść pojęciowa, jak i granice stosowalności są mało wyraziste, niekiedy wręcz niejasne, a sama nazwa nie 
spełnia wymagań terminologicznych. J. Warchala (2004: 48) podkreśla, że: „,...] nie mamy dostatecznie satysfakcjonującego opisu zjawiska manipulacji, które nie byłoby jednocześnie obciążone jednostronnie aksjologicznymi ocenami [...]". Część badaczy (por. Bralczyk 2000b: 244-252; Kamińska-Szmaj 2004: 13-27) kwestionuje zasadność samego określenia manipulacja w terminologii naukowej, wskazując na wyraźne negatywne nacechowanie emocjonalne wyrazu, które powoduje, że zastosowanie go jako terminu naukowego budzi zastrzeżenia ze względu na konotowaną ocenę, która „podważa postulowaną neutralność terminu" (Kamińska-Szmaj 2004: 25).

Perswazja i manipulacja często łączone są z działalnością polityczną, publicystyką, reklamą, dotyczą także sfery codziennej komunikacji językowej. M. Kita (2004: 199-200) podkreśla, że zjawisko manipulacji obejmuje swym zasięgiem także spontaniczne kontakty językowe, gdyż nadawca dobiera informacje, którymi chce podzielić się z innymi.

W dyskusjach terminologicznych, dotyczących badań nad zakresem pojęcia perswazja językowa, często stawiane jest pytanie: co decyduje o tym, że dany akt komunikacji można uznać za perswazję, a co, że za manipulację językową? Opracowania filologiczne, stawiając obok siebie takie słowa, jak: perswazja, manipulacja, agitacja, indoktrynacja, stymulacja, dostarczają interesującego materiału na ten wciąż otwarty temat. Ustalenie relacji między perswazja a manipulacja jest tym bardziej kłopotliwe, iż cel tych działań, dotyczących wkraczania w sferę zachowań człowieka, kształtowania jego postaw, poglądów, opinii, odbywa się etapami, od zainteresowania, poprzez emocje, przeżycia do zaangażowania i uzyskania poparcia odbiorcy dla wskazanej przez nadawcę idei.

Już samo pojęcie perswazja językowa wzbudza wśród badaczy kontrowersje. Proponują oni różne rozstrzygnięcia interpretacyjne w kwestii definiowania perswazyjnej funkcji języka. I. Kamińska-Szmaj (2004: 21) wskazuje, że: „,...] na rozumienie pojęcia perswazja duży wpływ miały badania wykorzystania języka jako narzędzia propagandy w systemie komunistycznym $\mathrm{i}$ - szerzej - w systemach totalitarnych (np. w Trzeciej Rzeszy). W systemie totalitarnym manipulacja uwarunkowana była uprzywilejowaną rolą nadawcy i zdegradowaniem roli odbiorcy, zadaniem nadawcy było narzucić odbiorcy swoją wizję świata i osłabić krytycyzm odbiorcy. W pracach tych większość językoznawców utożsamia perswazję z manipulacją".

Definicja funkcji perswazyjnej sformułowana przez S. Barańczaka (1983: 33) nie wyznacza granicy między perswazją i manipulacją, nie widać w niej wyraźnego rozgraniczenia pojęć. Autor (1975: 44-57) wyróżnia cztery podstawowe mechanizmy uruchamiające funkcje perswazyjna: mechanizm emocjonalizacji odbioru, mechanizm wspólnoty świata i języka, mechanizm symplifikacji rozkładu wartości, mechanizm odbioru bezalternatywnego.

Pojęcie manipulacji jest mniej ustabilizowane od pojęcia perswazji; termin na gruncie polszczyzny pojawił się stosunkowo niedawno, toteżjego definicja wymaga 
uściśleń i ograniczeń. Ważnym źródłem wiedzy na temat słowa są opracowania leksykograficzne, pierwotnie wyrazy manipulacja i manipulowanie (zob. Doroszewski 1958-1969; Dunaj 1996), wywodzące się z łacińskiego manipulo, które wskazują na posługiwanie się rękami, jako naturalnymi narzędziami w kontaktach z przedmiotami materialnymi, wiązały się ze sposobem wykonywania czynności. W łacinie manipulus oznacza 'naręcze, wiązkę lub kompanię wojskową', manus 'rękę', a manus pellere - 'trzymać w dłoni'. Większość definicji słownikowych (zob. Słownik języka polskiego 1979: 105; Kopaliński 2007: 264) odnosiła słowa do wykonywania ręcznie precyzyjnych czynności. Stownik warszawski podaje dwa znaczenia manipulacji; 1. ,porządek odbywania roboty, odbywania spraw wszelkich, procedura [...]; 2. kierowanie czym, prowadzenie interesu, zarząd, zawiadywanie". Podobnie Stownik języka polskiego pod red. W. Doroszewskiego: 1. „czynność wykonywana ręcznie, zwłaszcza czynność precyzyjna, wymagająca umiejętności i zręczności”; 2 . „sposób prowadzenia lub załatwiania jakiś spraw”. Psychologiczne znaczenie terminu "kształtowanie lub przekształcanie poglądów i postaw ludzi, dokonywane poza ich świadomością' pojawiło się w opracowaniach leksykograficznych znacznie później, bo dopiero w Słowniku wspótczesnego języka polskiego B. Dunaja (1996): manipulacja 1. „nieuczciwe wpływanie na cudze poglądy; naginanie, przeinaczanie faktów w celu osiągnięcia własnych korzyści"; 2. „tendencyjna interpretacja faktów i danych w celu osiągnięcia własnych korzyści" (zob. Kopaliński 2000: 305). Wyraz zaczął być często stosowany w ostatnich latach XX wieku w kontekście oceny działalności polityków oraz mediów i obecnie przyjmuje negatywne konotacje.

Istnieje wiele definicji manipulacji. J. Fras (1997: 97) uważa, że jest to: „niejawny, podstępny, nierzetelny dobór informacji i środków językowych, który ma na celu: wywarcie wpływu na nastroje, poglądy, opinie innych ludzi; uzyskiwanie możliwości kierowania zachowaniem ludzi, aby osiągnąć własne cele i korzyści”. Podobnie definiuje zjawisko A. Lepa. Według niego manipulacja to: ,celowe i skryte działanie, przez które narzuca się jednostce lub grupie ludzi fałszywy obraz pewnej rzeczywistości” (Lepa 2000: 122). W. Pisarek (2006: 116) podkreśla, że: „manipulacja językowa - polega na informowaniu o danym fakcie czy zjawisku za pomocą słów tak dobranych, aby odbiorca przekazu mógł zrozumieć i zinterpretować tę informację w taki sposób, w jaki życzy sobie tego manipulator - tylko tak".

Porównując oba pojęcia $w$ kategoriach etycznych, widać wyraźnie, że perswazja to przekonywanie, które służy odbiorcy i nie narusza jego wolności osobistej, posiada więc wydźwięk pozytywny, zaś manipulacja to oddziaływanie negatywne, ponieważ ma przynieść korzyść nadawcy i sprowadza się do osiągnięcia celu za wszelką cenę.

Jak podkreśla M. Jarymowicz (1980: 285): „Działania polegające na wywieraniu zamierzonego wpływu na inne osoby czy grupy ludzi mogą przybierać różnorodne, odrębne formy, takie jak: 
- nadmierna opiekuńczość, przejawiająca się w udzielaniu sugestii, dostarczaniu wzorców postępowania, wskazywaniu sposobu rozwiązywania problemów itp.

- jawne narzucanie własnej woli, stosowanie nacisku, rozkazywanie, kontrolowanie itp.

- manipulowanie innymi w sposób dla nich niedostrzegalny przez okłamywanie ich, dyskretne aranżowanie określonych sytuacji, schlebianie czy inne formy zachowań ingracjacyjnych".

Powstaje więc pytanie: czy można zatem oddzielić perswazję od działań manipulacyjnych? Badaniu terminów w kontekście próby ich rozgraniczenia poświęcono wiele opracowań (por. Lewiński 2001: 284-293; Kamińska-Szmaj 2004: 13-27; Kudrowie 2004: 91-100; Mamcarz, Warchala 2004: 41-60), w których podkreśla się, że problem zależności między perswazją i manipulacją można rozpatrywać z różnych perspektyw, z których najistotniejsza wydaje się perspektywa aksjologiczna, wskazująca na motywy istoty działania językowego, ich celowość i skutek. U podstaw wyodrębnienia i definiowania terminów leży problematyka uczciwości i zachowań etycznych w komunikacji językowej. W aspekcie etyki językoznawcy przypisują komunikacji określone powinności i wymogi, tzn. komunikowanie powinno mieć charakter rzetelny i przejrzysty, pozbawiony form manipulacji. Ważnym elementem w etyce - także w etyce komunikacji - jest intencyjność czynu, której poświęcił wiele uwagi w swoich pracach św. Tomasz z Akwinu. E. Gilson (1960: 364) interpretuje ją w następujący sposób: „Gdy zamiar jest zły - czyn jest nieodwracalnie zły, gdyż wszystko co się nań składa jest powołane do istnienia po to, by służyć złu. Kiedy natomiast zamiar jest dobry owo początkowe skierowanie woli ku dobru musi się niewątpliwie odbić na całym czynie, do którego prowadzi".

Za odrębnością tych dwóch pojęć opowiada się J. Puzynina, która wskazuje, że tym, co różni zjawiska jest cel użycia perswazji, różnica tych dwóch pojęć, wykorzystujących język, polega przede wszystkim na odmienności podejścia do nadawcy. W opracowaniach podkreśla się etyczny aspekt technik oddziaływania za pomocą języka. J. Puzynina i A. Pajdzińska w szkicu Etyka słowa (1996), analizując problematykę uczciwości w komunikacji międzyludzkiej, wskazują, że właściwe użycie języka powinno uwzględniać reguły: estetyczne, społeczne, moralne, obowiązujące uczestników konwersacji. Każdy tekst winien realizować zasady: wyrażaj się jasno; wyrażaj się grzecznie; nie bąd́ natrętny; daj możliwość wyboru; badź przyjazny.

Podstawowe zasady etyki słowa, związane z ogólnym ideałem dobra indywidualnego i zbiorowego, można sformułować na tak i na nie.

Zasady na nie:

1) jako nadawca nie krzywdź drugiego człowieka ani grup społecznych słowem wrogim, poniżającym, raniącym; nie okłamuj innych, nie manipuluj nimi za pomocą półprawd, pochlebstwa, demagogii, szantażu, 
2) jako odbiorca nie zrywaj dialogu, nie zamykaj się na słowo innych, nie przyjmuj ich ze z góry powziętymi uprzedzeniami; jednocześnie nie bądź naiwnym w odbiorze komunikatów, zdawaj sobie sprawę z możliwości okłamywania i manipulacji.

Zasady na tak:

1) jako nadawca mów tak, aby partnerzy czuli się bezpiecznie i mieli świadomość akceptacji; mów to, co się uważa za prawdę, chyba że przemilczenie lub nawet kłamstwo są uzasadnione dobrem innych; mów tak, by nie utrudniać partnerowi zrozumienia i nie denerwować go brakiem poprawności lub snobizmem językowym,

2) jako odbiorca wysłuchaj innych z dobrą wolą, choć bez naiwności, staraj się zrozumieć ich reakcje.

O najważniejszych dla etyki słowa kwestiach prawdy i szacunku jako istocie przekonywania w kontaktach międzyludzkich pisze M. Brzeziński (2008: 19): „Podstawą skutecznych technik wpływu jest szacunek dla ludzi, umiejętność wybaczania i ciekawość człowieka. Jeśli chcę na kogoś wpłynąć, bardziej interesuje mnie jego świat niż mój. Ufam drugiej osobie, pozostawiam jej wybór, motywuję, ale nie mam zamiaru jej skrzywdzić".

Uważam, że w działaniach o charakterze perswazyjnym rozmówcy powinni kierować się następującymi zasadami:

- zasada prawdy - informacje $\mathrm{w}$ przekazie powinny być zgodne $\mathrm{z}$ prawdą, bez zniekształceń, przedstawiać fakty we właściwym kontekście,

- zasada obiektywizmu - nadawca powinien przedstawić rzeczywistość niezależnie od swoich poglądów,

- zasada uczciwości - nadawca powinien działać w zgodzie z własnym sumieniem, nie ulegać wpływom,

- zasada szacunku i tolerancji - poszanowania ludzkiej godności, prawa, prywatności i dobrego imienia,

- zasada pierwszeństwa dobra odbiorcy - dobro odbiorcy powinno być nadrzędne wobec dobra nadawcy.

Zdaniem J. Puzyniny (1992: 214), która wyróżnia manipulacje językowa i manipulacje językiem, kryterium pozwalającym na odróżnienie perswazji i manipulacji jest występujący w przebiegu interakcji w zachowaniu element oszustwa. Perswazja i manipulacja wykorzystują wspólny zestaw środków retorycznych, ale przyjrzenie się obu działaniom z perspektywy jawnych i ukrytych intencji nadawcy pozwala je rozróżnić. Perswazja odwołuje się do kategorii prawdy w swych działaniach wobec innych ludzi, opiera się na szacunku dla odmiennych poglądów i zapatrywań. Manipulację można traktować jako rodzaj zachowania komunikacyjnego, w trakcie którego omija się zasady kooperacji w procesie interakcji między partnerami, czynnikiem różnicującym działania jest element aksjologiczny, tj. uczciwość w perswazji wobec nieuczciwości w manipulacji. Proponowana przez autorkę definicja manipulacji brzmi następująco: „X manipuluje Y-kiem = oddzia- 
łuje na Y-ka w taki sposób, aby Y poprzez swoją postawę i / lub zachowanie był narzędziem realizacji jakiś celów X-a. X działa bez użycia przemocy, ale tak, że Y nie wie, jaki jest cel działania X-a". O zjawisku badaczka (1992: 203) pisze: „Manipulacja - bywa zazwyczaj ukrytą, niejednokrotnie bardzo finezyjną, wyszukaną formą zniewalania. Często późno zauważamy jej istnienie, czasem w ogólne nie zdajemy sobie z niej sprawy".

Manipulacje językiem rozumie J. Puzynina jako splot nieuczciwości popełnionych w opisie języka jako kodu, a służących określonym celom. Manipulacja językowa to manipulacja ludźmi za pomocą tekstów języka naturalnego. Występuje ona w dwóch zakresach: szerszym i węższym. W szerszym znaczeniu będzie to manipulacja dokonywana za pomocą treści zawartych w tekście, w jej kręgu znajduje się wszelka demagogia, kłamstwo czy posługiwanie się stereotypami. Węższe znaczenie to manipulacja, przy której środki językowe (określone cechy wyrazów i struktury gramatyczne) umożliwiają wywieranie wpływu na odbiorcę, z którego on nie zdaje sobie sprawy. Podobnie ujmuje zagadnienie D. Zdunkiewicz-Jedynak (1996: 37), która określa perswazję jako wpływ na przekonania odbiorcy przez oddziaływanie na jego rozum, sferę emocji i wolę, i „odróżnia perswazję od manipulacji, przypisując tej drugiej niespełnienie warunku szczerości”.

Natomiast R. Grzegorczykowa (1991), różnicując pojęcia wpływu na odbiorcę uważa, że kluczową dla rozróżnienia perswazji i manipulacji jest kwestia realizacji intencji nadawcy. Funkcja perswazyjna i manipulacyjna są postaciami funkcji impresywnej, z tym, że perswazja jest działaniem na świadomość, manipulacja - poza świadomością odbiorcy, działanie manipulacyjne traktuje jako takie, które unika jawnego przekonywania. R. Grzegorczykowa (1991: 24) wyodrębnia w wypowiedzi różne funkcje (intencje), a wśród nich funkcję nakłaniająca, podkreślając jej zróżnicowanie: „nacisk na odbiorcę może mieć na celu: 1. wywołanie działania słownego (pytania) lub innego (dyrektywy: rozkazy, groźby, prośby itp.), a także: 2 . wpłynięcie w pewien sposób na odbiorcę, przede wszystkim na jego stan mentalny przez perswazję (rady i innego typu wypowiedzi przede wszystkim wartościujące), bądź też przez działanie manipulacyjne unikające jawnego przekonywania".

Z kolei P. H. Lewiński (2001: 285) wskazuje, że trudno jest ustalić granice perswazji, a zjawisko definiuje jako: ,[...] usiłowanie uzyskania realnego wpływu na sposób myślenia lub postępowania odbiorcy, jednakże nie drogą bezpośredniego rozkazu, lecz metodą pośrednią, poprzez podporządkowanie założonemu celowi wszystkich pozostałych zachowań komunikacyjnych, które odbiorca byłby w stanie zrozumieć i właściwie zinterpretować”. Definicja ta zakłada, że po pierwsze, odbiorca przeważnie orientuje się, że ma do czynienia z perswazją (sytuacja jawna i jednoznaczna). Po drugie, perswazja nie jest środkiem przymusu, ale zakłada wymianę komunikatów. Oczywiście perswazja działa także na emocje odbiorcy, jednak osiągnięciu celu perswazji stuży przede wszystkim argumentacja, która może być: logiczna, dialektyczna - wymaga dialogu, interakcji od- 
biorcy, konieczne przy tym jest zrozumienie, analiza i akceptacja lub odrzucenie argumentacji (sposób centralny) albo poprzez racjonalizację opartą na emocjach (sposób peryferyjny); erystyczna - steruje wrażeniami odbiorców, odwołuje się do logiki, ale polega na usprawiedliwieniu danego stanowiska. Perswazja według autora może być osiągana na dwa sposoby: droga centralna - przez zrozumienie i analizowanie argumentacji; droga peryferyjna - na skutek wpływu czynników akcydentalnych, jak sympatia dla nadawcy, jego wygląd, korzyści.

Natomiast J. Warchala traktuje perswazje jako stały element towarzyszący komunikowaniu, który z natury swojej jest działaniem nastawionym na współpracę i porozumienie, natomiast manipulacja służy ukrywaniu celów i realizowaniu ich za wszelką cenę. Autor (2004: 41) pisze: „Jeśli spojrzymy na mówienie jako na działanie o charakterze komunikacyjnym zdeterminowane teleologicznie, a zatem od strony spełnianych intencji i realizowanych celów, to szczególnie ważne okaże się zagadnienie perswazji jako drogi do wypełnienia założonych celów i manipulacji - realizowania celów za wszelką cenę. Wydaje się, że perswazja, której natura jest pragmalingwistyczna, związana być powinna z działaniami komunikacyjnymi sensu stricte, a więc działaniami nastawionymi na koordynację i porozumienie. W tym sensie perswazja jest mechanizmem koniecznie towarzyszącym komunikowaniu. O manipulacji, której natura jest psychologiczna, możemy mówić wówczas, gdy potrafimy dostrzec cele strategiczne uczestnika (uczestników) komunikacji”.

U. Żydek-Bednarczuk (2004b: 32-33) uważa, że: „Manipulacja językowa to takie ukształtowanie wypowiedzi przez nadawcę, które służy przekonaniu odbiorcy do czegoś, co może być dla niego niekorzystne, a jest pożądane z punktu widzenia nadawcy. Ze względu na nieuczciwe, najczęściej ukryte intencje nadawcy leżące u podstaw manipulacji językowej, jest ona oceniana negatywnie".

Z kolei J. Bralczyk (1999a: 218-227) traktuje manipulacje jako: „nieetyczne wykorzystywanie przewagi nadawcy do instrumentalnego lub przedmiotowego traktowania odbiorców" i wskazuje, że istotne znaczenie w badaniach nad perswazją i manipulacją ma rozróżnienie aspektów naktaniania: dyrektywności i perswazji (Bralczyk 1987: 17). Za dyrektywne uznaje autor wezwanie do zachowań aktywnych (nawet wezwania pośrednie), natomiast za perswazyjne - wypowiedzi stymulujące postawy, które powinny sprzyjać pożądanym zachowaniom.

W definicji manipulacji językowej oprócz nieuczciwych intencji nadawcy podkreśla się także towarzyszący im sposób przekazu informacji.

Badacze wskazują, że manipulacja przybiera różne formy i jest uzależniona od rodzaju sytuacji komunikatywnej. Jak podaje Mały stownik terminów z zakresu socjolingwistyki i pragmatyki językowej (Skudrzykowa, Urban 2000: 111): „W odróżnieniu od manipulacji zabiegi perswazyjne wpływają na stan mentalny odbiorców poprzez działanie na ich świadomość (odwołanie do przykładów, argumentacji logicznej itp.)", natomiast manipulacja „polega na działaniu na uczucia, na wolę i przekonania odbiorcy nie poprzez jawne odwoływanie się do racjonalnych argumentów, ale poprzez niejawne oddziaływanie na jego świadomość". 
P. Krzyżanowski (2004: 279) wyodrębnia dwa typy manipulacji: w języku i w tekście. Manipulacja w języku utrudnia, a czasem uniemożliwia adekwatne mówienie o świecie, co w konsekwencji ogranicza możliwości poznawcze użytkowników języka, ponieważ utrudnia wypełnienie przez język jednej z jego podstawowych funkcji - funkcji poznawczej.

W opracowaniach przedstawicieli innych dyscyplin wiedzy, np. politologów, psychologów czy socjologów manipulacja bywa łączona przede wszystkim z jednostronnością i fragmentarycznością informacji. Politolodzy wśród technik manipulacyjnych wskazują: techniki oparte na oddziaływaniu emocjonalnym, które wykorzystują uczucia i emocje: strach, dumę, chciwość, nadmierne ambicje oraz polegające na manipulowaniu informacja, odwołujące się do fragmentaryczności i natychmiastowości informacji. Manipulację polityczna (Chmaj, Sokół 1997: 158) definiują jako zjawisko, które: „Polega na ograniczeniu kontrolnych funkcji świadomości, oddziaływaniu na jednostkę w sposób powodujący powstanie zespołu przekonań, odpowiadających manipulującemu".

$\mathrm{Na}$ gruncie nauk psychologicznych manipulacja rozumiana jest szeroko, szczególnie w kontekście komunikacji jako centralnego procesu kulturowego (zob. Hałas 2001: 44) i oznacza posługiwanie się komunikacją jako narzędziem skutecznego oddziaływania na osoby, które traktuje się w sposób instrumentalny. $\mathrm{Z}$ manipulacją wiążą się bowiem określone działania językowe, które naruszają wolność jednostki. Służy ona do zaspokajania własnych potrzeb (także grupowych) (Sujak 2006: 81).

W ujęciu socjologicznym nacisk kładzie się także na związek perswazji z komunikacja. M. Marody (2003: 18-27) jest zdania, że warunkiem zaistnienia rzeczywistej perswazji jest dialog, bez którego nie może być mowy o faktycznych negocjacjach, o przekonywaniu świadomego adresata, a więc o perswazji we właściwym znaczeniu tego słowa.

Ze względu na różne cele perswazyjne badacze wyodrębniają trzy rodzaje perswazji: przekonujaca, nakłaniajaca i pobudzajaca (Korolko 1998: 34). Perswazja przekonująca, która zakłada aktywność intelektualną odbiorcy oraz uczciwość nadawcy, jest najbardziej rzetelnym rodzajem perswazji. Celem perswazji nakłaniajacej, zwanej propaganda, jest pozyskiwanie jak najwięcej zwolenników dla prezentowanych idei, dlatego w jej ramach wykorzystuje się różne techniki wpływu, może być stosowana jawnie lub skrycie, może także okazać się oddziaływaniem perswazyjnym zarówno uczciwym, jak i nierzetelnym, a nawet szkodliwym. Natomiast perswazja pobudzająca, czyli agitacja, obliczona na doraźne zjednywanie odbiorców dla idei czy inicjatywy, wykorzystuje sugestywne techniki przekonywania, które wyzwalają u odbiorców aktywne stany emocjonalno-intelektualne.

Ponieważ przekonywanie służy różnym celom, perswazję i manipulację traktuję jako zjawiska ze sobą powiązane, dotyczą bowiem oddziaływania na innych. Leżące u ich podstaw mechanizmy są podobne, różnica dotyczy intencji nakła- 
niania oraz odniesienia nadawcy do odbiorcy. Uważam, że tym, co w zasadniczy sposób różni perswazję od manipulacji jest motyw językowego działania, zamiar, zamysł nadawcy, który pragnie osiągnąć określony cel. Perswazję rozumiem jako pojęcie nadrzędne terminologicznie, zaś manipulację traktuję jako rodzaj wynaturzonej perswazji. W praktyce manipulacja oznacza brak szczerości, ukrywanie przed odbiorcą komunikatu prawdziwych intencji i myśli. Działania językowe w perswazji i manipulacji różnicuje stosunek względem interlokutora. W perswazji istotnym elementem komunikacji jest postawa nadawcy, która wychodzi poza jego egocentryczny interes, uwzględniając potrzeby i dobro odbiorcy, natomiast w manipulacji celem nadrzędnym jest przede wszystkim dobro nadawcy, w działaniach manipulacyjnych osoba ludzka nie jest traktowana jako autonomiczna wartość, staje się narzędziem do realizacji własnych celów. Perswazja tym różni się od manipulacji, że pozostawia jednostce swobodny wybór. U podłoża działań perswazyjnych leży troska i życzliwość dla innych, która jest impulsem językowego zachowania nadawcy. Cechuje ją bezinteresowność oraz zainteresowanie drugim człowiekiem dla niego samego, a nie dla realizacji własnych celów, perswazyjne środki językowego oddziaływania kończą się tam, gdzie zaczyna się przymus i przemoc.

Jak podkreśla E. Laskowska (2004: 81-90) bardzo trudno ustalić granice perswazji, zwłaszcza relacje między perswazją uczuciowa a nieuczciwa manipulacją. Problematyka rozróżnienia form nakłaniania wciąż pozostaje kwestią nierozstrzygniętą (por. Lewiński 2001: 284-293), ponieważ nadal brak skutecznych kryteriów formalnych i znaczeniowych, które doprowadziłyby do wyodrębnienia pojęć. Co więcej, nowe badania rozmyły na dobre granicę między zjawiskami, współcześnie w szczególności zjawisko manipulacji wymaga nowego zrozumienia.

Podstawowa trudność badań perswazji wynika z konieczności wypracowania metod wyjaśnienia związków między przekazami perswazyjnymi, postawami odbiorców i podejmowanymi przez nich działaniami społecznymi. Starając się ocenić, czy dane zjawisko jest perswazją, czy manipulacją, należy mieć na względzie następujące kwestie: intencję nadawcy, cel komunikacyjny (czy jest on jawny, czy ukryty), sposób uksztattowania komunikatu językowego, odbiorce (czy jest on dla nadawcy podmiotem komunikacji, czy narzędziem do uzyskania korzyści) oraz czy uwzględnia on prawa odbiorcy do samodzielnej decyzji (czy nadawca pozostawia odbiorcy wolność wyboru zachowań i postaw, czy narzuca mu własny punkt widzenia).

W definicji manipulacji badacze uwypuklają pewne elementy wspólne, traktując ją jako specyficzną formę działania na postawy i zachowania ludzi, polegającą na ukrywaniu intencji i posługiwaniu się wybranymi środkami językowymi oraz odpowiednimi technikami. Manipulacja niekiedy może przyjmować bardzo finezyjny kształt, ale zawsze prowadzi do zniewolenia. Wypowiedź jest środkiem manipulacji, kiedy nadawca zataja lub fałszuje prawdę, kiedy formułuje komunikat językowy tak, by uniknąć tego, co jest z jego punktu widzenia niepożądane, 
gdy jego celem będzie wykorzystanie akceptacji odbiorcy komunikatu dla własnych korzyści. Badacze zgodnie podkreślają, że manipulacja ma związek z osobistym interesem nadawcy, kojarzona jest z oszustwem, kłamstwem często dokonywanym w sposób wyszukany.

I. Kamińska-Szmaj (2004: 13) uważa, że: „Odróżnienie perswazji od manipulacji jest możliwe po rozpoznaniu całej sytuacji komunikacyjnej. Przy czym należy pamiętać, że to obserwator - osoba z zewnątrz analizująca całe wydarzenie komunikacyjne - na podstawie własnej wiedzy i przyjętych przez siebie kryteriów opisu i wartościowania stwierdza, że działania nadawcy to manipulacja".

Tymczasem na przekraczanie granic oddziaływania na odbiorcę i trudności związane z rozpoznaniem rzeczywistych pobudek, związanych z działaniami przynoszącymi pożytek innym zwraca się uwagę w opracowaniach psychologicznych, w których wskazuje się różne typy motywacji. Jak zauważa A. Gołąb (1980), rozpoznanie rzeczywistych intencji, skłaniających człowieka do działania na korzyść innych ludzi, jest zadaniem trudnym, ponieważ niekiedy intencje mogą wynikać z pobudek egoistycznych. Autor (1980: 229-230, podkr. - B. B.-R.) pisze: „Gdy człowiek pomaga komuś: może zabiegać w ten sposób o pomyślny dla siebie układ zewnętrznych okoliczności; może zmierzać do zapewnienia sobie jakichś osobistych korzyści (np. rewanż) lub zabezpieczenia się przed niepożądanymi dlań ewentualnościami (np. przykra wymówka); może kierować się współczuciem dla tego, komu pomaga, pragnieniem sprawienia mu przyjemności lub poprawienia jego sytuacji (a zatem działać pod wpływem emocji, jakie wywołuje w nim wyobrażenie aktualnych lub możliwych doznań drugiego człowieka); może dążyć do wypetnienia obowiązów, jakie nakładają nań aprobowane przez niego normy moralne (np. normy «miłości bliźniego», «uczynności», «solidarności koleżeńskiej», «wzajemności» itd.)".

Granica między perswazją a manipulacja jest płynna i tak naprawdę trudno stwierdzić, kiedy kończy się jedna, a zaczyna druga. Oba sposoby oddziaływania stosują podobne techniki i metody, obejmując swym zasięgiem niemal wszystkie pola aktywności człowieka: wychowanie, handel, politykę, media itd.

$\mathrm{W}$ pracy badawczej bardzo trudne lub wręcz niemożliwe jest oddzielenie perswazji od działań, które mogą uchodzić za manipulacyjne, ponieważ obserwator nie ma możliwości wglądu w świadomość czy intencje rozmówcy, a w związku z tym nie może być całkowicie bezstronny w ocenie tych działan. W konkretnych życiowych sytuacjach trudno rozdzielić perswazję i manipulację, często ich rozróżnienie bywa jednie zabiegiem teoretycznym. Pytanie zatem, co jest perswazją, a co manipulacją, pozostaje wciąż otwarte. 



\section{ROZDZIAŁ II}

\section{Środki wyrażania perswazji}

\section{Leksykalne środki perswazji}

\subsection{Wartościowanie, rodzaje wartości i sposoby wartościowania}

Elementem nieodłącznie towarzyszącym perswazji jest wartościowanie rozumiane jako proces wewnętrzny, polegający na poznawaniu wartości w przedmiocie i/lub przypisywaniu wartości przedmiotowi. Wartościowanie to mówienie, że coś jest dobre lub złe pod jakimś względem (zob. Puzynina 1992; Laskowska 1996: 76-82), to przekonanie wartościujące lub sąd wartościujący, który polega na przypisywaniu wartości jakiemuś przedmiotowi (zob. Laskowska 1992: 20).

Lingwistyczne badania wartości, dotyczące istoty hierarchii i podziału wartości, były przedmiotem wnikliwej analizy (zob. Puzynina 1990: 81-94; Bartmiński, Mazurkiewicz-Brzozowska 1993; Puzynina 1997; Bartmiński 2002). Perswazji służy na poziomie leksyki słownictwo wartościujące, wprowadzające ocenę pozytywną lub negatywną. Wartościowanie może być wyrażane wprost - poprzez wprowadzanie słów bezpośrednio nazywających zjawiska pozytywne lub negatywne, służą temu najczęściej: przymiotniki, przysłówki i rzeczowniki lub pośrednio - przez kontekst wypowiedzi. Świat wartości odgrywa niezwykle doniosłą rolę w życiu człowieka; wartości są przejawem swoistej orientacji światopoglądowej i sposobem interpretacji rzeczywistości. Od hierarchii wartości uzależniona jest w dużej mierze cała sfera odniesień do świata i innych ludzi, a także obszar decyzji i życiowych wyborów jednostek. Człowiek, odwołując się do wartości, nazywa pewne fragmenty świata, kieruje się przy tym prostymi regułami, które pozwalają mu go zrozumieć i uporządkować, przede wszystkim postrzega otoczenie dzięki zmysłom i skojarzeniom.

Zjawisko perswazji również odwołuje się do wartościowania, a akty perswazyjne zawierają w swej strukturze jakiś element aksjologiczny, wpływ wartościowania na perswazyjność komunikatu badano w aspekcie różnych typów przekazów: propagandowych (Bralczyk 1981a: 339-343), publicystycznych (Puzynina 1984b: 69-78), reklamowych (Zimny 1995: 239-254). S. Grabias (1994: 155) uważa, że: „Wartościami utrwalonymi w języku są niechciane lub pożądane 
stany, do których zmierza w swym postępowaniu człowiek jako faktyczny i potencjalny ich nosiciel i które, interpretując rzeczywistość, nadaje przedmiotom, wytworom ludzkiego działania lub zjawiskom od niego niezależnym”. Poglądy na temat wartości stanowią istotny składnik poglądu na świat. Najważniejsza jest dla jednostki wartość nadrzędna, usytuowana na szczycie piramidy wartości, nazywana w naukach o wychowaniu wartościa strukturalna. Hierarchia wartości, zwłaszcza wartość naczelna, przyjęta przez jednostkę rzutuje na różne sfery jej życia i na zachowanie.

W proces wartościowania zaangażowany jest nie tylko intelekt, ale również emocje. Emocjonalnej ocenie podlegają przede wszystkim ludzie, charakteryzowani - zwykle ujemnie - ze względu na cechy fizyczne i psychiczne, a w perswazyjnym oddziaływaniu istotną rolę odgrywa znajomość kontekstu środowiskowego i kulturowego odbiorcy, jego sfera wartości, przekonań i postaw.

Problematyka wartości w języku potocznym (zob. Laskowska 1992; 1996: 76-82) była przedmiotem wnikliwej analizy językowej. E. Grzelakowa (2002: 198) wskazuje, że: „Kategoryzacja jest wszechobecna w naszym życiu codziennym, nie tylko pomaga porządkować otaczającą nas rzeczywistość, ale także umożliwia interpretację aksjologiczną tej rzeczywistości, a przez to wpływa na nasze zachowania". Trzeba zaznaczyć, że nie każdy wartościujący akt mowy ma na celu nakłonić czy przekonać do czegoś odbiorcę. Zasadnicze znaczenie ma tutaj intencja komunikacyjna nadawcy, to ona bowiem decyduje o tym, czy w konkretnym działaniu językowym mamy do czynienia z perswazją. Przekaz perswazyjny jest sprytną techniką ingerencji w czyjśs wewnętrzny system wartości, pozwala interpretować i oceniać rzeczywistość zgodnie z czyimś planem, wydawać sądy zgodne z czyjąś wolą. Perswazja to typ oddziaływania, odwołujący się do wartościowania intelektualnego, etycznego lub emocjonalnego, który obejmuje wszystkie sfery ludzkiej komunikacji. W perswazji nadrzędną wartością zawsze jest prawda, a jej przyjęcie wymaga świadomego i dobrowolnego wyboru między różnymi wartościami. Proces oceny może dotyczyć różnych aspektów, ponieważ wartościowanie jest czynnością wysoce relatywną i odbywa się według wielu kryteriów: pragmatycznych, ekonomicznych, hedonistycznych, witalnych, społecznych, odczuć perfekcjonistycznych, estetycznych, poznawczych, etycznych, sakralnych.

Samo wartościowanie może być celem zasadniczym przekazu lub dodatkowym do niego komentarzem, dotyczy ludzi, rzeczy, zjawisk, a ocenie podlega zarówno nadawca, jak i odbiorca wypowiedzi. W opinii autora przekazu to, o czym się mówi, postrzegane jest jako dobre lub złe, piękne lub brzydkie, korzystne lub niekorzystne z jakiegoś punktu widzenia, budzące sympatię, życzliwość, niechęć, złość, gniew, pogardę. Dzięki wyrażaniu ocen nadawca ujawnia odbiorcy swój pogląd na świat, stosunek do ludzi, do różnych problemów życiowych, do spraw społecznych, politycznych i światopoglądowych, przekazując także informacje o sobie. 
J. Puzynina (1992: 118) podkreśla, że: „Podstawowym środkiem językowym służącym wyrażaniu wartości są słowa”. Wartościowanie wyrażane jest wprost, poprzez wprowadzanie słów bezpośrednio nazywających zjawiska pozytywne lub negatywne. Wyrazy wartościujące dzielimy na dwa typy. Do pierwszego zalicza się te, w których występuje składnik znaczeniowo wartościujący całą treść wyrazu. Ma on postać: 'nadawca sądzi, że to jest dobrze (dobre)' lub: 'nadawca sądzi, że to jest źle (złe)' i należy w sposób stały do cech definicyjnych tego wyrazu. Mówimy wtedy o wyrazach definicyjnie lub semantycznie wartościujacych, gdyż ich znaczenie w całości traktowane jest przez nadawcę jako złe lub dobre. Drugim typem wyrazów są te, które zależą od mniej lub bardziej ustabilizowanej konotacji i ich znaczenie zmienia się w zależności od kontekstu. Są to wyrazy pragmatycznie lub konotacyjnie wartościujace (Puzynina 1992: 119-120). I. Bajerowa (1988: 37) wskazuje, że: „W zakresie słownictwa znamiennego dla stylu perswazyjnego można wyróżnić następujące rodzaje wyrazów i zabiegów stylistycznych":

- wyrazy wartościujące,

- wyrazy schematyzujące,

- zmiany znaczeniowe wyrazów,

- wyrazy zachęcające i nakazujące,

- gromadzenie wyrazów o podobnej funkcji (wyrażenia szeregowe).

$\mathrm{W}$ analizowanych tekstach najczęstszym zabiegiem służącym perswazji jest wartościowanie bezpośrednie.

\subsubsection{Wartościowanie bezpośrednie. Wyrażanie ocen za pomocą słownictwa wartościującego - wyrazy wprowadzające pozytywną lub negatywną ocenę}

Perswazji służy słownictwo wartościujace, które wyraża wprost ocenę pozytywną lub negatywną. Obecność słownictwa aksjologicznego, nazywającego bezpośrednio wartości, do których rozmówca pragnie przekonać słuchacza lub antywartości, postrzegane przez J. Puzyninę (1990: 81) jako: „cechy, które uznajemy za złe i/lub odczuwamy jako takie", przed którymi przestrzega, ma związek z charakterem grupy społecznej, która w dużej mierze kształtuje sposób widzenia rzeczywistości, a więc sposób kategoryzowania świata i mówienia o nim.

Mieszkańcy wsi odwołują się i podkreślają w swoich rozmowach wartości powszechnie uznawane, takie jak: uczciwość, pracowitość, oddanie, tradycja, rodzina, miłość, przyjaźń, zdrowie. W analizowanym materiale wartościowaniu służą różne części mowy: rzeczowniki, czasowniki, przymiotniki, przysłówki, a także związki frazeologiczne. 
$\mathbf{D} / \mathbf{K}-\mathbf{M} / \mathbf{I I I} / \mathbf{I I I}^{1}$

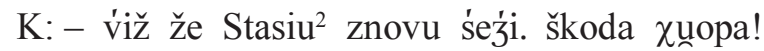

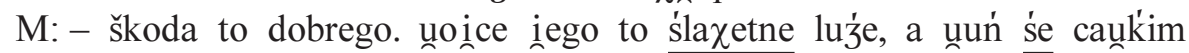
zgaunganiun.

Rozmówca nie podziela współczucia kobiety wobec mężczyzny, o którym opowiada. Wypowiedź zbudowana jest na zasadzie wyrazistego kontrastu postaw. Wartościowaniu często służą przymiotniki (zob. Lubaś 2003: 363-380). Przymiotnik szlachetny oznacza najpiękniejsze przymioty moralne, które czynią człowieka wyższym ponad pospolitych ludzi, odnosi się do osób, które postępują w sposób wspaniałomyślny, sprawiedliwy, bezinteresowny, prawy, natomiast czasownik zgałganić się w sposób bardzo sugestywny podkreśla degenerację mężczyzny, wskazując, że postępuje on w sposób odmienny niż rodzice.

\section{D / K1 - K2 / III / IV}

K1: - ńe každy dba o požundek.

K2: - ununa barzo lubi čystoś. vrući ze škouny torbe, buty pomyie, zešyty, k’sušški pookunado. to naunučycelka iei ušystkim pokazui ie, bo ne ma f škole jecka, coby tak čysto țšymauno śe.

Wartościowaniu estetycznemu służą leksemy: rzeczownik czystość, przysłówek czysto, czasowniki dystrybutywne: pomyje, pookłada, wskazujące na działanie dziecka. Uwiarygodnieniu wypowiedzi służy także odwołanie się nadawcy do autorytetu nauczycielki, która stawia dziewczynę za wzór pozostałym uczniom szkoły.

\section{D / K1 - K2 / IV / III}

K1: - tag dobže śe unucy, aš fainne iź do škouny. Janek pošed na

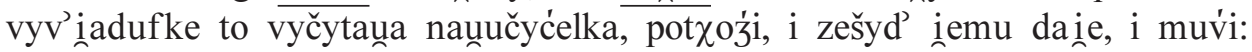
paćće, iak'i zešyt, i f̌syskim pokazuie.

K2: - tfoịa se dobže unucy, bo ma muṇdry unoincuf. ț̌seba ż żećak'iem rozmav'iać. ununy mu - ničym ne pomogom, ne naganaiom do naunuki.

Pierwsza kobieta podkreśla umiejętności poznawcze dziecka, por. przysłówek: dobrze i modne określenie wartościujące fajnie. Druga z rozmówczyń wskazuje, że sukces szkolny ucznia w znacznym stopniu zależy od inteligencji i pomocy rodziców, por. przymiotnik mądry, którzy tworzą odpowiednią atmosferę w domu, dostrzegają możliwości dziecka i motywują je do nauki. Brak takich działań, por. nie pomagaja, nie naganiają do nauki, może prowadzić do pojawienia się problemów szkolnych.

${ }^{1}$ Objaśnienia skrótów użytych do prezentacji tekstów gwarowych znajdują się w Wykazie skrótów zamieszczonym na początku niniejszej publikacji.

${ }^{2} \mathrm{~W}$ nazwach własnych (osobowych i geograficznych) występujących w tekstach gwarowych został zastosowany zapis ortograficzny. 


\section{D / K1 < K2 / II / III}

Matka rozmawia $\mathrm{z}$ córką.

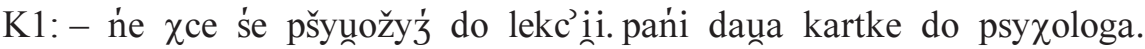

$\mathrm{K} 2$ : - sama $\mathrm{z}^{\prime}$ ńim ščeže pogadei. naíleṕi zaunatf'ić fšysko $\mathrm{v}$ roźine, sfui ze sfoim, po co unopcego ftaiem’ničać?

Kobieta przekonuje, że najlepszym rozwiązaniem problemów szkolnych będzie szczera rozmowa z dzieckiem. Wyrazami o zabarwieniu pozytywnym są: przymiotnik szczera i rzeczownik rodzina. Rodzina jest wspólnotą swoich, krewni to ludzie najbliżsi, znani, swojscy, którym można zaufać, powierzając szczegóły jakiejś sprawy. Zaprzeczeniem bliskości jest wyraz obcy. Kategorie ważności oraz bliskości, które mają wyraźną funkcję perswazyjną, zostały opisane przez J. Bralczyka (2001) w kontekście języka propagandy politycznej.

\section{$\mathbf{D} / \mathbf{M}-\mathbf{K} /$ III / III}

M: - pšećeš ty ńe muśiž gotovać.

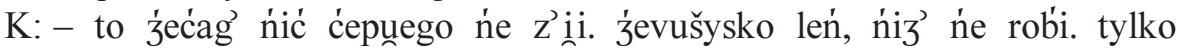
fstane p'ier'śćunkuv na unapy nazakuado, pazury pomaluie, kavy se narobi,

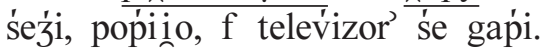

Negatywnemu wartościowaniu osoby, którą rozmówczyni prezentuje z dużą dozą sugestywności, służy atrakcyjnie przedstawiony obraz, trafiający do odbiorcy. W wypowiedzi zastosowano środki słowotwórcze: rzeczownik dziewuszysko z niechęcią o dziewczynie oraz środki leksykalne: rzeczowniki leń, łapa - rub. żart. 'ludzka dłoń, ręka', pazury - posp. 'paznokcie', tu iron. wypielęgnowane; czasownik gapić się - pot. 'przyglądać się czemuś bezmyślnie, tępo'. Osoba w ten sposób charakteryzowana jawi się jako kobieta zaniedbująca dziecko, próżna, mająca zamiłowanie do błyskotek, skupiona jedynie na własnej urodzie. Świadczy o tym odwołanie się do atrybutów i wartości estetycznych: pierścionki, malowanie paznokci. Realistyczny opis wyglądu osoby, który przedstawia ją w krytycznym świetle, jako nadmierną elegantkę, przenoszącą wygląd zewnętrzny ponad cechy charakteru, powiązany jest z opinią na temat jej postępowania. H. Pelcowa (1998: 107-108), która badała zjawiska dialektalne, ujmuje zagadnienie w następujący sposób: ,[...] jak wiadomo - postępowanie człowieka podlega określonemu systemowi wartości, wytworzonemu w danym środowisku, przy czym na wsi, gdzie wszyscy dobrze się znają, to wartościowanie jest wyrazistsze. W języku odbijają się formy i zasady współżycia społecznego, wyrażone zarówno stosunkiem do innych osób, jak i sposobem postrzegania przyrody, stosunkiem do pracy. $Z$ tym też ściśle łączy się, uwarunkowany czynnikami zewnętrznymi, sposób językowego reagowania na otaczający świat".

„Na temat postaw uzewnętrznianych przez słownictwo perswazyjne pisała przed trzydziestu laty A. Wierzbicka, analizując m.in. leksem Leń = ten, kto nie chce pracować + sądzę, że wiesz, że to źle [...]. Perswazyjność wyrazów [...] 
polega na odwołaniu się do systemu wartości akceptowanego przez nadawcę i odbiorców" (cyt. za: Pisarek 2004: 140-141). Wyraz leń ma jakby podwójną wartość perswazyjną - po pierwsze, nastawia słuchaczy nieprzychylnie do kogoś, kto jest leniem, po drugie, utrwala negatywną ocenę braku chęci do pracy.

\section{D / M1 - M2 / III / III}

M1: - tera puiźe na kurs, to śe poțškoli.

M2: - bapsko gunup'ie, ćimne, tuman zacofany. kto cymbauna rozumu naunučy?

Nagromadzenie zróżnicowanych środków leksykalnych o zbliżonej semantyce ma charakter wyrazistej inwektywy. Służy swoistej gradacji i przejaskrawieniu oceny intelektualnej kobiety, por.: glupia, ciemna, tuman zacofany, cymbat. Rozmówca podkreśla, że osoba, którą nazywa w sposób ironiczny babsko, mimo ukończenia kursu i tak nie podniesie swoich kwalifikacji.

\section{D / K - M / IV / IV}

Dziadkowie rozmawiają o wnuku.

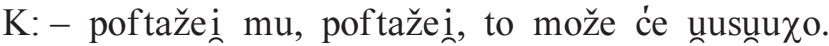

M: - k’iedyś to caúkim inacy byuno. źeći m’iauny šacuneg ḍla oịcuf,

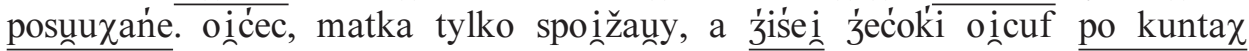
staviaium, robiom, co kcom.

Stosując opozycję kiedyś - dziś, nadawca podkreśla, że rodzice nie stanowią obecnie wzorca dla dzieci. Dialektolodzy wskazują, że wartościowanie w kulturze ludowej: „odbywa się przede wszystkim na zasadzie przeciwstawienia: przeszłość - teraźniejszość i obcość - swojskość" (zob. Pelcowa 1998: 114). Wartościowaniu pozytywnemu służą: rzeczownik szacunek oraz dopuszczalny w polszczyźnie potocznej czasownik stuchać się 'stosować się do czyichś poleceń', intensywniejszy pod względem emocjonalnym. Wyraźnie kontrastują z nimi frazeologizmy: robić, co się chce 'nie liczyć się z innymi' i stawiać po kątach, które w zabawny sposób wskazują na odwrócenie ról w rodzinie. Mężczyzna krytykuje swobodę pozostawioną dzieciom, rozpieszczanie i wszechogarniającą opiekę rodziców. Uważa, że czynniki te są działaniem utrudniającym rozwój samodzielności dziecka. Rozmówca wyraża opinię, że dzieci są przez rodziców chowane w sposób nieodpowiedzialny, dlatego nie szanują tradycyjnych wartości. Prowadzi to do zachowań opartych na zasadzie radykalnego odwrócenia norm i zasad obowiązujących w rodzinie. W sposób wyolbrzymiony mężczyzna podkreśla to, że dzieci zaczynają wychowywać rodziców.
D / M - K / IV / IV
M: - zažekaưa śe, že tag byuno.
$\mathrm{K}:-$ ununa poțraf'i kunamać, gunupoty gadać. muvii se iag' ies. 
Rozmówczyni podważa wiarygodność kobiety, eksponuje wartość uczciwego wygłaszania opinii na temat innych ludzi. Perswazji służy warstwa leksykalna, przede wszystkim wyrazy definicyjnie wartościujące, konotujące treści negatywne: czasownik kłamać, który należy do pola znaczeniowego 'wprowadzania w błąd' oraz rzeczownik: glupota. Leksyka oceniająco-emocjonalna jest narzędziem ośmieszania, a przez to korygowania niekorzystnych zjawisk występujących w życiu społecznym i relacjach międzyludzkich.

\section{D / K1 - K2 / IV / IV}

K1:- ununy to tak'ie sopki, tylko aby sob'ie.

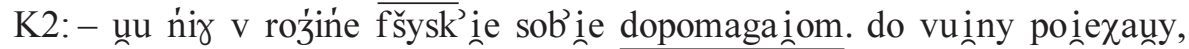
galanćce zarobiuny. źimi se dokuṕiuny, dobudovauny. tak povinno być.

Druga z kobiet kwestionuje opinię rozmówczyni, por. sobek 'egoista' i wskazuje, że wartością pozytywną jest rodzinna solidarność, ponieważ charakter poprawnych relacji z najbliższymi może przekładać się na wartości ekonomiczne. Nośnikiem dodatniej cechy jest czasownik: dopomagać, który w swe znaczenie ma wpisaną pozytywną wartość. O statusie materialnym rodziny świadczy przysłówek galancie oraz czasowniki z formantem prefiksalnym do-: dokupity, dobudowaty, które oznaczają wykonanie czynności dodatkowej, uzupełniającej całość, miarę, ilość itp. O relacjach między wartościowaniem ilościowym w znaczeniach leksemów pisała J. Puzynina (1988).

\section{D / M1 - M2 / IV / IV}

Mężczyźni rozmawiają o wojnie.

M1: - my m’iel'i mynke za Niemców, Niemiec tyž byư okrutny ḍla Polaków.

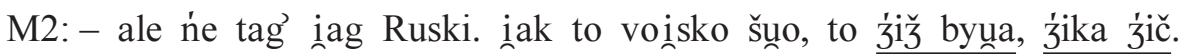
kraduno to, grabiuno, pal'iuno.

Drugi z rozmówców zgadza się z opinią poprzednika, ale podkreśla, że wojsko rosyjskie było w stosunku do ludności cywilnej bardziej okrutne niż niemieckie. Negatywnej ocenie służy hiperbolizacja dzika dzicz. E. Laskowska (1992: 14) wskazuje, że ze znakiem minus można wymienić leksem: dziki to słowo o ujemnej wartości w przeciwieństwie do cywilizowany. Istotne znaczenie w wypowiedzi mają również czasowniki o negatywnych konotacjach: kraść, grabić, palić.

Analizowane przykłady pokazują, że mieszkańcy wsi opowiadają się za tradycyjnymi wartościami, pożądane przez nadawcę postawy osiąga się m.in. dzięki wykorzystaniu mechanizmu symplifikacji rozkładu wartości, czyli łatwej orientacji aksjologicznej; odbiorca ma postrzegać wszystko w kategoriach „czarne-białe" (zob. Barańczak 1975: 44-57). Wpływ na przekonania czy poglądy odbiorcy dokonuje się poprzez mniej lub bardziej widoczne zawarcie oceny w wypowiedzi. D. Galasiński (1992: 26) twierdzi, że na wartościowaniu opiera się główny me- 
chanizm perswazji, a więc i pośredniość perswazyjnych aktów mowy - wszystkie pośrednio są aktami wartościującymi.

Istotne znaczenie ma to, które argumenty współbrzmią z wartościami, przekonaniami i potrzebami odbiorcy, które będą najbardziej przekonujące.

Według B. Wojciszke (1993: 433-447) sądy, jakie ludzie wypowiadają zarówno na własny temat, jak i na temat innych, można podzielić na dwie kategorie: sądy moralnościowe i sądy sprawnościowe. Pierwsza z wymienionych kategorii odnosi się do oceny funkcjonowania jednostki w relacjach społecznych, druga natomiast stanowi ocenę różnych kompetencji, np.: intelektualnych czy zawodowych człowieka.

Na wartościowanie jako jedną z różnorakich ról, jakie może pełnić język, wskazuje T. Zgółka (1991: 9-18). Według autora język może być środkiem poznania i wartościowania. Odpowiedzialność za filtrowanie (wartościowanie) obrazu rzeczywistości, które nie zostało w pełni dostrzeżone, spada na użytkownika języka.

Ważne są wartości moralne, których próbę systematyzacji przedstawiła M. Ossowska (1970), a więc waloryzujące czyny głównie na podstawie przyświecającej danemu działaniu intencji oraz pragmatyczne, czyli nawiązujące do kryterium pożytku społecznego.

\subsection{Leksyka potoczna}

Pierwszym i niewątpliwie najważniejszym środkiem perswazji jest słowo, które stanowi podstawę tekstu. Słowo jako nośnik treści pełni niezwykle ważną funkcję w przekonywaniu odbiorcy. Należy jednak pamiętać, że leksyka stanowi jedynie element wielowarstwowej budowy przekazu perswazyjnego.

W analizowanym materiale, ze względu na badany typ komunikacji, istotne znaczenie ma leksyka potoczna. Potoczność bywa ujmowana jako kategoria poznawcza i stylistyczna, która przejawia się na płaszczyźnie leksykalnej, w zakresie słowotwórstwa, składni oraz struktury tekstu. Obecność wykładników potoczności motywowana jest dążeniem do obrazowości i wyrazistości, a także ekspresywności i konkretności tekstu.

Leksyka potoczna przedstawia rzeczywistość w sposób konkretny, oddaje oceniający i wartościujący sposób ujmowania świata. Jak wskazują językoznawcy, charakterystyczną cechą leksyki potocznej jest ekspresywność (zob. Kamińska 1976: 77-84; Grzegorczykowa 1979: 118-122) i emocjonalne nacechowanie. Ekspresywność znaków językowych pozwala ujawnić stosunek nadawcy do komunikatu, postawę mówiącego wobec otaczających zjawisk.

Wyrazy potoczne, czyli takie, które są „używane w kontaktach nieoficjalnych (rodzinnych, towarzyskich, przyjacielskich), ale niemożliwe do użycia w sytuacji oficjalnej bez wywoływania negatywnej reakcji odbiorcy" (zob. Engelking, Markowski, Niemczuk-Weiss 1989) według D. Buttler (1991: 39) „odgrywają [...] rolę 
środków sekundarnej nominacji - nazywają obiekty realne już nazwane, ukazując je jak gdyby w nowym wymiarze, przez pryzmat żartu, ironii, parodii, zwykle familiarności, a przede wszystkim wartościowania, częściej negatywnego niż pozytywnego".

Do leksyki o charakterze potocznym należy zaliczyć ekspresywnie nacechowane słownictwo pogardliwe, lekceważące, z odcieniem politowania, do którego należą negatywne określenia ludzi ze względu na ich wygląd, cechy charakteru czy sposób postępowania.

W badanych tekstach dobór leksyki jest uwarunkowany stanem emocjonalnym mówiącego i ma służyć wyrażeniu zróżnicowanych uczuć. Nasycenie tekstu cechami uważanymi za wyznaczniki potoczności prowadzi do subiektywizmu sądów, przejawiających emocje nadawcy, ponadto leksyka potoczna służy zmniejszeniu dystansu między rozmówcami, wprowadza nastrój familiarności, a swoistą cechą wyróżniającą wyrazy potoczne jest to, że potęgują obrazowość wypowiedzi. Realizacji funkcji perswazyjnej służą różne części mowy: czasowniki, rzeczowniki, przymiotniki, przysłówki, zwłaszcza czasowniki potoczne, które służą do zaprezentowania cech fizycznych i emocjonalnych osób.

\section{D / K - M / III / IV}

$\mathrm{K}:-$ Łukaszek se mauno unučy.

M:- unuń se dužo unučy. unun taḱi kryinog ie, iag go pańi beǰe pytać, to se zataí i bej́e dukać.

Mężczyzna tłumaczy rozmówczyni, że niepowodzenia szkolne dziecka nie wynikają z braku wiedzy, ale ze strachu, który determinuje jego zachowanie i powoduje, że chłopiec ma problemy z wypowiadaniem się. Motywowany czasownikiem kryć się derywat kryjak oznacza 'osobę nieśmiałą, wstydliwą', wykorzystany w formacji sufiks -ak tworzy nazwy nosicieli cech i jak wskazuje R. Grzegorczykowa (1984: 44), „ma wyraźne nacechowanie potocznością”, podobnie jak czasownik dukać - pot. 'czytać niewyraźnie, mozolnie, jąkając się'. W przypadku derywatów nacechowanie potocznością może wynikać z potocznego nacechowania podstawy i/lub formantu oraz sposobu tworzenia derywatu.

\section{D / K - M / IV / IV}

Kobieta i mężczyzna rozmawiają o krewnej.

$\mathrm{K}:-$ pšece ununa ie $\chi$ oro.

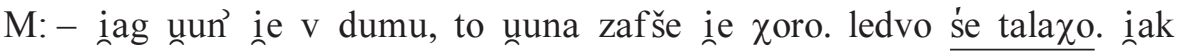
poịaźe do roboty, to zasuva do curki až miuno i iez zḍrovo.

Oceniając zachowanie kobiety, której dotyczy rozmowa, mężczyzna używa nacechowanych emocjonalnie, obrazowych antonimów czasownikowych: gwarowego talachać się - 'poruszać się z trudem, niezgrabnie' i zasuwać - pot. 'iść, maszerować; poruszać się szybko energicznie', poprzez zastosowany kontrast efekt perswazji nabiera dodatkowej głębi. 


\section{D / K - M / III / III}

Kolejne rozmowy dotyczą osoby, która odbywa karę pozbawienia wolności.

K: - zafše to čuov'ieka škoda.

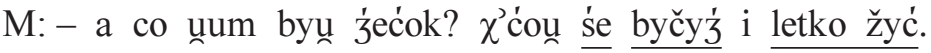

Mężczyzna nie podziela współczucia kobiety wobec człowieka, który przebywa w więzieniu. Negatywnemu wartościowaniu osoby służą: zastosowane pytanie retoryczne, w którym użyty został rzeczownik dzieciak - pot. 'człowiek dorosły, który postępuje jak dziecko' oraz czynność określana czasownikiem pochodnym od nazwy zwierząt, np.: byczyć się - leniuchować, która ma podobną semantykę, jak zwrot lekko żyć.

\section{D / M1 - M2 / III / IV}

M1: - m’ne śe ne $\chi$ ce v'i iežyć, že unun to zrobiuu.

M2: - nee sam pšeće, bo unun na to za gựupi. tyn facet, co tu pšyi ̌̌̌̌ou,

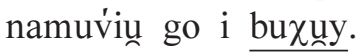

Drugi z rozmówców wyjaśnia, że osoba nie dokonała kradzieży samodzielnie, ale w niej uczestniczyła. Wyrażenia potoczne, por. facet - pot. 'mężczyzna mało znany', buchnać - pot. 'ukraść', sprawiają, że nadawca formułuje myśli w sposób prosty, ekonomiczny. Znaczenie perswazyjne ma również to, że zastosowane środki językowe mają wytworzyć poczucie bliskości z odbiorcą.

\subsection{Leksyka obca}

Znamienną cechą współczesnej gwary jest jej dynamiczny rozwój. Wielość dokonujących się w ostatnich dziesięcioleciach zmian w komunikacji mieszkańców wsi podkreślają liczne opracowania poświęcone tej problematyce (zob. Cygan 1996: 43-53; Pelcowa 1998: 105-117; Burska-Ratajczyk 2004: 247-256). Ogromna transformacja znajduje odzwierciedlenie m.in. w sposobach wykorzystania obcych środków językowych, nietrudno zauważyć tendencję do używania zapożyczeń. W świadomości użytkowników gwary istnieje przeświadczenie, że elementy obce czasem precyzyjniej oddają treść. Obce w strukturze danego języka wyrazy, zwroty, typy derywatów, formy fleksyjne, konstrukcje składniowe czy związki frazeologiczne (zob. Markowski 2009: 1139) wzbogacają zasoby słownictwa gwarowego. Klasyfikacja zapożyczeń zależna jest od ich formy, źródła, sposobu urabiania lub funkcji, wyróżnia się zapożyczenia wyrazowe (leksykalne), frazeologiczne, składniowe (syntaktyczne), znaczeniowe (semantyczne).

W zachowaniach językowych mieszkańców wsi obserwuje się wiele obcych struktur. Proces przenikania tych elementów językowych należy uznać za istotną zmianę w funkcjonowaniu systemu leksykalnego gwar. O kierunku i tempie procesów przekształcających sposób komunikacji mieszkańców wsi decydują 
przede wszystkim zmiany w świadomości mówiących (zob. Grybosiowa 2003: 42-50).

Elementy językowe przeniesione $\mathrm{z}$ innego języka lub stylu do wypowiedzi mającej ogólny jednorodny charakter językowo-stylistyczny mogą zyskać szczególną wartość perswazyjną. Zapożyczenia mają za zadanie przyciągnąć uwagę odbiorcy, zatrzymać bieg myśli, uatrakcyjnić przekaz, a także podnieść rangę wypowiedzi. Nazwy obcojęzyczne mogą wywoływać u odbiorcy pozytywne skojarzenia i być ważnym elementem w polemice, ponadto aktywizacja leksyki obcej świadczy o prestiżu jednostki.

W dobie współczesnej polszczyzna ludowa jest szczególnie podatna na rozległe wpływy obce, dynamicznie rozwijająca się cywilizacja prowadzi do przekształcania się języka jednostek i grup. W obrębie społeczności wiejskiej obserwuje się swoistą hierarchizację języka. Językoznawcy wielokrotnie podkreślali, że sytuacja jest ważnym czynnikiem warunkującym zachowania językowe. W kontakcie z osobą z zewnątrz wyraźnie widać, że nadawcy usiłują zapanować nad prymarnym kodem komunikacyjnym i starają się dostosować formę wypowiedzi do odbiorcy, podporządkowują słowa i zdania sztywnym regułom polszczyzny literackiej, ograniczającym swobodę i dynamizm rodzimego systemu. Zmienność kultury, nowy styl życia oddziaływa bezpośrednio na codzienną egzystencję człowieka, na sposób postrzegania świata i mówienia o nim. Skuteczne porozumiewanie się możliwe jest dzięki ciągłemu udoskonalaniu procesu komunikowania się.

W badanym materiale notowano zapożyczenia catkowite (zob. Markowski 2009: 1141), wyrazy pochodzące $z$ języka angielskiego, francuskiego, niemieckiego, łaciny, greki. Niektóre elementy obce na płaszczyźnie fonetycznej nie zostały zaadaptowane przez gwarowy system.

\section{D / M1 - M2 / III / III}

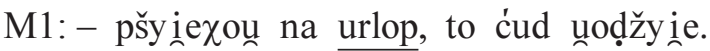

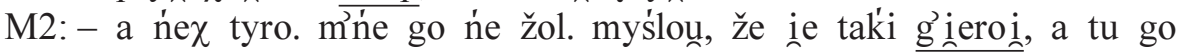
zaxaltovauny.

Występujące $\mathrm{w}$ pierwszej wypowiedzi eufemistyczne określenie urlop $\mathrm{w}$ zn. 'przepustka z więzienia' oraz zwrot ciut odżyje drugi z rozmówców odbiera jako element współczucia, którego on nie podziela. Zastosowana przez drugiego mężczyznę leksyka obcego pochodzenia może mieć w ocenie nadawcy wyższą rangę i być bardziej użyteczna w komunikacji, por. gieroj z ros. 'bohater'. Należy zaznaczyć, że wyrazy obce mogą być podstawą tworzenia nowych leksemów: zahaltować - niem. 'Halt! stój!' tu w zn. 'aresztować'.

\section{D / M - K / IV / III}

M: - unun dobže vylicy.

$\mathrm{K}:-$ dei to sountysevii. mo biznesmeisk ie stud’ia, to se leṕi zna. 
Użycie w wypowiedzi określenia biznesmeńskie studia służy budowaniu wizerunku osoby kompetentnej, której umiejętności nie można zakwestionować, por. derywat biznesmeńskie.

\section{D / K - M / III / IV}

$\mathrm{K}$ : - podobno unadna ta iego kobita.

M: - fspańauno, alegancko tako. iag iźe do koguś, to vyalegantovać śe muśi na t'ip top.

Często elementy obce służą ocenie wyglądu zewnętrznego kogoś lub czegoś, są ponętnym, ale trudnym do zinterpretowania przez użytkownika gwary środkiem językowym. Rozmówcy mają problem z ich poprawną artykulacją, elegancka fr. z łac., por. elegantować się - pot. żart. 'ubierać się z przesadną elegancją, modnie, wytwornie', na tip-top - z ang., przestarz. 'bardzo dobry, najwyższej klasy, doskonały; bardzo dobrze, doskonale'.

Biorąc pod uwagę stopień przyswojenia zapożyczeń obok form poprawnych, można zaobserwować modyfikacje fonetyczne.

$$
\begin{aligned}
& \text { D / K }<\text { M / II / IV } \\
& \text { K: - fainy facet. } \\
& \text { M: - fainy, fainy, ale bab’ inoš. }
\end{aligned}
$$

Zastosowane wyrazy: przymiotnik fajny - z niem. 'ciekawy, dobry, ładny' tu odnoszący się do wyglądu zewnętrznego, facet - pot. 'mężczyzna mało znany' świadczą o chęci nawiązania wspólnego języka z osobą młodą. Aby skutecznie przekonać, nadawca musi zyskać zaufanie odbiorcy, dlatego podporządkowuje środki językowe swojemu rozmówcy. W wypowiedzi wartościowany pozytywnie wygląd kontrastuje z zachowaniem osoby, przyrostek -arz w derywacie babiarz charakteryzuje osobę ze względu na jej pewne słabości.

Leksyka obca może być wykorzystywana jako środek służący eufemizacji.

\section{P / K1 < K2 - M / II / III / IV}

$\mathrm{K} 1$ :- 'sf'ietl'icy iuž ne ma?

K2: - tero to tam? iest klup, som potaincufki.

M: - iak'ie potaincufkí muv́i śe iag ies. tam ie tero danc'ing $\mathrm{z}$ dupciningem.

Nadawca zastosował opartą na kontraście stylistycznym kontaminację wyrazu obcego dancing - z ang. 'lokal publiczny, w którym odbywają się tańce; dyskoteka' i rodzimego, silnie nacechowanego emocjonalnie słowa dupa - wulg. 'pośladki'. Powstała w ten sposób żartobliwa, nacechowana ironią hybryda oznaczająca 'dom publiczny'. Wyraz ma służyć złagodzeniu tonu wypowiedzi, ponadto innowacja jest sposobem zwrócenia uwagi odbiorcy, wzmacnia i uatrakcyjnia formę przekazu, a taki sposób wypowiedzi odbierany jest jako bardziej przekonujący. Oryginalna leksyka, będąca elementem dowcipu językowego, ma na celu również 
ożywienie wypowiedzi i wywołanie efektów ekspresywno-perswazyjnych. Indywidualność i niezwykłość przekazu daje nadawcy szansę na zwrócenie uwagi na siebie i na przedmiot wypowiedzi.

Leksyka obca w komunikacji mieszkańców wsi jest interesującym zjawiskiem językowym, wynikającym z poszukiwania atrakcyjniejszego sposobu wyrażenia treści, ma także związek z chęcią zamanifestowania przez rozmówcę biegłości językowej.

\subsection{Zapożyczenia wewnątrzjęzykowe - słownictwo pochodzące $z$ innych odmian języka}

H. Kurkowska i S. Skorupka (2001), badając problem zróżnicowania stylowego, stwierdzają, że głównych odmian stylowych nie można postrzegać jako zamkniętych systemów, ponieważ wpływają na siebie i ulegają kontaminacjom, współistnieją w obrębie jednego języka, silnie na siebie oddziaływają, wzajemnie się przenikają i mieszają.

W opracowaniach dialektologicznych (zob. Ożóg 2001: 215-223; Kajtoch 2009: 208-220) podkreśla się, że do gwar ludowych także przenika wiele elementów z różnych odmian stylistycznych polszczyzny, co sprzyja tworzeniu się „nowej jakości języka wsi” (Ożóg 2001: 21). Słownictwo specjalistyczne, szczególnie zaś terminologia, może w wypowiedziach mieszkańców wsi zyskać szczególną wartość stylistyczną. Poprzez wykorzystanie tych środków nadawca stara się zadziwić odbiorcę, wywołać imponujące wrażenie, pochwalić umiejętnością jasnego i precyzyjnego wyrażania swoich myśli.

Wymienione czynniki, odgrywają bardzo ważną rolę w ludzkich zachowaniach językowych, wpływając na perswazyjność przekazu. Jak wykazują badania, terminologia specjalistyczna (zob. Gajda 1990) może posiadać nacechowanie emocjonalne i perswazyjne, por. np. występujące w politologii terminy marksizm, kapitalizm, reakcyjny, postępowy.

W badanych tekstach pojawiają się formy charakterystyczne dla specjalistycznego języka lekarskiego i administracyjnego. Użycie słownictwa grupy zawodowej lub środowiskowej w zamyśle nadawcy ma nobilitować daną wypowiedź, ma przekonać odbiorcę o oczytaniu i erudycji rozmówcy, ponadto jest środkiem leksykalnym służącym ekspresji i wzmocnieniu perswazyjności przekazu.

\section{D / K1 - K2 / IV / IV}

K1: - tera, iak $\chi$ tuś mo dobrom robote, to vii, že žyie.

K2: - moim k’iedyź byư lépi. unun kiramy ieźźiu, ve valuće unobcokrainovy mu puaciuny, a tero ma taksufke, ale inuš tyle ne zarobi, bo kazauny pomontovać te kasy f'ćiskalne. 
W wypowiedzi wyraźna jest opozycja: teraz - kiedyś. Rozmówczyni traktuje formy: kir w zn. 'tir', waluta obcokrajowa, kasa fiskalna jako element bardziej eleganckiego stylu, który ma podkreślić umiejętność posługiwania się urozmaiconym słownictwem (zob. Burska-Ratajczyk 2002: 65-74). Ponieważ użyte środki charakterystyczne są dla języka specjalistycznego, kłopoty sprawia właściwa wymowa i semantyka. Ciekawa jest innowacja w zakresie wyrażenia kasa fiskalna, którego drugi człon wskutek motywacyjnego skojarzenia (zob. Cienkowski 1972) utożsamiony został z popularnym, swojskim czasownikiem wciskać, co jest logicznie uzasadnione ze względu na istotne podobieństwo brzmieniowe. Nadawca nie ma zbyt dużej świadomości językowej, więc taka forma wydaje mu się najzupełniej logiczna i umotywowana znaczeniowo. Nie doszłoby do pomyłki, gdyby znaczenie leksemu fiskus tkwiło w świadomości mówiącego.

\section{D / K - M / III / IV}

K: - muv'iom tera, že tak’ie luźe tyž mušom być.

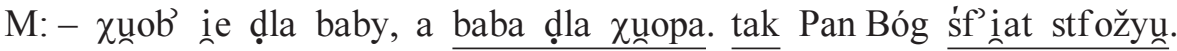

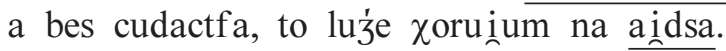

Określenie z zakresu medycyny, która należy do języków specjalistycznych, ma nadać wypowiedzi znamiona naukowości. Mężczyzna bardzo starannie formułuje myśli, by przekaz był przejrzysty znaczeniowo. Opisuje i diagnozuje czasy współczesne, potępia swobodę obyczajową, używanie życia, odwracanie tradycyjnych wartości rodzinnych. Przekonuje, że swobodne zachowanie i ekscesy seksualne, por. cudactwo, są wbrew woli Boga i przyczyniają się do rozpowszechniania choroby.

\section{P / K1 < K2 - K3 / II / IV / IV}

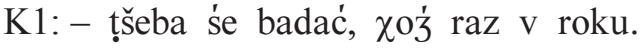

K2: - pevno to byư zavaun. može udar? bo tag momyntal'ńe zgasuna.

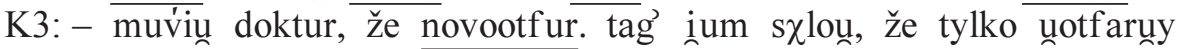
i zašyuñy, bo f̌̌ysko ve śrotku zežar, same j́ury byụy.

Modulant pewnie wyraża przypuszczenie, że prawdopodobną przyczyną nagłego zgonu, o którym mówi eufemistyczny czasownik zgasnać - 'mieć lekką śmierć, umrzeć szybko, bezboleśnie', był udar lub zawał. Kolejna rozmówczyni powołuje się na opinię lekarza i wyjaśnia, że przyczyną śmierci był nowotwór, który po cichu niszczył organizm kobiety. Niepoprawna wymowa i błędna etymologia słowa wydobywa z wyrazu nieoczekiwany sens. Nadawca szuka odpowiedniej formy językowej, żeby zwerbalizować myśli, chce nadać wypowiedzi znamiona stylu naukowego, co jest istotnym elementem sprzyjającym przekonywaniu. Słownictwo specjalistyczne często kierowane jest do osób spoza środowiska wiejskiego, ponieważ rozmówca ma świadomość, że tylko określona grupa odbiorców będzie mogła poprawnie odebrać komunikat, liczy się z doświadczeniem językowym odbiorcy. Zastosowanie terminu specjalistycznego ma ułatwić identyfikację i porozumienie się. 


\section{D / K1 - K2 / III / IV}

$\mathrm{K} 1:-$ pinunze to ne fšysko.

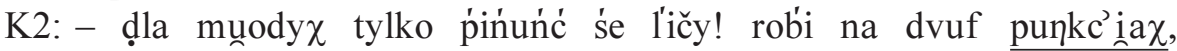
i mauno! i mauno!

Czasem nadawca może mieć problem $\mathrm{z}$ właściwym zrozumieniem pojęcia, myli wyraz z podobnym brzmieniowo, por. funkcja - łac. 'czynność' i punkcja - med. 'nakłucie'.

\section{D / M1 - M2 / III / III}

M1: - mauno dostoun. ot's'satke.

M2: - ne tag mauno, ale unoice unadny grož vybul'iuny, to mu anulovauny

W rozmowie uwagę zwraca kontrast stylistyczny w zakresie środków leksykalnych, który powoduje, że przekaz jest ciekawszy, por. wyrazistszy semantycznie czasownik bulić - pot. 'płacić za coś dużo pieniędzy', także 'przepłacać', rzeczownik odsiadka i czasownik anulować - z łac. 'unicestwić, unieważnić, odwołać, kasować, znosić', charakterystyczny jest dla stylu urzędowego.

Przeobrażenia zachodzące w życiu i otaczającym świecie mają wpływ na dynamiczne zmiany w zasobie leksykalnym polszczyzny ludowej. Zmieniają się codzienne zachowania werbalne mieszkańców wsi, którzy starają się wykorzystywać zróżnicowane środki stylistyczne. Warstwa leksykalna polszczyzny ludowej ulega dynamicznym modyfikacjom, użytkownicy gwary próbują wypowiadać się w nowoczesnym kształcie słownym, który ma być bardziej komunikatywny, ma służyć precyzji i dokładności przekazu oraz świadczyć o wyrobieniu językowym rozmówcy.

Kształtuje się nowy, bardzo ciekawy styl wypowiedzi (zob. Pisarkowa 1978a: 163-172), stanowiący obiekt wnikliwych badań dialektologicznych (zob. Kajtoch 2009: 208-220).

\subsection{Wyrazy modne}

Niekiedy w tekstach gwarowych słowa rodzime zastępowane są tzw. wyrazami modnymi. Wyrazy modne (zob. Buttler, Kurkowska, Satkiewicz 1987) to elementy leksykalne, które w jednym ze swoich znaczeń są w pewnym okresie używane o wiele częściej, niżby to wynikało z potrzeb komunikacyjnych.

$\mathrm{W}$ analizowanym materiale językowym były nimi najczęściej obce leksemy i zwroty, pochodzące z języka angielskiego.

$\mathrm{D} / \mathrm{K}<\mathrm{M} / \mathrm{II} / \mathbf{I V}$

$\mathrm{K}$ : - o tu iez na zd’ieńcú. taki sob’ie.

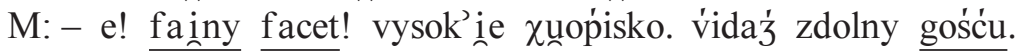


Rozmówca chwali mężczyznę, używając w tym celu modnego przymiotnika fajny, który często pojawia się w przekazach perswazyjnych, ponadto stosuje rzeczowniki: facet $\mathrm{z}$ łac., i pot. żart. z odcieniem ironii gość. Wymienione środki leksykalne wnoszą do rozmowy pozytywne konotacje, pojawiają się po to, by nadać wypowiedzi znamiona stylu młodzieżowego i w ten sposób zmniejszyć dystans między rozmówcami. Zabieg ma ułatwić nawiązanie bliskiego, bezpośredniego kontaktu $\mathrm{z}$ osobą młodą, co jest istotnym elementem sprzyjającym przekonywaniu.

\section{D / K1 - K2 / III / IV}

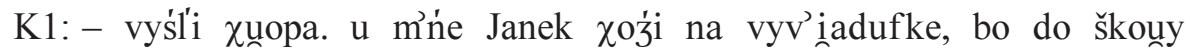
daleko, a tu i krove țšeba doiź i j̇eći m’neinse ț̌seba pațšeć. tag dobže se učy, aš fainne iź do škouny.

$\mathrm{K} 2:-\mathrm{mu}$ i to se ne interesui ie źećokim.

Używając wyrazów modnych, kobieta pragnie wyróżnić się sposobem mówienia.

\subsection{Neologizmy}

W wyniku nieustannego rozwoju komunikacji powstają nowe elementy języka - wyrazy, ich znaczenia i zwroty (zob. Markowski 2009: 1085). Służą nazywaniu nowych zjawisk lub przedmiotów i są jednym ze sposobów wzbogacania słownictwa; mogą być także, jak wskazuje J. Sławiński (1988: 311): „,elowo stosowanymi rozwiązaniami stylistycznymi”, których prymarną funkcją jest ekspresja. W neologizmach przejawia się potrzeba nazwania elementów materialnej i duchowej kultury oraz chęć wyrażenia indywidualnego ,ja” twórczego (zob. Markowski 2006: 1625).

Według D. Buttler (1976) o innowacji można mówić wtedy, gdy twórca tekstu odchyla się od normy danego języka lub jego systemu i normy. Innowacje mogą powstawać po to, by wzbudzić zainteresowanie treścią przekazu, nadawca poszukuje sposobu dotarcia do odbiorcy, nowych sposobów zwerbalizowania myśli.

Innowacje językowe są następstwem przemian cywilizacyjnych, wyrazem doskonalenia się umiejętności w zakresie komunikowania. K. Handke (2008: 258-271) uznaje innowacje językowe jako fakty bądź zjawiska wprowadzane spontanicznie przez użytkowników do komunikacji społecznej, które nie mogą być uznane za trwały element języka do momentu, aż nie zweryfikuje ich czas. Autorka zauważa, że po 1989 roku aktywność językowa Polaków zdecydowanie wzrosła, co składa się na większą otwartość społeczeństwa w przyswajaniu językowych nowinek i umiejętność zabawy językiem (reklama, polityka, media, środowiska młodzieżowe, kabarety).

Nowe wyrazy, nowe znaczenia i formy oraz związki wyrazowe mają na celu uzupełnienie i wzbogacenie słownictwa danej społeczności. Głównymi przyczy- 
nami tworzenia nowych słów jest przede wszystkim rozwój kultury, nauki i techniki. Neologizmy mogą pełnić w tekstach różnorodne funkcje: nazywają nowe przedmioty, zjawiska, pojęcia, sytuacje itp., czasem: zapewniają skrótowość, zwięzłość wypowiedzi. Ponadto wzbogacają wartość estetyczno-znaczeniową przekazu, ponieważ opisują stany emocjonalne i subiektywne przeżycia nadawcy - są więc środkiem ekspresji i oceny.

W komunikacji mieszkańców wsi innowacje językowe (zob. Burska-Ratajczyk 2004: 247-256) wypełniają luki w słownictwie i zaspokajają potrzebę wyrażenia różnorodnych emocji. Ze względu na rodzaj pełnionej funkcji neologizmy można podzielić na: neosemantyzmy nominatywne i neosemantyzmy ekspresywne (zob. Buttler, Kurkowska, Satkiewicz 1987: 147). Pierwsze uzupełniają zasób leksykalny, natomiast główną funkcją neosemantyzmów ekspresywnych jest wyrażanie emocji oraz określonego stosunku do danego przedmiotu/sytuacji; tego typu wyrazy są charakterystyczne dla języka potocznego oraz odmian środowiskowo-profesjonalnych.

S. Grabias (1981), uwzględniając rodzaj innowacji oraz charakter jednostki leksykalnej, która innowacji podlega, proponuje następującą klasyfikację neologizmów: strukturalne, znaczeniowe, funkcyjne, natomiast z punktu widzenia funkcji językowych wyróżnia neologizmy: nominatywne, stylistyczne o funkcji uwydatniającej lub ekspresywnej.

Neologizmy zwiększają szansę zainteresowania odbiorcy przekazem, czynią wypowiedź atrakcyjną pod względem językowym, ale żeby atrakcyjność wypowiedzi mogła się ujawnić, konieczna jest metajęzykowa refleksja odbiorcy, polegająca na umiejscowieniu neologizmu w systemie leksykalnym. Kiedy operacja taka w świadomości odbiorcy zachodzi, nowość, której neologizmy są nośnikami, może pozostawać komponentem komizmu językowego, być oznaka intensywniejszego zaangażowania nadawcy lub składnikiem ironii leksykalnej.

Neologizmy wykorzystywane są jako typowe środki ekspresji, zwłaszcza w poezji, ale także w utworach prozatorskich, w tekstach publicystycznych. Natomiast neologizmy ludowe świadczą o kreatywnej postawie mieszkańców wsi wobec rzeczywistości oraz o szczególnej wrażliwości na zjawiska życia codziennego. Są znakiem czasu, rejestrującym wpływ zmian cywilizacyjnych na rozwój wyrazów. Mieszkańcy wsi używają tych środków językowych, gdy pragną wyrazić treści bardzo odległe od spraw życia codziennego, uatrakcyjnić formę przekazu lub nacechować wypowiedź stylistycznie.

\subsubsection{Neologizmy słowotwórcze}

Proces wzbogacania języka dokonuje się dzięki innowacjom słowotwórczym, ponieważ podstawowym środkiem uzupełniania systemu leksykalnego w polszczyźnie jest derywacja. Tendencje słowotwórcze w gwarach (zob. Cyran 1977), także w języku współczesnej wsi, były przedmiotem wnikliwych badań (Sierociuk 1998: 265-272; Gala 2000b: 29-36). 
Również słownictwo gwarowe jest ciągle wzbogacane i odświeżane, gdyż język mówiony zmienia się w sposób bardziej dynamiczny niż język pisany, ponadto nie zawsze podporządkowuje się sztywnym normom obowiązującym polszczyznę ogólną. Po innowacje językowe sięgają mieszkańcy wsi, kiedy brakuje im słów na określenie nowych rzeczy i zjawisk, które postrzegają wokół siebie, potrzeba nazwania dotyczy przedmiotów czy pojęć, obiektywnie nowych, np. urządzeń lub gdy rozmówca chce wyrazić swoje emocje.

Z punktu widzenia realizacji funkcji perswazji neologizmy podnoszą atrakcyjność przekazu, zaskakują odbiorcę błyskotliwą formą i nacechowaniem emocjonalnym.

W tekstach występują różne typy słowotwórcze neologizmów. Wzorem dla utworzenia wyrazu mogą być zarówno sufiksy rodzime, jak i obce, a także takie, których zasięg użycia ograniczony jest wyłącznie do gwar.

\section{D / K1 - K2 / III / III}

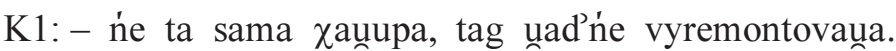

K2: - ununa niźs ne robiuna, to f̌̌ysko curka z m’inasta. meble im pšyv’iezua, navet te podgževaịke.

Niekiedy polszczyzna ogólna, która nazywa skomplikowane urządzenia czy abstrakcyjne pojęcia zbyt odległe poznawczo mieszkańcom wsi, zastępowana jest swoistymi, oryginalnymi formami językowymi, które są bardziej przystępne i łatwiejsze w użyciu. Innowacyjne leksemy mieszczą się w systemie słowotwórczym gwary, powielają struktury znane i wykorzystują sufiksy typowo gwarowe -ajka, por. neologizm podgrzewajka w zn. kuchenka mikrofalowa, utworzony od czasownika podgrzewać. Formacje gwarowe z sufiksem -ajka analizowała H. Popowska-Taborska (1974: 87-92).

Nominacja językowa w gwarze jest zjawiskiem niezwykle ciekawym. Sposób nazywania nowych dla mieszkańców wsi realiów może łączyć i wiązać się z tym, co przyswojone, znane.

\section{D / K1 < K2 / II / IV}

K1:- żiśei časy trudne. dobže, že se iakoź raźi.

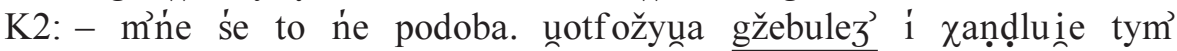
źadostfym, tymy bublamy, starymy lumpamy iag Żyd.

Druga z kobiet podkreśla, że nie pochwala sposobu zarobkowania osoby, której dotyczy rozmowa. Neologizm grzebulec motywowany czasownikiem grzebać oznacza 'sklep z odzieżą używaną', negatywnemu wartościowaniu służy nagromadzenie rzeczowników: dziadostwo, buble, lump z niem. Lump - gałgan. W wypowiedzi wartościowaniu służy także stereotyp odwołujący się do postrzegania Żydów przez pryzmat handlu używaną odzieżą. 


\section{$\mathrm{D} / \mathrm{K} 1<\mathrm{K} 2$ / II / IV}

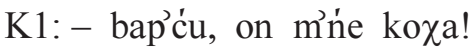

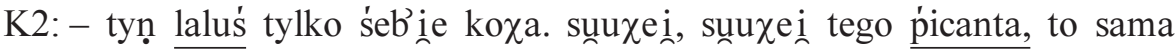
beźež ǰećoka dyrtośić.

Babcia przestrzega wnuczkę przed niestosownością wyboru partnera, kwestionuje uczciwość jego zamiarów i wizję wspólnego szczęśliwego związku. W ironiczny sposób podkreśla urodę, por. laluś, i egoizm kawalera, por. kochać siebie. Negatywnemu wartościowaniu mężczyzny służy mocno nacechowane emocjonalnie określenie picant od picować 'gładko kłamać, zręcznie kpić', które oznacza natrętnego podrywacza, uwodziciela, usiłującego robić dobre wrażenie. W derywacie zwraca uwagę kontrast stylistyczny zespolenia: nacechowanej podstawy i obcego formantu -ant, na upowszechnienie się przyrostka, szczególnie w środkach masowego przekazu, zwrócił uwagę B. Dunaj (1993: 59-62).

\section{D / K - M / III / III}

Kobieta opowiada o mężu kuzynki.

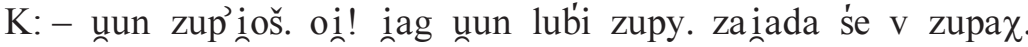

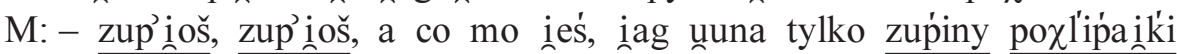
gotuie.

Konotacje ośmieszające posiada nazwa atrybutywna zupiarz z sufiksem - arz, tworzącym nazwy nosicieli cech, które odnoszą się do obiektu czynności. R. Grzegorczykowa (1984: 46) uważa, że o charakterze atrybutywnym można mówić w przypadku, gdy: „desygnat podstawy jest przedmiotem zamiłowania osoby nazwanej lub charakteryzuje tę osobę". Wyrazistej ocenie służą leksemy związane z życiem codziennym, nazwy potrawy: formacja zupina, w której suf. -ina ma wydźwięk politowania oraz motywowany czasownikiem pochlipać derywat z suf. -ajka - pochlipajka 'byle jaka, niesmaczna zupa'.

\section{D / M1 - M2 / III / III}

Rozmowa dotyczy kupna domu.

M1: - drogo kupiuny, byuno čekać.

M2: - barzo ḍrogo! vyžyunas! tyle ṕininzy v’źuun. ale muśauny śe s kredytu vyličyć.

Derywat wyżłas 'człowiek bez skrupułów, walczący o zysk za wszelką cenę, wyzyskiwacz, zdzierca', utworzony formantem -as, tworzącym zgrubienia o charakterze pejoratywnym i augmentatywnym, podkreśla, że osoba zbywająca dom kierowała się chęcią zysku, por. wyżyłować - pot. 'zmusić kogoś do pracy ponad siły; wyzyskać, wyeksploatować', tu w zn. wyzyskiwać kogoś materialnie.

Współcześnie gwara żywo reaguje na dynamiczne przemiany dokonujące się w otaczającej rzeczywistości (zob. Burska-Ratajczyk 2004: 247-256; Kajtoch 
2009: 208-220). Podkreślić należy kreatywność leksykalną użytkowników polszczyzny ludowej.

\subsubsection{Derywaty złożone}

Według S. Grabiasa (1981: 115) złożenie „stanowi jednostkę leksykalną powstałą z dwu innych jednostek semantycznie samodzielnych”, która ujmuje treść w sposób syntetyczny.

$\mathrm{W}$ analizowanym materiale derywaty złożone podnoszą atrakcyjność wypowiedzi, używane są zazwyczaj w celu wyrażenia emocjonalnej oceny osób i realiów, ponieważ umożliwiają krótsze, zwarte wyrażenie myśli. Ponadto są źródłem różnorodnych efektów estetycznych, np. znakomitym środkiem sygnalizowania ironii, negatywnej oceny, niechęci.

\section{D / M1 - M2 / III / III}

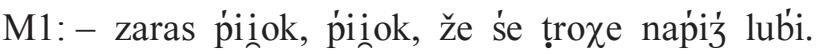

M2: - ne piinok, tylko unoi ščynoga. s porțčyn butelčyne vyćungo i $\underline{\chi l o}$ pot sklepym pokunt 'se ne unobol'i.

Deprecjonujące określenie ojszczynoga służy dosadnej charakterystyce osoby, jest obrazowym, wzgardliwym komentarzem, wskazującym na stopień uzależnienia mężczyzny od nałogu. Silne nacechowanie emocjonalne posiada 1 człon złożenia, por. szczać ordynarnie 'oddawać mocz', ponadto leksemy: portyczyny, butelczy$n a$, chlać, obalić się. Dezaprobata wobec osoby może mieć różną intensywność - od formy żartobliwo-ironicznej do zdecydowanej krytyki.

\section{D / K - M / III / III}

$\mathrm{K}:-$ ia to lub'ie lużi oščyndny $\chi$.

M: - unun’ ne ie unoščyndny, unun ie $\chi$ ory. beźe kobićc pyry v sagane l'ičyun, l'ičypyra.

Złożenie, czasownik + -i//-y + rzeczownik, którego motywację nadawca wskazuje, użyte jest w sensie jednoznacznie negatywnym i oznacza człowieka chorobliwie skąpego, chciwego. Mężczyzna w celach perswazyjnych stosuje oryginalną formę, budującą właściwe skojarzenia, złożenie liczypyra, utworzone na zasadzie czytelnej analogii, por. liczykrupa, ma przyciągnąć uwagę odbiorcy. W polszczyźnie ludowej leksemy złożone należą często do nazw epitetów o wyrazistym ujemnym zabarwieniu emocjonalnym.

\section{D / K - M / III / III}

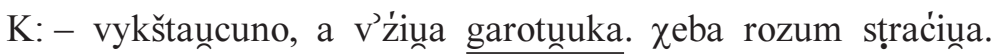

M: - zakoxauna śe i tyle.

Równie czytelna jest nazwa garottuk mająca zabarwienie ironiczno-kpiarskie, wynikające ze specyficznego ujęcia istoty zawodu. 


\subsubsection{Neosemantyzmy}

Neologizmami nazywa się zarówno wyrazy nowe pod względem formalnym i znaczeniowym, jak i wyrazy formalnie podobne do wcześniej istniejących, ale nowe pod względem treści i zakresu (zob. Michalewski 1993b: 119). Neosemantyzm definiowany bywa jako obiekt, którego forma jest identyczna $\mathrm{z}$ formą innego obiektu leksykalnego, już istniejącego w języku, ale treść różni się od tamtego obiektu, w taki sposób, że widoczne jest wyprowadzenie z obiektu podstawowego, czyli jest derywowana semantycznie. Oznacza to, że pojęcie neosemantyzmu nie odnosi się do wyrazu, którego nowe znaczenie w żaden sposób nie nawiązuje do znaczenia pierwotnego.

$\mathrm{W}$ analizowanym materiale zanotowałam jeden przykład zabiegu polegającego na nadaniu nowego znaczenia wyrazowi już istniejącemu (por. Urbańczyk 1991: 222).

\section{D / K1 - K2 / IV / IV}

$\mathrm{K} 1$ : - pov́ińin by3́ $\mathrm{v}$ dumu.

K2: - a co ununy moguny zrobić. do roboty mušom iś. lekož unobadou i muv́i: ia ńic tu inuž ne pumoge, a unop’ieke muśs mić. i zabrauny do

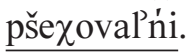

Słowo przechowalnia, tu w zn. 'hospicjum', staje się swego rodzaju neosemantyzmem, ponieważ przyjmuje sens, którego poprzednio nie posiadało.

\subsection{Stereotyp jako środek wartościowania}

Stereotyp definiowany jest jako funkcjonujący w świadomości społecznej uproszczony i zabarwiony wartościująco obraz rzeczywistości, często oparty na niepełnej lub fałszywej wiedzy o świecie, utrwalony jednak przez tradycję jako „gotowa forma myślenia”, która wynika z tendencji psychiki człowieka do dokonywania uogólnień oraz stałej niechęci do poddawania owych uogólnień czynności sprawdzania.

L. Kołakowski (2000: 97-98) podkreśla, że: „Nieczęsto zauważyć nam się zdarza, że wielka część naszej przestrzeni duchowej, naszych obrazów i naszych sposobów reagowania na świat i na innych ludzi, urobiona jest czy też wytworzona przez stereotypy, to znaczy spontanicznie ukształtowane, quasi- empiryczne generalizacje, które - gdy się utrwalą - niemal nie dają się korygować przez późniejsze doświadczenia".

Nasza świadomość jest owładnięta przekazywanymi z pokolenia na pokolenie poglądami, często ulegamy temu, co stereotypowe, zakorzenione w przesądach i niechętnie dokonujemy w tej sferze przewartościowań. Dlatego stereotypy funkcjonują poza kontrolą ze strony człowieka i stają się w perswazji środkiem 
dogodnym i w dużej mierze decydującym o jej skuteczności. Stereotyp, jako środek informacji o innych, odgrywa wyjątkowo szkodliwą rolę, gdy w stosunkach międzyludzkich prowadzi do uprzedzeń, niechęci, a nawet nienawiści czy agresji.

Pojęcie stereotypu, ujętego jako „obraz w głowie ludzkiej” - jednostronny, cząstkowy i schematyczny - zostało wprowadzone w 1922 roku przez W. Lippmana (1922) i stało się przedmiotem wnikliwych badań językoznawczych (zob. Pisarek 1975: 73-78; Pisarkowa 1976a: 5-26; Bartmiński, Panasiuk 2001: 371-396). Problematyka stereotypu analizowana była także z punktu widzenia pragmatyki (Schaff 1981: 60-70; 127-136). A. Schaff definiuje stereotyp jako „sąd wartościujący (negatywny lub pozytywny) połączony z przekonaniem”, jego przedmiotem są ludzie lub grupy ludzi. Sąd ten jest emocjonalny i niezależny od doświadczenia osobistego, całkowicie lub częściowo sprzeczny z faktami, oporny na zmiany, związany ze słowem - nazwą.

Stereotyp pełni następujące funkcje: integrująca, tj. „funkcję spójnika grupy", obronna, polegającą na utrzymywaniu umysłu w stanie zamkniętym na nowe, obiektywne informacje, ideologiotwórcza i polityczna, polegającą na socjotechnicznym wykorzystaniu stereotypów do celów ideologicznych (zob. Bartmiński 1998: 35-37). M. Szyszkowska (1997: 11) podkreśla, że: „,...] wychowując wpaja się nam pewne przekonania, które przyjmujemy jako niepodważalne na mocy autorytetów i ich powszechnego funkcjonowania". W badaniach nad stereotypami R. Tokarski (1995a) wskazuje, że dla współczesnego człowieka niebezpieczne są slogany, zbiorowe opinie oraz gotowe wzorce myślenia, których perswazji łatwo może ulec (zob. Galloway 1988: 92).

Stereotyp (zob. Anusiewicz, Bartmiński 1998) jest nośny perswazyjnie, ponieważ zawiera w sobie pewną nadwyżkę znaczeniową, konotację emocjonalną. Jak wykazują badania (Bartmiński, Panasiuk 2001: 374), ,[...] jest nierozłącznie związany z językiem i słowem [...]. Każde użyte wyrażenie zabarwia na swój sposób przekazywaną informację [...], nazywa, nieuchronnie aktywizuje określony typ doświadczeń, model poznawczy i wartościowanie, a w kolejności schemat odbioru i interpretacji”. Często stereotypy uwarunkowane są wartościami i zachowaniami społecznymi oraz uprzedzeniami. Ich przejawami w języku są głównie etykiety. W zdecydowanej większości są to uogólnienia negatywne, dotyczące płci, grup społecznych, także etnicznych.

$\mathrm{W}$ badanym materiale stereotypy są istotnym elementem budowania przekazu oraz skutecznym i prostym sposobem wpływania na odbiorcę.

Istotne znaczenie ma $\mathrm{w}$ tradycji ludowej stereotypowy wizerunek kobiety i mężczyzny, który określa ramy zachowań zgodne z rolami społecznymi przypisywanymi obu płciom. Kulturowy stereotyp kobiety i mężczyzny w środowisku wiejskim badał J. Kąś (1994b: 119-130), natomiast szczegółowy obraz kobiety utrwalony w przysłowiach, aforyzmach i anegdotach polskich zawiera opracowanie E. Jędrzejko (1999). 


\section{Stereotypy dotyczące płci}

Stereotyp kobiety
D / K1 - K2 / III / III
K1: - ununa ie bžytko.
K2: - ư⿱ ưdna ḿiska ieź ne do. važne, že robotna.

Druga rozmówczyni podkreśla, że w ocenie kobiety wrażenia zmysłowe nie są najważniejsze. Swoiste uprzedmiotowienie, które zawarte jest w porównaniu urodziwej dziewczyny do tadnej miski, wskazuje, że estetyczny, odpowiadający wymogom piękna, wygląd kobiety nie jest w stanie zastąpić innych walorów, np. pracowitości.

Stereotyp mężczyzny

D / K - M / III / III

$\mathrm{K}:-$ ne pošçyśćiuno se $\chi$ unopu.

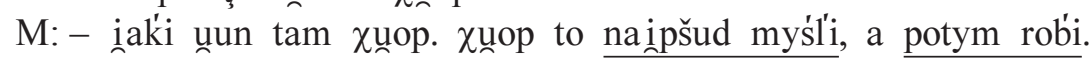

Jak zauważa J. Wasilewski (2006: 285-306), kategoria mężczyzny jest tworzona w myśleniu i komunikowaniu jako kategoria kulturowa, czyli trzeba na nią zasłużyć, a bardzo łatwo ją stracić poprzez nieodpowiednie zachowanie, ponieważ wartość mężczyzny wyznaczają jego dokonania.

\section{Stereotypy zawodowe}

Badania nad stereotypami obejmują także stereotypy zawodowe: stereotyp polskiego lekarza (zob. Olszewska, Nowik 2002: 335-347), polityka (Węgrzyn 2002: 225-241), biznesmena, uczonego, robotnika (zob. Zgółkowie 1998).

\section{Lekarz}

\section{D / K1 < K2 / II / IV}

K1:- lekaš ći pomože.

K2: - niz' ne pomože. o nić 'se ne pyta, ne zbada, tylko kce, žeby zaraz za nastempnom vízyte zapunaćić.

Druga z kobiet podważa kompetencje lekarza. Wskazuje, że nie interesuje się on stanem zdrowia pacjenta, tylko oczekuje korzyści finansowych.

D / K - M - Bu / IV / IV / II

$\mathrm{K}:-$ pomyliu śe.

M: - lekaž ńe može se mylić. oịeị! k'ivaựa gunovum, kivauna. v leḱi popațšauna i tag go dur'niuna, tag go dur'niuna. 
Zastosowany w wypowiedzi czasownik durnić w zn. 'wyzywać', motywowany wyrazem pogard. dureń, jest mocno nacechowany emocjonalnie, zawiera bardzo czytelną ocenę braku umiejętności lekarza.

Polityk

\section{D / M1 - M2 / III / III}

M1: - žuńṅỉ́ ńe tag unatfo.

M2: - pev’ńe, že ńe ưatfo. ale ununy ńe žonzom, tylko śe užonzaĩom. Mężczyzna popiera stwierdzenie rozmówcy, a następnie w przewrotny sposób dowodzi, że politycy są pazerni, cenią pieniądze i wartości materialne, dbają jedynie o własne interesy. W wypowiedzi istotny walor perswazyjny mają czasowniki o wspólnym rdzeniu rządzić - 'sprawować władzę na kimś' i urządzać się - iron. 'stwarzać sobie warunki do życia'.

\section{Robotnik}

\section{D / M1 - M2 / III / III}

M1: - šypko ś z robotom uvinyuny.

M2: - bo te źiśei iňe robot'niki, to rob’iom kšyvo, prosto, byle osțro!

W wypowiedzi rozmówca wyraźnie wskazuje, że obecnie zaangażowanie robotnika w wykonywaną pracę jest niewielkie. Ocenie służy rymowane wyrażenie: krzywo, prosto, byle ostro, które wskazuje na pośpiech, bylejakość i niedokładność pracy, prowadzącą do tego, że efekty czynności są słabe.

Badania nad stereotypami (Zgółkowie 1998: 249) wykazują, że współcześnie obraz robotnika jest niejednoznaczny, według jednych jest on pracowity, rzetelny, a zdaniem innych to „obibok, który wiecznie strajkuje”, osoba silna fizycznie, której atrybutami są: „drelich, beret, gumiaki (kalosze)”.

\section{Stereotypy rodzinne}

Lingwistyczne badania nad stereotypem obejmują również relacje rodzinne, na temat stereotypu matki (zob. Bartmiński 1998: 63-83).

\section{Teściowa}

\section{D / K - M / III / III}

$\mathrm{K}:-$ i ešče se múnode pogozom.

M: - by se inakoź uư⿱ožyuno, ale mamuśa paluški mača.

Tekst utrwala negatywny obraz teściowej, która postrzegana jest jako osoba wścibska, chcąca zepsuć relacje między małżonkami. Zdrobnienie mamusia w wypowiedzi nabiera cech pogardy, występuje tu dodatkowa konotacja pejora- 
tywna, której podstawą jest negatywne skojarzenie zwrotu maczać palce z pospolitą czynnością fizyczną, powodującą brudzenie się rąk.

Znacznie mniej jest stereotypów, które wnoszą uogólnienia pozytywne.

Matka

D / M > K / II / IV

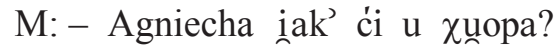

$\mathrm{K}:-$ po iapoisku vui in. iako-tako.

M: - ńi ma inag u matki. unu matki varkocyg gunatkii.

Zastosowane przez mężczyznę przysłowie $u$ matki warkoczyk gładki kreśli obraz matki - osoby troskliwej, dbającej o dziecko, zapewniającej mu miłość, wsparcie i pomoc. Rozmówca odwołuje się do stereotypu, eksponując przymioty przypisywane matce jako 'osobie bliskiej, życzliwej'.

\section{Stereotypy narodowe}

Zjawisko stereotypizacji łączy się z postrzeganiem pewnych nacji i kultur. Literatura poświęcona stereotypom narodowym jest bogata: na temat stereotypu Polaka (zob. Łukaszyński 2002: 147-160), Niemca (zob. Wieczorek 1994: 268-277), Żyda (zob. Kaczor, Romanowski 2002: 53-67).

Stereotyp jest jedną z częstszych technik propagandowych. Podział na „swoich” i „obcych” z jednej strony prowadzi do silnej integracji grup społecznych, z drugiej zaś wprowadza ograniczenie do kręgu własnego narodu bądź państwa, co bywa niebezpieczne w skutkach. Język jest elementem, który może dzielić społeczność na: swoich (lepsi) i obcych (gorsi). Obcy często w sposób irracjonalny traktowany jest jako zagrożenie interesów całej grupy, służy temu wpajana od pokoleń niechęć do innych.

W badanym materiale duży wpływ na kształtowanie określonych stereotypów narodowych miały konflikty etniczne i religijne. Rosjanie i Niemcy nadal postrzegani są negatywnie, głównie przez pryzmat wojny oraz zatargów politycznych z Polską.

\section{Polak}

\section{D / K - M / II / III}

$\mathrm{K}:-\mathrm{a}$ iag' ńe dostańe vizy.

M: - dostańe, dostańe. Polak se zafše poraźi.

Mężczyzna przypisuje Polakowi spryt i ambicję. Badania nad stereotypami (Łukaszyński 2002: 147-160) pokazują, że w stereotyp wpisana jest także prostolinijność, przebiegłość. Polak to wścibski kombinator, wywyższający się, nieuczciwy. 


\section{Niemiec}

D / K - M - Bu / III / III / II

K: - pšetfur'ńa tyž uopcego.

M: - robiuny u śeb’ie, a tero to fšysko ie Niemca.

Rozmówcy przekonują, że znaczna część majątku narodowego stała się własnością obcego kapitału. Wiele stereotypów przekazywanych jest obecnie przez media, jak wskazuje U. Wieczorek (1994: 271): „Znacznie częściej pojawia się w mediach stereotyp bogatego kapitalisty (głównie Niemca), który dąży do wykupienia majątku narodowego, co w konsekwencji może doprowadzić do utraty suwerenności kraju".

\section{Rosjanin}

W wypowiedziach występuje negatywny stereotyp Rosji i Rosjanina. Rosjanom przypisuje się najgorsze cechy: dzikość, okrucieństwo, ciemnotę, wiarę w zabobony, podstępność.

D / K1 - K2 / III / IV

K1: - zabobony byli. pšyšŭa Rosjanka, ale z gưembi Rosji. cauna červona byuna, to muviuna, že iei d’iabeu poščypau. K2: - luźe i tera tez zabobony maíom.

D / M1 - M2 / III / IV

M1: - Niemiec tež grabiun.

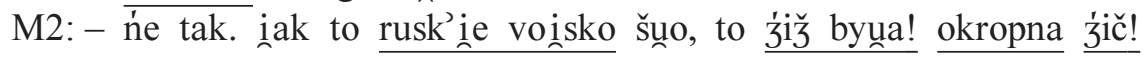

Amerykanin

D / K1 - K2 / III / III

K1: - tera i $\mathrm{v}$ Ameryce o robote țrudno.

K2: - ale dolaruv' i zuota z Ameryki pšyv'i ezuny, dum’ i pšetfur'ńe postaviuny.

Ameryka kojarzy się przeciętnemu odbiorcy z bogactwem, dobrobytem, postępem i kultem piękna. Druga kobieta podkreśla, że mimo wzrastającego bezrobocia w USA, osoby, które tam wyjechały do pracy, przywiozły środki, por. dolary, złoto, dzięki którym wybudowały dom i przetwórnię.

$\dot{Z} y d$

D / M - K / IV / IV

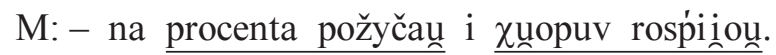

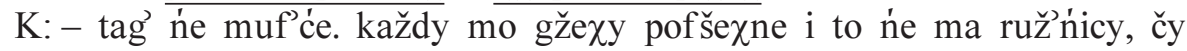
to beńże Żyd, oń ńe vińen, že on Żydem se uroz̉iun, čy Cyganem, ieželi čunov'i iek'i iem? iez dobrym. 
Żyd postrzegany jest przez rozmówcę jako osoba, która zajmowała się lichwą, prowadziła karczmy i rozpijała chłopów. Badania nad stereotypami wykazują, że Żyd jest postrzegany jako religijny, pracowity, wykształcony, oszczędny, zaradny, ale chytry i chciwy, zakłamany. Druga wypowiedź przełamuje ten stereotypowy obraz.

\subsection{Słownictwo normatywne}

Stownictwo normatywne stanowi liczną grupę środków stylistycznych, które pozwalają nadawcy wyrazić przekonanie, że tylko akceptacja wskazanego sposobu i zgodne z nim działanie jest dobre dla odbiorcy. Jednym z najczęściej stosowanych środków perswazji jest użycie wyrazów zachęcających czy nakazujących, typu: trzeba, mus, czasowników, typu: musieć, powinien oraz ich form zaprzeczonych z modulantem nie.

Formy te znaczeniowo bliskie są wyrażeniom imperatywnym, ponieważ zawierają duży stopień kategoryczności. Jednak nie mają one charakteru stanowczego nakazu czy zakazu, raczej wskazują na obowiązek czy powinność.

Silnie nacechowane perswazyjnie są sformułowania, które zawierają konstrukcje zaprzeczone: nie można, nie powinien, nie trza. Wskazując, że pewne postawy są nie do przyjęcia, nadawca stara się w określony sposób pokierować postępowaniem rozmówcy.

\section{D / M1 - M2 / III / III}

M1:- v m’ieść ńe zakumbinuie. luźe ćịško pracuiom.

M2: - źimi tyś śe ne unošuka. ńi možna śe spuźńić. țša rob́iź żiń v źiń.

\section{D / K - M / III / III}

$\mathrm{K}:-$ żiśei f pracy to naîvažńeišse vykštauncene.

M: - dośf inațčene țša míć, ale nauka tyš poțšebno.

Na sugestię kobiety, że współcześnie najważniejsze jest wykształcenie, mężczyzna odpowiada, że osiąganie dobrych wyników w pracy w jednakowym stopniu uzależnione jest od wiedzy i zdobytego doświadczenia, ponieważ wiedza, dzięki umiejętnościom, może mieć praktyczne zastosowanie.

\subsection{Wyrazy uogólniające}

Szczególną rolę spełniają w komunikacji mieszkańców wsi wyrazy uogólniające, zwłaszcza: każdy, wszyscy, nikt, zawsze, które często powtarzane w obrębie jednej wypowiedzi przekonują odbiorcę do określonego sposobu postrzegania osób lub zjawisk. 


\section{D / M - K / IV / IV}

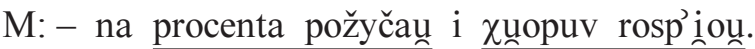

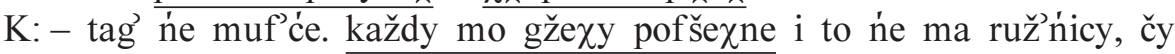
to beńże Żyd, on n'e vinen, že on Żydem se urożiu, čy Cyganem, ieželi čunov'iek'iem’ iez dobrym.

Rozmówczyni przeciwstawia się stereotypowemu widzeniu ludzi i zjawisk. Podkreśla, że nie ma ludzi, którzy nie popełniają grzechów, por. modyfikację wyrażenia grzechy powszednie: grzechy powszechne i że w ocenie człowieka najważniejszą przesłanką jest jego postępowanie, a nie narodowość.

\section{D / K1 - K2 / III / III}

K1: - moguna pšeće poiexać. dostauna vize.

K2: - ni moguna. žyće luck ie zaviune, pokrentne, zagmatfane, zafše śe cuź na zue od’miníi.

Wyraz uogólniający zawsze służy podkreśleniu przeszkód, które uniemożliwiły realizację planów.

\section{D / K1 - K2 / IV / IV}

K1: - sama se iez vinna.

K2: - a ia tylko oiccuv vinuie. ununa muodo to gunupio, a unun stary unog'ier. frsystk'ie go tu znauny, to Wacki niz ne v'ieźauny.

Wyrazy uogólniające: wszyscy, każdy wskazują, że opinia na temat mężczyzny była w środowisku powszechnie znana. Nadawca podkreśla, że nie była to tylko jego opinia, ponieważ to, co mówi, było wiadome także rodzicom dziewczyny.

\section{D / K1 < K2 / Bu / II / III / II}

K1: - a mine tag dobže.

K2: - co to tera za maunžeistfa? unun pracuie f Krakowie, a ty tutei iesteś. muode maǔžeistfo, dva lata i iak to tag dalí? pov'iec, co ty za žyće

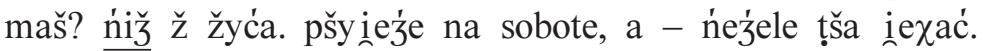

Kobieta krytykuje wyjazdy do pracy poza miejscem zamieszkania i pragnie unaocznić córce, w jakim trudnym znalazła się położeniu.

\subsection{Perswazyjny walor danych liczbowych}

Innym przejawem wpływu perswazji na język jest możliwość wykorzystania w komunikacie danych liczbowych oraz określeń dotyczących ilości. Do świadomości odbiorcy przemawiają liczby, zwłaszcza, gdy ujęte są w odpowiednim kontekście. Dane liczbowe służą do ukształtowania zespołu sądów orzekających i są często stosowanym chwytem w różnego typu przekazach perswazyjnych. Liczby wykorzystują zasadę społecznego dowodu słuszności i stanowią wyrazisty wyróż- 
nik komunikatu, a ich ogromna moc dowodowa przekonuje odbiorcę o prawidłowości podjętego działania.

W ludzką naturę wpisane jest ograniczone zaufanie do percepcji zmysłowej, dlatego należy wszystko sprawdzać, nasze pragnienia często weryfikuje wymowa cyfr. W. Pisarek (2004: 132-133) podkreśla, że liczby mają moc dowodową większą niż cytaty i nawiązania. „Ludzie czują się względnie pewnie, operując liczbami do stu, ewentualnie do tysiąca. Kiedy w grę wchodzą setki tysięcy i miliony, różnice między nimi zaczynają się zacierać”.

W analizowanym materiale językowym liczby służą uszczegółowieniu, wyliczeniu składników, wskazaniu rozmiarów jakiegoś zdarzenia. Zastosowane we właściwym momencie rozmowy, zawsze robią wrażenie na odbiorcy. Oznaczenia cyfrowe, które wyrażają wielkości, służą uintensywnieniu opisywanych zjawisk.

Często oceny jakiegoś przedsięwzięcia mówiący dokonuje w kategoriach dobro - zło, zysk - strata. Pragmatyczny walor zysku E. Lewandowska-Tarasiuk (2005: 44) ujmuje w następujący sposób: „Szczególnie skuteczne okazuje się odwołanie się w perswazji do spraw postrzeganych w kategoriach korzyści, zwłaszcza materialnych. [...] Pragnienie zysku, materialnego dostatku, zaspokojenia potrzeb konsumpcyjnych, także najbardziej wyrafinowanych, należy do sfery pragnień ludzkich, do których, jak się okazuje, warto się odwoływać, chcąc być przekonującym".

Wśród językowych technik perswazyjnych wykorzystujących dane liczbowe w tekstach gwarowych znajdują się niektóre kategorie semantyczne, wyodrębnione przez K. Ożoga (2001: 103-125) w odniesieniu do tekstów reklamowych. Kategorie ceny, skuteczności oraz wygody mogą być opisane w kategoriach ilościowych i jakościowych.

Kategoria ceny, w przeciwieństwie do dyskursu reklamowego, rzadko wskazuje na wyjątkowość i opłacalność oferty.

\section{D / K1 - K2 / III / III}

K1: - țrudno se luj́om žyịe.

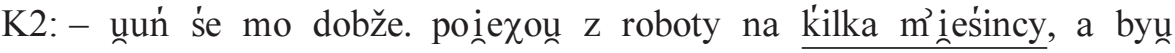
ṕinź lat. grož unadny pšyv'i ius.

Druga rozmówczyni wskazuje, że w czasach kryzysu ekonomicznego mężczyzna, o którym rozmawiają, ma dobrą pracę, przynoszącą godziwy zarobek, por. fraz. tadny grosz.

\section{D / K1 > K2 / IV / II}

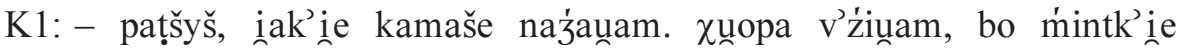

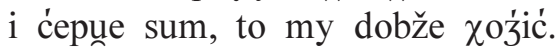

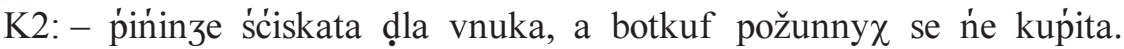

K1: - țrepuv u m’ne ie do d’iabuna, cauno klatka. popač, šeś par tamui

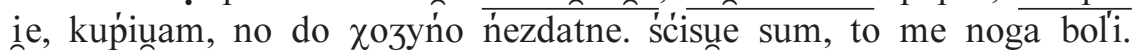


Starsza kobieta przekonuje sąsiadkę, że ma dużo butów, por. określenia: do diabła, cała klatka, liczby: sześć par, ale nie może ich nosić, ponieważ są niewygodne.

Dane liczbowe najczęściej mają na celu przekonać odbiorcę o nieopłacalności pewnych zabiegów i przedsięwzięć, wymowa liczb ma mu uzmysłowić bezsensowność działań.

\section{D / M1 - M2 / III / III}

M1: - latoś to śe fcale ne unopunaći iapkuv zbirać, po dvaźeśća pińż grošy za kilo daịum, a spaduf fcale ne b’ierum. tero luźi naínńć, zapunaj́ d'ńufke ze dv'ie dy $x y$, ieź dei, to ńi mo ńiiaki karkulac'ii.

M2: - u m’ne to fšysko źcćoki zb’iorom, to na sfoine iakoź vyinde.

Pierwszy z rozmówców podkreśla nieopłacalność działań, ponieważ praca w sadzie nie przynosi oczekiwanego zysku.

Liczebniki występujące w tekstach podkreślają skalę jakiegoś zjawiska.

\section{D / K1 - K2 / Bu / IV / IV / II}

K1: - ununa to miauna dužom škoune.

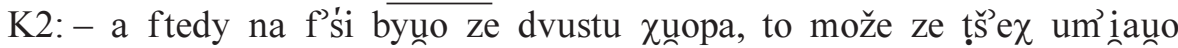
se potpisać. kto tam k'inedyś um inau čytać albo pisać.

W analizowanej wypowiedzi liczebniki wskazują na rozmiar analfabetyzmu.

Dane liczbowe służą ocenie ludzkiej wiedzy i umiejętności, mogą być wykorzystane jako istotny środek hiperbolizacji.

\section{D / K - M / III / III}

K: - pšyšunam, žeby my Ania f'irany pšešyuna.

M: - a g'̉̉e ći ununa co ušyine. na krafcovom se țšy lata školii, a o inigle ńi inakigo poinćca ńi mo.

Mają podkreślić i napiętnować pewne niewłaściwe zachowania i cechy charakterologiczne osób.

\section{D / K1 - K2 / III / IV}

K1: - može țša byuno lečyć.

K2: - a $\chi$ tury ṕiiok' se $\chi$ ce lečyć. prośiuna, ale za niiź ne k'ćoun. a taḱi $\chi$ luń byư, že ṕińż mỉeśincy naved’ ne v́ymiššauna.

Druga z kobiet wskazuje, że przyczyną szybkiego rozpadu małżeństwa wnuczki było uzależnienie mężczyzny od nałogu.

\section{D / M1 < M2 / III / IV}

M1: - Zocha pov́inna vaz do lekaža zaviiś.

M2: - țšy razy na żiń byuna, puki gospodarka na m’ne stauna. a tero nig ne zaižy, ańi ununa, ańi unun, ani źećokí. 
Rozmówca, wskazując częstość wizyt kobiety, podkreśla, że służyły one realizacji nieuczciwych planów.

Podobną funkcję pełnią w badanym materiale określenia wskazujące na ilość, np.: w bród, caly, dużo, parę, do diabta. Ostatnie wyrażenie w tekstach gwarowych badała J. Gardzińska (2004: 73-82).

D / K1 - K2 - Bu / IV / IV / II

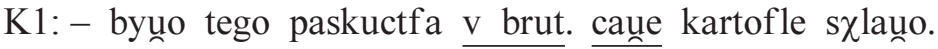

K2: - tera mainom na fřssko sposup.

D / M - K / III / IV

M: - zvalńainom i ze škouny.

$\mathrm{K}$ :- mušom, bo k' iedyś to $\mathrm{v}$ unod'źale byuno dužo unučñi, tero tylko pare.

Kobieta tłumaczy, że zwolnienia w szkolnictwie związane są z niżem demograficznym.

\subsection{Rozbudowana synonimika a intensywność ocen}

Jako środek perswazji mogą być wykorzystywane wyrazy bliskoznaczne, bogata synonimika jest cechą charakterystyczną języka potocznego. Synonimy to wyrazy, które można stosować wymiennie, ale ich bliskoznaczność nie oznacza przynależności do jednej klasy semantycznej (zob. Kurkowska, Skorupka 2001: 142). Zjawisko całkowitej jednoznaczności ma z reguły charakter przejściowy ze względu na silnie przejawiającą się dążność do zróżnicowania znaczeniowego i stylistycznego jednoznaczników. Synonimia jest skrajnym rozluźnieniem identyczności brzmienia przy zachowaniu tożsamości znaczenia wyrazu. Powtórzenie obok siebie jednostek synonimicznych ma na celu wyeksponowanie w przekazie tego, co ważne, istotne, co ma budzić określoną pozytywną lub negatywną konotację.

Jak wyjaśniają badania z zakresu psychologii, rejestrując kolejne spostrzeżenia, zupełnie nieświadomie włączamy je w pewne zbiory na zasadzie podobieństwa lub odrębności, co może prowadzić do pewnych uogólnień poznawczych wyrażających się w budowaniu zafałszowanego obrazu.

Z badań I. Kamińskiej-Szmaj (1994: 68-69) wynika, że w tekstach propagandowych wyrazy bliskoznaczne układają się „,W większe ciągi synonimiczne, których ośrodkiem jest wyraz neutralny stylistycznie, zastępowany w konkretnych wypowiedziach leksemami różniącymi się nacechowaniem emocjonalnym, intensywnością ocen".

W komunikacji mieszkańców wsi powtórzenia synonimiczne są wykorzystywane jako środki językowe służące wartościowaniu oraz uwiarygodnieniu przekazywanych treści. Jak podkreśla H. Pelcowa (1998: 105): „[...] wartościowanie prowadzi do wariantywności i używania często zamiennie różnych cech gwarowych i właściwości ogólnopolskich”. 
Synonimy w tekstach gwarowych pojawiają się często, a ich użycie nie jest przypadkowe, ponieważ wybór kolejnego wyrazu wzmacnia emocjonalny wydźwięk poprzedzającego. Przede wszystkim stosowane są obok siebie jednostki o określonym ładunku emocjonalnym. Dobór wyrazów w wypowiedzi jest szczególnie ważny, zależy od niego reakcja, jaką nadawca chce wywołać u odbiorcy. Określenia bliskoznaczne i synonimiczne są istotnym zabiegiem wzmacniającym funkcję perswazyjną tekstów, ponieważ służą uwydatnieniu treści emocjonalnych łączących się z powtarzanymi wyrazami, przy czym istotne znaczenie ma ranga stylistyczna leksemów. Słowa piętnujące, szydercze, obraźliwe mają wzbudzić pogardę, niechęć i złość w stosunku do osoby, sytuacji czy zjawiska tak nazywanego.

$\mathrm{W}$ analizowanych tekstach znajdujemy elementy synonimiczne typowe dla polszczyzny ogólnej oraz środki o ograniczonym zasięgu, używane w konkretnej społeczności. W ten sposób ta sama treść może być przekazana raz w sposób staranny, książkowy, innym razem swobodnie, potocznie, wreszcie przy użyciu środków pospolitych, a nawet trywialnych. Synonimia obejmuje różne wyrazy, powtarza się czasowniki, rzeczowniki oraz przymiotniki, które zestawione są w szeregi synonimiczne (Apresjan 1980: 318-327), jeśli zaś chodzi o budowę, szeregi mogą zawierać bliskoznaczniki różnordzenne, jednowyrazowe i wielowyrazowe.

W dłuższych szeregach synonimicznych wyodrębniają się grupy lub pary wyrazów ściślej ze sobą związanych. Znajdujemy wśród nich ekspresywne, metaforyczne określenia ludzi, czynności, a także nazwy zastępcze - eufemizmy. Wykorzystane synonimy determinują sposób odbioru komunikatu, ich nagromadzenie oddziałuje na tok myślenia odbiorcy, wzmaga sympatię lub pogłębia niechęć względem opisywanych osób, przedmiotów czy zjawisk. Ponadto synonimy pozwalają nadawcy oddać treść w sposób najbardziej odpowiadający jego intencjom, decydują o precyzji logicznej tekstu i zapewniają odbiorcy możliwość lepszego utrwalenia kierowanego do niego przekazu. Środki te koncentrują uwagę odbiorcy.

W analizowanych wypowiedziach wykorzystuje się potencję semantyczną różnych części mowy, najwięcej jest synonimów czasownikowych. Czasowniki wskazują na przebieg czynności, jej rezultat, służą do zaprezentowania zachowania: opisują uczucia, emocje, stan psychiczny osób.

Zestawienia 2 czasowników zostały zaprezentowane poniżej.

\section{D / M1 - M2 / III / III}

M1: - do luźi muv́i, že se sam’ śf iet’ne raźi.

M2: - a iag do oicuf poinexauna, to punakou, becou iag mauny jećok.

Drugi z mężczyzn wskazuje, że osoba, o której rozmawiają, jest niezaradna życiowo, uzależniona od opieki żony. Środkiem zespalającym zastosowane czasowniki jest najogólniejsze znaczenie: płakać - 'wylewać, ronić łzy', beczeć - pot. 'głośno płakać', por. bek 'głos owcy lub przypominający jego brzmienie płacz ludzki'. 


\section{D / M1 - M2 / IV / III}

M1: - narobiu se čunov'i inek, natyrou se, fšysko ț̌sa byuno ryncno zbirać.

M2: - a muode mainum mašyny, a i tag robić se ne $\chi$ ce.

Rozmówca podkreśla, że kiedyś praca na wsi wymagała ogromnego wysiłku fizycznego, w wypowiedzi wykorzystał czasowniki potoczne: narobić się, natyrać się, konotujące zmęczenie i długą, ciężką pracę.

\section{D / M - K / III / III}

M: - škoda. taki unadny dum postaviiun. inak' śe ćešyun, inak’ se radovoun. vypacykovoun, vycackoun $\mathrm{i}$ ńe pomiškoun. a munode raz dva spšedauny.

$\mathrm{K}:-$ munode maium inny gust, stare inny.

Nadawca w celu zaznaczenia emocji wykorzystuje w wypowiedzi wspólne cechy czasowników: cieszyć się, radować się, które dotyczą doznawania i przejawiania radości. Pozostałe synonimy podkreślają wartości estetyczne budynku: wypacykować, wycackać 'przygotować bardzo precyzyjnie, dopracować w każdym szczególe, wykonać z wyjątkową precyzją', por. cackać się 'poświęcać wiele czasu na wykonanie czegoś'.

\section{D / K1 - K2 / III / IV}

K1:- ńe dbaž o śeb’ie. pev'ńe ńe z'i iež iak poț̌sa.

K2: - ỉem, iem. čunov'ieg na staroś sx’né, kurčy śe.

Druga rozmówczyni w metaforyczny sposób wyjaśnia, że zmiana wyglądu ma związek z procesem starzenia się, por. czasownik schnać - pot. 'gwałtownie tracić na wadze, chudnąć, mizernieć'; kurczyć się - przen. 'zmniejszać się tu pod względem wagi'.

\section{D / K1 - K2 / III / IV}

K1: - ununa dobže gotuie.

K2: - ńe každy poțraf'i uvažyć. unugotuie to smaḱi ńi mo.

W wypowiedzi wykorzystano przestarzały czasownik warzyć i neutralny gotować, które służą podkreśleniu, że nie każda gospodyni ma talent kulinarny.

Szczególne znaczenie ma wykorzystanie w wypowiedzi środków językowych o ograniczonym zasięgu występowania, charakterystycznych dla określonego środowiska wiejskiego.

\section{D / K1 - K2 / III / IV}

K1:- ne gotui sama! ńe $\chi$ ći j̇ećoḱi gotuiom.

K2: - ne iez' iešče ze mnom tag źle. sama se ungotuie. a to kašy, a to mlika, a to zupine iakom. cuś śe zafše uśf'irgoli, tego kapecke, tego kapecke. 
Sąsiadka stara się namówić swoją rozmówczynię (starszą kobietę), by część obowiązków domowych powierzyła mieszkającym z nią wnukom. Druga rozmówczyni podkreśla, że jest jeszcze na tyle sprawna fizycznie, że nie potrzebuje pomocy. Zastosowane w wypowiedzi czasowniki to neutralny znaczeniowo ugotować i nacechowany ekspresywnie gwarowy uświrgolić, zawierający znaczenie 'mniej smacznie'.

\section{D / K1 - K2 / III / IV}

K1: - nig ne v'iežyŭ, že ununa dum postaví.

K2: - a ia v'ieżaunam. unoščynzauna, śćimboliuna, to se pobudovauna.

Rozmówczyni przekonuje, że odpowiednio planując wydatki, można zrealizować takie plany, co do których wszyscy mają poważne wątpliwości. Istotne znaczenie w wypowiedzi ma neutralny czasownik oszczędzać 'żyć wydając niewiele pieniędzy, żyć skromnie, nie być rozrzutnym' oraz nacechowany emocjonalnie gwarowy czasownik ścimbolić w zn. ‘żyć bardzo skromnie', który uwypukla intensywność i służy hiperbolizacji przekazu.

Niekiedy w rozmowach występują synonimy zróżnicowane chronologicznie.

\section{D / K1 - K2 / III / III}

K1:- pev'ńe ńe v'iejoun, že to taḱi unadny mebel. leńu

K2: - co ne v'ieźoun! fšysk' ie luźe z' iei f's's pov'iadauny, muviuuy, že

Pierwsza z kobiet próbuje tłumaczyć decyzję mężczyzny niewiedzą, wykorzystuje w tym celu modulant pewnie oraz wyrażenie gwarowe ladny mebel, będące ironicznym określeniem osoby, która udaje kogoś, kim naprawdę nie jest. Druga rozmówczyni odwołuje się do powszechnie znanej opinii lokalnej społeczności na temat kobiety, wykorzystuje w wypowiedzi czasowniki o znaczeniu 'informować, podawać do wiadomości': neutralny mówić i przestarz. powiadać.

\section{D / M1 - M2 / III / IV}

M1: - ia bym unod’ ńix pińenzy ńe v’źuu.

M2: - tak' ce unomamiom, unocygańom, že sam ir beźeš prośiun, žeby tylko $\chi$ 'ćauny dać.

$\mathrm{Na}$ stanowcze stwierdzenie rozmówcy drugi z mężczyzn odpowiada, że sprawni pracownicy tak potrafią przedstawić korzyści oferty bankowej, że człowiek koniecznie chce z niej skorzystać. W wypowiedzi istotne znaczenie mają czasowniki: rzad. omamić 'wprowadzić w błąd, zwieść, otumanić, oszukać' i pot. ocyganić 'rozmyślnie wprowadzić w błąd; oszukać; okpić'.

\section{D / K1 - K2 / III / IV}

K1: - ununa tylko $\mathrm{z}$ roboty do roboty lata. škoda j́evuxy.

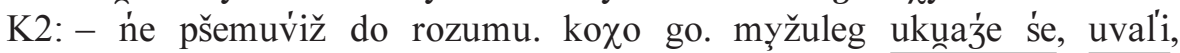
a ununa tyro. 
Druga z kobiet wyjaśnia, że thumaczenie nie odnosi pożądanego skutku. Pracowitość kobiety została wyraźnie skontrastowana z lenistwem mężczyzny, por. iron. określenie mężulek. Istotne znaczenie mają użyte w wypowiedzi synonimiczne formy czasownikowe, por. klaść się i walić się, pot. 'kłaść się ciężko, bezwładnie'; zob. fraz. ktoś wali się jak kłoda - 'ktoś upada bezwładnie, całym ciężarem ciała'.

\section{D / K - M / III / III}

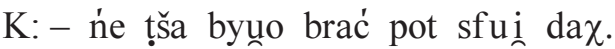

M: - ano čunov’iek se myśloun, že se ta żič scyvilizuie i ugunaźi.

Rozmówca, stosując czasowniki cywilizować się - 'przyjąć cywilizację, rozwinąć się' i ugładzić, por. przen. 'nabrać gładkości w zachowaniu', podkreśla niepowodzenie czynności. Negatywnie waloryzuje osobę rzeczownik $d z i c z$ - 'człowiek niecywilizowany, okrutny, powodujący się biologicznymi odruchami'.

W grupie synonimów wyróżniają się także inne ekspresywne, metaforyczne czasowniki.

\section{D / M1 - M2 / III / III}

M1: $-\chi c o m$, žeby im otpisać.

M2: - ne otṕisui, i iešce počekei. pamintož Gienia. cauny mainonteg

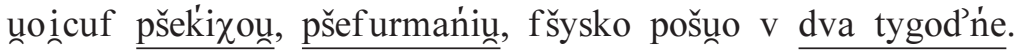

Użyte przez nadawcę czasowniki: przekichać, por. kichać na co - 'lekceważyć sobie co', przefurmanić od stereotypu furman 'człowiek nadużywający alkoholu i brzydkich słów', powodują, że przedstawione zdarzenie staje się bardziej wymowne. Relacjonując je, nadawca odwołuje się do wyobraźni odbiorcy, ekspresję językową wzmaga zastosowany sposób obrazowania. Ważne jest ponadto określenie dotyczące czasu - dwa tygodnie, które także intensyfikuje opis.

Perswazyjność przekazu wzmaga się, gdy zestawienie obejmuje 3 czasowniki.

\section{D / K - M / III / III}

K: - može g’źe iakom robote dostańe.

M: - g’źe dostańe, iak pońiščyuny, zdemolovauny, zdevastovauñy fřysko.

Wybór synonimów determinowany jest skojarzeniami emocjonalnymi i oceną zjawiska, które ulega hiperbolizacji, por. czasowniki: poniszczyć 'zniszczyć wiele czegoś, kolejno jeden po drugim', zdemolować, zdewastować 'burzyć, niszczyć, rozwalać'.

\section{D / M1 - M2 / IV / IV}

M1: - unun byư v oboźe i tego čuov'ieka poznou.

M2: - fstyd nazyvaź go čunov'iek'im. biux, myṇčyun, katovou luźi.

Czasowniki, mające wspólne centrum semantyczne 'uderzać w celu zadawania bólu', służą budowaniu wizerunku osoby zwyrodniałej, która była kapo w obozie 
koncentracyjnym; por. bić 'zadawać rany, ciosy; chłostać, smagać'; męczyć 'zadawać komuś męki, torturować kogoś, sprawiać cierpienie fizyczne lub moralne; znęcać się nad kimś'; katować 'bić, torturować, zadawać ból w okrutny, bestialski sposób'.

D. Buttler (1982: 59) podkreśla, że: „Układ kategorii czasowników w polszczyźnie potocznej odzwierciedla bardzo dokładnie sposób funkcjonowania tej odmiany języka: dialogowej, obliczonej na podtrzymywanie więzi rodzinnych i koleżeńskich, na wyrażanie oceny najbliższego środowiska. Zestaw tego słownictwa - to przeważnie lustrzane odbicie tematyki codziennych rozmów, koncentrujących się głównie na stosunkach międzyludzkich. Niechętnie ujawnia się w nich głębsze i szlachetniejsze uczucia, [...] za to niejednokrotnie manifestuje się ironiczny dystans wobec zjawisk, ich lekceważenie lub przynajmniej postawę protekcjonalną w stosunku do nich".

Zestawienie 2 rzeczowników ilustrują poniższe przykłady.

$\mathrm{P} / \mathrm{K} 1<\mathrm{K} 2 / \mathrm{Ub} / \mathrm{II} / \mathrm{III} / \mathrm{I}$

K1:- Krzysiu! pobaf' śe, $\chi$ ce z bap'ćom porozmav'iać.

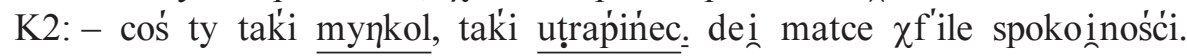

Babka ocenia naganne zachowanie wnuka, używając określeń wartościujących: mękol - 'ten, kto męczy', utrapieniec tu w zn. 'niesforne, nieposłuszne dziecko; psotnik'.

\section{D / K - M / III / IV}

$\mathrm{K}:-$ tựumaž mu, rozmav'iei, može zrozumí.

M: - ńik tumana, dur'ńa ćimnego, unograńičunego rozumu ne naunucy.

Efekt perswazyjny przekazu wzmaga hiperboliczne nagromadzenie wyrazów odnoszących się do właściwości intelektualnych, por. rzeczowniki: tuman z ros. i tur. 'obłok', przen. 'człowiek ociężały umysłowo, niedouczony', dureń oraz bliskich mu znaczeniowo przymiotników: ciemny, ograniczony, uwypuklających związek treściowy z rzeczownikami.

Zestawienie 3 rzeczowników prezentuje poniższy przykład.

D / K1 - K2 / III / IV

K1: - ńey go gna do roboty.

K2: - leń, nygus, p piecušysko v'ierutne i tyle. robiż im se ne $\chi c e$, a co ununa može.

Na plan pierwszy w wypowiedzi wysuwa się zarówno ilość, jak i różnorodność rzeczowników, których nadawca używa do opisu osoby, por. leń 'człowiek leniwy; próżniak; nierób’; nygus pot. 'ten, kto zaniedbuje swoje obowiązki; leń, próżniak, wałkon'; piecuszysko pogardliwe gwarowe określenie 'tego, kto siedzi przy piecu; leniuch, próżniak'. 
Zestawienie 3 przymiotników zostało przedstawione poniżej.

Synonimy przymiotnikowe służą uszczegółowieniu znaczenia, różnią się zakresem lub gradacją cechy.

\section{D / K1 - K2 / III / III}

K1:- moguna pšećeš poie exać. dostauna vize.

K2: - ńi moguna. žyće luck’ie zav́iue, pokrentne, zagmatfane, zaf̌̌e se cuź na zue od’minín.

Druga rozmówczyni podkreśla, że nie zawsze można zrealizować życiowe plany. Wyjazd kobiety nie doszedł do skutku, ponieważ pojawiały się przeszkody, na które wskazuje zwrot: odmienić się na złe. Istotne znaczenie w wypowiedzi mają także określenia synonimiczne: zawite 'trudne do zrozumienia, pełne niejasności, skomplikowane', pokrętne przen. 'trudne do zrozumienia, pełne niejasności, skomplikowane', zagmatwane.

Synonimy przymiotnikowe mogą być elementem oceny wiarygodności przekazu.

\section{D / K1 - K2 / III / IV}

K1:- muvivi, že ununa o ńičym n'e v'ieźaúa.

K2: - ununa ie pšekrentno, faušsyvo i obunudno v mov'ie.

Treści wyrazów - przekrętna, fatszywa 'podrobiona, imitowana, obłudna, nieszczera, przewrotna'i obłudna 'świadcząca o obłudzie' - nakładają sięna siebie częściowo, podkreślając nieszczerość działań osoby, o której nadawca mówi. Szereg synonimiczny podważa szacunek i zaufanie do kobiety, uwydatnia niepożądane cechy jej charakteru.

W zebranym materiale odnotowano również synonimy różnoksztaltne.

D / M - K / III / IV

M: - n'e $\chi$ prubuiom śe dogadać. j́ećokuf škoda!

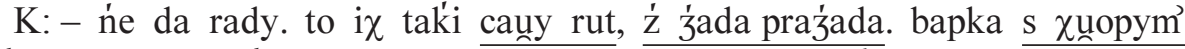

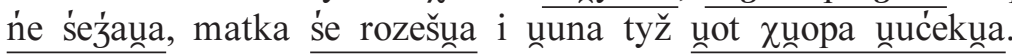

Zwroty: nie siedzieć z chtopem, uciec od chłopa, czasownik: rozejść się, w połączeniu z rzeczownikiem ród i wyrażeniem $z$ dziada pradziada 'od dawna' wskazują, że w domu osoby, której dotyczy rozmowa, brak było właściwych wzorców rodzinnych i odniesień małżeńskich, co stało się przyczyną rozkładu jej związku.

\section{$\mathrm{D} / \mathrm{K} \mathbf{1}<\mathrm{K} 2$ / Bu / II / IV / II}

$\mathrm{K} 1:-$ on by ćoće lečyu i lečyŭ.

K2: - ta lekarka to tylko gunovom k'ivauna. uhod naingoršy go vyzyvauna, ale go dur'ńiuna.

Zwrot wyzywać od najgorszych - pot. 'obrzucać kogoś wyzwiskami, wymyślać komuś, używając obelżywych słów' i czasownik durnić, por. pogard. określenie dureń 'człowiek głupi; głupiec' obok wymownego określenia kiwać głowa w spo- 
sób sugestywny opisują reakcję lekarki, która była zaskoczona niewłaściwą diagnozą i nieprawidłowym leczeniem pacjentki.

Nagromadzenie określeń synonimicznych to bardzo ekspresywna figura stylistyczna, z którą mamy do czynienia w następujących tekstach.

\section{D / K1 < K2 / II / IV}

K1:- barzo dobže ćoća vyglonda.

K2: - luj̉e dobže vyglondaíom i um’ierainom. čunov'inek' śe inuš kuịncy, lata do źimí congnom. íuś se ie na vycugu.

Rozmówczyni, odpowiadając na komplement, wskazuje, że ładny wygląd nie jest wyznacznikiem zdrowia. Niezwykle interesujące i sugestywne są eufemistyczne określenia dotyczące starości i zbliżającej się śmierci, por. człowiek się kończy, lata do ziemi ciagna, gwarowy zwrot metaforyczny być na wycugu, por. od niem. Zug przestarzałe 'przeciąg'.

Interesujący językowy obraz starości ludzi i zwierząt zawiera artykuł Wolny (2003: 189-199).

\section{D / K1 - K2 / IV / IV}

K1: - užykaụa sob’ie Wacka, že se quatuainum, gryzum, do gardeụ skačom, za uby b’ierum.

K2:- munożi, iak to munoźi, żin pokunući, noc pogożi.

W pierwszej wypowiedzi czasowniki: gryźć się - przen. 'żyć w niezgodzie, dokuczać sobie nawzajem, kłócić się’, gwarowe nacechowane ekspresywnie określenie chattać się 'kłócić się' oraz frazeologizmy: skakać sobie do gardet 'kłócić się z kimś, być wobec kogoś agresywnym', brać - wziać się za łby 'toczyć z kimś spór, prowadzić z kimś walkę', por. wziąć kogoś za łeb 'podporządkować kogoś sobie', wskazują na niewłaściwe relacje między młodymi, ponieważ kłótnie i awantury są stałym elementem pożycia małżeńskiego. Druga z rozmówczyń, odwołując się do przysłowia, przekonuje, że nie należy zbytnio martwić się sytuacją, ponieważ młodzi małżonkowie z reguły szybko dochodzą do porozumienia.

\section{D / M - K / III / III}

M: - ńe ies taki zuny.

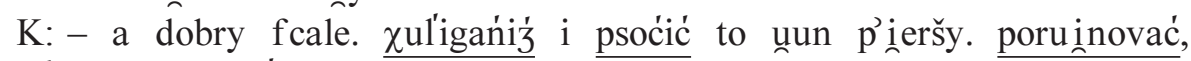
popsuć tylko poțraf'i.

Kobieta zaprzecza opinii sformułowanej przez mężczyznę. Czasowniki: chuliganić 'zachowywać się chuligańsko'; psocić 'płatać figle, robić psoty' oraz porujnować, popsuć, podkreślają, że wnuczek jest wyjątkowo niesfornym dzieckiem.

Bogactwo i różnorodność zastosowanych w tekstach gwarowych środków synonimicznych nie dziwi, ponieważ jak podkreśla H. Pelcowa (1996: 157): „Wszystkie $[\ldots]$ gwary charakteryzują się ogromnym bogactwem form gramatycznych i wyrazów, a także w zasadzie nieograniczonymi możliwościami obocz- 
nego ich występowania. Z tym, że największa wariantywność, uwarunkowana przede wszystkim geograficznie oraz pokoleniowo, cechuje słownictwo i fleksję gwarową".

\subsection{Antonimy}

W funkcji perswazyjnej wykorzystywany jest nie tylko związek podobieństwa znaczeń wyrazów, ale także ich przeciwstawności. Perswazyjność obejmuje również relacje antonimiczne, słowa o znaczeniach kontrastowych są ważnym elementem komunikacji, zwłaszcza wtedy, gdy nadawcy zależy na podkreśleniu przeciwieństwa treści. Pary wyrazowe przeciwstawne na poziomie znaczeniowym wskazują skrajnie różne postawy i przyczyniają się do wzbudzenia sympatii lub antypatii, przedstawiają daną osobę, zjawisko, sytuację w korzystny lub niekorzystny sposób. Antonimy służą konfrontacji oczekiwań i wartości. Na wartościowanie za pomocą antonimów w polszczyźnie potocznej zwraca uwagę W. Lubaś (2003: 528-531).

Antonimy rzeczownikowe prezentują poniższe przykłady.

\section{D / M1 - M2 / III / III}

M1: - bratu tyš časem țšeba ustuḿpić.

M2: - inimu poțšebny potaḱivač, a ne pšećifca.

Derywaty antonimiczne - potakiwacz od potakiwać 'ktoś, kto komuś potakuje, bezwarunkowo z kimś zgadza się', określenie osoby bezkrytycznie potwierdzającej czyjeś zdanie oraz przeciwca 'ten, kto się sprzeciwia, ma własne zdanie' wskazują, że relacja między braćmi poprawi się pod warunkiem, że jeden z nich będzie uległy wobec drugiego.

\section{D / K1 - K2 / III / IV}

K1:- m’ne se to ńe podoba, pšebačei i pšebačei.

K2: - Pan Bóg umar na kšyžu ne za śf'ienty $\chi$, tylko za gžešnikuf. a to țšeba v'ielk'iei v'iezy na to, a to luźe tego ne rozumieinom.

Druga z rozmówczyń wykorzystuje opozycję święty - grzesznik. Odwołując się do Biblii, podkreśla, że należy przebaczać i być wyrozumiałym dla omylności oraz niedoskonałości ludzkiej.

Antonimy przymiotnikowe są wykorzystane jako element służący skrajnie odmiennej ocenie sposobu postępowania, charakteru i wyglądu osób.

\section{D / K1 - K2 / IV / III}

K1: - tag ne poviinno być. Jasia pracoviito, a Romek letkorobickí, to tyž ununa ćinko, a unun iak soflik.

K 2:- v ie Pan Bóg, co robi, unončonć ćer'ne i gunogii. 
Pierwsza z kobiet operuje kontrastem na dwóch poziomach wypowiedzi. Relacja antonimii obejmuje przymiotniki: pracowita-lekkorobicki, podkreślając różny stosunek osób do pracy, przeciwieństwo dotyczy również opisu wyglądu zewnętrznego: ona cienka - on jak szaflik. Porównanie, nawiązujące do apelatywu gwarowego szaflik 'okrągłe naczynie, zwykle drewniane, z jednym lub dwoma uchami, używane w murarstwie i w gospodarstwach wiejskich', wskazuje, że osoba jest otyła, ciężka, ledwo się porusza. Wykorzystane w wypowiedzi środki językowe nadają jej wyrazistości, opis ukazuje szczegóły zabawne, groteskowe, które służą wyrazistej charakterystyce i ocenie osób. Zastosowane przeniesienie nazwy, czyli wtórna nominacja według I. Szczepankowskiej (1998: 120) - „radykalna zmiana znaczenia”, „[...] stanowi jedną z możliwości wzbogacenia słownictwa emocjonalnie nacechowanego. Nazwa [...] neutralna w znaczeniu podstawowym, staje się wybitnie ekspresywna w znaczeniu wtórnym", jak wykazuje badaczka (1998: 12): „Gwarowe nomina attributiva obfitują w nazwy ekspresywne, charakteryzujące się zmiennością znaczeń i nacechowania emocjonalnego. [...] mówiący dysponuje bowiem dużą swobodą doboru określeń, a także ich tworzenia w razie potrzeby". Kontrast zastosowany w drugiej wypowiedzi podkreśla, że ludzie, łącząc się na zasadzie przeciwieństw, realizują plan i zamysł Boga.

\section{D / K1 - K2 / IV / IV}

K1: - sama se iez vinna.

K2: - a ia tylko oicuv vinuie. ununa muodo to gunupio, a unun stary unog'ier. fřystk' ie go tu znauny, to co unoince niz' ne v'ieźauny.

Druga z kobiet uważa, że osoba młoda, która nie miała żadnych doświadczeń miłosnych, mogła ulec starszemu mężczyźnie. Winą obarcza rodziców dziewczyny, którzy odpowiednio nie zareagowali, gdy dowiedzieli się, że córka spotyka się ze starszym mężczyzną, który miał w środowisku opinię rozpustnika, por. ogier przen. 'rozpustnik'. Złożoną i różnorodną charakterystykę zooinwektyw zawiera artykuł J. Szerszunowicz (2006: 279-290).

W zebranym materiale odnotowano również antonimy przystówkowe.

\section{D / K1 - K2 / III / III}

K1: - ununa to može l'ičyź na roźine.

K2: - rożina daleko, a suḿśad' ie blisko, to p’ieršy čuneka poratui ie v b'iźe.

Perswazyjny walor ma także cecha odległości ujęta w dwóch skrajnych punktach: daleko - blisko, którą dodatkowo wzmacnia liczebnik pierwszy użyty w zwrocie poratować w biedzie.

\section{D / K1 - K2 / IV / IV}

K1:- denervuie śe. i śeźi, i čyto, i ńiz mu ńe iźe.

K2: - nervy ńe pomogom. ineden unap’i ie šypko, barzo šypko, a ḍruǵi volno. 
Druga z kobiet przekonuje, że negatywne emocje nie pomagają $\mathrm{w}$ nauce, ponieważ ludzie przyswajają wiedzę w różnym, właściwym sobie tempie, co podkreśla kontrastowym połączeniem, por. szybko - wolno.

Antonimy zaimkowe zaprezentowano na poniższych przykładach.

D / K - M / III / IV

$\mathrm{K}:-$ Sławek ńe $\chi$ ce go znać.

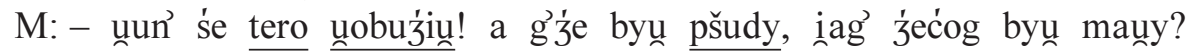

Brak więzi między ojcem a synem mężczyzna uzasadnia jako rezultat dawniejszych zaniedbań, wynik lekkomyślności ze strony ojca, który wcześniej nie utrzymywał z dzieckiem żadnych kontaktów, por. bardzo obrazową metaforę obudzić się oraz parę antonimów: teraz - przódy.

D / M - K / III / IV

M: - zafše nažekauua.

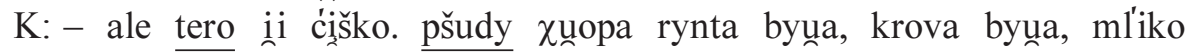
spšedauny, pore grošy na vyxody byuno.

Zastosowana w wypowiedzi opozycja wskazuje, że obecnie sytuacja materialna osoby rzeczywiście uległa znacznemu pogorszeniu.

\section{D / K1 - K2 / III / III}

K1:- dobre žyće mo, na fšysko iom stać.

K2: - co to za žyće. ununa i j̇ećaḱi tu, unun tam.

Druga z rozmówczyń podkreśla, że środki finansowe nie są w stanie zrekompensować rodzinie rozstania, por. parę antonimów: tu-tam.

Antonimy czasownikowe zostały przedstawione na poniższych przykładach.

\section{D / K1 < K2 / II / IV}

K1: - ćoću ńe moge sob’ie poraźić. na ńic teraz ńe mam času. pšyinde s pracy, to ne $\mathrm{v}^{\prime}$ iem za co śe zabrać.

K2: - bo za dobže m’iaunaś. do roboty pošunaś, matka nagotovauna, uprauna, uprasovauna. vruciunaś, fšysko zrob’ione.

Przy pomocy par kontrastowych czasowników pójść - wrócić kobieta podkreśla, że jej rozmówczyni miała bardzo dobrą matkę, która starała się wyręczyć ją w większości obowiązków domowych.

Szczególny walor perswazyjny mają zdania, w których występują podwójne antonimy, zwłaszcza antonimy czasownikowe.

\section{D / K - M / III / III}

$\mathrm{K}:-$ ńe $\chi$ Kaziu veźm’ie te gospodarke.

M: - nik tera ne veźm’ ie. i zaṕisyvou i otṕisyvoun, i davou i odbiroun, tylko luj̧om na śmi 
Przy pomocy antonimów czasownikowych mężczyzna ukazuje dynamiczny obraz zmian: zapisywat - odpisywat, dawat - odbierat i podkreśla brak konsekwencji osoby w rozporządzaniu majątkiem.

\section{D / K1 - K2 / III / III}

$\mathrm{K} 1$ : - raz zrupta $\mathrm{z}$ '́nim požondek.

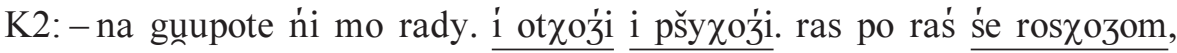
puźńi śe sxozom.

Antonimy: odchodzić, przychodzić; rozchodzić, schodzić wskazują, że małżeństwo przechodzi poważny kryzys.

Niekiedy w wypowiedzi nadawca stosuje antonimy obejmujące różne części mowy:

\section{D / M1 - M2 / III / IV}

M1:- spšedei kavaunek satku i bej́e na remont.

M2: - pospšedaź unatfo, a puźńi nabyć tego trudno.

Drugi z rozmówców na propozycję sąsiada odpowiada, stosując antonimy, mające podkreślić, że pochopne działanie może prowadzić do ryzykownych posunięć, których skutki mogą być nieodwracalne, por. latwo - trudno; posprzedać - nabyć.

\subsection{Polisemia}

Sporą część zasobu leksykalnego polszczyzny stanowią wyrazy wieloznaczne. Polisemia rozumiana bywa jako „posiadanie przez wyrażenie językowe (morfem, wyraz, zwrot lub zdanie) kilku znaczeń” (zob. Polański 1999: 447). Ciekawym zabiegiem perswazyjnym jest wyzyskiwanie systemowej lub kontekstowej polisemii leksemów. Określenia wieloznaczne występują zazwyczaj w określonym kontekście i sytuacji, dlatego nie stanowią przeszkody w porozumiewaniu się.

Wieloznaczność wyrazów w badanych tekstach jest wykorzystywana w celach humorystyczno-ironicznych. Źródłem komizmu może być zestawienie znaczeń realnych i metaforycznych (abstrakcyjnych) oraz jak wskazuje D. Buttler (1974: 301), „Reaktywizacja semantyczna wyrazów związanych konstrukcyjnie”, czyli takich, które składają się na określoną konstrukcję składniową mającą pewne znaczenie całościowe lub wieloznaczność na tle jednoznacznego kontekstu.

\section{D / M1 - M2 / III / III}

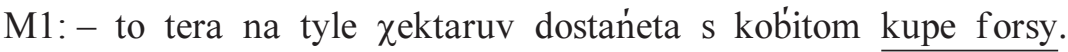

M2: - škoda gadać. dazom kupe forsy s pševagom kupy.

Rozmowa dotyczy dopłat unijnych. Żeby wskazać na wielkość dochodu, rozmówca używa rzeczownika kupa pot. 'wielka ilość, liczba czegoś, mnóstwo'; natomiast interlokutor wykorzystuje znaczenie posp. 'odchody, kał'. 


\section{D / K - M / III / IV}

Rozmowa dotyczy wspólnego znajomego. zrobiu.

$\mathrm{K}$ : - ina śe go pytam: skut to iźeš, a unun: s kośćouna i se červuny taki

M: - unun caune žyće byư červuny, dobže, že se na staroź navrućiun.

Efekt humorystyczny został osiągnięty dzięki rozdźwiękowi pomiędzy dwoma sposobami rozumienia słowa czerwony. W wypowiedzi kobiety wyraz czerwo$n y$ dotyczy 'koloru podobnego do krwi', natomiast mężczyzna używa go w znaczeniu 'ten, kto jest związany z komunizmem, lewicą'. Czerwony to pogardliwe określenie komunisty, członka partii lewicowej. Wykorzystanie wieloznaczności słowa służy ośmieszeniu osoby, która zmieniła światopogląd polityczny.

Treści humorystyczne w sejmowych wypowiedziach polityków analizowała I. Kamińska-Szmaj (2001: 132), wskazując, że śmiech może mieć potrójną funkcję: terapeutyczno-rozrywkową, tworzenia i integrowania wspólnoty oraz degradującą. Autorka pisze: „śmiech jest wyrazem wrogości, a nawet pogardy, bywa złośliwy i szyderczy, wymierzony przeciwko ludziom o odmiennych poglądach politycznych".

\subsection{Homonimia}

Jako element oddziaływania perswazyjnego wykorzystywane są także homonimy, czyli dwa różne wyrazy przypadkowo tylko identyczne w swym kształcie zewnętrznym, które mogą powstawać w wyniku dezintegracji wyrazów wieloznacznych, utożsamiania wyrazu zapożyczonego z wyrazem swojskim, identyfikacji dwóch zapożyczeń z języków obcych.

\section{D / K - M / III / III}

Żona rozmawia z mężem o bardzo widocznej różnicy charakterologicznej między młodymi małżonkami.

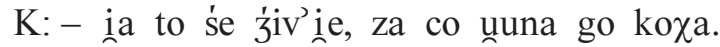

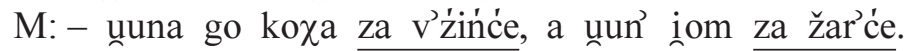

Budowaniu humoru służy homonimia tekstowa, polegająca na utożsamieniu się dwóch różnych odcinków wypowiedzi, co powoduje dwuznaczność przekazu. Mężczyzna odwołuje się do przysłówków: zawzięcie 'z zapałem, z wielką energią' i zażarcie 'z zawziętością, zaciekle', które można odczytać jako stopień nasilenia uczucia, por. fraz. być do wzięcia 'być osobą wolną, mogącą wstąpić w związek małżeński' oraz rzeczowników: odczasownikowego wzięcie i posp. żarcie 'o pokarmie dla ludzi'. Zadaniem odbiorcy jest odkrycie żartobliwo-ironicznego charakteru wypowiedzi. 


\subsection{Wulgaryzmy}

W języku istnieje szereg środków służących do sygnalizowania emocji, jednym z nich jest wulgaryzm - specyficzna jednostka leksykalna, o równie specyficznym zabarwieniu emocjonalnym. Wulgaryzm definiowany bywa jako: ,wyraz, wyrażenie lub zwrot odczuwany współcześnie przez użytkowników języka jako ordynarny, prostacki” (Urbańczyk 1991: 380). W opracowaniach lingwistycznych (zob. Grybosiowa 1998: 361-369; Grochowski 2001; Markowski 2009: 1135) podkreśla się, że jest środkiem nieakceptowanym przez ogół użytkowników języka ogólnego i dialektów ze względu na grubiaństwo, nieprzyzwoitość albo wyraźną przynależność do języka grupy społecznej uważanej za niższą. W ostatnich latach wulgaryzmy przeniknęły ze środowisk marginesu społecznego do języka przedstawicieli innych warstw społecznych i jak podkreśla Markowski (2009: 1135), „stały się atrakcyjnymi, uniwersalnymi sposobami wyrażania myśli”.

Wulgaryzmy to wyrazy i zwroty dosadne, nieprzyzwoite i ordynarne, które występują przeciwko estetyce słowa oraz etykiecie językowej (zob. Biernacka-Ligięza 1999: 166-182; Mosiołek-Kłosińska 2000: 112-119; Marcjanik 2007), naruszają one normy życia społecznego i grzeczność językową. Przez grzeczność językowa (zob. Marcjanik 2007) należy rozmieć stosowanie w komunikacji takich określeń i sformułowań, jakie świadczą o życzliwości i szacunku dla rozmówcy lub innego adresata przekazu, o uwzględnieniu właściwych im przyzwyczajeń językowych i kulturowych, a nawet sposobu percepcji świata. Grzeczność językowa, jako wyrażony werbalnie składnik kultury ogólnej człowieka, jest także składnikiem jego kultury językowej, powiązanym ściśle z estetyką i etyką słowa.

Należy zaznaczyć, że o wulgarności danej wypowiedzi nie musi wcale świadczyć liczba użytych w niej wulgaryzmów. Jak dowodzi K. Mosiołek-Kłosińska (2000: 116), ,efekt obsceniczności można wywołać także poprzez stworzenie obrazu metaforycznego jednoznacznie przywołującego te sfery życia, do których odnoszą się wulgaryzmy".

Klasyfikacja wulgaryzmów nie jest łatwa, M. Grochowski (2001) stosuje podział na wulgaryzmy systemowe i referencjalno-obyczajowe. Pierwsze z nich, to wyrazy, które objęte zostały tabu językowym bez względu na właściwości semantyczne i kontekst użycia, drugie natomiast, obejmują jednostki leksykalne, które obowiązuje tabu przez wzgląd na ich cechy semantyczne i zakres odniesienia przedmiotowego.

J. Kowalikowa (1994: 107-113) dzieli wulgaryzmy na: prymarnie wulgarne - dotyczą sfery fizjologii, anatomii oraz związanych z nimi nazw organów, ich funkcji, a także zachowań oraz prymarnie neutralne, które pierwotnie nie były uznawane za ordynarne, lecz obecnie są tak postrzegane.

Z punktu widzenia perswazji językowej istotne znaczenie mają funkcje przypisywane wulgaryzmom. I. Biernacka-Ligięza (1999: 169) wskazuje, że: „Funkcja ekspresywna pozwala mówiącemu za pośrednictwem [...] przekleństw zaprezen- 
tować swoje uczucia w sposób zamierzony, jak też nieświadomy, spontaniczny. Nadawca posługuje się niekiedy wulgaryzmami w celu rozładowania własnego napięcia psychicznego”, natomiast: „Funkcja impresywna [...] wiąże się [...] z dążeniem do spotęgowania mocy wykonawczej komunikatu, zwłaszcza kiedy przybiera on formę polecenia, którego siła illokucyjna powinna stymulować postawy i działania odbiorcy [...] lub z realizacją zamiaru obrażenia albo zirytowania partnera" (1999: 170). Badaczka (2001: 77) wyróżnia także funkcję ludyczną, mającą na celu rozbawienie adresata i nadawcy, np. w dowcipach.

W analizowanych tekstach wulgaryzmy wyrażają różne emocje: zaskoczenie, złość, irytację itp., głównym powodem ich pojawienia się w wypowiedzi jest zamiar wzmocnienia przekazywanej treści (funkcja intensyfikująca), wyrażenia emocji oraz rozładowania napięcia (funkcja terapeutyczna). Używając wulgaryzmów, nadawca niezależnie od nacechowania ekspresywnego przekazuje odbiorcy informację o nieoficjalności sytuacji komunikacyjnej.

\section{D / M $<$ K / II / IV}

M: - ona ínš po tygod’nu ńi ma pińinzy. poineże do m’iasta, to dupereli, guvineg nakupi.

$\mathrm{K}:-$ to davei na zakupy tylko pare grošy.

Intensywne zabarwienie ironiczno-pejoratywne posiadają użyte w wypowiedzi mężczyzny rzeczowniki, które służą do zilustrowania niegospodarności kobiety, por. derywat gówienko utworzony na zasadzie kontrastu pomiędzy wulgarną podstawą a deminutywnym sufiksem -ko; duperele - wulg. 'androny, bzdury, głupstwa'.

\section{D / M1 - M2 / III / III}

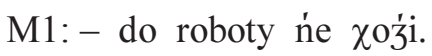

M2: - može se urlob v'źuu.

M1: - a skunt, vyp’iepšylí za vude.

Określenie: wypieprzyć za wódę, por. czas. wypieprzyć - grub. 'wyrzucić' i formacja augm. wóda, mają zaskakiwać, szokować, a przede wszystkim bardzo wyraźnie dać do zrozumienia odbiorcy komunikatu, co nadawca myśli o danej osobie, sytuacji i problemie, który omawia.

\section{D / K1 $<$ K2 / II / IV}

K1: - zaras puíźemy, tylko i iešč iego pokui ogarne.

K2: - škoda tfoi roboty, bo unun tylko veỉze, to zaro tu p’iepšning zrob́i.

Wydźwięk emocjonalny ma derywat pieprznik 'miejsce, w którym jest nieład, nieporządek', motywowany czasownikiem pieprznać wulg. 'cisnąć, rzucić, uderzyć', który zastosowany w wypowiedzi, charakteryzuje mężczyznę jako osobę, która nie dba o porządek. 
D / K - M / III / III

K: - muviuu, že z rok pośeźi, zarobi i iešče i vrući do ńi.

M: - može vrući, ale inuž ńe do ni. guv'ńaš! žyće క̧evuše sp’ iepšyun.

Rozmówca podkreśla, że mężczyzna jest nieodpowiedzialny, por. gówniarz wulg. 'człowiek niepoważny, niedojrzały' i nie wierzy w składaną przez niego obietnicę powrotu do kraju, ponieważ wielokrotnie oszukał kobietę, por. zwrot spieprzyć życie. Nadawca, używając dosadnych określeń, daje jasno do zrozumienia, co myśli o osobie.

\section{D / M - K / III / III}

M: - tag m’ne zdenervovauna.

$\mathrm{K}:-$ byuno ne gadać s tom piierdoluśnicom.

Motywowany czasownikiem pierdolić - wulg. 'kłamać, mówić od rzeczy, niedorzeczności' - derywat pierdoluśnica z sufiksem -uśnica jest gwarowym określeniem 'kobiety, która mówi dużo i bez sensu', por. zwrot gw. w pierdołach chodzić ‘być obgadywanym'. S. Gala (2000a: 173) wskazuje, że: „o aktywności formantu w gwarze zdaje się świadczyć jego zdolność występowania w postaci rozszerzonej, nie notowanej w polszczyźnie literackiej”.

\section{D / K1 - K2 / III / IV}

K1:- pošunabyź do j́eći, dobže byź mỉiauna.

K2: - u koguś, to u koguś. iak to śe muvi: volnoź dupce, f sfoi

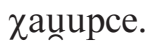

W formie zmodyfikowanej przysłowie wolnoć, dupce, w swojej chatupce jest bardziej ekspresywne, por. wolnoć, Tomku, w swoim domku.

\section{D / K - M / III / III}

$\mathrm{K}$ : - dunugo im sqoźi ta budova.

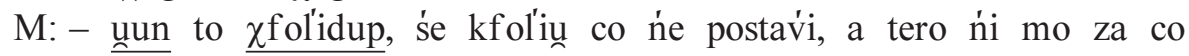
vykuincyć.

„Chwalenie się i pozytywne sądy - pisze H. Popowska-Taborska (1998: 257) wydają się w ludowej świadomości mniej potrzebne niż sądy piętnujące określone postawy i sposoby życia (lenistwo, powolność, niestaranność w pracy, włóczęgostwo, zrzędliwość, nadmierną gadatliwość, skąpstwo, niegospodarność, niemoralne prowadzenie się, pijaństwo, obżarstwo)". Derywat chwalidup jest etykietką językową, która służy wyrażaniu dezaprobaty i ma za zadanie wzmocnić walor perswazyjny przekazu.

Wykorzystywane w tekstach gwarowych wulgaryzmy są środkiem deprecjacji, którą M. Majewska (2005) określa jako takie zachowanie językowe i niejęzykowe, świadome bądź mimowolne, które ma na celu zagrożenie pozytywnemu aspektowi twarzy interlokutora, a szczególnie stanowi atak na jego pozytywnie 
zintegrowany obraz samego siebie. Deprecjacja, tak jak inne akty mowy, zanurzona jest w szeroko rozumianej komunikacji, prototypowymi aktami deprecjacji są: wyzwiska, epitetowanie, etykietowanie, które służą złośliwej dyskredytacji (zob. Karwat 2006).

Według M. Karwata (2006: 317) wulgaryzmy „,są dziwną mieszanką rubaszności i agresywności; opierają się na prowokowaniu otoczenia przekształceniem pojęć intymno-wstydliwych w żetony czy wytrychy pozwalające „dosadnie” określić wszelkie zjawiska i własne emocje bulwersujące czy kłopotliwe”.

\subsection{Nazwy własne}

Nazwa własna (zob. Kania, Tokarski 1984: 197-201) to wyraz, bądź ciąg wyrazów, który w sposób indywidualny nazywa dany obiekt i zjawisko, noszące znaczenie jednostkowe. Nazwy własne w procesie komunikowania wyróżniają konkretną osobę lub jeden obiekt spośród wszystkich innych, nadrzędną funkcją nazw własnych jest funkcja identyfikacyjna, ale stosowanie nazw własnych, mających określone konotacje wartościujące (por. termin konotacja-Tokarski 1984: 13-15), jest ważnym sposobem wartościowania w płaszczyźnie leksykalnej tekstu.

Imiona własne wykorzystywane są także jako element perswazji (zob. Kudra 2001; Michalewski 2004a: 352-363), szczególnie w tekstach politycznych (zob. Kudra 2001), literackich (Sarnowska-Giefing 1993: 99-106), publicystycznych, w reklamach itp.

O funkcji nazw własnych decyduje nie tylko struktura, ale także kontekst językowy i sytuacyjny ich użycia. Wartość stylistyczną ma także ich kształt językowy, który w istotny sposób wpływa na charakter przekazu.

W procesie komunikacji twarzą w twarz imiona własne mogą być wykorzystywane pod kątem mechanizmów perswazyjnych. Podanie nazwy własnej służy uwiarygodnieniu przekazu; nadawca podkreśla w ten sposób prawdziwość przekazywanej informacji. Ponadto w bezpośrednim kontakcie nazwy własne wpływają na zachowania i postawy uczestników rozmowy, zachęcając do nawiązania kontaktu, ponieważ odbiorca ulega sile komunikatu, który skierowany jest bezpośrednio do niego.

W wielu opracowaniach znaleźć można opinię, że wyrazy pospolite coś znaczą, podczas gdy imiona własne nazywają (por. Urbańczyk 1991: 216). Stwierdzenie takie sugeruje, że nazwy własne nie posiadają znaczenia, co uznać można za daleko posunięte uproszczenie, ponieważ wiele przykładów wskazuje na semantyczność nazw własnych. E. Rzetelska-Feleszko (2001: 408) konkretyzuje zagadnienie w następujący sposób: „[...] zespół cech istotnych dla danego obiektu, które nadawca lub odbiorca komunikatu językowego uświadamia sobie w chwili użycia nazwy własnej - jest jej treścią. Cechy te są znamienne w zależności od posiadanej wiedzy o przedmiocie. W tym sensie treść nazwy jest zazwyczaj bardzo 
bogata, może być jednak również bardzo uboga, gdy użytkownik ma niewielką ilość informacji o nazywanym obiekcie [...]".

W badanym materiale językowym nazwy własne są bogato reprezentowane, szczególnie nazwy osobowe: imiona, nazwiska, przezwiska (odnoszące się do osób z najbliższego grona, z kręgu rodzinnego i sąsiedzkiego), występują także nazwy własne (osób powszechnie znanych) oraz nazwy miejscowe: nazwy państw, miast, wsi.

Szczególny walor perswazyjny mają fikcyjne nazwy własne, które są wykorzystywane jako element wartościowania i budowania komizmu przekazu, posłużenie się nimi daje efekt humorystyczny.

\subsubsection{Antroponimy}

W analizowanym materiale, zazwyczaj w zależności od rodzaju kontaktu, środowiska czy sytuacji, używano albo imienia pełnego i nazwiska (najczęściej w sytuacji oficjalnej), albo imienia zdrobniałego, nazwiska lub przezwiska, jest to zjawisko reprezentatywne dla codziennej praktyki językowej, w której imię jest środkiem przekazu takich czy innych treści emocjonalnych, stanowi także ich charakterystyczny wykładnik.

Wśród nazw własnych, których obecność w badanych tekstach łączyć można z zabiegami perswazyjnymi, na pierwszy plan wysuwają się formacje o charakterze ekspresywno-hipokorystycznym, obejmujące derywaty powstałe od imion, które stanowią grupę ekspresywizmów o dominującej funkcji emocjonalnej. Nazwy te wyrażają różne stany uczuciowe nadawcy wobec odbiorcy.

\subsubsection{Hipokorystyka imienne}

Sposób użycia imienia ma związek z tradycją kulturową (zob. Umińska-Tytoń 2000: 131-206), może kształtować profil całej wypowiedzi i budzić różnorakie skojarzenia - od pieszczotliwych, wyrażających życzliwość, sympatię względem nosiciela imienia, przez litość, niechęć po wrogość. Z form nieoficjalnych (o różnym nacechowaniu emocjonalnym) derywowanych od imion oficjalnych chętnie korzysta polszczyzna mówiona, ponieważ jako ekspresywne odpowiedniki neutralnych imion podstawowych formy te są wyrazem uczuciowego stosunku do adresata, a ponadto, $\mathrm{z}$ uwagi na skrótową formę, pozostają w zgodzie z tendencją do ekonomiczności wypowiedzi. Imiona własne są wykładnikami charakteru kontaktów i zróżnicowanych relacji między nadawcą a odbiorcą. W wypowiedziach są mocno eksponowane na tle całości komunikatu i same W sobie stanowią coś więcej niż tylko środek przekazu, stają się wykładnikiem silnych emocji.

Odnotowane w materiale hipokorystyka imienne sygnalizują relacje rodzinne, sąsiedzkie, przyjacielskie, zachowując właściwą sobie barwę (z reguły do- 
datnią), znamionują poufałość zrodzoną w codziennych kontaktach, wskazują na bliski kontakt między nadawcą i odbiorcą, są jednocześnie wyrazem aprobaty nadawcy wobec nosiciela imienia.

Formy hipokorystyczne tworzone są na drodze typowych zabiegów słowotwórczych - sufiksacji i zmiany wykładnika rodzaju gramatycznego (zob. Zarębina 1954: 180-187). Najliczniej reprezentowane są derywaty z sufiksami spieszczającymi tworzone od:

- początkowej części imion sufiksem -ek, -uś, -sia:

\section{D / K - M / III / III}

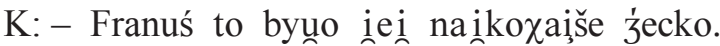

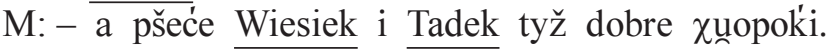

\section{D / M1 - M2 / III / III}

M1: - na vnuki čekam.

M2: - paț̌̌yta tylko, čy aby Marysia fpad'ne.

- pełnych imion pochodnych sufiksem -ek, -ka:

D / K - M / III / IV

$\mathrm{K}:-$ ńig' im’ ne pumože

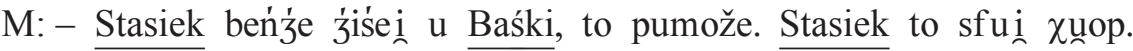

Hipokorystyka predysponowane są do wyrażania pozytywnych emocji względem nosiciela, jednak w określonych sytuacjach mogą być również nośnikami współczucia czy politowania.

\section{D / K - M / III / III}

K: - lużom ne ț̌sa ve fšysko v'i ežyć. luźe to ruźne gadainom.

M: - sam Franczyna muviun my: vuiu ino vim, to ne mui źećok, ale co

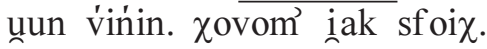

Interlokutor wskazuje, że informacja jest wiarygodna, ponieważ pochodzi bezpośrednio od mężczyzny, o którym osoby rozmawiają. Wśród zastosowanych zabiegów słowotwórczych wymienić należy dobór formy imienia, która w kontekście wypowiedzi jest dodatkowym elementem budzącym empatię, por. Franczyna z suf. -yna wyrażającym współczucie. Celem nadawcy komunikatu oprócz uwiarygodnienia przekazu było także wywołanie określonej reakcji kobiety, tj. wzbudzenie sympatii dla mężczyzny, który wybaczył żonie zdradę i wychowuje jej dziecko jak własnych synów.

Hipokorystyka pod pozorem uprzejmości, wręcz czułostkowości mogą również skrywać emocje negatywne, wskazywać na niechętny stosunek do współrozmówcy, stają się wtedy wyraźnym sygnałem ironii.

\section{D / K1 < K2 - Bu / II / IV}

K1: - pošuna do op’ieki i nagadauna, že bap’ća sama seźi. 
K2:- sama pšeće ne séze. a to Edziowa pšyleći, a to baśina matka, a to źećoki Weryńskich, a to se našy gụuṕi Halinci ne podobo. v unočy îudaž unad'ńe či bé̉e muvić.

O lekceważącym stosunku do osoby świadczy hipokorystyczna forma imienia Halincia połączona z epitetem głupia. Mamy tu do czynienia z zastosowaniem zwrotu pieszczotliwego, semantycznie nacechowanego pozytywnie Halincia, który w kontekście uzyskuje dezaprobujący wydźwięk, sygnalizując ironiczny dystans nadawcy do nosiciela imienia. Uwiarygodnieniu przekazu służą zastosowane nazwy własne: por. Edziowa 'żona Edzia', Weryńskich dzieciaki i utworzone od nich przymiotniki dzierżawcze basina - matka Basi. Istotne znaczenie w kontekście wypowiedzi ma także deonimizacja (zob. Michalewski 1993a: 183-190), użycie określenia judasz, synonim zdrajcy, które łączy się z osobą apostoła Judasza z Kariotu i podkreśla nieetyczne postępowanie kobiety. Zabieg ma na celu przede wszystkim dyskredytację osoby niesłusznie oskarżającej innych ludzi. Problematyce pejoratywizacji lub melioracji nazw własnych użytych w funkcji appellatywów poświęcone jest opracowanie E. Masłowskiej (1991).

Niekiedy swoistego wydźwięku nabiera oficjalna forma imienia użyta w przysłowiu lub rymowance.

D / K - M / III / IV

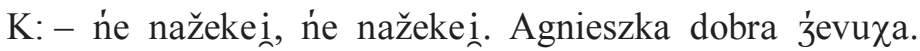

$\mathrm{M}$ : - dobra Agnieszka, kto $\mathrm{z}$ 'ńom’ ńe m’i ieška.

Wypowiedź ma charakter żartobliwo-ironiczny, neutralna nazwa Agnieszka w odpowiednim kontekście, dobra Agnieszka, kto z niq nie mieszka, służy przewrotnej ocenie osoby.

\subsubsection{Bezpośrednie zwroty do rozmówcy}

Ludzie, komunikując się ze sobą, zmuszeni są do wyboru któregoś z wariantów językowych. Koniecznością jest stosowanie form adresatywnych, wybór sposobu zwracania się do odbiorcy jest istotnym elementem komunikacji, związanym z grzecznościa językowa, która jest wieloaspektowa i stanowi ważny składnik procesu porozumiewania się (zob. Marcjanik 2007). Gwarowe zwroty grzecznościowe jako element więzi społecznej łączącej rozmówców były przedmiotem badań (zob. Kąś, Sikora 1994: 83-93; Sikora 1994: 195-204).

Polacy pozostają $\mathrm{w}$ relacjach dwojakiego rodzaju: na ty (w liczbie mnogiej: wy) oraz na pan, pani (państwo). Różne formy zwracania się do odbiorców uzależnione są od relacji między nadawcą i odbiorcą. Relacje na ty dają rozmówcy poczucie równorzędności. Można wówczas poruszać tematy prywatne - bycie na ty jest rodzajem obustronnej zgody na wkraczanie w obszar prywatności drugiej 
osoby. Zasada używania form pan, pani obejmuje relacje osób na różnych szczeblach hierarchii zawodowej czy społecznej.

W analizowanych tekstach przywoływane imię i/lub nazwisko, służy podkreśleniu, że właśnie do tej osoby kierowana jest wypowiedź, w tej funkcji wykorzystywany bywa także stopień pokrewieństwa czy powinowactwa rodzinnego (np.: ciotko, wuju, tatusiu, mamusiu, dziadku, wujenko itp.). Bezpośrednie zwroty do rozmówcy podtrzymują kontakt nadawcy z odbiorcą, ułatwiają porozumienie, ale także, jak podkreśla K. Pisarkowa (1974: 41-84), są ważnym wykładnikiem spójności tekstu.

Imię człowieka to jego tożsamość. Gdy nadawca zwraca się do kogoś po imieniu, nawiązuje z nim szczególną nić porozumienia. Dzięki formie adresatywnej odbiorca łatwiej utożsamia się z przesłaniem i tym większe wywiera ono na nim wrażenie; imię zwraca uwagę rozmówcy na konkretną osobę. M. Brzeziński (2008: 99) pisze: „Używajcie imion waszych znajomych, kiedy chcecie powiedzieć coś ważnego [...]. Imię jest dla każdego słowem wyjątkowym".

\section{D / K1 - K2 / Dz / III / III / I} śp ievauna.

K1: - Ludeczka ia do Mani. zbuj̉ iein. mui syn prośiun, žeby ona

K2: - Mania! Mania! f stań!

K1: - Mania! ia pšyšŭa, žeby ty śp’i inevauna.

Dz: - coću, a čy ia dam rady?

$\mathrm{K} 1:-\overline{\text { daš, }}$ daš. ty fšysko um in ieš. prośiu barzo mui syn, to muśis speunnić. Nadawca stosuje formacje o charakterze ekspresywno-hipokorystycznym: $\mathbf{L u}$ deczka, Mania, które sygnalizują pozytywny, ciepły stosunek do odbiorcy i służą budowaniu z nim więzi. Imię skierowane do konkretnej osoby służy zacieśnieniu relacji między nadawcą a odbiorcą i sprzyja tworzeniu atmosfery zaufania. Bezpośredni zwrot wzmacnia nastawienie na kontakt i obniża stopień oficjalności. Formy zdrobniałe imion są przykładem działania tendencji do zmniejszenia dystansu między rozmówcami, w ten sposób relacje między nadawcą a odbiorcą stają się mniej oficjalne, a bardziej familiarne.

Świadome skracanie dystansu między nadawcą i odbiorcą poprzez zwracanie się do rozmówcy jak do osoby znanej, bliskiej, określane jako metoda wzajemności i metoda budowania sympatii, jest typowym zabiegiem chętnie wykorzystywanym np. w marketingu, także politycznym.

\section{D / K > M / IV / III}

M: - ve vakac'ie śeze v domu.

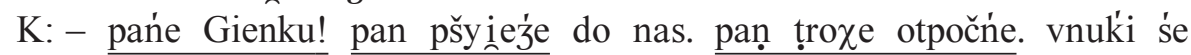
unućešom.

Stopień zażyłości między rozmówcami wyznacza użycie samego imienia bądź konstrukcji: pan + imię spieszczone. W wypowiedzi forma imienia, która została 
utworzona od środkowej części nazwy oficjalnej sufiksem -ek rozpoczyna rozmowę, jest elementem wyraźnie wskazującym adresata zaproszenia.

O funkcjonowaniu w mowie mieszkańców wsi konstrukcji pan pisze K. Sikora (1993: 298-307).

\subsubsection{Nazwiska}

Nazwiska mieszkańców wsi, które występują w tekstach, służą uwiarygodnieniu przekazu, z reguły nadawca, odwołując się do nich, wskazuje odbiorcy charakterystyczne postawy, które uosabiają ich nosiciele, nawiązuje do sytuacji, w jakich te osoby uczestniczyły, podkreśla ich pewne kompetencje.

D / K - M / III / III

$\mathrm{K}$ : - dunugo im sqoźi ta budova.

M: - Weryński to $\chi$ fol'idup, zafše śe kfoliun co unuń ne zrobi. a tero postav́iu i íni mo za co vykuịncyć.

D / K1 - K2 / III / III

K1:- cuź m’ne ostat'ńo noǵi bolom.

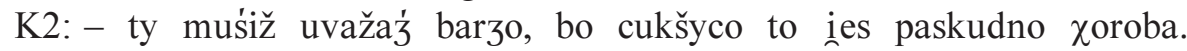
u noz Barylski iez' i tyž mu v noǵi ot cukšycy vešuno.

D / M1 - M2 / II / II

M1:- martf'ie se tom krovom.

M2:- iak' se beźe ćuź źać, to naịleṕi do Szpakowskiego na Muchówkę.

Konstrukcja pani + nazwisko w odniesieniu do autochtona może wyrażać szacunek lub przybierać zabarwienie ironiczne, wrogie i wskazywać na negatywny stosunek nadawcy do osoby tak określonej.

\section{D / K - M / III / III}

M: - poviinnaś śe lečyź u ńego.

$\mathrm{K}:$ - ia ieźżiunam s pańom Pawlikowską i ini śe tam fřysko unad'ne zgoiuno, a víżišs, a mine ńe.

\section{D / K - M / IV / IV}

K: - povinna mu kobita pumuc.

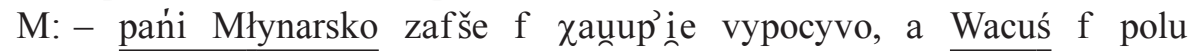
tyro.

\subsubsection{Przezwiska}

W celach perswazyjnych mogą być także wykorzystywane przezwiska, w których wyraża się emocjonalny stosunek (niechęć lub życzliwość) do pojedynczej osoby lub grupy ludzi. Zagadnienia dotyczące formalnej i znaczeniowej 
strony przezwisk zostały omówione w bogatej literaturze przedmiotu (zob. Popowska-Taborska 1960: 113-121; Gala 1975: 43-55).

\section{D / K - M - Bu / III / III / II}

$\mathrm{K}:-$ leć, može to g’iermańez unoțčyta?

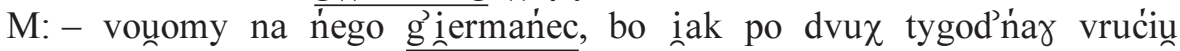
unot' ćotki z' Niemiec, to țša byuno brać tunumača, žeby śe dagadać.

Geramaniec to dyskredytujące przezwisko utworzone od nazwy narodowości, wyrażające ironiczny stosunek nadawcy do osoby i jej kompetencji językowych. Mężczyzna, wyjaśniając rozmówcy przyczynę jego nadania, podkreśla przekorną, żartobliwą motywację przezwiska.

\subsubsection{Nazwy narodowości}

Określone konotacje wartościujące mogą mieć również nazwy narodowości.

\section{D / K1 - K2 / III / IV}

K1:- Ruskie ḍla naz zue byli.

K2: - a pr’ iets' iedat'iel byun ńezuym čunov' iek' iem. on Ruskim byu, ale dobrym čuov'iek'iem. tag' i on vezvau samolod' i muvi ne puččce, bo pov'ieźli iei f sanator'ium, a tam mauno $\chi$ to dostańet's'ia. tu tylko pšyinežžainud z Moskwy, z Leningradu samyr učony źeći.

Na uwagę zasługują także wartościujące określenia osób ze względu na ich pochodzenie etniczne, określenie Ruski w szerszym kontekście wypowiedzi w odniesieniu do przedstawiciela władzy nie zawiera negatywnego ładunku emocjonalnego, ale ukazuje stereotypowy obraz Rosjan (por. punkt II.1.7. Stereotyp jako środek wartościowania).

\section{D / K1 - K2 / III / III}

K1:- tam pšeće ńe fšysk’ie byli Polakami i ženili'i śe z Ruskimi.

K2: - mamuśa i tatuź byli Polakami. tak, tak tam u nas, kouno nas fšysk'ie byli Polakami, fřysk'ie.

Nazwa Polacy w kontekście opisywanych realiów historyczno-politycznych (po 17 września 1939 r.) ma dla rozmówcy szczególne znaczenie wartościujące, jest poświadczeniem przynależności narodowej, którą w wyniku działań wojennych odebrano miejscowej ludności. Nadawca podkreśla polskość nie tylko najbliższych członków rodziny, ale także pozostałych mieszkańców wsi i okolicznych miejscowości.

D / K1 - K2 / III / IV

K1: - nevola se skuịnčyuna, to byưo lžy. fšysko.

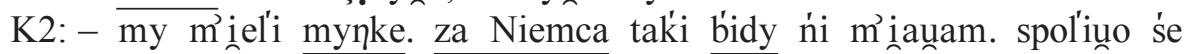


Określenie za Niemca nie tylko lokalizuje w czasie, ale ma także swój walor emocjonalny związany z trudnym okresem okupacji. Perswazyjny wymiar mają w wypowiedzi wyrazy związane ze sferą polityczno-społeczną i materialną: niewola, męka, bieda.

\subsubsection{Toponimy}

Autentyczne nazwy miejscowe: wsi, miast, państw, wskazując na bliższą lub dalszą okolicę, służą do lokalizacji zdarzeń w określonej przestrzeni. Funkcję tę J. Adamowski (1987: 7-22) określa jako funkcję organizacji przestrzeni. Przekaz perswazyjny rozmówca stara się umiejscowić w rzeczywistości, którą odbiorca bardzo dobrze zna i z którą się w jakiś sposób utożsamia, ponieważ ludzie mają z natury skłonność do identyfikacji z najbliższym otoczeniem. Konkretne miejsca, osadzone w wiejskich realiach, w środowisku dobrze znanym odbiorcy, są również istotnym elementem wartościującym przekaz, służą nie tylko lokalizacji opisywanych wydarzeń, ale także ich uwiarygodnieniu. Użyte nazwy wprowadzają rozmówcę w wydarzenie lub w historię związaną z określonym miejscem, tworząc nastrój bliskości, swojskości, a świat znany, ograniczony przestrzennie, nasycony realnymi szczegółami zwykle lepiej przemawia do wyobraźni odbiorcy.

\section{D / K1 - K2 / Bu / III / III / II}

K1:- my m’ieškali'iśmy Grodno, tutai bližei iešče do polsk'ie iei granicy. i my fčeśni fšysk’ie u Białegostoku byli.

K2: - roźice dostali zgode na vyiazd do Polski, to tata zaraz m'ne pšyie $\chi a u$ zabraź na vứnasnom proźbe.

Polska - ojczyzna jest wartością ponadindywidualną; w dążeniach niepodległościowych inne wartości są usuwane w cień, gdyż ojczyzna nabiera najwyższej wartości. Tematyce konotacji semantycznej nazw narodowości poświęcony jest artykuł K. Pisarkowej (1976a: 5-26).

\section{D / K1 < K2 / II / IV}

K1:- poznal'i śe i dobže lečylí.

K2: - iei tylko Matka Boska uzḍroviuna na Jasnej Górze. caụy čaz ležauna $f$ takím gorseće, a ia modliuna se na Jasnej Górze [...] i zd’iel'i my ten gorset cauny i pšestauno iei boleć.

Kobieta opowiada o niecodzienności zjawiska, którego doświadczyła, choć nie umie go racjonalnie wytłumaczyć i nazwać. Fakt nadnaturalnego wyleczenia córki przypisuje wstawiennictwu Matki Boskiej. Dla chrześcijan pozytywna wartość łączy się z wymienionymi nazwami: Matka Boska, Jasna Góra.

\section{D / M1 - M2 / II / II}

M1:- martf'ie se tom krovom.

M2:- inak’ se beǰe ćuź j́ać, to naịleṕi do Szpakowskiego na Muchówkę. 


\subsubsection{Przekształcenia nazw wlasnych}

W analizowanych tekstach przekształcenia dotyczą form imion i nazwisk, innowacje obejmują także sposoby tworzenia nazw przestrzennych. Asocjacje semantyczne związane z nazwami własnymi są bardzo czytelne, w ich wyniku powstaje szczególnego rodzaju ekspresja. Każda celowa modyfikacja posiada określoną moc wartościującą i jest językowym sposobem służącym skupieniu uwagi odbiorcy na obiekcie, któremu nadawca przypisuje wyraźną ocenę. Negatywne określenia, wykorzystujące zmianę nazw własnych, były przedmiotem analiz językowych (zob. Kochan 1994: 85-89; Kudra 2001; Burska-Ratajczyk 2010a: 211-224).

\section{D / K - M / III / III}

$\mathrm{K}:-$ iešče se pogoźita $\mathrm{z}$ Grażyną.

M: - po tym, co zrobiuna Gadzinka, ne bej́e zgody.

Określenie Gadzinka jest ironicznym przekształceniem imienia Grażyna, na które zostały przeniesione negatywne konotacje związane $\mathrm{z}$ wyrazem pospolitym, por. gadzina 'gad, żmija, wąż, przen. osoba nikczemna, fałszywa, zdradziecka, podstępna'. Imię w sugestywny sposób uwypukla naganny sposób postępowania osoby.

W komunikacji mieszkańców wsi oprócz imion ekspresja jako czynnik nazwotwórczy obejmuje także nazwiska. Ich modyfikacje służą wyrażeniu sympatii lub antypatii względem ich nosicieli.

\section{D / K - M / III / III}

$\mathrm{K}:-$ spokoiñe ii vytunumač.

M: - z' nom ńi ma rozmovy. ununa každego obgado. to ne ies pańi Czekalska tylko Szczekalska.

Parodystyczna modyfikacja autentycznego nazwiska Czekalska jest dezawuującą etykietą brzmieniową, wskazującą, że osoba lubi plotkować, por. rzecz. szczekacz posp. 'ktoś, kto mówi dużo, głośno, w sposób zaczepny, oczernia kogoś'.

\section{D / K1 - K2 / III / III}

K1: - byuny jećoḱi. daunam’ im pare grošy.

K2: - oi ! Badosia, Badosia! pomyś ty o sobine.

Świadomym zabiegiem jest zmiana formalna nazwiska Badowska. Hipokorystyczna struktura wyraża pozytywny emocjonalny stosunek do osoby, natomiast nadrzędną funkcją kontekstu wypowiedzeniowego jest przestroga, wskazująca, że kobieta jest zbyt szczera w stosunku do własnych dzieci. 


\subsubsection{Nazwy pseudoonomastyczne}

Ciekawymi formami gwarowymi, służącymi perswazji, są fikcyjne nazwy własne (osobowe i przestrzenne) o charakterze ekspresywnym. Użycie w funkcji identyfikacyjnej wyrazu pospolitego, któremu nadaje się status nazwy własnej, ma istotny walor stylistyczny. Nazwy takie mają charakter prześmiewczej, złośliwej aluzji, polegającej na mniejszym lub większym podobieństwie do nazwy autentycznej, tworzone są na wzór rzeczywistych imion własnych, a ich uprawdopodobnieniu służą typowe modele i sufiksy nazwotwórcze. O wzajemnym oddziaływaniu słowotwórczym nazw własnych i wyrazów pospolitych pisali Smoczyński (1962: 61-82) i Hrabec (1968: 284-332). Problematyce aluzyjności nazw własnych w tekstach literackich poświęcone są również artykuły (zob. Kosyl 1988: 39-50, Sarnowska-Giefing 1993: 101-106).

W badanym materiale występują iluzoryczne nazwy własne o dominującej funkcji semantycznej, tzw. nazwy mówiące spotykane w literaturze (zob. Sarnowska-Giefing 1993: 101-106). Przypominają one nazewnictwo typowe dla epoki oświecenia z upodobaniem do nazw satyryczno-groteskowych, których funkcja polega na typizacji charakterologicznej bohaterów i wskazaniu pewnych cech zarówno potępianych, jak i postulowanych.

Aluzyjność nazw zastosowanych w tekstach gwarowych służy działaniom ekspresywnym, a zarazem wartościującym, utrwala w formie językowej obraz pewnej rzeczywistości, odpowiednio ją oceniając. Użyte w wypowiedziach nazwy wywołują określone skojarzenia i są nośnikami ekspresji, która budzi emocje u odbiorcy, zwiększając perswazyjne oddziaływanie przekazu.

\section{D / K1 - K2 / III / III}

K1:- muviuua Halina, že poiexauny do Ameryki.

K2: - ty ńe v’i ieš f to, co ći pov́i Halincia Głupkowa z Głodowej Wólki.

Nadawca wyraźnie neguje prawdziwość informacji podanej przez wymienianą osobę. Podkreśleniu braku wiarygodności kobiety służą, oprócz użytej formy trybu rozkazującego, także zastosowane nazwy własne, będące swego rodzaju dyskredytującą etykietką językową. Nazwisko i miejscowość mają wyraźny ironiczno-sarkastyczny wydźwięk. Ciekawy jest kontrast, który zachodzi między hipokorystyczną formą imienia (wartościowaną pozytywnie), por. Halincia, a nacechowanym ujemnie i kompromitującym pseudonazwiskiem Glupkowa, przyrostek -owa tworzy m.in. nazwiska żon. Zdeprecjonowaniu służy również nazwa miejscowa, do autentycznego toponimu Wólka, będącego miejscem pochodzenia osoby, dodany został wyraz Glodowa, por. rzecz. głód. Nazwa Wólka nawiązuje do nazw miejscowości lokowanych kiedyś na prawie polskim, w których zasadźca otrzymywał na kilka lat wolę (zwolnienie) od podatków, w zamian za zorganizowanie warunków do życia w danej miejscowości. Natomiast świadoma modyfikacja Głodowa Wólka ma charakter alegoryczny, nawiązuje do przysłowiowej biednej, wręcz głodowej wólki. 


\section{$\mathbf{D} / \mathbf{K}-\mathbf{M} / \mathbf{I I I} / \mathbf{I V}$}

K: - zafše śe možna uod lużi čegoź naunučyć.

M: - unun’ m’ne bej́e unučyź roboty, Leżuchowski z Pierzynowic.

Semantyka nazwy Leżuchowski, por. gw. pogard. leżuch - 'ten, który lubi leżeć; leń, nierób, bumelant', w sposób metaforyczny piętnuje postawę, nieakceptowaną w kulturze ludowej, która w połączeniu z pseudonazwą miejscową, por. Pierzynowice, ulega groteskowej hiperbolizacji.

\section{D / M1 - M2 / III / III}

M1:- m’ne se tam podoba, ćíša, spokui.

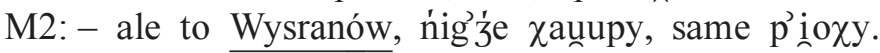

Ironiczno-dezaprobujący wydźwięk ma nazwa Wysranów, która wpleciona w kontekst wypowiedzi wskazuje na miejscowość odludną, usytuowaną z dala cywilizacji, a także zacofaną i zaniedbaną.

Obecność powyższych formacji w mowie mieszkańców wsi świadczy o kreatywności językowej i specyficznym poczuciu humoru (zob. Skorupka 1949: 21-26; Buttler 1974: 118-119) użytkowników polszczyzny ludowej. Fikcyjne nazwy służą waloryzacji znaczeniowej i przydają wypowiedziom swoistej pikanterii.

\section{Przekształcenia semantyczne w tekstach gwarowych a mechanizm przekonywania i nakłaniania}

Nośność perswazyjną tekstu wzmacniają środki stylistyczne. Już retoryka starożytna doceniała ich wpływ na sugestywność wypowiedzi. Przedstawiają one treść w sposób obrazowy, zapewniają wypowiedzi ozdobność, wzniosłość, a także zwiększają jej oddziaływanie na odbiorcę.

Szczególne znaczenie wśród środków stylistycznych, decydujących o perswazyjności przekazu, ma metaforyka, która dodaje wypowiedzi uroku, czyni ją bardziej atrakcyjną, a przede wszystkim ułatwia realizację założonego przez nadawcę celu. Wyrażenia metaforyczne nie nazywają opisywanych zjawisk wprost i - jak pisze T. Dobrzyńska (1994: 140) - „stanowią wygodny środek perswazji”. Trafny dobór wyrazów, umieszczenie ich w odpowiednim otoczeniu składniowym wpływa na charakter i semantykę wypowiedzi.

W badanym materiale językowym wyróżniono perswazyjne środki stylistyczne, w tym najbardziej charakterystyczne: epitet, oksymoron, metaforę, porównanie oraz ironię. 


\subsection{Epitet}

Nośnikami perswazji mogą być epitety uważane za środek potęgujący plastyczność tekstu. Retoryka zalicza epitety do najważniejszych figur słownych przy ich użyciu wypełnia się bowiem prezentowany wycinek rzeczywistości detalami, a ich nagromadzenie ułatwia opis.

W ujęciu gramatyki, poetyki i retoryki epitet jest określeniem rzeczownika, modyfikującym jego znaczenie, pełni wobec rzeczownika funkcję określającą, wpływa na znaczenie wyrazu, do którego się odnosi, może także wyrażać stosunek uczuciowy mówiącego do danego przedmiotu lub zjawiska (zob. Kurkowska, Skorupka 2001: 103; Kopaliński 2007: 153), niekiedy obie te funkcje są zespolone (zob. Krzyżanowski 1984: 244). Epitet może być wyrażony różnymi częściami mowy: epitet przymiotnikowy, rzeczownikowy, imiestowowy; ponadto epitet złożony - utworzony z połączenia dwu wyrazów; ze względu na stopień zespolenia wyrazów wyróżnia się: epitet staty - skonwencjonalizowany, który może występować w znaczeniu konkretnym lub metaforycznym (zob. Kurkowska, Skorupka 2001: 203), epitet metaforyczny - animizujący i antropomorfizujący oraz metonimiczny; a także epitet sprzeczny (oksymoron) (zob. Okopień-Sławińska 1984: 244). Wyodrębnia się również epitety złożone - przymiotniki powstałe z połączenia dwóch członów (najczęściej odprzymiotnikowego i odrzeczownikowego). Epitet jako środek stylistyczny pełni następujące funkcje: estetyczna, równie ważną - semantyczna, ponieważ uzupełnia nazwę przedmiotu przez określenie jego właściwości, indywidualizująca (określa te cechy, które pozwalają na wyodrębnienie ich od innych desygnatów danej kategorii) i obrazotwórczq (Miodońska-Brookes, Kulawik, Tatara 1980: 324). Wskazując na cechę desygnatu, epitet nie musi rozszerzać bądź zawężać zakresu pojęcia, może natomiast wzmacniać plastykę i obrazowość, a także zwiększać zabarwienie emocjonalne (Kurkowska, Skorupka 2001: 203-204) oraz wyrażać stosunek nadawcy do przedmiotu wypowiedzi.

Duże znaczenie perswazyjne mają epitety wartościujace, w których widać skłonność do hiperbolizacji, do popadania w przesadę oraz epitety metaforyczne i semantyczne skupione wokół pola wyrazów określających zmysły, głównie zaś zmysł wzroku. Epitety chętnie wykorzystywane są jako element ironii.

W analizowanym materiale określony środek stylistyczny występuje często, konstruuje niemal każdą wypowiedź. Oczywiście rodzaj określenia uzależniony jest od celu, jaki przekaz ma spełnić. Istotną rolę perswazyjną odgrywa nagromadzenie, które ma ułatwić charakterystykę zewnętrzną i wewnętrzną osoby, opis przedmiotu, zjawiska itp. - przy jednej podstawie występuje wtedy więcej niż jeden określnik. Większość pojawiających się w wyliczeniach epitetów ma postać przymiotnikową lub imiesłowową. Niekiedy funkcję epitetu spełnia frazeologizm, ogólne stwierdzenie konkretyzowane jest w dalszej części wypowiedzi przez następujące po nim przymiotniki i imiesłowy. 
Przekaz jest silniejszy, jego perswazyjna nośność wzrasta, jeśli gromadzi się w bliskim sąsiedztwie epitety podobne znaczeniowo. W tekstach gwarowych często pojawiają się epitety bezpośrednie - takie, które wyrażają właściwość, cechę bez posługiwania się przenośnią, kojarzeniem z innym przedmiotem, sprzyjają one obrazowości wypowiadanych fraz. Szczególne znaczenie mają epitety superlatywne wskazujące na najwyższy stopień cechy charakteryzującej dany desygnat. Zdarza się, że przy jednej podstawie występują obok siebie trzy określniki - epitety potrójne, stanowiące tzw. symetryczną konstrukcję.

\section{D / K - M / IV/ IV}

K: - taki ưadny j́ećocyna. gựufka kštauntno, vunoski corne, j́urki

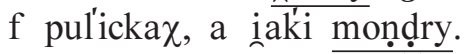

M: - sam ie, sam śpi, same mu vưosy na gunov’ ie rosnom.

Opis dziecka w wypowiedzi kobiety dzięki zastosowanym epitetom jest szczegółowy, ponieważ eksponuje walory estetyczne, por. przymiotniki: ładny, ksztattna, czarne, wyrażenie: dziurki w policzkach oraz intelektualne - mądry. Rozmówca celnie i dowcipnie podważa zachwyt kobiety, dostosowuje się do narzuconej przez nią konwencji, na pozór zgadza się z opinią, śmieszność tkwi w przedstawionych przez niego argumentach, które zupełnie odwracają sens wypowiedzi.

\section{D / M1 - M2 / III / III}

M1: - caukkim bida iźe na luži. v m’ieśce to roboty níiaḱi ńi mo. na f's'si to iešče.

M2: - a Adaś f cukrov'ńi țšyźeśći lat pšerobiuu. zaras po voinsku munody

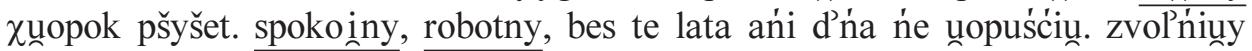
i kunec. a g’źe unun tero robote zunap̉ie? a žyć țšeba.

Drugi z mężczyzn przekonuje rozmówcę, że trudna sytuacja dotyka zarówno ludzi w mieście, jak i na wsi. Odwołuje się do przykładu konkretnej osoby znanej w środowisku, podkreśla jej pracowitość i obowiązkowość, por. przymiotniki: młody, spokojny, robotny, istotne znaczenie mają w wypowiedzi także dane liczbowe.

\section{D / K - M / III / III}

$\mathrm{K}:-$ pov́ińin cuś posażić.

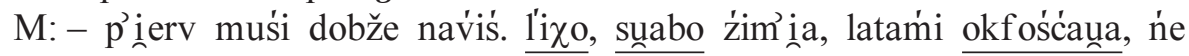
urożi.

Mężczyzna podkreśla, że marna, nieurodzajna ziemia, por. licha, słaba, ochwaściała 'porośnięta chwastami', musi najpierw zostać odpowiednio użyźniona, by mogła wydać plon. 


\subsubsection{Epitet sprzeczny}

Oksymoron określany jest jako epitet sprzeczny, ponieważ obejmuje dwa znaczeniowo przeciwstawne wyrazy (najczęściej rzeczownik i jego określenie), które zestawione ze sobą wydobywają nowy, metaforyczny sens. W analizowanych tekstach pojawiły się nietypowe i zaskakujące połączenia wyrazów, niekonwencjonalne ze względu na wykluczające się znaczenia, zbliżone do oksymoronów. W. Chlebda (1984: 135) nazywa je oksymoronami rzekomymi, czyli takimi, które wyrażają sprzeczność pozorną.

\section{D / M1 - M2 / III / III}

M1: - bapka i tag ńe sứy̌y.

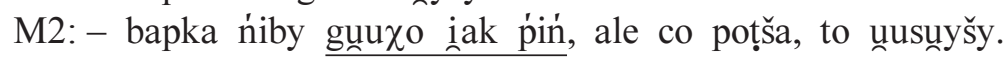

Porównanie głucha jak pień ‘zupełnie głucha' wyklucza możliwość percepcji słuchowej.
D / M - K / III / III
M: - luźe ruz’ńe o ńim muv'iom.
$\mathrm{K}:-$ a ía muv'ie, že dobry zư⿱宀

Określenie dobry złodziej i łobuz nadaje wypowiedzi znamiona ironii.

\section{2. Środki metaforyczne o funkcji perswazyjnej}

Metafora to niezwykle ciekawe zjawisko tekstowo-stylistyczne, które polega na tym, że zespół wyrazów zyskuje odmienne znaczenie od tego, jakie wynikałoby ze znaczeń poszczególnych wyrazów, jest nowym zestawieniem semantycznym, które nie da się odtworzyć przy użyciu innych wyrazów. M. Korolko (1998: 106) uważa, że jest: „korzystną zmianą znaczenia właściwego na inne, dokonaną w słowie lub wyrażeniu". Metafory stosowane są dla oryginalnego, obrazowego przedstawienia rzeczywistości, służą uwypukleniu pewnych aspektów opisywanej rzeczywistości.

Metafora, uważana za jeden z najbardziej perswazyjnych środków stylistycznych (zob. Bańko 2006: 60), wywołujących określone uczucia i kierujących uwagę odbiorcy na treść, służy kształtowaniu postaw i opinii oraz przekonaniu odbiorcy do określonego stanowiska. Czyni to w sposób prosty i skuteczny ze względu swoją skrótowość i dostępność, ponieważ, jak dowodzi T. Dobrzyńska (1995: 202), wykorzystuje ,tworzywo pojęciowe dobrze zakorzenione w osobistym doświadczeniu przeciętnego odbiorcy". Badaczka (1995: 203) uważa, że przenośnia jest doskonałym środkiem perswazji, gdyż „odsłania nie tylko pewne oblicze rzeczy lub zjawiska, ale z reguły ukazuje swój przedmiot odniesienia w pewnej perspektywie aksjologicznej, narzucając tym samym odbiorcy określo- 
ną perspektywę wartościującą". I. Kamińska-Szmaj (1994: 77) wskazuje, że metafora pozwala ukryć pozytywny lub negatywny ładunek uczuć związany z danym desygnatem poprzez przeniesienie emocji łączonych z określoną nazwą na inne zjawiska, osoby, pojęcia.

Zastosowanie tej figury stylistycznej nie ogranicza się do poezji, w której pełni przede wszystkim funkcję estetyczną (zob. Krzyżanowski 1984: 656-657), wykorzystywana jest w prozie, obecna w publicystyce (zob. Sławek 2005: 79-91), w przemówieniach, w reklamie, a także w stylu naukowym. Badacze (zob. Bańko 2002: 9) wskazują, że wiele metafor występuje również w polszczyźnie potocznej, ponieważ ,[...] metafory, są nie tylko poetyckim ozdobnikiem, figurą stylistyczną, lecz narzędziem poznania i postrzegania świata, myślenia o nim i działania w nim", służą do kształtowania postaw, opinii, do przekonania odbiorcy do określonego stanowiska. Czynią to w sposób prosty i skuteczny ze względu na swoją skrótowość i dostępność, ponieważ wykorzystują „tworzywo pojęciowe dobrze zakorzenione w osobistym doświadczeniu przeciętnego odbiorcy" (Dobrzyńska 1995: 202). Przenośnia wydatnie wzmacnia siłę perswazji, ponieważ ułatwia swobodne sterowanie poszczególnymi znaczeniami wyrazów, kształtując nacechowanie emocjonalne i wartościujące wypowiedzi. Prawidłowo skonstruowana metafora umożliwia przekazanie informacji lub osiągnięcie określonego rezultatu dużo szybciej i skuteczniej niż tzw. obrazowe linearne objaśnienie. Istotne dla metafory są zmiany walencyjne, czyli nietypowe połączenia wyrazowe i nieoczekiwane ich zestawienia. K. Michalewski (1993b: 121) podkreśla, że: „Metaforyczną wartość pojedynczych wyrazów postrzega odbiorca tekstu wtedy, gdy znane mu wcześniej (jako ciągi brzmieniowe) odnoszą się do nowych odmiennych pojęć i zakresów. Identyczność formalna ciągów brzmieniowych sugeruje ich genetyczną jedność i nakłania odbiorcę do kojarzenia także treści i zakresów, do doszukiwania się związków między nimi. Rodzaje rzeczywistych lub domniemanych związków stanowią podstawę klasyfikacji metafor".

Ponieważ wyrażenia metaforyczne zmieniają sposób postrzegania świata, ukazując rzeczywistość w sposób uproszczony i odbierając poszczególnym wyrazom ich pierwotne znaczenie, częściowo lub całkowicie (zob. Miodońska-Brookes, Kulawik, Tatara 1980: 332), są często wykorzystywane jako wygodny środek perswazji w dyskursie politycznym czy reklamowym. I. Kamińska-Szmaj (1994: 77) uważa, że za ich pomocą można w łatwy sposób ukształtować postawę odbiorcy, bowiem ,subiektywny dobór metafor przesądza o sposobie oglądu, wydobywa jedne cechy zjawiska, przesłaniając inne".

Metafory dzieli się na poetyckie i potoczne, zwane też językowymi, różni je stopień konwencjonalności (zob. Wróblewski 1998). Metafory potoczne są wielokrotnie powtarzanymi zestawieniami słownymi, których znaczenie jest powszechnie rozumiane przez użytkowników języka, ,[...] bez konieczności uzasadnień i odwołań do niemetaforycznych znaczeń składających się na nie wyrazów" (Sławiński 1988: 274). 
Szczególną wagę do badania metafor przywiązują kognitywiści, a stworzona przez nich typologia semantyczna mówi, że: „każdy człowiek posiada naturalną zdolność do pojmowania całych klas zjawisk w kategoriach pewnych pojęć" (zob. Sławek 2007: 147). Kognitywizm zakłada odwołanie się przy badaniu języka do świadomości użytkowników, do kultury, w której żyją.

Metafora potoczna, która została wnikliwie zanalizowana przez G. Lakoffa i M. Johnsona (1988), jest powszechna w życiu codziennym i stanowi istotny element wielu komunikatów językowych. Jest łatwa w odbiorze, ponieważ wykorzystuje pojęcia dobrze znane przeciętnemu odbiorcy, przez co wpływa na dostępność poznania, stwarza plastyczny, bardziej przyswajalny dla człowieka obraz rzeczywistości. Funkcja metafory potocznej jest podobna do stosowanej w języku polityki (zob. Maćkiewicz 1995: 229-239; Ożóg 2002: 21-24) czy w reklamie, ponieważ także narzuca odbiorcy własny punkt widzenia. T. Dobrzyńska (1995: 202), która badała język współczesnej polityki, stwierdza, że figura jest bardzo sugestywnym środkiem komunikacji, służącym wyjaśnianiu złożonych zjawisk społecznych i politycznych: „Metafora, odwołując się do dobrze przyswojonych zespołów pojęciowych, modeluje za ich pomocą zjawiska będące przedmiotem wypowiedzi. Naświetla w ten sposób pewne aspekty analizowanych zjawisk. Ma to niewątpliwie walor poznawczy, jednym rzutem odsłania bowiem cały kompleks cech i uwikłań przedmiotu, których ujawnienie wymagałoby długiego procesu analitycznego".

Właściwe zrozumienie metafory umożliwia kontekst oraz pewien zasób wiedzy o rzeczywistości pozajęzykowej, której elementy są przedmiotem kojarzenia, ponieważ jak podkreśla W. Pisarek (2006: 119) - jest to wyrażenie ,[...] w obrębie którego dochodzi do zamiany lub wzajemnej wyraźnej modyfikacji znaczeń słów", co prowadzi do nowego odczytania sensu takiego połączenia.

W analizowanym materiale metafory przydatne są szczególnie wówczas, gdy zachodzi potrzeba opisu pojęć abstrakcyjnych. Przenośnia narzuca się uwadze odbiorcy, dominuje w przestrzeni leksykalnej tekstu, koncentrując uwagę słuchacza nie na treści, a na formie, w jakiej została przedstawiona. Metafora ma za zadanie skłonić odbiorcę do zastanowienia się nad przesłaniem wypowiedzi i do wydobycia z przekazu jego głębi. Definiując metaforę (zob. Urbańczyk 1991: 199), często określa się ją jako skrócone porównanie (bez użycia spójników) oparte na podobieństwie przedmiotów lub pojęć, gdyż u jej źródła zawsze leży jakieś skojarzenie.

Kreowanie świata przez metaforyzację w badanych tekstach jest ciekawe i zróżnicowane, ponieważ metafora jest konstrukcją opartą na skrócie, jak wskazuje K. Szymanek (2001: 197), umożliwia: „niekonwencjonalne, zaskakujące, i przez to przyciągające uwagę, przedstawienie myśli, daje możliwość odwołania się do doświadczeń odbiorcy i jego podstawowej wiedzy o świecie zewnętrznym, jest przez to doskonałym środkiem zwartego, skondensowanego, a przy tym czytelnego i wyrazistego przedstawienia treści: idei, koncepcji, haseł itp.”. 


\subsection{Struktury metaforyczne - klasyfikacja semantyczna}

Szczególny środek językowego oddziaływania stanowią w badanych tekstach metafory, które są ważnym elementem budującym sugestywność przekazu. Zastosowane określenia metaforyczne są mocno osadzone w ludowej rzeczywistości i kulturze, odnoszą się wprost do elementów wiejskiego otoczenia, są wyraziste, konkretne, a mimo to oryginalne, nadają wypowiedzi znamiona swoistej ekspresji.

Językoznawcy podkreślają zależność języka od kultury i warunków życia. R. Grzegorczykowa (2001: 162) pisze: „warunki kulturowo-społeczne wpływają na kształt języka, a następnie język determinuje sposób ujmowania świata". Metafory ludowe są barwnym sposobem opisu rzeczywistości, służą konkretyzacji trudnych pojęć (nazywają skomplikowane działania intelektualne) lub dosadnej, często karykaturalnej charakterystyce ludzi, zjawisk, przedmiotów. Czasem bywają wykorzystywane do wywoływania określonych skojarzeń: pozytywnych lub negatywnych, poważnych lub lekkich, wesołych lub smutnych. Codzienne i zwykłe z pozoru wyrazy użyte w nowych kontekstach otrzymują nową wartość wyobrażeniową i nabierają niecodziennego znaczenia, skupiając na sobie uwagę odbiorcy. Określenia przenośne czynią tekst ciekawym i pozwalają z innej perspektywy spojrzeć na omawiane zagadnienie.

\section{Metafora witalności}

\section{D / M1 - M2 / III / III}

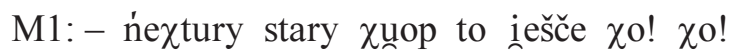

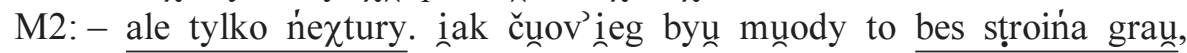
a tero to se goźine sțroi, a gro pińź minut.

Mężczyzna niezupełnie zgadza się z przedmówcą. Utrzymane w żartobliwej konwencji innowacyjne zastosowanie wyrazów: stroić się, grać, kojarzonych z dziedziną sztuki, nadaje wypowiedzi swoisty wydźwięk i wpływa na oryginalność wypowiedzi.

D. Wężowicz-Ziółkowska (1991: 149), która badała wzory miłości wieśniaczej w polskiej poezji ludowej, podkreśla, że: „Nie ma w życiu ludu dziedziny, która nie mogłaby stanowić źródła skojarzeń i odniesień seksualnych”.

Metafora etapów życia biologicznego człowieka - metafora starości

\section{D / K1 - K2 / III / IV}

K1: - ńe dbaž o śeb’ie. pev'ńe ńe z’iež iak poțšeba.

K2: - iem, iem. čunov'ieg na staroś sxne, kurčy śe.

Druga z kobiet, opisując zmianę wyglądu spowodowaną procesem starzenia, odwołuje się do bardzo sugestywnych doznań zmysłowych, wykorzystuje czasow- 
niki: schnąć - pot. 'gwałtownie tracić na wadze, chudnąć, mizernieć', kurczyć się tu pod względem wagi, przen. 'zmniejszać się'.

Jak dowodzi E. Lewandowska-Tarasiuk (2005: 55): „Obrazowość opisu czy relacji może wyrazić się użyciem słownictwa, odnoszącego się do zmysłów - doznań słuchowych, wzrokowych, smakowych, węchowych, dotykowych czy kinestetycznych”, ponieważ obrazowanie „odnoszące się do doznań zmysłowych zwiększa perswazyjną siłę komunikatów”.

\section{Metafora śmierci}

\section{D / K1 - K2 / IV / IV}

K1: - fšyski $\chi$ čeko iednaki kuńec.

K2: - pev'ńe, ale nigg ne vii, k’inedy pšyỉ̧e iego čas. țša muṇḍže žyć.

Metafora może także być nazwą zastępczą - eufemizmem, por. rzeczownik koniec, wyrażenie przyjdzie czas oznaczające śmierć. Wypowiedź drugiej kobiety zachęca i nakłania do mądrego życia, por. stwierdzenie o charakterze dyrektywnym - trzeba madrze żyć.

Metaforyka nadaje ludowym wypowiedziom cech obrazowości. Ciekawe efekty perswazyjne wprowadzają metaforyczne porównania, które mają wyrazić treść w sposób przystępny dla odbiorcy.

\section{Metafora opieki}

\section{D / K1 - K2 / III / IV}

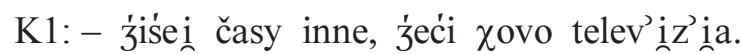

K2: - ununa to ḍržy o źećoki. beźe kurcokamy.

Metafora jest bardzo skuteczną metodą wartościowania, wskazuje rozmówcy określoną ocenę. Porównanie chodzić za kimś jak kura za kurczakami w sposób obrazowy kreśli niezwykle pozytywny wizerunek matki - osoby oddanej dzieciom, troskliwej, czułej.

\section{Metafora życia}

\section{D / M - K / III / III}

M: - unuń ne pov́inin tag zrobić!

$\mathrm{K}:-$ pov́ińin, ne povínin. iak $\chi$ ceš koguś suńżić, to vzui iego buty i pšeỉ í iego ḍroge.

Kategoryczne stwierdzenie mężczyzny rozmówczyni podaje w wątpliwość. Życie ludzkie utożsamia z droga, którą człowiek ma do przejścia. Kobieta dowodzi, że nie należy wypowiadać się o postępowaniu innych ludzi w sposób zdecydowany i stanowczy, ponieważ trzeba doświadczyć tego, co oni, by właściwie 
pojmować i interpretować cudze czyny. Formy trybu rozkazującego czasowników: wzuj, przejdź wskazują, że należy postawić się w czyimś położeniu, wczuwać się w czyjąś sytuację.

Jak wykazują badania D. Piekarczyk (1999: 103): „Pojęcie ŚWIAT i zbliżone do niego ŻYCIE, RZECZYWISTOŚĆ należą do podstawowych w systemie pojęciowym człowieka. Ich zakres jest jednak tak szeroki, że umykają wprost wszelkim próbom nazwania i opisania. Są zbyt abstrakcyjne, a ich granice niewyraźne. Rzeczywistość jest zmienna, dynamiczna i nieskończenie różnorodna. Aby człowiek mógł ją ogarnąć, musi zredukować jej złożoność, narzucić pewne ograniczenia. Określanie i kategoryzacja są konieczne, by pojęcia sprostały wymogom codziennej komunikacji. Dążenie do tego to naturalna potrzeba człowieka. Głównym narzędziem porządkowania staje się język, a jednym ze sposobów metafory, które pozwalają uchwycić świat w kategoriach bardziej konkretnych".

Metafora pracy

\section{D / K - M / III / III}

$\mathrm{K}:-$ zrobiš to na iuțro.

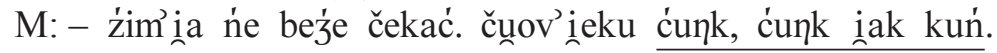

Poprzez zastosowanie porównania ze zreduplikowanym czasownikiem użytym w trybie rozkazującym rozmówca nadaje wypowiedzi znamiona hiperbolizacji. Podkreśla, że na wsi trzeba ciężko pracować, bo efekty przynosi jedynie codzienne, uczciwe i sumienne wykonywanie obowiązków.

A. Batko (2005: 115) uważa, że: „Metafora jest dobrze dobrana wtedy, kiedy doskonale pasuje do sposobu, w jaki postrzega świat osoba, na którą wywieramy wpływ". Badacz wskazuje, że metafora nie zawsze musi być rozbudowana i długa, aby wywołała zamierzony rezultat. Czasami wystarczy tylko zbudowane z zaledwie kilku słów porównanie, a efekty mogą być naprawdę imponujące. Wykorzystując ten wzorzec perswazji, konieczna jest jednak głęboka znajomość sposobu, w jaki postrzega świat człowiek, na którego zachowanie chcemy wpłynąć.

\section{Metafora klopotów}

\section{D / K1 - K2 / III / IV}

$\mathrm{K} 1:-$ iźe ku dobremu.

K2:-g'śe tam. cunek' śe vygmyrou z' iedny źury, a fpod v dirugom.

Metafora dolu i ekspresywny czasownik wygmyrać się mają ewokować u odbiorcy powtarzające się niekorzystne zdarzenia i niemożliwość zmiany złego losu. 
Metafora niegospodarności

D / M1 - M2 / III / III

M1: - $\chi$ com, žeby im otṕisać.

M2: - ne otṕisui, iešče počekei. pamintož Gienia. cauny mainonteg

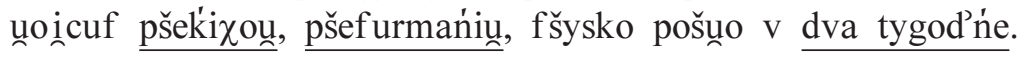

Relacjonując wydarzenie, drugi z rozmówców wykorzystuje ciekawy sposób obrazowania, por. metaforyczne czasowniki: przekichać, przefurmanić, które na poziomie interpretacji wnoszą informację, że osoba roztrwoniła majątek. Dzięki ich zastosowaniu wzmocnieniu ulega stopień ekspresji i wyrazistości wypowiedzi. Czasownik przekichać, por. kichać na co - 'lekceważyć sobie co', dynamizuje opis, drugi - przefurmanić - odwołuje się do stereotypu furman - 'człowiek nadużywający alkoholu i brzydkich słów'.

I. Kraśnicka-Wilk (2001: 343) pisze: „Widzenie abstrakcyjnej rzeczywistości w kategoriach rzeczywistości materialnej jest jej metaforyzacją, dokonywaną w sposób naturalny w umyśle człowieka. Metafora jest więc nie tylko figurą retoryczną czy tropem poetyckim, ale dzięki kognitywnemu spojrzeniu na nią powszechną figurą myśli. [...] Metafora jest więc obecna nie tylko w języku, ale przede wszystkim w systemie konceptualnym człowieka, stając się podstawowym środkiem opisu i zrozumienia rzeczywistości”.

\subsection{Animizacja i antropomorfizacja}

Animizacja oraz antropomorfizacja to odmiany metafory. Animizacja polega na nadawaniu przedmiotom nieożywionym, zjawiskom przyrody, pojęciom abstrakcyjnym cech istot żywych (zob. Zdunkiewicz-Jedynak 2008), antropomorfizacja zaś to przypisywanie zjawiskom natury, tworom nieożywionym, pojęciom abstrakcyjnym, zwierzętom, cech psychicznych i fizycznych właściwych człowiekowi. Są to zjawiska stylistyczne o bardzo szerokim zasięgu we wszystkich rodzajach wypowiedzi, wprowadzają ruch, dynamikę, ponadto są sposobem nacechowania opisu (zob. Dominowa, Dominow 2001: 13).

Żeby skutecznie zjednywać, trzeba umieć przekonująco przekazać swoje stanowisko, zilustrować je odpowiednim przykładem, toteż ożywiona rzecz wydaje się jedną z podstawowych kategorii ludowego myślenia. W tekstach gwarowych ten rodzaj metafory jest stosowany przede wszystkim w celu sugestywnego przedstawienia pojęć zbyt odległych poznawczo, a wszechstronność i częstość odwołań świadczy o potrzebie uczynienia przekazu bardziej przystępnym. Użycie do charakterystyki pojęć abstrakcyjnych wyrazów konkretnych, powoduje, że stają się one bliższe odbiorcy, ponadto zabieg taki bez wątpienia służy zwiększeniu obrazowości, jasności i konkretności wypowiedzi. 
D / M - K / III / III

M: - i ešče mam sporo času.

$\mathrm{K}:-$ tag žyće pšeleći, navet' se ne unobeinžys.

D / M - K / III / III zrobi.

M: - taki zaf̌se byư vesouny, požartovoun. ńik’ se ne spoźivoun, že tag

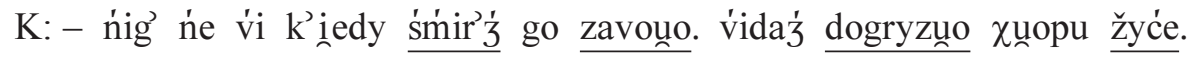

D / M1 - M2 / III / III

M1: - pšeće unun’ ći̧ško robi.

M2: - bo śe dobže čuie. ne v’iežy v lekažy. myślí, že se z unapskuf

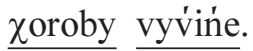

\section{$\mathbf{D} / \mathbf{D z}<\mathbf{K} / \mathbf{I} / \mathbf{I V}$}

Dz: - bap'ću ia íuž ne moge.

$\mathrm{K}:-$ muśiš, bo iak cunov'ieg ne ini, skunt śiuna pšyinże?

\subsection{Peryfraza}

Peryfraza (zob. Bańko 2002) to metafora polegająca na zastąpieniu nazwy danego obiektu rozbudowanym opisem lub charakterystyką osoby, rzeczy, zjawiska, miejsca lub pojęcia. Wprowadza do tekstu element obrazowości, służy wartościowaniu i może być ciekawym środkiem wyrażania emocji. Zastąpienie nazwy przez bardziej lub mniej rozbudowany opis jest próbą odbanalniania słownictwa i służy zwiększeniu pojemności znaczeniowej wypowiadanych słów. Badacze (Skorupka, Kurkowska 2001: 94) uważają, że używając peryfrazy, nadawca stara się ,narzucić nam nową, własną, indywidualną interpretację znanej już rzeczywistości, pokazać jakąś rzecz, zjawisko, z innej, nowej strony, nakierować niejako nasze spojrzenie pod określonym kątem". Ważne jest to, by odbiorca zauważył formę językową, odebrał i zrozumiał właściwie. M. Bańko (2002: 5) podkreśla, że peryfrazy stosowane są ze względów „ornamentacyjnych lub eufemizacyjnych”, a więc dla ozdobienia lub złagodzenia wypowiedzi”.

Peryfraza jako środek wartościowania była przedmiotem badań w języku propagandy marksistowskiej (zob. Głowiński 1990: 31-37), ten rodzaj metafory wykorzystuje się jako zamierzony sposób utajenia znaczenia bezpośredniego za określeniem będącym aluzją do niego, zabieg może być również stosowany w celu uwypuklenia ironicznych i humorystycznych treści (zob. Skorupka, Kurkowska 2001: 88-92), może wreszcie wynikać z chęci zastąpienia wyrażenia objętego sferą tabu.

W badanym materiale językowym peryfraza może być środkiem o charakterze eufemistycznym (zob. Krawczyk-Tyrpa 2001; Kaczor 2003: 46-49). 
$\mathrm{D} / \mathrm{K} 1>\mathrm{K} 2 / \mathrm{IV} / \mathrm{II}$

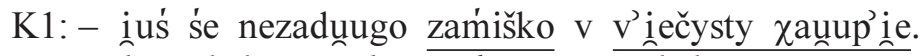

K2: - ne $\chi$ ' coća tag ne muvii, zḍrova coća ies.

Warto porównać eufemizm czas. zamieszkać i eufemistyczne wyrażenie wieczysta chatupa - 'trumna'.

\section{D / K1 < K2 / II / III}

K1:- pev'ńe mamuśi ńe smakuie.

K2: - smakuie barzo! tylko pšes te ślepe zymby ńe moge ieś.

Ślepe zęby oznaczają 'protezę'.

Peryfraza może też nadawać wypowiedzi ironiczny wydźwięk.

D / K1 $<$ K2 / II / III

K1: - țšeba z’ ńim dužo romav'iać.

K2: - možež mu muviić. tylko pšy tym śklanym bošku bej́e śeźić, caụy j̉iń i kavou $\mathrm{v}$ noc.

Zastosowane w wypowiedzi wyrażenie szklany bożek - 'komputer', por. bożek w zn. 'przedmiot bezkrytycznie uwielbiany, czczony', ma charakter interpretacyjno-wartościujący, podkreśla uzależnienie, swoiste zniewolenie osoby od medium.

\subsection{Hiperbola}

Hiperbola to trop służący przejaskrawieniu, wyolbrzymieniu określonych kwestii, opisywanych osób czy zdarzeń, jest środkiem stylistycznym, który polega na przesadnym zaprezentowaniu zjawiska, przerysowaniu jego charakterystycznych cech. Hiperbolizacja często prowadzi do nadużyć leksykalnych (por. Grochala 2008: 413-421).

\section{D / K1 - K2 / II / III}

$\mathrm{K} 1$ : - za dužo to ńe zarobiuny.

K2: - oi zarobiuuy, zarobiuny iag ńe v'iem co.

Obok powtórzenia, osobliwe hiperboliczne porównanie - jak nie wiem co, którego człon stanowi nieokreślona ilość czegoś, coś, co trudno jest sobie wyobrazić, podkreśla wielkość zarobionych pieniędzy.

D / M - K / III / IV

M: - krova cuź mauno mleka daie.

$\mathrm{K}:$ - ta čarna, co vym'iona tak'ie unadne mo, to sika ml'ik'iem. Hiperboliczna pochwała zwierzęcia wspiera emocjonalizację odbioru przekazu. 


\section{D / K - M / III / III}

K: - pšyšŭam, žeby my Ania f'irany pšešyuna.

M: - a g'źe ći ununa co ušyine. na krafcovom’ se țšy lata školi, a o inigle ńi inakigo poińća ńi mo.

Elementem służącym humorystycznej ocenie braku umiejętności dziewczyny są dane liczbowe.

\subsection{Eufemizmy jako środki perswazji}

Encyklopedyczna definicja eufemizmu mówi, że jest to: „zastępczy środek językowy używany w celu uniknięcia wyrazu, wyrażenia lub zwrotu zakazanego przez tabu językowe lub niewskazanego ze względów perswazyjnych" (Urbańczyk 1991: 78). A. Dąbrowska (1999: 216) wskazuje, że: „Eufemizm w ujęciu retoryki to pojęcie częściowo zachodzące na inne tropy - metaforę, ironię, peryfrazę". Badaczka (1999: 215) pisze: „Przyjmując, że język jest systemem wartościującym, można stwierdzić [...], że możliwe jest odmienne przedstawianie tych samych zjawisk. Naświetlanie jakiegoś zjawiska zależy od nadawcy: czy nazwie on rzecz po imieniu, używając nazwy wprost, czy też użyje określenia dowartościującego bądź deprecjonującego wartość tego zjawiska. Jeśli pragnieniem nadawcy jest złagodzenie, zasłonięcie lub zamaskowanie stanu rzeczy, mamy do czynienia z eufemizmem".

Eufemizm jest formą językowej kurtuazji, dyplomacji oraz taktu w komunikacji społecznej (zob. Krawczyk-Tyrpa 2001; Kaczor 2003: 46-49; Dąbrowska 2006a: 323-332; 2006b), użytkownicy języka muszą się niekiedy podporządkować określonym regułom z zakresu kultury słowa.

Ten środek w dyskursie ideologicznym może służyć manipulacji językowej, w ujęciu A. Dąbrowskiej (1999: 222-223): ,[...] za główną funkcję eufemizmów politycznych przyjmuje się maskowanie. Przedstawiają jakieś zjawisko w taki sposób, że uwaga odbiorcy skierowana jest na te opinie i fragmenty wypowiedzi, na które życzy sobie nadawca. Reakcja odbiorcy jest więc niejako sterowana przez odpowiedni dobór środków językowych".

K. Michalewski (2001: 3-8) proponuje nazwać „,wszelkie przeobrażenia wartości wyrazów służące perswazji, dezinformacji ułatwiającej manipulowanie odbiorcą, «kreowaniem wartości wyrazów»".

W komunikacji mieszkańców wsi zakazy językowe mają związek z tabu (zob. Krawczyk-Tyrpa 2001), silnie wpływającym na strukturę języka i sposób komunikacji międzyludzkiej. Określenia eufemistyczne mają neutralizować, łagodzić lub niwelować negatywny wydźwięk pewnych sformułowań (zob. Dąbrowska 2006a; 2006b), które są uważane za niewłaściwe i które mogą obrazić bezpośredniego lub potencjalnego odbiorcę komunikatu. Głównym powodem użycia eufemizmów jest przyzwoitość, skromność, wstyd, szacunek dla innych osób, chęć zaprezentowania się rozmówcy w sposób kulturalny. Przyczyny występowania 
eufemizmów są więc pozajęzykowe, głównie społeczne, psychologiczne, ideologiczne (zob. Szewcow-Szewczyk 1974: 285-293).

Eufemizmy używane z powodu działania tabu obyczajowo-zwyczajowego, są wyrazem dostosowania się do istniejących w społeczności wiejskiej norm językowego zachowania. W analizowanych tekstach neutralizowanie tonu wypowiedzi (zob. Michalewski 2006a: 81), czyli takie zaprezentowanie „spraw społecznie bulwersujących, oburzających, wywołujących sprzeciw, gniew" zdarza się często, zabiegi tego typu są stosowane do łagodnego przedstawienia sytuacji, mogących wzbudzać zbyt duże emocje wśród odbiorców. Środki eufemistyczne służą ukryciu emocji (zwłaszcza negatywnych), pomagają nadawcy zdystansować się wobec bolesnych problemów: bólu, nieszczęścia, starości, zniedołężnienia oraz śmierci, ukazują rzeczywistość w sposób bardziej łagodny i bezpieczny, pozwalają komunikować się z odbiorcą elegancko i uprzejmie.

Środki te świadczą także o wyjątkowej wrażliwości użytkowników gwary, która często skrywana jest pod powierzchnią żartu, humoru czy groteski.

W celach złagodzenia wypowiedzi mogą być stosowane środki leksykalne.

D / K1 - K2 / III / III

$\mathrm{K} 1$ : - naileṕi $\mathrm{z}^{\prime}$ ńom fcale o tym ńe gadać.

K2: - tera to dauna spokui, bo cur'ća mo samośeike.

Użyty w wypowiedzi derywat samosiejka oznacza 'panieńskie dziecko', żartobliwy eufemizm wpleciony w kontekst wypowiedzi uwydatnia zmianę sposobu oceny postępowania innych pod wpływem osobistych przeżyć.

Chętnie wykorzystywane są peryfrazy eufemistyczne.

D / M - K / III / III

M: - barzo țrudo śe odzvyčaić.

$\mathrm{K}:-$ țša $\chi$ ćić. Durczok tyš k’iedyś śe vypov’iadoun, že śe zaunamoun,

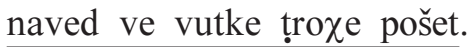

Kobieta, odwołując się do przykładu osoby publicznej, dziennikarza K. Durczoka, wskazuje, że można skończyć z nałogiem, por. peryfrazę pójść trochę w wódkę, pod warunkiem, że się tego bardzo chce.

D / K - M / III / III

K: - țšeba kogoź zunapaj́ za rynke.

M: - naved - iego roźine muviuuy, bap’ća rynte dostauna, vnucuś

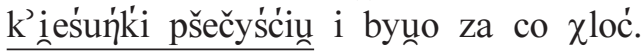

Rozmówca wyjaśnia, że jego wiedza na temat postępowania mężczyzny pochodzi bezpośrednio od członków rodziny osoby, której dotyczy wypowiedź. Peryfraza przeczyścić kieszonki 'ukraść' sprawia, że tak przedstawione zjawisko nie wymaga oceny, już zostało w sposób sugestywny zaopiniowane, ironiczny wydźwięk ma także przewrotnie zastosowana forma hipokorystyczna - wnuczuś. 
Łagodzeniu drastyczności opisu mają służyć frazeologizmy i peryfrazy, zastępujące zjawiska czy wydarzenia przerażające, pełne grozy, okrutne.

D / M1 - M2 / III / IV

M1:- unoice iego godauny, že poiexou do m’iasta na stud'ía.

M2: - a co śe m’iouny kfol'ić, že śej̉i pot klucym.

Mężczyzna wskazuje, że rodzice, podając informację o dziecku, ukryli prawdziwy powód jego nieobecności, wynikający z nieprzyjemnej sytuacji, por. siedzieć pod kluczem - 'odbywać karę pozbawienia wolności', fraz. pod kluczem 'w zamknięciu'.

Czasem zastosowany eufemizm zamiast łagodzić drastyczność opisu dodaje przekazowi swoistej dramaturgii.

\section{D / K1 - K2 / III / III}

K1: - tak'ie spravy to povinny oḍ razu rossuńzić.

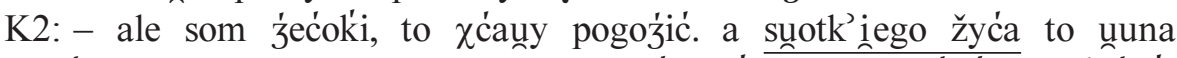

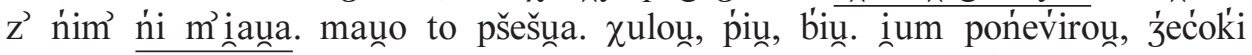
loụ. neros to $\mathrm{mu}$ rong byuno mauno, to noǵi šŭ $\mathrm{v}$ robote. ile razy $\mathrm{v}$ nocy ućekauny, po sum'śada $\chi$ spauny.

Zachowania, będące przejawem bezwzględnego okrucieństwa i znęcania się nad najbliższymi, zostały przedstawione przy użyciu zmodyfikowanego związku frazeologicznego: nie mieć słodkiego życia, por. fraz. pot. mieć stodkie życie 'bardzo wygodne, beztroskie, przyjemne warunki egzystencji' i eufemistycznej peryfrazy - nieraz to mu rąk byto mato, to i nogi szly w robotę, która wskazuje na rodzaj przemocy fizycznej i oddaje realizm zagrożenia. Dzięki zastosowanym środkom opis budzi współczucie wobec agresji i cierpienia innych, bardziej przemawia do odbiorcy, pobudza wyobraźnię, wpływa na opinię i odczucia rozmówcy. Jednym z ważnych kierunków perswazyjnego oddziaływania jest emocjonalizacja przekazu, wypowiedź jest na tyle sugestywna, że sprawia wrażenie uczestnictwa w zdarzeniu. Odbiorca widzi świat oczyma nadawcy, staje się bezpośrednim świadkiem prezentowanej sytuacji. Eufemizmy powodują, że osoba, o której mowa, jawi się odbiorcy jako człowiek lubiący zdawać ból innym, bezlitosny, bezwzględny sadysta.

\section{D / M1 - M2 / II / III}

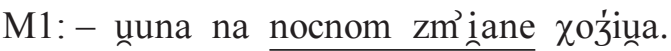

M2: - to ne byuna nocna zmiana, tylko zaińća nocne.

Drugi mężczyzna, modyfikując wyrażenie: nocna zmiana, por. zajęcia nocne, podkreśla, że kobieta zdradzała męża.

Eufemizm może mieć postać aluzji, czyli świadomego nawiązania do wiedzy odbiorcy po to, by mógł ją samodzielnie rozwinąć. 


\section{D / M1 - M2 / III / III}

M1: - stareita se iešče, tero bećikove daium.

M2: - čuov'ieg byŭ munody, to spšynd buu na b’inegu. tero spšynd se pšestažoun, zar’źzev’ ioun, kapitalny remond by se zdaun.

Drugi z rozmówców, zachęcany do powiększenia rodziny, w sposób aluzyjny używa wyrażenia sprzęt byt na biegu, oznaczającego sprawność seksualną, temperament.

Czasem w celu złagodzenia tonu wypowiedzi rozmówcy wykorzystują litote - zastąpienie jakiegoś wyrażenia przez zaprzeczone określenie antonimiczne. Litota traktowana jest jako przeciwieństwo hiperboli (zob. Pisarek 2006: 209).

D / K1 - K2 / III / III

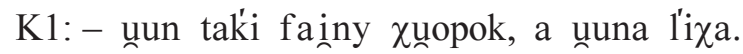

K2: - urodno to una ne ine, ale iak to se muvii, unadno miska ineź ńe do. Przez określenie nie być urodnym - 'być brzydkim' kobieta zaznacza, że w malżeństwie uroda żony nie jest najważniejsza.

\subsection{Porównanie}

Nazywanie to zazwyczaj wyodrębnianie przez zestawienie, ponieważ umysł ludzki nieustannie coś ze sobą zestawia. Porównywanie, ,zestawianie na podstawie cech wspólnych i różnych dwóch lub większej ilości rzeczy, osób, zjawisk" (Doroszewski 1964, t. 6: 1069), służy ustaleniu istotnych podobieństw i różnic między obiektami, stanowi podstawę poznania rzeczywistości, a samemu procesowi zazwyczaj towarzyszy wartościowanie.

Porównanie ukazuje ponadto rozmaite relacje między obiektami: wzajemne odniesienia i powiązania, a także wielkości istotnych parametrów (zob. Szymanek 2001: 239). To szczególny element stylu, rodzaj figury retorycznej, która może występować zarówno w postaci prostej ograniczonej do dwóch słów, jak i bardzo rozbudowanej, która służy uwypukleniu, pełniejszej charakterystyce oraz ustaleniu odniesień między porównywanymi obiektami. W porównaniu wyróżnia się trzy istotne elementy: komparat - lewa strona porównania, komparans - prawa strona porównania i funktor. Komparans przez swój definicyjny charakter jest konceptualną istotą porównania, a tym samym kognicji i wartościowania. Wychodzi się od komparatu, czyli przedmiotu i szuka się jego odbicia, budując tzw. zestawieniowy obiekt chiralny (zob. Kudra 2004: 18).

Walory perswazyjne porównania doceniano już w starożytności. Arystoteles (1988: 212) uznaje porównanie za trop, odmianę metafory. Wzajemna relacja między porównaniem a metaforą dotyczy wartościowania, ponieważ jak wykazują badania (zob. Wróblewski 1998: 63-66; Wysoczański 2005), porównanie wartościujące służy, podobnie jak inne tropy stylistyczne z metaforą na czele, do wyrażania przez subiekt oceny faktów otaczającego świata. 
Niekiedy uznaje się porównanie za figurę semantyki (zob. Todorov 1977: 285), ponieważ jest zabiegiem dotyczącym treści i opiera się na wzmocnieniu pewnych reguł znaczeniowych, czyli na intensyfikacji znaczenia wspólnego dla obu członów porównania, choć może także dochodzić do ich osłabienia. Analiza semantyczna pozwala na sformułowanie wniosku, że porównanie jest najważniejszym tropem o charakterze aksjologiczno-kognitywnym.

Wyodrębnia się porównania stereotypowe (zob. Kurkowska, Skorupka 2001: 158) oraz porównania sprzeczne, które najczęściej służą realizacji ironii (zob. punkty: II.1.7. Stereotyp jako środek wartościowania i II.3. Ironia - jej rodzaje ifunkcje).

\section{D / K - M / III / III}

$\mathrm{K}$ : - ńe dam ańi groša.

M: - daš, daš, bo ći beźe îioičyź inag Żyd.

Mężczyzna, stosując stereotypowe porównanie, por. czas. jojczyć, wyjaśnia, że kobieta pod wpływem usilnych namów zmieni powziętą decyzję.

D / K1 < K2 / II / IV

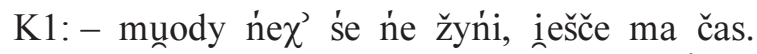

K2: - ńiz ńe poraźišs. rv îe śe do žeńački inak koza do unobirek.

W drugiej wypowiedzi porównanie służy ironicznemu uwypukleniu zaangażowania $\mathrm{w}$ planowany ślub.

\section{D / M - K / II / III}

M: - sұuduna, unodmunod'ńauna.

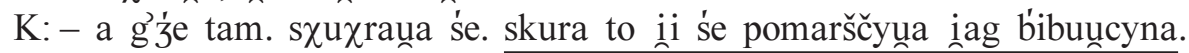

Porównanie wskazuje na stopień intensywności procesu.

Metafora to ciekawy trop stylistyczny, który pokazuje swoisty sposób postrzegania przez współczesnych mieszkańców wsi pewnych dziedzin życia. „Jest to - jak mówi T. Dobrzyńska (1994: 135) - jeden z tych środków językowych, których użycie w symptomatyczny sposób odzwierciedla zmiany sytuacji komunikacyjnej, aktualny stan świadomości uczestników komunikacji”.

\section{Ironia - jej rodzaje i funkcje}

Encyklopedyczna definicja ironii mówi, że jest to „właściwość stylu polegająca na sprzeczności między dosłownym znaczeniem wypowiedzi a jej znaczeniem nie wypowiedzianym wprost, ale założonym przez autora" (Krzyżanowski 1984). C. Kerbrat-Orecchioni (1986: 293) uważa, że następuje tu „odwrócenie hierarchii poziomów semantycznych". Sens kontekstualny (wtórny, pochodny) staje się niejako uprzywilejowany względem sensu dosłownego (pierwotnego, jawnego). 
Pojęcie ironia bywa bardzo różnie pojmowane i klasyfikowane (zob. Sławiński 1988: 203-204; Głowiński 2002). A. Kulawik (1994: 112) ujmuje ironię jako osobną figurę stylistyczną ,pośród tych, zaliczonych do metafory - polega ona na przypisywaniu osobom, przedmiotom, zjawiskom cech, których absolutnie nie posiadają”. Definiowana bywa jako: „Drwina, lekki sarkazm lub kpina w wypowiedzi, której zamierzony sens nie jest wyrażony wprost, a jest odwrotnością dosłownego znaczenia słów, jest rozpoznawalny dla słuchacza, np. z tonu głosu" (zob. Praktyczny słownik współczesnej polszczyzny 1998, red. H. Zgółkowa, t. 14: 373-374).

Ze względu na swą niejednoznaczność ironia stanowi wygodne, a zarazem bezpieczne narzędzie perswazji, ponieważ, jak podkreśla M. Sarnowski (1991: 41), ,nadawca określa swój punkt widzenia w taki sposób, że świadomość językowa odbiorcy kwalifikuje go jako wartościujący dodatnio, a kontekst i szerzej sytuacja komunikatywna korygują go tak, że musi być odczytany jako wartościujący ujemnie". Ze względu na tę cechę ironia postrzegana jest jako specyficzna forma oceny negatywnej. Przy czym ocena ta może mieć różny stopień nasilenia - od zwykłej negacji jakiegoś zjawiska czy osoby, poprzez drwinę, szyderstwo, aż do obelżywych inwektyw.

Ze względu na stopień jawności oraz formy sygnalizujące ironię D. S. Muecke (1986: 255-258) wyróżnia jej trzy rodzaje: ironię jawna, ukryta i prywatna. Z ironia jawna mamy do czynienia wówczas, gdy osoba, przeciwko której została ona użyta lub współuczestnik komunikacji bez trudu rozpoznają i odczytają rzeczywistą intencję nadawcy. Ironia jawna jest bardzo wyrazista i odbiorca (ofiara) może „od razu zorientować się, co ironista ma naprawdę na myśli” (Muecke 1986: 255), towarzyszy jej szereg sygnałów pozajęzykowych, np. ton głosu (ton spokojny wyrażający oczywistą sprzeczność, sygnalizujący sarkazm), określone gesty, mimika (np. ironiczny uśmiech).

Natomiast ironia ukryta jest bardziej subtelna, ,należy ją nie tyle dostrzec, co raczej wykryć" (Muecke 1986: 257), a sposób mówienia czy zachowania ironisty jedynie w minimalny sposób pozwala rozpoznać ironię.

Ironia prywatna (Muecke 1986: 260-261) jest niedostrzegalna zarówno dla ofiary ironisty, jak i innych potencjalnych odbiorców.

Rolę ironii doceniał już Teofrast, 300 lat p.n.e., który radził, aby: „mówca nie wypowiadał wszystkiego, co jest do powiedzenia, lecz dzielił się zadaniem ze słuchaczem, aby podsuwał mu myśli, które tamten sam wysnuje" (zob. Łaguna 1984: 22). Terminem ironia (zob. Muecke 1986) w zn. „,udawana skromność” posługiwał się Arystoteles, który zwracał uwagę na ironiczny sposób wyrażania się. Klasyczna retoryka doceniała przede wszystkim ironię sokratyczna, która jako swoisty chwyt odniesiony bezpośrednio do zjawisk i osób, miała pełnić funkcję płaszczyzny wyższego porozumiewania mówcy i odbiorcy. W retoryce zabieg sytuuje się w sferze elocutio i jest podzielony na kilka szczegółowych odmian, które związane są ze swoistymi formami dowcipu. Szczerbowski (1994: 48) wskazu- 
je, że do rozpoznania ironii niezbędne jest uświadomienie sobie przez odbiorcę „sprzeczności kontekstualnej i pewnego dysonansu poznawczego”.

Ironia może pełnić różne funkcje, jako forma opisu rzeczywistości ma ogromną siłę perswazji, ponieważ pozwala nadawcy przedstawić własne stanowisko, ośmieszyć przekonania oponenta i co ważne, wzbogaca wypowiedź, uatrakcyjniając tekst i ułatwiając jego zapamiętanie. M. Głowiński (2002) podkreśla, że wykorzystywana bywa do wykpienia poglądów, postępowania, postawy czy cech przeciwnika; może służyć wzmocnieniu myśli, argumentu; urozmaiceniu wywodu; zacieśnieniu więzi z grupą, zjednaniu sobie publiczności. Istotną rolę odgrywa także autoironia, która charakteryzuje się okazaniem dystansu wobec zjawisk, osób, a również wobec samego siebie.

Badacze doceniają pragmatyczny walor ironii (zob. Grzelak 2001: 239-247; Fąka 2008: 161-169). E. Grzelak (2001) pisała o ironii, wskazując, że zastosowanie tej figury stylistycznej ma sens jedynie wtedy, gdy prawdziwa treść komunikatu zostanie odebrana przez słuchacza. Ironia jest wówczas illokucyjnym aktem mowy o wyraźnym skutku perlokucyjnym oraz jedną z form perswazji językowej, tekstowym nawiązaniem do rzeczywistości pozajęzykowej. Dla rozważań związanych z pragmatyczną funkcją ironii ciekawa jest koncepcja sytuująca trop w obrębie takich kategorii estetycznych, jak komizm, tragizm, tragikomizm i ujmująca ironię jako postawę. P. Łaguna (1984: 25) uważa, że: ,jest to taka świadomość, którą cechuje poczucie kontrastu, sprzeczność między zjawiskami świata wewnętrznego lub zewnętrznego danej jednostki [...]; przy czym uświadamiana przez jednostkę sprzeczność zostaje podporządkowana określonej idei bądź wizji świata i bytu ludzkiego" oraz jako wyraz świadomości ironicznej, polegający na: „skontrastowaniu sensu literalnego wypowiedzi lub wartości działania człowieka z sensem rzeczywistym, który zostaje zasugerowany podmiotowi apercypującemu poprzez szeroko rozumiany kontekst lub przedstawienie na innym miejscu prawdziwego stanu rzeczy".

Ironia jako jeden z najskuteczniejszych sposobów przekonywania jest zjawiskiem bardzo często wykorzystywanym w polityce (zob. Habrajska 1994: 57-68; Grzelak 2001: 239-247), dziennikarstwie, zwłaszcza w felietonach czy polemikach prasowych (Burska-Ratajczyk 2006: 21-32).

Mieszkańcy wsi sprawnie posługują się ironią, zabieg służy charakteryzowaniu osób i reprezentowanych przez nie postaw.

\subsection{Kontrast a wyrażanie postawy ironicznej}

O wystąpieniu ironii mogą świadczyć zestawienia kontrastujących ze sobą wyrazów, nagła zamiana stylu wypowiedzi, dysonans pomiędzy przekazywaną informacją a wiedzą o świecie, którą posiada odbiorca. 
D / K - M / III / IV

$\mathrm{K}$ :- muśi śe nagotovać, bo unun lubi dobže z’i ieś.

M: - tak, unun i ies taki vyvredny, že tylko by iot kartofle s kumpotym.

Druga wypowiedź jest zbudowana na zasadzie wyrazistego kontrastu do użytego wcześniej frazeologizmu dobrze zjeść. Przymiotnik wybredny wskazuje na osobę mającą wysublimowane upodobania kulinarne, natomiast wyrażenie kartofle z kompotem podkreśla bardzo proste skłonności żywieniowe.

Ironia nacechowana jest dodatkowym znaczeniem, kiedy nadawca świadomie używa sformułowań ostrzejszych, aby poprzez kontrast podnieść wartość tego, o czym mówi. W tej wypowiedzi ironię uznać można za semantyczny środek potęgowania komicznej atmosfery, stanowi ona swoisty komentarz do zajmowanych postaw lub opisywanych sytuacji, a im więcej niedorzeczności, tym silniejszy efekt komiczny.

\subsection{Leksyka, frazeologia, metaforyka, gra słów, znaczeń jako element ironii}

Wyrażaniu ironii służą także zastosowane $\mathrm{w}$ tekstach derywaty proste i złożone, będące przejawem dowcipu językowego. W opracowaniach słownikowych (Zgółkowa 2003: 104) dowcip językowy „to celowy przejaw komizmu, utrwalony najczęściej w formie językowej, która jest bądź przekaźnikiem komicznej treści bądź też samoistnym źródłem komicznych efektów. Jest popisem intelektualnej inwencji twórcy i wymaga analogicznych dyspozycji ze strony odbiorcy. Jego podstawą jest wielopłaszczyznowość semantyczna, gra sensu i bezsensu, równoczesność lub następstwo znaczeń rozmaitych lub wzajemnie się wykluczających tworzących zazwyczaj spoistą i wyodrębnioną konstrukcję słowną [...]”.

D / M1 < M2 / II / III

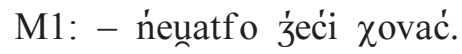

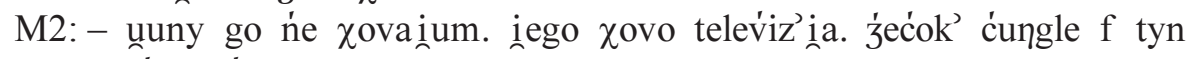
unogunup iač ś se gapii.

Mężczyzna podkreśla, że wychowanie jest procesem trudnym, który nie może polegać na uleganiu kaprysom dziecka i który nie powinien ograniczać się do wzorców krzewionych przez współczesne media. Telewizja określana została bardzo pejoratywnie, w derywacie ogłupiacz silne zabarwienie emocjonalne ma podstawa - czasownik ogtupiać.

D / K1 < K2 / II / IV

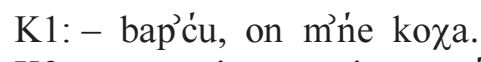

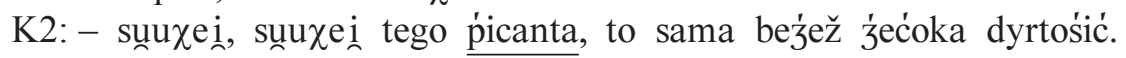

Zastosowany przez babkę wyraz picant jest wyrazistą semantycznie negatywną etykietą językową. Słowo swoją formą przyciąga uwagę odbiorcy i wzmacnia 
dobitność wypowiedzi. Derywat zbudowany jest na zasadzie niezgodności stylistycznej, kontrast obejmuje łac. przyrostek -ant, który nawiązuje do stylu wysokiego i tworzy rzeczowniki, oznaczające najczęściej męskich wykonawców czynności, i rodzimą wulg. podstawę, por. czasownik picować.

\section{D / K - M / III / III}

K: - muvii, že na v'iosne postavii.

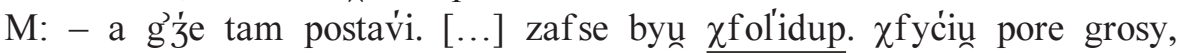
to se kfol'iu co unuń ne postaví. a Stacha mu muviuna: ne bej́ez m’iou za

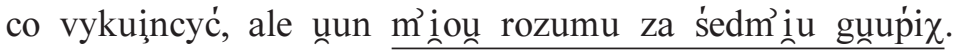

Wyraz chwalidup - nazwa-epitet i zwrot, w którym występuje liczebnik mieć rozити za siedmiu głupich, są określeniami w najwyższym stopniu negatywnymi. Obrazowe, silnie nacechowane emocjonalnie złożenie, którego drugim członem jest wulgarny rzeczownik, ujmuje treść w skondensowanej formie, bardziej przemawiającej do rozmówcy. Warto podkreślić, że w kulturze ludowej chwalenie się jest oceniane negatywnie. Odczytanie ironii możliwe jest także dzięki istnieniu „wspólnego świata" nadawcy i odbiorcy; rozmówca odwołuje się do kompetencji językowej i socjokulturowej słuchacza.

Efekt ironiczny osiągany jest również przez wprowadzenie frazeologii, metaforyki lub słownictwa wywołującego efekt komiczny w zestawieniu z kontekstem wypowiedzi. Ironia wiąże się z przypisywaniem osobom, przedmiotom, zjawiskom, o których się mówi, cech, których absolutnie nie posiadają.

\section{D / K - M / III / III}

K: - Jasiu pšyunob’iecoun, že rano pšyleći i ći pumože.

M: - a g'źe unuń ći tag rano pšyleći, inag unun fstaĩe skoro śf int kole pounud'ńa.

Sposobem odebrania wiarygodności wypowiedzi kobiety jest stwierdzenie, wykorzystujące żartobliwe oraz ironiczne znaczenie konstrukcji wstawać skoro świt - koło poludnia, którego absurd wynika z zestawienia elementu oznaczającego rozpoczynający się dzień - świt z porą oznaczającą jego środek - koło południa, dodatkowo podkreślone wyrazem skoro. Mężczyzna wskazuje, że obietnice składane przez osobę nie są wiarygodne.

\subsection{Deminutywum jako znak ironii}

Zabarwienie uczuciowe zdrobnień i spieszczeń nie zawsze jest pozytywne, w pewnych kontekstach mogą być one wyrazem dezaprobaty i nabierać znaczenia pejoratywnego (zob. Kurkowska, Skorupka 2001: 44-52). Środki te mogą charakteryzować się przeróżnymi odcieniami ekspresywnymi i w zależności od sytuacji stawać się wykładnikami ironii, humoru, lekceważenia, politowania, pogardy. 
Nadawca, wykorzystując je w celu ironicznym, używa sposobu, który gwarantuje lepsze rezultaty perswazyjne.

Zdrobnienia jako wykładnik ironii, negatywnej oceny, niechęci przemycają złośliwość pod maską komplementu. Taki mechanizm bywa często wyzyskiwany w dyskursie politycznym (zob. Kamińska-Szmaj 2001; Karwat 2006; Burska-Ratajczyk 2010a: 211-224).

W analizowanych tekstach deminutywne formy rzeczownikowe tracą znaczenie pieszczotliwości, aktualizując się nabierają znaczenia ironicznego lub pejoratywnego. Problematyki tej dotyczą artykuły Nowotnej-Szybisowej (1969: 362-369) i Sarnowskiego (1991: 43). Z ironicznymi deminutywami mamy do czynienia wtedy, gdy wyraz jest tworzony za pomocą „sufiksów zdrabniających dodawanych do leksemów z jednoznacznie dodatnią (ale również i neutralną lub czasami ambiwalentną) charakterystyką aksjologiczną"; ma to związek „,z pragmatyczną kategorią intencji nadawcy, czyli rzeczywistych motywacji użycia konkretnego deminutivum" (Sarnowski 1991: 43).

\section{D / K - M / III / III}

K: - iedyn tylko byư⿱ puźno go m’inauny, to pațšauny - ńego iag V unobrazek.

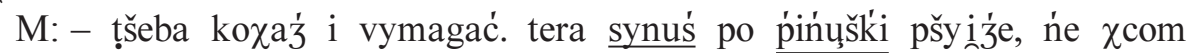
dać, to unad’ne tatuśa, mamuśe pod gar’źel uunapi.

Formy deminutywne: pieniążki, synuś, tatuś, mamusia w połączeniu z eufemistycznym określeniem tadnie pod gardziel ułapić nabierają w wypowiedzi wartości ironicznej, stając się wyrazistym środkiem ekspresji. Ironia może być bardzo elegancką formą wyrażania inwektyw, por. dem. synuś. R. Przybylska (2002: 205) wskazuje, że: „Ironia łączy się też czasem z użyciem sufiksu formalnie deminutywnego do utworzenia nazwy osobowej nosiciela [...]". Zabieg opiera się na wieloznaczności pod pozytywnymi określeniami ukrywa się aluzyjnie, ale jakże jadowicie, wyrażona ocena negatywna. Nadawca, stosując eufemistyczną parafrazę, łagodzi treść, a ironia potęguje jej negatywny wydźwięk. Można ją odczytać dzięki spostrzeżeniu, że dosłowne znaczenie wyrazów nie pasuje do ich kontekstu oraz okoliczności użycia.

Wykorzystanie ironii w wypowiedzi jest wartościowym środkiem językowego wpływu na postawy i na percepcję społeczną (zob. Habrajska 1994: 57-67; Grzelakowa 2001: 239-247).

\section{D / K - M / III / IV}

$\mathrm{K}$ : - te spravy to śe źeśińż lat' congnom. tyle ṕinenzy!

$\mathrm{M}$ : - iag gunup'i $\mathrm{i}$, to n'e $\chi$ puacom. prekuratoreg i mecenasik tylko rynce

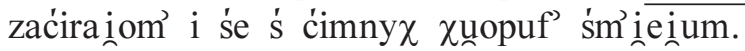

Postawa lekceważąco-ironiczna ujawnia się w wyniku połączenia sufiksu formalnie deminutywnego z neutralnymi nazwami zawodów przedstawicieli wymiaru sprawiedliwości: prokuratorek, mecenasik. 


\section{D / K1 - K2 / III / III}

K1: - zminini śe, zminini.

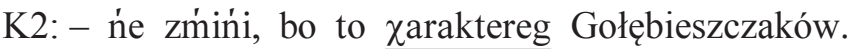

Podobną wymowę emocjonalną posiada także nazwa o większym stopniu abstrakcyjności: charakterek - iron. 'przykry, dokuczliwy charakter'.

\subsection{Ironiczne porównania}

W codziennej komunikacji porównania mają szczególną wartość znaczeniową, ponieważ pobudzają wyobraźnię odbiorcy. Są uwydatnieniem jakiś właściwości opisywanego zjawiska poprzez wskazanie na jego podobieństwo do innego zjawiska (Sławiński 1988: 376-377).

Istotny element komunikacji perswazyjnej stanowią porównania ironiczne, sarkastyczne, zawierające złośliwą ocenę osoby, sytuacji, zjawiska. Główną zasadą tworzenia porównań o charakterze ironicznym jest ich obrazowość, oparta na odwołaniach do skojarzeń bardzo typowych, powszechnych, ale ujętych w sposób niezwykły i zaskakujący.

Używając tych środków stylistycznych, nadawca sygnalizuje, że wypowiadana treść powinna być rozumiana z pewnym dystansem, czyli niedosłownie. Ten rodzaj tropu wzmacnia perswazyjny walor komunikatu, ponieważ jest czytelnym elementem ironii, mającej często znamiona hiperbolicznego przerysowania ocenianego zjawiska.

\section{D / K1 - K2 / III / IV}

K1:- ununa tak podunug mody śe unubiro.

K2: - țšeba śe unubirać podunug luži. stara baba, a zesțroi śe $f$ tak'ie fruvoki, iak to tero munode nošom. pasuịe ii to iak koźi dup’ ie kośula.

Porównanie pasuje jak koziej dupie koszula - iron. 'zupełnie nie pasuje', podkreśla niestosowność stroju osoby do jej wieku. Kobieta przekonuje, że nie należy za wszelką cenę naśladować mody, zaleca zachowanie pewnej miary, wskazanej przez rozsądek i dobry smak. Porównanie jest zwięzłym komentarzem do waloryzującego rzeczownika fruwak, oznaczającego element krytykowanego ubioru. Uszczypliwa ocena sposobu ubierania się zaskakuje przez nietypowe skojarzenie, które odwołuje się do zestawień słów sprzecznych względem siebie. Zabieg taki uświadamia niedorzeczność i wyostrza ironię.

D / K1< K2 / III / IV

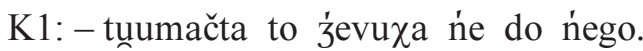

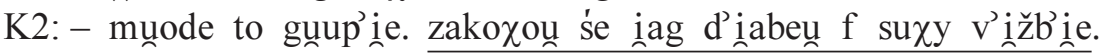

Porównanie zakochać się jak diabeł $w$ suchej wierzbie - iron. 'o niewłaściwie ulokowanych uczuciach', w żartobliwo-ironiczny sposób wskazuje na charakter 
i intensywność uczucia, podkreśla wielkie zauroczenie. Diabet w kulturze ludowej niekiedy kojarzony jest z głupcem, natomiast wierzba uważana jest za siedlisko diabła.

\section{D / M1 - M2 / III / III}

M1: - țšeba luźom v’iežyć.

M2: - ia ini ńe v’íeže, kryńći inak p’iez unogunem.

Dzięki użytemu porównaniu kręcić jak pies ogonem - iron. 'zmieniać zdanie w zależności od sytuacji', rozmówca wypowiada się stanowczo, że osoba jest niewiarygodna.

\section{D / K - M / III / III}

$\mathrm{K}:-$ dužo rozmav íaita.

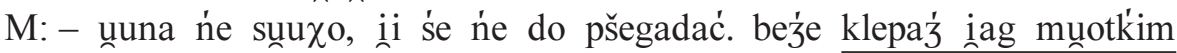
po pustym kovaḍle.

Zwrot klepać jak mlotkiem po pustym kowadle - iron. 'mówić niepotrzebnie, bez sensu', podkreśla gadulstwo i upór żony, jest bardzo sugestywny przez swoje nawiązanie do wykonywania niepotrzebnej pracy, takiej, która nie przynosi rezultatów. Porównanie zawiera znaczenie wykonywać czynność wymagającą niewspółmiernego wysiłku w stosunku do efektu, a więc bezcelową.

D / K1 < K2 / II / IV

K1:- ńe moge śe z' ńim dogadać.

K2: - iak’ ći času ne škoda. iź do ni. toto gụup’ie inak pynk sunomy. ununa mo vincy rozumu $\mathrm{f}$ pince, iag unun $\mathrm{f} \overline{\text { caụy gunov ie. }}$

Oceniając intelekt mężczyzny, kobieta używa nacechowany emocjonalnie leksem toto oznaczający istotę nieokreśloną, a więc człowieka niewartego uwagi oraz ironiczno-obraźliwe porównanie mające charakter inwektywy, por. głupi jak pęk słomy. Perswazji służy także odwrócenie metaforyczne. Negatywne skojarzenia budzi waloryzowanie oparte na relacjach przestrzennych góra - dół: pięta-dolna część nogi, będąca przeciwieństwem głowy - 'górnej części ciała', uważanej za siedlisko rozumu, myśli.

Sugestywność ironii, zdaniem G. Habrajskiej (1994: 57): „wynika z tego, że pozwala ona domyślać się czegoś innego i/lub czegoś więcej niż to, co zostało dosłownie wypowiedziane".

\subsection{Pytania ironiczne}

Skierowanie do odbiorcy pytania ironicznego ma na celu ośmieszenie i zlekceważenie osoby, a tym samym pomniejszenie jej wartości i wzmocnienie własnej. Jego funkcja polega na tym, że wyraźnie występuje przeciw komuś/czemuś, 
ma misję prowokacji, służy przewartościowaniu dotychczasowego sposobu myślenia odbiorcy. Nadawca zadaje je nie po to, by uzyskać odpowiedź, ale dlatego, że chce podać odnoszące się do rozmówcy fakty czy sądy w wątpliwość lub zasiać wobec nich niepewność. Pytanie ironiczne, które kończy całą wypowiedź, stanowi jej specyficzne podsumowanie. Może być połączone z ironicznym uśmiechem.

\section{D / K - M / III / III

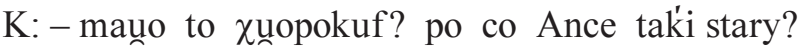 \\ M: - stary, stary! a co gotovaj́ go beźe?}

W sposób zwięzły i humorystyczny mężczyzna podkreśla, że wiek nie powinien być żadnym przeciwwskazaniem do zawarcia związku małżeńskiego. Zaskakujące i niefortunne pytanie kobiety narusza normy grzecznościowe, ponieważ niejako zmusza rozmówcę do odpowiedzi, której nie chce lub nie powinien udzielić. Mężczyzna zręcznie ripostował, również stosując formę pytania, mającego ton kpiarski, drwiący, ironiczno-żartobliwy. Wypowiedzi towarzyszy uśmiech oraz ironicznie uniesienie brwi. Elementy te dodatkowo sugerują właściwą interpretację przekazu, którego celem jest przełamanie utartych stereotypów dotyczących małżeństwa. Źródłem humorystycznego efektu staje się urealniony absurd. Rozmówca zastosował chwyt paradoksu, czyli efektownego i zaskakującego swoją treścią sformułowania, zawierającego myśl skłóconą z powszechnie żywionymi przekonaniami, sprzeczną wewnętrznie, która jednak przynosi nieoczekiwaną prawdę.

Jak podkreśla U. Eco (2003: 68): „Co się zaś tyczy paradoksu, to trzeba, aby odwrócenie przestrzegało pewnej logiki i ograniczało się tylko do pewnego fragmentu świata".

\subsection{Pochwala jako strategia wprowadzania ironii}

W przypadku ironii wyodrębnia się wiele technik i sposobów wprowadzania jej do wypowiedzi: pozorowana zgoda $\mathrm{z}$ ofiarą ironii; pozorowana zachęta, rada dla ofiary; pozorowana obrona ofiary; pozorowany atak na przeciwników ofiary; pochwała $\mathrm{w}$ formie nagany/nagana $\mathrm{w}$ formie pochwały; pozorowana wątpliwość; powoływanie się na niedorzeczne poglądy - rzekomo wyznawane przez większość; ironiczne nominacje, np. nazwy nieistniejących urzędów, tytuły, przydomki (Głowiński 2002: 208).

Opracowania leksykograficzne (Sławiński 1988: 203) podkreślają, że zależnie od sytuacji ironia może służyć celom satyrycznym, być formą dowcipu, parodii, przejawem drwiny, szyderstwa i sarkazmu. 
D / K - M / IV / III

$\mathrm{K}:-$ kuṕiuna k’śǔ̧ḱki s pšeṕisamy i beǰe se škol'ić.

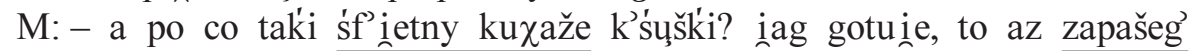

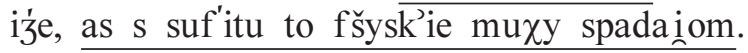

Sygnałem ironii bywa także niezgodność pewnych twierdzeń z uzupełniającym je komentarzem. Ocenie zdolności kulinarnych kobiety służy pozornie aprobujące określenie świetna kuchara, które nie jest komplementem, ponieważ dalsza część wypowiedzi nadaje mu znamiona drwiny i szyderstwa. W przedstawionym kontekście wyrażenie służy zakwestionowaniu jej umiejętności kucharskich. Ironiczny wydźwięk ma dem. zapaszek, będące przewrotnym eufemizmem. Przekazowi swoistej pikanterii dodaje żartobliwy, hiperboliczny opis, przedstawiający muchy spadające z sufitu. Humor pełni tu funkcję degradującą; kpina jest istotnym elementem o dużej sile perswazyjnej. Hiperbola to ,przedstawienie jakiegoś zjawiska wyolbrzymiające jego wygląd, znaczenie, działanie [...]. Uważana za jedną z figur retorycznych nie jest wyspecjalizowanym chwytem stylistycznym, lecz raczej efektem współdziałania rozmaitych tropów i figur, szczególnego doboru słownictwa oraz ekspresywnych intonacji. Używanie hiperboli bywa znakiem silnego zaangażowania emocjonalnego mówcy lub poety i ma podobną reakcję wywołać u odbiorcy" (Zgółkowa 2003: 397).

G. Habrajska (1994: 57-62) wskazuje, że: „Wypowiedź ironiczna może zostać odebrana i zinterpretowana jako negacja kogoś lub czegoś, negacja czyichś zachowań; pozwala ona domyślić się ukrytego sensu wypowiedzi, może przyczynić się do nawiązania więzi nadawcy z odbiorcą poprzez wskazanie wspólnego wroga i uwydatnienie jego wad $[\ldots]$ ".

\section{D / K1 - K2 / III / III}

K1: - kobita ze f's'si, žeby ćasta ne unum'iauna unup'iec.

K2: - unup inece, ale iak kurom žući, to v loce zabii

Druga z kobiet wprowadza do wypowiedzi zabawną dwuznaczność, tylko pozornie zaprzecza słowom przedmówczyni, ponieważ zastosowana hiperbola: jak kurom rzuci, to w locie zabije, służy ironicznemu przewartościowaniu treści. Zastosowana strategia pochwały w formie nagany, wsparta odpowiednią intonacją i mimiką, może skuteczniej skupiać uwagę odbiorcy na opinii mówiącego niż w przypadku wyrażenia nagany wprost.

\subsection{Pozajęzykowe sygnały ironii (ton glosu, gesty, mimika)}

Jednym z sygnałów zastosowania ironii jest specyficzne brzmienie głosu przejawiające się m.in. w opadającym tonie oraz wydłużeniu elementów wypowiedzi (Szczerbowski 1994: 52). Badacze zajmujący się wyodrębnianiem sygnałów ironiczności w tekstach zwracają uwagę, że ton wypowiedzi ma wyłącznie 
charakter uprawdopodobniający jej wystąpienie, ponieważ cechy wyróżniające ironię występują także w tekstach neutralnych. O ironicznej intencji, do której rozmówca się odwołuje, kwestionując znaczenie dosłowne, świadczy intonacja, mimika, kontekst wypowiedzi oraz znajomość lokalnych spraw i ludzi. Część tekstów ironicznych nie mogłaby być odczytana bez znajomości realiów kulturowych. Sygnałem wystąpienia tego zjawiska jest w tekście niezgodność opisu ze stanem rzeczywistym.

\section{D / K - M / III / III

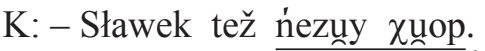

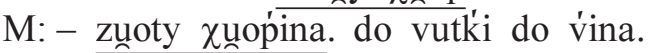

Ironia to specyficzna forma oceny negatywnej, w konwersacji wyrażenia ironiczne ulegają przewartościowaniu. Środki językowe zastosowane w pierwszej części wypowiedzi kreują jak najlepszą opinię o osobie. Pozytywnie wartościuje wyrażenie złoty chlop, dodatkowo wzmocnione wymianą komponentu na leksem chłopina. Ironicznemu przewartościowaniu komunikatu służy pauza, która czasem bywa silniejszym środkiem wyrazu niż sam dźwięk; rozmówca wykorzystuje ją z perswazyjnym zamysłem, kształtując napięcie emocjonalne przekazu, które służy zainteresowaniu odbiorcy i zwiększa efekt zaskoczenia. Ważna jest także gestykulacja nadawcy - ruch dłoni w stronę szyi, który podkreśla przewrotną intencję komunikatu. Gest jest czytelnym i sugestywnym komentarzem do wypowiedzi, wspomagającym jej warstwę słowną. Wyrazistość wypowiedzi została wzmocniona także przez znaczacy uśmiech. Kod pozawerbalny pozostaje w relacji funkcjonalnej z treścią, ułatwiając odbiór komunikatu słownego. Relacje między wypowiadanym tekstem a towarzyszącą mu komunikacją pozasłowną, wprowadzającą dodatkowe informacje, narzucają właściwy sposób interpretacji, dopełniają się i wzmacniają ekspresywność przekazu. Nadawca bawi odbiorcę, wykorzystuje humor, nadając wypowiedzi kpiarski, ironiczny ton. Monotonię przekazu rozbija rym, który zwraca uwagę na wybrane fragmenty i ułatwia zapamiętanie treści. Uczestnik procesu komunikacji odwołuje się do ironii jawnej, która potęgowana jest określonymi sygnałami, zauważalnymi na poziomie językowym i w sferze pozajęzykowej: w gestykulacji, mimice, intonacji. Ironiczną charakterystykę dodatkowo wzmacniają towarzyszące wypowiedzi elementy: wtaściwa intonacja, tembr glosu, rytm oraz gestykulacja i mimika, które czynią przekaz bardziej sugestywnym.

Ironia stanowi strategię aktywizacji odbiorcy; w przypadku wypowiedzi ironicznej odbiorca jest zmuszony do samodzielnego odczytania przekazu. Analizowana wypowiedź jest formą „obelżywej pochwały” (Bachtin 1975: 258), która odwraca sens przekazywanej treści w stosunku do formalnej intencji. Zabieg taki jest często wykorzystywany w strategii politycznej.

W analizowanym materiale ironii służyły różnorodne środki językowe. Ironia to sposób wypowiadania się, w którym nadawca świadomie odwołuje się do 
niezgodności, opierającej się na przeciwieństwie dwóch poziomów wypowiedzi: dosłownego i ukrytego. M. Karwat (2006: 333) wskazuje na siłę sugestii w taktyce ironicznej, która „polega na wytworzeniu wrażenia, że ktoś dostrzega, wie i rozumie więcej niż mówi (pisze, rysuje) i więcej niż są w stanie odgadnąć (przynajmniej w pierwszej chwili) odbiorcy jego komunikatu". Ironia werbalna odwołuje się do: niezgodności stylistycznej, porównania, hiperboli czy też pytania retorycznego i często jest wspomagana ironią pozasłowną wyrażoną gestem, mimiką, intonacją. Zabieg taki pozwala nawiązać swoistego rodzaju więź między nadawcą i odbiorcą. Porozumienie jest realizowane zarówno na płaszczyźnie ekspresji (swoista gra z odbiorcą), jak i na płaszczyźnie treści komunikatu (wskazanie podobnego sposobu postrzegania tematu). Umiejętnie zastosowana ironia pozwala w sposób zawoalowany wyrazić uczucia negatywne, takie jak drwina, sarkazm czy pogarda. Jako środek stylistyczny wzbogaca wypowiedź, dzięki niej nadawca wyśmiewa ludzkie wady i przywary, wyznacza swój stosunek do świata i opisywanych zjawisk.

Ironia jako strategia wartościowania wymaga od odbiorcy rekonstrukcji intencji nadawcy, tj. wydobycia rzeczywistych motywów użycia danego środka językowego.

\section{Związki frazeologiczne jako środek perswazji}

Frazeologizmy (zob. Chlebda 1996) to specjalna grupa jednostek językowych. Gotowe, odtwarzane z pamięci struktury są istotnym elementem perswazji, ponieważ wyrażają uogólnione znaczenie. Wynikający z ich zastosowania efekt polega na tym, że wzbogacają tekst poprzez obrazowe przedstawienie treści, które ma istotny wpływ na odbiór i wartościowanie wypowiedzi (Burska-Ratajczyk 2008: 71-84). Problematyka wartościowania we frazeologii została omówiona przez A. Pajdzińską (2006b: 129-147). W wielu frazeologizmach uobecnia się komizm, który, umiejętnie spożytkowany dla celów humorystycznych i parodystycznych, służy uwypukleniu absurdalnych zachowań czy postaw. Połączenia wyrazowe często zawierają silny ładunek emocjonalny, który jest przydatnym środkiem przekonywania (zob. Lewicki 1995).

Trwałe połączenia wyrazowe są wyjątkowo użyteczne w komunikacji językowej, ponieważ odzwierciedlają doświadczenia życiowe społeczności, a ponadto charakteryzują się swoistym dydaktyzmem, są proste, zwięzłe, posiadają wartość jako swego rodzaju prognostyki. A. Pajdzińska (2006b: 8) pisze: „Frazeologizmy są [...] materiałem szczególnie cennym. Powszechnie uznaje się je przecież za jednostki charakterystyczne dla danego języka, decyzujące o jego swoistości, odrębności, można więc zakładać, że właśnie w nich odzwierciedla 
się specyfika myślenia pewnej wspólnoty, właściwe jej sposoby konceptualizacji elementów świata $[\ldots] "$ ".

Frazeologizmy uzupełniają system językowy i powiększają zasób synonimicznych środków leksykalnych. Badacze (zob. Kurkowska, Skorupka 2001: 152) zaliczają je do leksykalnych środków stylistycznych, które stanowią o urodzie tekstu i jego atrakcyjności dla odbiorcy.

Istotny walor perswazyjny mają związki wyrazowe, funkcjonujące w polszczyźnie potocznej. Posiadają one określony ton uczuciowy, a ich charakterystycznym wyróżnikiem jest antropocentryzm (zob. Pajdzińska 2006a: 104-113; Rak 2006: 367-375). D. Buttler (1981: 202) wskazuje, że: „,...] frazeologię potoczną różni od pisanej wyraźniejsze nasycenie emocjonalne i charakter na ogół żartobliwy, ironiczny lub szyderczy. Stanowi ona środek wyrażenia określonej, zwykle negatywnej postawy mówiących wobec pewnych zjawisk realnych".

Frazeologizmy potoczne sprawiają, że wypowiedź jest łatwiejsza w odbiorze. Słuchacz ma wrażenie, że nadawca mówi tym samym językiem, stosuje te same zwroty, co on. Zatem stylistyczna funkcja związków frazeologicznych łączy się zarazem z procesem przekonywania odbiorcy oraz kształtowaniem jego opinii i postaw, wspomaga więc funkcję impresywną wypowiedzi.

\subsection{Frazeologia gwarowa. Pojęcie frazeologizm gwarowy}

Połączenia gwarowe były już przedmiotem eksploracji (zob. Treder 1982: 125-133; Krawczyk 1985: 129-137; Krawczyk-Tyrpa 1987; Rak 2006: 367-375), nadal jednak stanowią ciekawy, trudny, nie do końca jeszcze zbadany i wciąż wymagający opracowania obszar badań (zob. Czesak 1998: 285-293).

Pojęcie frazeologizm gwarowy może być różnie ujmowane: szeroko jako każda jednostka obecna w gwarze, przynależna do tradycji i doświadczenia społeczności wiejskiej także tożsama z literacką lub wąsko - jako jednostka różna w porównaniu z polszczyzną ogólną (por. Górnowicz 1975: 80-84).

W pracy ludowa jednostka frazeologiczna rozumiana jest szeroko bez względu na jej zasięg użycia. W analizowanych tekstach warstwa frazeologiczna jest bogata i różnorodna. Czasem pojawiają się związki dosadne, a nawet frazeologiczne wulgaryzmy, które nasycają mowę mieszkańców wsi silnym pierwiastkiem emocjonalnym, nie są one jednak pozbawione elementów humoru. Występujące połączenia wyrazowe określają semantykę wypowiedzi, nadając jej charakterystyczny rys. Ponadto urozmaicają przekaz, budzą zainteresowanie odbiorcy, czasem zaskakują go swą przewrotną wymową. Dzięki frazeologizmom wypowiedź staje się bardziej wyrazista i sugestywna. 


\subsection{Frazeologizmy potoczne}

W komunikacji ludowej chętnie wykorzystywane są frazeologizmy stylu potocznego, zwłaszcza ekspresywne, wartościujące, które mają istotne znaczenie w przekonywaniu, ponieważ wzmacniają perswazyjność przekazu.

D / K - M / III / IV

K: - cungńe śe ta budova. ie ešče ne vykuịnčyuny.

M: - tak to ie, iak' śe zacyno unod dupy sțruny.

Silnie perswazyjną wymowę ma brak racjonalnych zasad działania, który podkreśla zwrot: zaczynać od dupy strony. Nadawca wskazuje, że plany i projekty, które osoba zamierzała zrealizować, oparte były na niewłaściwych podstawach, a działanie chaotyczne, bez planu musi zakończyć się niepowodzeniem.

D / K1 < K2 / III / IV

K1:- ńiz ne leṕi. ne robi, pii ine, ł́ećakom dokučo, m’ne vyzyvo.

K2: - pov́inunaź źada vyval'ỉ́ na zbity pysk. na luźi ne pațš. višs, že na naz možež l'ičyć. j̇ećokom śe pumože.

Za pomocą frazy ekspresyjnej wywalić kogoś na zbity psyk matka namawia córkę do poczynienia radykalnych zmian w życiu. Wskazuje, że nie powinna godzić się z uzależnieniem współmałżonka tylko mu zdecydowanie przeciwdziałać. Obiecuje wsparcie, buduje zaufanie i poczucie bezpieczeństwa. Wypowiedź ma skłonić kobietę do obiektywnego spojrzenia na to, co dzieje się w jej rodzinie i zawiera wezwanie do podjęcia właściwych środków zaradczych. Rozmówczyni przekonuje córkę do odrzucenia lęku, podkreśla, że nie należy przejmować się krytyką innych, ale polegać na własnej ocenie sytuacji. W wypowiedzi zawarta jest także obietnica pomocy wnukom. Wzmocnieniu przekazu służy odwołanie się do $z a$ sady bliskości.

Frazeologizmy wyrażają silne emocje nadawcy, pośrednio go charakteryzując (Lewicki, Pajdzińska 2001: 328). Potęgują plastyczność tekstu i siłę jego oddziaływania. Badacze (zob. Kurkowska, Skorupka 2001: 177) podkreślają, że zaletą związków frazeologicznych jest również to, że: ,abstrakcyjne cechy, pojęcia, stany psychiczne, przeżycia wewnętrzne, czynności i zdarzenia są w nich niejako przetłumaczone na to, co widzialne i dotykalne". Wyborowi frazeologizmów jako środków perswazji sprzyja także ich obrazowość i metaforyczność.

\section{D / M - K / III / III}

M: - j́ćak'i, ne tak'ie, iag u Stachy.

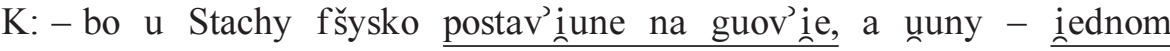
rypke idum.

Zwrot iść w jedna rękę, por. iść z kimś ramię w ramię, ręka w rękę - 'współpracować, współdziałać z kimś', podkreśla, że sukces wychowawczy zależy od tego, 
czy rodzice wspólnie uzgadniają działania dotyczące rozwoju dziecka. Semantyka zwrotu postawić coś na głowie - 'postępować wbrew utartym zwyczajom, ustalonemu porządkowi', odwraca naturalny bieg rzeczy, a działanie takie nie ma szans na powodzenie. Glowa traktowana jest jako najważniejsza część ludzkiego ciała, siedlisko myśli. Użyty zwrot krytykuje próbę odwracania naturalnego porządku rzeczy jako przejaw głupoty i braku pragmatyzmu.

Niekiedy w wypowiedzi nadawca wykorzystuje więcej niż jeden związek frazeologiczny.

D / K - M / III / III

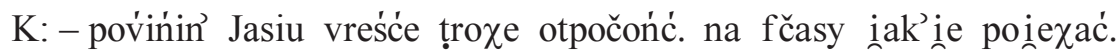

M: - g'źe ći unun poiaźe. sadeg dokupiuny, to tyro, śs inuntek p’iuntek, bes cauny božy žiń, unot’ śfytu do puźny nocy.

Użyty w wypowiedzi czasownik tyrać i zestawienie wyrażeń: świątek piatek'codziennie', cały boży dzień - 'od chwili powstania jasności dziennej do chwili zapadnięcia ciemności', od świtu do późnej nocy, por. dzień - 'okres aktywności człowieka', noc - 'pora odpoczynku, czas snu', służą hiperbolizacji, podkreślają wyjątkową pracowitość osoby. Nagromadzone w wypowiedzi powiązane znaczeniowo połączenia wyrazowe służą gradacji, intensyfikują ocenę i czynią przekaz wyjątkowo ekspresywnym.

\section{D / K1 $<$ K2 / II / IV}

K1:- zafše ia mam ustomṕić.

K2: - moṇụžeinšy muśi. po co žyź iak p’ies s kotym?, co to da, že se beźeta skakaj́ do gardeụ? ț̆a iakoź doịż do porozuminá.

Niejednokrotnie w celach perswazyjnych nadawca wykorzystuje połączenia bliskie sobie znaczeniowo, por. żyć jak pies z kotem - 'w niezgodzie', skakać sobie do gardet - 'kłócić się zawzięcie', przez co jeszcze bardziej akcentuje najważniejsze elementy przekazu.

\subsection{Frazeologizmy o ograniczonym zasięgu występowania}

W grupie połączeń wyrazowych, stosowanych w komunikacji mieszkańców wsi, istotne znaczenie mają te, które są właściwe dla określonego kręgu kulturowego, ich rozumienie ma związek ze znajomością lokalnej gwary. Zastosowane w wypowiedzi frazeologizmy o ograniczonym zasięgu występowania mają szczególny walor komunikacyjny, są bowiem wyrazem poszukiwania wspólnej płaszczyzny językowej z odbiorcą komunikatu. T. Zgółka (2001: 417-418) pisze: „Pojawienie się takiego połączenia słownego stanowi niejednokrotnie sygnał nadawcy, skierowany do potencjalnego odbiorcy, będącego uczestnikiem tej samej wspólnoty kulturowej opartej na podobnych doświadczeniach historycznych, 
symbolice, aksjologii itp. To demonstracja wspólnego kodu, służąca m.in. «skróceniu dystansu» między nadawcą a odbiorcą".

W przypadku omawianych połączeń istotne znaczenie ma fakt, że nadawca i odbiorca posiadają podobną wiedzę kulturową. Elementy te są czasem niezbędne dla właściwego zrozumienia przekazu. Ponadto środki te pokazują swoisty sposób widzenia i wartościowania świata, utrwalają określoną hierarchię wartości i cementują lokalną wspólnotę.

\section{D / K1 - K2 / III / III}

K1:- Romek iexau, to se zabraunam, ale može ne f pore?

K2: - tylko nuški opsypać pop’ioungm.

Pierwsza z kobiet pyta, czy niezapowiedzianą wizytą nie sprawiła gospodyni kłopotu. Rozmówczyni kieruje do niej słowa obsypać nóżki popiołem. Ten gwarowy zwrot oznacza radość z wizyty niespodziewanego, miłego gościa. Używając go, kobieta podkreśla życzliwość wobec gościa, zaznacza, że wita go serdecznie.

\section{D / M - K / III / III}

M: - tưumačta, bo škoda taki kobitki ḍla ńego.

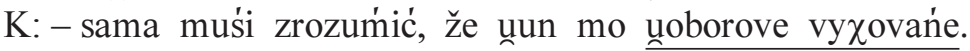

Wyrażenie o charakterze eufemizmu - oborowe wychowanie wskazuje, że mężczyzna zachowuje się w sposób, który narusza normy dobrego tonu i etykiety, podkreśla niestosowność jego postępowania. Przymiotnik oborowe eksponuje 'brak kultury, manier, taktu'. Samo wyrażenie kojarzy się z używanym w polszczyźnie ogólnej połączeniem wyrazowym staranne wychowanie i w przewrotny sposób modyfikuje treść pierwowzoru.

\section{D / K1 - K2 / III / IV}

K1:- Romek $\chi$ eba byu ślepy, v'żuu se taki unadny mebel.

$\mathrm{K} 2:-$ to ne šklanka, ne pšeižyš.

Pierwsza z kobiet podkreśla, że mężczyzna źle ulokował swoje uczucia, służy temu metaforyczne użycie przym. ślepy oraz ironiczno-złośliwe wyrażenie ładny mebel - przen. 'o osobie podstępnej, która chce uchodzić za naiwną'. Druga rozmówczyni sformułowaniem to nie szklanka, nie przejrzysz wskazuje, że wybór jest zawsze trudny, ponieważ pewnych sytuacji życiowych nie da się przewidzieć. Prawdopodobieństwo udanego związku jest równe prawdopodobieństwu zaistnienia nieudanego.

\section{D / K - M / III / III}

$\mathrm{K}:-$ tyle ty $\chi$ spaf, zagućta se i iuš.

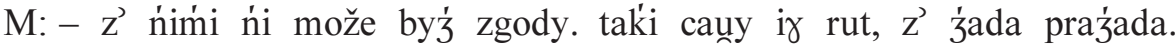
bedum se pravovaź uno kumarove saduno. 
Kobieta namawia rozmówcę do rozwiązania sąsiedzkiego konfliktu. Użyty przez mężczyznę frazeologizm $z$ dziada pradziada - 'od dawna, od wielu pokoleń', podkreśla, że pieniactwo jest cechą właściwą członkom zwaśnionej strony. Humorystyczne wyrażenie komarowe sadto - 'drobiazg, rzecz małej wagi, głupstwo' wskazuje na błahy powód, nieistotną przyczynę sporu. Tak skonstruowana wypowiedź charakteryzuje się sporym ładunkiem komicznym, który uwypukla dezaprobatę wobec niepohamowanej chęci procesowania się z byle powodu. Absurd, jaki jest wpisany w przekaz, powoduje, że nabiera on wartości ironicznej, służy budowaniu dowcipu, który staje się istotnym elementem służącym negatywnej ocenie przedstawionego postępowania.

\section{D / K - M - Bu / III / IV / I}

$\mathrm{K}$ : - $\chi$ lebeg mu ḍrobno pokraiaunam i proše i proše, a unuń ńe $\chi$ ce ieś. M: - to ne pšymušein! mamuśa go sứvičymí i̧zyčkami kar’mi.

Mężczyzna przekonuje, że nie należy zmuszać dziecka do jedzenia. Wyrażenie słowicze języczki w zabawny sposób podkreśla, że dziecko jest przesadnie wybredne, rozpieszczone przez matkę, dogadzającą jego wyszukanym upodobaniom kulinarnym.

\section{D / K - M / III / IV}

$\mathrm{K}$ : - robiu u ćotki, to mo odunožune.

M: - g’źe tam unun mo ṕininze? robiun d’ iabunu na kapeluš.

Zwrot robić diablu na kapelusz - 'pracować za darmo', jest przejawem ludowego dowcipu i inwencji, odwołuje się do działań, które nie przynoszą efektu. Dzięki wyrazistości i humorowi lepiej przemawia do odbiorcy.

\section{D / K - M / III / IV}

$\mathrm{K}:-$ ńe fṭruncei se do muody $\chi$.

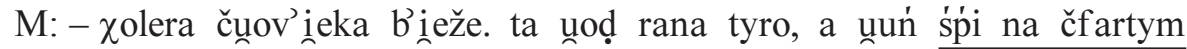
boku.

Rozmówcę denerwuje fakt, że kobieta ciężko pracuje, co podkreśla czasownik tyrać, a mężczyzna odpoczywa, por. zwrot spać na czwartym boku - żart. iron. 'spać bardzo mocno, głębokim snem'. Frazeologia zawierająca liczebniki (Burska-Ratajczyk 2010b: 25-36) jest nacechowana emocjonalnie, silniej wpływa na odbiorcę. Połączenia tego typu służą hiperbolizacji, często mają określony wydźwięk ekspresywny (najczęściej zawierają pewien pozytywny lub negatywny) ładunek uczuciowy.

\section{D / K1 - K2 / III / III}

K1:- zafše śe muśi sṕirać.

K2: - to z’ ńim ne gadeî. ne višs, že unun frsysko vii, a mo rozumu za śedmin gunupix. 
Kobieta przekonuje rozmówczynię, żeby nie wdawała się w dyskusję z osobą, która w każdej z poruszanych kwestii jest przekonana o swojej nieomylności. Wypowiedź dzięki zastosowaniu przeciwstawnych semantycznie zwrotów, por. wszystko wiedzieć i gw. mieć rozumu za siedmiu głupich - 'być wyjątkowo głupim', nabiera silnego wydźwięku ironicznego i służy hiperbolicznej ocenie intelektu osoby, o której mowa.

\subsection{Innowacje frazeologiczne}

Związki frazeologiczne bywają w wypowiedziach poddawane różnorodnym modyfikacjom strukturalnym, które czasem prowadzą do śmiesznych deformacji, jednak zawsze powodują, że słuchacz staje się jednocześnie dociekliwym i krytycznym odbiorcą. Modyfikacje świadome da się uzasadnić funkcjonalnie jako przejaw kreatywnego stosunku do języka (zob. Majkowska 1988: 143-144) czy też dbałości o niepowtarzalny, oryginalny kształt wypowiedzi (por. Bąba 1989:34).

Odmienny sposób wyrażania treści zmusza rozmówcę do wnikania w głęboki sens znaków językowych. Zmiana utrwalonych w tradycji językowej połączeń wyrazowych to nie tylko nowy sposób mówienia, to również nowe efekty i nowe wartości znaczeniowe, które przyczyniają się do uplastycznienia i ukonkretnienia wypowiedzi. Innowacje frazeologiczne wprowadzane z rozmysłem służą możliwie najbardziej adekwatnemu wyrażeniu treści oraz jednoznacznemu wartościowaniu poprzez uwypuklenie zalet lub wskazanie wad.

W wielu frazeologizmach modyfikacja uruchamia komizm, umiejętne spożytkowanie połączeń dla celów humorystycznych i parodystycznych uwypukla absurdalność zachowań. Innowacje zawierają silny ładunek emocjonalny, chodzi w nich nie tylko o odświeżenie konstrukcji, wprowadzenie elementu humoru, ale także o zwrócenie uwagi na sam komunikat, co z punktu widzenia retoryki daje wyrazisty efekt.

Wszelkie modyfikacje (świadome lub niezamierzone) wpływają na treść i zmieniają nacechowanie wypowiedzi. W stałych związkach frazeologicznych, które mają utrwalony szyk, skład leksykalny oraz kształt gramatyczny, tylko w niewielkiej części połączeń dopuszczalne jest naruszenie ich stabilności.

$\mathrm{W}$ analizowanych wypowiedziach związki frazeologiczne bywają poddawane różnorodnym modyfikacjom strukturalnym, a naruszenie normy jest obliczone na osiągnięcie zamierzonych efektów perswazyjnych. Innowacje powodują, że wypowiedź staje się bardziej obrazowa, przykuwa uwagę odbiorcy i łatwiej do niego dociera. S. Bąba (1989: 67) podkreśla, że: „Innowacja zamierzona jest często wynikiem działania, mającego zaskoczyć odbiorcę wypowiedzi, programowej nieufności do języka jako narzędzia subiektywnego opisu i interpretacji świata, a także przekory językowej czy też poczucia troski o niepowtarzalny, oryginalny kształt wypowiedzi i sposób przyoblekania myśli w słowa". 
Wszelkiego rodzaju odstępstwa od normy frazeologicznej pełnią funkcję stylistyczną i perswazyjną, wykorzystywane są w celu wzmocnienia oddziaływania na odbiorcę, na jego zachowanie, opinie, postawy czy sądy (zob. Jachimowska 2001: 93). W. Chłopicki (2002: 23) widzi w połączeniach wyrazowych istotny element przekazu, kształtujący profil wypowiedzi: „Uczestnicy procesu komunikacji szukają różnych sposobów uatrakcyjnienia sobie tego procesu, [...] wykorzystują bardzo pożyteczną cechę komunikacji, jaką jest jej wieloznaczność i możliwość wielorakiej interpretacji kontekstowej w zależności od intonacji, szyku wyrazów, zastosowanych frazeologizmów, wywołanych konotacji itp.”.

\subsubsection{Innowacje rozwijające}

Innowacje rozwijające polegają na uzupełnieniu składu leksykalnego jednostki frazeologicznej nowymi komponentami (zob. Bąba 1989: 5). Są nimi najczęściej wyrazy nacechowane emocjonalnie (obiektywnie lub subiektywnie). Zmiany w składzie słownym wyrażają treść w sposób bardziej sugestywny.

\section{D / M1 - M2 / III / IV}

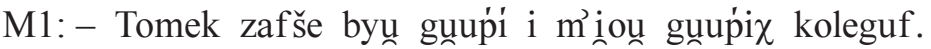

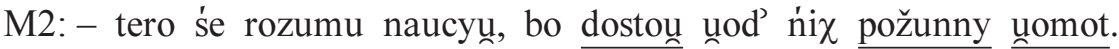

Zwrot dostać łomot - 'zostać zbitym', został uzupełniony leksem porzadny, który wzmacnia siłę przekazu.

\section{D / K1 - K2 / III / III}

K1: - tak'ie spravy to povinny oḍ razu rossuńżić.

K2: - ale som' źećoki, to $\chi$ 'ćauny pogoźić. a suotk iego žyća to ununa

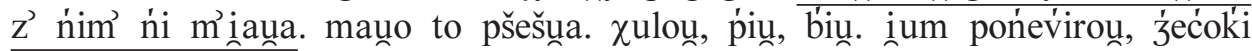
loụ. neros to $\mathrm{mu}$ rong byuno mauno, to noǵi sŭuy $\mathrm{v}$ robote. íle razy $\mathrm{v}$ nocy ućekauny, po sum'śada $\chi$ spauny.

Zwrot nie mieć słodkiego życia, por. fraz. pot. mieć słodkie życie - 'bardzo wygodne, beztroskie, przyjemne warunki egzystencji', jest elementem służącym przewartościowaniu, który wprowadza odbiorcę w dokładny opis przemocy rodzinnej.

\subsubsection{Innowacje skracające}

Innowacje skracajace polegają na uszczupleniu składu leksykalnego danej jednostki frazeologicznej (zob. Bąba 1989: 49).

D / K - M / III / III

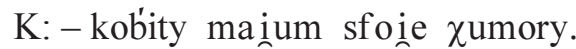

M: - a moina kobita do rany pšyunuš, iag in pšytakuieš. 
Nadawca odwołał się jedynie do drugiej części frazeologizmu, por. dobry, mity, zacny itp., że choć do rany przytóż - 'bardzo, nadzwyczaj dobry, miły itp.' . Redukcja pozytywnie waloryzowanych określeń zawartych w pierwszej części związku oraz dalszy ciąg wypowiedzi sugerują, jaką postawę powinien przyjąć odbiorca względem przekazywanej treści. Istotne znaczenie ma także akcent, padający na czasownik. Element prozodyczny podkreśla ironiczny charakter wypowiedzi.

\subsubsection{Kontaminacje frazeologiczne}

Efekty ekspresyjne osiąga się również w wyniku kontaminacji dwóch związków frazeologicznych, które zawierają w strukturze leksem, będący ich wspólnym komponentem. Następuje wtedy skondensowanie wartości jednostek i przewartościowanie znaczenia.

\section{D / K1 - K2 / III / III}

K1:- Ewa roboty šuko.

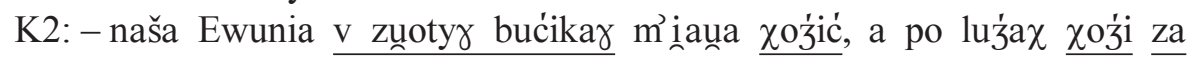
robotom.

W wypowiedzi wykorzystano dwa zwroty: gw. chodzić w złotych bucikach - 'opływać w bogactwie, dostatku', w którym połączenie złote buciki rozumiane jest jako symbol bogactwa, przepychu, zbytku, życia w luksusie i wskazuje na to, co nieosiągalne oraz połączenie chodzić za robota 'szukać pracy'. Konfrontacja znaczenia związków podkreśla nieprzystawalność przedstawionych realiów i nadaje wypowiedzi charakter swoistego sarkazmu, który wzmacnia perswazyjność przekazu.

\subsubsection{Innowacje wymieniające}

Według S. Bąby (1989: 49) innowacje wymieniajace ,[...] powstają w wyniku wymiany komponentu na jakiś inny wyraz, który mówiącemu wydaje się atrakcyjniejszy od występującego w danym frazeologizmie". Mogą obejmować jeden lub $d w a$ wyrazy.

D / K1 - K2 / III / III

K1: - $\chi$ ce, vrućić.

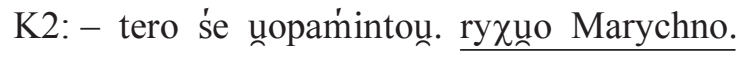

Wyrażenie rychto w czas używane wtedy, gdy się chce powiedzieć, że 'na coś jest za późno', zastąpiono por. rychło Marychno, w którym nieoficjalna forma imienia własnego jest elementem służącym rytmizacji wypowiedzi.

D / M - K / III / III

M: - ale ununa muvii, že ie inno.

$\mathrm{K}$ : - tako inag mamuśa. pšygańauna motyka gracy. 
Kobieta podkreśla, że matka i córka mają podobne wady. We współczesnej polszczyźnie funkcjonuje zwrot: przyganiał kocioł garnkowi, różniący się od wariantu gwarowego: przyganiała motyka gracy końcowymi komponentami, które zawierają typowe ludowe realia.

Wymiana komponentu w obrębie frazeologizmu wyraźnie wpływa na zmianę związku, służy podkreśleniu tego, co niesie istotną dla odbiorcy treść. Nadawca stosuje zabieg dla wywarcia określonego efektu. Zmiany w obrębie połączeń wyrazowych są chętnie wykorzystywane jako środek perswazji w różnych typach komunikatów, np. w reklamie, w dyskursie politycznym, religijnym, ponieważ wprowadzają określone konotacje, służące wzmocnieniu oddziaływania perswazyjnego.

\subsubsection{Innowacje regulujące}

Innowacje regulujące (zob. Bąba 1989: 60) dotyczą przekształceń, takich jak: zmiana w zakresie kategorii liczby, strony, aspektu, postaci słowotwórczych komponentu i zmiana schematu składniowego całej jednostki frazeologicznej. Zmiana w zakresie postaci słowotwórczej komponentu polega na zastosowaniu formacji o charakterze ekspresywnym. Zabieg taki podnosi nacechowanie emocjonalno-stylistyczne (żartobliwe, familiarne, dosadne, rubaszne) wypowiedzi, zwiększając skuteczność przekazu.

\section{D / K1 - K2 / III / III}

$\mathrm{K} 1$ : - poraźi se, poraźi.

K2: - ńe poraźi, bo ununa go caune žyće za ruṇčke provazo.

Kobieta podkreśla, że matka poprzez nadopiekuńczość, nie dopuszcza do ujawnienia się samodzielności dziecka, por. prowadzić kogoś za rękę - 'nie pozwalać dziecku na wykazanie się własną inicjatywą', tu: rączkę.

\section{D / M - K / IV / IV}

M: - țšeba luźom v’i ežyć.

K: - m’ne ne unošuko. unocyska beje vybaunušać, božyć se beźe, a kryńći iak p’iez unogunem.

Ocenie nieuczciwego zachowania osoby służą czasowniki: oszukać, bożyć się 'przysięgać', tu w zn. krzywoprzysięgać. Istotne znaczenie ma ponadto dokładny opis mimiki twarzy kobiety, który oddaje zwrot wybałuszać oczy, ślepia - 'patrzeć na kogoś, na coś z ciekawością, uważnie, z natężeniem'. Użyty w nim wyraz oczyska augm.-ekspr. od oko jest bardziej sugestywny. Tę obrazowość wzmacnia metaforyczny zwrot kręcić jak pies ogonem - 'mówić oczywistą nieprawdę; zmieniać zdanie w zależności od sytuacji', który wpływa na sposób oceny przekazu. Odbiorcy w zapamiętaniu informacji służy ponadto kod pozawerbalny (ruch gałek ocznych i ruch dłoni w kierunku serca), który ma naśladować zdziwienie i uroczysty gest przysięgi. Wzrok odgrywa ważną rolę w codziennej interpretacji zjawisk, 
ponieważ jak podkreśla B. Bergström (2009: 79): „Nasz zmysł wzroku wysyła do mózgu najwięcej sygnałów”. Doświadczenia wizualne mają istotne znaczenie w odczytywaniu i interpretowaniu przekazu słownego.

D / K - M / III / III

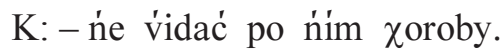

M: - bo tero tu vyglundo iak puncuxno.

Zastosowany rzeczownik paczuchna, por. jak paczek w maśle - 'bardzo dobrze', w szczególny sposób podkreśla cechy fizyczne, doskonały wygląd mężczyzny.

D / M - K / III / III

M: - unun by za j́ećokamy f p’iekuo vlos.

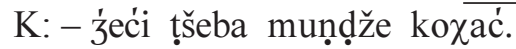

Użyty przez mężczyznę leksem pot. wleźć wskazuje na najwyższy stopień poświęcenia. Podkreśla, że osoba jest bezgranicznie oddana dzieciom, por. iść, pójść za kimś do piekła - 'być gotowym zrobić dla kogoś wszystko'.

D / K - M / III / IV

$\mathrm{K}:-$ zafše to čuov'ieka škoda.

M: - m’ne tam ńe škoda. myśloun, že se unudo sund unošukać, a tu kartecka se odvruciuna i klamecka zapaduna.

Mężczyzna informuje rozmówczynię, że nie jest mu żal osoby, która postępowała w sposób nieuczciwy, ponieważ człowiekowi, o którym mowa, wydawało się, że jego dobra passa będzie trwała wiecznie, ale sprzyjające okoliczności minęły. W zwrotach zastosowano formacje deminutywne: karteczka, klameczka, por. fraz. kartka się odwróciła - 'sytuacja się zupełnie zmieniła' i klamka zapadła, zapadnie - 'stało się, stanie się coś, czego nie da się cofnąć, odwołać'. Zmodyfikowane połączenia nadają wypowiedzi odcień ironiczny.

\subsubsection{Dopelnienie jednostki frazeologicznej}

Dopetnienie jednostki frazeologicznej tworzy zupełnie nową jakość przekazu. Zabieg ma wywołać efekt zaskoczenia i zainteresować odbiorcę treścią. Czasem modyfikacja prowadzi do istotnego przewartościowania, które zmienia pierwotny sens połączenia wyrazowego i zmusza rozmówcę do odgadnięcia rzeczywistych intencji nadawcy.

\section{D / M1 - M2 / III / III}

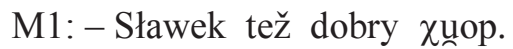

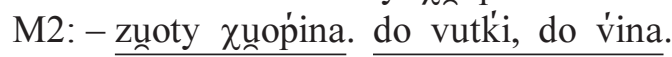

Pierwsza część wypowiedzi kreuje najlepszą opinię o osobie, co oprócz pozytywnie wartościującego wyrażenia, por. równy, złoty chtop, dodatkowo podkreśla wy- 
miana komponentu na leksem chłopina. Dopiero druga część przekazu wprowadza ironiczne przewartościowanie. Ironia stanowi strategię aktywizacji odbiorcy. W przypadku wypowiedzi ironicznej jest on zmuszony do samodzielnego odczytania treści. W analizowanym przekazie mamy do czynienia z formą „obelżywej pochwały" (zob. Bachtin 1975: 258), która odwraca sens przekazywanej treści w stosunku do formalnej intencji.

\section{D / M - K / III / III}

M: - z' ńim to i iešče možna pogadać.

$\mathrm{K}$ : - ia to naved $\mathrm{z}^{\prime}$ ńim n'e gadam, unun tys sparty iak ośeu f kapuśce.

Niekiedy w tekstach pojawiają się porównania znane z codziennej praktyki językowej, które poprzez uzupełnienie składu leksykalnego uzyskują dodatkowe wzmocnienie emocjonalne: uparty jak osioł, por. sparty jak osioł w kapuście. Zabieg ma na celu podkreślenie wyjątkowego uporu osoby, ponieważ osiot - przen. 'określenie człowieka głupiego i upartego', zresztą niesłusznie, uważany jest za zwierzę głupie i uparte.

Zaprezentowany materiał pokazuje, że w gwarach odnajdujemy jednostki charakterystyczne dla polszczyzny potocznej oraz swojskie połączenia wyrazowe, które utrwalają świat wartości charakterystyczny dla danej grupy społecznej. Frazeologizmy potoczne przyczyniają się do wyrazistości i plastyki obrazu, dzięki nim nadawca ujmuje zjawiska, które wymagałyby dłuższego opisu, w sposób zwięzły, nadając im jednoznaczną aksjologiczną ocenę. Frazeologizmy o ograniczonym zasięgu występowania mają dodatkowy walor perswazyjny, ponieważ tworzą szczególny rodzaj porozumienia między nadawcą i odbiorcą, dają poczucie bliskości, swojskości, które jest czynnikiem integrującym rozmówców.

Ciekawym zabiegiem są modyfikacje połączeń. Wykorzystując je, nadawca intensyfikuje ocenę i podnosi ekspresywność informacji. Czasem innowacja powoduje, że zespolenie nabiera humorystycznego lub ironicznego wydźwięku.

\section{Intertekstualność jako atrakcyjny środek strategii perswazyjnej}

Istotne znaczenie $\mathrm{w}$ procesie przekonywania ma także umiejętność improwizacji nadawcy, która służy uatrakcyjnieniu przekazu i zaciekawieniu odbiorcy prezentowanymi treściami. Intertekstualność w ujęciu M. Głowińskiego (1986: 75-100) oznacza pewnego typu związki łączące dany tekst z innymi, dzięki niej możliwa jest interdyskursywność oraz zawiązanie relacji międzysystemowych w obrębie literatury i kultury. Intertekstualność może być pojmowana jako obszar wszelkich asocjacji tekstowych konkretnego odbiorcy. R. Nycz (1990: 95-116) definiuje ją jako: ,[...] ogół właściwości i relacji tekstu, który wskazuje na uzależnienie jego wytwarzania i odbioru od znajomości innych tekstów oraz «ar- 
chitekstów» (reguł gatunkowych, norm stylistyczno-wypowiedzeniowych) wśród uczestników procesu komunikacyjnego, jest zarówno określeniem sfery niezbywalnej mediatyzacji między ogółem intratekstualnych właściwości i relacji a polem ekstratekstualnych odniesień i uwarunkowań w społecznej, historycznej, kulturowej rzeczywistości [...]".

D. Zdunkiewicz-Jedynak (2008) uważa, że intertekstualność w jakimś stopniu obejmuje problematykę stylizacji. W obręb intertekstualności wchodzą zamierzone, a nie przypadkowe relacje z innymi utworami. Tradycja literacka, wpływy literackie, zapożyczenia, cytaty, system stylistyczny - wszystko to tworzy układ odniesienia dla danego tekstu. Wewnątrz jednego tekstu wytwarza się interakcja $\mathrm{z}$ innymi tekstami.

Intertekstualność, choć najlepiej zbadana na gruncie literatury, nie zamyka się w obrębie utworów literackich. Jest zjawiskiem dotyczącym nie tylko pisanych, ale i mówionych odmian mowy.

H. Markiewicz (1988: 245-263) przez intertekstualizm rozumie interakcję tekstową, która wytwarza się wewnątrz jednego tekstu. Wyznacznikami tego zjawiska są:

- intekstualizacje,

- cytaty,

- transformacje tematyczne,

- nawiązania tematyczne,

- ikonizacje,

- stylizacje, pastisze, parodie,

- imitacje,

- konfrontacje,

- metatekstualizacje.

Jak wynika z badań, człowiek wychowany w kulturze wizualnej nie potrafi już śledzić ani zapamiętać logicznie skonstruowanej mowy, angażuje go natomiast anegdota, przypowieść, opowiadanie, czyli to, co pobudza wyobraźnię, zaciekawia swą akcją i obrazem, co jest swoistym przeniesieniem w teraźniejszość wraz z pierwotną jakością - „wizualizacją”, o której pisze E. Wolicka-Wolszleger (1995: 64-75). Krótkie żartobliwe opowiadanie, zabawna historyjka z dowcipnym, zaskakującym zakończeniem, anegdotyczne potraktowanie tematu to środki silnie oddziałujące wychowawczo, za ich pomocą można sformułować przekorną myśl, deklarując swój dystans wobec pewnych teraźniejszych rozstrzygnięć.

Spośród wyróżnionych przez teoretyków literatury typów intertekstualności, w analizowanym materiale językowym wykorzystywana jest przede wszystkim intertekstualność intencjonalna (zamierzona) oraz immanentna (sugerowana w tekście).

Do tekstów wprowadzane są cytaty, a więc fragmenty dosłownie zaczerpnięte z prototekstu oraz parafrazy, czyli wypowiedzi niedokładne, które zachowują sens podstawowy. 
Intertekstualność jest zabiegiem wymagającym od odbiorcy aktywności. Musi on wykonać wysiłek intelektualny, by prawidłowo odczytać zamiar nadawcy komunikatu, który odwołuje się do wiedzy pozajęzykowej swojego rozmówcy.

W wypowiedziach mieszkańców wsi jest kilka obszarów, w których nawiązania do innych tekstów są widoczne. Najczęściej odniesienia dotyczą spraw współczesnych: społecznych i politycznych. Nadawcy odwołują się także do powszechnie znanych faktów historycznych, kulturalnych oraz niekiedy literackich. Nie są to odwołania wymagające specjalistycznej wiedzy, ze względu na możliwości percepcyjne odbiorców, którzy posiadają przeważnie wykształcenie podstawowe, ale mogą być elementem urozmaicającym przekaz. Dzięki zastosowanym intertekstualnym nawiązaniom nadawca ma możliwość prowadzenia gry z odbiorcą i wyrażenia własnej, zakamuflowanej opinii na określony temat.

Do intertekstualności zalicza się również stylizację językową, której podstawową funkcją jest nadawanie tekstowi odpowiedniego kolorytu w celu wzmocnienia wiarygodności przekazu.

\subsection{Nawiązania do wydarzeń historycznych i wspólczesnych}

Odwołania do faktów historycznych i zdarzeń współczesnych, przywołania konkretnych osób, uczestników opisywanych wydarzeń, służą urealnieniu przekazu. Do prawidłowego rozpoznania zastosowanych nawiązań niezbędna jest wiedza pozajęzykowa odbiorcy.

\section{P / K1 < K2 / Bu II / IV / II}

K1: - pšećes Stalin iag umarun, to ia barzo punakaunam, bo to pšećež oićez narodu umar.

K2: - ia pšyie $\chi$ auna i muv'ie: a čego ty tak punačešs a ona muví: bo zmar naž oịcec. inaki oi ćcec? no, Stalin. to ty puačez za Stalinem? ty punač, bo tfui oịcez v viziziníu śeźi. može śe teroz osfoboźi, iag on umarŭ. tak f ty ruski škole j̇eći tumańili.

Wypowiedzi w realistyczny sposób przedstawiają rzeczywistość społeczno-polityczną czasów stalinowskich i pokazują mechanizm manipulowania dziećmi w rosyjskiej szkole. Walor perswazyjny ma zestawienie rzeczownika ojciec z peryfrazą ojciec narodu - J. Stalin. Druga rozmówczyni podkreśla, że dziecko uczy się przez obserwację i naśladownictwo najbliższego otoczenia.

Perswazji służą także odwołania do zdarzeń i postaci współczesnych, np. do dziennikarza K. Durczoka.

D / K1 - K2 / III / III

K1: - ńe tag unatfo pšestać pić. a g’̉̇e unun pšestańe.

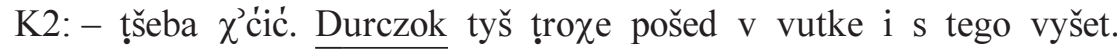


Eufemistyczna peryfraza trochę poszedt $w$ wódkę i z tego wyszedt wskazuje, że silna wola jest niezbędna do rzucenia nałogu.

\subsection{Odwołania polityczne}

W analizowanych tekstach występują także odwołania do aktualiów, takich jak ważne wydarzenia społeczne czy polityczne. Rozmówcy wskazują na sytuacje związane ze sferą polityki, dotyczące znanych osób publicznych.

\section{D / M1 - M2 / III / III}

M1: - luże tyž go rosp'iaium.

M2: - za moine se ne naṕi

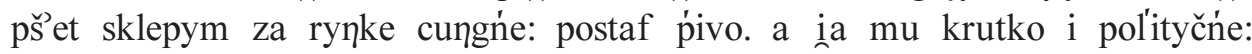

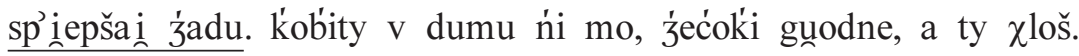

Aluzja polityczna w wypowiedzi drugiego rozmówcy służy podkreśleniu asertywności. Nadawca nawiązuje do słów wypowiedzianych przez Lecha Kaczyńskiego przy wsiadaniu do samochodu tuż po zakończeniu spotkania wyborczego na Pradze Północ w 2002: „Panie, spieprzaj pan! Spieprzaj dziadu!”. Spieprzaj wyraz prymarnie wulgarny, 'idź stąd', mężczyzna wykorzystuje jako formę bardzo wyraźnej odmowy skierowanej do człowieka nieodpowiedzialnego, który pod nieobecność żony nie dba o zostawione pod jego opieką dzieci.

\section{D / K - M / III / IV}

K: - pšy ie $\chi 0 u$ Wacek, pininzy k'ćou požyčyć. pytoun, čy im pomožemy.

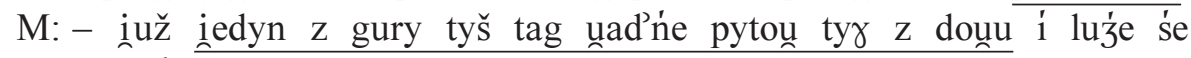
dauny unošukać.

Pytanie skierowane przez Edwarda Gierka w 1971 roku do stoczniowców w Gdańsku: „To jak, pomożecie?”, do którego odwołuje się mężczyzna, jest elementem strategii perswazyjnej, służącym podkreśleniu, że rozmówca nie jest skłonny udzielić pożyczki, ponieważ nie widzi szans na jej oddanie.

\subsection{Odniesienia do znanych tekstów}

O sile perswazji decyduje także atrakcyjność przekazu. Ciekawa forma zwiększa skuteczność oddziaływania tekstu na odbiorcę, ponieważ inwencja językowa czy dowcip nadawcy wzbudzają zainteresowanie słuchaczy. Na istotne znaczenie sposobu wyrażenia podstawowej idei całej wypowiedzi w formie krótkiej, dosadnej i wpadającej w ucho zwraca uwagę W. Pisarek (zob. 2004: 128). 


\subsubsection{Odwolania do Biblii}

W zebranym materiale pojawiają się odwołania do Biblii lub do nauczania Kościoła katolickiego.

D / K1 - K2 - Bu / III / IV/ II

K1:- pozvoliu dać tak'ie im’ie?

K2: - nig i iešče tedy ńe davau Weronika, a unun ne znou písma śfyntego. a mine ve śne tato pov'ieźeli, že ta j́efcynka ma śe nazyvaź Weronika. ia pytam: tato čemu? a on muvi: bo Weronika otaruna tfaš Chrystusowi. i tag my dal'i.

Rozmówczyni wyjaśnia powód nadania córce imienia Weronika, niespotykanego wśród ludności wiejskiej na obszarze ZSRR. Nie ulega wątpliwości, że dla ludzi wierzących odniesienia religijne stanowią największą wartość i są powszechnie akceptowane.

\section{D / K1 - K2 / III / IV}

K1:- mine śe to ńe podoba, pšebačei i pšebačei.

K2:- Pan Bóg umar na kšyžu ne za śf’ienty $\chi$, tylko za gžešńnikuf. a to țšeba v'ielk'iei v'iezy na to, a to luźe tego ne rozum'ieiom.

Druga z kobiet uzasadnia koniczność przebaczania, odwołując się do misji Chrystusa na ziemi, który oddał życie za ludzi grzesznych.

\section{$\mathrm{D} / \mathrm{K} 1<\mathrm{K} 2$ / II / III}

$\mathrm{K} 1$ : - $\chi$ yba ńe ma goršy roboty iag $\mathrm{v}$ dopunata $\chi$.

K2: - a ty myślíšs, že f škole leṕi. tys sodoma i gomora s tymy jećokamy.

Biblijne wyrażenie (zob. Komornicka 1994; Godyń 1995) sodoma i gomora, tu w zn. 'wielkie zamieszanie, rozgardiasz, awantura', wskazuje, że praca z młodzieżą jest również bardzo stresująca.

\subsubsection{Piosenki ludowe}

Fragmenty piosenek ludowych, znanych w lokalnej społeczności, umiejętnie wkomponowane w wypowiedź decydują o sile oddziaływania komunikatu. Teksty mają za zadanie uatrakcyjnić przekaz i skoncentrować na sobie uwagę odbiorcy. Nadawca w nietypowy sposób zwraca się do interlokutora. Ciekawa forma ma zainteresować słuchacza i zwiększyć odbiór prezentowanych treści. Nawiązania świadczą ponadto o zręczności językowej i umiejętności improwizacji nadawcy. Przywołanie piosenki daje także efekt humorystyczny, pozwala sformułować przewrotną, zaskakującą myśl, która powoduje, że wypowiedź jest cięta, zjadliwa, staje się zwięzłym, skondensowanym sposobem formułowania myśli. Odniesienia 
takie świadczą o tym, że mieszkańcom wsi nie brakuje poczucia humoru i zręczności w posługiwaniu się słowem.

D / M1 - M2 / III / IV

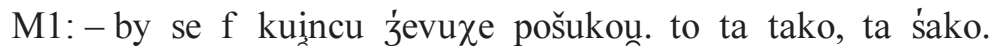

M2: - oi ! ne počuu iešče minty. iak to muody. iag zobocy panne unadnom, to mu same portki spadnom. iag zobocy panne l'ixom, to ne

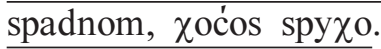

Drugi mężczyzna, używając zmodyfikowanego fraz. nie poczuć mięty, por. poczuć miętę - pot. 'kochać się w kimś, czuć do kogoś sympatię', wskazuje, że młody chłopak nie jest jeszcze gotów na związek z kobietą. Krótki, frywolny fragment piosenki, wskazujący na rezultat zauroczenia płcią przeciwną, łamie tabu i wprowadza aluzje erotyczne, w eufemistyczny sposób przedstawia relacje damsko-męskie.

\section{D / K1 - K2 / III / IV}

K1: - nee pozvulta se im spotykać.

K2: - co se cưov'ieg nagado. bopka tưnumacy: z muzykanta i z munynoža, to n'e bej̇e gospodoža, bo muzykant pii e dužo, muynož munke poroskužo. $\mathrm{i}$ ne pomago.

Krótki, celnie dobrany fragment tekstu piosenki jest bardzo skutecznym środkiem spointowania rozmowy.

D / M1 - M2 / III / IV

M1: - ty víš, iaki unun bogaty!

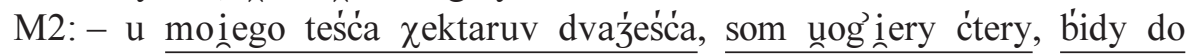
$\underline{\text { qolery. }}$

Fragment piosenki, w przewrotny sposób pointuje informację o bogactwie. Jej początek ma świadczyć o zamożności, por. dwadzieścia hektarów, cztery ogiery, natomiast zaskakujące zakończenie służy ironicznemu przewartościowaniu - biedy do cholery.

\section{D / M1 - M2 / III / III}

M1: - m’ne by tako gospodarka pasovauna.

M2: - ne vyrobiubyś! iak' se $\chi$ ce mainuntkuf, to țša robić: do dvunasty ne iśs spać, po dvunasty zaro fstać.

Przywołany fragment piosenki: do dwunastej nie iść spać, po dwunastej zaraz wstać, w żartobliwy sposób tłumaczy, że posiadanie dużego gospodarstwa wymaga wielu godzin ciężkiej pracy. 


\subsection{Przysłowia jako skuteczny chwyt perswazyjny}

Ciekawą formą wezwania czy zachęty do przyjęcia określonej postawy, mającą walory perswazyjne, są przysłowia. Odgrywają one istotną rolę w procesie komunikowania się, ponieważ silnie oddziałują wychowawczo. Przysłowia to zwykle twory anonimowe, wywiedzione z języka mówionego, skąd zostały przejęte do języka ogólnego. Ponieważ głoszą prawdy ogólne, bywają chętnie wykorzystywane w tekstach ze względu na fakt, że treści, o których mówią, są niepodważalne, co wzmacnia argumentację wypowiedzi.

Przysłowia utrwalają wielowiekowe doświadczenie ludzi, zawierają zarówno przesłania natury filozoficznej, pewne wskazówki życiowe, jak i praktyczne porady. Oprócz sensu dosłownego mają znaczenie uogólnione.

W wypowiedziach mieszkańców wsi występują przystowia wspólnoodmianowe, a także połączenia o ograniczonym zasięgu występowania, które sięgają do określonych wzorców kulturowych, wykorzystują motywy i zdarzenia szczególnie charakterystyczne dla świata ludowego oraz utrwalają językowy obraz świata, który J. Bartmiński (1990: 110) określa jako: „zawartą w języku interpretację rzeczywistości, którą można ująć w postaci zespołu sądów o świecie. Mogą to być sądy bądź utrwalone w samym języku, w jego formach gramatycznych, słownictwie, kliszowych tekstach (np. przysłów), bądź to przez formy i teksty języka implikowane".

O funkcjonowaniu przysłów jako „nośników doświadczeń i przemyśleń określonej grupy społecznej”, pełniących rolę „,regulatora zachowań [...] oraz miernika przy ocenie czynów i intencji” pisała J. Kowalikowa (1997: 37-46). Autorka zwraca uwagę na ich „d w u w a r s tw o w ą budowę”. „Warstwa pi e rw sza, zewnętrzna mówi o k onkretnych osobach, przedmiotach i zjawiskach. R ealn e elementy układają się w obrazy lub zdarzenia, które można pojmować dosłownie [...]. W warstwie d r u g i ej sytuuje się znaczenie pr ze n o śn e, s y m boliczne, aluzyjne, u ogólnione" (Kowalikowa 2001: 139-140).

\subsubsection{Przysłowia wspólnoodmianowe}

Perswazyjny walor przysłów polega na trafności ich doboru pod kątem tematyki wypowiedzi. Często wyróżniają się swoistym humorem lub dosadnością w ujęciu poruszanego zagadnienia. W wielu przysłowiach występują rymy, które służą wzmocnieniu ekspresji przekazu i łatwiejszemu zapamiętaniu określonej treści przez odbiorcę. Istotnym walorem przysłów jest to, że ujmują treść w sposób konkretny i obrazowy (Kurkowska, Skorupka 2001: 153).

$\mathbf{D} / \mathbf{K}<\mathbf{M} /$ II / IV

K: - može śe ńe udać.

M: - iak' śe ne pševrućiš, to śe ne naunucys. 
Przysłowie mówi o sprawdzeniu pewnych prawd teoretycznych na drodze eksperymentalnej, doświadczalnej. Każda próba, nawet jeśli zawodzi, zawsze czegoś uczy, np. wyciągania wniosków z popełnionych błędów.

\section{D / M1 - M2/ III / III}

M1:- maxloie robiu i dobže se ma.

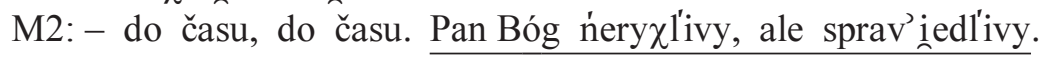

Rozmówca podkreśla, że człowiek jest zależny od Stwórcy, dlatego jeśli postępuje nieuczciwie, na pewno spotka go zasłużona kara.

\section{D / K1 - K2 / III / III}

K1:- i mynce se tyle lat $\mathrm{s}$ tym $\chi$ ulakom.

K2: - v́i Pan Bóg co robi, unoṇconc' ćir'ne i guxoǵi.

Druga z kobiet przekonuje, że zamysłem Boga jest połączenie ludzi w związek, w którym solidna i zapobiegliwa osoba opiekuje się nieodpowiedzialnym partnerem.

D / K - M / III / III

$\mathrm{K}:-$ pov́ińin zostać.

M: - zostańe - ńi mo roboty, a vyịaźe - kobite i j́ećoḱi zostavii. i tag źle i tag ńedobže.

Mężczyzna wskazuje na skomplikowaną sytuację, wymagającą dokonania trudnego wyboru między dwoma różnymi rozwiązaniami, z których każde jest złe.

D / K1 < K2 / II / IV

K1: - ne bende teraz zdavać, zrob’ie ten kurz za dva lata.

K2: - čego śe Jaś ńe naunucy, tego Jan ńe bej́e unum’ịioun.

Kobieta wygłasza opinię, że umysł człowieka najbardziej kształtuje się w dzieciństwie i w młodości.

\subsubsection{Przysłowia ludowe}

Istotne znaczenie w komunikacji językowej mieszkańców wsi mają przysłowia, których zasięg użycia jest ograniczony do określonej społeczności. Budują one swoistą więź między nadawcą i odbiorcą. Przysłowia ludowe to ważny element komunikacji, odwołujący się do doświadczenia społecznego. Przechowują szczegóły obyczajowe, wierzenia czy przesądy, są zwierciadłem przekonań dotyczących życia i pracy na roli, pogody, zasiewów, zbiorów, hodowli itp. Odsyłają odbiorcę do tekstu, który jest mu od dawna znany, w ten sposób przemawiają do niego w jego własnym żywym języku. Przekazują mu jedną z mądrości zakorzenioną w tradycji ludowej i są środkiem integrującym rozmówców. Przysłowia ludowe pozwalają na wartościowanie przekazywanych treści. Umożliwia to wspólna wiedza o świecie, zbieżne sposoby oceniania i interpretowania rzeczywistości. 
Dzięki swej obrazowości, posiadają wyjątkową użyteczność perswazyjną, doskonale uatrakcyjniają wywód, apelują do zdrowego rozsądku interlokutora i nakłaniają go do zmiany postawy. Odwołują się do wyrazistych zasad moralnych, charakteryzują z naiwną i na pozór niezdarną prostotą, która nadaje wypowiedzi określony walor emocjonalny.

Istotne jest postrzeganie paremii jako tekstu w kontekście (zob. Dundes 1984: 42). Kontekst przysłowia to sytuacja, w której zostało ono użyte w tekście. Ma ułatwić recepcję treści, uatrakcyjnić argumentację, a przede wszystkim pokazać wartości, które nie podlegają dyskusji i nie mogą zostać zakwestionowane. Zawarta w przysłowiu prawda nie jest szczególnie odkrywcza, jest jednak tak prosta i oczywista, że trudno jej nie przyjąć.

Przysłowia (zob. Bogusławski 1976: 145-72) funkcjonują w pamięci odbiorców, czemu sprzyja prostota. Są krótkie, łatwe do zapamiętania i powtórzenia. Zwięzłość sprawia, że kondensują informacje, które trzeba by ująć w sposób opisowy.

\section{D / K1 - K2 / III / III}

K1:- ne povinna tag muvić.

K2: - Jasia pšyganauna motyka gracy.

Przysłowie przyganiała motyka gracy, w którym nazwy naczyń zastały zastąpione nazwami narzędzi, por. przyganiał kociot garnkowi, wyróżnia się dosadną obrazowością, por. czasownik przyganiać - 'robić ustawiczne wymówki'.

\section{D / K1 - K2 / III / IV}

K1:- pošunabyź do żeći, dobže byź m’iauna.

K2: - u koguś, to u koguś. inak to ś muvi: volnoź dupce, f sfoị

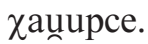

Przysłowie wolnoć, Tomku, w swoim domku w zmodyfikowanej formie - wolnoć, dupce, w swojej chatupce jest bardziej ekspresywne.

\section{D / M1 - M2 / III / III}

M1: - muviuu, že bej́e plac kupovoun.

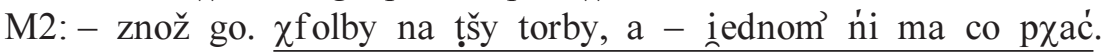

Używając przysłowia, mężczyzna kwestionuje prawdziwość słów osoby niezamożnej, która pyszni się, chełpi, popisuje się czymś, czego nie posiada.

Przysłowia ludowe wiążą się z kulturą agrarną, a w środowisku wiejskim praca jest szczególnie ważna i ceniona.

D / M1 - M2 / III / II

M1: - poviim mu, že ne dam rady.

M2: - iagžeś kavoun leịby, ne b’ies śe do seíby.

Mężczyzna podkreśla, że nie należy podejmować działań, które przerastają czyjeś możliwości. 
$\mathrm{D} / \mathrm{K}<\mathrm{M} / \mathrm{II} / \mathbf{I V}$

$\mathrm{K}:-$ n'e vuieg mu tưnumačy.

M: - iedyn muv́i śfynte sunova, ḍruǵi muv́i moina krova.

Przysłowie jeden mówi: święte słowa, drugi mówi: moja krowa oznacza 'całkowity brak chęci porozumienia się z kimś', upieranie się przy swoim zdaniu nawet wówczas, gdy istnieją dowody, że pogląd jest niezgodny z nauką lub doświadczeniem.

\section{D / K - M / IV / IV}

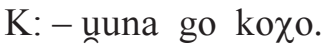

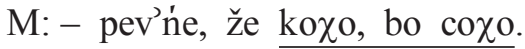

Mężczyzna, odwołując się do przysłowia kocha, bo czocha, por. gwar. czas. czochrać - 'drapać', piętnuje chciwość, pod wpływem której człowiek zdolny jest do pozorowania uczuć wyższych.

\subsection{Gwarowe powiedzenia}

Walor perswazyjny mają także powiedzenia gwarowe, czyli krótkie teksty o ograniczonym zasięgu użycia, które są elementem swoistej więzi między nadawcą a odbiorcą. Powiedzenie, zgodnie z definicją słownikową (Słownik języka polskiego, t. 2, 1979: 866), to „krótka, zwięzła wypowiedź, często o charakterze przysłowia, zwierająca jakąś myśl ogólną, morał, sąd o czymś”.

\section{D / K - M / III / III}

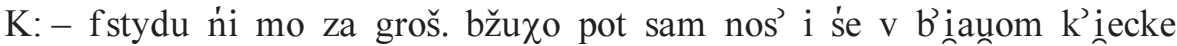
do ślubu zestroiuna.

M: - Anka pannom byunam, j́ecko mi iaunam, ale co to, to ńe.

Mężczyzna, stosując powiedzenie panna bytam, dziecko miałam, ale co to, to nie, podkreśla hipokryzję. Wskazuje na sprzeczność między głoszonymi przez kobietę poglądami, a jej wcześniejszym postępowaniem.

\subsection{Rymowanki}

Dzięki zastosowaniu rymowanej formy te ciekawe teksty są łatwiejsze do zapamiętywania, a przekaz atrakcyjny w odbiorze zwraca uwagę rozmówcy. Rymowanki pełnią różne funkcje komunikacyjne. Ich celem jest, według M. Nagajowej (1995: 8-9), rozśmieszenie adresata, rozładowanie ciężkiej atmosfery, nadanie sytuacji mówienia niefrasobliwego nastroju, stworzenie wreszcie wzajemnego, beztroskiego, często cwaniackiego porozumienia, więzi na zasadzie „równy z równym” i ,sami swoi”. Jak podkreśla badaczka, rymowanki nie są napastliwe, wprowadzają ton żartobliwy i atmosferę pełną humoru i kpiny. 
W analizowanych tekstach rymowanki ośmieszają pewne zjawiska rzeczywistości, szczególnie nieetyczne postawy, które nie są aprobowane w społeczności wiejskiej. Teksty te rozśmieszają i wywołują przyjazny nastrój, ale istotne znaczenie mają skutki takiego dowcipnego mówienia. Rymowanki mają bowiem charakter pouczeń, niekiedy wzmacniają krytyczne wyrażenie dystansu do określonych zachowań. Ich wyróżnikiem jest rytmiczność, krótkość, łatwość zapamiętania, odznaczają się prostotą sformułowań. Ponadto cechuje je swoista ekspresywność, niekiedy ze skłonnością do wyolbrzymienia lub pomniejszenia opisywanych zjawisk.

\section{D / M1 - M2 / III / III}

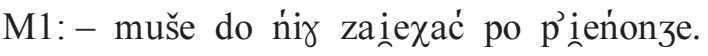

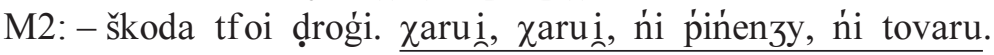

Nadawca podkreśla, że osoba, której rozmówca powierzył mienie, jest nieuczciwa i mężczyzna nie ma większych szans na jego odzyskanie.

\section{D / M1 - M2 / III / IV}

M1: - pev́in byun, že ư⿱o⿰̣ lużi żim’ie vycyganii.

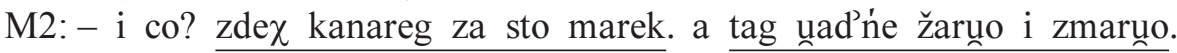
Mężczyzna mówi o przedsięwzięciu, które miało przynieść znaczny dochód, a zakończyło się fiaskiem.

\subsection{Stylizacja a stylizowanie. Typy stylizacji}

W aspekcie intertekstualności postrzegane jest zjawisko stylizacji. Stownik terminów literackich (Sławiński 1988: 495) definiuje stylizacje jako „celowe wprowadzenie do wypowiedzi realizującej określony styl pewnych istotnych właściwości stylu innego, będącego wzorcem stylizacyjnym [...]". Stylizacja językowa (Polański 1999: 568) może być ujmowana jako „Świadome i celowe kształtowanie tekstu według obranego wzoru, nadanie mu zamierzonej postaci stylistycznej".

A. Wilkoń (1999: 91-114) oddzielił stylizację od stylizowania i wyróżnił dwa typy stylizacji: literacka i językowa. Stylizacja i stylizowanie to zjawiska pokrewne w zakresie użycia środków językowych, ale odmienne w zakresie funkcji. Stylizacja polega na podszywaniu się pod wybrany wzorzec języka, odniesieniu się do rzeczywistości językowej występującej poza tekstem. Stylizowanie to użycie wypowiedzi lub elementów, z jakiegoś wzorca językowego, które służą ekspresji artystycznej, zabarwieniu tekstu, podkreśleniu intencji przekazu. Przedmiotem stylizacji może być każda określona systemowa lub niesystemowa odmiana języka pod warunkiem, że w obrębie danej wypowiedzi tworzy ona wyraźnie „obcy” subkod językowy.

Natomiast M. Wojtak (1994: 135-142) poszerzyła pojęcie stylizacji, wskazując, że wzorcem stylizacyjnym nie musi być odmiana języka, może on być przypisany rozmaitym typom wypowiedzi. 
$\mathrm{W}$ analizowanym materiale językowym perswazji służą nawiązania gatunkowe oraz stylizowanie wypowiedzi.

\subsubsection{Nawiązania gatunkowe}

Nawiązania gatunkowe opierają się na wykorzystaniu elementów charakterystycznych dla gatunków użytkowych lub literackich, na odwołaniu do określonych konwencji gatunkowych. Odniesienia takie wzbogacają i urozmaicają przekaz, a ich celowa, zabawna modyfikacja staje się źródłem komizmu.

\section{D / K - M / III / IV}

Rozmowa o spłacie długu zaciągniętego przez sąsiada.

$\mathrm{K}:$ - na śfynta my oddo.

$\mathrm{M}$ : - na kture?

$\mathrm{K}:-$ na te.

M: - za śedm’ioma možamy, za śedmi ioma guramy.

W wypowiedzi uwagę zwraca zabawa gatunkiem artystycznym (zob. Ożóg 2007: 264-265). Nawiązując do zwyczajowego początku baśni: za siedmioma morzami, za siedmioma górami, mężczyzna podkreśla, że nie wierzy w obietnicę zwrotu pieniędzy. Zastosowane odwołanie ma wyraźnie aluzyjny charakter, uwypukla dystans rozmówcy wobec deklaracji, którą traktuje jak nierealną obietnicę.

\subsubsection{Stylizacja na idiolekt}

Uzupełnieniem warstwy językowej mogą być świadomie użyte specjalne efekty dźwiękowe, które mają naśladować sposób wypowiadania się konkretnej osoby. Idiolekty w różnych sferach komunikacji były przedmiotem lingwistycznego opracowania (zob. Żurek 2011). Ten typ stylizacji, działając na wyobraźnię odbiorcy, służy uwiarygodnieniu przekazu, urealnia opisywaną sytuację i przybliża osobę w niej uczestniczącą.

\section{D / K - M / III / IV}

K: - Wacuś! ț̣̌a byuno ruvno poźel'ić, a iei tylko sad zapisać.

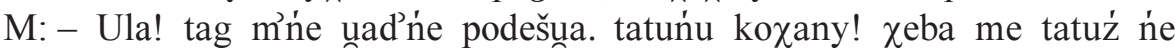

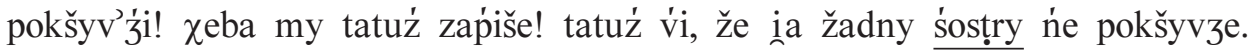

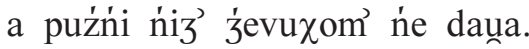

Mężczyzna wykorzystuje chwyty typowe dla parodii, nadaje przekazowi charakter komunikatu prześmiewczego. Moduluje głos, zmienia intonację, odwołuje się do zindywidualizowanych nawyków językowych osoby, którą naśladuje, np. w miejscu głoski $r$ w sposób przesadny artykułuje $r$ języczkowe, starając się w ten sposób osiągnąć fonetyczną autentyczność. W niezwykle ekspresywny spo- 
sób wypowiada każde kierowane do niego zdanie. Stylizacja jest także środkiem służącym charakterystyce, wskazuje na materialne podłoże poczynań kobiety.

M. Karwat (2006: 327), który badał różne środki językowe służące dyskredytacji, wskazuje, że: „Parodia stosowana jest w dwóch wersjach - jako dobroduszny pastisz, jako rodzaj hołdu przepleciony akcentami żartobliwości, przekory, przytyku, oraz jako złośliwa karykatura, w której deformacja obrazu ma wyrazić, i wywołać uczucia dystansu, dezaprobaty, niechęci”.

\section{D / K - M / III / IV}

$\mathrm{K}$ : - tera iuž Maryśka ńiz' ne muv́i.

M: - a co mam muv́ić: taḱi aleganck'i, taḱi bogaty amerykanski nažecuny. byun, byun i se zbyun.

W kolejnej rozmowie również mamy do czynienia z przekazem stylizowanym, który służy ironicznemu wyjaskrawieniu. Mężczyzna naśladuje głos i gesty sąsiadki, która wychwalała przyszłego zięcia. Planowane małżeństwo nie doszło do skutku, o czym informuje rymowane powiedzenie: byt, byt $i$ się zbyt, por. czasownik potoczny, żartobliwy, wręcz frywolny zbyć się - 'wyjść, wyjechać'. Przekaz, angażujący zmysł słuchu i wzroku odbiorcy, lepiej zapada w pamięć i ma większą nośność perswazyjną.

\subsubsection{Stylizacja na język obcy}

Elementem, który ma uwiarygodnić przekaz, jest stylizacja na język obcy. W prezentowanych tekstach stylizacji służą środki fonetyczne, składniowe oraz leksykalne, zwłaszcza słownictwo dotyczące realiów społecznych i politycznych.

\section{D / K1 < K2 / Bu / III / IV / II}

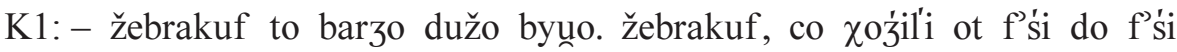
i žebral'i. a mamuśa ńigdy, nigdy ne otpraviuua.

K2: - co mi inaunam, to se dauno. a iag ras pšyšuna do naž žebračka, a ia

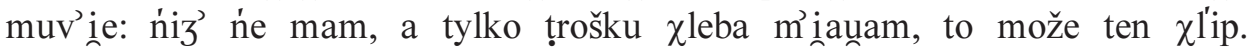
a ona muvi: to ḍla jeći. a tam u ćeb ie coś pšyvi ionzane v vorečku. a tam to krup. dai m’ne z garstke, a ia tob’ ie koš kartoflí. iag' ia bende od vas to brauna. dai m'ne to vezme - ona muvi: bo kartošku to m’ne f každym

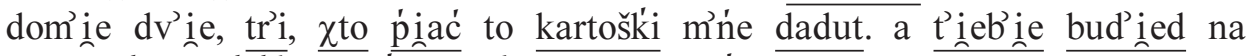

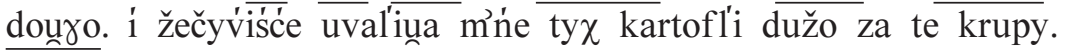

Druga $\mathrm{z}$ kobiet nadaje fragmentowi swojej wypowiedzi, w której przytacza słowa żebraczki, swoistego charakteru brzmienia mowy rosyjskiej, imituje język potoczny.

\section{D / K1 - K2 / IV / IV}

K1: - ununy byli ḍ̣la naź źlii.

K2: - ale pr’iets'iedat'iel byú nezunym čnov'iek'iem. on Ruskim byụ, ale dobrym čunov'iek'iem. tag' i on vezvau samolod’ i muvi: ne puačcé, 
bo pov'ieźli iei f sanator'ium, a tam mauno $\chi$ to dostanet's'ia. tu tylko pšy i ě̌žaiud z Maskwy, z Lienigradu samyz učony żeći.

\section{6. Środki morfologiczne stosowane w celu ksztaltowania opinii i odbioru rzeczywistości zgodnie z intencją nadawcy}

Pragmatyczny charakter mają także kategorie gramatyczne. Przeciętny użytkownik języka nie zwraca na nie uwagi i tym samym przyjmuje narzucony przez nadawcę sposób widzenia świata. Gramatyka wyraża treść imperatywną nakazu bądź zakazu, prośby czy życzenia, toteż istotne znaczenie ma w tekstach wykorzystanie odpowiednich struktur gramatycznych. Na poziomie morfologicznym funkcja perswazyjna przejawia się w wykorzystywaniu kategorii gramatycznej osoby, która w szczególny sposób kształtuje relacje między rozmówcami oraz w odpowiadających jej zaimkach osobowych.

\subsection{Kategorie gramatyczne}

\subsubsection{Kategoria gramatyczna osoby - czasownikowe formy 1 i 2 os. 1. poj., 1 i 2 os. 1. mn. oraz odpowiadające im zaimki ja, ty, my, nasz}

Użycie zaimków my, nasz podkreśla wspólnotę przekonań nadawcy i odbiorcy oraz wspólny system wartości. Zabieg pozwala nadawcy zasugerować poglądy, które budują solidarność i dają odbiorcy poczucie bezpieczeństwa. Jak zaznacza S. Barańczak (1975: 53), to „umacnianie poczucia wspólnoty w ramach owego «my» powoduje, że z coraz bardziej agresywnym nastawieniem spotykają się «oni» - ci, którzy pozostają poza obrębem wspólnoty”. O funkcji 1 os. 1. mn. my, często pojawiającej się w tekstach propagandowych, J. Bralczyk (1987: 55) pisze: „Każda [...] władza przypisuje sobie prawo do wypowiadania się w imieniu społeczeństwa przez formę $m y$ - niezależnie od tego, w jakim stopniu jej to prawo przysługuje".

\section{$\mathbf{D} / \mathbf{M}-\mathbf{K} / \mathbf{I I} / \mathbf{I I I}$}

M: - ia sam se ne poraze. j̇ećaki iešče maune.

K: - aa vyiaje, my ći pumožemy. zafše možež na naz' l'ičyć.

Używanie form 1 os. 1. poj. daje subiektywizację wypowiedzi, zwłaszcza gdy 1 os. jest zaimkowo podkreślona, natomiast zastosowanie 1 os. $1 . \mathrm{mn}$. sprzyja budzeniu u odbiorcy poczucia bliskości z rozmówcą, ma znaczną moc perswazyjną, ponieważ podkreśla wspólnotę. 


\section{D / K1 $<$ K2 / II / III}

K1: - ońi ḿi žyź ne dazom. f̌šscy bedom ḿi dogadyvać.

K2:- pogadaíom i pšestanom. ununy ći ieź ńe dazom. a my ne $\chi$ cemy na zune. kupuiemy i buduiemy dila vas.

Szczególną wymowę perswazyjną ma 3 os. 1. mn. czasownika i odpowiadający jej zaimek oni, który służy wprowadzaniu kategorii przeciwnika.

\section{D / K - M / III / III}

$\mathrm{K}$ : - ununa niz' ne $\chi$ ce nam pumuc.

M: - vy sami i esteśta vinne. byư⿱o ot počuntku pšyunučaź do roboty.

Posługiwanie się 2 os. $1 \mathrm{mn}$. wprowadza wyraźny podział między mówiącym a jego odbiorcami. Rozmówca przeciwstawia się słuchaczom, dystansuje się do nich i do głoszonych przez nich poglądów czy opinii.

\section{D / K1 $<$ K2 / II / III}

K1:- mogom mii dać kredyt.

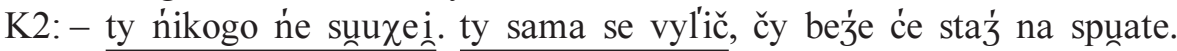

Druga os. 1. poj. to naturalna forma dla dialogu, rozmowy, zakładająca bliskość interlokutorów w aspekcie życzliwej bezpośredniości. Na co dzień jest to forma próśb, poleceń, pytań. Łatwiej znosi dyrektywny charakter wypowiedzi, które brzmią bardziej naturalnie. Zaimek ty przywołuje sposób myślenia związany z kimś bliskim odbiorcy, podkreśla integrację.

\subsection{Kategoria trybu}

Modalność bywa uważana za jedną z istotnych, a nawet definicyjnych cech zdania. Wyraża ona subiektywny stosunek nadawcy do treści jego własnej wypowiedzi. Za klasyczne wykładniki modalności uważa się tradycyjne kategorie trybów czasowników oraz modalne czasowniki i partykuły modalne zastępujące tryby. Zagadnienie modalności w tekstach gwarowych było przedmiotem badań (zob. Gardzińska 1993b: 99-108; 1996).

Wykorzystanie trybu kształtuje sposób wypowiedzi, która może mieć formę kategorycznego rozkazu lub grzecznej prośby, może przybierać znamiona żądania lub delikatnego apelu. Istotne znaczenie perswazyjne mają także propozycje lub rady, które nadawca podpowiada do rozpatrzenia odbiorcy. Forma trybu może być użyta do wyrażania rozkazu emocjonalnego i do propozycji roboczej.

\subsubsection{Tryb oznajmujący}

Za pomocą trybu oznajmującego orzeka się o czynności lub stanach rzeczywistych, które się odbywają obecnie, odbywały się w przeszłości lub odbędą się 
w przyszłości. Tryb oznajmujący nie jest nacechowany perswazyjnie, ale może zostać użyty w funkcji nakłaniającej.

\section{D / K1 < K2 / II / III}

K1:- sama ne v'iem, co robić. tyle razy mu darovaunam.

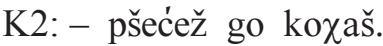

Sformułowanie przecież go kochasz w kontekście wypowiedzi może być odczytane jako zachęta do zgody.

\section{D / M - K / III / III \\ M: - fcale ne ies tag źle, iag muvíš. \\ $\mathrm{K}:-$ poịeźeš tam! to se pšekunaš.}

Mocno zaakcentowana forma pojedziesz tam! jest wyraźnie sprecyzowanym poleceniem skierowanym do odbiorcy.

\subsubsection{Tryb rozkazujący}

Służy do wyrażania przede wszystkim rozkazów lub poleceń, za jego pomocą wyrażamy także prośbę, życzenie czy błaganie. J. Bralczyk (2000a) podkreśla, że jest to forma pierwotniejsza od orzekania - język wcześniej miał służyć wydawaniu poleceń niż opowiadaniu. Natura nakłaniania realizuje się w imperatiwie, ale pewne społeczne uwarunkowania sprawiają, że jest sporo sytuacji, w których używanie trybu rozkazującego uznaje się za niewskazane i unika się go. Przede wszystkim ze względu na rozmówcę, który może odbierać wypowiedź jako formę manifestowania przez nadawcę przewagi nad nim i w związku z tym może poczuć się urażony takim sposobem zwracania się do niego. Wiele tekstów oficjalnych, w których wstępuje ta kategoria, przypomina radę, zachętę, propozycję, a nawet życzenie.

Najczęściej wykorzystywanym sposobem służącym nakłonieniu odbiorcy do pewnych działań jest zastosowanie form 2 os. trybu rozkazującego, który szczególnie chętnie jest wykorzystywany we wszelkiego rodzaju poleceniach, życzeniach, apelach. W. Pisarek (2004: 138-139) podkreśla, że: „Najprostszym językowym sposobem skłaniania odbiorcy do pożądanego postępowania jest druga osoba trybu rozkazującego [...]. Znaczenie trybu rozkazującego można też wyrazić odpowiednimi czasownikami o formie trybu oznajmującego, mówiąc: chce, żadam, rozkazuję, zabraniam, a także formami czasu przyszłego [...].".

$\mathrm{W}$ analizowanych przykładach formy trybu rozkazującego pełnią raczej funkcję pouczeń i przestróg $\mathrm{w}$ odniesieniu do przekazywanych przez nadawcę porad życiowych, nie są odczuwane jako kategoryczne polecenia.

\section{D / K - M / II / III}

K: - muše te żauke iakoś poźelić. počekam na vnuki.

M: - ne čekai na ńikogo. iź i zaunatf spravy sama. 
Forma skierowana bezpośrednio do kobiety, por. nie czekaj, idź i załatw, wskazuje, że sytuacja wymaga podjęcia decyzji samodzielnej i natychmiastowej, ale nie ma charakteru stanowczego nakazu, jest raczej podpowiedzią.

\section{$\mathbf{D} / \mathbf{K}<\mathbf{M} /$ II / III}

K: - țrudo zapom’néé, dav'ńi taki zừ ne byun.

M: - ty pațš pšeć śeb’ie, a ne do tyunu!

Mężczyzna podpowiada rozmówczyni, że sposobem rozwiązania rodzinnego problemu jest skoncentrowanie się na przyszłości, bez wracania do przeszłości, por. patrz przed siebie, a nie do tyłu!, ponieważ dzień jutrzejszy można odpowiednio kształtować, a zdarzeń minionych nie można zmieniać.

\section{D / M1 - M2 / III / III}

M1: - pogucta se! zḍrov’ia škoda.

M2: - goźić śe možna z moṇḍrym.

Pierwszy z mężczyzna zachęca rozmówcę do podjęcia kroków w celu ugodowego załatwienia roszczeń sądowych z sąsiadem.

\section{D / K $<$ M / II / IV}

$\mathrm{K}$ : - fšysko źle i źle.

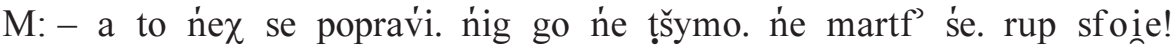
dbei o śeb’ie i o źeći!

Do określonego działania mają zachęcać rozmówcę formy trybu rozkazującego, które K. Michalewski (2000: 25) uważa za „nacechowane poufałością, familiarnością”. Formy imperatywu, szczególnie 2 os. 1. poj., są także chętnie wykorzystywane w różnego typu przekazach reklamowych. Istotne znaczenie mają polecenia $\mathrm{w}$ kampaniach wyborczych oraz $\mathrm{w}$ dyskursie religijnym.

\subsubsection{Bezpośrednie zwroty do nadawcy - używanie 2 os. l. poj. i 2 os. l. mn.}

Drugim widocznym przez swą częstotliwość zjawiskiem jest szeroki zakres występowania w 2 os. 1. mn. trybu rozkazującego końcówki -ta.

W. Pisarek (2004: 142) podkreśla, że: „Wśród form fleksyjnych szczególną wartość perswazyjną przedstawia pierwsza osoba liczby pojedynczej [...], a zwłaszcza liczby mnogiej [...]. Pierwsza osoba liczby pojedynczej i odpowiadający jej zaimek dzierżawczy (ja, mnie, mój) przekonuje wiarygodnością osobistego doświadczenia, pierwsza osoba liczby mnogiej (my, nam, nas, nasz) odwołuje się do wspólnoty doświadczeń mówiącego i słuchających. Owo my odróżnia $\mathrm{n}$ as od was, a zwłaszcza od nich. Czasem my - to tylko nas dwoje, czasem - wszyscy obecni, czasem - cały naród, czasem - wszyscy Europejczycy, czasem - wszyscy współcześni, a czasami - wszyscy ludzie jacy kiedykolwiek żyli. 
W tekstach perswazyjnych wszyscy wiemy znaczy też często tyle samo, co każdy wie, albo nawet tyle, co każdy powinien wiedzieć".

$\mathbf{P} / \mathbf{K}-\mathbf{M}>\mathbf{D z} /$ III / III / I

$\mathrm{K}:-$ ia se sama poraze.

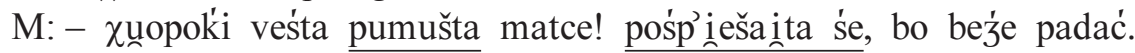

$\mathbf{P} / \mathbf{D z}<\mathbf{K} / \mathbf{I} / \mathbf{I V}$

Dz: - on m’ne biie i zab'iera zabaf'ki.

K: - țšeba se unad'ne bav́ić. inak' se bii eta, to zostafta zabafki i ićta do śeb'ie.

Gdy rozmówcy nie znają się dobrze lub gdy dzieli ich duża różnica wieku, nadawca stosuje 2 os. 1. mn. czasownika, będącą grzecznościową formą oficjalną, która wyraża szacunek dla odbiorcy. Końcówka -cie stosowana jest w zwrotach kierowanych do osób starszych, cieszących się autorytetem, szanowanych lub do osób spoza wiejskiej społeczności. O etykiecie językowej w gwarach i stosowanych przez mieszkańców wsi formach pisała J. Waniakowa (1992: 273-283).

D / M1 - M2 / So

Mężczyzna rozmawia z lekarzem i sanitariuszem pogotowia.

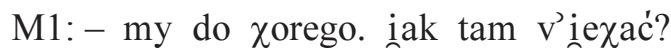

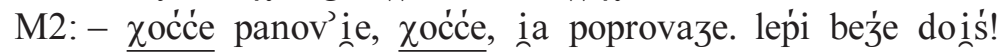

$\mathbf{D} / \mathbf{M}<\mathbf{K} / \mathbf{I I} / \mathbf{I V}$

Mężczyzna zwraca się do starszej kobiety.

$\mathrm{M}:-$ dokont to ćotko?

$\mathrm{K}$ : - do sklepu, ale volno ide, bo noǵi me bolum.

M: - pov'iećće, co poț̌šbuiece to ia vam kup’ie.

$\mathbf{D} / \mathbf{K}<\mathbf{M} / \mathbf{I I} / \mathbf{I V}$

Rozmowa na przystanku autobusowym.

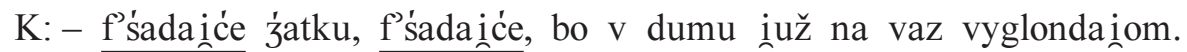
M: - o starego nik' se ne mortf'i.

W społeczności wiejskiej ludzie starsi, nawet nieznani, darzeni są szczególnym szacunkiem, zatem i rozmowom z sędziwymi osobami towarzyszą specyficzne zwroty adresatywne, np. stosowanie określeń typu: ciotko, dziadku, stryjno, wujno czy form pluralis maiestaticus. Te jednak powoli wychodzą z użycia i są sporadycznie stosowane przez młodsze pokolenie użytkowników polszczyzny ludowej. 


\subsubsection{Tryb warunkowy (przypuszczający)}

Służy do przekazywania informacji o czynnościach lub stanach, które rzeczywiście się nie dzieją, ale przypuszczalnie mogłyby się odbyć. Cząstka by oznacza w orzeczeniu uzależnienie jednej czynności od innej. Gdy w zdaniu występuje tylko jedno orzeczenie, w sposób dobitny wyraża hipotezę, przypuszczenie. Tryb ten używany jest dla zasugerowania innej, najczęściej lepszej rzeczywistości, ma za zadanie pobudzić marzenia, a oddalić obawy odbiorcy.

D / K1 - K2 / III / III

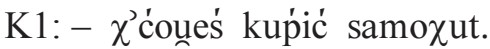

K2: - țša ḿiź za co, kupiunoby śe, lžyby byuno.

D / M1 - M2 / III / III

M1: - času na ńiz’ ńi ma.

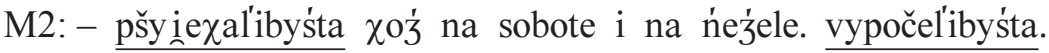

D / K - M / II / III

$\mathrm{K}:-$ ńe moge ńiz znaleś.

M: - zrobiunbyś požundek, to byź ne šukou.

Szczególne znaczenie perswazyjne ma inicjalna pozycja czasownika w trybie przypuszczającym, która sprawia, że odbiorca zwraca uwagę właśnie na czynność lub stan oznaczany przez dany czasownik.

\subsection{Czasowniki modalne}

Czasowniki modalne: trzeba, można, powinien wykorzystuje rozmówca, by nakłonić słuchacza do przestrzegania ustalonych zasad postępowania. Szczególny walor perswazyjny ma ten typ czasownika w połączeniu z bezokolicznikiem, ponieważ pełni w zdaniu funkcję predykatywną i wyraża konieczność, nadając przekazowi charakter kategorycznego twierdzenia, o którego słuszności nadawca jest bezwzględnie przekonany, np.: trzeba myśleć, powinien robić.

\section{D / M1 - M2 / III / III}

M1: - a taki miou być solidny.

M2: - żiśei tag robiom. rospaprou robote i zostaviun. a to inag ne da

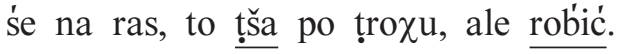

D / K1 - K2 / III / IV

$\mathrm{K} 1:-$ tu ńi ma mieissca.

K2: - to musita dostav́ić pokui. jéćog muśi mić sfui kund do naunuki. 
$\mathrm{D} / \mathrm{M}-\mathrm{K} / \mathbf{I V} / \mathbf{I V}$

M: - pov́inin' iom zrozumić.

$\mathrm{K}:-$ ńe țša luźom vypov’íeźić sfoịi boluṇčki, bo cuze ne bolii.

\subsection{Kategoria czasu}

Czas jest kategorią koniugacyjną, wskazującą na to, kiedy odbywa się czynność wyrażona przez czasownik lub jak należy zlokalizować w czasie zjawisko lub stan. Kategoria czasu może być również wykorzystywana jako środek perswazji.

\subsubsection{Czas teraźniejszy}

Forma ta wskazuje na równoczesność trwania czynności mówienia o niej. Czas teraźniejszy może być także użyty zarówno w stosunku do przeszłości, jak i przyszłości.

W przekonywaniu istotne znaczenie ma habitualne użycie czasu teraźniejszego, służące podkreśleniu czynności odbywających się często, zawsze, zwykle oraz formy praesens historicum, które mają za zadanie przybliżyć odbiorcy czynności, jakie odbyły się wcześniej. Ich funkcja polega na aktualizowaniu minionych zdarzeń.

\section{D / M - K / III / III}

M: - sam pevno ne naṕisau, bo níz ne ví.

$\mathrm{K}:-$ vii, vii, bo unụ̣ čyta k’şş̌kí, gazety, uxoglundo f'ilmy.

\section{D / K - M / III / III}

$\mathrm{K}:-$ sam može oddo.

M: - ia poiexaunem, zapukaunem, a unun fstaie i muvi: oddam’ iag zapunacom. ne oddo tylko unad'ne muvi.

\subsubsection{Czas przyszły}

Formy czasu przyszłego oznaczają czynność lub stan, które mają się wydarzyć w przyszłości, czyli później niż moment mówienia o nich.

Przyszłość, szczególnie przez osoby starsze, postrzegana jest jako zjawisko, które budzi negatywne emocje.

D / K - M / III / IV

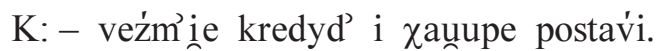

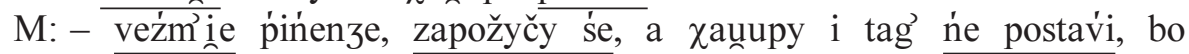
fšysko bej̧e ḍrožyć. 
D / M1 - M2 / III / III

M1: - spšedaiom, bo na emerytury ńi mo.

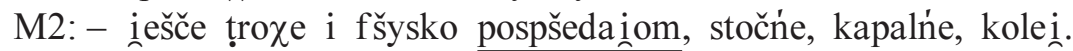

\subsubsection{Czas przeszły}

Czas przeszły wskazuje i nazywa czynność lub stan wcześniejszy niż moment mówienia o nich. Przeszłość może wystąpić w dwóch funkcjach; najczęściej wywołuje skojarzenia pozytywne, rzadziej negatywne.

W badanych tekstach rozmówcy często odwołują się do sentymentalnych przypomnień, przeszłość jawi się jako coś lepszego niż teraźniejszość, a dużo gorszego od przyszłości. Działa tu zasada odwrotna od obowiązującej w większości przekazów reklamowych, w których mamy do czynienia z działaniem afirmatywnym: wczoraj było złe, dziś jest lepsze, jutro będzie bardzo dobre.

\section{D / M1 - M2 / III / III}

M1: - narobiu se i mu ne zapuaćiuy.

M2: - k’iedyź robiueś, tyraueź, ale pininzy pucaciuny. tera roboty ni ma, ńi ma pińinzy. robota ie i tyz ńi ma pińinzy.

\section{D / K - M / II / III}

K: - țšeba kupiż źećokom.

M: - Zdzich tyš kupovoun, robiun, a jećoḱi pospšedauny.

\subsection{Konstrukcje nieokreślone}

Zastosowanie form nieosobowych powoduje, że nie mówi się wprost o tym, kto jest odpowiedzialny za daną sytuację. Konstrukcje te są chętnie wykorzystywane w dyskursie propagandowym, głównie w odniesieniu do przeciwnika. Zabieg ma sprawić wrażenie, że postępowanie osoby ma charakter nieetyczny.

D / K - M / III / III

$\mathrm{K}:-$ ńe $\chi$ kredyd veźm’ie.

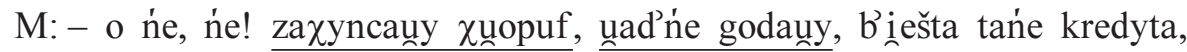
a tero na same procenta ne vyrobi.

\section{D / M - K / III / IV}

M: - otumańiuny luz̧i i tyle. veś śe tero suńć.

$\mathrm{K}$ : - a kto za b’idnym puiźe?!

D / M1 - M2 / II / III

M1: - muviiuyy, že ma byś leṕi.

M2: - leṕi to inuž byuno i ne beźe. 


\subsection{Aspekt czasownika}

Kategoria koniugacyjna, która wiąże się z istniejącymi w języku polskim opozycjami między czasownikami dokonanymi i niedokonanymi może mieć wpływ na retoryczność przekazu. Funkcję perswazyjną pełnią czasowniki w formie dokonanej. Nazywają czynności (stany, procesy), które zostały ukończone i stwarzają wizję tego, co odbiorca osiągnął, zrealizował.

D / K - M / III / III

$\mathrm{K}$ : - robi i robi, f'cúu̧ž $\mathrm{v}$ roboće.

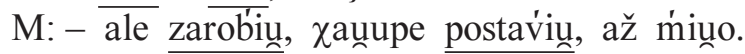

D / K1 - K2 / III / II

K1: - ile to ṕininzy. iźe i tylko gro. 3̉ii - żin puščo zakunady.

K2: - vygrau, to se l'ičy, že znuf țraf'

\subsection{Kategoria stopnia}

Przymiotnikowa i przysłówkowa kategoria stopnia wyższego i najwyższego jest dla analizowanych tekstów ważną kategorią perswazyjną. Przymiotnik i przysłówek to forma wyrażania cech i ocen, a zatem najprostszy sposób pokazywania zalet obiektów.

Z kategorią stopnia wiążą się treściowo inne sposoby nazywania natężenia cechy, absolutyzacja i porównywanie, które dokładnie omawia J. Bralczyk (1994) w kontekście dyskursu reklamowego. Perswazyjnie wykorzystywane są paradygmaty, czyli zestawienia różnych form stopnia.

\subsubsection{Stopień równy}

Przymiotniki w stopniu równym mają wymiar perswazyjny ze względu na cechę, którą oznaczają; można jednak tę cechę podkreślać, emocjonalność przekazu mogą zwiększać zestawienia i porównania.

Funkcję emocjonalno-perswazyjną może też mieć zestawienie cechy w stopniu równym z opisem skutków tej cechy lub z innym opisem pożądanego stanu.

D / K - M / III / III

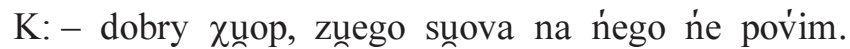

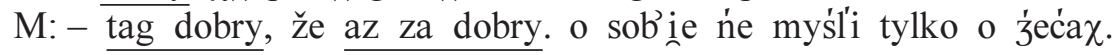

Określenie aż za dobry wskazuje, że mężczyzna całkowicie podporządkował swoje działania dobru najbliższych. 


\subsubsection{Stopień wyższy}

Użycie stopnia wyższego ma wymiar perswazyjny, ponieważ stopień wyższy to wynik porównania, które uwzględnia pozytywny lub negatywny aspekt zjawiska. Natężenie cechy może być wyrażone w sposób prosty lub opisowy, może także przybierać formę wyrazistego porównania.

D / K1 - K2 / III / III

K1: - unun bažy zgodlivy, to ustuḿpi.

K2: - tera ńe ustuḿpi, zrobiu śe gožy zaịaduny iak p’ies.

Zastosowane w drugiej wypowiedzi porównanie gorzej zajadty jak pies wskazuje na stopień natężenia cechy.

$\mathbf{D} / \mathbf{D z}<\mathbf{K} / \mathbf{I} / \mathbf{I V}$

Dz: - on' mi ńe $\chi$ ce pomuc.

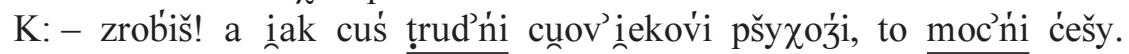

\subsubsection{Stopień najwyższy}

Jest wyraźną kategorią o charakterze perswazyjnym, ponieważ przymiotniki i przysłówki w stopniu najwyższym są formami bardzo wyrazistymi ekspresywnie. Superlatywy za pomocą określonych wykładników formalnych (morfemów $n a j-,-s z y,-e j$ ) intensyfikują cechy i tym samym znaczenie afektywne. Formy stopnia najwyższego służą wyeksponowaniu oceny pozytywnej lub negatywnej konkretnych osób, przedmiotów czy wydarzeń.

\section{D / M - K / IV / III}

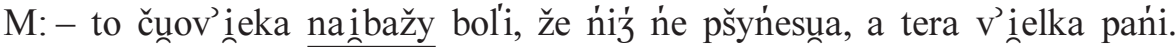

$\mathrm{K}:-$ fšysk'ie muode tera tak'ie pyšne. ńic se $\mathrm{s}$ tego ne rup, $\mathrm{z}$ gunupoty tag gado.

D / K - M / III / III

K: - pšy cukšycy, iag ia mam, to ne možna m’iodu.

M: - minut to ie nai lepše lekarstfo na ružne $\chi$ oroby, f cukšycy tyš pumocny.

D / M - K / III / III

M: - kupiuem mietue f sklep'ie, to se zaraz rozlećauna.

K: - țša byuno na targu kuṕić. tam sum dobre mietuy, šypko śe ne zeḍrum, bo sum z dobry v'inežbiny, noinlepše to sum gaunu̧sḱi luty, mažec.

\section{8. Środki slowotwórcze jako wykładniki pozytywnych i negatywnych emocji}

O znaczącej roli słowotwórstwa w wyrażaniu ekspresji pisze R. Przybylska (2000: 206), zwracając uwagę na istotny aspekt słowotwórstwa potocznego, który 
„umożliwia realizację takich funkcji pragmatycznych, jak: wyrażanie grzeczności i niegrzeczności, wyrażanie emocji i ocen, a przede wszystkim - stylizowanie wypowiedzi tak, aby ewokowała ona określony typ relacji społecznej, w jakiej rozmówcy chcą się odnaleźć nawzajem w danej sytuacji komunikacyjnej”.

\subsubsection{Deminutywa i augmentatywa rzeczownikowe}

Celom perswazyjnym służą także środki słowotwórcze. W analizowanych tekstach najczęściej wykorzystywane są zabarwione ekspresywnie formacje, wyrażające pozytywne lub negatywne emocje. Słowotwórcze sygnały wartościowania mają zdrobniałe lub zgrubiałe formy wyrazów, stanowiące wyrazisty element oceny osób, przedmiotów, wydarzeń.

Różne aspekty słowotwórstwa gwarowego były przedmiotem wnikliwej analizy językowej (por. Karaś 1964: 153-162; Kowalska 1975; Malec 1976; Cyran 1977; Gala 2000a, 2000b, 2002: 147-154). W kontekście realizacji funkcji perswazyjnej istotne znaczenie ma wskazywana przez badaczy charakterystyczna dla gwar tendencja do wykorzystywania derywatów sygnalizujących emocjonalną ocenę, zwłaszcza formacji deminutywno-ekspresywnych i augmentatywnych. Formy deminutywne mogą pełnić różne funkcje, m.in.: wskazują niewielki rozmiar i nikłe znaczenie obiektu, wyrażają pozytywny lub negatywny stosunek nadawcy do niego, mogą być wyznacznikiem pogardy (por. Kurkowska, Skorupka 2001: 45), rozumianej jako specyficzna forma oceny negatywnej. Złożone i różnorodne funkcje stylistyczne deminutywów polskich omawia S. Reczek (1968: 373-386).

\section{D / K - M / III / III}

K: - im’ se može ne spodobać.

M: - muv’i ie ći Ula, placuvečka v dobrym punkće, pšy samei šosy, iag zobačyunem, to unočy my se śm’iauny. kup’iom to oḍ razu.

Nadawca posługuje się określeniami w najwyższym stopniu pozytywnymi, por. derywat placóweczka, fraz. oczy się komuś śmieją, środki służące lokalizacji: dobry punkt, przy samej szosie, które dodatkowo podkreślają walor opisywanego obiektu.

\section{D / K1 < K2 / II / IV}

K1: - ununa voli byź u matki.

K2: - tam n'e vyśezom. śonecka malutko, kuxynecka ta s tylo i aby pokoik. vygody ńiiaki ńi mo, ćasnota, iedno uno dirug’ie se ț̌še.

Dla właściwego odczytania ekspresywnej wartości formacji rzeczownikowych: sioneczka, kucheneczka, pokoik istotna jest rola kontekstu zewnętrznego. M. Sarnowski (1991: 41) pisze: „W tekście nadawca określa swój punkt widzenia w taki sposób, że świadomość językowa odbiorcy kwalifikuje go jako wartościujący dodatnio, a kontekst, a szerzej sytuacja komunikatywna, korygują go tak, że 
musi być on odczytany jako wartościujący ujemnie". Zastosowane derywaty wraz z leksemem ciasnota podkreślają istotne braki opisywanego miejsca.

\section{D / K - M / III / III}

$\mathrm{K}$ : - barzo na ńego nažekaíom.

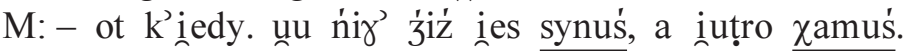

Spieszczenia mogą zyskać ironiczny wydźwięk emocjonalny i stawać się elementem wyraziście wartościującym przekaz, por. formacje: synuś, chamuś, które wskazują, że opinia wygłaszana na temat osoby jest zmienna i nie należy jej traktować poważnie. O nacechowaniu derywatu chamuś decyduje nie tylko charakter podstawy, ale i wybór melioratywnego formantu -uś (por. Grabias 1981: 71). Badacz (1981: 63) podkreśla, że „ekspresywność na poziomie morfologicznym, podobnie zresztą jak i na poziomie leksykalnym, jest jedynie wartością potencjalną, wyznaczającą bardzo różne możliwości konkretyzacji w tekście”.

\section{D / M - K / III / III}

M: - spšedei te krove. tylko se myṇčyš.

$\mathrm{K}:-$ ies pšy ty krovine roboty, ale zafše mam mliko, a to se syreg zrob'ie, a to masuno.

Komunikowane przez formant -ina/l-yna (por. Grzegorczykowa, Laskowski, Wróbel 1984: 369) emocje o charakterze współczucia, politowania w przypadku derywatu krowina ulegają w tekście przewartościowaniu, wyraz oddaje pozytywne emocje nadawcy, tj. tkliwość względem zwierzęcia.

\subsubsection{Ekspresywizmy rzeczownikowe}

W badanych tekstach zróżnicowane uczucia wobec przedmiotów, osób i świata wyrażane są niekiedy za pomocą wulgarno-rubasznego sposobu mówienia (zob. Grzegorczykowa, Laskowski, Wróbel 1984: 370), charakterystycznego dla stylu potocznego.

\section{D / K - M / III / III}

K: - myncy mine ta klepańina.

M: - j́ećoki mušom se vygadać.

Formacja z sufiksem -anina wskazuje na czynność chaotyczną, por. czas. klepać - 'mówić bez sensu, bezładnie' i zgodnie z intencją rozmówczyni nadaje wypowiedzi większą ekspresję.

\section{D / M - K / IV / III}

M: - muvii, že tylko Boga śe boi.

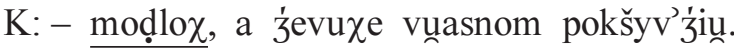

Przyrostek -och, który tworzy rzeczowniki, wprowadza do ich znaczenia element 
nacechowania negatywnego. Rozmówczyni podkreśla, że mężczyzna jedynie manifestuje swoją pobożność.

\section{D / K1 - K2 / III / III}

K1: - dam iei ubrańa po Lili.

K2: - škoda ir ḍla ty nedbal'icy.

W formacji feminatywnej niedbalica 'kobieta, która nie dba o rzeczy' nacechowane są zarówno podstawa, jak i sufiks -ica.

\subsubsection{Deminutywa przymiotnikowe i przysłówkowe}

Występują także deminutywa przymiotnikowe i przysłówkowe, które traktowane są w literaturze naukowej jako słowotwórcza forma stopniowania przymiotników i przysłówków. Formanty wnoszą do derywatów informację o stopniu natężenia cechy nazwanej przez podstawę słowotwórczą (przymiotniki) bądź o intensywności wykonywanej czynności (przysłówki). Derywaty z sufiksami: -uchny, -usieńki, -uteńki, -utki mają znaczenie uogólniająco-hierarchizujące i precyzujące.

\section{$\mathbf{D} / \mathbf{D z}<\mathbf{K} / \mathbf{I} /$ III}

Dz: - ńe moge.

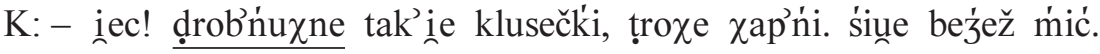

$\mathrm{D} / \mathrm{K1}$ - K2 / III / III

K1: - caune noce punače.

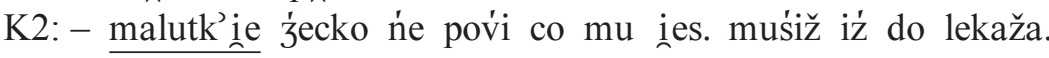

Zwiększenie ekspresji wnoszą także do derywatów prefiksy: prze- i przy-:

D / K1 - K2 / III / III

K1:- dam’ ći proški na sen.

K2: - ia za to ne śp í ie, že unap’ie m’ne pšeunokropny bul i caluśeńka noga my drryntf'ieie.

\section{D / M1 - M2 / III / III}

M1:- pšymauny tyn dum postaviiuny.

M2: - ḍla ńi starčy.

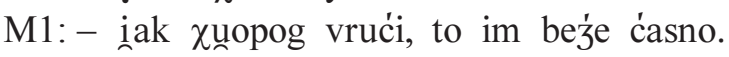

Wymowę emocjonalną posiadają także utworzone od intensywów przymiotnikowych na -utki, -uteńki formacje przysłówkowe.

\section{D / M - K / IV / III}

M: - takimu pryntkusevii do rozumu se ńe pšemuvii.

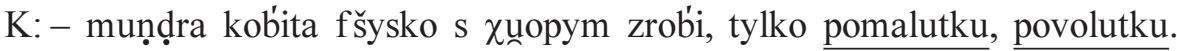




\section{D / K1 - K2 / III / III}

K1: - ia sama ne dam rady poźabać, kupa času na to zeỉ́e.

K2: - požyče ći piune, šyp'úuteńko se pot'ńeš.

\section{7. Środki składniowe a perswazyjność przekazu}

Organizacja systemu składniowego, która obejmuje budowę zdań, jest również czynnikiem wpływającym na perswazyjność wypowiedzi. Łączenie słów w większe jednostki syntaktyczne służy logicznemu uporządkowaniu treści, eksponowaniu ważnych dla nadawcy informacji oraz skupieniu na nich uwagi odbiorcy. Sposób budowania wypowiedzeń ma wartość stylistyczną równie ważną, jak zastosowane w tekście słownictwo. Walor perswazyjny ma rodzaj i budowa zdań, sposób ich łączenia, ekspresywne wykorzystywanie długości zdań, różnorodność zastosowanych środków konstrukcyjnych (ingerencja w neutralny szyk wyrazów, posługiwanie się zdaniami pytajnymi, elipsą, wykrzyknieniami) (por. Bańko 2006: 66). Istotne znaczenie ma ponadto zagęszczenie oraz powtarzalność pewnych struktur. Na charakter ekspresji wpływa przede wszystkim długość zdań. Dobieranie zdań krótkich i długich stosownie do tematu oraz zamierzeń komunikacyjnych nadawcy - to ważny element stylizacji tekstu.

Syntaktyka jest ponadto bardzo ważnym i istotnym współczynnikiem stylu potocznego. Tok języka mówionego posiada swoistą budowę zdań, prostą i nieskomplikowaną składnię. Wyróżnikiem mowy potocznej jest obecność dodatkowych wyznaczników sądów w postaci partykuł i różnych wykładników emocji, wykrzykników oraz wyrażeń wykrzyknikowych. Tendencje rządzące konstrukcją składniową stylu potocznego polegają na utrzymywaniu stałego kontaktu między rozmówcami; odbijają ścisły związek między myślami, odczuciami i intencjami nadawcy a wypowiedzianym tekstem. Zastosowanie odpowiednich środków syntaktycznych w znacznym stopniu wpływa na charakter przekazu. Dostrzegając istotny wpływ składni na styl wypowiedzi, Z. Klemensiewicz (1961: 157) podkreślał, że: ,jeżeli język nadaje kształt myśli, to właśnie w składni ma mówiący najwięcej sposobności wyboru kształtów dla tej myśli”".

Składnia gwarowa jest obszarem badań, który skupia uwagę wielu badaczy (zob. Perczyńska 1975; Węgier, Oronowicz 1992; Gardzińska 1997: 31-38, Sędziak 1999: 279-303). W kontekście realizacji perswazyjnej funkcji syntaktyki ważna jest szczególnie problematyka emocji, obejmująca budowę przekazu.

\subsection{Pojęcie składni emocjonalnej}

Emocjonalność wyraża się także w syntaktycznej sferze używanego języka (por. Kurkowska, Skorupka 2001: 208-209; Siwek 1992: 156). Składnia emocjo- 
nalna jest stosunkowo mało opracowanym naukowo zagadnieniem językoznawczym (zob. Bieńkowska, Umińska-Tytoń 1991; Grzesiuk 1995; Smoleń-Wawrzusiszyn 2004: 221-230; Michalewski 2006b: 147-151). Z. Klemensiewicz (1969: 15) tak ujmuje funkcje składni: „Każdego rodzaju wypowiedzenie prócz właściwej sobie funkcji oznajmienia, pytania lub żądania może wyrazić także uczuciową postawę mówiącego, np.: podziw, zachwyt, wstręt, odrazę, gniew, bojaźń, miłość, przyjaźń, nienawiść, w ogóle osobisty stosunek mówiącego do przedmiotu, o którym mówi, oraz do odbiorcy wypowiedzenia". Nacechowanie emocjonalne zawierają poszczególne składniki tworzące wypowiedzenia, typy struktur składniowych, zwłaszcza wypowiedzenia zdaniowe: wykrzyknieniowe, imperatywne, pytajne, ich powtórzenia, ponadto wskaźniki nawiązania, międzyskładnikowe i międzywypowiedzeniowe, a także operatory tekstowe.

Wyrażaniu emocji służą: aposjopeza, powtórzenia, parenteza, anafora, epifora, inwersja, równoważniki zdań, nagromadzenie pytań retorycznych, elipsa.

\subsection{Składnia wewnątrzwypowiedzeniowa}

\subsubsection{Podmiot}

Stanowi obok orzeczenia trzon budowy zdania. W badanych tekstach ze względu na typ struktury zwraca uwagę podmiot szeregowy lub podwojony, którego rozbudowana forma skupia uwagę odbiorcy.

D / M - K / IV / III

M: - fšyskí ruvno poźelta.

K: - daịe se tymu, co unušanuịe. dobre i muṇḍre skožysta.

\section{D / K - M / II / III}

$\mathrm{K}$ : - matka mu ne pumože.

M: - matka, matka j̇ecka ńe pokšyvži.

\subsubsection{Orzeczenie}

Jest najważniejszą częścią zdania, za pomocą której informuje się o czynności, stanie. Orzeczenie w języku ustnym było przedmiotem szczegółowych badań lingwistycznych J. Bartmińskiego (1978: 159-177). Ze względu na realizację funkcji perswazyjnej istotne znaczenie w badanym materiale mają orzeczenia modalne i peryfrastyczne.

Orzeczenie modalne to osobliwy rodzaj orzeczenia złożonego. Tworzy ono predykację dopiero w połączeniu z bezokolicznikiem, w którym mieści się właściwa jego treść. W tej niejednolitej klasie formalnej mieszczą się czasowniki: musieć, móc, raczyć, mieć; czasowniki supletywne nieosobowe: godzi się, należy, 
uchodzi, przystoi, wypada (także w postaci zaprzeczonej); czasowniki niefleksyjne: trzeba, można, wolno, warto, niepodobna, nie sposób, nie powinno się.

$\mathbf{D} / \mathbf{K}<\mathbf{M} / \mathbf{I I} / \mathbf{I V}$

$\mathrm{K}:-$ boine se, že bej́e zakalec.

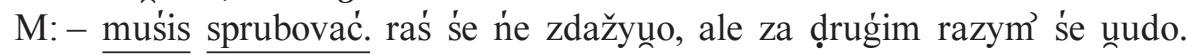

D / K1 - K2 / III / III

K1:- un se sam ńe poraźi.

K2: - ne možeta go ve f̌šskim vyrenčać, muśi se sam raźić.

D / M1 - M2 / III / III

M1: - iešče zdu̧žyta zviśs.

M2: - muz robić. muviuny, že dešče nadeindom.

Zastosowanie orzeczenia modalnego powoduje, że komunikat jest bardziej dynamiczny i bezpośredni. To właśnie dzięki słowom: musieć, móc, należy, trze$b a$, warto, wolno, powinno łatwiej dotrzeć do odbiorcy i przekonać go o tym, że wskazana przez nadawcę sugestia jest jedyną właściwą.

Użyte $\mathrm{w}$ analizowanych tekstach orzeczenia peryfrastyczne miały postać stałych związków wyrazowych.

\section{D / M1 / M2 / III / III}

M1: - muviiuna, že fšysko iez' ii.

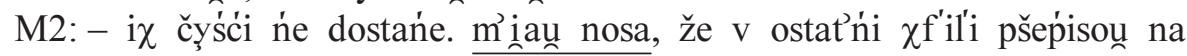
żećí.

\section{D / K - M / III / IV}

$\mathrm{K}:-$ pšeće unun bes prafka ieżżiú.

M: - by śȩ́oun, ale unup̉iekuno mu śe. doun pare grošy i śe zagoźziuny.

Wykorzystane w orzeczeniach peryfrastycznych związki posiadają utrwaloną w świadomości rozmówców treść, odwołanie się do niej jest celowym działaniem obliczonym na osiągnięcie zamierzonych efektów perswazyjnych.

Kolejny typ to orzeczenie podwójne (zob. Bartmiński 1978: 159-177). Konstrukcja, która występuje w języku mówionym, zwłaszcza w polszczyźnie ludowej, jest nacechowana ekspresywnie, ponieważ wyraża w specyficzny sposób znaczenie długotrwałości lub ciągłości procesu. Pojawia się najczęściej wtedy, gdy nadawca podsumowuje jakieś fakty z życia lub zmierza do uogólnienia przekazywanej treści. Ten typ orzeczenia wskazuje na intensyfikację czynności w aspekcie czasowym (przedłużenie przebiegu akcji) lub wpływa na natężenie czynności, czasem chodzi o wzmocnienie rozkazu lub wskazanie rozmówcy na bezcelowość jakiegoś przedsięwzięcia.

\section{D / M1 - M2 / III / III}

M1: - ze dva lata pośej́oun. 
M2: - co ty muv́iš. śejoun i śejoun. doṕiro po śmỉer'ci Stalina go vypuśćiuny.

\section{D / K - M / III / IV}

$\mathrm{K}$ : - ț̌seba s takom osobom dužo rozmav' iać.

M: - to níz n'e do. paț̌sy i pațšy $\mathrm{v}$ bok, sunovym ńe pšemuvii.

\section{D / K1 - K2 / III / III}

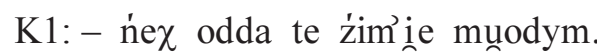

K2: - na ńikogo ne pšepiše. unun tyro i tyro, bo mo $f$ tym caune zadovoleńe.

\subsection{Typy wypowiedzeń a perswazyjność przekazu}

Ekonomia języka i lapidarność słów odgrywa w komunikacji codziennej ogromną rolę. Dyskurs potoczny związany jest z minimalizacją, redukcją zbędnych elementów. Formułując wypowiedź, nadawca ogranicza się do tego, co konieczne, by w sposób funkcjonalny zasugerować odbiorcy najistotniejszą treść przekazu. Stąd w swobodnej komunikacji potocznej naturalne jest zjawisko elipsy czy niedokończenie konstrukcji składniowej. Nie wszystkie konieczne gramatycznie wyrazy pojawiają się na powierzchni tekstu, część odbiorca może uzupełnić sam, a taki zabieg ma za zadanie aktywizować rozmówcę.

Ponieważ w tekście perswazyjnym zdania proste są dobitniejsze i celniejsze, dlatego w zebranym materiale sporą grupę stanowią: równoważniki zdań, zdania oznajmujące nierozwinięte i rozwinięte, zdania pojedyncze, a wreszcie zdania złożone, zwłaszcza dopełnieniowe, przydawkowe, okolicznikowe, czyli proste konstrukcje składniowe, które lapidarnie ujmują rzeczywistość i są bardziej sugestywne.

\subsubsection{Równoważniki zdań}

Charakterystycznym rysem polszczyzny potocznej są skróty myślowe. W przekazie pomija się wszystko, co można zastąpić odpowiednim gestem, mimiką, intonacją. W analizowanym typie komunikacji często pojawiają się wypowiedzenia niewerbalne, które dopuszczają możliwość wprowadzenia orzeczenia czasownikowego, a ich stosowaniu sprzyja ekonomia języka. Równoważniki są nośnikami cech stylistyczno-ekspresywnych, wykorzystywanymi, jak podkreśla D. Buttler (1974: 72-73), do ,zasygnalizowania natłoku zjawisk, narzucających się uwadze obserwatora". W monologach pojawiają się, by zdynamizować opowiadanie, w dialogach - mają na celu skrótowe przekazywanie informacji, ponieważ odbiorca jest w stanie domyślić się z kontekstu, o co chodzi nadawcy. Czasem służą uzupełnieniu tekstu podstawowego przez dopowiedzenie treści lub 
wygłoszenie dodatkowej opinii. W języku mówionym równoważniki zdań, jako elementy składni ekspresywnej, pojawiają się często (ze względu na skrótowość). Pełnią trzy główne funkcje: umożliwiają skrótowe przedstawienie wydarzenia (przypominające streszczenie), dynamizują obraz oraz pozwalają na szybkie przekazanie informacji.

Równoważniki zdań zwracają uwagę przede wszystkim wówczas, gdy występują $\mathrm{w}$ formie nagromadzenia. Prezentacja świata przy ich użyciu czyni opis szkicowym i dynamicznym. Krótkie formacje syntaktyczne służą podkreśleniu odmiennego stanowiska w jakiejś kwestii, szybkiemu wyrażeniu opinii o osobie czy jej postępowaniu.

D / K - M / III / III

$\mathrm{K}:-$ tak’ie pšeznačeńe.

$\mathrm{M}:-$ ńe pšeznačeńe tylko guxupota.

D / M - K / II / III

M: - zaradno kobita.

$\mathrm{K}:-$ cfano, a ńe zaradno.

D / M1 - M2 / IV / III

M1: - tag duugo śe šykuie.

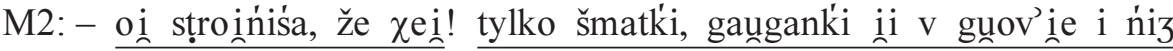
vincy.

\subsubsection{Zdania pojedyncze nierozwinięte: oznajmujące, żądające, pytajne}

Ten typ wypowiedzeń zawiera tylko składniki konieczne; wśród nich wyodrębnia się zdania oznajmujące, żądające, pytajne.

Zdania oznajmujace, określane jako neutralna odmiana zdań ze względu na intencję nadawcy, mogą jednak charakteryzować się pewnym zabarwieniem emocjonalnym.

D / K - M / III / III

$\mathrm{K}:-$ gunupi, že oddoun.

M: - mo $\chi$ unor.

D / K1 < K2 / II / IV

K1: - teśće go ne bedom ț̌šmać! fčorai go spakovauny.

K2: - rospakuịum go. zobočyš.

Zdania żądające są jedną z odmian zdań wyróżnianych ze względu na intencję mówiącego. Służą one spełnieniu rozkazu, prośby, nakazu, zachęty, rady itp. Różnym odcieniom znaczeniowym zdania rozkazującego odpowiadają zróżnicowane środki formalne: tryb rozkazujący, tryb przypuszczający, grzecznościowa forma proszę z bezokolicznikiem, tryb orzekający, forma pytajna zdania. 
W analizowanych tekstach często przyjmowały one postać trybu rozkazującego.

D / K - M / II / III

$\mathrm{K}$ : - naved vnuka ne ćekave zobačyć.

$\mathrm{M}:-$ to ty iej z' źećk'iem.

D / M1 - M2 / III / III

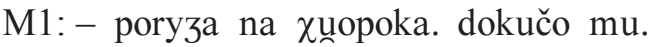

M2: - nagadei mu.

D / K - M / III / III

$\mathrm{K}:-$ ne beźemy i iešče źelić.

M: - poźelta tera. potym ružńe može być.

Zdania pytajne to jedna $\mathrm{z}$ odmian zdań wyróżnianych ze względu na intencję mówiącego. Za ich pomocą domaga się on udzielenia odpowiedniej informacji. Według B. Bonieckiej (1978) struktury pytajne można podzielić na pytania o rozstrzygnięcie i pytania o uzupełnienie (por. Jodłowski 1977). Za pomocą pierwszych rozmówca szuka potwierdzenia lub zaprzeczenia danej treści, drugie są zwrotem do słuchaczy o uzupełnienie informacji jakimś brakującym elementem.

Pytania o rozstrzygnięcie wyznaczają zasadniczo dwie możliwości odpowiedzi: twierdzącą lub przeczącą. Mogą mieć charakter alternatywny, tzn. sugerować dwie lub więcej odpowiedzi, z których jedną trzeba wybrać. Liczba odpowiedzi na pytania o uzupełnienie zależy od sytuacji i z reguły jest większa niż dwie, ponieważ w pytaniach o uzupełnienie może chodzić o więcej szczegółów.
$\mathbf{D} / \mathbf{D z}<\mathbf{K} / \mathbf{I} / \mathbf{I V}$

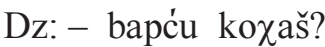

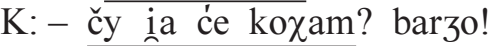
D / M - K / III / III
$\mathrm{M}:-$ daž mu na te gre?
$\mathrm{K}:-\overline{\text { daž mu? a š čego? }}$

Zaletą wypowiedzi o charakterze sprawozdawczo-rejestrującym jest to, że pozwalają na kondensację treści lub wydobycie kontrastów przez zestawienie obok siebie odmiennych postaw. Krótkie zdania nie opisują dokładnie zdarzeń, jedynie sygnalizują pewne obrazy, dlatego silnie działają na wyobraźnię odbiorcy, pobudzając go do ich współtworzenia (por. Kurkowska, Skorupka 2001: 205-207). Proste struktury mają skondensować i ułatwić przekaz.

\subsubsection{Zdania pojedyncze rozwinięte: oznajmujące, żądające, pytajne}

Konstrukcje składniowe, które zawierają obok składników koniecznych także składniki fakultatywne, czyli przyłączone, pozwalają przedstawić bogatszą treść.

Zdania oznajmujące służą dokładnemu opisowi osób, wydarzeń, miejsc. 
D / M - K / IV / III

M: - žeby tak'ine gưupoty vyčynać.

$\mathrm{K}:-$ muododym guxupota barzo śe podobo. puźńi rozumu nab’i ieže.

D / K1 - K2 / III / III

K1: - važne, že mo robote.

$\mathrm{K} 2$ : - unun co m’ieśunz - innym m’ieiscu robi. to ne robota.

Zdania żadajace nadawca wprowadza, gdy stan rzeczy jest wiadomy, ale niekorzystny; mówiący domaga się jego zmiany, wypowiadając odpowiednie żądanie. Wypowiedzenie żądające może mieć różne odcienie znaczeniowe: od najbardziej nieśmiałej prośby - przez różne stopnie nasilenia życzenia, zachęty, rady - do bezwzględnego surowego czy gwałtownego rozkazu.

D / M1 - M2 / III / III

M1: - samymu na gospodarce çǐ̧ko.

M2: - pošukaúbyś kobity $\mathrm{f}$ tfoim v’i ieku. ve dvoine zafše lžy.

D / K - M / III / III

$\mathrm{K}$ : - tyle se tego sadu marnuie.

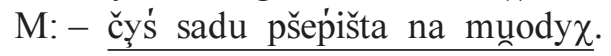

D / K1 - K2 / III / III

K1:- tag m’ne boli, že ne iże vyțšymać.

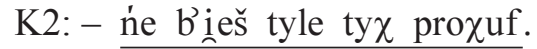

Zdania pytajne nadawca stosuje, gdy nie zna interesującego go stanu rzeczy i zwraca się do współrozmówcy o udzielenie mu wyjaśniającej informacji lub w celu wywarcia wrażenia na odbiorcy.

D / K - M / III / III

$\mathrm{K}:-$ g’źe to se vnuśa vybiro?

M: - do miasta.

$\mathrm{K}:-$ pininze $\chi$ ce vydać? gụupotuv nakupić?

D / M1 - M2 / III / III

M1: - ńe viš čy bedom m’iežyś j̇aukiki?

M2: - bedom, ne bedom, a kto ví?

\subsection{Zdania zlożone}

Do składni, jak i do innych poziomów języka odnosi się postulat atrakcyjnej różnorodności. Dłuższą wypowiedź trudno zbudować, używając wyłącznie konstrukcji prostych, równoważników, zdań nierozwiniętych czy rozwiniętych, stąd konieczność zastosowania zdań dłuższych, złożonych. Wielość użytych konstrukcji jest nie tylko atrakcyjniejsza estetycznie, lecz także skuteczniejsza perswazyjnie. 
Zdania złożone, czyli konstrukcje składające się z co najmniej dwóch zdań pojedynczych odpowiednio ze sobą zespolonych, bywają dzielone według dwóch kryteriów: liczby zespolonych zdań składowych i według stosunku wiążącego zadnia składowe.

Z punktu widzenia liczby zdań składowych wyróżnia się zdania jednokrotnie i wielokrotnie złożone, z punktu widzenia wiążącego je stosunku - dwie klasy zdań złożonych. Pierwszą wyznacza stosunek współrzędności, drugą stosunek podrzędności (por. Jodłowski 1977).

Granica między zdaniami współrzędnie i podrzędnie złożonymi nie jest dostatecznie ostra, wynika przede wszystkim z niejasności co do tego, czy pojęcia te odnoszą się do płaszczyzny treści czy formy.

\subsubsection{Zdania współrzędne w funkcji ekspresywnej}

Funkcji perswazyjnej podporządkowane są różne typy zdań współrzędnych. Sposobem, w jaki nadawca może wpływać na odbiorcę, jest ukazanie własnego stosunku do opisywanej rzeczywistości. Wykorzystuje on wtedy funkcję ekspresywną, reprezentowaną przez część parataksy: zdania łączne, rozłączne i przeciwstawne (zob. Pisarkowa 1975: 87).

Jest to najprostsza forma konstruowania wypowiedzi złożonej, uważana za zjawisko składniowe typowe dla języka mówionego (potocznego). Zdania łączą się w toku rozmowy spójnikiem $i$, który pełni funkcję dodawania, spójnikiem a lub albo.

\section{D / M1 - M2 / III / IV}

M1: - po co śe byuno martf'ić?

M2: - kožden' śe mortf’i i boi, i myśl'i co dal'i beźe.

\section{D / K - M / III / III}

$\mathrm{K}:-$ pumuž żevuše, maš p’ieńonze.

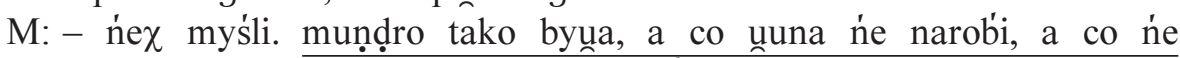

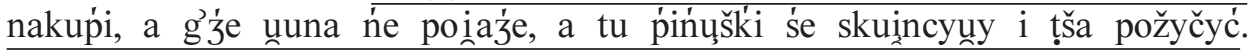

\section{D / K1 - K2 / III / III}

K1:- dazom ći zapumoge. sama iesteź i maž mauy doxut.

K2: - i ešče se raze i b́iźe śe ńe daie. ryńcíne mam, i pare kureg mam, i ovoc sfui mam, i iažynke mam, i syreg zrob’ie, i masuno zrob’ie, i caune utšsymańe mam.

\section{D / K - M / III / III}

$\mathrm{K}$ : - do roboty ńe $\chi^{\prime}$ iźe.

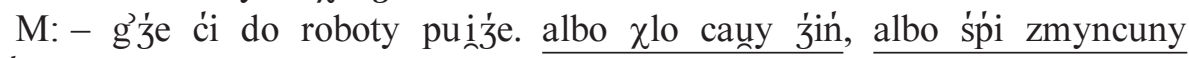
po piiaistf'ie. 
Zdania parataktyczne odejmowane zawierają alternatywę, ich treści wykluczają się nawzajem. Tworzy się je, dodając kolejno spójnik albo.

\subsubsection{Wypowiedzenia złożone podrzędnie}

Stosunek podrzędności (por. Jodłowski 1977: 185-192) w wypowiedziach o charakterze perswazyjnym najczęściej wskazuje na przyczynę, warunek lub skutek jakiegoś działania. Ten typ relacji składniowej charakteryzuje język publicystyki, polityki, religii, w którym większa częstość występowania zdań złożonych podrzędnie służy tzw. składni interpretacyjnej (zob. Pisarek 2002). Badacze zwracają uwagę, że zdania wskazujące na przyczynę zaistnienia danej sytuacji zaliczane są do podstawowych środków syntaktycznych stosowanych w języku propagandy politycznej (por. Pisarek 2002). Ich wartość perswazyjna opiera się na wpływaniu na odbiorcę poprzez wyjaśnianie oraz uświadamianie pewnych działań i zjawisk.

D / M - K / III / III

$\mathrm{M}$ : - stary byun, to ne operovauyy.

$\mathrm{K}$ : - lekaž ńez ne mug zrobić, bo unun za puźno śe zdecydovou na unoperac'ie.

\section{D / M1 - M2 / III / III}

M1: - muk' śeźić f kraíu i roźiny ṕilnovać.

M2: - vyiexou, bo roboty ni mioun.

Istotne znaczenie w przekonywaniu odbiorcy ma także wskazanie warunku. Według S. Jodłowskiego (1977: 191) „Warunek to zespół okoliczności sprzyjających czy środków koniecznych lub wystarczających, aby zaszło określone zdarzenie". Wskazuje się warunek konieczny i wystarczający.

D / K - M / III / III

$\mathrm{K}:-\chi$ lo na unokrungúo.

M: - iagby ṕinuuškuv' ne byuno, ne $\chi$ uloubby.

D / M - K / III / III

M: - za mauno dostoun.

$\mathrm{K}:-$ sézounby, gdyby mu unoince ne pumoguny.

D / M - K / III / III

M: - oddei, iak tu za barzo ńi ma š čego.

$\mathrm{K}:-$ iak se pužyčy, to musovo oddaź na čas.

Perswazyjny walor ma także wyjaśnienie celu określonego działania.

D / K - M / III / III

$\mathrm{K}$ : - mogụy ne brać kredytu, leṕi oḍ luźi požyčyć.

M: - v’żiuny kredyt, žeby go spunaćić. požyčyź oḍ lużi to možeš pare grošy. 
D / M1 - M2 / III / III

M1: - țšeba íedno ḍruǵimu pumuc.

M2: - čunov'in iek' śe muśi sam zadunužyć, žeby im pumuc.

Zdania dopetnieniowe pozwalają wyrazić stosunek nadawcy do otaczającej rzeczywistości, są chętnie wykorzystywane w tekstach prasowych. W tym typie wypowiedzeń nadawca w zdaniu nadrzędnym mówi o rodzaju przeżycia mentalnego lub doznania zmysłowego, a zdanie podrzędne nazywa treść tego przeżycia lub doznania (zob. Polański 1999: 423). W ten sposób nadawca skupia na sobie uwagę odbiorcy, podkreślając, że w dalszej części wypowiedzi zostanie wyrażony jego stosunek do pewnych zjawisk.

D / K - M / III / III

$\mathrm{K}:-$ pov́inny ći pomuc.

M: - munode myślom, že ia mam ćungle tšyžeśći lat.

D / K - M / III / III

K: - źle zrobiun! ț̣̌a byuno ne pšeṕisyvać.

M: - ńe v’ieźoun, že spšedazum.

\subsection{Zdanie eliptyczne}

Elipsa jest figurą retoryczną, polegającą na celowym opuszczeniu tej części zdania, która daje się zrekonstruować na podstawie kontekstu lub sytuacji towarzyszących wypowiedzi (zob. Sławiński 1988: 117). Jak podkreśla T. Ampel (1978: 15-34), zdanie niepełne, niedopowiedziane jest konstrukcją składniową często pojawiającą się w komunikacji ustnej. Występuje w sytuacji, kiedy nadawca może liczyć na współpracę myślową z odbiorcą. Pominięcie w zdaniu lub wyrażeniu jakiegoś składnika prowadzi do tego, że powstaje struktura niekompletna syntaktycznie, która jednak nie powoduje żadnej luki znaczeniowej, ponieważ może być łatwo wypełniona dzięki znajomości kontekstu bądź sytuacji lub dzięki wspólnej nadawcy i odbiorcy wiedzy o opisywanej rzeczywistości.

Elipsa świadczy o oszczędności środków językowych w ustnym komunikowaniu, jest wyrazem tendencji do skrótowego i szybkiego przekazywania informacji, dlatego w analizowanych tekstach występuje często i może obejmować różne człony wypowiedzi (najczęściej czasownik), stąd wiele w tekstach mówionych konstrukcji nominalnych - równoważników zdań, wykrzyknień.

K. Michalewski (2006b: 148) wskazuje na perswazyjny charakter wypowiedzi eliptycznych, które jeśli są „niezamierzone, wywołują nieporozumienia, zaś umyślnie stosowane są środkiem manipulacji językowej”.

D / K1 - K2 / III / IV

K1:- muvii, že śe źle gospadažyta. 
K2: - ununa muṇ̣ro, bo cotka fšysko pšyv'i iezuna. i zuota, i dolaruv’

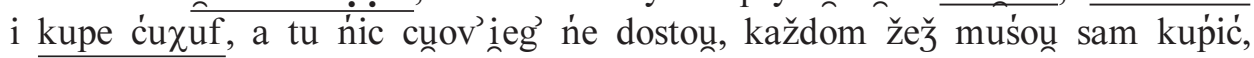
nig mu ńiz' ne doun.

Ponadto elipsa może prowadzić do wieloznaczności komunikatu i pełnić funkcję komiczną. Pominięcie, zgodnie z intencją nadawcy, jakiegoś słowa w wypowiedzi może doprowadzić do aktualizacji niepożądanego wariantu znaczeniowego leksemu. Zabieg pobudza wyobraźnię odbiorcy i zmusza go, żeby dokonał pewnego przewartościowania poglądów czy opinii.

$$
\begin{aligned}
& \text { D / M1 - M2 / III / III } \\
& \text { M1: - a čy unun pšyimuięe? } \\
& \text { M2: - zaležy ot kogo i ile? }
\end{aligned}
$$

Rozmowa dotyczy godzin przyjęć pacjentów, drugi rozmówca podkreśla interesowność lekarza.

\subsection{Parenteza}

Parenteza jest środkiem językowym, którego zadaniem jest wprowadzenie dodatkowych informacji, komentarzy lub wyjaśnień w formie zdań wtrąconych. Parenteza wydaje się przeciwieństwem elipsy, polega na rozszerzeniu, wzbogaceniu wypowiedzenia o człon dodatkowy. Nie jest to jednak kolejny, nadprogramowy składnik wypowiedzenia, ale wyraz lub grupa wyrazów, które nie wchodzą $\mathrm{w}$ jego podstawową strukturę.

J. Gardzińska (2000: 53) traktuje parentezę jako kategorię tekstową i wskazuje, że wyrażenie parenetyczne współwystępuje z wypowiedzeniem głównym (tekstem głównym, przedmiotowym), ale nie jest od niego zależne syntaktycznie, ,jest [...] bezpośrednim zwrotem do słuchacza, formą odwołania się do ewentualnej wiedzy rozmówcy na temat treści całego wypowiedzenia lub tylko jego segmentu”. Podkreśla się, że: „Treści wprowadzane za pomocą parentezy stanowią - w stosunku od osi głównej tekstu - nadbudowę o charakterze metatekstowym, ujawniającą drugą perspektywę narracji” (Polański 1999: 420).

Natomiast J. Sławiński (2000: 133) definiuje parentezę jako „,nawiasowe wtrącenie do zdania niezwiązanego z nim składniowo wyrazu, zwrotu lub innego zdania". Zabieg powoduje powstanie odautorskiego komentarza, który dookreśla wypowiadaną treść i dzięki temu odbiorca uzyskuje pełniejszy obraz sytuacji. Dopowiedzenie może uwydatniać jakąś część zdania, emocjonalnie lub moralnie kwalifikować przedstawiane zdarzenia (zob. Bańko 2006: 70) oraz uzupełniać, precyzować lub rozszerzać przedstawiane informacje.

Ze względu na rodzaj informacji dodatkowej (zob. Bąba, Mikołajczak 1973: 11-16) wyróżnia się: parentezę wyjaśniająca, kontynuująca (czyli zdanie wtrącone, które powiązane jest treściowo z poprzednią częścią wypowiedzenia i stanowi 
pewnego rodzaju uzupełnienie bądź reakcję na wcześniejszą część komunikatu) lub parentezę asocjacyjna.

N. Perczyńska (1975) wyróżnia wtrącenia marginalne, które uzupełniają lub modyfikują sens wypowiedzi, natomiast nie określają stosunku mówiącego do treści komunikatu, i modalne.

$\mathrm{W}$ analizowanych tekstach dopowiedzenia pełnią funkcję uzupełniającą względem jakiegoś elementu wypowiedzi lub waloryzują ekspresywnie.

\section{D / K1 - K2 / III / III}

K1: - iak čyšče te noge, bo lekaž muśi mić caúkim čystom noge, to punače $\mathrm{z}$ bulu, unzy vylevam.

K2: - ńe čyś sama, ne $\chi$ to ći lepi p’ielengnarka čyśći.

\section{D / K1 - K2 / III / IV}

K1: - matka zdolna to i j́eći tyš.

K2: - ona ot p'ieršei klasy barzo dobže učyuna se. naved naučyćel moinemu to davau pap'îerosy. a k'iedyź drog ie byli. jeći pošli do škouny to do dvuźestu, a ona do stu unum’iana ličyć.

\section{D / K1 - K2 / III / IV}

K1: - f pralke vžuce, prošku dam' i dop'iere.

K2:- ale tak' ie čyste ne beńże. a pomyi ieš pranik' iem, prańik to tak'i ḍrev'-

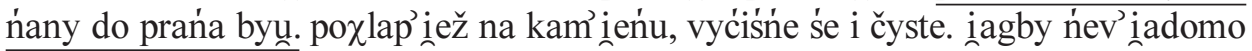
iak’iego mydua dau, byuno tak'ie čyste. i to bez myduna, bez' nič čyste.

\section{D / K1 < K2 / III / IV}

K1:- m’ne potem te zaščyki dalí.

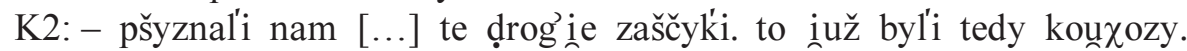

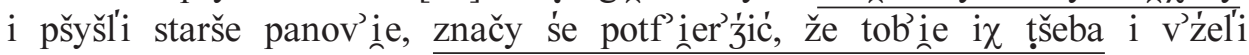

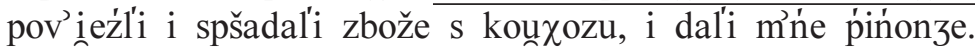

Dopowiedzenia stanowią pewnego rodzaju korektę, próbę uściślenia treści, która służy usunięciu niejasności. Precyzowanie jako działanie językowe pełni ważną funkcję także w komunikacji potocznej. Służy podtrzymaniu kontaktu między rozmówcami, ma na celu zwrócenie uwagi odbiorcy na pewne kwestie, to uzupełnienie drugoplanowych informacji na temat opisywanych wydarzeń.

\subsection{Aposjopeza}

Słowo aposjopeza pochodzi z łac. aposiopesis i znaczy „zamilczenie, [...] niedokończenie myśli [...] zwykle przez urwanie zdania i rozpoczęcie nowego" (Kopaliński 2007: 41). Jest jedną z figur retorycznych, motywowanych stanami psychicznymi i emocjonalnymi nadawcy. Zabieg jest wyzyskiwany do wyrażenia emocji. Gwałtownie przerwane wypowiedzenie występuje w tekstach kolokwial- 
nych, spontanicznych, nieprzygotowanych, kiedy nadawca zbiera myśli i dlatego nie formułuje ich wyraziściej, staranniej.

Niekiedy rozmówca może być zakłopotany tematem wypowiedzi, aposjopeza bywa wtedy spontanicznym objawem szczególnego poirytowania albo wyjątkowego zachwytu. Odbiorca nie odnosi wówczas wrażenia, że nadawcy brakuje odpowiednich słów, lecz jakby niewypowiedziane było to, co najistotniejsze, a co daje się łatwo dekodować, co znane, bo stosowane przez nadawcę w podobnych sytuacjach. Takie zamknięcie może też być obliczone na porozumienie z odbiorcą, który sam dopowiada sobie brakujące elementy, często nawet wyolbrzymiając to, co mogło być intencją nadawcy. Przy zastosowaniu tego środka zakłada się wspólnotę doświadczeń kulturowych uczestników komunikacji. Zadaniem aposjopezy jest wprowadzenie wieloznaczności, niedomówień, a także elementów komizmu.

A. Dąbrowska (2006b: 366) wskazuje, że trop może być także zastosowany w funkcji eufemizmu, kiedy „ma przekonać słuchacza, że mówiący pewnego określenia nie chciał użyć i wolał zamilknaćc". Powodem zamilknięcia mogą być względy społeczne, religijne, kulturowe itp. Wypowiedź może zostać urwana w momencie, w którym powinien pojawić się wulgaryzm. Nadawca komunikatu milknie, a odbiorca ma możliwość samodzielnego jej dokończenia.

Podobne niedopowiedzenia są również wykorzystywane w tekstach literackich, w celu wzmocnienia ekspresji przekazu (zob. Michalewski 2006b).

\section{D / K - M / III / III}

$\mathrm{K}$ : - co ći bede muviić. sam viiš, že na nego bžytko vounainum $[\ldots]$

$\mathrm{M}:-($...syn) nadenty!

\section{D / K1 - K2 / IV / IV}

K1: - ne pomyślaunam, že to taki obus.

K2: - to paskudny j́ot, unun inacy na ńinum ne pov́i iak: ty ku...!

\subsection{Zdanie pytajne}

Sposób zadawania pytań jest sztuką, ponieważ zręcznie sformułowane pytanie uatrakcyjnia wypowiedź, ma pobudzać ciekawość i wpłynąć na osobiste zaangażowanie odbiorcy. Wznosząca się intonacja przełamuje monotonię zdań orzekających, które zwykle występują w wypowiedziach, ponadto pytanie otwiera w świadomości słuchaczy miejsce na odpowiedź, budzi oczekiwanie na nią. Pytanie aktywizuje słuchaczy, zwłaszcza tych, do których jest bezpośrednio skierowane; ożywia i urozmaica przekaz, wzmacniając jego perswazyjny efekt. W. Pisarek (2004: 133) twierdzi, że „[...] pytania są chyba najbardziej perswazyjną ze wszystkich form wypowiedzenia”.

Pytania dzieli się zwykle na otwarte i zamknięte, wśród których wyodrębnia się pytania o uzupetnienie i o rozstrzygnięcie, ponadto wyróżnia się pytania: 
analizujące, oceniajace, konkluzyjne oraz pytania retoryczne, na które nie wymaga i nie oczekuje się odpowiedzi, stosowane dla ożywienia intonacyjnego wypowiedzi.

Inny sposób klasyfikacji pytań uwzględnia to, do kogo są one kierowane i kto ma na nie odpowiedzieć. Pytania takie służą aktywizacji rozmówcy i zawierają swoistą argumentację, która ma ukształtować określone stanowisko odbiorcy.

Termin zdanie pytajne może być rozumiany bardzo szeroko, jako wypowiedź obdarzona intonacją pytajną. Część zdań, które nie służą zapytaniu, językoznawcy określają mianem pytań pozornych (zob. Danielewiczowa 1991: 159-168). Do tego typu zdań zalicza się pytania retoryczne, które w pewien sposób „presuponują sąd nadawcy”. M. Danielewiczowa (1991: 159) uważa, że: „Nie wyrażają one ani znaczeniowej pytajności, ani alternatywy. Są jakby z góry doskonale zamknięte, nie otwierają miejsca na żadną odpowiedź, a jeśli już, to na tę właśnie, która zawarta jest w pytaniu, a co za tym idzie, jest dokładniejsza niż samo TAK lub NIE". W ujęciu K. Michalewskiego (2002: 56) taki zabieg językowy pozwala „odbiorcy czuć się partnerem nadawcy, współautorem odpowiedzi, odkrywcą [...]”. H. Zgółkowa (2003: 457) wskazuje, że pytanie retoryczne jest jedną z bardziej znanych figur retorycznych, która nie służy wyrażeniu wątpliwości i uzyskaniu odpowiedzi; stosowana jest „dla podkreślenia przekonań mówcy, który pytając, angażuje mocniej uwagę słuchaczy i apeluje do ich współudziału mocniej, niż gdyby wypowiadał zdania twierdzące". Pytanie retoryczne jest również zabiegiem stylistycznym służącym nadawcy do potwierdzenia faktu, co do którego nie ma on wątpliwości, lub do jego zaprzeczenia w sposób nieco ironiczny (zob. Kurkowska, Skorupka 2001: 210).

Ważną strukturą składniową jest nagromadzenie pytań retorycznych, które służy ukazaniu stanowiska mówiącego wobec przedmiotu wypowiedzi i wyrażeniu emocji (często są to emocje negatywne: oburzenie, niezadowolenie, gniew).

Pytanie retoryczne występuje w stylu artystycznym, w poezji (Kurkowska, Skorupka 2001: 210) oraz w stylu przemówień, zwłaszcza w dyskursie politycznym, w którym jest środkiem szczególnie nośnym perswazyjnie, ponieważ według M. Danielewiczowej (1991: 161): „kamufluje tu kategoryczne sądy, które narzuca się odbiorcy”. Badaczka wskazuje, że ważną funkcję pełni także w codziennej komunikacji, ponieważ ,[...] jest w rozmowie argumentem tak mocnym, że użyte we właściwy sposób i we właściwym miejscu powinno ucinać dyskusję na dany temat, nie dopuszczając do żadnych kontrargumentów. Jeśli jest inaczej, świadczy o tym, że zostało użyte niefortunnie".

$\mathrm{W}$ analizowanych tekstach występują obok siebie różne typy pytań, które stanowią ważny element kompozycyjny przekazu. Istotne znaczenie perswazyjne mają zwłaszcza pytania retoryczne, które służą podtrzymaniu kontaktu między rozmówcami i mają za zadanie skłonić odbiorcę komunikatu do refleksji. Ukazują subiektywny punkt widzenia nadawcy, jego wątpliwości, wahania czy ambiwalencję uczuć; kondensują znaczenie i podkreślają wagę konkretnego problemu. Ponadto wpływają na ożywienie intonacji wypowiedzi i mogą pełnić funkcję przerywnika, oddzielającego poszczególne części przekazu. 
1. Pytania kierowane do osób obecnych, od których oczekuje się rzeczywistej odpowiedzi.

D / K1 - K2 / III / III

K1: - tera se fšysko pogmatfauno.

K2: - íle u voś śézauy?

K1: - pińż lad bej́e abo i dužy.

K2: - oduožyuny se iak'i groš?

$\mathrm{K} 1$ : - ñig im pininzy ne licyun.

2. Pytania, na które odpowiada sobie sam pytajacy. Występują zwykle na początku wypowiedzi, aby treść komunikatu mogła posłużyć za odpowiedź na postawione pytanie i mogła przekonać odbiorcę o słuszności wywodu.

D / K1 - K2 / III / III

K1: - ale mu nagadaunam.

K2: - ile to ía iuz $z^{`}$ ńim ńe gadam? bej́e ze țšy lata. i mam spokui. ty tyš fcale z’ ńim ne gadei. zḍrov’ị škoda.

D / M - K / III / III

M:- zrozum’iou, že țša unoicom pumuz’ i vraco na v’ieź na gospodarke.

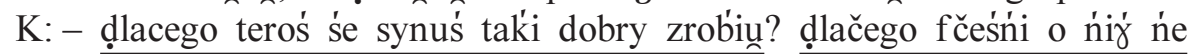
myśloun? bo z roboty go vyvaliuny i ni mo za co žyć.

3. Pytania retoryczne, które w ogóle nie wymagaja odpowiedzi, bo tak bardzo jest ona oczywista. W wypowiedziach pojawiają się, żeby ostatecznie wpłynąć na decyzję odbiorcy.

\section{D / K1 - K2 / III / III}

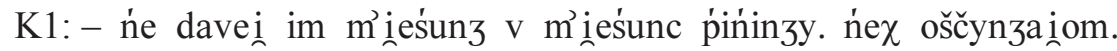

K2: - muodym zafše cuś poț̌a, a mine i tag zostaie. ryńcine cuovoviek

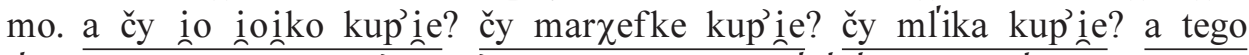
misisa, to ile stary cunov’ieg z $\mathrm{z}$ ii? a na co bede pininíze tšymać?

\section{D / M - K / II / II}

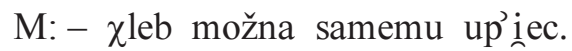

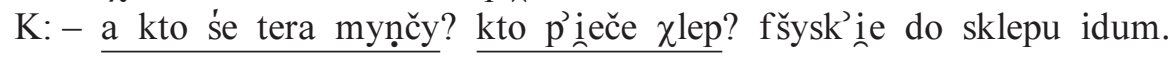

D / K - M / III / III

$\mathrm{K}$ : - ńe možež mu ńic pov'ieźić, bo unun tylko sfoie.

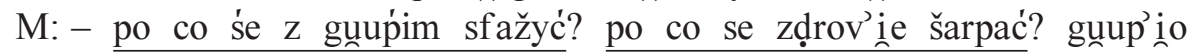
gado, gadei i ty tyš tak samo, a beže zadovoluny. 


\subsection{Modulant}

Do wywierania wpływu wykorzystywane są modulanty, określane także jako modalizatory - dzięki nim efekt werbalnych kontaktów z otoczeniem wzrasta, ponieważ zmniejszają stopień oficjalności wypowiedzi i wyrażają emocje. Modulanty tylko pozornie nie mają wartości perswazyjnej, odbiorca z reguły nie odczuwa ich wpływu na treść przekazu, lecz w rzeczywistości są środkami języka szczególnie kształtującymi wymowę tekstu. Modulanty jako oddzielne elementy języka, wcześniej włączane do szerokiej grupy partykuł, wyodrębnił S. Jodłowski (1977: 22), który uważa, że: „,...] towarzyszą składnikom wypowiedzenia czy wypowiedzeniom, nie zmieniając ich treści ani zakresu".

Ekspresywna funkcja tych wyrazów polega na wzmocnieniu lub osłabieniu przekazywanej treści myślowej. A. Awdiejew (1987) zalicza leksemy do grupy operatorów modalnych, które funkcjonują na poziomie interakcyjnym. Układ interakcyjny występuje tylko w warunkach bezpośredniej komunikacji w formie dialogu czy polilogu. Modulant ma na celu wyrażenie przypuszczenia co do prawdziwości wypowiadanego sądu. Jak podkreśla Awdiejew (1987: 115) „tego rodzaju postępowanie ma sens wówczas, gdy mówiący nie ma możliwości weryfikacji, czyli ustalenia prawdziwości omawianego zdarzenia", natomiast R. Rodak (2000) uważa, że „[...] modulanty nie mają zdolności przedstawiania rzeczywistości, pozbawione są charakteru ideacyjnego. Ten właśnie warunek pozwala sklasyfikować je jako czyste operatory interakcyjne, które powodują wprowadzanie do wypowiedzenia treści dodatkowej (naddanej) w stosunku do treści przedstawionej. Treści naddane mogą być różne w zależności od działającego operatora. Zarówno wykrzykniki, jak i modulanty są, oprócz frazemów, jednostkami języka szczególnie predysponowanymi do wyrażania funkcji emocji”.

K. Michalewski (2010: 330) wskazuje na stosowność perswazyjną modulantów, która: „wiąże się nie tylko z tym, że pozwalają przypisywać tej samej wypowiedzi różne, pożądane przez nadawców wartości, ale i z tym, że zaznaczając stosunek autora do treści tekstu, uwalniają go od zarzutu kłamstwa. Blokują weryfikację wypowiedzi”.

Modulanty występujące w analizowanych tekstach można podzielić na kilka kategorii:

1. Modulanty wzmacniajace treść informacji, ich zadaniem jest podkreślenie faktu czy zjawiska.

D / K1 - K2 / II / III

K1: - tež ma sfoịe vady.

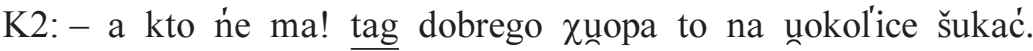

Modulant tak wskazuje, że mężczyzna jest wyjątkowo dobrym mężem, o wiele lepszym, niż gdyby kobieta powiedziała o nim, że jest dobry. 
D / K1 - K2 / III / III

K1: - żiśei prav’ie fřysk'ie stud'iuiom.

K2: - na punatny $\chi$. s cauny klasy tylko on' se dostou na darmove stud'ia.

Modulant tylko podkreśla wyjątkowe zdolności ucznia.

D / K - M / III / III

$\mathrm{K}$ : - jećoki unop’ieka zabrauna.

M: - muviunem to i iuž davno. tam tylko vuda i tylko vuda.

Modulant już wskazuje, że mężczyzna od dawna spodziewał się takiej decyzji, zreduplikowany rzeczownik augm. wóda i powtórzony modulant tylko w bardzo sugestywny sposób akcentują patologię.

2. Modulanty podkreślajace informację. Stosowane są, aby uwypuklić treść, wskazać na doniosłość lub niestosowność pewnych działań.

D / M1 - M2 / II / III

M1: - vyị̌zž na sfoịe.

M2: - a g'j̉e tam. tylko na unopryski pošuño țšy tyśunce.

Modulant wskazuje, że wydatków związanych z pracami w sadzie jest znacznie więcej, a opryski są jednym z wielu, co w konsekwencji powoduje nieopłacalność produkcji sadowniczej.

3. Modulanty stanowiace pozorne punkty odniesienia. Modulanty zostały nazwane pozornymi punktami odniesienia, ponieważ pozwalają odbiorcy - tylko pozornie - usytuować przekazaną informację. Mają służyć weryfikacji, czy podana ilość jest duża czy mała, ale w rzeczywistości, mimo konkretnych przykładów czy liczb, odbiorca musi zawierzyć nadawcy, który może przekazać dane nieprawdziwe. Dzięki takiemu zabiegowi można bardzo łatwo kształtować tekst tak, by w odpowiedni sposób wpłynąć na jego odbiór przez słuchacza.

D / K - M / III / IV

$\mathrm{K}:-$ muśi i $\chi$ spunaćić.

M: - š čego. s ty ryńćiny ledvo na $\chi$ lep starča.

Mężczyzna przekonuje, że wyrok sądu jest niemożliwy do zrealizowania, ponieważ świadczenia kobiety są niewielkie, por. rzecz. rencina oraz modulant ledwie, który dodatkowo wskazuje, że renta wydaje się bardzo mała, ponieważ wystarcza jedynie na pokrycie podstawowych potrzeb życiowych, por. określenie na chleb.

4. Modulanty zaznaczające stopień wiedzy o realności treści. Ta grupa leksemów stanowi swego rodzaju zabezpieczenie dla nadawcy tekstu. Wypowiedź $\mathrm{z}$ takim właśnie modulantem jest z jednej strony bliska przekazywanym faktom, ale z drugiej - pozwala uchronić się nadawcy od zarzutu mówienia nieprawdy.

D / K - M / III / III

$\mathrm{K}:-$ ńe $\chi^{\prime}$ 'se buduiom. 
M: - ńe maíom g’źe. na taḱim pasečku.

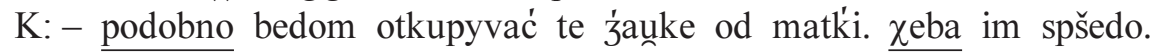

Przypuszczenie wyrażone modulantem podobno jest w domyśle bliskie twierdzenia, a nadawca jest w pewien sposób usprawiedliwiony, ponieważ jedynie przedstawia domysły. Stosując leksem chyba, rozmówca daje wyraz własnemu mniemaniu, że jakiegoś faktu należy się spodziewać, że coś ma dużą szansę na realizację, jest możliwe, przypuszczalne, ewentualne.

\section{D / K1 - K2 / III / III \\ K1: - oddou dunuk. \\ K2: - na šçýśce zmuṇḍžoun.}

W tej klasie wyrazów występują także słowa, które J. Mayen (1972: 101) określa ,jako dodatkowe sądzące składniki językowe”, np.: oczywiście, na szczęście.

Modulanty są bardzo popularnym środkiem wykorzystywanym przy przekazywaniu informacji, właściwie dobrane mogą, ze względu na niewielkie znamiona perswazyjności, w łatwy i prawie niezauważalny sposób być stosowane jako istotny element, który kształtuje emocjonalny charakter przekazu. A. Batko (2005: 65), który dokładnie analizował język wpływu i manipulacji, pisze: „Słowa oprawiają «W ramy» nasze doświadczenia, wynosząc pewne aspekty na plan pierwszy, inne pozostawiając w tle”.

\subsection{Presupozycja}

Jednym z mechanizmów perswazji językowej jest stosowanie presupozycji. Bezpośredni wpływ na podświadomość odbiorcy może mieć także ukryty przekaz informacji. Komunikacji pośredniej poświęcono w lingwistyce wiele miejsca i uwagi (zob. Wiertlewski 1995; Bralczyk 1989: 17; Zgółka 2001: 415-425; Maciuszek 2007: 29-48). Wiadomość zawarta jest nie tylko w warstwie treści, o której mówi zdanie i którą rozmówca odbiera w sposób świadomy, ale także w płaszczyźnie głębszej - tj. w płaszczyźnie założeń, tkwiących u podstaw zdania. Przyjęte założenia, o których nie wiadomo, czy są prawdą czy fałszem, kształtują odbiór informacji.

S. Wiertlewski (1995) przez pośrednie akty mowy rozumie taki sposób użycia języka, w którym dokonuje się pewnego aktu przez równoznaczne dokonanie innego aktu, a więc to, co nadawca chce powiedzieć, obejmuje znaczenie dosłowne oraz wykracza poza nie. W szerszym znaczeniu (zob. Urbańczyk 1991: 266) „jest to każda informacja nie wyrażona w zdaniu, ale wynikająca z jego treści”.

\section{D / K1 - K2 / III / III}

K1:- požyčyunam mu. beźe míioun, to my unoddo.

K2: - tfoịe pinininze. vincy požyčyš, vincy pšețraći. 
Założenia zawarte w drugiej wypowiedzi:

- osoba może dysponować swoimi pieniędzmi w dowolny sposób;

- mężczyzna, który pożyczył pieniądze, nie potrafi planować wydatków, lekkomyślnie dysponuje pieniędzmi.

D / K - M / III / IV

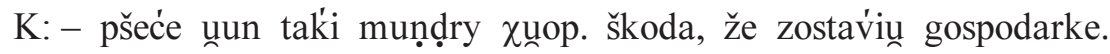

M: - iagby byu muṇ̣̂ry, to by śézou na f'śi.

Założeniem zawartym w drugiej wypowiedzi jest twierdzenie, że osoba, która opuściła wieś i zostawiła własne gospodarstwo, jest głupia.

D / M1 - M2 / III / III

M1: - pšeće śȩ́i u ćotkí.

M2: - śé̉i, ale za iazde bes prafka.

Druga wypowiedź zawiera założenie, że mężczyzna odbywa karę pozbawienia wolności.

Pośrednie akty mowy służą nadawcy do wyrażania w sposób niejawny ocen osób, sytuacji, zjawisk, pozwalają narzucać pewne przekonania niejako bezdyskusyjnie. Ich walor perswazyjny polega na tym, że są mniej zauważalne przez odbiorcę, gdyż pozostają w tle głównej intencji komunikatu, a przez to mogą niepostrzeżenie włączyć się w system wyznawanych przez odbiorcę ocen.

\subsection{Kompozycja tekstu}

Wśród zjawisk składniowo-stylistycznych, które uwarunkowane są postawą mówiącego i spontanicznością wypowiedzi, istotne znaczenie perswazyjne ma kompozycja tekstu. Kompozycja polega na doborze elementów słownych i ich wzajemnym zharmonizowaniu tak, by tworzyły naturalną, sensowną oraz logiczną całość (zob. Buttler, Kurkowska, Satkiewicz 1987: 45-46). Uporządkowany układ sprawia, że tekst nie jest prostą sumą tworzących go zdań, ale funkcjonuje jako złożona struktura, współzależna od wszystkich elementów, od ich porządku, harmonijności językowej i stylistycznej. Im bardziej spójny tekst, tym większe prawdopodobieństwo, że cel nadawcy komunikatu zostanie osiągnięty.

\subsection{Powtórzenie jako emocjonalne zaakcentowanie sądów}

Powtórzenie polega na celowym użyciu tego samego elementu językowego (wyrazu, zespołu wyrazów), jest to atrakcyjny zabieg językowy, dzięki któremu nadawca podkreśla najistotniejsze treści wypowiedzi - słowa stanowiące „uczuciową dominantę". Powtórzenie jest najprostszym sposobem podkreślenia emocji (zob. Kurkowska, Skorupka 2001: 220-223) oraz istotnym czynnikiem spajającym 
tekst (zob. Krauz 1992: 247-252). Nagromadzenie powtórzeń w wypowiedzi służy uwypukleniu ważnych treści oraz wyeksponowaniu faktów z całości przekazu.

Walor perswazyjny powtórzeń polega także na tym, że mogą one pełnić funkcję opóźniającą. Nadawca, powtarzając pewne słowa, spowalnia wprowadzenie jakichś treści, a w ten sposób zmusza odbiorcę do oczekiwania i skupienia uwagi.

W badanych tekstach powtórzenia, zarówno pojedynczych słów, jak i całych struktur składniowych, służą emocjonalnemu zaakcentowaniu wyrażanych sądów, umacniają głoszone przekonania, uwypuklają treści najważniejsze i w ten sposób ze zdwojoną siłą trafiają do odbiorcy. Zabieg pozwala także na przekazywanie wyselekcjonowanych informacji, pojęć, ocen, na które nadawca chce zwrócić szczególną uwagę odbiorcy.

W badanych tekstach powtórzenia wyrazów „służą podkreśleniu ciągłości bądź intensywności danej czynności lub cechy" (Grzesiuk 1995: 134) i świadczą o silnym nacechowaniu emocjonalnym nadawcy. Wyróżnia się powtórzenie intensyfikujace, które polega na jedno- lub kilkukrotnym powtórzeniu wyrazu - najczęściej dla uwydatnienia i wzmocnienia jego ładunku znaczeniowego, co służy także zwróceniu uwagi odbiorcy na najważniejsze sformułowania, którymi mogą być różne człony wypowiedzenia: rzeczowniki, zaimki, czasowniki.

\section{D / K1 - K2 / III / III}

K1:- povininin ś ú uščynzać.

K2: - i emu ne pšetuonačyš. tylko robota i robota ot' śf'itu do nocy, pole i pole.

\section{D / K1 - K2 / III / IV}

K1:- tylko moía źimia i moía źimia.

K2: - poviiz mu, že $\mathrm{v}$ roźine f̌sysko ies fspulne.

\section{$\mathrm{D} / \mathrm{K} 1$ - K2 / IV / III}

K1: - cerpl'ivoś śe vyčerpauna. ina inuš tego ne z'ńese.

K2: - z'ńeśeš. ile to žečy čuovien ing muśi z'néz i znośi. neraz mu śe vydaie, že ne vytšsymo i vyțšymuie.

Powtórzenia semantyczne (zob. Bartmiński 1973: 49-51; Umińska-Tytoń 1995: 241-248) polegają na mówieniu tego samego w innej formie, różnica dotyczy części mowy.

\section{D / K - M / III / III}

$\mathrm{K}$ : - myncy se barzo, a ia ńiz ńe moge pumuc.

M: - ńiz ne poražiš, tylko se modlićc. ni možna umžyć, inak śm’ier’’́

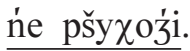

\section{D / K1 < K2 / II / IV}

K1: - každa uadno, iak se vystroi.

K2: - ńe gadei i. unadno kobita. dobže, že alegancko śe ńośi, gust mo. 


\subsection{Paralelizm syntaktyczny}

Jednym ze sposobów kształtowania komunikatu jest analogiczny układ zdań, który stanowi czynnik porządkujący przekaz, doprowadza do regularnego, niemal geometrycznego kształtu wypowiedzi (zob. Kurkowska, Skorupka 2001: 217218). Podkreśla zawarte w zdaniach przeciwstawienia, porównuje i wydobywa kontrasty. Paralelizm mowy oddaje paralelizm myśli.

Powtórzenie $\mathrm{w}$ formie paralelizmu składniowego pozwala na porównanie danych elementów rzeczywistości, niekiedy wywołuje u odbiorcy określone nastawienie do treści. Jego produktywne typy to anafora i epifora, dzięki którym uwypukla się znaczenie poszczególnych wyrazów i zdań.

\subsubsection{Anafora}

Anafora według M. Dłuskiej (1996) jest stylistyczno-składniowym środkiem, polegającym na rozpoczynaniu tym samym leksemem lub zwrotem kolejnych segmentów wypowiedzi: grup składniowych, zdań w celu uwypuklenia treści komunikatu. Funkcją tej figury retorycznej jest wskazanie i podkreślenie wybranych elementów wypowiedzi, które z określonych przyczyn rozmówca uważa za najważniejsze. Wykorzystując anaforę, nadawca zwraca uwagę odbiorcy na osoby, przedmioty, sytuacje lub czynności. Ponadto anaforyzacja uwydatnia paralelizm i efekt symetrii (zob. Polański 1999: 41-43); anafora odnosi się do replik występujących na początku wersów lub zdań. W badanych tekstach obejmuje pojedyncze leksemy - czasowniki, rzeczowniki, przysłówki.

D / K1 - K2 / III / III

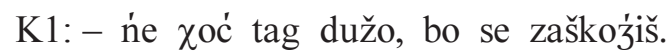

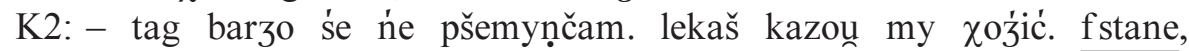

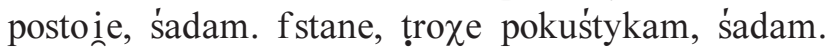

\section{D / M - K / III / II}

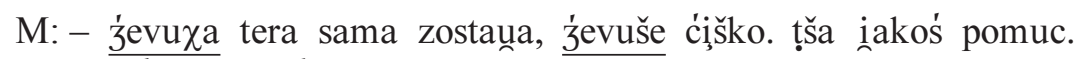

$\mathrm{K}$ : - m’ne samy ćiško.

M: - ale ty mož rynte, a ununa ńi mo roboty.

D / K - M / III / IV

$\mathrm{K}$ : - gưovy ńi m’iou, žeby tyle nabrać.

M: - za cuź muśoun postavićc. dužo v’źuu, dužo muśi puacicić. darmo ne daiom. 


\subsubsection{Epifora}

To środek językowy polegający na powtarzaniu tego samego leksemu lub zwrotu na końcu kolejnych segmentów wypowiedzi: grup składniowych, zdań lub kolejnych członów zdania rozwiniętego. Stosowana jest w celu podkreślenia funkcji ekspresywnej, uzyskania paralelizmu składniowego, uwydatnienia treści komunikatu. W analizowanych tekstach wyodrębniona została epifora rzeczownikowa i czasownikowa.

\section{D / K - M / III / III}

$\mathrm{K}:-$ tera to na to uxoperuiom.

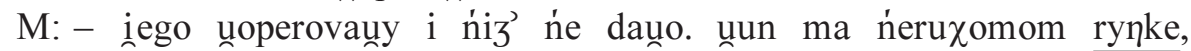

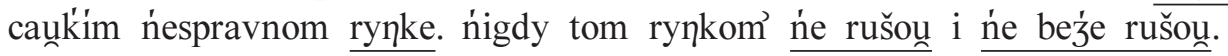

\section{D / K1 - K2 / II / III}

K1: - curce tyž dauna.

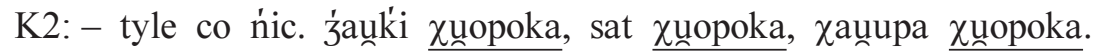

D / M - K / III / III

M: - zažykaụa se, že tag zrobii.

$\mathrm{K}$ : - ty ini ne v'i ieš! muvić, to ununa poțraf'i. unob'i iecyvać, to ununa poțraf'i $\mathrm{i}$.

\subsection{Szyk wyrazów}

Szyk wyrazów wskazuje na subiektywny stosunek mówiącego do zjawisk otaczającej rzeczywistości i subiektywny sposób przedstawienia ich w wypowiedzi.

Inwersja definiowana jako „odchylenie od zwykłego szyku” (Kurkowska, Skorupka 2001: 215), niewątpliwie wpływa na kształt stylistyczno-językowy tekstu (zob. Wierzbicka 1963). Zabieg ma na celu wyeksponowanie najistotniejszych słów, nadanie wyrazom nowego odcienia znaczeniowego lub uwydatnienie emocji, ponieważ odwrócenie wydobywa właściwości semantyczne poszczególnych leksemów, nadając im wartości emocjonalne. Zmiana obowiązującego w zdaniu szyku podkreśla najistotniejszy z punktu widzenia nadawcy element wypowiedzi i służy wyrazistości stylu (zob. Urbańczyk 1991: 350-351). Język polski charakteryzuje się dużą swobodą w zakresie szyku zdania, rozumianego jako układ leksemów w wypowiedzeniu i wypowiedzeń względem siebie (por. Górny 1960). Szyk wyrazów w wypowiedzeniu podlega określonym prawom syntaktycznym (zob. Jodłowski 1965), mimo to w polszczyźnie mamy znaczne możliwości w zakresie zmiany układu wyrazów w zdaniu bez naruszenia treści przekazu. Pozwala to nadawcy formułować wypowiedzenie tak, aby najlepiej przekazywało sens. Inwersja wyrazów umożliwia przesunięcie akcentu logicznego zdania, ma na celu zwrócenie uwagi odbiorcy na te słowa, które uzyskują akcent ekspresywny, zajmują uprzywilejowane miejsce na początku lub końcu zdania. 
W analizowanym materiale inwersja polega na rozbiciu grupy podmiotu i orzeczenia, przestawieniu kolejności podstawy i określnika w okolicznikach:

D / K1 - K2 / III / III

K1: - žeby tak postomṕpić.

K2: - luźi zụy $\chi$ tera vincy iag dobry $\chi$. ne źif’ 'se, tera tak’ie časy.

D / K1 - K2 / III / III

K1: - naibar’źei lubie ńeźele.

K2: - d’ńim nainuokrop’neiňšm zafše iez' neźela. pațše iag jećoki z unoịcamy $\overline{\text { idum }} \overline{\text { do koścouna, a unun }}$ ź źatkamy.

D / M - K > Ub / IV / IV / II

M: - my ńe mogli ty krovy zabrać.

K: - a inak puźńei my do Polski od iežžali, a to kupcuv dužo do nei barzo byuno.

\section{D / K - M / III / III}

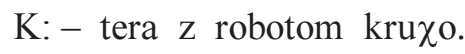

M: - do roboty ne $\chi c e$ iść. iagby k'ćoun, to robote znaij́ze.

Wysunięcie leksemu na początek lub na koniec zdania w sposób intencjonalny kształtuje semantykę wypowiedzi, podkreśla i eksponuje to, co w komunikacie najważniejsze, ujawnia hierarchiczną zależność składniową między leksemami. Semantycznie najważniejszy element wypowiedzi zajmuje najczęściej pozycję inicjalną. Pierwszy wyraz w szczególny sposób skupia na sobie uwagę rozmówcy, a nadawca - rozpoczynając wypowiedź - w sposób wyrazisty uświadamia odbiorcy swoje stanowisko. Gdyby nie inwersja, przekaz byłby bardziej stonowany.

\subsection{Sposób lączenia zdań}

Na postawę uczuciową odbiorcy istotny wpływ ma także sposób łączenia zdań. W języku mówionym w porównaniu z językiem pisanym (zob. Wilkoń 1982: 19-32) występuje uboższy zasób wskaźników zespolenia, wynikający przede wszystkim ze spontanicznego tworzenia tekstu mówionego, a także z tendencji do ekonomii językowej.

W rejestrowanym materiale, którym są najczęściej wypowiedzi ludzi starszych, niewykształconych, jako budulec wypowiedzi wykorzystywane są proste, bardzo wyraziste, ekonomiczne środki składniowe.

W komunikacji twarzą w twarz najważniejsze jest porozumienie, wypowiadana treść, natomiast mniej ważna jest forma językowa, stąd konstrukcje w tekstach gwarowych są proste, krótkie, nierozwinięte, powiązane spójnikowo lub bezspójnikowo i mogą tworzyć dłuższe ciągi. 


\subsubsection{Asyndeton}

Połączenie bezpośrednie, bezspójnikowe jest charakterystyczne dla języka mówionego. Pozostawia pewną swobodę interpretacyjną odbiorcy. Zastosowanie asyndetonu prowadzi do większej zwartości, kondensacji treści (zwłaszcza emocjonalnej i wyobrażeniowej), sugeruje wysokie napięcie uczuciowe nadawcy, uintensywnia narrację i wzmaga tempo wypowiedzi (zob. Kurkowska, Skorupka 2001: 211).

$\mathrm{D} / \mathrm{K}-\mathbf{M} / \mathbf{I V} / \mathbf{I V}$

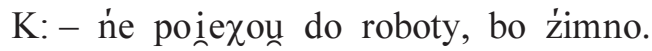

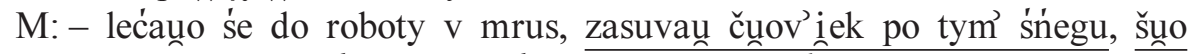
śe po ty gruźe. a tero źimom za źimno, latym za ćepuno.

\section{D / K1 - K2 / III / IV}

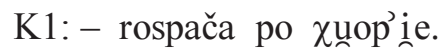

K2: - veḍle lużi aby. pšeće ununa go za ńiz miauna, vyzyvauna go, do bića skakauna, nevad na pogžeb’i ie ne zapunakauna.

D / K1 < K2 / II / IV

$\mathrm{K} 1$ : - fcale mi $\mathrm{v}$ domu ńe pomaga.

K2: - a ty mu f polu pumagaš? pšeće unun mo grande roboty. sady vypryskać, żelska povyžynać, klatki popšynośić, ovoz zebrać, iexać pospšedać.

\subsubsection{Polisyndeton}

Polisyndeton (zob. Kurkowska, Skorupka 2001: 211) polega na łączeniu kilku jednorodnych części zdania albo kilku zdań współrzędnych za pomocą tego samego spójnika. Przez zastosowanie polisyndetonu można lepiej powiązać poszczególne elementy, zwłaszcza, jeśli mamy do czynienia z rozbudowaną treścią.

Powtarzanie spójników robi wrażenie pewnej prostoty, zabieg jest często wykorzystywany jako środek stylizacji w poezji ludowej i literaturze dla dzieci. W badanych tekstach obejmuje części zdania i wypowiedzenia.

D / K1 - K2 / III / III

K1: - s samy rynty se íakoź uțšymaš.

K2: - ne vystarčy. dobže, že mam krove. s krovy i mliko i smo inetane i syr i masuno mam.

$\mathrm{D} / \mathrm{K}-\mathrm{M} / \mathbf{I I I} / \mathbf{I V}$

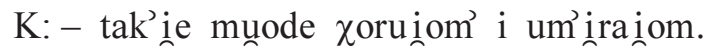

M: - ńiz’ ne poraźišs. uḿiraiom i muode i stare, i bogate i bidne.

D / K - M / III / III

K: - veśta vy te źem'ie.

M: - zapisoun i otpisoun. i davoun i odbiroun. tera nig ńe veźm’ie. 


\section{D / K1 - K2 / III / III}

K1:- $\chi$ yba na zúne śe ma.

K2: - beźe dobže. Durczok bid'ńe vyglundou i tyž m’iou raka. i u nos

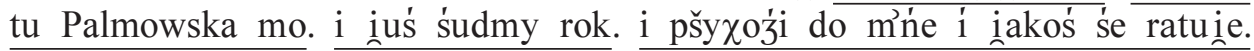
i pšežutuv’ ńi mio.

\section{$\mathrm{D} / \mathrm{K} 1<\mathrm{K} 2$ / II / IV}

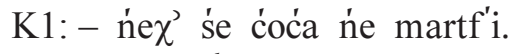

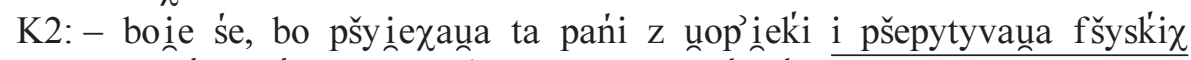
co i iag i muśauny se tunumačy 3 i mauno co m’ne ne zabrauny.

\subsection{Pauza uczuciowa}

Pauzy to zjawisko charakterystyczne dla składni języka mówionego, pozwalają domyślić się uczuć nadawcy i wpływają na emocje odbiorcy. Wypowiedzi ustne, w przeciwieństwie do języka pisanego, charakteryzują się mniejszą spójnością logiczną, często bowiem proces konkretyzowania zamierzonych myśli następuje w toku mówienia. Moment, w którym ,zastanawiamy się”, zaznaczony jest w mowie użyciem określonych form językowych: pauz i zwrotów retardacyjnych (opóźniających), np. niepotrzebnych powtórzeń czy treściowo pustych słów (por. Kurkowska, Skorupka 2001: 224). Głównym celem spowalniania narracji przez stosowanie pauz jest podkreślenie uczuć nadawcy. Inne, poboczne funkcje to: retardacja (opóźnienie) wskazująca na tok konstruowania przebiegu myślowego mówiącego (w tym znaczeniu opóźnienie można uznać za element stylizacyjny) oraz potęgowanie napięcia - chęć zwrócenia uwagi odbiorcy na treści, które dopiero mają nastąpić.
D / K - M / III / III

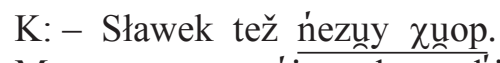

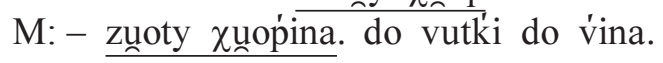

Pauza czasem bywa środkiem wyrazu silniejszym niż sam dźwięk. Rozmówca może zastosować ją z perswazyjnym zamysłem, świadomie kształtując napięcie emocjonalne przekazu. Zabieg służy ironicznemu przewartościowaniu komunikatu, buduje napięcie, ma zainteresować odbiorcę i zwiększyć efekt zaskoczenia.

\subsection{Wykrzyknienie}

Eksklamacja jest figurą retoryczną, która ma na celu spotęgowanie ekspresji. W analizowanych tekstach często przybiera formę zdania wykrzyknikowego, które wskazuje na emocjonalne zaangażowanie nadawcy, które powinno udzielić się odbiorcy. 


\section{D / M1 - M2 / III / IV}

M1: - ty víš, iakí unun bogaty!

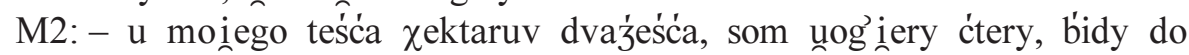

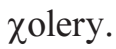

\section{D / K - M / III / III}

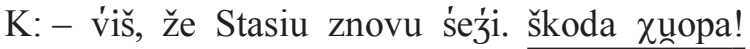

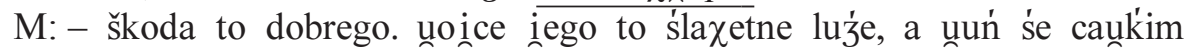
zgaunganiun.

\section{D / K1 < K2 / II / IV}

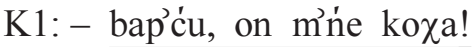

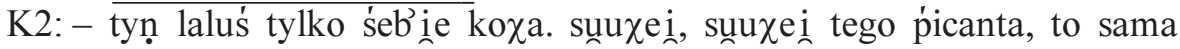
beǰež j̇ećoka dyrtośić.

\section{D / K - M / III / III}

$\mathrm{K}$ : - ne možeš tag muvić.

M: - O Boże! dei i iuš spokui.

Funkcję ekspresyjno-impresywną zawierają w sobie występujące w tekstach wykrzyknienia, zawołania, wykrzykniki. Liczną grupę w analizowanym materiale stanowią te zawierające w składzie leksem Bóg. Pełnią one funkcję wyrażania stanów emocjonalnych, semantycznie należą bowiem do struktur „pustych”, które mogłyby być z powodzeniem pominięte w każdym kontekście. Są znakiem silnych uczuć nadawcy, emocjonalnym komentarzem do całej wypowiedzi.

W tekstach jest sporo wykrzykników (zob. Wojtczuk 2004: 291-300; Wojtczuk 2006: 347-358) charakterystycznych dla potocznej odmiany mówionej języka.
$\mathrm{D} / \mathrm{K} 1-\mathrm{K} 2$ / II /III

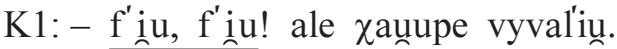

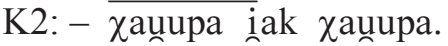

Fiu! Fiu! - wykrzyknik parokrotnie powtórzony wyraża uznanie.

$$
\begin{aligned}
& \text { D / M - K / III / II } \\
& \text { M: - može musita } \mathrm{f} \text { pole? } \\
& \mathrm{K}:-\underline{\chi 0 !} \chi \mathrm{o} ! \text { ale nespoźanka. }
\end{aligned}
$$

Ho! Ho! - powtórzony wykrzyknik służy mówiącemu do wyrażenia radości z powodu niezapowiedzianej wizyty.

Składnia potoczna badanych tekstów stanowi odbicie potocznego sposobu myślenia, charakteryzuje się tendencją do skrótu, licznymi elipsami oraz osobliwym szykiem, obecnością zdań krótkich, niekompletnych (pozbawionych orzeczeń), jak i dłuższych z powtórzeniami i wtrąceniami. Stosowanie wybranych środków składniowych zależy od celu, który zamierza osiągnąć nadawca. 


\section{Pojęcia argumentowanie, argumentacja, argument}

Głównym celem perswazji jest argumentowanie (zob. Perelman 2004; Szymanek 2005) tj. aktywność myślowa, która ma uzasadnić lub obalić czyjeś twierdzenie, tezę lub przekonanie, w procesie przekonywania warunkuje ono osiągnięcie zamierzonych efektów perswazyjnych. Argumentacja to zespół argumentów, motywacja, sposób dowodzenia słuszności. Ch. Perelman (2004) uważa, że „Argumentacja zmierza do oddziaływania na słuchaczy, do zmodyfikowania ich przekonań i nastawień za pomocą mowy, która ma na celu zdobycie ich przychylności [...]”. Przy czym ,argumentacja nie ma wyłącznie na celu uzyskania u słuchaczy zgody czysto intelektualnej. Bardzo często chce ona pobudzić do działania, lub co najmniej stworzyć do niego dyspozycję [...], aby stworzona w ten sposób dyspozycja była dostatecznie mocna, tak, żeby mogła pokonać ewentualne przeszkody" (Perelman 2004: 25).

O sile oddziaływania przekazu decyduje rodzaj wykorzystanych argumentów, sposób ich formułowania i jakość argumentacji. Argument to dowód, racja; przesłanka dowodu, twierdzenie uzasadniające albo obalające tezę.

W tekście perswazyjnym argumentacja polega na szczególnym sposobie opisywania osób, zdarzeń i wartości, na akcentowaniu i uwypukleniu najważniejszych. Poprzez stosowanie argumentacji nadawca stara się przekonać odbiorcę o słuszności i sensowności tego, o czym informuje. Istotą argumentacji według Perelmana (2004: 22-23), ,jest wywołanie lub wzmocnienie poparcia audytorium dla tez, przedkładanych mu do akceptacji [...]".

Rolę argumentacji doceniał Arystoteles (1988: 70), który sformułował podstawy różnych argumentacji i podkreślał, że: „skoro to, co przekonywające przekonuje kogoś, dzieje się tak dlatego, że albo jest to przekonywające i wiarygodne samo przez się, albo ponieważ wydaje mu się udowodnione na podstawie przekonywających i wiarygodnych argumentów".

Siła argumentu zależy od tego, czy odbiorca w niego uwierzy, nie zaś od tego, czy argument jest prawdziwy. Perswazyjny walor argumentów akcentuje W. Pisarek (2004: 124), który uważa, że: „Na dobieranie argumentów i sposób ich przedstawienia zezwala prawo selekcji motywowanej perswazyjnie". Argumentacja może być jednostronna - przedstawienie tylko argumentów za, lub wielostronna - przytoczenie argumentów za i przeciw. Odpowiednia argumentacja odgrywa ważną rolę w procesie przekonywania odbiorcy, a finalny efekt działań perswazyjnych uzależniony jest od sposobu wykorzystania argumentów. Ludzi przekonują różne argumenty: spokój wewnętrzny, pochwała, uznanie, pieniądze, czasem pobudzająco działa strach. Przy wyborze rodzaju argumentacji istotne znaczenie ma charakter grupy, jej wykształcenie, nastawienie do tematu. W przypadku osób niewykształconych skuteczniejsza jest argumentacja jednostronna, ten typ argumentacji sprawdza się także u ludzi 
od początku aprobujących główne założenia przedstawianego stanowiska (zob. Awdiejew 2004b: 71-80).

Perswazyjnie sformułowana argumentacja ma służyć przekonaniu odbiorcy, może ona wykorzystywać sposób argumentowania oparty na myśleniu racjonalnym lub odwołujący się do emocji.

Oddziaływanie perswazyjne w codziennych interakcjach mieszkańców wsi opiera się nie tyle na argumentacji racjonalnej, ile na sferze emocjonalnej. Wywołanie silnych emocji prowadzi do obniżenia krytycyzmu odbiorcy i umożliwia dominację nadawcy. Perswazyjne zachowania nadawcy mają służyć nakłonieniu odbiorcy do wyboru wartości czy przekonań najbardziej mu odpowiadających (zob. Korolko 1998). Ponadto argumentacja w języku naturalnym może wykorzystywać dwuznaczności, których nie da się z góry wykluczyć (por. Perelman 2004: 22).

W procesie przekonywania istotne znaczenie ma również waga i sposób hierarchizacji argumentów, ponieważ właściwy wybór i przedstawienie argumentów decyduje o sile perswazji. W argumentacji pomocne są zasady retoryki. W celu sprawnego wyjaśnienia i przekazania informacji nadawca może układać je według schematów i zasad organizujących wypowiedź:

- przyczynowo-skutkowych,

- uporządkowania chronologicznego,

- uporządkowana przestrzennego,

- przez porównanie z obiektami i zjawiskami szczególnie bliskimi odbiorcy.

W komunikacji mieszkańców wsi występuje argumentacja rzeczowa i uczuciowa. Argumentacja rzeczowa przedstawia obiektywnie zebrane, sprawdzone dane i fakty oraz wynikające $\mathrm{z}$ nich logiczne wnioski. W dowodzeniu słuszności nadawca nie zawsze sięga po argumenty rzeczowe. Niejednokrotnie odwołuje się do uczuć, stosując argumentację uczuciową. Odwołanie do emocji służy przeniesieniu uczuć z nadawcy na odbiorcę i ma wzmocnić jego przekonanie o słuszności danego sądu, o sensowności realizacji przedstawionego celu lub skuteczności proponowanych sposobów osiągnięcia go. Ważne jest także sugestywne podkreślenie, że inne cele nie są tak samo wartościowe.

$\mathrm{W}$ analizowanych tekstach argumentowanie polega na uzasadnianiu i wyjaśnianiu, a o jego skuteczności decyduje nadawca, odwołując się do pewnego typu argumentów, które są w stanie przekonać odbiorcę. Istotny walor perswazyjny ma argumentacja odwołująca się do zdrowego rozsądku, szczególne znaczenie mają argumenty powiązane z życiem i wiejskimi realiami. Dzięki nim wypowiedź staje się przystępna, a argumentacja trafia do odbiorcy ze względu na swą prostotę, oczywistość i mocny rodowód kulturowy. 


\subsection{Typy argumentacji}

\subsubsection{Argumentacja odwołująca się do natury}

$\mathrm{D} / \mathrm{K}-\mathrm{M} / \mathrm{III} / \mathbf{I V}$

K: - unoice śe pšed’ źimom pšeńesom do m’iasta.

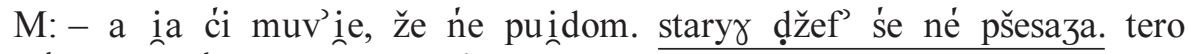
za puźno. v žyću, iak f pšyroźe, fšysko ma sfui čas.

Przeciw stanowisku przedstawionemu przez kobietę występuje mężczyzna, który - by przekonać ją do swoich racji - posługuje się obrazem przyrody. Sformułowanie starych drzew się nie przesadza akcentuje mądrość życia zgodnie z prawami natury. Taki sposób argumentowania świadczy o wrażliwości i umiejętności spojrzenia na ludzi, a ze względów kulturowych jest bliski odbiorcy.

\section{D / M1 - M2 / III / III}

M1: - tako faina kobita, a unun taki ńemotovaty

M2: - važne, že im dobže. luźe mušom byş ružne. źim’ina unod źimi unotstaiie, to i čnov’ieg unoḍ čunov'ieka.

Pierwszy rozmówca krytycznie wypowiada się o związku kobiety i mężczyzny, a podkreśleniu różnic służą wartościujący pozytywnie modny przymiotnik fajna i przymiotnik niemotowaty - gw. 'ślamazarny, powolny, flegmatyczny'. Drugi z mężczyzn wyjaśnia różnice między ludźmi, odwołując się do przykładu ziemi, której podobnie jak ludziom, została przypisana sprecyzowana charakterystyka. Przekonuje, że w relacjach między osobami bliskimi, mimo istniejących rozbieżności, najważniejsza jest umiejętność porozumienia.

\section{D / M - K / III / III}

M: - ia bym' se ne dou takimu malịstfu podeińs.

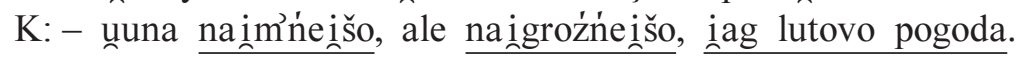

Porównanie najmniejsza, ale najgroźniejsza - jak lutowa pogoda, odwołuje się do doświadczenia, które zwraca uwagę na to, że ktoś wyglądający niepokaźnie czy zgoła ułomnie może okazać się wyjątkowo sprawny i groźny.

\section{D / K1 - K2 / III / III}

K1: - ńe moža tag robić.

K2: - unatfo śe muv́i. vzui i ego buty i pšeỉ í iego ḍroge.

Ze stanowczym stwierdzeniem pierwszej z kobiet, wyrażającym negatywną ocenę postępowania osoby, nie zgadza się druga z rozmówczyń. Metaforyczne określenie życie ludzkie to droga wskazuje, że uczciwe wygłaszanie opinii na temat innych ludzi możliwe jest jedynie wtedy, gdy ma się identyczne doświadczenia życiowe. Aby właściwie pojmować i interpretować cudze poczynania, należy 
znać wszystkie fakty. Przekaz zyskuje na sile poprzez żywość i barwność przedstawienia.

Jak wskazuje W. Pisarek (2004: 127-128): „Do wyobraźni słuchacza i czytelnika najskuteczniej znajdują drogę pr z y k ła dy, które ilustrują przekazywane myśli”.

\subsubsection{Argumentacja podkreślająca zaangażowanie w pracę}

\section{D / M1 - M2 / III / III}

M1: - v m’ieśće ne zakumbinuie, luźe ćịško pracuiom.

M2: - żimi tyś śe ne unošuka. ńi možna śe spuźńić. țša robiż żin v żiń.

Pierwszy z mężczyzn podkreśla w wypowiedzi uczciwość i wysiłek jako charakterystyczne cechy osoby pracującej w mieście. Drugi rozmówca zgadza się z tą opinią, argumentuje jednak, że podobnie wygląda praca na wsi. Użycie w odniesieniu do leksemu ziemia czasownika oszukać, który łączy się z rzeczownikami żywotnymi, podkreśla szczególny wysiłek rolników, którzy - aby zbierać płody - muszą także ciężko pracować, dotrzymywać terminów sadzenia i siania, obserwować i pielęgnować rośliny przez cały czas wegetacji. Wyrażenie dzień $w$ dzień uwypukla codzienny trud systematycznej pracy na roli. Nadawca zręcznie odwołuje się do reguły naturalnej, logiczna argumentacja ma przekonać odbiorcę swą przystępnością.

\subsubsection{Argumentacja ukierunkowana na przewidywanie przyszłości}

\section{$\mathbf{D} / \mathbf{K}-\mathbf{M} / \mathbf{I I I} / \mathbf{I I I}$}

K: - ne bej́e se martf'iu i narab’iau, bo inemu vystarčy, né každy o seb'ie dbo.

M: - tako polityka, aby na żiśei starčyuno, to ne na dunugo.

W pierwszej wypowiedzi wyraz uogólniający każdy podkreśla, że mężczyzna jest egoistą, ponadto nie przykłada się do pracy, a postawę swoją uzasadnia niewielkimi potrzebami. Drugi rozmówca ripostuje, że koncentrowanie uwagi na działaniach zawężonych do zaspokajania własnych, doraźnych potrzeb, w przyszłości nie pozwoli na sprawne funkcjonowanie i utrzymanie gospodarstwa. Człowiek, który żyje z dnia na dzień, jest osobą nieodpowiedzialną i lekkomyślną.

\section{D / M1 < M2 / II / IV}

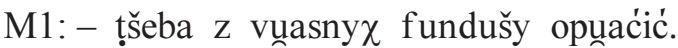

M2: - zapuać, zapuać. ńe v'iadomo, co se može v žyću pšydać. dobže, že mam papiry pščelarsk'ie. zafše pare grošy ies.

Stosując metonimię papiery 'dyplom', mężczyzna zachęca rozmówcę do podnoszenia kwalifikacji, argumentację wspiera przykładem dotyczącym własnego 
postępowania. Sposób argumentowania, odwołujący się do przyszłości oraz do osobistych przeżyć i doświadczeń, służy uwiarygodnieniu przekazu.

\subsubsection{Argumentacja odwołująca się do podnoszenia wiedzy}

\section{$\mathbf{D} / \mathbf{D z}<\mathbf{K} / \mathbf{I} / \mathbf{I V}$}

Dz: - bap'cu! škoda tyle p’ieńenzy na ten kurs. l'ičom.

$\mathrm{K}$ : - ia ći dam p’ieńonze. uć śe, beje ći lžy. z moṇḍrym zafše śe

Babka oferuje pomoc finansową, nakłania wnuka do nauki i podnoszenia kwalifikacji, stara się rozbudzić jego ambicje. Uzasadnia, że decyzji nie należy uzależniać jedynie od kwestii finansowych i podkreśla, że inwestycja w wykształcenie przyczyni się do zdobycia umiejętności, które będą przydatne w pracy zawodowej, zapewnią lepsze wynagrodzenie i prestiż - por. stopień wyższy przysłówka lizej, stwierdzenie z mądrym zawsze się liczą.

\section{D / K - M / III / III}

$\mathrm{K}:-$ żiśei f pracy to naivvažńeinše vykštauncene.

M: - dośf'inațčene ț̌a mić, v’ỉeza śe tyš pšydo, unatf'i śe coź ulepšy.

Na sugestię rozmówcy, że współcześnie najważniejsze jest wykształcenie, mężczyzna odpowiada, że osiąganie dobrych wyników w pracy w jednakowym stopniu uzależnione jest od wiedzy i zdobytego doświadczenia, ponieważ wiedza dzięki umiejętnościom może być praktycznie zastosowana.

\subsubsection{Argumentacja odwołująca się do interesów materialnych słuchacza}

\section{$\mathbf{D} / \mathbf{M}<\mathbf{K} / \mathbf{I I} / \mathbf{I V}$}

M: - bede țšymać, može puźńi, iak cena puij̉e $\mathrm{v}$ gure, to spšedam.

K: - albo spšedaš, albo ne spšedaš. leṕi unopuź i spšedei. a iak puźńi ne bedom kupovać, a na v'i inosne iapko, gruška se psui in. škoda tfoi roboty. a pińunze țša znuv v unopryskii vunožyć.

Mężczyzna podkreśla ponoszenie wysokich nakładów i nieopłacalność sprzedaży owoców. Proponowana cena skupu nie pokrywa poniesionych kosztów produkcji. Kobieta przekonuje go do sprzedaży płodów rolnych mimo niskiej ceny produktu. Jako istotny argument podnosi możliwość braku zbytu na owoce i kolejne wydatki związane z sadownictwem.

\section{D / K - M / III / III}

K: - kup se piue, raz dva pot’neš.

M: - kupiunoby śe v'ieś, žeby pińunze m’ieć.

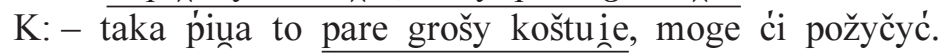


Mężczyzna, używając przysłowia, wskazuje na brak pieniędzy, uniemożliwiający realizację zakupu. Kobieta wyraża gotowość udzielenia pożyczki i przekonuje, że zakup nie wymaga dużych nakładów finansowych.

\subsubsection{Argumentacja odwołująca się do wiary religijnej}

\section{D / K1 - K2 / III / IV}

K1: - vidaź muśaú ten lekaž byj́ dobry i pomuk.

K2: - iei tylko Matka Boska uzdroviuna na Jasnej Górze. cauny čaz ležauna f takim gorseće, a ia modliuna se na Jasnej Górze. [...] i zd’iel'i my ten gorset cauny i pšestauno iei boleć. to sam lekaž żiviun śe.

Istotne znaczenie w życiu mieszkańców wsi ma świat duchowy i związana z nim wiara w moc nadprzyrodzoną. Rozmówczyni przekonuje, że córka została uleczona dzięki jej gorącym modlitwom na Jasnej Górze - w sanktuarium słynącym $\mathrm{z}$ cudownych uzdrowień. Podkreśla, że ludzkie poznanie jest niedoskonałe i nawet lekarz specjalista nie był w stanie zrozumieć nagłej poprawy stanu zdrowia dziecka. Powołanie się na opinię eksperta, który ma specjalistyczną wiedzę, jest elementem wywierającym silny wpływ na perswazyjność przekazu.

\subsubsection{Argumentacja podkreślająca więzi międzyludzkie}

\section{D / K1 - K2 / III / III}

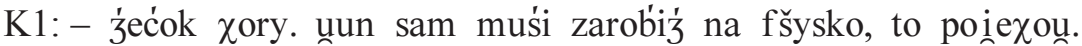

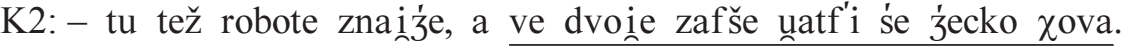

Druga z kobiet podkreśla, że zintegrowana rodzina lepiej radzi sobie z problemami, ponieważ wspólny wysiłek rodziców stwarza większe szanse na prawidłowy rozwój chorego dziecka. Wskazuje, że brak któregoś z rodziców zaburza prawidłowe funkcjonowanie rodziny, matka $\mathrm{z}$ ojcem wspólnie powinni wychowywać dziecko, por. wyraz uogólniający zawsze, st. wyższy przysłówka łatwiej.

\section{D / K1 - K2 / III / III}

K1: - $\chi$ ce vrućis do Zochy.

K2: - tero śe unobuźiun! a g’źe byu fpšudy, iag źećog byu mauny, iak țša byuno v nocy fstaiać? jećog go ne zno.

Rozmówca wskazuje, że mężczyzna zaburzył prawidłowe funkcjonowanie rodziny, ponieważ był nieodpowiedzialny wobec swoich najbliższych. Argumentacja moralna, odwołująca się do motywu miłości do dziecka, wiąże się z kwestią rzetelności i odpowiedzialności ojca wobec syna. Obowiązek wychowania dziecka rozpoczyna się od momentu jego narodzin. Istotne znaczenie ma w wypowiedzi metaforyczne zastosowanie czasownika obudzić się, antonimy: tero - wprzódy 
oraz zaimki każdy, wszyscy, które narzucają odbiorcy przekonanie, że brak więzi emocjonalnych między ojcem a synem wynika z zaniedbań ojca.

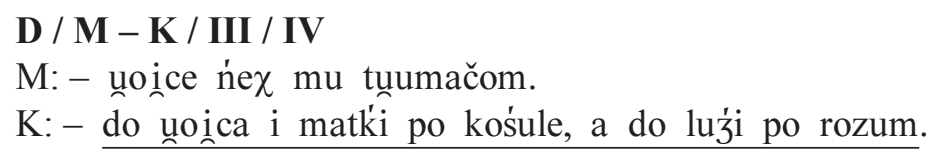

Wykorzystując przysłowie, kobieta podkreśla, że prawdziwego życia uczy się człowiek w kontaktach z obcymi ludźmi.

$\mathrm{W}$ analizowanych tekstach stosowano argumenty racjonalne i pozaracjonalne. Wartość argumentów polega na wykorzystywaniu różnorodnych środków językowych, którymi są: metafory, frazeologizmy, przysłowia, wyrazy upowszechniające.

\subsection{Techniki erystyczne}

Przedstawiamy argumenty i przekonujemy rozmówców do naszych racji nie tylko w publicznych sporach, ale także w życiu codziennym. W działaniu tym pomocne są klasyczne chwyty erystyczne (zob. Kochan 2005), umiejętność zastosowania odpowiednich technik przekonywania pozwala zdobyć przychylność odbiorcy. W analizowanych spontanicznych interakcjach werbalnych wykorzystuje się różne metody i techniki.

\subsubsection{Technika autorytetu}

Istotny czynnik w komunikacji perswazyjnej stanowią autorytety. Jak zauważa Ch. Perelman (2004: 111): „W momencie sporu nie podajemy zazwyczaj w wątpliwość argumentu autorytetu, lecz sam powoływany autorytet. [...] Przywoływane autorytety są bardzo różne: raz będzie to «jednomyślne zdanie» lub «opinia powszechna», innym razem będą to pewne kategorie ludzi - «uczeni», «filozofowie» [...], czasami autorytet będzie bezosobowy [...] «doktryna», «religia», «Biblia»; czasami wreszcie mowa będzie o autorytetach imiennie wskazanych".

Psychologowie podkreślają, że w każdym człowieku istnieje subiektywna potrzeba ocen jako znaków orientacyjnych. Ocena jest przeważnie porównywaniem z jaką́s normą, często idealną, nie zawsze osiągalną powszechnie. Ludzie często kierują się przekonaniami czy opinią innych, nawet jednostki bardzo niezależne, tj. osoby o silnym wewnętrznym autorytecie (zob. Batko 2005: 126), mające tendencję do podejmowania wszelkich działań tylko na podstawie własnych osądów i przekonań, które również efekty swoich działań oceniają, kierując się wyłącznie własnymi wewnętrznymi odczuciami, czasem szukają osób, na których mogłyby się wzorować. Opinia innych działa stymulująco, wyzwala pewne doznania czy przemyślenia. Ocena innych jest szczególnie ważna dla osób o silnym zewnętrz- 
nym autorytecie, osoby te mają tendencję do podejmowania wszelkich działań, opierając się głównie na opinii i ocenie innych, także efekty podjętych przez siebie działań oceniają przez pryzmat reakcji z zewnątrz. Uważają, że dobrze wykonali swoją pracę dopiero wtedy, gdy uzyskają aprobatę z zewnątrz (Batko 2005: 126).

Mieszkańcy wsi często wykorzystują w argumentacji wzorcotwórcze opinie, wśród których wymienić należy autorytet rodzinny, społeczny, autorytety zawodowe, spoleczne, polityczne.

\section{Autorytet rodzinny}

Ludzie mają z natury skłonność do identyfikacji z bliskim otoczeniem, z członkami najbliższej rodziny. Rodzina jest miejscem wzorcotwórczym. Matkę, ojca, dziadków oraz dalszych krewnych uważa się za osoby bezinteresowne i sprawiedliwe, postępujące uczciwie. Odwoływanie się do konkretnych doświadczeń osób, z którymi nadawca jest związany emocjonalnie, często poparte miarodajnymi obserwacjami powoduje, że przekaz staje się bardziej oczywisty i wiarygodny.

\section{D / K - M / III / III}

$\mathrm{K}$ : - ununa ńi moguna tego zrobić.

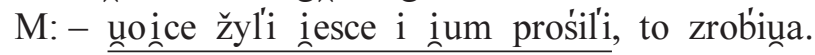

\section{D / K - M / III / III}

$\mathrm{K}$ : - ne bede sob'ie zostav'iauna, bo mi na raźe na níz ne poțša.

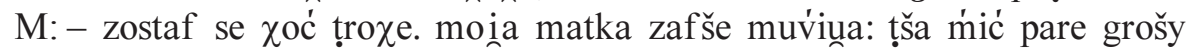

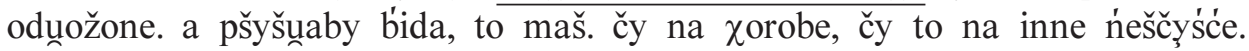

Element osobisty, prywatny ma stanowczą moc perswazyjną. Przytaczanie cudzych wypowiedzi wzmacnia wiarygodność przekazu, służy identyfikowaniu się z rzeczywistym autorem wypowiedzi (por. Michalewski 1999: 63-69). Cytaty spełniają swą perswazyjną funkcję, gdy dotyczą kogoś, kogo odbiorca zna.

\section{Autorytety zawodowe}

Dla osiągnięcia celu perswazyjnego nadawca wykorzystuje także autorytety zawodowe związane z wykonywaną profesją lub pełnioną funkcją: nauczyciel, lekarz, sołtys.

\section{D / M - K / III / III}

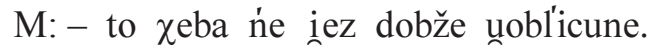

$\mathrm{K}$ : - sountyś śe zno, na pevno dobže vyličyun.

Odwoływanie się do opinii fachowcy, specjalisty, człowieka, który zna się na czymś lepiej niż inni, ma skłonić słuchacza do akceptacji tego, o czym mówi nadawca. 


\section{D / K1 - K2 / IV / III}

K1: - navet’ 'se ńi mam kumu vyžaliź i tak te nervy f sob’ie tưamše.

K2: - lekaž muviuu, že ne țša nervuf $f$ sob’ie duśić. poviz' im, co ći se ne podoba.

\section{D / K - M / III / III}

$\mathrm{K}:-$ a ía luźom v'i ieže.

M: - naš k’śun3 muvii: żiśei v'iežyź možna tylko umarunym.

Perswazji służą odwołania do niekwestionowanych autorytetów moralnych, których słowa mogą mieć znaczną siłę sprawczą. Nadawca przywołuje opinię księdza - osoby o określonym prestiżu społecznym i dużym autorytecie moralnym.

\section{Autorytet społeczny}

Skuteczność przekazu zwiększa wspieranie argumentów postawą zbiorowości. Odwoływanie się do opinii ogółu zapewnia nadawcy wiarygodność i pozwala budować własny autorytet. Należąc do pewnej społeczności, trzeba szanować jej wzorce wpisane w kulturę. Walor argumentacyjny mają przykłady z życia rodziny i bliskich znajomych.

\section{D / K1 - K2 / III / III}

K1: - i ešč śe do spravy zagozom.

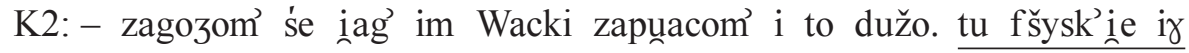
znaiom.

Nadawca puentuje wypowiedź argumentem odwołującym się do powszechnej opinii, por. tu wszystkie ich znaja, która wzmacnia skuteczność perswazji.

\section{D / K - M / III / III}

$\mathrm{K}:-$ nee v'źuu tego.

M: - sum'śady pațšm, to vizom.

\section{Autorytet mediów}

Nieocenionym narzędziem oddziaływania na świadomość i postawę ideową człowieka jest telewizja, która rozszerza zakres informacji, popularyzuje wiedzę i determinuje postawy ludzi niemal we wszystkich dziedzinach życia.

\section{D / M - K / III / III} zbirać.

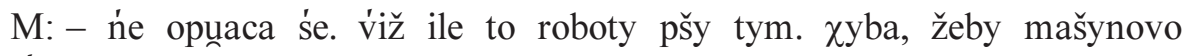

$\mathrm{K}:-\mathrm{f}$ telev’iz'ii muviuuxy, f tym roku grož na čorny pužycce naipryṇțšy do zrobina. 


\section{Autorytet instytucji}

\section{D / K - M / III / III}

$\mathrm{K}$ : - ununy povinny tyn $\mathrm{V}^{\prime}$ iazd zrobiź z ḍruǵi sṭruny.

$\mathrm{M}$ : - tak f sunźe nakazaŭy, to tag vidaź naịleṕi ḍla fšyski $\chi$.

Odwołanie się do informacji potwierdzonych przez ekspertów i specjalistów powoduje, że informacji takich nie można podważyć.

\subsubsection{Technika porównań i przykładu}

Perswazyjny walor danych liczbowych doceniał H. Lemmermann (1997: 84), który tak pisał o magii danych liczbowych: „Ponieważ w nauce najbardziej dokładne, konkretne i rzeczowe są liczby, we wszystkich współczesnych debatach przywoływanie materiału liczbowego okazuje się najsolidniejszym sposobem argumentowania. Dzieje się tak choćby dlatego, że nikt nie jest w stanie w krótkim czasie zakwestionować przedstawionych kolumn liczbowych. [...] Dzięki dowolności w wyborze i zestawieniu materiału liczbowego bardzo łatwo ustawić tu akcenty w wygodny dla mówcy sposób" (zob. II.1.10. Perswazyjny walor danych liczbowych).

$\mathrm{W}$ argumentacji istotne znaczenie ma także podobieństwo i analogia.

\subsubsection{Technika nagromadzenia, akcentowania}

Akcentowanie może wynikać z powtarzania, gromadzenia szczegółów, podkreślania niektórych fragmentów. Zabieg ten pozwala skupić uwagę odbiorcy na wybranych i odpowiednio wyselekcjonowanych przez nadawcę fragmentach wypowiedzi (zob. II.1.11. Rozbudowana synonimika a intensywność ocen; II.7.12. Powtórzenie jako emocjonalne zaakcentowanie sądów).

\subsubsection{Technika uprzedzania zarzutów}

Figurę retoryczną prolepsis stosuje się do odparcia zarzutów przed ich sformułowaniem. Rozmówca uprzedza nasuwające się zarzuty i próbuje je osłabić, pomniejszyć.

D / M - K / III / III

M: - daš mu na te gre?

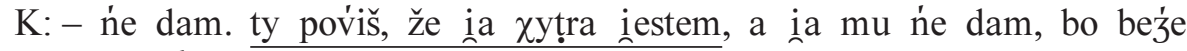
śeźau caụy żiń i tylko groun. 


\section{Komunikacja niewerbalna jako element wzmacniający perswazyjność przekazu}

Kod werbalny nie wyczerpuje $\mathrm{w}$ dostatecznym stopniu istoty perswazji w spontanicznej komunikacji, ponieważ wypowiedź jest odbierana i interpretowana na różnych poziomach percepcji. Z. Nęcki (1996a: 55) ujmuje komunikację międzyludzką w następujący sposób: „Kontakt interpersonalny rozgrywa się na dwóch płaszczyznach: na płaszczyźnie powierzchniowej, na której następuje wymiana komunikacyjna i na płaszczyźnie głębokiej, na której następuje interpretacja sensu przekazów, ich wewnętrzne opracowanie. Wszystko, cokolwiek człowiek robi, jest pewną formą jego ekspresji, wyrażania samego siebie. Ruchy ciała, gesty, subtelności wymowy, momenty zawahania, sposób wyrażania się, ujmowanie treści w słowach i aktach niewerbalnych tworzą bogato ukształtowaną powierzchnię kontaktu, a zarazem jedyne «twarde» fakty dostępne obserwacji”.

Perswazję słowną wspierają elementy pozasłowne, często tworząc sieć zależności, która przekształca się w spójny, uzupełniający się przekaz, istotny dla pełnego odczytania komunikatu językowego.

Środki niewerbalne wywierają duży wpływ na komunikację językową i mają swoisty status, ponieważ zwiększają potencjał komunikacyjny tekstu. Istotne znaczenie przy całościowym odbieraniu przekazu mają w codziennej komunikacji językowej: gesty, mimika, a także barwa i ton głosu. Elementy te skutecznie wzmacniają treści komunikatu słownego i powodują, że jest on bardziej sugestywny i wiarygodny, ponieważ odzwierciedla stany wewnętrzne, tj. emocjonalne nastawienie nadawcy i jego intencje. Kod pozasłowny wspomaga argumentację, przekazuje istotne informacje, które pomagają odbiorcy właściwie interpretować całość przekazu. Towarzysząca komunikacji mowa ciała zwraca uwagę na wybrany składnik komunikatu, najczęściej nadawca poprzez pozajęzykowe sygnały podkreśla pewien istotny fragment wypowiedzi. Sposób obrazowania stanów uczuciowych rozmówcy, na który wskazują mimika, gesty oraz ton głosu, to ważny element wzmacniający przekaz.

Jak wskazują badania J. Antas (2001: 439), gesty i zachowania niewerbalne, będące składnikiem wypowiedzi, są podstawowymi i najbardziej pierwotnymi sposobami wyrażania myśli ikonicznie, wspomagają one komunikat werbalny, wzbogacając go w nowe treści semantyczne. Komunikacja niewerbalna jest związana z wybranym fragmentem rzeczywistości, o którym mówi nadawca. Włączenie kodu niewerbalnego przyczynia się do bardziej efektywnego opisu, ułatwia zapamiętanie treści, stwarza również możliwość sugestywnego zobrazowania treści. Uzupełnienie informacji słownej służy współgraniu przekazów. Treści przekazywane mimiką, gestem czy odpowiednim tonem są istotnym odautorskim dopowiedzeniem. Połączenie kodów daje możliwość skonfrontowania odczuć, które niosą słowa i znaczenie, z tymi, które przekazuje i utrwala obraz i dźwięk. 
Perswazja przejawia się we wszystkich warstwach komunikacji i może zostać w pełni odczytana dopiero na tle innych kodów, od których niejednokrotnie jest uzależniona.

\subsection{Specyfika tekstów mówionych}

W codziennych kontaktach interpersonalnych zachowania komunikacyjne kształtujące relacje międzyludzkie są zjawiskiem bogatym i złożonym, ponieważ przekaz informacji odbywa się różnymi kanałami. Informowaniu służą wszystkie zmysły, szczególnie: wzrok, stuch i dotyk. Specyfika dyskursu, który odbywa się twarzą w twarz, narzuca mu pewne charakterystyczne cechy, towarzyszy mu spontaniczna, naturalna mimika i gestykulacja.

Perswazja jest zjawiskiem, które łączy w jednym przekazie elementy różnych kodów. Jej istotę stanowi integracja słowa i obrazu, opierająca się na zasadzie komplementarności. Z. Nęcki (1996a: 13) uważa, że: „komunikacja niewerbalna stanowi niezmiernie ważną część procesu porozumiewania się, czasem ważniejszą niż wymiana słowna. [...] szczególnie wtedy, gdy dochodzi do wyrażenia przeżywanych uczuć i formułowania ocen”.

Wśród swoistych reguł i wyznaczników rozmowy wymienia się właściwą wypowiedzi słownej koordynację słów z zachowaniami niewerbalnymi. Rolę komunikacji pozasłownej we współczesnej kulturze podkreśla wielu badaczy (zob. Hall 1987; Jarząbek 1996; Brocki 2000; Antas 2001), niewerbalne środki i zabiegi służą głównie modalnej ocenie zabiegów nadawcy i mają pomóc odbiorcy w wyrobieniu sobie własnej oceny na temat przedstawianych wydarzeń. Wykorzystywane w tej odmianie środki pozajęzykowe ułatwiają porozumiewanie się ludzi. Istotną rolę odgrywają gesty narracyjne, które mają za zadanie uplastycznić i zobrazować, a także podkreślić najważniejsze idee i przesłania werbalne przekazu słownego. Odbiorca odczytuje je jako zintegrowane semantycznie przekazy (zob. Antas, Załazińska 2004: 184).

Sygnał niewerbalny, wspomagający perswazję (zob. Szkudlarek-Śmiechowicz 2007: 299-308), może obejmować różne zachowania gestyczne, ekspresję twarzy, znaczenie zawarte w tonie i intonacji mowy, dotyk jako wskaźnik relacji międzyludzkich, a także dostosowanie pozycji ciała i dystansu interlokutorów zależne od stopnia zażyłości, płci, ról społecznych itp. Kod niewerbalny powiązany jest z treścią wypowiedzi, a sposób połączenia różnych subkodów sugeruje rozmówcy właściwy odbiór rzeczywistości i wzmacnia perswazyjność przekazu.

\subsection{Wizualne komponenty przekazu}

Wrrok odgrywa ważną rolę w codziennej interpretacji zjawisk, ponieważ, jak dowodzi B. Bergström (2009: 79), ,[...] zmysł wzroku wysyła do mózgu naj- 
więcej sygnałów". W analizowanym materiale na postawę odbiorcy wpływają zachowania gestyczno-mimiczne, które dostarczają dokładnych i jednoznacznych informacji o stosunku emocjonalnym nadawcy do przekazywanych treści i w założeniu mają wywoływać określone reakcje odbiorcy. Siła oddziaływania obrazu jest ciekawym sposobem służącym utrwaleniu informacji.

M. Knapp (zob. Nęcki 1996a: 218-223), analizując relacje między zachowaniami niewerbalnymi i werbalnymi w tworzeniu spójnego znaczenia przekazu komunikacji, wyodrębnia: powtarzanie, zastąpienie (substytucję), regulację konwersacji, akcentowanie tekstu mówionego, maskowanie. Funkcja zachowań gestyczno-mimicznych polega na tym, że: dopełniają wypowiedź, podkreślając słowa i nadając im bardziej wyraziste znamiona; mogą osłabiać oddziaływanie słów, modyfikować je lub im zaprzeczać; mogą być samodzielnym źródłem przekazu informacji; dzięki ogromnym możliwościom ekspresywnym można nimi niekiedy zastąpić słowa.

W badanych tekstach funkcji perswazyjnej sprzyjają bogate środki obrazowania myśli, gesty narracyjne (zob. Antas, Załazińska 2004: 185), ale także niewerbalne zachowania interakcyjne, które mają za zadanie zjednać partnerów dla prezentowanych poglądów, idei czy stanowisk.

a) gesty i zachowania mimiczne, będące dla odbiorcy istotnym bodźcem wizualnym, wspomagającym odbiór przekazu:

\section{P / M - K < Dz III / III / I}

M: - smačne bap'ća gotuie! j́ecko unad'ńe ie.

$\mathrm{K}:-$ ne ini, tylko tag bej́e duxubać f tym taližu.

Opowiadanie o sposobie jedzenia dziecka wspiera przekaz wizualny. Użyty w zn. przen. czasownik dlubać - ‘jeść powoli, z niesmakiem' został wzmocniony przez kobietę, która naśladuje powolne ruchy i grymas twarzy dziecka, towarzyszący spożywaniu posiłku.

D / K - M / III / III

$\mathrm{K}:-$ pušy śe, bo mo vy̌̌še vykštauncyńe.

M: - ale ńi mo potstavovego. zuny $\chi 0$ ži, nigdy śe ne uśmi $\chi$, zafše ponury taki.

Kobieta charakteryzuje zachowanie osoby, por. przen. zn. czasownika puszyć się - 'wywyższać się, być nad wyraz nieprzystępnym w kontaktach z ludźmi'. Określenie wyksztatcenie podstawowe użyte przez mężczyznę ironicznie nawiązuje do wypowiedzi kobiety wyższe wykształcenie i podkreśla, że ukończone studia nie świadczą o kulturze osobistej osoby. Rozmówca naśladuje kwaśnq minę i sprężysty sposób poruszania się mężczyzny. Kontakt wzrokowy między nadawcą i odbiorcą, gesty i mimika zawsze wyraziściej oddają opis i wzmacniają oddziaływanie przekazu. 


\section{D / K1 - K2 / III / III}

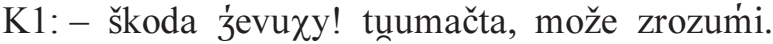

K2: - ńi mo rady, ununa ie za ńim. (kiwanie glowa, smutny wyraz twarzy)

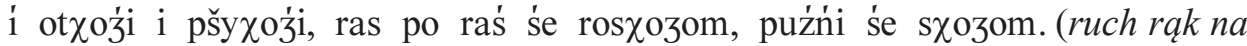
zewnatrz od siebie - ilustruje odchodzenie, ruch do siebie, do środka - powrót)

Wyraz twarzy i gesty kobiety tworzą nastrój wypowiedzi, przede wszystkim zaś przyciągają i skupiają uwagę rozmówczyni, która odnosi wrażenie, że osoba ta chciałaby pomóc, ale wobec przedstawionych faktów jest bezradna.

b) w niektórych przekazach komunikacja pozawerbalna służy modyfikowaniu i przewartościowaniu pierwotnego znaczenia komunikatu:

\section{D / K - M / III / III

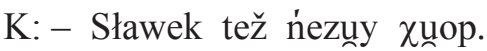

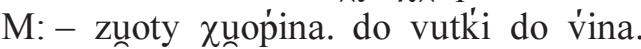

Działanie rozmówcy polega na zaskoczeniu odbiorcy, w pierwszym fragmencie wypowiedzi zgadza się z opinią kobiety. Natomiast pauza, gest otwartej dłoni skierowany do szyi, znaczacy uśmiech nadawcy wpływają na sposób odbioru dalszej części komunikatu. Rozmówca stosuje ironiczny szyfr, zmusza odbiorcę do dokonania pewnych przewartościowań w odbiorze początkowego fragmentu przekazu słownego. Kod niewerbalny narzuca odmienny sposób interpretacji drugiej części wypowiedzi, pozwala ją odczytać z przymrużeniem oka, jako żart. W toku narracyjnym istotna jest pauza uczuciowa. Stosując ją, nadawca daje odbiorcy czas na zastanowienie się, na refleksyjne odczytanie przekazu. Chwilowa rezygnacja $z$ werbalnego sposobu przekazywania informacji uwydatnia znaczenie wypowiedzi i wzmaga siłę przesłania. Warto także zauważyć rym, który służy zapamiętywaniu przekazywanych treści. Wypowiedź wskazuje, że słowa powinny być zgodne z tym, co „mówi” ciało - w przeciwnym razie odbiorca staje się podejrzliwy i zaczyna weryfikować treść komunikatu.

c) niektóre gesty są na tyle czytelne, że stają się samodzielnym źródłem przekazu informacji, wzmacniającym ekspresywność komunikatu:

D / M - K / IV / IV

M: - ne gadai, ne byu taki zư⿱⺈.

$\mathrm{K}$ : - a dobry fcale. takom k'śu̧ške moge napisać.

Rozmówczyni nie zgadza się z opinią wypowiedzianą na temat mężczyzny. Gest oddalonych od siebie dłoni wskazuje na wielkość książki, która przekłada się na rozmiar doznanych krzywd i służy swoistej hiperbolizacji komunikatu.

\section{D / K - M / III / III}

$\mathrm{K}$ : - unu ńi tylko ta źim’ia i tylko te mainuntki.

M:- ńe važne, co iest tu (ruch obu dłoni w kierunku kieszeni, palce naśladuja gest liczenia pieniędzy), ale co iest tu. (pukanie się wskazującym palcem w skroń) 
Bardzo wyraźnie uwydatniona gestykulacja służy do podkreślenia stanowiska, że dla rozmówcy najważniejsze w ocenie człowieka jest to, czy jest on osobą mądrą, a nie to, czy jest zamożny. Mimika, pozy i ruch ciała precyzują treść.

Uzupełnieniem perswazyjnego oddziaływania przekazu mogą być przedmioty, które nadawca wykorzystuje w toku wypowiedzi. Mogą one mieć odrębną wartość komunikacyjną i służyć żartobliwemu przewartościowaniu wypowiedzi.

\section{D / M - K / III / II}

M: - squdne, squdne.

$\mathrm{K}$ : - na ty d'ieće na pevno! na pevno! (potakiwanie glowa)

Kobieta gestem potwierdza wypowiedź mężczyzny, a następnie podnosi do góry puszkę piwa.

D / M - K / III / III

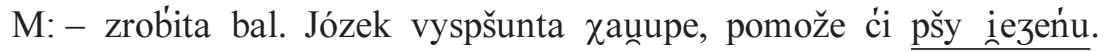

$\mathrm{K}:-$ pšy iezeńu to tak!

Kobieta puszcza oko do rozmówcy i podnosi do ust lyżkę, wskazując, że pomoc mężczyzny nie będzie polegała na przygotowaniu potraw, ale ograniczy się jedynie do ich konsumpcji.

\subsection{Parametry akustyczne}

Głos jest potężną siłą. Jak wynika z badań szwajcarskiego psychologa K. Scherera, na podstawie cech wokalnych potrafimy rozpoznać różne stany emocjonalne człowieka, najłatwiej zidentyfikować smutek, radość i złość, nieco trudniej strach i wstręt. E. Lewandowska-Tarasiuk (2005: 57) dowodzi, że: „Swoboda ekspresji wypowiedzi wyraża się także w ekspresji brzmieniowej - właściwej intonacji i modulacji, umiejętnym frazowaniu i akcentowaniu [...]".

Wśród składników paralingwistycznych, które mają bezpośredni związek z wypowiedzią, istotnymi elementami przekazu odbieranymi przez rozmówców są: intonacja, akcent, tembr oraz barwa głosu. Głosową realizację charakteryzują także takie właściwości dźwięków mowy jak: natężenie, wysokość i czas ich trwania, które mają wpływ nie tylko na skuteczność mówienia, ale mogą być także środkiem informującym o stosunku nadawcy do odbiorcy (zob. Bloch 2006: 44-67).

Prozodia, tembr głosu wzmagają siłę perswazji, działają bowiem na emocje, a nie na intelekt odbiorcy, intonacja oraz akcent wzmacniają ekspresywność wypowiedzi (Grabias 1994: 257). Często nie tyle środki językowe użyte w wypowiedzi, a właśnie intonacja pozwala na dotarcie do właściwego sensu przekazu. Tekst jako całość spełnia komunikatywną funkcję powiadomienia o pewnym określonym stanie rzeczy. Zorganizowany jest nie tylko dzięki językowo-gramatycznym 
właściwościom, ale także dzięki czynnikom wymawianiowym, takim jak prozodemy, które uwydatniają to, czego sam dobór wyrazów i tło wypowiedzi nie daje w dostatecznej mierze.

\section{Intonacja}

W języku mówionym intonacja i odpowiednie modulowanie głosu pozwalają najtrafniej i najpełniej przekazać odbiorcy to, co nadawca myśli, co czuje, czego żąda, bowiem jak podkreśla M. Kita (2005: 104): „głos stanowi jeden z ważniejszych instrumentów wyrażania emocji, a ekspresywna funkcja językowa realizowana jest przede wszystkim za pomocą różnicowania siły i barwy głosu".

Wśród czynników, które pozwalają wyrazić intencję wypowiedzi, istotne znaczenie ma: dobór właściwej barwy dźwiękowej przekazu, umiejętne operowanie siłą głosu, świadome posługiwanie się liną intonacyjną. K. Michalewski (2009: 41) uważa, że: „toniczna modulacja tekstu, na którą składają się: melodia, akcent zdaniowy, pauza, rytm, tempo, siła głosu, tembr, czas trwania głosek zależna jest od woli emitenta" i może pełnić funkcje stylistyczne (zob. Mayen 1972). Ton głosu i ciepła barwa mają wpływ na odbiór informacji, wzmagają zdolność komunikowania się. Intonacja wnosi w wypowiadany tekst dodatkowy ładunek emocji; pewne fragmenty wypowiedzi dzięki rosnącej intonacji, antykadencji, można mimo braku tradycyjnej struktury zdań pytajnych, tj. braku formalnych wykładników w postaci partykuł i zaimków pytajnych, włączyć do pytań. Ponadto intonacja w tekście mówionym, oprócz funkcji semantycznej, pełni istotną funkcję segmentacyjną (zob. Kriger 1983).

Celowe przedłużanie artykulacji niektórych głosek, szybkie wypowiadanie fraz, podniesiony głos oraz zamierzone pauzy nadają wypowiedzi cech ekspresywnych, służą eksponowaniu emocji, podkreśleniu stanowiska nadawcy wobec przedmiotu rozmowy.

\section{D / K - M / III / III}

$\mathrm{K}:-$ to iei curka. podobna do oica.

Kobieta pokazuje album ze zdjęciami.

M: - a g'j̉e tam, do matkí. unadnnna! barzo unadnnna! iag Zocha.

Mężczyzna uważnie ogląda zdjęcie, nie zgadza się z opinią kobiety, świadczy o tym mimika: marszczy nos i gestykulacja - przeczaco kiwa głowa. Pozytywnie wyrażoną opinię na temat urody dziewczyny dodatkowo wzmacniają walory brzmieniowe wypowiedzi: świadomie przedłużona artykulacja głoski, podwyższenie rejestru głosu, co dodaje przekazowi mocy. 


\section{Podwyższenie lub obniżenie rejestru głosu}

Zależnie od natężenia głosu wypowiedź może zawierać rozkaz, życzenie albo prośbę.

\section{$\mathbf{D} / \mathbf{D z}<\mathbf{K} / \mathbf{I} / \mathbf{I I}$}

Dz: - ne $\chi c e$, žeby poiexaúa!

$\mathrm{K}:-$ ne punač, coća muśi zabrać Paulinkę do domu.

Matka w przeciwieństwie do dziecka, które mówi bardzo głośno, odzywa się szeptem, nachyla się w jego stronę. Pragnie wyciszyć, zmniejszyć emocje syna, mówi cicho, żeby uspokoić dziecko.

Wzmocnienie siły głosu służy wyeksponowaniu istotnego z punktu widzenia nadawcy elementu wypowiedzi.

\section{D / K - M / III / III}

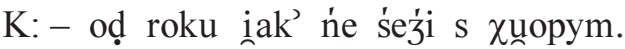

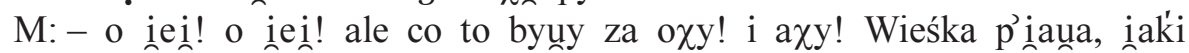
dobry, iag dobže țraf'iuna.

Wykrzykniki zostały wyartykułowane ze szczególnym natężeniem głosu, co zwiększa wyrazistość przekazu. Mężczyzna podkreśla, że wcześniej kobieta bardzo pochlebnie wypowiadała się o przyszłym zięciu, głośniej wypowiada także przymiotnik dobry oraz przysłówek dobrze. Wyodrębnianie i podkreślanie poszczególnych elementów wypowiedzi za pomocą akcentu ma wywołać u odbiorcy określony efekt emocjonalny i pomóc we właściwym zrozumieniu treści. Podniesienie głosu i powtórzenie informacji wzmacnia przekaz językowy, jaki nadawca kieruje do odbiorcy.

Zapamiętywaniu treści komunikatu sprzyja także właściwy sposób użycia głosu i odpowiednie brzmienie.

D / K - M / III / III

$\mathrm{K}:-$ țšeba mu v'źuńź dodatkove lekc’ie.

M: - sam tež muśi śe unučyć, a unun v ogule se ńe unučy! ńiz a ńic. Rozmówca wskazuje, że postępy w nauce uzależnione są nie tylko od udziału w zajęciach, ale przede wszystkim od zaangażowania dziecka. W obrębie wypowiedzi mężczyzna różnicuje tempo mówienia, co uwypukla istotne elementy przekazu. Po wyartykułowaniu negacji czasownikowej, która zawiera najważniejszą myśl, mówi wolniej. Zapamiętaniu komunikatu sprzyja powtarzanie treści, por. $w$ ogóle się nie uczy oraz zastosowana negacja frazeologiczna nic a nic podzielona na ciągi głoskowe. 


\section{Naśladowanie głosu}

Innym sposobem wzmocnienia perswazyjności komunikatu może być imitowanie cudzego sposobu mówienia, szczególnie formy dźwiękowej, naśladowanie intonacji czy charakterystycznej artykulacji niektórych głosek. Zabieg stanowi rodzaj stylizacji, polega na parodiowaniu indywidualnych zachowań językowych.

\section{D / K - M / III / IV}

$\mathrm{K}:-$ ț̌seba byuno iešče ńe pšepisyvać.

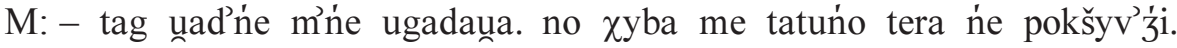
no tera to oḍ razu na mine tatuź zapiše.

Mężczyzna relacjonuje kobiecie przebieg rozmowy między nim a córką, naśladuje sposób zwracania się córki do niego, jej zachowanie i mówienie: parodiuje ruchy i gesty oraz nawyki artykulacyjne, charakterystyczną języczkową wymowę głoski $r$. Istotne znacznie ma także szybkie, nerwowe tempo wypowiedzi, nienaturalnie wysokie tony, wyrazisty akcent, padający na czasowniki: nie pokrzywdzi, zapisze. Wzajemnie uzupełniające się słowo, obraz i dźwięk pogłębiają wrażenie autentyczności. Interpretacja głosowa nadaje słowom określoną wartość emocjonalną, ma wyrazić oburzenie wobec nieuczciwego postępowania kobiety.

Niekiedy nadawca stylizuje wypowiedź na język obcy w celu podkreślenia opisywanych realiów środowiskowych.

\section{D / K1 < K2 / Bu / III / IV / II}

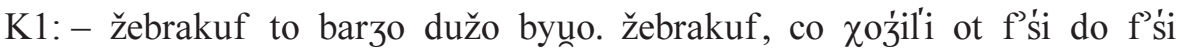
i žebrali. a mamuśa ńigdy, nigdy ne otpraviuna.

K2: - co m’iaunam, to se dauno. a iag ras pšyšuna do naž žebračka, a ia

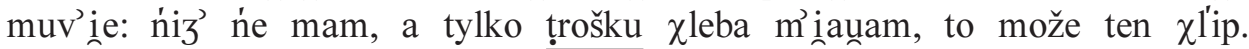
a ona muvi: to ḍla jeći. a tam u ćeb’ie coś pšyvi ionzane v vorečku. a tam to krup. dai m’ne z garstke, a ia tob í koš kartofli. iag ia bende od vas to brauna. dai mine to vezme - ona muvii, bo kartošku to mine f každym domie dv'ie, trie $\chi$ to ṕiać to kartoški m’ne dadut. a t’ieb’ie bud'ied na

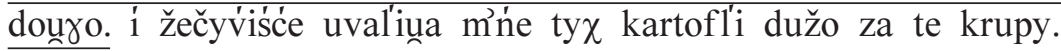

Jak podkreśla W. Pisarek (2004: 127): „Rzeczywiste zaangażowanie mówcy okazuje się bardzo zaraźliwe, sprzyja zainteresowaniu słuchaczy tematem i wciąga ich w omawianą sprawę".

W komunikacji interpersonalnej głos w sposób naturalny informuje o stanach emocjonalnych nadawcy, wzmacnia siłę wypowiedzi, właściwości fizyczne głosu rozmówcy, tj. barwa, wysokość czy tembr, pozwalają także uzupełnić i zweryfikować wiedzę na temat opisywanych wydarzeń. 


\subsection{Perswazja gestu}

W komunikowaniu perswazyjnym ważny jest również kontakt dotykowy, będący elementem pośredniczącym w procesie interpretacji rzeczywistości. Relacje przestrzenne między rozmówcami, styczność cielesna, dotyk stanowią istotny składnik przekazu. Czasem osoby, które pozostają ze sobą w bliskich kontaktach rodzinnych lub przyjacielskich świadomie wybierają niewerbalną formę komunikacji.

D / M - K / III / III

M: - ńig mí ńe bej́e žońżiu moinom oịcov́iznom!

Mężczyzna uderza dłonia w stół. Zachowanie wyraża silne wzburzenie, gniew.

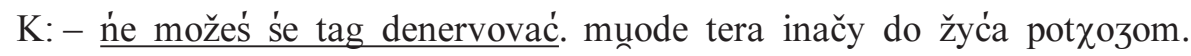
Kobieta ujmuje dłoń męża. Głaskanie świadczy o bliskich relacjach między rozmówcami i jest elementem mającym uspokoić negatywne emocje mężczyzny.

D / K1 - K2 / III / III

K1:- zabraunam 'se $z$ 'nimi, ale može ńe f pore?

$\mathrm{K} 2$ : - f pore, f pore. taḱi goś to zafše radoś!

Kobieta wykonuje przyjacielskie gesty: obejmuje, tuli i całuje przybyłą osobę, wyraża w ten sposób swoją radość z powodu niespodziewanych odwiedzin.

\section{D / K - M / III / III}

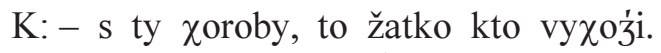

M: - n̉e țša zaraz myślej́ o naịgoršym.

Mężczyzna ujmuje w swoje ręce dtoń kobiety, gestem tym dodaje jej otuchy.

\subsection{Dźwięki paralingwistyczne}

Istotne znaczenie perswazyjne w komunikacji mają dodatkowe dźwięki towarzyszące rozmowie, np.: śmiech, szept, gwizd, które informują o uczuciach czy intencjach rozmówców.

P / K1 - K2 - M / III / III / III

K1:- smakuie?

K2: - unun to se zunośći inag inažynki nakraine. ne lubi taḱi zupy.

M: - pyšna! palce l'izać.

Mężczyzna kwestionuje wypowiedź drugiej kobiety. Dotyka palcami prawej dloni ust i gwiżdze przeciagle. Gwizd jest wyrazem ukontentowania, zachwytu dla umiejętności kulinarnych gospodyni, które potwierdza, używając fraz. palce lizać. 


\section{D / K1 - K2 / III / IV}

K1: - tera vyiexauny, to se otpočneš.

K2: - ia se fcale ne narobiuam, to ununy kole m’ne skakauny. a tera

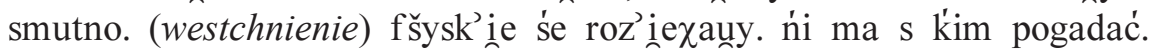

Rozmówczyni neguje opinię kobiety i wyjaśnia, że to wnuki wyręczały ją w obowiązkach domowych. Wypowiedzi towarzyszy głębokie westchnienie, które uwypukla uczuciowe elementy przeżywanego rozstania z najbliższymi.

\section{D / K - M / III / III \\ $\mathrm{K}$ : - ununa śf'iet'ne gotuie. \\ M: - tak, tak!}

Wypowiedzi mężczyzny towarzyszy głośne nabieranie powietrza w płuca, jakby coś nadawcy dolegało, co świadczy o tym, że akceptacja jest przewrotna, obejmuje tylko płaszczyznę językową komunikatu, ponieważ charakterystyczne chrzaknięcie jest wyrazem dezaprobaty dla stanowiska przedstawionego przez kobietę.

Na wieloznaczność śmiechu i uśmiechu w komunikacji językowej zwraca uwagę P. Szarota (2006: 23). Śmiech pełni różne funkcje, może ośmieszać, degradować, ale także wychowywać, integrować określoną grupę, jest także środkiem rozładownia napięć i frustracji. Uśmiech odgrywa ważną rolę w życiu prywatnym i w publicznym, jest istotnym elementem strategii marketingowej. Szczególne znaczenie ma uśmiech w kampaniach reklamowych, docenia się jego pozytywny wydźwięk zwłaszcza w marketingu politycznym.

\section{D / K - M / III / III}

$\mathrm{K}$ :- pevno ći śe ńe podoba?

M: - podoba, barzo! tak' se ćeše! tak' śe ćeše!

Mężczyzna tapie się za głowę, następnie klaszcze $w$ dłonie i caluje kobietę. Mówi śmiejąc się jednocześnie, wesołość i żywa gestykulacja podkreślają radość $\mathrm{z}$ otrzymanego prezentu.

\section{D / K - M / III / III}

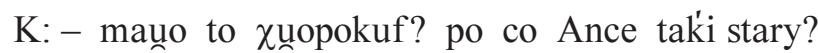

M: - stary, stary! a co gotovaź go beźe?

Nadawca mówi bardzo poważnie, bez emocji, w sposób spokojny i opanowany, uśmiechając się ironicznie, przez co wypowiedź staje się bardziej wyrazista.

W komunikacji istotne znaczenie ma uśmiech ironiczny, który według P. Szaroty (2006: 129) ,łączy się z negatywnym nastawieniem do partnera interakcji i niesie ze sobą przekaz: «co ty powiesz?», «w twoim myśleniu jest usterka», «kpię z ciebie», «jesteś śmieszny» dominuje więc ton dezaprobaty wobec czyjejś wypowiedzi czy zachowania". 


\section{$\mathbf{D} / \mathbf{D z}<\mathbf{M} /$ I / III}

Dz: - ia $\chi$ ce do taty! (płacz dziecka)

M: - ne puač, tata ies f pracy. čego bučyš, źle ći u nas.

Mężczyzna, żeby dziecko przystało płakać, najpierw miauczy, buczy, poświstuje, a następnie zaczyna płakać razem z dzieckiem, ale głośniej i boleśniej, co wywołuje śmiech wnuka.

\section{D / K - M / III / III}

$\mathrm{K}:-$ unun ie $\chi$ ory, ledvo źip'ie.

Kobieta głośno sapie, żeby uzmysłowić odbiorcy, że osoba, o której mówi, jest chora i ma poważne kłopoty z oddychaniem.

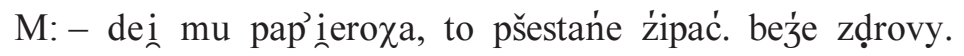

\subsection{Dystans fizyczny między rozmówcami}

Wpływ na sposób interpretacji komunikatu i wzmocnienie wybranych elementów przekazu ma także kod proksemiczny. Odległość między interlokutorami może w trakcie rozmowy ulegać zmianie: osoby odsuwają się, zbliżają, przysuwają, podobnie jak pozycja ciała: mówiący opiera się, wstaje, stoi lub chodzi.

\section{D / K - M / III / IV}

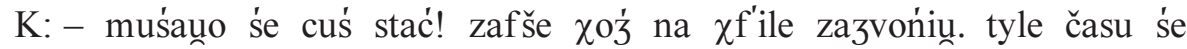
ne unodzyva, cuś ś stauno. (kobieta energicznie chodzi po mieszkaniu, następnie siada na krześle, opuszcza głowę i zaczyna płakać)

M: - zara śe cuś stauno. robote dostaú pevno g’źe dali i ńe može zazvunić.

Mężczyzna wstaje, zbliża się do kobiety i dotyka dłonią jej policzka.

D / M - K / III / III

M: - ńiģźe ńe poieźe! ńe dam! u m’ne suxovo to suxovo.

Mężczyzna gwałtownie podnosi się, chodzi po mieszkaniu, staje obok kobiety i mówi stanowczym głosem.

$\mathrm{K}:-$ caune žyće ne beźe pot klošem.

Kobieta odwraca się plecami, odchyla głowę do tytu, a następnie odchodzi od mężczyzny, jej zachowanie wyraża niezadowolenie.

W komunikacji mieszkańców wsi wykorzystywane są różne środki pozajęzykowe, szczególne znaczenie mają: gesty, mimika, natężenie głosu i tempo mówienia. Elementy te ze środkami językowymi współtworzą zintegrowany przekaz wzmacniający jego perswazyjność. Kod niewerbalny dopełnia, modyfikuje warstwę werbalną, niekiedy zastępuje przekaz słowny. Przenikanie się różnych 
subkodów przyczynia się do opisowego i pogłębionego ujęcia zagadnienia. Komunikacja niewerbalna wzmacnia plastykę przekazu, ma istotny wpływ na przebieg i sposób interpretacji zachowań komunikacyjnych rozmówców. W sposób dynamiczny współuczestniczy z kodem werbalnym w budowaniu przekazu.

Istotną rolę komunikacji niewerbalnej K. Michalewski (2009: 12) ujmuje w następujący sposób: „Jak dawniej, także współcześnie (choć z inną częstotliwością i intensywnością) w bezpośrednich kontaktach posługujemy się w dalszym ciągu niejednorodnymi, nie werbalnymi wyłącznie, ale mieszanymi komunikatami, zatem składającymi się prócz słów, także z gestów, mimiki, dźwięków [...]”. 


\title{
Podsumowanie
}

\author{
Retoryka przypomina zatem zbiór kamieni \\ Przygotowanych i zebranych z myśla o ułożeniu mozaiki \\ Jak się ułoży, zależy od intencji układającego, \\ Od czasu, w którym żyje: \\ Każdy odciska w niej swoje indywidualne piętno.
}

(Lichański 2000: 7)

Celem pracy było zwrócenie uwagi na rolę, jaką w komunikacji językowej mieszkańców wsi odgrywa perswazja, rozumiana jako integralna część komunikacji oraz pokazanie mechanizmów i środków językowych, służących realizacji funkcji perswazyjnej. Perswazja to umiejętność zaprezentowania poglądów i przekonania odbiorcy do własnego systemu wartości, zjednania go do realizacji określonych planów oraz nakłonienia do działań zgodnych z intencją nadawcy.

Badaniami została objęta polszczyzna ludowa, stanowiąca środek porozumiewania się w gronie osób bliskich, a więc w grupach ludzkich, które łączą kontakty nieoficjalne. Jest ona określana jako język familijny (rodzinny), będący mówioną, potoczną odmianą języka wykorzystywaną w środowisku rodzinno-przyjacielsko-sąsiedzkim. K. Handke (2006: 98-121) określa język familijny jako „portret języka we wnętrzu", a wnętrze to jest bardzo prywatnym obszarem egzystencji bliskiej sobie wspólnoty ludzi, przyswajających ów język i jednocześnie odciskających na nim swoje własne piętno.

Analizowany wariant języka stanowi ciekawy przykład dyskursu potocznego, bowiem zawiera środki słowne, sygnalizujące w sposób wyrazisty oceny i emocje oraz ukazuje bardzo charakterystyczny stosunek użytkowników gwary do otaczającego świata. Polszczyzna mieszkańców wsi jest typową formą barwnego, żywego dialogu, w którym znajduje zastosowanie bogactwo środków leksykalnych, swoisty dowcip i wyjątkowa kreatywność językowa. Badany typ komunikacji obejmuje określone zachowania interpersonalne i odzwierciedla ludową hierarchię wartości, dlatego nie może być opisywany w oderwaniu od przestrzeni społecznej i reguł nią rządzących. Dla zrozumienia działania językowego niezwykle istotne jest uwzględnienie: ramy socjalnej, typu relacji oraz kompetencji komunikacyjnej rozmówców, dotyczącej wspólnej nadawcy i odbiorcy wiedzy, szczególnie w zakresie systemu wartości. Wymienione parametry stanowią istotny czynnik, rozstrzygający o tym, czy dana sytuacja komunikacyjna jest perswazyjnym 
aktem mowy, ponieważ skuteczność nakłaniania uwarunkowana jest właściwym odczytaniem intencji nadawcy przez odbiorcę.

Perswazja w komunikacji naturalnej jest procesem wielowarstwowym, złożonym i dynamicznym. Na proces przekonywania składają się zjawiska językowe, pozajęzykowe i psychologiczne, stanowiące bodziec do aktywizowania jednostki lub grupy. Analiza środków językowych, służących perswazji, dokonywana była w określonej perspektywie kulturowej oraz szerzej rozumianej - ramie doświadczenia.

Pragmatyka językowa do działań mownych zalicza oprócz środków językowych (werbalnych) także środki niewerbalne (np.: gesty, wyraz twarzy, mowę ciała) oraz efekty parajęzykowe (np.: ton, tempo emisji, rytm, głośność), dlatego w pracy omówione zostały środki językowej i pozajęzykowej organizacji tekstów perswazyjnych.

W badanym obszarze językowym zjawisko perswazji obejmuje swym zasięgiem zarówno słowo, wykorzystując szczególnie wartościowanie, odwołujące się do środków leksykalnych, ciekawej metaforyki, frazeologizmów, konotacji kulturowych, stereotypów oraz wartościujących wyrażeń porównawczych. Istotne znaczenie ma ponadto struktura gramatyczna przekazu oraz płaszczyzna pozasłowna. Uzupełnieniem przekazu werbalnego są elementy pozajęzykowe przynależne do warstwy dźwiękowej i wizualnej, które nadają wypowiedzi spójny charakter, mogą one stymulować zainteresowanie słowem mówionym, wskazywać dodatkowe informacje, wzbogacać emocjonalnie treść, co pobudza wyobraźnię odbiorcy i utrwala komunikat.

Podstawowy cel - nakłanianie - realizuje się przez wykorzystanie różnorodnych form illokucyjnych aktów mowy (rady, prośby, nakazu, polecenia, ostrzeżenia itp.), a służy mu przede wszystkim wartościowanie. W badaniach uwzględniono materiał językowy o wyraźnym zróżnicowaniu gatunkowym. Pomocniczą wobec funkcji nakłaniającej jest funkcja pobudzająca, która realizuje się poprzez apele i różnorodne środki słowne służące wyrażaniu humoru.

Szczególnym rysem komunikacji ludowej, obecnym w wielu tekstach, jest stosowanie w perswazji środków językowych zawierających wyrazistą ocenę aksjologiczną oraz użycie prostych struktur składniowych, co powoduje, że wypowiedzi są komunikatywne i sugestywne. Rozmówcy unikają obcych intelektualnych konstrukcji czy skomplikowanych struktur składniowych, wykorzystują leksykę i połączenia wyrazowe codzienne, bezpośrednie, bliskie odbiorcy. W komunikacji naturalnej, w sytuacjach nieformalnych, prywatnych zastosowanie mają przede wszystkim typowe środki językowe polszczyzny potocznej, stanowiące charakterystyczny budulec swobodnych, codziennych rozmów, obejmujących sferę kontaktów osobistych. W aspekcie lingwistycznym uwagę zwraca zastosowanie wyrażeń ekspresywnych, semantyki i frazeologii aksjologicznej. Słownictwo oraz związki potoczne, o intensywnym nacechowaniu emocjonalnym, zawierają czytelną ocenę poszczególnych zjawisk, jednoznacznie określają stosunek nadaw- 
cy do prezentowanej treści, pokazują sposób myślenia i postrzegania świata oraz odzwierciedlają charakterystyczną hierarchię wartości. Odpowiednio dobrane i skomponowane środki językowe stanowią dla odbiorcy impuls, motyw działania. Rozmówcy odwołują się zarówno do sfery intelektualnej, wolicjonalnej, jak i emocjonalnej słuchaczy. Osiągnięciu efektu perswazyjnego służy wyolbrzymianie określonych zjawisk i zachowań, pomniejszanie wartości innych, zestawienia ujawniające podobieństwa lub wykorzystujące kontrast.

Język, będący narzędziem komunikacji z innymi ludźmi, służy przekazywaniu informacji, ale przede wszystkim umożliwia wyrażanie emocji. Sugestywne przekazywanie doznań i przeżyć związanych ze światem jest tym elementem przekazu, który w istotny sposób wpływa na kształtowanie postaw odbiorcy. O skuteczności perswazji decydują zarówno umiejętności nadawcy - na które składa się m.in. znajomość systemu znaków oraz obowiązujących w nim reguł, określających możliwości przekształcania tych znaków w sensowne przekazy o określonej strukturze - jak i odbiorcy komunikatu perswazyjnego, który dodatkowo musi wyodrębnić najistotniejsze elementy składowe przekazu, ich szczególne uporządkowanie, wreszcie dotrzeć do znaków utajonych oraz podjąć próbę wyjścia poza dosłowność tekstu.

W pracy omówiono kolejno zagadnienia dotyczące cech językowych tekstów, sposobu ich kompozycji, wykorzystanej argumentacji, ponadto środki niewerbalne, mające wpływ na kształtowanie opinii, ponieważ elementy służące perswazji nakładają się na siebie i wzajemnie uzupełniają.

Sposób codziennej komunikacji mieszkańców wsi, który był przedmiotem badań pod kątem wykorzystania środków językowych służących perswazji, jest giętki, konkretny i dosadny, odbija zdroworozsądkową wizję świata i potwierdza obserwację I. Bajerowej (2003: 99), że ,prawda codziennego języka jest przysłonięta warstwami przyzwyczajeń językowych”.

Nie uda się wpłynąć na zachowanie człowieka bez wzbudzenia zainteresowania treścią przekazu, bez odwołania się do emocji odbiorcy czy do jego świata wartości. W kulturze ludowej w hierarchii wartości szczególne znaczenie ma: życzliwość i przyjaźń dla rodziny oraz sąsiadów, praca, przyzwoitość, skromność, otwieranie się na potrzeby innych, delikatność i uprzejmość, a także przezorność.

Komunikacja słowna mieszkańców wsi nastawiona jest na osiągnięcie pewnych praktycznych celów życiowych, toteż argumentacja w dużej mierze odwołuje się do racjonalizmu potocznego, a dominujący antropocentryczny punkt widzenia pozwala na ujawnienie wielu aspektów konceptualizacji. Otaczający świat jest przeżywany kompleksowo za pomocą odwołań do konkretnych wrażeń: wzrokowych, słuchowych, dotykowych, węchowych czy smakowych. Perswazja posługuje się wieloma komponentami, tworzy sobie właściwy i charakterystyczny sposób przekazu treści. 


\section{Wnioski z badań}

W analizowanym materiale występowały zróżnicowane środki językowe, mechanizmy i techniki retoryczne. Obserwacja wszystkich elementów przekazu i wykorzystanych technik przekonywania pokazuje pewne prawidłowości. Środki perswazji, wykorzystywane w gwarze, są proste i pozbawione zbędnego patosu. Wśród tendencji, uwzględniających właściwości najbardziej istotne dla komunikacji mieszkańców wsi, wymienić należy w zakresie środków językowych leksykę.

1. Bogate i różnorodne słownictwo gwarowe jest istotnym elementem kształtującym perswazyjność wypowiedzi mieszkańców wsi. Słowo służy obrazowaniu, ubarwia i urozmaica przekaz. Leksemy są wyspecjalizowanymi środkami, doskonale precyzującymi intencje nadawcy. Szczególne znaczenie perswazyjne ma wszelkiego rodzaju słownictwo wartościujące, emocjonalne i ekspresywne. Jak podkreśla H. Popowska-Taborska (1998: 257): ,z warstwy ekspresywnej słownictwa gwarowego wyłania się bowiem obraz określonych postaw społecznych, zamknięty w zawartych w tym słownictwie konotacjach".

Słownictwo wprowadzające ocenę pozytywną lub negatywną pozwala kształtować światopogląd odbiorcy, sposób postrzegania przez niego pewnych zjawisk, zgodny z intencją nadawcy. Zdecydowanie zabiegiem najczęściej stosowanym w oddziaływaniu perswazyjnym jest wartościowanie leksykalne, które może odbywać się na poziomie definicji leksemu, stanowić jego konotację bądź wynikać z jego presupozycji. Wartościowanie odbywa się najczęściej pod względem kryterium pragmatycznego, etycznego, perfekcjonistycznego lub estetycznego. Często służy mu odwołanie do świata roślin, zwierząt czy przedmiotów. Motywy te, będące elementami konstytutywnymi, bez których trudno wyobrazić sobie siłę argumentacji, świadczą o silnym związku człowieka z naturą, o umiejętności wnikliwej obserwacji otaczającej przyrody i wrażliwości językowej mieszkańców wsi.

W zasobie leksykalnym gwary znaczną część stanowią wyrazy potoczne, w których emocjonalność jest jednym ze składników semantycznych. Wiele spośród nich zawiera ukrytą ocenę estetyczną - „to mi się podoba lub nie”, bądź moralną - „uważam to za dobre lub złe”, połączoną zazwyczaj z określonym ustosunkowaniem emocjonalnym. Częste wykorzystanie leksyki nacechowanej stylistycznie i aksjologicznie ma kształtować określone opinie odbiorcy komunikatu językowego.

Ekspresywność na poziomie leksyki osiągana jest za pomocą takich zabiegów, jak: wartościowanie leksemów, kwalifikacja leksemu do danej odmiany funkcjonalnej, ograniczony zasięg chronologiczny leksemów, zastosowanie leksemów obcych oraz dwoistość semantyczna wyrazu. Szczególnie często wykorzystuje się leksykę wartościującą, która czyni przekaz jednoznacznym i sugestywnym.

Celom perswazyjnym służy swoiste słownictwo gwarowe, warstwa leksykalna sprzyja budowaniu wspólnoty i więzi emocjonalnej między nadawcą a odbiorcą. 
H. Kurek (2001: 122) wskazuje, że: „w gwarach ludowych znaleźć można często większe bogactwo nazw i subtelniejsze ich zróżnicowanie aniżeli w języku ogólnym”.

Do zabiegów opartych na doborze słownictwa zalicza się także synonimię i kontrast (np. zestawienie elementów językowych zróżnicowanych stylistycznie czy antonimię). Leksykalne mechanizmy kształtowania tworzywa słownego (synonimy) pomagają w zapamiętywaniu prezentowanych treści, czynią tekst bardziej plastycznym, obrazowym, podnoszą efektywność komunikacji. Środki synonimiczne, zwłaszcza synonimy czasownikowe, rzeczownikowe, przymiotnikowe i przysłówkowe, podkreślają najistotniejsze treści wypowiedzi i uwypuklają emocje łączące się z powtarzanymi wyrazami. Perswazja wyzyskuje także $d w u p ł a s z-$ czyznowość semantyczna wyrazów, zabieg taki pobudza odbiorców do większej aktywności komunikacyjnej.

2. Istotne znaczenie w budowaniu przekazu perswazyjnego mają tropy stylistyczne, a ich zastosowanie $\mathrm{w}$ wypowiedzi ma na celu przeciwstawienie się schematom i szablonowemu mówieniu. W badanym materiale wystąpiły liczne: epitety, metafory, porównania, eufemizmy, które warunkują skuteczność przekonywania.

Ważne są metafory, ponieważ umieszczają zjawisko w pewnej perspektywie aksjologicznej, a tym samym narzucają odbiorcy określoną wartość. Metafora, jako świadomie wprowadzone przekształcenie znaczeniowe, odgrywa w wypowiedzi szczególną rolę, ukazuje zaskakujące, niekonwencjonalne skojarzenia i zmusza odbiorcę do aktywności myślowej. Dzięki kreatywnym połączeniom opisywane doznania stają się na tyle silne, że poruszają wyobraźnię słuchacza i wzmacniają skuteczność oddziaływań perswazyjnych. Środek ten nie tylko nazywa, ale także interpretuje otaczający świat. Stosowane w tekstach metafory świadczą o zaangażowaniu emocjonalnym nadawcy w przedstawiane zagadnienie.

Specyficznie skonstruowane porównania służą obrazowości przekazu, są elementem wypowiedzi wywołującym określone uczucia i kierują uwagę odbiorcy na treść. Obrazowość wzmacnia przesłanie, ponieważ łatwiej zapamiętuje się obrazy niż słowa, zatem im bardziej sugestywny jest komunikat, tym większe prawdopodobieństwo, że zostanie zapamiętany. Zastosowane w tekstach epitety i porównania mają wyraźny parametr aksjologiczny, najczęściej odnoszą się do wybranych cech wyglądu lub charakteru ludzi i są nacechowane emocjonalnie.

Kolejnym sposobem wpływania na odbiorce jest wykorzystanie ironii i eufemizmów. Tropy te umożliwiają maskowanie rzeczywistego stanu rzeczy, służą przedstawieniu znaczeń w sposób bardziej zawoalowany. Ironia jest specyficzną formą oceny negatywnej, a ze względu na swą niejednoznaczność stanowi wygodne, a zarazem bezpieczne narzędzie perswazji, służy przede wszystkim uwypukleniu i napiętnowaniu ludzkich wad. Wykorzystaniu ironii sprzyja możliwość odczytania tzw. sensów naddanych, zawartych w zachowaniach niewerbalnych. Jej walorem perswazyjnym jest to, że ma ona skłonić odbiorcę do odczytania aluzji i ukrytych sensów wypowiedzi. Stosowanie wymienionych chwytów, sto- 
sunkowo często, łączy się z próbą nadania wypowiedzi wartości żartobliwej, komicznej i ma służyć dyskredytacji wskazanej osoby czy zjawiska.

J. Puzynina (1984b: 539-556) wskazuje, że dojście do znaczenia intencjalnego wymaga, by odbiorca znał również kod pragmatyczny, rozumiany jako ogólne mechanizmy przenośni, ironii, hiperboli, aluzji, konstrukcji skrótowych, sposoby wykorzystywania konotacji wyrazów, uzyskiwania nadwyżek ekspresji poprzez łamanie konwencji. Odbiorca, szukający niesprzecznego i najbardziej w danej sytuacji prawdopodobnego rozumienia tekstu nadawcy, by je wykryć, musi znać wszystkie te mechanizmy, którymi posługuje się nadawca.

3. Prostym i jednocześnie skutecznym środkiem perswazji są stałe, utarte połaczenia słowne, szczególnie te mocno zakorzenione w świadomości mieszkańców wsi. Stosowane w tekstach czynią wypowiedź bliższą odbiorcy, ponieważ odwołują się do jego mowy codziennej, a także do jego sposobu opisu i wartościowania świata. Tekst opatrzony nacechowanymi emocjonalnie związkami frazeologicznymi jest silnie perswazyjny. Obrazowa, ukonkretniająca frazeologia wzmaga żywotność i plastyczność wypowiedzi. Istotną cechą frazeologizmów jest także ich zwięzłość, powodująca kondensację treści; minimum słów - maksimum konotacji. Połączenia wyrazowe nie tylko informują o pewnych zjawiskach, ale także je interpretują, zastosowane w wypowiedzi uzewnętrzniają emocje nadawcy, świadczą o jego zaangażowaniu w opisywane wydarzenia.

W celu perswazyjnym wykorzystywane są różne typy frazeologizmów, szczególnie sugestywna jest frazeologia potoczna. Połączenia charakterystyczne dla rejestru polszczyzny potocznej są konkretne, czasem dosadne, istotne znaczenie mają także związki wyrazowe o ograniczonym zasięgu występowania, które służą budowie swoistej więzi porozumienia między rozmówcami.

Ekspresywność na poziomie frazematyki jest osiągana także dzięki wykorzystaniu różnych zabiegów w obrębie struktury połączeń. Ciekawe, oryginalne modyfikacje, przewartościowujące semantykę wypowiedzi, uatrakcyjniają komunikat, wzbudzają zainteresowanie i przykuwają uwagę odbiorcy. Innowacje frazeologiczne, będące celowym odstępstwem od normy, świadczą o tym, że nadawca dla uzyskania perswazyjności przekazu decyduje się na różne modyfikacje. D. Buttler (1968: 103) podkreśla, że mogą one „modyfikować treść wyrazu albo jego barwę stylistyczną”.

$\mathrm{W}$ badanych tekstach modyfikacje normy frazeologicznej obejmują zabiegi realizowane na płaszczyźnie formalnej i znaczeniowej związku oraz naruszają stylistykę kontekstu, w jakim połączenie jest umieszczone. Większość zmian formalnych powoduje jednocześnie modyfikacje w obrębie semantyki związku, np. wszelkiego rodzaju innowacje wymieniające i rozwijające mają na celu konkretyzację treści. Wprowadzenie elementu w strukturę związku frazeologicznego skutkuje zmianą jego znaczenia wyjściowego poprzez dodanie nowej cechy semantycznej. Modyfikacje formalne mają na celu uszczegółowienie albo rozszerzenie znaczenia frazeologizmu, określają semantykę wypowiedzi i nadają jej szczególnego charakteru. 
4. Nawiązania intertekstualne, które pojawiają się w analizowanych tekstach, wzbogacają przekaz perswazyjny, dają nadawcy możliwość operowania asocjacjami, odwołują się do mechanizmów gry słownej. Celem odwołań intertekstualnych jest także chęć uatrakcyjnienia formy przekazu. Wszechstronność i częstość ich użycia świadczy o potrzebie, a nawet o konieczności łączenia przez nadawcę sądów z elementami kultury wysokiej. Pojawiają się także zabiegi stylizacyjne, które przykuwają uwagę odbiorcy atrakcyjnym przedstawieniem tematu.

5. Na poziomie słowotwórczym perswazji służą deminutywne i augmentatywne formacje emocjonalno-stylistyczne, rzadko stosowane w stylu oficjalnym, neutralnym, poważnym oraz słownictwo żartobliwe, ironiczne, realizowane przez ekspresywne neologizmy i aluzyjne kontaminacje. Wskazane elementy decydują o wartości i sile perswazyjnej przekazu.

Istotne znaczenie w tekstach ma kreatywność językowa rozmówców, wypowiedzi sformułowane nieszablonowo mają większą nośność perswazyjną. Odbiorca czuje się w pewien sposób wyróżniony przez nadawcę. Neologizmy, także onomastyczne, zmuszają odbiorcę do skojarzeń i refleksji, wzmacniają i uatrakcyjniają przekaz. Gwarowe derywaty wyróżniają się konkretnością, ich walor emocjonalny wynika z nacechowania podstawy i/lub formantu oraz sposobu ich tworzenia. Aktywność słowotwórcza użytkowników gwary świadczy o ich kompetencji i wrażliwości językowej.

Warto też wspomnieć o poczuciu humoru i jego roli w komunikacji mieszkańców wsi. Stanowi ono mechanizm wspomagający przekaz perswazyjny, jest elementem komunikowania i wartościowania określonych zjawisk. Teksty, które zawierają treści humorystyczne, sformułowane w sposób dowcipny, wzmacniają perswazyjność komunikatu. Żartobliwe podejście do wielu zjawisk sprawia, że rozmowa przebiega w przyjemnej atmosferze, sprzyjającej porozumieniu. Dowcip i poczucie humoru są pomocne w komunikacji, ponieważ uatrakcyjniają przekaz i budują swoistą więź porozumienia między nadawcą i odbiorcą.

6. Elementy perswazji obecne są w strukturze gramatycznej przekazu. Obejmują apele i formy rozkazujące czasowników, bezpośrednie zwroty do odbiorcy, które w sposób sugestywny służą oddziaływaniu na słuchacza.

7. Do środków składniowych, realizujących funkcję perswazyjną, należą: krótkie, proste zdania, które są łatwe w odbiorze, powtórzenia (pojedynczych słów) i paralelizmy sktadniowe, które uwypuklają najważniejsze treści komunikatu oraz skupiają uwagę odbiorcy na wybranych, odpowiednio wyselekcjonowanych fragmentach wypowiedzi.

Elementy syntaktyczne podporządkowane są także celom ekspresywnym. Składnia emocjonalna ma skłonność do: uproszczeń, urwań, elips, zdań wykrzyknieniowych, pytajnych. Nośne perswazyjnie jest zwłaszcza pytanie retoryczne, które pozwala niepostrzeżenie przemycić sądy nadawcy, nie zostawiając miejsca na żadną odpowiedź. Walor perswazyjny ma skumulowanie w bliskim sąsiedztwie konstrukcji składniowych, które służy wyrażaniu emocji (w przypadku zdań py- 
tajnych - najczęściej chodzi o uwypuklenie emocji i podkreślenie argumentacji; w wypadku zdań wykrzyknieniowych - zaznaczenie zdenerwowania i zdziwienia).

W komunikacji perswazyjnej ważnym środkiem syntaktycznym jest kompozycja tekstu, służąca podkreślaniu treści, dynamizowaniu akcji, precyzowaniu znaczeń czy nadawaniu określonym elementom wypowiedzi szczególnego znaczenia.

8. Wśród technik argumentacyjnych, służących nadawcy do osiągnięcia przyjętego celu, wymienić należy odwoływanie się do autorytetów, szczególnie osób bliskich, wykorzystanie danych liczbowych, posłużenie się przykładem, które czyni argumentację bliższą odbiorcy, a także użycie argumentów przeciwnika na swoją korzyść.

9. Osobne zagadnienie stanowi komunikacja niewerbalna, bogata w swoim wyrazie, która pełni ważną funkcję wspomagającą i wzmacniającą komunikację słowną. W budowaniu przekazu perswazyjnego warstwę słowną dopełnia gestykulacja, mimika oraz środki pragmalingwistyczne - szczególnie intonacja, barwa głosu, tempo wypowiedzi.

Gest, mimika są na ogół harmonijnie powiązane z kodem werbalnym, tworząc jednolitą strukturę, która aktywizuje odbiorcę i intensyfikuje perswazyjność przekazu. W perswazji czasem słowo odgrywa rolę drugoplanową, pomaga zrozumieć sens obrazu lub jest jego uzupełnieniem. Postawa, mimika, gest sprawiają, że perswazja za pośrednictwem słowa odnosi większą siłę i skuteczność, poprzez kod niewerbalny następuje głębokie utrwalenie informacji słownej.Ten prymat obrazu nad słowem jest konsekwencją psychiki człowieka, która sprawia, że otaczający świat odbieramy w pierwszym rzędzie przez zmysł wzroku, a dopiero potem słuchu.

Ekspresja brzmieniowa wypowiedzi powoduje, że tekst zyskuje na wyrazistości, niekiedy sprawia, że jego znaczenie słowne ulega przewartościowaniu. Dzięki odpowiedniemu wykorzystaniu elementów niewerbalnych nadawca oddziałuje na zmysł wzroku i słuchu odbiorcy, sprawia, że kierowany do niego komunikat jest ciekawszy i bardziej sugestywny. Środki niewerbalne dookreślają wypowiedź i wpływają na jej odbiór.

Badania pokazują, że gwara jest nieprzebranym źródłem ciekawego materiału językowego.W tekstach wyodrębniono wiele środków językowych, gramatycznych i pozawerbalnych, służących perswazji: nacechowane wartościująco słownictwo i frazeologię, innowacje leksykalne i frazeologiczne, wyrażenia metaforyczne, które zmieniają sposób odbioru treści i sprawiają, że wypowiedź staje się bardziej interesująca.

\section{Charakterystyczne cechy komunikacji perswazyjnej w środowisku wiejskim a realizacja perswazyjnej funkcji w innych typach dyskursu}

Najważniejszym kryterium oceny perswazji - jak uważają badacze - jest jej skuteczność. Istotne znaczenie ma umiejętność przekonania odbiorcy, bo jak pod- 
kreśla A. Mamcarz (1998: 22-23) „to on ma przecież odrzucić lub przyjąć sposób myślenia sugerowany przez nadawcę". Najbliższe środowisko, rodzina (zob. Ziemska 1975), przyjaciele, sąsiedzi mają bardzo ważny wpływ na kształtowanie opinii jednostki. Element ten nie tylko wzmacnia, ale często przesądza o skuteczności perswazji.

Badacze współczesnego języka podkreślają, że w sposobach nakłaniania niewiele się zmieniło (Mamcarz 1998: 17). W dyskursach perswazyjnych wykorzystane są $\mathrm{w}$ większości przypadków mechanizmy nakłaniania zaczerpnięte z przeszłości, od dawna znane retoryce. Po analizie materiału językowego okazuje się, że związki między przekonywaniem w polszczyźnie ludowej a innymi typami dyskursu są bliskie, natomiast wyraźna różnica dotyczy sposobu wykorzystania środków językowych.

Mowa mieszkańców wsi podporządkowana jest ekonomii językowej i skrótowemu, zwięzłemu przekazywaniu treści. Realizacji funkcji perswazyjnej służy przede wszystkim nacechowana aksjologicznie leksyka i frazeologia, środki morfologiczne i struktury składniowe, zwłaszcza składnia emocjonalna oraz elementy pozawerbalne (istotny składnik komunikacji). Ważne jest także ukształtowanie stylistyczne wypowiedzi, które powoduje, że przekaz staje się bardziej wiarygodny i w sposób sugestywny przemawia do odbiorcy.

W gwarze, podobnie jak w innych typach komunikatów perswazyjnych, np. w wystąpieniach polityków, w literaturze czy przekazach reklamowych, chętnie wykorzystywane jest obrazowanie. Należy podkreślić, że nacechowanie konotacyjne środków językowych służących obrazowaniu odwołuje się do sfery doświadczeń potocznych, do wiedzy zdroworozsądkowej. Istotne znaczenie mają także czynniki wzmacniające (powtarzanie, sugestywna forma, prostota języka itp.), które warunkują skuteczność działań perswazyjnych.

Jak wykazują przedstawione przykłady, w realizacji perswazyjnej komunikacji mieszkańców wsi niezwykle ważny jest aspekt kulturowy, łączący obyczajowość, wierzenia z językowymi mechanizmami opisu i oceny ludzi oraz świata. Sposób myślenia zakodowany kulturowo ma związek z wartościami, wśród których najważniejsza jest rodzina i sąsiedzi, oraz poprawne relacje między bliskimi i członkami lokalnej wspólnoty.

Dokonana interpretacja użytych mechanizmów i środków retorycznych ukazuje w wymiarze ogólnym zarówno odrębność kultury ludowej, jak też dające się ustalić powiązania między polszczyzną publiczną i potoczną. Uderza podobieństwo technik perswazyjnych, które są charakterystyczne dla polszczyzny ludowej, ale również dla języka reklamy, polityki, religii.

Teksty realizują analogiczne przesłania i mechanizmy retoryczne, lecz za pośrednictwem odmiennych, prostych środków językowych, zgodnych z doświadczeniem i wiedzą użytkowników gwary. Rozmówcy operują prostą leksyką, odwołują się do językowych wykładników wiejskiego świata, wykorzystują elementy uwarunkowane kulturowo, z różnych względów bliskie człowiekowi 
wsi, którymi są: drzewa, kwiaty, zwierzęta, ptaki, owady, narzędzia i przedmioty codziennego użytku. Te wiejskie realia odnajdujemy także w przysłowiach i wyrażeniach metaforycznych. Przywołanie obrazów z najbliższego otoczenia służy spotęgowaniu odczuć i stanów psychicznych odbiorcy oraz skonkretyzowaniu zjawisk, które nie podlegają bezpośredniej obserwacji.

Często w badanych tekstach funkcja ekspresywna i impresywna mieszają się ze sobą i splatają, dając w efekcie przekaz o niezwykłej plastyczności.

W przekonywaniu wykorzystywane są podstawowe ludzkie potrzeby, do których m.in. zalicza się: poczucie przynależności do pewnej grupy, potrzebę uznania, ekonomiczny dobrobyt, panowanie nad własnym życiem. W argumentacji mówiący odwołują się do subiektywnych doznań i doświadczeń. Wykorzystują swoistą argumentację, która odzwierciedla sposób pojmowania świata przez mieszkańców wsi. Część zastosowanych mechanizmów jest typowa dla specyficznego tworu, jakim jest tekst mówiony z całym szeregiem emocjonalnej leksyki i frazeologii, powtórzeń, zdań wtrąconych i komentujących.

Warto podkreślić, że niektóre środki perswazji charakterystyczne dla dyskursu potocznego coraz częściej są wykorzystywane także w marketingu, języku mediów czy polityki (zob. Ożóg 2001: 48-72).

Niniejsza praca, w której przedstawiono nowy materiał językowy, nie jest pełnym opisem problematyki związanej z perswazją, ponieważ nie wyczerpuje wszystkich możliwych aspektów zjawiska, jest ich jednak na tyle dużo, że daje to podstawę do wyciągnięcia wniosków dotyczących ich stosowania. Autorka ma świadomość, że wiele zagadnień, obejmujących techniki oraz narzędzia oddziaływania, można rozwinąć. Przebadanie mechanizmów nakłaniania w tak specyficznym rodzaju wypowiedzi jak tekst gwarowy, będący ciekawym obiektem do analizy językoznawczej, otwiera także szerokie pole do badań tekstu, wykraczającego poza ściśle określone ramy gatunkowe.

Należy zgodzić się z opinią W. Pisarka (2004: 147), który podkreśla, że: „W życiu codziennym kierujemy się intuicją i zdroworozsądkową wiedzą, demonstrując mistrzostwo perswazji, godne wytrawnego znawcy retoryki i erystyki". 


\section{Bibliografia}

Abramczyk G. (red.), 2006, Przegląd technik manipulacji mediów, Warszawa.

Adamowski J., 1987, Geograficzne nazwy własne w pieśniach ludowych regionu lubelskiego a wybrane problemy semantyki przestrzeni, [w:] Język: doświadczenie a teoria, Lublin, s. 7-22.

Albin K., 2000, Reklama. Przekaz, odbiór, interpretacja, Warszawa.

Ampel T., 1978, Elipsa i powtórzenie w żywej mowie, [w:] Studia nad składnia polszczyzny mówio$n e j$, red. T. Skubalanka, Wrocław, s. 177-182.

Antas J., 2001, Co mówia ręce. Wprowadzenie do komunikacji niewerbalnej, [w:] Retoryka dziś. Teoria i praktyka, red. R. Przybylska, W. Przyczyna, Kraków, s. 437-459.

Antas J., Załazińska A. 2004, Niewerbalne środki i strategie przekonywania stosowane w telewizyjnych debatach polityków, [w:] Sztuka perswazji. Socjologiczne, psychologiczne i lingwistyczne aspekty komunikowania perswazyjnego, red. R. Garpiel, K. Leszczyńska, Kraków, s. 183-194.

Anusiewicz J., 1986, Pragmatyka języka a kultura języka, „Poradnik Językowy”, z. 9-10, s. 612-624.

Anusiewicz J., 1992, Potoczność jako sposób doświadczania świata i jako postawa wobec świata, [w:] Język a Kultura, t. 5: Potoczność w języku i w kulturze, red. J. Anusiewicz, F. Nieckula, Wrocław, s. 9-20.

Anusiewicz J., 1994, Lingwistyka kulturowa. Zarys problematyki, Wrocław.

Anusiewicz J., Bartmiński J. (red.), 1998, Język a Kultura, t. 12: Stereotyp jako przedmiot lingwistyki. Teoria, metodologia, analizy empiryczne, Wrocław.

Anusiewicz J., Dąbrowska A., Fleischer M., 2000, Językowy obraz świata i kultura. Projekt koncepcji badawczej, [w:] Język a Kultura, t. 13: Językowy obraz świata i kultura, red. A. Dąbrowska, J. Anusiewicz, Wrocław, s. 11-44.

Anusiewicz J., Nieckula F., 1978, Charakterystyka tekstów mówionych na tle klasyfikacji aktów komunikacji, [w:] Studia nad składnia polszczyzny mówionej, red. T. Skubalanka, Wrocław, s. $21-39$.

Anusiewicz J., Nieckula F. (red.), 1992, Język a Kultura, t. 5: Potoczność w języku i kulturze, Wrocław.

Apresjan L., 1980, Semantyka leksykalna, Wrocław.

Aronson E., 1994, Człowiek istota społeczna, Warszawa.

Arystoteles, 1988, Retoryka - poetyka, przeł. H. Podbielski, Warszawa.

Austin J. L., 1987, Mówienie i poznawanie. Wykłady i rozprawy filozoficzne, Warszawa.

Awdiejew A., 1987, Pragmatyczne podstawy interpretacji wypowiedzi, Kraków.

Awdiejew A. (red.), 1999, Gramatyka komunikacyjna, Kraków.

Awdiejew A., 2004a, Gramatyka interakcji werbalnej, Kraków.

Awdiejew A., 2004b, Systemowe środki perswazji, [w:] Manipulacja w języku, red. P. Krzyżanowski, P. Nowak, Lublin, s. 71-80.

Awdiejew A., Habrajska G., 2004, Wprowadzenie do gramatyki komunikacyjnej, t. 1, Łask.

Awdiejew A., Habrajska G., 2006, Wprowadzenie do gramatyki komunikacyjnej, t. 2, Łask.

Bachtin M., 1975, Twórczość Franciszka Rabelais'a a kultura ludowa średniowiecza i renesansu, przeł. A. i A. Goreniowie, Kraków. 
Bajerowa I., 1988, Kilka problemów stylistyczno-leksykalnych współczesnego polskiego języka religijnego, [w:] O języku religijnym. Zagadnienia wybrane, red. M. Karpluk, J. Sambor, Lublin, s. $21-44$.

Bajerowa I., 1994, Swoistość języka religijnego i niektóre problemy jego skuteczności, „Łódzkie Studia Teologiczne", nr 3, s. 11-17.

Bajerowa I., 2003, Główne kierunki ewolucji specjalnych odmian językowych, [w:] eadem, Zarys historii języka polskiego 1939-2000, Warszawa.

Banach J., 1983, Model komunikacji językowej typu face-to-face, „Socjolingwistyka”, t. 3, red. W. Lubaś, Warszawa-Kraków-Katowice, s. 37-51.

Bańko M., 2002, Stownik peryfraz, czyli wyrażeń omownych, Warszawa.

Bańko M. (red.), 2006, Polszczyzna na co dzień, Warszawa.

Barańczak S., 1975, Stowo - perswazja - kultura masowa, „Twórczość”, z. 7, s. 44-57.

Barańczak S., 1977, Problematyka funkcji perswazyjnej tekstów literackich i paraliterackich w świetle tez semantyki ogólnej, „Studia Polonistyczne”, nr 4, s. 44-57.

Barańczak S., 1983, Człowiek ubezwłasnowolniony. Perswazja w masowej kulturze PRL, Paryż.

Bartmiński J., 1973, O języku folkloru. Z dziejów form artystycznych $w$ literaturze polskiej, Wrocław, s. 49-51.

Bartmiński J., 1977, O derywacji stylistycznej. Gwara ludowa w funkcji języka artystycznego, Lublin.

Bartmiński J., 1978, Swoiste formy orzeczeń w języku ustnym (orzeczenie onomatopeiczne, kompozycjonalne, zaimkowe, podwojone), [w:] Studia nad sktadnia polszczyzny mówionej, red. T. Skubalanka, Wrocław-Warszawa-Kraków, s. 159-177.

Bartmiński J., 1985, Stereotyp jako przedmiot lingwistyki, [w:] Z problemów frazeologii polskiej i stowiańskiej, t. 3, red. M. Basaja, D. Rytel, Wrocław, s. 25-27.

Bartmiński J., 1990, Punkt widzenia, perspektywa, językowy obraz świata, [w:] Jęzkowy obraz świata, red. J. Bartmiński, Lublin, s. 109-127.

Bartmiński J., 1993, Styl potoczny, [w:] Encyklopedia kultury polskiej XX wieku, t. 2: Wspótczesny język polski, red. J. Bartmiński, Wrocław, s. 115-134.

Bartmiński J., 1998, Podstawy lingwistycznych badań nad stereotypem - na przyktadzie stereotypu „,matki”, [w:] Język a Kultura, t. 12: Stereotyp jako przedmiot lingwistyki. Teoria, metodologia, analizy empiryczne, red. J. Anusiewicz, J. Bartmiński, Wrocław, s. 63-83.

Bartmiński J., 2001a, Język w kontekście kultury, [w:] Współczesny język polski, red. J. Bartmiński, Lublin, s. 13-22.

Bartmiński J., 2001b, Styl potoczny, [w:] Wspótczesny język polski, red. J. Bartmiński, Lublin, s. $124-125$.

Bartmiński J. (red.), 2002, Język w kręgu wartości. Studia semantyczne, Lublin.

Bartmiński J., Boniecka B. (red.), 1998, Tekst. Problemy teoretyczne, Lublin.

Bartmiński J., Mazurkiewicz-Brzozowska M. (red.), 1993, Nazwy wartości. Studia leksykalno-semantyczne, Lublin.

Bartmiński J., Niebrzegowska-Bartmińska S., 2006, Intencja a funkcja tekstu, [w:] Oblicza komunikacji 1: Perspektywy badań nad tekstem, dyskursem, komunikacja, t. 1, red. I. Kamińska-Szmaj, T. Piekot, M. Zaśko-Zielińska, Kraków, s. 25-44.

Bartmiński J., Panasiuk J., 2001, Stereotypy językowe, [w:] Wspótczesny język polski, red. J. Bartmiński, Lublin, s. 371-396.

Batko A., 2005, Sztuka perswazji, czyli język wptywu i manipulacji, Gliwice.

Bąba S., 1989, Innowacje frazeologiczne wspótczesnej polszczyzny, Poznań.

Bąba S., Mikołajczak S., 1973, Parenteza we wspótczesnej prozie polskiej (klasyfikacja i funkcje), „Studia Polonistyczne”, nr 1, Poznań, s. 11-16.

Bednarczuk L., 1981, Władza nad mowa (nowomowa), „Pismo”, nr 2, s. 93-102. 
Benedikt A., 2003, Motywowanie pracowników w sytuacjach kryzysowych, Wrocław.

Benedikt A., 2006, Reklama jako proces komunikacji, Wrocław.

Benveniste E., 1980, Struktura języka i struktura społeczeństwa, [w:] Język i społeczeństwo, red. M. Głowiński, Warszawa.

Bergström B., 2009, Komunikacja wizualna, Warszawa.

Bieńkowska D., Umińska-Tytoń E., 1991, O ekspresywnych elementach leksykalno-sktadniowych w języku familijnym Łodzi, [w:] Regionalizmy w języku familijnym (zbiór studiów), red. K. Handke, Wrocław-Warszawa-Kraków, s. 33-40.

Biernacka-Ligęza I., 1999, Wulgaryzmy a tamanie normy kulturowej, [w:] Mowa rozświetlona myślą, red. J. Miodek, Wrocław, s. 166-182.

Biernacka-Ligęza I., 2001, Wulgaryzmy w slangu młodzieżowym, [w:] Kształcenie językowe, red. K. Bakuła, J. Miodek, t. 2, Wrocław, s. 73-96.

Bietka E., Kierubiński W., 1982, Jak cię stysza - czyli język twój codzienny, Warszawa.

Birdwhistell R. L., 1970, Kinesics and Context. Essay an Body Motion Communication, Philadelphia.

Bloch J., 2006, Czy glos ludzki może prawić grzeczności? O uprzejmości w handlu, [w:] Retoryka codzienności. Zwyczaje językowe wspótczesnych Polaków, red. M. Marcjanik, Warszawa, s. 44-67.

Bloomfield L., 1933, Language, New York.

Błażejewska J., 2000, Językowe środki perswazji w nagłówkach publikacji politycznych, [w:] Regulacyjna funkcja tekstów, red. K. Michalewski, Łódź, s. 140-150.

Boguslawski A., 1976, O podstawach ogólnej charakterystyki przystów, „Pamiętnik Literacki”, R. LXVII, z. 3, s. 145-72.

Bokszański Z., 1972, Uwarstwienie społeczne a koncepcje różnic językowych w socjolingwistyce, „Kultura i Społeczeństwo”, t. XVI, nr 2, s. 103-113.

Bokszański Z., 1983, Komunikowanie znieksztatcone, „Przegląd Humanistyczny”, nr 3, s. 15-27.

Boniecka B., 1978, Podstawowe typy struktur pytajnych polszczyzny mówionej, [w:] Studia nad składnia polszczyzny mówionej, red. T. Skubalanka, Wrocław-Warszawa-Kraków, s. 147-158.

Boufal A. I., 2004, Nomina attributiva - nazwy ekspresywne ,, z natury”, [w:] Funkcja emocjonalna jednostek językowych i tekstowych, red. K. Wojtczuk, A. Wierzbicka, Siedlce, s. 21-28.

Bralczyk J., 1981a, O języku polskiej propagandy politycznej, [w:] Wspótczesna polszczyzna. Wybór zagadnień, red. H. Kurkowska, Warszawa, s. 336-354.

Bralczyk J., 1981b, Poza prawda i fatszem, „Teksty”, 6, s. 122-133.

Bralczyk J., 1986a, Język polskich tekstów propagandowych, Warszawa.

Bralczyk J., 1986b, O języku polskiej propagandy politycznej lat siedemdziesiatych, Kraków.

Bralczyk J., 1987, O języku polskiej propagandy politycznej lat siedemdziesiatych, „Acta Universitatis Upsaliensis. Studia Slavica Upsaliensia", Uppsala.

Bralczyk J., 1989, O języku naszej propagandy, „Zeszyty Prasoznawcze”, nr 3, s. 11.

Bralczyk J., 1991, Strategie propagandy politycznej, [w:] Język a Kultura, t. 4: Funkcje języka $i$ wypowiedzi, red. R. Grzegorczykowa, J. Bartmiński, Wrocław, s. 105-115.

Bralczyk J., 1994, Reklama - perswazja informacji, [w:] Sztuka reklamy, red. E. Kisielewska, Warszawa.

Bralczyk J., 1996, Język na sprzedaż, Warszawa.

Bralczyk J., 1999a, O językowych zwyczajach polskiej reklamy, [w:] Polszczyzna 2000. Orędzie o stanie języka na przetomie stuleci, red. W. Pisarek, Warszawa, s. 218-227.

Bralczyk J., 1999b, O użwaniu języka w polskiej polityce lat dziewięćdziesiatych, [w:] Polszczyzna 2000. Orędzie o stanie języka na przełomie stuleci, red. W. Pisarek, Warszawa, s. 197-217.

Bralczyk J., 2000a, Język na sprzedaż, czyli o tym, jak język służy reklamie i jak reklama używa języka, Warszawa-Bydgoszcz. 
Bralczyk J., 2000b, Manipulacja językowa, [w:], Dziennikarstwo i świat mediów, red. Z. Bauer, E. Chudziński, Kraków, s. 244-252.

Bralczyk J., 2001, O języku polskiej propagandy politycznej lat siedemdziesiatych, Warszawa.

Bralczyk J., Majkowska G., 2000, Język mediów - perspektywa aksjologiczna, [w:] Język w mediach masowych, red. J. Bralczyk, K. Mosiołek-Kłosińska, Warszawa, s. 43-50.

Brocki M., 2000, Język ciała w ujęciu antropologicznym, Wrocław.

Brown S., 1996, Jak mówić, aby ludzie stuchali, Warszawa.

Brzeziński M., 2008, Pracować i nie zwariować, Warszawa.

Buck R., 1984, The communication of emotion, New York.

Budzyński W., 2001, Reklama: techniki skutecznej perswazji, Warszawa.

Bugajski M., 1993, Język jako element interakcji kulturowych, „Poradnik Językowy”, z. 6, Warszawa, s. 311-316.

Bugajski M., 2000, O perswazyjnej funkcji terminów naukowych, [w:] Regulacyjna funkcja tekstów, red. K. Michalewski, Łódź, s. 419-424.

Bugajski M., 2007, Język w komunikowaniu, Warszawa.

Burska-Ratajczyk B., 2002, Zmiany stowotwórcze i leksykalne w gwarze jako językowy znak socjokulturowych procesów, [w:] Dialektologia jako dziedzina językoznawstwa i przedmiot dydaktyki, red. S. Gala, Łódź, s. 65-74.

Burska-Ratajczyk B., 2004, Gwarowe innowacje leksykalne na tle tendencji rozwojowych wspótczesnej polszczyzny, [w:] Współczesne odmiany języka narodowego, red. K. Michalewski, Łódź, s. 247-256.

Burska-Ratajczyk B., 2006, Skibq w mur - związi frazeologiczne jako środek wyrażania emocji w felietonach Krzysztofa Skiby, [w:] Wokót językowej funkcji emocjonalnej. Fakty dawne $i$ współczesne, red. K. Wojtczuk, V. Machnicka, Siedlce, s. 21-32.

Burska-Ratajczyk B., 2008, Wartościowanie komunikacji językowej (na materiale frazeologii gwar mazowieckich), [w:] Język - społeczeństwo - wartości, red. E. Laskowska, I. Benenowska, M. Jaracz, Prace Komisji Językoznawczej Bydgoskiego Towarzystwa Naukowego, t. XVIII, Bydgoszcz, s. 71-84.

Burska-Ratajczyk B., 2010a, Kreowanie własnego wizerunku w kontekście językowej prezentacji przeciwnika politycznego (na przykladzie wypowiedzi Lecha Wałesy), [w:] Język w prawie, administracji i gospodarce, red. K. Michalewski, Łódź, s. 211-224.

Burska-Ratajczyk B., 2010b, Ocena aktywności człowieka w połaczeniach wyrazowych z komponentem liczebnikowym, [w:] Ilość - wielkość - wartość, red. E. Umińska-Tytoń, Łódź, s. 25-36.

Burska-Ratajczyk B., 2012, Antroponimy jako element groteski w powieści „Telemaniak” Jacka Dąbaty, [w:] Język nowej literatury, red. K. Michalewski, Łódź, s. 30-40.

Buttler D., 1974, Polski dowcip językowy, Warszawa.

Buttler D., 1976, Innowacje składniowe współczesnej polszczyzny, Warszawa.

Buttler D., 1981, Tendencje rozwojowe w zasobie słownym powojennej polszczyzny, [w:] Współczesna polszczyzna. Wybór zagadnień, red. H. Kurkowska, Warszawa, s. 187-218.

Buttler D., 1982, Czasowniki potoczne współczesnej polszczyzny, „Socjolingwistyka”, 4, Warszawa-Katowice-Kraków, s. 55-66.

Buttler D., 1991, Przenośnie polszczyzny potocznej, „Prace Filologiczne”, t. XXXV, Warszawa, s. $39-46$.

Buttler D., Kurkowska H., Satkiewicz H., 1986, Kultura języka polskiego, t. 1: Zagadnienia poprawności gramatycznej, Warszawa.

Buttler D., Kurkowska H., Satkiewicz H., 1987, Kultura języka polskiego, t. 2: Zagadnienia poprawności leksykalnej (stownictwo rodzime), Warszawa.

Buttler D., Furdala A., Skubalanka T., 1991, Wprowadzenie do gramatyki stylistycznej języka polskiego, Lublin. 
Carnegie D., 1996, Jak zdobyć przyjaciót i zjednać sobie ludzi, Warszawa.

Cegieła A., Markowski A., 1982, Z polszczyzna za pan brat, Warszawa.

Charbonnier G., 1968, Rozmowy z Claude Lévi-Straussem, Warszawa.

Chlebda W., 1984, Oksymoron versus oksymoron, „Przegląd Humanistyczny”, z. 4. s. 131-139.

Chlebda W., 1996, Frazeologia potocznych gatunków mowy, [w:] Problemy frazeologii europejskiej, red. A. M. Lewicki, Warszawa, s. 15-28.

Chłopicki W., 2002, Humor w komunikacji językowej, [w:] Język trzeciego tysiaclecia II, t. 1: Nowe oblicza komunikacji we wspótczesnej polszczyźnie, red. G. Szpila, Kraków, s. 23-32.

Chmaj M., Sokól W. (red.), 1997, Mała encyklopedia wiedzy politycznej, Toruń.

Chudzik A., 2002, Mowne zachowania magiczne w ujęciu pragmatyczno-kognitywnym, Kraków.

Cialdini R. B., 1999, Wywieranie wplywu na ludzi. Teoria i praktyka, Gdańsk.

Cienkowski W., 1972, Teoria etymologii ludowej, Warszawa.

Covey S. R., 2003, 7 nawyków skutecznego działania, Poznań.

Cwalina W., 2000, Telewizyjna reklama polityczna, Lublin.

Cygan S., 1996, Zmiany w słownictwie mieszkańców wsi w kontekście przemian społeczno-kulturowych, red. I. Bobrowski, „Kieleckie Studia Filologiczne”, 10, s. 43-53.

Cygan S., 2004, Wyrazy nacechowane w świadomości mieszkańców wsi, [w:] Funkcja emocjonalna jednostek językowych i tekstowych, red. K. Wojtczuk, A. Wierzbicka, Siedlce, s. 39-48.

Cyran W., 1977, Tendencje słowotwórcze w gwarach polskich, Łódź.

Czesak A., 1998, Frazeologia gwarowa - problemy i postulaty, [w:] Teoretyczne, badawcze i dydaktyczne założenia dialektologii, red. S. Gala, Łódź, s. 285-293.

Czyżewski F., Warchoł S., 1998, Polskie i ukraińskie teksty gwarowe ze wschodniej Lubelszczyzny, Lublin.

Danielewiczowa M., 1991, Zdania pytajne o funkcji ekspresywnej, [w:] Język a Kultura, t. 4: Funkcje języka i wypowiedzi, red. R. Grzegorczykowa, J. Bartmiński, Wrocław, s. 159-168.

Dąbrowska A., 1999, Zniekształcenie obrazu rzeczywistości poprzez użycie pewnych środków językowych (eufemizm i kakofemizm), [w:] Językowy obraz świata, red. J. Bartmiński, Lublin, s. $215-227$.

Dąbrowska A., 2006a, Dynamiczna jazda, kreatywna księgowość, bezstresowe zdawanie egzaminu, [w:] Retoryka codzienności. Zwyczaje językowe wspótczesnych Polaków, red. M. Marcjanik, Warszawa, s. 323-332.

Dąbrowska A., 2006b, Eufemizmy współczesnego języka polskiego, Łask.

Dąbrowski K., 1975, Trud istnienia, Warszawa.

Dąbrowski K., 1979, Dezintegracja pozytywna, Warszawa.

Dejna K., 1973, Dialekty polskie, Wrocław.

Dejna K., 1991/1992, Z zagadnień ewolucji gwary, „Roczniki Humanistyczne”, z. 6, s. 81-86.

Dejna K., 1998, Gwara i jej stosunek do innych odmian języka ogólnonarodowego, [w:] Teoretyczne, badawcze i dydaktyczne założenia dialektologii, red. S. Gala, Łódź, s. 13-29.

Dłuska M., 1996, Anafora, [w:] Poetics. Poetyka. Poetika II.

Dobek-Ostrowska B. (red.), 2001, Nauka o komunikowaniu. Podstawowe orientacje teoretyczne, Wrocław.

Dobek-Ostrowska B., 2004a, Media masowe i aktorzy polityczni w świetle studiów nad komunikowaniem politycznym, Wrocław.

Dobek-Ostrowska B., 2004b, Podstawy komunikowania społecznego, Wrocław.

Dobek-Ostrowska B., Fras J., Ociepka B., 1997, Teoria i praktyka propagandy, Wrocław.

Dobrzyńska T., 1993, Tekst - próba syntezy, Warszawa.

Dobrzyńska T., 1994, Mówiąc przenośnie... studia o metaforze, Warszawa.

Dobrzyńska T., 1995, Metafory wartościujące w publicystyce $i$ wypowiedziach polityków, [w:] Kreowanie świata w mediach, red. A. M. Lewicki, R. Tokarski, Lublin, s. 201-214. 
Doliński D., 2005, Techniki wpływu społecznego, Warszawa.

Dominowej Z., Dominowa M. (oprac.), 2001, Słownik terminów literackich i gramatycznych, Białystok.

Doroszewski W., 1973, O funkcji poznawczo-społecznej języka, Warszawa.

Dubisz S., 1983, Uwarunkowania i wyznaczniki stylu tekstów propagandowych, „Poradnik Językowy", z. 3, s. 150-158.

Dubisz S., 1992, Język i polityka. Szkice z historii stylu retorycznego, Warszawa.

Dubisz S., 2004, Ksztattowanie się standardów odmian komunikacyjno-stylowych w dziejach języka polskiego, „Poradnik Językowy”, z. 8, s. 3-19.

Dunaj B., 1980, Zagadnienie interferencji $w$ badaniach dialektologicznych, „Biuletyn Polskiego Towarzystwa Językoznawczego", s. 99-108.

Dunaj B., 1981, Odmiana oficjalna i nieoficjalna języka mówionego, [w:] Studia nad polszczyzna mówiona Krakowa, „Zeszyty Naukowe Uniwersytetu Jagiellońskiego”, „Prace Językoznawcze", z. 70, s. 11-20.

Dunaj B., 1985, Sytuacja komunikacyjna a zróżnicowanie polszczyzny potocznej, „Język Polski”, 45 , s. $88-97$.

Dunaj B. i in. (red.), 1986a, Badania języka mówionego w Polsce $i$ w Niemczech, Kraków.

Dunaj B., 1986b, Dialektologia a socjolingwistyka, „Acta Universitatis Lodziensis”, Folia Linguistica, 12 .

Dunaj B., 1993, Nowe singulatiwa z przyrostkiem -ant, „Język Polski”, LXXII, s. 59-62.

Dunaj B. (red.), 1996, Stownik wspótczesnego języka polskiego, Warszawa.

Dunaj B., Lubaś W., 1996, Teoretycznie i praktycznie o relacjach między dialektologia a socjolingwistyka, [w:] Studia dialektologiczne, red. B. Dunaj, J. Reichan, Kraków, s. 41-46.

Dundes A., 1984, On Whether Weather „Proverbs” Are Proverbs, „Proverbium” 1.

Duszak A., 1998, Tekst, dyskurs, komunikacja międzykulturowa, Warszawa.

Dziewiecki M., 2000, Psychologia porozumiewania się, Kielce.

Eco U., 2003, Wilde. Paradoks i aforyzm, [w:] idem, O literaturze, Warszawa.

Edwards P., Edwards S., Clampitt Douglas L., 2006, Niech klienci tłoczq się u Twoich drzwi. Niezawodne sposoby pozyskiwania klientów $i$ odnoszenia sukcesów $w$ działalności gospodarczej, Gliwice.

Engelking A., Markowski A., Niemczuk-Weiss E., 1989, Kwalifikatory w słownikach - próba systematyzacji, „Poradnik Językowy”, nr 5, Warszawa-Lódź, s. 300-309.

Falkowski A., Cwalina W., 2005, Marketing polityczny. Perspektywa psychologiczna, Gdańsk.

Fąka P., 2008, Funkcje pragmatyczne wypowiedzi ironicznych, [w:] Problemy komunikacji spolecznej, red. G. Habrajska, seria: Rozmowy o komunikacji 2: Motywacja psychologiczna i kulturowa w komunikowaniu, Łask, s. 161-169.

Filipiak M., 1996, Socjologia kultury. Zarys zagadnień, Lublin.

Fish S., 2002, Interpretacja, polityka, retoryka, Kraków.

Fleischer M., 2001, Podstawy konstruktywistycznej i systemowej teorii komunikacji (teoria i praktyka), [w:] Język w komunikacji, t. 1, red. G. Habrajska, Łódź, s. 83-104.

Fleischer M., 2002, Teoria kultury $i$ komunikacji. Systemowe $i$ ewolucyjne podstawy, thum. M. Jaworowski, Wrocław.

Florczak J., 2004, Zasady funkcjonowania chwytów typograficznych w tekstach o charakterze perswazyjnym, „Biuletyn Polskiego Towarzystwa Językoznawczego”, z. LX, s. 71-88.

Fras J., 1997, Język propagandy politycznej, [w:] B. Dobek-Ostrowska, J. Fras, B. Ociepka, Teoria i praktyka propagandy, Wrocław, s. 84-112.

Friske J., 1999, Wprowadzenie do badań nad komunikowaniem, Wrocław.

Gadamer H. G., 1979, Człowiek i język, [w:] idem, Rozum, słowo. Dzieje. Szkice wybrane, Warszawa. 
Gajda S., 1990, Wprowadzenie do teorii terminu, seria: Studia i monografie, Opole.

Gajda S., Rymut K., Żydek-Bednarczuk U., (red. nauk.), 2002, Język w przestrzeni spolecznej, Opole.

Gala S., 1975, Z zagadnień klasyfikacji nazw osobowych (na przykładzie przezwisk nauczycieli), „Rozprawy Komisji Językowej Łódzkiego Towarzystwa Naukowego”, 21, s. 43-55.

Gala S., 1995, Kierunki zmian w gwarach polskich (zarys problemu), [w:] Kultura, język, edukacja, t. 3, red. R. Mrózek, Katowice, s. 129-138.

Gala S. (red.), 1998, Teoretyczne, badawcze i dydaktyczne założenia dialektologii, Łódź.

Gala S., 2000a, O pewnych wyznacznikach słowotwórstwa gwarowego, „Prace Filologiczne”, t. XLV, s. 173-178.

Gala S., 2000b, Stowotwórstwo gwarowe a stowotwórstwo polszczyzny ogólnej, „Rozprawy Komisji Językowej Łódzkiego Towarzystwa Naukowego", 45, s. 29-36.

Gala S., 2002, O potrzebie badań słowotwórstwa gwarowego, [w:] Dialektologia jako dziedzina językoznawstwa i przedmiot dydaktyki, red. S. Gala, Łódź, s. 147-154.

Gala S., 2006, Diachronia czy synchronia w badaniach stowotwórstwa gwarowego?, „Rozprawy Komisji Językowej Łódzkiego Towarzystwa Naukowego", t. LI, Diachronia w badaniach nad językiem i w dydaktyce szkoły wyższej, Łódź, s. 79-84

Galasiński D., 1991, Mury. Analiza perswazyjności sloganów wyborczych, „Socjolingwistyka”, XI, red. W. Lubaś, Katowice, s. 85-97.

Galasiński D., 1992, Chwalenie się jako perswazyjny akt mowy, Kraków.

Galloway Ch., 1988, Psychologia uczenia się i nauczania, t. 1, Warszawa.

Gardzińska J., 1989, Mowa mieszkańców Mogielnicy. Studium socjolingwistyczne, Siedlce.

Gardzińska J., 1993a, Teksty gwarowe z poludniowego Podlasia, Siedlce.

Gardzińska J., 1993b, Z badań nad modalnościa w wypowiedziach gwarowych (na materiale językowym z pótnocno-wschodniej Polski), [w:] Polszczyzna Mazowsza i Podlasia. Kultura języka a regionalizmy, red. B. Bartnicka, B. Falińska, A. Kowalska, H. Sędziak, Łomża-Warszawa, s. 99-108.

Gardzińska J., 1996, Językowe wykładniki stopnia pewności sądów w gwarach ludowych (na podstawie tekstów z Mazowsza i Podlasia), Siedlce.

Gardzińska J., 1997, Tradycja badań nad zjawiskami sktadniowymi w dialektach polskich, [w:] Tradycja badań dialektologicznych w Polsce, red. H. Sędziak, Olsztyn, s. 31-38.

Gardzińska J., 2000, Socjolingwistyczne aspekty funkcjonowania języka, Siedlce, s. 53-62.

Gardzińska J., 2001, O pewnych funkcjach sktadniowych wyrazu „co” w podlasko-mazowieckich tekstach gwarowych, [w:] Leksyka a gramatyka w tekście językowym, red. K. Wojtczuk, Siedlce, s. 183-194.

Gardzińska J., 2004, Diabel, licho, czort, szatan, antychryst, lucyfer w ekspresywnych wyrażeniach językowych wspótczesnej polszczyzny potocznej, [w:] Funkcja emocjonalna jednostek językowych i tekstowych, red. K. Wojtczuk, A. Wierzbicka, Siedlce, s. 73-82.

Gardzińska J., Zagadnienie interferencji językowej w badaniach sktadni gwarowej (na materiale z poludniowego Podlasia), „Zeszyty Naukowe WSRP”, „Polonistyka”, z. 1, nr 42, Siedlce, s. $27-52$.

Garpiel R., Leszczyńska K. (red.), 2004, Sztuka perswazji. Socjologiczne, psychologiczne i lingwistyczne aspekty komunikowania perswazyjnego, Kraków.

Giedz T., 2000, Współczesna reklama rosyjska-specyfika środków perswazji wobec nieprzychylnej postawy odbiorców, [w:] Regulacyjna funkcja tekstów, red. K. Michalewski, Łódź, s. 216-224.

Gilson E., 1960, Tomizm. Wprowadzenie do filozofii św. Tomasza z Akwinu, thum. J. Rybałta, Warszawa.

Głowacki J., 1992, Przezwiska nauczycieli i uczniów w opowiadaniach i powieściach E. Niziurskiego, „Język Polski”, 72, 4-5, s. 289-296. 
Glowiński M. (red.), 1980, Język i społeczeństwo, Warszawa.

Glowiński M., 1986, O intertekstualności, „Pamiętnik Literacki”, z. 4, s. 75-100.

Głowiński M., 1990, Nowomowa po polsku, Warszawa, s. 31-37.

Glowiński M., 1991a, Marcowe gadanie, Warszawa.

Głowiński M., 1991b, Nowomowa po polsku, Warszawa, s. 7-23.

Glowiński M., 1993, Peereliada, Warszawa.

Glowiński M., 1996, Mowa w stanie oblężenia (1982-85), Warszawa.

Głowiński M., 2002, Ironia, Gdańsk.

Goban-Klas T., 2004, Media i komunikowanie masowe, Warszawa.

Godyń J., 1995, Od Adama i Ewy zaczynać. Mały stownik biblizmów języka polskiego, KrakówWarszawa.

Golka M., 1994, Świat reklamy, Warszawa.

Goląb A., 1980, Normy moralne a gotowość do udzielania pomocy innym, [w:] Osobowość a spoteczne zachowanie się ludzi, red. J. Reykowski, Warszawa, s. 229-230.

Gołąb Z., Heinz A., Polański K., 1968, Słownik terminologii językoznawczej, Warszawa.

Górnowicz H., 1975, Frazeologia w gwarach w stosunku do języka literackiego na przykładzie gwar malborskich, [w:] Stownictwo gwarowe a kultura, red. M. Karaś, Wrocław, s. 80-84.

Górny W., 1960, O stylistycznej interpretacji składni, „Pamiętnik Literacki”, z. 2, Wrocław.

Grabias S., 1981, O ekspresywności języka. Ekspresja a słowotwórstwo, Lublin.

Grabias S., 1994, Język w zachowaniach społecznych, Lublin.

Grabias S., Skubalanka T., 1979, Społeczne uwarunkowania stylów języka, „Socjolingwistyka”, t. 2, Katowice, s. 29-61.

Grać J., 1985, Persu'azia, Martin.

Grice H. P., 1980, Logika a konwersacja, [w:] Język w świetle nauki, red. B. Stanosz, Warszawa, s. 91-114.

Griffin E., 2010, Podstawy komunikacji społecznej, Gdańsk.

Grochala B., 2008, Hiperbolizacja jako narzędzie marketingowe, [w:] Język w marketingu, red. K. Michalewski, Łódź, s. 413-421.

Grochowski M., 2001, Stownik polskich przekleństw i wulgaryzmów, Warszawa.

Grodziński E., 1983, Język jako narzędzie manipulacji, „Poradnik Językowy”, z. 7, s. 397-401.

Grybosiowa A., 1998, Liberalizacja społecznej oceny wulgaryzmów, [w:] Człowiek - dzieło - sacrum, red. S. Gajda, J. Helmut, J. Sobeczka, Opole, s. 361-369.

Grybosiowa A., 2003, Dynamika zmian językowych o podtożu kulturowym u progu XXI wieku (na materiale polskim), [w:] Język wtopiony w rzeczywistość, Katowice, s. 42-50.

Grzegorczykowa R., 1979, Struktura semantyczna wyrażeń ekspresywnych, [w:] Z zagadnień stownictwa współczesnego języka polskiego, red. M. Szymczak, Wrocław-Warszawa-KrakówGdańsk, s. 118-122.

Grzegorczykowa R., 1984, Zarys słowotwórstwa polskiego, Warszawa.

Grzegorczykowa R., 1985, Nowomowa a problem funkcji wypowiedzi, „Poradnik Językowy”, z. 6, s. 378-381.

Grzegorczykowa R., 1991, Problem funkcji języka tekstu w świetle teorii aktów mowy, [w:] Język a Kultura, t. 4: Funkcje języka i wypowiedzi, red. R. Grzegorczykowa, J. Bartmiński, Wrocław, s. $11-28$.

Grzegorczykowa R., 2001, Wprowadzenie do semantyki językoznawczej, Warszawa.

Grzegorczykowa R., Bartmiński J. (red.), 1999, Język a Kultura, t. 4: Funkcje języka i wypowiedzi.

Grzegorczykowa R., Laskowski R., Wróbel H. (red.), 1984, Gramatyka wspótczesnego języka polskiego. Morfologia, Warszawa.

Grzelakowa E., 2001, Ironia w dyskusji politycznej, [w:] Język w komunikacji, t. 1, red. G. Habrajska, Łódź, s. 239-247. 
Grzelakowa E., 2002, O sposobach kategoryzowania w regionalnych odmianach języka polskiego, [w:] Dialektologia jako dziedzina językoznawstwa i przedmiot dydaktyki, red. S. Gala, Łódź, s. $197-204$.

Grzesiuk A., 1995, Składnia wypowiedzi emocjonalnych, Lublin.

Grzesiuk L., Trzebińska T., 1978, Jak ludzie porozumiewają się, Warszawa.

Habrajska G., 1994, Wykorzystywanie ironii do walki politycznej, [w:] Język a Kultura, t. 11: Język polityki a wspótczesna kultura polityczna, red. J. Anusiewicz, B. Siciński, Wrocław, s. 57-68.

Habrajska G., 1998, Dialektologiczne metody we współczesnym językoznawstwie, [w:] Teoretyczne, badawcze i dydaktyczne założenia dialektologii, red. S. Gala, Łódź, s. 55-61.

Habrajska G., 2000, Wyktadnia językowa aktów prawnych a standardy semantyczne (na przyktadzie wybranych orzeczeń Trybunatu Konstytucyjnego), [w:] Regulacyjna funkcja tekstów, red. K. Michalewski, Łódź, s. 70-83.

Habrajska G., 2006, Styl a cele komunikacyjne, [w:] Style konwersacyjne, red. B. Witosz, Katowice.

Habrajska G. (red.), 2008, Motywacja psychologiczna i kulturowa w komunikacji, seria: Rozmowy o komunikacji 2, Lask.

Habrajska G. (red.), 2009, Problemy komunikacji społecznej, seria: Rozmowy o komunikacji 3, Łask.

Hall E. T., 1987, Bezgłośny język, Warszawa.

Hałas E., 2001, Symbole w interakcji, Warszawa.

Handke K., 2006, Co to jest język familijny, [w:] Retoryka codzienności. Zwyczaje językowe wspótczesnych Polaków, red. M. Marcjanik, Warszawa, s. 98-121.

Handke K., 2008, Innowacje językowe, [w:] eadem, Socjologia języka, Warszawa, s. 258-271.

Hogan K., 1996, Psychologia perswazji, Warszawa.

Hołówka T., 1986, Myślenie potoczne, Warszawa.

Homa E., 1979, Współczesne gwary Pomorza Środkowego. Studium socjolingwistyczne, cz. 1 i 2 , Słupsk.

Hrabec S., 1968, Polskie apelatywa toponomastyczne, „Rozprawy Komisji Językowej Łódzkiego Towarzystwa Naukowego", 14, s. 284-332.

Humboldt W., 1965, O różnicach $w$ budowie języków ludzkich $i$ wpływie tych różnic na rozwój duchowy ludzkości, przeł. T. Dmochowska, [w:] Teoria badań literackich za granica, t. 1: Romantyzm i pozytywizm, cz. I, red. S. Skwarczyńska, Kraków, s. 141.

Hymes D., 1980, Socjolingwistyka i etnografia mówienia, [w:] Język i społeczeństwo, red. M. Głowiński, Warszawa, s. 41-82.

Jachimowska K., 2001, Funkcje frazeologizmów i ich przeksztatceń formalno-znaczeniowych w tekstach telewizyjnych, [w:] Współczesna leksyka, red. K. Michalewski, Łódź, cz. I, s. 90-98.

Jakobson R., 1989, W poszukiwaniu istoty jezzyka, red. M. R. Mayenowa, cz. 2, Warszawa.

Jarymowicz M., 1980, Makiawelizm - osobowość ludzi nastawionych na manipulowanie innymi, [w:] Osobowość a społeczne zachowanie się ludzi, red. J. Reykowski, Warszawa, s. 285-315.

Jarymowicz M., Ohme R. K. (red.), 2003, Automatyzmy w regulacji psychicznej. Nowe perspektywy, Warszawa.

Jarząbek K., 1989, Znaki kinetyczne wspomagające komunikację mowna i ich miejsce w nauczaniu języków obcych (na przykładzie komunikacji Polaków i Rosjan - ujęcie konfrontatywne), Katowice.

Jarząbek K., 1992, Znakowe ruchy rąk jako istotny element porozumiewania się ludzi, „Socjolingwistyka”, XII-XIII, Kraków, s. 285-297.

Jarząbek K., 1996, Gestykulacja i mimika. Stownik, Katowice.

Jędrzejko E., 1999, Kobieta w przystowiach, aforyzmach i anegdotach polskich. Konotacje i stereotypy, [w:] Język a Kultura, t. 9: Pteć w języku i kulturze, red. J. Anusiewicz, K. Handke, Wrocław, s. 159-172. 
Jodłowski S., 1965, O gramatycznej i stylistycznej funkcji szyku wyrazowego, [w:] Symbolae linguisticae in honorem Georgii Kuryłowicz, red. S. Drewniak, Wrocław.

Jodłowski S., 1977, Podstawy polskiej sktadni, Warszawa.

Kacprzak A., 2008, Sztuka perswazji zaczyna się od słowa, [w:] Język w marketingu, red. K. Michalewski, Łódź, s. 69-73.

Kaczor D., Romanowski J., 2002, Stereotyp polskiego Żyda, [w:] Polskie stereotypy i uprzedzenia, red. J. Jarco, G. Dolińska, Wrocław, s. 53-67.

Kaczor M., 2003, Tabu a estetyka językowa, „Język Polski”, LXXXIII, z. 1, s. 46-49.

Kajtoch K., 2009, Nabytki w języku wsi - na przykładzie Brzezin w województwie podkarpackim, „Język Polski”, LXXXIX, z. 3, s. 208-220.

Kajtoch W., 1999, Odlotowe bez dwóch zdań! Kultura języka stylu perswazji w czasopiśmie dla młodzieży, „Zeszyty Prasoznawcze”, nr 3-4, s. 159-169.

Kajtoch W., Kołodziej J., Planeta P., 2000, Język czasopism dla młodzieży: świat, wartość, perswazja, [w:] Język mediów masowych, red. J. Bralczyk, K. Mosiołek-Kłosińska, Warszawa, s. 120-134.

Kalisz R., 1993, Pragmatyka językowa, Gdańsk.

Kamińska M., 1976, Różnice językowe między dwoma pokoleniami łodzian (formacje ekspresywne), „Rozprawy Komisji Językowej Łódzkiego Towarzystwa Naukowego”, XXII, s. 77-84.

Kamińska M. (red.), 1989, Wybór tekstów języka mówionego mieszkańców Łodzi i regionu łódzkiego. Generacja najstarsza, Łódź.

Kamińska M., 1991, Wybrane zagadnienia polszczyzny familijnej Łodzi, [w:] Regionalizmy w języku familijnym. Zbiór studiów, red. K. Handke, Wrocław, s. 23-31.

Kamińska M. (red.), 1992, Wybór tekstów języka mówionego mieszkańców Łodzi i regionu łódzkiego. Generacja starsza, średnia i najmłodsza, Łódź.

Kamińska-Szmaj I., 1994, Judzi, zohydza, ze czci odziera. Język propagandy politycznej w prasie 1919-1923, Wrocław.

Kamińska-Szmaj I., 1998, Stownictwo nacechowane reklamowo, [w:] Leksyka w komunikacji językowej, red. M. Grabska, J. Korzeniowska-Berczyńska, Gdańsk.

Kamińska-Szmaj I., 2001, Słowa na wolności. Język polityki po 1989 roku, wypowiedzi, dowcip polityczny, stownik inwektyw, Wrocław.

Kamińska-Szmaj I., 2003, Perswazja w tekstach reklamowych - spojrzenie językoznawcy, [w:] Język perswazji publicznej, red. K. Mosiołek-Kłosińska, T. Zgółka, Poznań, s. 77-79.

Kamińska-Szmaj I., 2004, Propaganda, perswazja, manipulacja - próba uporządkowania pojęć, [w:] Manipulacja w języku, red. P. Krzyżanowski, P. Nowak, Lublin, s. 13-27.

Kamińska-Szmaj I., Piekot T., Zaśko-Zielińska M., (red.), 2006, Oblicza komunikacji 1: Perspektywy badań nad tekstem, dyskursem, komunikacja, t. 1, Kraków.

Kania S., Tokarski J., 1984, Zarys leksykologii i leksykografii, Warszawa.

Karaś M., 1964, Z problematyki stowotwórstwa gwarowego, „Prace Filologiczne”, 18, 3, s. 153-162.

Karłowicz J., Kryński A., Niedźwiecki W., Stownik języka polskiego, Warszawa 1900-1927.

Karwat M., 1999, Sztuka manipulacji politycznej, Torun.

Karwat M., 2006, O złośliwej dyskredytacji. Manipulowanie wizerunkiem przeciwnika, Warszawa.

Karwatowska M., 2004, Dwa światy w gazetkach szkolnych - manipulacja czy perswazja?, [w:] Manipulacja w języku, red. P. Krzyżanowski, P. Nowak, Lublin, s. 175-186.

Kąś J., 1994a, Interferencja leksykalna słownictwa gwarowego i ogólnopolskiego (na przykładzie gwar orawskich), Kraków, s. 33-79.

Kąś J., 1994b, Kulturowy stereotyp mężczyzny i kobiety w środowisku wiejskim. Na materiale gwar orawskich, [w:] Język a Kultura, t. 9: Płeć w języku i kulturze, red. J. Anusiewicz, K. Handke, Wrocław, s. 119-130.

Kąś J., Sikora K., 1994, Konwencjonalne zwroty grzecznościowe w gwarach (na przykladzie kilku gwar Małopolski południowej), „Etnolingwistyka”, 6, red. J. Bartmiński, Lublin, s. 83-93. 
Kerbrat-Orecchioni C., 1986, Ironia jako trop, „Pamiętnik Literacki”, z. 1.

Kita M., 1993, Perswazyjne użycie języka potocznego w kontakcie ogólnym, [w:] Z problemów wspótczesnego języka polskiego, red. A. Wilkoń, J. Warchala, Katowice, s. 33-41.

Kita M., 2001, Język potoczny jako język bliskości, [w:] Język w komunikacji, cz. 1, red. G. Habrajska, Łódź, s. 170-179.

Kita M., 2004, Czy można nie manipulować? O audiowizualnej retoryce $w$ dyskursie politycznym, [w:] Manipulacja w języku, red. P. Krzyżanowski, P. Nowak, Lublin, s. 199-210.

Kita M., 2005, Językowe rytuały grzecznościowe, Katowice.

Klemantowicz T., 1982, Poradnik manipulatora: środki językowe, „Edukacja Polityczna”, nr 1, s. $247-260$.

Klemensiewicz Z., 1961, Problematyka sktadniowej interpretacji stylu, [w:] W kręu języka literackiego i artystycznego, Warszawa.

Klemensiewicz Z., 1969, Zarys sktadni polskiej, Warszawa.

Kleszcz K., 1998, Przemiany językowe na ziemiach zachodnich a metody ich badania, [w:] Teoretyczne, badawcze i dydaktyczne założenia dialektologii, red. S. Gala, Łódź, s. 159-167.

Kłoskowska A., 1983a, Kultura masowa, Warszawa.

Kłoskowska A., 1983b, Socjologia kultury, Warszawa.

Kneblewski R. A., 1980, Komunikacja werbalna i niewerbalna $w$ aspekcie filozoficznym. Rozważania metodologiczne w kierunku teorii aktów komunikowania, [w:] Zagadnienia socjo- i psycholingwistyki, red. A. Schaff i in., Wrocław, s. 237-249.

Kobjoll K., 2004, Szybciej, lepiej, więcej. Sztuka motywowania pracowników, Wrocław.

Kochan M., 1994, ,,Przyklejanie etykietek”, czyli o negatywnym określeniu przeciwnika, [w:] Język a Kultura, t. 11: Język polityki a wspótczesna kultura polityczna, red. J. Anusiewicz, B. Siciński, Wrocław, s. 85-89.

Kochan M., 2002, Slogany w reklamie i polityce, Warszawa.

Kochan M., 2005, Pojedynek na stowa. Chwyty erystyczne w publicznych sporach, Kraków.

Koj L., 1991, Uwagi o funkcjach języka i mowy, [w:] Język a Kultura, t. 4: Funkcje języka i wypowiedzi, red. R. Grzegorczykowa, J. Bartmiński, Wrocław, s. 36-52.

Kolakowski L., 2000, O stereotypach narodowych, [w:] Mini wyktady o maksi sprawach, Kraków, s. $97-98$.

Komornicka A. M., 1994, Stownik zwrotów i aluzji biblijnych, Łódź.

Kopaliński W. (red.), 2000, Stownik wyrazów obcych i zwrotów obcojęzycznych, Warszawa.

Kopaliński W., 2007, Stownik wyrazów obcych i zwrotów obcojęzycznych z almanachem, Warszawa.

Kopertowska D., 2000, Język tekstów perswazyjnych (na podstawie wspótczesnych reklam), [w:] Regulacyjna funkcja tekstów, red. K. Michalewski, Łódź, s. 231-237.

Korolko M., 1998, Sztuka retoryki. Przewodnik encyklopedyczny, Warszawa.

Korolko M., 2003, Przekonuj i daj się przekonać. Dialektyka, retoryka, erystyka z ćwiczeniami, Piotrków Trybunalski.

Kosyl Cz., 1988, Aluzyjność nazw własnych $w$ dziele literackim, „Annales Universitatis M. Curie-Skłodowska", vol. VI 4, sectio FF, Lublin, s. 39-50.

Kowalewska-Dąbrowska J., 2007, Rola perswazyjna słowotwórczych gier językowych w tekstach publicystycznych, [w:] Stowotwórstwo i tekst, red. V. Maldjiewa, Z. Rudnik-Karwatowa, Warszawa, s. 79-87.

Kowalikowa J., 1994, Znaczenie i funkcja tzw. wyrazów brzydkich we współczesnej polszczyźnie mówionej, [w:] Współczesna polszczyzna mówiona w odmianie opracowanej (oficjalnej), red. Z. Kurzowa, W. Śliwiński, Kraków, s. 107-113.

Kowalikowa J., 1997, Świat wyobrażeń i doświadczeń człowieka w przystowiach polskich i koreańskich, „Zeszyty Naukowe Uniwersytetu Jagiellońskiego”, MCCX, „Prace Językoznawcze”, z. 118, Kraków, s. 37-46. 
Kowalikowa J., 2001, Świat roślin w przystowiach koreańskich, [w:], Język a Kultura, t. 16: Świat roślin w języku i kulturze, red. A. Dąbrowska, I. Kamińska-Szmaj, Wrocław, s. 139-147.

Kowalikowa J., 2002, O nowy wymiar dialektów $i$ dialektologii $w$ edukacji $i$ w badaniach, [w:] Dialektologia jako dziedzina językoznawstwa i przedmiot dydaktyki, red. S. Gala, Łódź, s. 243-250.

Kowalska A., 1975-1979, Zróżnicowanie słowotwórcze gwar Mazowsza i Podlasia. Rzeczownik, t. 1-2, Wrocław.

Kozielecki J., 1975, Psychologiczna teoria decyzji, Warszawa.

Kraśnicka-Wilk I., 2001, Kognitywne schematy wyobrażeniowe leżace u podstaw frazeologizmów z leksemem ,glowa”, „Język Polski”, LXXXI, z. 5, s. 339-343.

Krauz M., 1992, Powtórzenie jako czynnik spajajacy tekst, [w:] Systematyzacja pojęć w stylistyce, Opole, s. 247-252.

Krawczyk A., 1985, Co wiemy o frazeologii gwarowej, [w:] Z problemów frazeologii polskiej i słowiańskiej, t. 3, red. M. Basaj, D. Rytel, Wrocław-Warszawa-Kraków-Gdańsk-Lódź, s. 129-137.

Krawczyk-Tyrpa A., 1987, Frazeologia somatyczna w gwarach polskich. Zwiąki frazeologiczne o znaczeniach motywowanych częściami ciała, Wrocław.

Krawczyk-Tyrpa A., 2001, Tabu w dialektach polskich, Bydgoszcz.

Kriger U., 1983, Wyznaczniki składniowej segmentacji tekstu miejskiego języka mówionego mieszkańców miast Górnego Śląska i Zagłębia, Katowice.

Krzyżanowski J. (red.), 1984, Literatura polska. Przewodnik encyklopedyczny, Warszawa.

Krzyżanowski P., 2004, Manipulacja w języku. Manipulacja w tekście, [w:] Manipulacja w języku, red. P. Krzyżanowski, P. Nowak, Lublin, s. 277-282.

Krzyżanowski P., Nowak P. (red.), 2004, Manipulacja w języku, Lublin.

Kucala M., 1960, O słownictwie ludzi wyzbywajacych się gwary, „Biuletyn Polskiego Towarzystwa Językoznawczego", XIX, s. 141-156.

Kudra A., 2004, Porównanie w poezji Stanisława Grochowiaka. Teoria chiralności i przyczynowości tropu, Łódź.

Kudra B., 1997, O sposobach realizacji funkcji perswazyjnej $w$ stownictwie z zakresu polityki, „Rozprawy Komisji Językowej Łódzkiego Towarzystwa Naukowego”, t. XLII, s. 169-176.

Kudra B., 2001, Kreatywność leksykalna $w$ dyskursie politycznym polskiej prasy lat osiemdziesiatych i dziewięćdziesiatych, Łódź.

Kudrowie B. i A., 2004, Między manipulacja a perswazja (o funkcjonowaniu antroponimów w tekście prasowym), [w:] Manipulacja w języku, red. P. Krzyżanowski, P. Nowak, Lublin, s. $91-100$.

Kulawik A., 1994, Poetyka. Wstęp do teorii dzieła literackiego, Kraków.

Kurcz I., 1975, Język i mowa, [w:] Psychologia, red. T. Tomaszewski, Warszawa.

Kurcz I., 1976, Psycholingwistyka. Przegląd problemów badawczych, Warszawa.

Kurcz I., 1992, Język a psychologia. Podstawy psycholingwistyki, cz. IV: Rozważania nad językiem w jego funkcji komunikacyjnej, Warszawa

Kurcz I., 2000, Psychologia języka i komunikacji, Warszawa.

Kurek H., 1987, Przetaczanie kodu językowego, czyli socjolingwistyczne aspekty wzajemnego oddziaływania języka literackiego i dialektów, „Język Polski”, LXVII, z. 1-2, s. 63-69.

Kurek H., 1988, Jak się mówi na wsi, czyli kilka słów o zanikaniu gwar (system fonologiczny), „Język Polski”, LXVIII, z. 1, s. 50-54.

Kurek H., 1994, Zachowania komunikacyjne mieszkańców wspótczesnej wsi, [w:] Kształcenie porozumiewania się, red. S. Gajda, J. Nocoń, Opole, s. 109-114.

Kurek H., 1995, Przemiany językowe wsi regionu krośnieńskiego. Studium socjolingwistyczne, Kraków. 
Kurek H., 1996, Metoda socjolingwistycznego badania fleksji gwarowej, [w:] Studia dialektologiczne, red. B. Dunaj, J. Reichan, Kraków, s. 169-173.

Kurek H., 1997, Tradycja badań dialektologicznych a problemy językowe, [w:] Tradycja badań dialektologicznych w Polsce, red. H. Sędziak, Olsztyn, s. 129-133.

Kurek H., 2001, Przemiany językowe wsi (na przykladzie wybranych nazw roślin z okolic Dukli), [w:] Język a Kultura, t. 16: Świat roślin w języku i kulturze, red. A. Dąbrowska, I. Kamińska-Szmaj, Wrocław, s. 117-122.

Kurkowska H. (red.), 1981, Wspótczesna polszczyzna. Wybór zagadnień, Warszawa.

Kurkowska H., Skorupka S., 2001, Stylistyka polska. Zarys, Warszawa.

Kwiatkowski S., 1974, Stowo i emocje w propagandzie, Warszawa.

Labocha J., 1999, Tekst gwarowy jako dyskurs, II Konferencja Dialektologiczna w Mogilanach, 18-19 listopada $1999 \mathrm{r}$.

Lakoff G., Johnson M., 1988, Metafory w naszym życiu, przeł. T. P. Krzeszowski, Warszawa.

Lalewicz J., 1975, Komunikacja językowa i literatura, Warszawa.

Lalewicz J., 1985, Socjologia komunikacji literackiej, Wrocław.

Laskowska E., 1992, Wartościowanie w języku potocznym, Bydgoszcz.

Laskowska E., 1996, Typy wartości w tekstach potocznych, [w:] Poznańskie spotkania językoznaw$c z e$, t. I, red. Z. Krążyńska, Z. Zagórski, Poznań, s. 76-82.

Laskowska E., 2000, Językowe środki wartościujące w funkcji nakłaniającej (na przykładzie wypowiedzi na sesjach Rady Miejskiej Bydgoszczy), [w:] Regulacyjna funkcja tekstów, red. K. Michalewski, Łódź, s. 342-348.

Laskowska E., 2004, Emotywizacja jako środek perswazji, [w:] Manipulacja w języku, red. P. Krzyżanowski, P. Nowak, Lublin, s. 81-90.

Laskowska E., 2007, O jednym z przejawów perswazji we współczesnym dyskursie politycznym, [w:] Język-historia - polityka, red. E. Laskowska, M. Jaracz, Prace Komisji Językoznawczej Bydgoskiego Towarzystwa Naukowego, t. XVII, Bydgoszcz, s. 93-100.

Laskowska E., 2008, Wartościowanie jako środek perswazji, [w:] Język - spoleczeństwo - warto$s ́ c i$, red. E. Laskowska, I. Benenowska, M. Jaracz, Prace Komisji Językoznawczej Bydgoskiego Towarzystwa Naukowego, t. XVIII, Bydgoszcz, s. 219-226.

Laskowska E., 2009, Wartościowanie w dyskursie publicznym, [w:] Problemy komunikacji społecznej, red. G. Habrajska, seria: Rozmowy o komunikacji 3, Łask, s. 55-71.

Lemmermann H., 1997, Komunikacja werbalna. Szkoła dyskutowania. Techniki argumentacji, dyskusje, dialogi, Wrocław.

Lepa A., 2000, Pedagogika mass mediów, Łódź.

Lewandowska-Tarasiuk E., 2005, $W$ teatrze prezentacji. O sztuce perswazji, Warszawa.

Lewicki A. M., 1995, Frazeologizmy w sloganach reklamowych, [w:] Kreowanie świata w tekstach, red. A. M. Lewicki, R. Tokarski, Lublin, s. 215-228.

Lewicki A. M., 2004, Nagłówki w formie ustalonych związów wyrazowych jako narzędzie manipulacji, [w:] Manipulacja w języku, red. P. Krzyżanowski, P. Nowak, Lublin, s. 101-114.

Lewicki A. M., Nowak P., 2000, Manipulacja językowa w mediach, [w:] Język w mediach masowych, red. J. Bralczyk, K. Mosiołek-Kłosińska, Warszawa, s. 34-42.

Lewicki A. M., Pajdzińska A., 1993, Frazeologia [w:] Encyklopedia kultury XX wieku. Wspótczesny język polski, red. J. Bartmiński, Wrocław, s. 307-326.

Lewicki A. M., Pajdzińska A., 2001, Frazeologia [w:] Współczesny język polski, red. J. Bartmiński, Lublin, s. 328.

Lewiński P. H., 1999, Retoryka reklamy, Wrocław.

Lewiński P. H., 2001, Granice perswazji, [w:] Język w komunikacji, t. 1, red. G. Habrajska, Łódź, s. 284-293. 
Liberek J., 1991, Informacja czy manipulacja. Jak „, Gazeta Wyborcza” pisze o Kościele?, „Więź”, nr 11, s. 21-42.

Liberman D. J., 2005, Postaw na swoim! Niech inni robia to, co zechcesz, Warszawa.

Libura A., 2000, Struktura i właściwości perswazyjne tekstów wzywających do zapłaty, [w:] Regulacyjna funkcja tekstów, red. K. Michalewski, Łódź, s. 92-103.

Lichański J., 1996, Co to jest retoryka?, Kraków.

Lichański J. Z., 2000, Retoryka od renesansu do wspótczesności, Warszawa.

Lippman W., 1922, Public Opinion, Nowy Jork.

Lis-Turska M., 1980, Ingracjacja, czyli manipulowanie innymi ludźmi za pomoca zwiększenia własnej atrakcyjności, [w:] Osobowość a społeczne zachowanie się ludzi, red. J. Reykowski, Warszawa, s. 317-354.

Lizisowa M. T., 2006, Tekst - kontekst - interpretacja. W poszukiwaniu semiotyczno-dyskursywnych wzorców konkretyzacji języka, Kraków.

Lizisowa M. T., 2009, Informacja czy manipulacja, [w:] Jaka informacja?, red. L. Dyczewski, Lublin, s. 89-100.

Lubaś W., 1979a, Socjolingwistyka jako metoda badawcza, „Socjolingwistyka” 2, s. 11-27.

Lubaś W., 1979b, Społeczne uwarunkowania wspótczesnej polszczyzny. Szkice socjolingwistyczne, Kraków.

Lubaś W., 1982, Socjolingwistyka - metoda interdyscyplinarna, „Socjolingwistyka” 4, s. $11-18$.

Lubaś W., 1988, Potoczność i jej wyznaczniki w tekstach słowiańskich, „Socjolingwistyka” 8, s. $45-57$.

Lubaś W., 2003, Polskie gadanie. Podstawowe cechy i funkcje potocznej odmiany polszczyzny, Opole.

Lubaś W., 2006, Język w komunikacji, w perswazji i w reklamie, Dąbrowa Górnicza.

Labuz P., Urbański M., 2006, Marketing perswazyjny. 25 niezmiennych praw skutecznej perswazji w tekstach marketingowych, Gliwice.

Laguna P., 1984, Ironia jako postawa i jako wyraz, Kraków-Wrocław.

Lobodzińska R., Peisert M., 2004, Antroponimia ekspresywna w Internecie, [w:] Manipulacja w języku, red. P. Krzyżanowski, P. Nowak, Lublin, s. 211-220.

Luczeńczyk P., 2007, Mechanizmy perswazji w komunikacji przez Internet $w$ procesie dydaktycznym, [w:] Mechanizmy perswazji i manipulacji, red. G. Habrajska, A. Obrębska, Łódź, s. $383-396$.

Lukaszyński J., 2002, Studencki stereotyp Polaka, [w:] Polskie stereotypy i uprzedzenia, red. J. Jarco, G. Dolińska, Wrocław, s. 147-160.

Maas U., Wunderlich D., 1972, Pragmatik und sprachliches Handeln. Mit einer Kritik am Funkkolleg ,, Sprache”, Frankfurt am Main.

Maciuszek J., 2007, Presupozycje i negacja jako lingwistyczne narzędzia komunikacji perswazyjnej, [w:] Mechanizmy perswazji i manipulacji, red. G. Habrajska, A. Obrębska, Łódź, s. 29-48.

Maćkiewicz J., 1995, Metafora w reklamie, [w:] Kreowanie świata w tekstach, red. A. M. Lewicki, R. Tokarski, Lublin, s. 229-239.

Maćkiewicz J., 2001, Językowy obraz świata $w$ działaniu, czyli podstawowe założenia potocznej pragmatyki, [w:] Językoznawstwo kognitywne II, Zjawiska pragmatyczne, red. W. Kubiński, D. Stanulewicz, Gdańsk, s. 328-347.

Majewska M., 2005, Akty deprecjonujące siebie i innych. Studium pragmalingwistyczne, Kraków.

Majkowska G., 1988, Klasyfikacja semantyczna zamierzonych modyfikacji zwiazków frazeologicznych, [w:] Z problemów frazeologii polskiej i stowiańskiej, t. 5, red. M. Basaj, D. Rytel, Wrocław, s. 143-144.

Makuchowska M., 2001, Perswazja w komunikowaniu religijnym, [w:] Najnowsze dzieje języków słowiańskich. Język polski, rozdz.: Język religijny, red. nauk. S. Gajda, Opole, s. 392-402. 
Malec T., 1976, Budowa słowotwórcza rzeczowników i przymiotników w gwarze wsi Rachanie pod Tomaszowem Lubelskim, Wrocław.

Małyska A., 2006, „Zwycięzca poszukiwany” - strategie perswazyjne w komunikacji marketingu bezpośredniego, [w:] Teksty kultury. Oblicza komunikacji XXI wieku, red. J. Mazur, M. Rzeszutko-Iwan, Lublin, s. 245-257.

Mamcarz A., 1998, Metodologia badań nad językiem nakłaniania. Zarys problematyki, „Pamiętnik Literacki", nr 5-6, s. 14-24.

Mamcarz A., Warchala J., 2004, Horyzonty manipulacji: perswazja, manipulacja, interpretacja, [w:] Manipulacja w języku, red. P. Krzyżanowski, P. Nowak, Lublin, s. 41-60.

Marcjanik M. (red.), 2006, Retoryka codzienności. Zwyczaje językowe współczesnych Polaków, Warszawa.

Marcjanik M., 2007, Grzeczność w komunikacji językowej, Warszawa.

Markiewicz H., 1988, Odmiany intertekstualności, „Ruch Literacki”, z. 4-5, s. 245-263.

Markowski A., 2000, Stownik poprawnej polszczyzny, Warszawa.

Markowski A. (red.), 2006, Wielki stownik poprawnej polszczyzny, Warszawa.

Markowski A., 2008, Kultura języka polskiego. Teoria. Zagadnienia leksykalne, Warszawa.

Markowski A. (red.), 2009, Stownik poprawnej polszczyzny, oprac. L. Drabik, L. Sobol, Warszawa.

Marody M., 2003, Socjologiczne zaplecze języka perswazji publicznej, [w:] Język perswazji publicznej, red. K. Mosiołek-Kłosińska, T. Zgółka, Poznań, s. 18-27.

Masłowska E., 1991, Z problemów pejoratywizacji lub melioracji nazw własnych użytych w funkcji appellatiwów, [w:] Język a Kultura, t. 3: Wartości w języku i tekśsie, red. J. Puzynina, J. Anusiewicz, Wrocław, s. 29-40.

Mattelart A., Mattelart M., 2001, Teorie komunikacji. Krótkie wprowadzanie, Warszawa-Kraków.

Matuszczyk B., 2002, O definicjach projektujacych w perswazji kaznodziejskiej, [w:] Regulacyjna funkcja tekstów, red. K. Michalewski, Łódź, s. 318-323.

Mayen J., 1972, O stylistyce utworów mówionych, Wrocław.

Mayenowa R. M., 1979, Poetyka teoretyczna: zagadnienia języka, Wrocław.

Mazur J., 1990, Styl i tekst w aspekcie pragmatycznym, „Socjolingwistyka”, 9, s. 71-72.

Mazur J., Rzeszutko-Iwan M. (red.), 2006, Teksty kultury. Oblicze komunikacji XXI wieku, t. 1 i 2, Lublin.

Michalewski K., 1993a, Mechanizm zapożyczania imion własnych w języku polskim, „Acta Universitatis Lodziensis. Folia Linguistica Polonica”, 27, Łódź, s. 183-190.

Michalewski K., 1993b, Neologizm, neosemantyzm, metafora, „Rozprawy Komisji Językowej Łódzkiego Towarzystwa Naukowego", t. XXXVIII, Łódź, s. 119-124.

Michalewski K., 1994, Polityczna nowomowa, „Dziś. Przegląd Społeczny”, nr 6 (45), Warszawa, s. $65-70$.

Michalewski K., 1999, Przytaczanie cudzych wypowiedzi jako środek perswazji w telewizji, „Rozprawy Komisji Językowej Łódzkiego Towarzystwa Naukowego”, t. XLIV, Łódź, s. $63-69$.

Michalewski K., 2000, Funkcja form czasownikowych w tekstach regulacyjnych, [w:] Regulacyjna funkcja tekstów, red. K. Michalewski, Łódź, s. 25-33.

Michalewski K., 2001, Kreowanie wartości wyrazów, [w:] Współczesna leksyka, cz. II, red. K. Michalewski, Łódź, s. 3-8.

Michalewski K., 2002, Obiektywizm informacji, [w:] Jazyková komunikácia v 21 storoci, red. J. Klincková, Banská Bystrica, s. 50-65.

Michalewski K., 2004a, Imiona własne w funkcji perswazyjnej, [w:] Metodologia badań onomastycznych, red. M. Biolik, Olsztyn, s. 352-363.

Michalewski K., 2004b, Prezentacja i autoprezentacja polityków w telewizji, [w:] Sučasná jazyková komunikácia v interdisciplinárnych súvislostiach, red. V. Patráš, Banská Bystrica, s. 271-280. 
Michalewski K., 2004c, Telewizyjna manipulacja zespolona, [w:] Manipulacja w języku, red. P. Krzyżanowski, P. Nowak, Lublin, s. 187-198.

Michalewski K., 2006a, Neutralizowanie emocji, [w:] Wyrażanie emocji, red. K. Michalewski, Łódź, s. 77-83.

Michalewski K., 2006b, Składniowe środki wyrażania emocji, [w:] Wokół językowej funkcji emocjonalnej. Fakty dawne i wspótczesne, red. K. Wojtczuk, V. Machnicka, Siedlce, s. 147-151.

Michalewski K., 2009, Komunikaty mieszane, Łódź.

Michalewski K., 2010, Elementy obudowy wypowiedzenia jako środek perswazji w tekstach stowiańskich, [w:] Z zagadnień semantyki i stylistyki tekstu, red. A. Ginter, Łódź, s. 327-333.

Mikułowski-Pomorski J., Nęcki Z., 1983, Komunikowanie skuteczne?, Kraków.

Miodońska-Brookes E., Kulawik A., Tatara M., 1980, Zarys poetyki, Warszawa.

Miodunka W., Ropa A., 1979, Z zagadnień socjolingwistycznego opisu sytuacji. Na przykładzie sytuacji telewizyjnych, „Socjolingwistyka”, 2, s. 63-76.

Mosiołek-Kłosińska K., 1996, Językowa prezentacja przeciwników politycznych w wypowiedziach kandydatów na prezydenta w kampanii 1995 r., „Poradnik Językowy” z. 1, s. 12-20.

Mosiołek-Kłosińska K., 2000, Wulgaryzacja języka w mediach, [w:] Język w mediach masowych, red. J. Bralczyk, K. Mosiołek-Kłosińska, Warszawa, s. 112-119.

Mosiołek-Kłosińska K. i Zgółka T. (red.), 2003, Język perswazji publicznej, Poznań.

Mrózek R., 1998, Teoretyczno-badawcze związki dialektologii i onomastyki, [w:] Teoretyczne, badawcze i dydaktyczne założenia dialektologii, red. S. Gala, Łódź, s. 63-68.

Mrózek R., 2002, Gwara w zachowaniach komunikacyjnych a polityka i edukacja językowa, [w:] Dialektologia jako dziedzina językoznawstwa i przedmiot dydaktyki, red. S. Gala, Łódź, s. 353-358.

Muecke D. S., 1986, Ironia: podstawowe klasyfikacje, „Pamiętnik Literacki”, LXXVII, z. 1, s. 254-260.

Muecke D. S., 2002, Ironia: podstawowe klasyfikacje, [w:] Ironia, red. M. Głowiński, słowo/obraz, terytoria, Gdańsk.

Nagajowa M., 2005, Stownik rymowanek potocznego języka polskiego, czyli o naszym stosunku do ludzi, języka i realiów codzienności, Warszawa.

Nagy L. K., 2004, Manipulowanie odbiorem i odbiorca na przykładzie emigracyjnej prozy o tematyce łagrowej, [w:] Manipulacja w języku, red. P. Krzyżanowski, P. Nowak, Lublin, s. 243-260.

Nęcki Z., 1996a, Komunikacja międzyludzka, Kraków.

Nęcki Z., 1996b, Komunikowanie niewerbalne, [w:] idem, Komunikacja międzykulturowa, Kraków, s. 212-213.

Nieckula F., 1992, Język mówiony i język pisany, [w:] Język a Kultura, t. 5: Potoczność w języku i kulturze, red. J. Anusiewicz, F. Nieckula, Wrocław, s. 87-94.

Niedzielski H., 1991, Sposób komunikowania się bez słów, czyli komunikacja pozawerbalna w Polsce, „Socjolingwistyka”, 11, s. 109-114.

Nitsch K., 1915, Dialekty języka polskiego, Kraków.

Nowicka E., 1991, Świat człowieka - świat kultury, Warszawa.

Nowotna-Szybistowa M., 1969, Rzeczownikowe neologizmy deminutywne w języku Stanistawa Ignacego Witkiewicza, „Język Polski”, XLIX, s. 362-369.

Nycz R., 1990, Intertekstualność i jej zakresy: teksty, gatunki, światy, „Pamiętnik Literacki”, z. 2, s. 95-116.

O'Keefe D. J., 1990, Persuasion: Theory and research, London: Sage Publications.

Obremski K., 2004, Retoryka dla studentów historii, politologii i dziennikarstwa, Toruń.

Obrębska A., 2007, Perswazja poprzez kreowanie wizerunku polityka, [w:] Mechanizmy perswazji i manipulacji, red. G. Habrajska, A. Obrębska, Łódź, s. 489-498.

Ohmann R., 1977, Mowa, działanie, styl, [w:] Znak, styl, konwencja, red. M. Głowiński, Warszawa, s. $122-145$. 
Ohme R. K., 2003, Podprogowe informacje mimiczne: ujęcie eksperymentalne, Warszawa.

Ohme R. K. (red.), 2007, Nieuświadomiony afekt, Sopot.

Okopień-Slawińska A., 1984, hasło: epitet [w:] Literatura polska. Przewodnik encyklopedyczny, red. J. Krzyżanowski, Warszawa, s. 244.

Olechnicki K., Załęcki P., (red.), 1988, Słownik socjologiczny, Toruń.

Olszewska B., Nowik J., 2002, Stereotyp polskiego lekarza, [w:] Polskie stereotypy i uprzedzenia, red. J. Jarco, G. Dolińska, Wrocław, s. 335-347.

Ossowska M., 1970, Normy moralne. Próba systematyzacji, Wrocław.

Ożdżyński J., 1993, Z zagadnień konceptualizacji stownej (w kontekście kultury), „Socjolingwistyka", 12/13, Kraków, s. 7-20.

Ożóg K., 1990, Leksykon metatekstowy wspótczesnej polszczyzny mówionej. Wybrane zagadnienia, Kraków.

Ożóg K., 1998a, Język kampanii wyborczej z 1997 r. na tle polszczyzny lat dziewięćdziesiatych, „Język Polski”, LXXVIII, z. 3-4, s. 171-178.

Ożóg K., 1998b, Język polskiej wsi na tle przemian wspótczesnej polszczyzny, [w:] Teoretyczne, badawcze, dydaktyczne założenia dialektologii, red. S. Gala, Łódź, s. 119-125.

Ożóg K., 2001, Polszczyzna przełomu XX i XXI wieku. Wybrane zagadnienia, Rzeszów.

Ożóg K., 2002, Metafory potoczne w języku polityki, „Język Polski”, LXXXII, z. 1, s. 21-24.

Ożóg K., 2007, Karnawalizacja polskich kampanii wyborczych, [w:] Humor i karnawalizacja we współczesnej komunikacji językowej, red. J. Mazur, M. Rumińska, Lublin, s. 264-265.

Pabijańska M., 2007, Psychomanipulacja w polityce, Wrocław.

Pajdzińska A., 2006a, Antropocentryzm frazeologii potocznej, [w:] eadem, Studia frazeologiczne, Łask, s. 104-113.

Pajdzińska A., 2006b, Wartościowanie we frazeologii, [w:] eadem, Studia frazeologiczne, Łask, s. $129-147$.

Palka P., 2006, Perswazja w dyskursie handlowym - wpływ obcych wzorców, [w:] Przemiany języka na tle przemian wspótczesnej kultury, red. K. Ożóg, E. Oronowicz-Kida, Rzeszów, s. 117-130.

Paryl W., 1998, Metody badania gwar polskiej ludności z kresów poludniowo-wschodnich osiedlonej na Dolnym Ślasku, [w:] Teoretyczne, badawcze i dydaktyczne założenia dialektologii, red. S. Gala, Łódź, s. 153-158.

Pelc J., 1982, Wstęp do semiotyki, Warszawa.

Pelcowa H., 1994, Mechanizmy nazwotwórcze i zmiany leksykalne w gwarach (na materiale gwar Lubelszczyzny), [w:] Uwarunkowania i przyczyny zmian językowych. Zbiór studiów, red. E. Wrocławska, Warszawa, s. 105-111.

Pelcowa H., 1996, Wariantywność a interdialektalność zjawisk gwarowych, „Prace Naukowe Uniwersytetu Śląskiego”, red. A. Kowalska, A. Grybosiowa, Katowice, s. 156-169.

Pelcowa H., 1998, Zmiany językowe jako problem badawczy współczesnej dialektologii, [w:] Teoretyczne, badawcze i dydaktyczne założenia dialektologii, red. S. Gala, Łódź, s. 105-117.

Pelcowa H., 2000, Kompetencja językowa i kompetencja komunikacyjna mieszkańców wsi regionu lubelskiego, [w:] Język polski. Wspótczesność - historia, red. W. Książek-Bryłowa, H. Duda, Lublin, s. 91-104.

Perczyńska N., 1975, Wybrane cechy składniowo-stylistyczne polszczyzny mówionej (na materiale gwary pótnocnomazowieckiej wsi Szczutowo i okolic), „Prace Instytutu Języka Polskiego PAN", 7, Wrocław.

Perelman Ch., 2004, Imperium retoryki. Retoryka i argumentacja, przeł. M. Chomicz, Warszawa.

Piekarczyk D., 1999, Językowy obraz świata w metaforze ,,świat to teatr”, ,Język Polski”, LXXIX, 1-2, s. 96-104.

Pilch W., 1958, Wykład zasad kościelnej wymowy, Poznań.

Piotrowski A., Ziółkowski M., 1976, Zróżnicowanie językowe a struktura społeczna, Warszawa. 
Pisarek W., 1956, Język stuży propagandzie, Kraków.

Pisarek W., 1974, Perswazyjna funkcja języka, [w:] Studia indoeuropejskie, Wrocław, s. 175-179.

Pisarek W., 1975, Wyobrażenia o polskich stereotypach regionalnych, „Zeszyty Prasoznawcze”, z. 1, s. 73-78.

Pisarek W., 1993, O nowomowie inaczej, „Język Polski”, LXXXIII, z. 1-2, s. 1-9.

Pisarek W., 2002, Nowa retoryka dziennikarska, Kraków.

Pisarek W., 2003, Perswazja - jak ja widza, jak ja pisza, [w:] Język perswazji publicznej, red. K. Mosiołek-Kłosińska, T. Zgółka, Poznań, s. 9-17.

Pisarek W., 2004, Stowa między ludźmi, Warszawa.

Pisarek W. (red.), 2006, Stownik terminologii medialnej, Kraków.

Pisarkowa K., 1974, O spójności tekstu mówionego, [w:] Tekst i język. Problemy semantyczne, red. M. R. Mayenowa, Wrocław, s. 41-84.

Pisarkowa K., 1975, Składnia rozmowy telefonicznej, Wrocław.

Pisarkowa K., 1976a, Konotacja semantyczna nazw narodowości, „Zeszyty Prasoznawcze”, z. 1, s. $5-26$.

Pisarkowa K., 1976b, Pragmatyczne spojrzenie na akt mowy, „Polonica”, II, s. 265-279.

Pisarkowa K., 1978a, Odchylenia twórcze w języku potocznym, [w:] Tekst. Język. Poetyka. Zbiór studiów, red. M. R. Mayenowa, Wrocław-Warszawa-Kraków-Gdańsk, s. 163-172.

Pisarkowa K., 1978b, Zdanie mówione a rola kontekstu, [w:] Studia nad składnia polszczyzny mówionej, red. T. Skubalanka, Wrocław, s. 7-20.

Pisarkowa K., 1994, Pragmatyczne spojrzenie na akt mowy, [w:] Z pragmatycznej stylistyki, semantyki i historii języka. Wybór zagadnień, Kraków, s. 11-23.

Pogonowska E., 2007, Artura Oppmana , stużba poety” - perswazja w poezji patriotycznej o tematyce historycznej, [w:] Mechanizmy perswazji i manipulacji, red. G. Habrajska, A. Obrębska, Łódź, s. 125-140.

Polański K. (red.), 1999, Encyklopedia językoznawstwa ogólnego, Wrocław-Warszawa-Kraków.

Popowska-Taborska H., 1960, O przezwiskach nauczycieli, „Język Polski”, z. 2, s. 113-121.

Popowska-Taborska H., 1974, Kaszubskie formacje z sufiksem -ajek, -ajka na szerszym polskim tle gwarowym, „Studia z Filologii Polskiej i Słowiańskiej”, 13, s. 87-92.

Popowska-Taborska H., 1998, O pewnych nie w petni postrzeganych możliwościach badania dialektalnej leksyki, [w:] Teoretyczne, badawcze i dydaktyczne zatożenia dialektologii, red. S. Gala, Łódź, s. 253-257.

Pratkanis A., Aronson E., 2003, Wiek propagandy. Używanie i nadużywanie perswazji na co dzień, przeł. J. Radzicki, M. Szuster, Warszawa.

Proctor II Russell F., 2006, Relacje interpersonalne. Proces porozumiewania się, thum. G. Skoczylas, Poznań.

Przybylska R., 2000, Uwagi o nowszych potocznych formacjach słowotwórczych, „Język Polski”, LXXX, z. 3-4, s. 197-206.

Przybylska R., Przyczyna W. (red.), 2001, Retoryka dziś, Kraków.

Puzynina J., 1984a, O dyskursie oceniajacym i dyrektywnym w tekstach prasy codziennej, „Poradnik Językowy", z. 2, s. 69-78.

Puzynina J., 1984b, Problemy aksjologiczne w językoznawstwie, „Poradnik Językowy”, z. 9-10, s. $539-556$.

Puzynina J., 1987, Funkcje języka i akty mowy, „Polonistyka”, nr 3, s. 163-172.

Puzynina J., 1988, O relacjach między wartościowaniem ilościowym w znaczeniach wyrazów, „Annales Universitatis Mariae Curie-Skłodowska”, vol. VI, Lublin, s. 273-281.

Puzynina J., 1990, Z problemów wartości i słownictwa wartościujacego „,Vade-mecum”, [w:] Stowo Norwida, „Zeszyty Naukowe Uniwersytetu Jagiellońskiego”, „Prace Językoznawcze”, 119 , s. 81-94. 
Puzynina J., 1992, Język wartości, Warszawa.

Puzynina J., 1997, Stowo - wartość - kultura, Lublin.

Puzynina J., Pajdzińska A., 1996, Etyka słowa, [w:] O zagrożeniach i bogactwie polszczyzny, red. J. Miodek, Wrocław, s. 35-45.

Rak M., 2006, Antropocentryzm gwarowej frazeologii zwierzęcej z Gór Świętokrzyskich i Podtatrza, „Język Polski”, z. 5, s. 367-375.

Reardon K. K., 1981, Persuasion. Theory and Context, London.

Reczek S., 1968, Deminutywa polskie. Charakterystyka, rozwój funkcji stylistycznej, „Rocznik Naukowo-Dydaktyczny”, z. 3 (5), Rzeszów, s. 373-386.

Reczek S., 1973, Polip morfologiczny. Lekcja fonetyki, [w:] idem, Na tropach słów, Wrocław.

Reichan J., 1999, Gwary polskie końca XX wieku, [w:] Polszczyzna 2000, red. W. Pisarek, Kraków, s. $262-278$.

Rejakowa B., 2004, Myślę, czuję i chcę tego, co każe moda (O perswazyjności tekstów o modzie), [w:] Manipulacja w języku, red. P. Krzyżanowski, P. Nowak, Lublin, s. 161-174.

Rodak R., 2000, Frazemy jako emotywne operatory interaktywne, „Acta Universitatis Wratislaviensis", No 2229, t. 14, Wrocław.

Rodziński A., 1989, Osoba, moralność, kultura, Lublin.

Rusinek M., Załazińska A., 2005, Retoryka podręczna, Kraków.

Ryzza-Woźniak A., 2000, Motywacja marketingowa i językowa nazwy firmowej (marki) a jej funkcja perswazyjna na przykładzie słownictwa z euro-, [w:] Regulacyjna funkcja tekstów, red. K. Michalewski, Łódź, s. 261-267.

Rzetelska-Feleszko E., 2001, Nazwy własne, [w:] Współczesny język polski, red. J. Bartmiński, Lublin, s. 408.

Sambor J., 1985, Nowomowa - język naszych czasów, „Poradnik Językowy”, z. 6, s. 365-377.

Sapir E., 1978, Kultura, język, osobowość, Warszawa.

Sarnowska-Giefing I., 1993, Funkcje nazewnictwa w satyrze staropolskiej, [w:] Onomastyka literacka, red. M. Biolik, Olsztyn, s. 101-106.

Sarnowski M., 1991, Deminutiwum jako znak ironii, [w:] Język a Kultura, t. 3: Wartości w języku i tekście, red. J. Puzynina, J. Anusiewicz, Wrocław, s. 41-50.

Saussure F. de, 1961, Kurs językoznawstwa ogólnego, tłum. K. Kasprzyk, Warszawa.

Schaff A., 1981, Stereotypy a działanie ludzkie, Warszawa, s. 60-70; 127-136.

Sędziak H., 1996, Łomżyńskie teksty gwarowe, cz. 1, Łomża-Kielce.

Sędziak H., 1999, Składnia zdania złożonego w tomżyńskich tekstach gwarowych, [w:] Polszczyzna pólnocno-wschodnia, cz. 2, red. B. Nowowiejski, Białystok, s. 279-303.

Sędziak H., 2004, Emocjonalizmy składniowe w tomżyńskich tekstach gwarowych, [w:] Funkcja emocjonalna jednostek językowych $i$ tekstowych, red. K. Wojtczuk, A. Wierzbicka, Siedlce, s. 201-211.

Sędziak H., Frąckiewicz M., 1999, Łomżyńskie teksty gwarowe, cz. 2, Łomża.

Sierociuk J., 1998, Słowotwórstwo języka wspótczesnej wsi (zarys problemu), [w:] Teoretyczne, badawcze i dydaktyczne założenia współczesnej dialektologii, red. S. Gala, Łódź, s. 265-272.

Sierotwiński S. (red.), 1986, Stownik terminów literackich. Teoria i nauki pomocnicze literatury, Wrocław.

Sikora K., 1993, Jak „pan” zawędrowat na wieś, „Język Polski”, LXXIII, s. 298-307.

Sikora K., 1994, Gwarowe formuty adresatywne jako narzędzia identyfikacji więzi społecznej łaczącej rozmówców (na przykładzie gwar okolic Krakowa), [w:] Język a Kultura, t. 10: Języki subkultur, red. J. Anusiewicz, B. Siciński, Wrocław, s. 195-204.

Siwek A., 2002, Perswazja i sposoby jej wyrażania w miesięczniku „, Twój Styl”, „Poradnik Językowy", z. 1, s. 29-41.

Siwek G., 1992, Przepowiadać skuteczniej. Elementy retoryki kaznodziejskiej, Kraków. 
Skawiński J., 1992, Polszczyzna potoczna w funkcji interdialektu, [w:] Język a Kultura, t. 5: Potoczność w języku i kulturze, red. J. Anusiewicz, F. Nieckula, Wrocław, s. 81-86.

Skorupka S., 1949, Elementy formalne humoru w języku, „Poradnik Językowy”, 6, s. 21-26.

Skorupka S., Kurkowska H., 2001, Stylistyka polska. Zarys, Warszawa.

Skowronek K., 1993, Reklama. Studium pragmalingwistyczne, Kraków.

Skubalanka T., 1991, Wprowadzenie do gramatyki stylistycznej języka polskiego, Lublin.

Skubalanka T., 1993, O rozwoju stylów językowych, „Stylistyka”, 2, red. S. Gajda, Opole, s. $5-13$.

Skubalanka T., 1995, O definicjach stylu, „Stylistyka”, 4, red. S. Gajda, Opole, s. 7-23.

Skudrzyk A., 2004, Współczesny komunikacyjny status gwar ludowych w opinii społecznej, [w:] Polszczyzna Mazowsza i Podlasia, cz. VIII: Antroponimia i toponimia Mazowsza i Podlasia, red. H. Sędziak, Łomża, s. 169-176.

Skudrzykowa A., Urban K. (red.), 2000, Mały stownik terminów z zakresu socjolingwistyki i pragmatyki językowej, Kraków-Warszawa.

Sławek J., 2005, Funkcja perswazyjna metafor i ironii we wspótczesnych prasowych tekstach informacyjnych, [w:] Język polski. Współczesność. Historia V, red. W. Książek-Bryłowa, H. Duda, Lublin, s. 79-91.

Sławek J., 2007, Czytelnik uwolniony? Perswazja we wspótczesnej informacji, Poznań.

Slawiński J., (red.), 1988, Stownik terminów literackich, Wrocław-Warszawa-Kraków-GdańskŁódź.

Sławkowa E., (red.), 2002, Kategorie stylistyki pragmatycznej, Cieszyn.

Stownik języka polskiego, 1807-1815, S. B. Linde, Warszawa.

Stownik języka polskiego, 1900-1927, red. J. Karłowicz, A. A. Kryński, W. Niedźwiecki, Warszawa.

Stownik języka polskiego, 1958-1969, red. W. Doroszewski, Warszawa.

Stownik języka polskiego, 1978, red. M. Szymczak, Warszawa.

Stownik wyrazów obcych, 2002, red. J. Tokarski, Warszawa.

Smoczyński P., 1962, Nomina appellativa i propria we wzajemnym oddziaływaniu słowotwórczym, „Biuletyn Polskiego Towarzystwa Językoznawczego”, 21, s. 61-82.

Smoleń-Wawrzusiszyn M., 2004, Skladniowe wykladniki emocji $w$ tekstach publicystycznych polskiego oświecenia, [w:] Funkcja emocjonalna jednostek językowych i tekstowych, red. K. Wojtczuk, A. Wierzbicka, Siedlce, s. 221-230.

Smól J., 2000, Wykorzystanie środków pozaleksykalnych w celach perswazyjnych w prasie, „Język Polski”, LXXX, z. 3-4, s. 233-244.

Sobstyl K., 2008, Językowe mechanizmy perswazyjne w internetowych tekstach reklamowych Klubu Świat Ksiązki, [w:] Język w marketingu, red. K. Michalewski, Łódź, s. 242-249.

Spence G., 2001, Jak skutecznie przekonywać: ...wszędzie i każdego dnia, przeł. M. Baranowski, Poznań.

Stefańczyk A., 2008, Psychologia wywierania wpływu, Gliwice.

Steward J. (red.), 2005, Mury zamiast mostów. Podręcznik komunikacji interpersonalnej, Warszawa.

Sujak E., 2006, ABC psychologii komunikacji, Kraków.

Szarota P., 2006, Psychologia uśmiechu. Analiza kulturowa, Gdańsk.

Szczepankowska I., 1993, Pokoleniowe uwarunkowania współczesnej świadomości językowej mieszkańców wsi, [w:] Polszczyzna Mazowsza i Podlasia. Różnice w mowie pokoleń, red. B. Bartnicka, Łomża-Warszawa, s. 87-91.

Szczepankowska I., 1998, Nomina attributiva $w$ gwarze tomżyńskiej. Studium leksykalno-słowotwórcze, Białystok.

Szczerbowski T., 1994, O grach językowych w tekstach polskiego i rosyjskiego kabaretu lat osiemdziesiąych, Kraków. 
Szerszunowicz J., 2006, Z badań nad zooinwektywami w ujęciu kontrastywnym (na materiale języka polskiego i włoskiego), [w:] Wokót językowej funkcji emocjonalnej. Fakty dawne i wspótczesne, red. K. Wojtczuk, V. Machnicka, Siedlce, s. 279-290.

Szewcow-Szewczyk M., 1974, Tabu i eufemizmy językowe dawniej i dziś, „Poradnik Językowy”, z. 6, Warszawa, s. 285-293.

Szkudlarek-Śmiechowicz E., 2007, Niewerbalne środki komunikacji a moc perswazyjna wypowiedzi, [w:] Mechanizmy perswazji i manipulacji, red. G. Habrajska, A. Obrębska, Lask, s. 299-308.

Sztucki T., 1995, Promocja. Sztuka pozyskiwania nabywców, Warszawa.

Szwabe J., 2008, Odbiór komunikatu jako zadanie poznawcze, Poznań.

Szymanek K., 1999, Formalna teoria zmiany przekonań, Katowice.

Szymanek K., 2001, Sztuka argumentacji. Stownik terminologiczny, Warszawa.

Szymanek K., Wieczorek K. A., Wójcik A. S., 2005, Sztuka argumentacji. Ćwiczenia w badaniu argumentów, Warszawa.

Szyszkowska M., 1997, W poszukiwaniu sensu życia, Warszawa.

Ślósarska J., 2000, Konstrukcja autometafor dyrektywnych, stosowanych w treningach interpersonalnych, [w:] Regulacyjna funkcja tekstów, red. K. Michalewski, Łódź, s. 45-50.

Tabakowska E., 2001, Kognitywne podstawy języka i językoznawstwa, Kraków.

Tkaczyk L., 2000, Postawa, mimika, gest, Wrocław.

Todorov T., 1977, Tropy i figury, przeł. W. Krzemień, „Pamiętnik Literacki”, LXVIII, z. 2, Wrocław-Warszawa-Kraków-Gdańsk, s. 275-293.

Tokarski R., 1984, Struktura pola znaczeniowego (studium językoznawcze), Warszawa, s. 13-15.

Tokarski R., 1995a, Kreowanie stereotypu w reklamie, „Aida-Media”, nr 12, s. 32-33.

Tokarski R., 1995b, Mechanizmy perswazyjne w reklamie, „Aida-Media”, nr 10, s. 34-36.

Tokarski R., Nowak P., 1999, Językowy obraz świata a perswazyjna funkcja tekstów (o poszukiwaniu wspólnoty kulturowej), [w:] Język - teoria - dydaktyka, red. B. Grzeszczuk, Rzeszów, s. 207-215.

Tokarz M., 2006, Argumentacja, perswazja, manipulacja. Wykłady z teorii komunikacji, Gdańsk.

Tołstoj N. I., 1992, Język a kultura (niektóre zagadnienia słowiańskiej etnolingwistyki), „Etnolingwistyka", 5, red. J. Bartmiński, Lublin, s. 15-25.

Tomasik W., 1988, Polska powieść tendencyjna 1945-1955. Problemy perswazji literackiej, Wrocław.

Tomiczek E., 1992, Z badań nad istota grzeczności językowej, [w:] Język a Kultura, t. 6: Polska etykieta językowa, red. J. Anusiewicz, M. Marcjanik, Wrocław, s. 15-26.

Treder J., 1982, Z idiomatyki frazeologicznej Kaszub i Śląska Cieszyńskiego, [w:] Z problemów frazeologii polskiej $i$ słowiańskiej, t. 1, Wrocław, s. 125-133.

Turk Ch., 2003, Sztuka przemawiania, Wrocław.

Umińska-Tytoń E., 1995, O tzw. konstrukcjach tautologicznych w polszczyźnie mówionej, „Rozprawy Komisji Językowej Łódzkiego Towarzystwa Naukowego", t. XL, s. 241-248.

Umińska-Tytoń E., 2000, Imiona w Polsce używane na tle tradycji kulturowych, „Rozprawy Komisji Językowej Łódzkiego Towarzystwa Naukowego", t. XLV, s. 131-206.

Urbańczyk S., 1968, Zarys dialektologii polskiej, Warszawa.

Urbańczyk S. (red.), 1978, Encyklopedia wiedzy o języku polskim, Wrocław-Warszawa-KrakówGdańsk.

Urbańczyk S. (red.), 1991, Encyklopedia języka polskiego, Wrocław.

Urbański P. (red.), 2003, Retoryka na ambonie, Kraków.

Waniakowa J., 1992, Etykieta językowa w gwarach polskich na przyktadzie trzech zbiorów tekstów gwarowych, „Socjolingwistyka”, 12/13, Kraków, s. 273-283.

Warchala J., 1991, Dialog potoczny a tekst, Wrocław.

Warchala J., 2001, Warunki wspótprodukowania tekstu potocznego, [w:] Język w komunikacji, t. 1, red. G. Habrajska, Łódź, s. 165-169. 
Warchala J., 2004, Horyzonty manipulacji: perswazja, manipulacja, interpretacja, [w:] Manipulacja w języku, red. P. Krzyżanowski, P. Nowak, Lublin, s. 41-60.

Wasilewski J., 2006, Fallocentryzm szarego człowieka, [w:] Retoryka codzienności. Zwyczaje językowe współczesnych Polaków, red. M. Marcjanik, Warszawa, s. 285-306.

Wesołowska D., 1996, Nowomowa koniecznie potrzebna, „Język Polski”, z. 4-5, s. 349-354.

Węgier J., 1978, Integracja i dezintegracja języka na Pomorzu Zachodnim, Szczecin.

Węgier J., Oronowicz E., 1992, Język mówiony mieszkańców wsi Polski poludniowo-wschodniej. Teksty i omówienia, Rzeszów.

Węgrzyn A., 2002, Stereotyp polskiego polityka, [w:] Polskie stereotypy i uprzedzenia, red. J. Jarco, G. Dolińska, Wrocław, s. 225-241.

Wężowicz-Ziólkowska D., 1991, Miłość ludowa. Wzory miłości wieśniaczej w polskiej poezji ludowej XVIII-XX wieku, Wrocław.

Whorf B. L., 1982, Język, myśl i rzeczywistość, Warszawa.

Wieczorek U., 1994, O dychotomicznym widzeniu świata, czyli o zwalczaniu wroga za pomoca słów, „Język Polski”, LXXIV, z. 4-5, s. 268-277.

Wieczorek U., 1999, Wartościowane, perswazja, język, Kraków.

Wiertlewski S., 1995, Pytania bez odpowiedzi: pytania jako pośrednie akty mowy, Poznań.

Wierzbicka A., 1963, Lingwistyczne narzędzia w stylistycznej analizie szyku wyrazów, „Pamiętnik Literacki", z. 2, Wrocław.

Wierzbicka A., 1965, O języku - dla wszystkich, Warszawa.

Wierzbicka A., 1978, Sapir a wspótczesne językoznawstwo, [w:] E. Sapir, Kultura, język, osobowość, Warszawa, s. 5-31.

Wilk E., 2000, N@wigacje stowa. Strategie werbalne w przekazach audiowizualnych, Kraków.

Wilkoń A., 1979, O odmianach współczesnej polszczyzny mówionej, „Opuscula Polono-Slavica”, Wrocław, s. 405-414.

Wilkoń A., 1982, Język mówiony a język pisany, „Socjolingwistyka”, 4, s. 19-32.

Wilkoń A., 1987, Typologia odmian językowych współczesnej polszczyzny, Katowice.

Wilkoń A., 1999, Język artystyczny. Studia i szkice, Katowice, s. 91-114.

Winiarska J., 2007, Retoryka tekstów użytkowych, „Język Polski”, LXXVII, z. 4-5, s. 320-322.

Witosz B., 2009, Dyskurs i stylistyka, Katowice.

Wlodek-Chronowska J., 1993, Komunikacja perswazyjna w poradnictwie zawodowym, WrocławWarszawa-Kraków.

Wojciszke B., 1993, Moralność i sprawność jako kategorie percepcji spolecznej i politycznej, „Przegląd Psychologiczny”, 36, s. 433-447.

Wojciszke B., 2006, Człowiek wśród ludzi. Zarys psychologii społecznej, Warszawa.

Wojtak M., 1993, Role spoleczne a styl (wybrane zagadnienia), „Socjolingwistyka”, 12/13, Kraków, s. 235-244.

Wojtak M., 1994, Pojęcie stylizacji jako narzędzia opisu utworów literackich, „Stylistyka”, 3, Opole, s. 135-142.

Wojtasik L., 1973, Zarys psychologii propagandy, Warszawa.

Wojtczuk K., 2000, Nakazy i zakazy w języku zawodowym nauczycieli i ich tekstowa funkcja regulacyjna, [w:] Regulacyjna funkcja tekstów, red. K. Michalewski, Łódź, s. 391-398.

Wojtczuk K., 2004, Wykrzykniki polskie jako jednostki sktadni emocjonalnej. Próba opisu wybranych tendencji funkcjonalnych, [w:] Funkcja emocjonalna jednostek językowych i tekstowych, red. K. Wojtczuk, A. Wierzbicka, Siedlce, s. 291-300.

Wojtczuk K., 2006, Zapożyczenia w klasie wykrzykników polskich. Ich formy oraz wybrane funkcje pragmatyczne, [w:] Wokół językowej funkcji emocjonalnej. Fakty dawne i współczesne, red. K. Wojtczuk, V. Machnicka, Siedlce, s. 347-358. 
Wolicka-Wolszleger E., 1995, Obraz i stowo w obszarze języka religijnego, „Znak”, 12, s. 64-75. Wolińska O., 1987, Język XIX-wiecznych wiadomości prasowych, Katowice.

Wolny M., 2003, Językowy obraz starości ludzi i zwierząt w polszczyźnie, [w:] Język a Kultura, t. 15: Opozycja homo - animal w języku i kulturze, red. A. Dąbrowska, Wrocław, s. 189-199. Wolski P., 1998, Proces komunikacji, [w:] Aby osiagnać cel, red. K. Sedlak, Kraków.

Woźniakiewicz-Dziadosz M., 2004, Tekst literacki jako widowisko komunikacji zmanipulowanej, [w:] Manipulacja w języku, red. P. Krzyżanowski, P. Nowak, Lublin, s. 233-242.

Wronicz J., 2007, Pozycja dialektu wobec innych odmian polszczyzny, ,Język Polski”, LXXXVII, z. 2, s. 91-96.

Wróblewski P., 1998, Struktura, typologia, frekwencja polskich metafor, Białystok.

Wyderka B., 1994, Przemiany językowe na Ziemiach Zachodnich i Pólnocnych a problem tzw. integracji językowej, [w:] Przemiany wspótczesnej polszczyzny, Opole.

Wysoczański W., 2005, Językowy obraz świata w porównaniach zleksykalizowanych, Wrocław.

Zachwieja M., 2000, Językowe środki perswazji w świetle podręczników homiletyki, [w:] Regulacyjna funkcja tekstów, red. K. Michalewski, Łódź, s. 329-336.

Zagórski Z., 1998, Gwara z punktu widzenia teoretycznego i praktycznego, [w:] Teoretyczne, badawcze i dydaktyczne zatożenia dialektologii, red. S. Gala, Łódź, s. 23-29.

Zarębina M., 1954, O niektórych sposobach spieszczeń, „Język Polski”, XXXIV, 3, s. 180-187.

Zdunkiewicz-Jedynak D., 1991, Językowe środki perswazji w homiliach (na przykładzie tekstów Jana Pawła II), [w:] Język a Kultura, t. 4: Funkcje języka i wypowiedzi, red. R. Grzegorczykowa, J. Bartmiński, Wrocław, s. 149-157.

Zdunkiewicz-Jedynak D., 1996, Językowe środki perswazji w kazaniu, Kraków.

Zdunkiewicz-Jedynak D., 2008, Wyktady ze stylistyki, Warszawa.

Zgólka T., 1991, Język jako filtr aksjologiczny, [w:] Zagadnienia komunikacji językowej dzieci i młodzieży. Materiały ogólnopolskiej konferencji, red. J. Poayski-Pomsta, Warszawa, s. 9-18.

Zgółka T., 2001, Pośrednie akty mowy w retoryce współczesnej, [w:] Retoryka dziś. Teoria i praktyka, red. R. Przybylska, W. Przyczyna, Kraków, s. 415-425.

Zgółka T., Zieliński M., 2003, Perswazja w tekstach prawnych i prawniczych, [w:] Język perswazji publicznej, red. K. Mosiołek-Kłosińska, T. Zgółka, Poznań, s. 182-189.

Zgólkowa H. (red.), 2003, Praktyczny słownik współczesnej polszczyzny, Poznań.

Zgółkowie H. i T., 1998, Biznesmen, uczony i robotnik. Aksjologiczne podstawy stereotypu językowego. Rekonesans, [w:] Język a Kultura, t. 12: Stereotyp jako przedmiot lingwistyki. Teoria, metodologia, analizy empiryczne, red. J. Anusiewicz, J. Bartmiński, Wrocław, s. 245-251.

Ziemska M., 1975, Rodzina a osobowość, Warszawa.

Zimny R., 1995, Wartościowanie i magia w języku reklamy, [w:] Kreowanie świata w tekstach, red.

A. M. Lewicki, R. Tokarski, Lublin, s. 239-254.

Ziomek J., 1990, Retoryka opisowa, Wrocław.

Ziółkowski M., 1981, Znaczenie, interakcja, rozumienie, Warszawa.

Znyk P., 2008, Od komunikacji do manipulacji, Keżmarok.

Żurek A. (red.), 2011, Język a Kultura, t. 22: Idiolekty w różnych sferach komunikacji, Wrocław.

Żydek-Bednarczuk U., 1993, O kilku problemach metodologicznych badania rozmowy potocznej, „Socjolingwistyka”, 12/13, Kraków, s. 24-37.

Żydek-Bednarczuk U., 2004a, Struktura tekstu rozmowy potocznej, Katowice.

Żydek-Bednarczuk U., 2004b, Zmiany $w$ zachowaniach komunikacyjnych a problem strategii i manipulacji, [w:] Manipulacja w języku, red. P. Krzyżanowski, P. Nowak, Lublin, s. 32-33.

Żydek-Bednarczuk U., 2005, Wprowadzenie do lingwistycznej teorii tekstu, Katowice. 



\section{Résumé}

Le document presente analyse la persuasion linguistique et il concerne la dimention pragmatique de la communication linguistique des habitants de la campagne qui n'etait pas encore etudiee du cote des mecanisme de la persuasion. Le dossier est basse sur les pieces de source:il s'agit des textes de patois enregistres dans les annees 1995-2010. Ces etudes touchent 12 campagnes situees aux environs de Lodz, de Grojec et de Czestochowa. Dans cet expose il y a des textes representatifs pour des dialectes et des patois divers. Les informateurs ce sont des personnes qui se different du point de vue de l'age, du sexe et de la formation. La transcription des enonces venant des enregistrement a ete inseree dans ce dossier avec le consentement des informateurs.

Le terme la persuasion est commente de diverses facons, parfois il est meme identifie a la manipulation, alors dans la chapitre theorique de ce dossier il y a quelques definitions de ce terme et leur confrontation. Le sujet principal c'est le probleme de la persuasion dans la language et dans le texte. On a montre aussi des difficultes liees avec le manque des criteres precices et equivalantes qui permettent de separer des actions de persuasion des actions de manipulation.

L'objectif de la chapitre d'analyse c'est la distinction des elements importants du communique (phenomens de lanques, moyens extralinguistiques) qui incitent le mieux le destinataire a agir avec l'intention de l'expediteur. Le problem majeur de la persuasion se rapporte aux questions suivantes: choix du vocabulaire et de la phraseologie, moyens stylistiques, construction des phrases, organisation du texte, argumentation, moyens nonverbaux de se communiquer.

On a fait une analyse detaillee de la lexique, de la phraseologie, des differentes resources stylistiques qui donnent aux enonces une valeur de la persuasion. Dans la communication des habitants de la campagne existent quelques moyens stylistiques qui sont vraiment importants: epithete, oxymorone, metaphore, comparaison ainsi que la particularite stylistique des textes p.ex.: l'ironie (manifeste, cachee et privee).

Le probleme essentiel constitue aussi l'intertextualite qui est un moyen de la strategie de persuasion. Dans l'aspect de l'intertextualite- surtout les rapports aux evenements historiques et contemporains, les rapports politiques, les connexions avec les textes bien connus, de plus les stylisations a l'idiolecte ou a la lanque etrangere.

Les moyens morphologiques ont aussi le caractere pragmatique: cathegories grammaticales, 1 et 2 personne du singulier et du pluriel, ainsi que les pronoms qui y correspondent, cathegories des modes, locutions indirectes au destinataire, verbes modales, cathegories du degre, moyens de morphologie (deminutiva et augmentiva) de meme que les expressivismes nominals, deminutiva adjectifs et adverbiaux.

Pour former l'opinion et la perception de la realite d'apres l'intention de l'expediteur on peut utiliser quelques moyens syntaxiques p.ex.: repetitions, parenteses, anaphores, epiphores, inversions, equivalents, questions rhetoriques, elipses, modulants. Parmi les moyens syntaxiques et stylistiques influant sur la composition du texte, venant de l'attitude de l'orateur et de la spontanite de l'enonce il faut citer: ordre des mots facons de la conjonction des phrases, pause emotive, exclamation. 
Dans le polonais populaire l'argumentation emotive et objective est tres importante, surtout les rapports a la natture, aux liens entre les gens, a la foi, aux interets materiels. Pendant le proces de la persuasion des interlocuteurs on utilise des techniques et des manieres erystiques surtout la technique de l'autorite familiale, de media ou des institutions.

L'element qui renforce la persuasion de transmission verbale est la communication nonverbale nottament le contact visuel, la mimique et les gestes. De plus les parametres acoustiques: intonation, tonalite, rythme, vitesse de l'enonce ou les sons paralinguistiques: souffle, soupir, rire, pleurs.

D'apres les etudes, la persuasion se manifeste dans les textes de patois par l'application de differents moyens lexicaux et phraseologiques, ainsi que par la metaphorique de la vie quotidienne, les nuances des diminutifs et meme par les comparaisons ironiques ou sarcastique. La fonction de persuation des textes de patois renforce aussi l'humeur specifique de cette langue, le jeu des mots et des sinifications car l'attraction de la forme de transmission des mots sert a atteindre un effet linguistique et rhetoriques.

L'analyse de tout ce materiel basee sur la methode comparative montre les analogies et les differences concernant les moyens linguistiques qui servent a realiser la fonction de persuasion. L'element essentiel de communication de persuasion dans les textes de patois est l'utilisation des moyens suggestifs, de la lexique et de la phreseologie marque axiologiquement, de la metaphorie interessante, des simples constructions syntaxiques. Le timbre de voix, la tonalite, les gestes et la mimique sont dans ce cas-la aussi importants. Les experiances de la vie et de la culture ainsi que les coutumes des habitants de la campagne forment le communique linguistique et la fonction convenable de persuasion. La maniere de penser vient de la culture et des valeurs codes tels que la famille, les voisins, les bonnes relations avec leurs proches et la communaute locale. 


\section{Od Redakcji}

Beata Burska-Ratajczyk od momentu ukończenia studiów polonistycznych na Uniwersytecie Łódzkim pracuje w Katedrze Współczesnego Języka Polskiego UŁ. Stopień doktora nauk humanistycznych w zakresie językoznawstwa uzyskała w 1996 roku. Prowadzi zajęcia dydaktyczne z gramatyki opisowej języka polskiego, kultury języka, stylistyki, teorii i analizy tekstu, zajęcia specjalistyczne i specjalizacyjne, seminarium magisterskie oraz wykłady kursowe i wykłady z elementami konwersatorium dla studentów innych kierunków, takich jak: Informacja Naukowa i Bibliotekoznawstwo, Wydział Zarządzania i Marketingu, Wydział Fizyki, Wydział Chemii. Jest promotorem kilkunastu prac magisterskich na kierunku filologia polska, recenzentem licznych prac dyplomowych, licencjackich i magisterskich.

Uczestniczyła w wielu konferencjach naukowych i dydaktycznych. Głównym przedmiotem jej zainteresowań jest polszczyzna ludowa. Z tego zakresu opublikowała szereg artykułów, dotyczących różnych aspektów komunikacji gwarowej, zwłaszcza kompetencji językowej i komunikacyjnej mieszkańców wsi: Odbicie kompetencji językowej w mowie mieszkańców wsi, Łódź 2001; Gwarowe innowacje leksykalne na tle tendencji rozwojowych wspótczesnej polszczyzny, Łódź 2004; Wartościowanie komunikacji językowej (na materiale frazeologii gwar mazowieckich), Bydgoszcz 2008. Badała teksty współczesnej polszczyzny, opisując m.in. środki stylizacji ludowej: Tekst folklorystyczny w kulturze massmedialnej-językowe środki stylizacji ludowej w piosenkach zespołów: Brathanki, Golec uOrkiestra, Kapela, Łódź 2012. Interesuje się także zagadnieniem perswazji językowej i skutecznej prezentacji w reklamie oraz w polityce: Kategoria natury jako językowy środek perswazji w prasowych reklamach wyrobów kosmetycznych, Bydgoszcz 2009; Kreowanie własnego wizerunku w kontekście językowej prezentacji przeciwnika politycznego (na przyktadzie wypowiedzi Lecha Watesy), Łódź 2010. 